General method for the synthesis of $\alpha$ - or $\beta$-deoxyaminoglycosides bearing basic nitrogen.

Kevin M. Hoang, ${ }^{1}$ Nicholas R. Lees, ${ }^{1}$ and Seth B. Herzon ${ }^{* 1,2}$

${ }^{1}$ Department of Chemistry, Yale University, New Haven, Connecticut 06520, United States.

${ }^{2}$ Department of Pharmacology, Yale School of Medicine, New Haven, Connecticut 06520, United States.

*seth.herzon@yale.edu

Index:

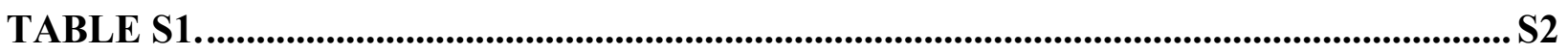

GENERAL EXPERIMENTAL PROCEDURES............................................................... S3

MATERIALS. .................................................................................................................... S3

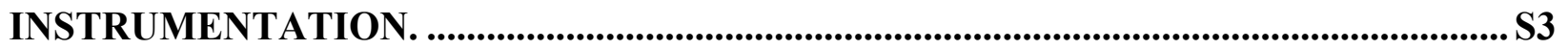

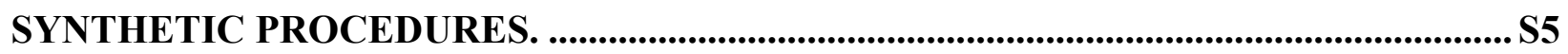

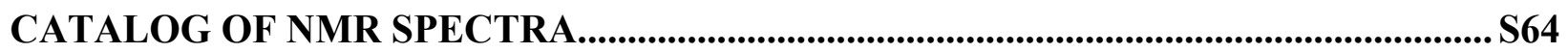

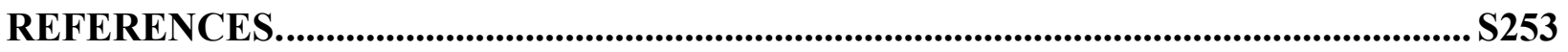

Hoang et al. "General method for the synthesis of $\alpha$ - or $\beta$-deoxyaminoglycosides bearing basic nitrogen" 
Table S1. Temperature studies of $30 \beta$.

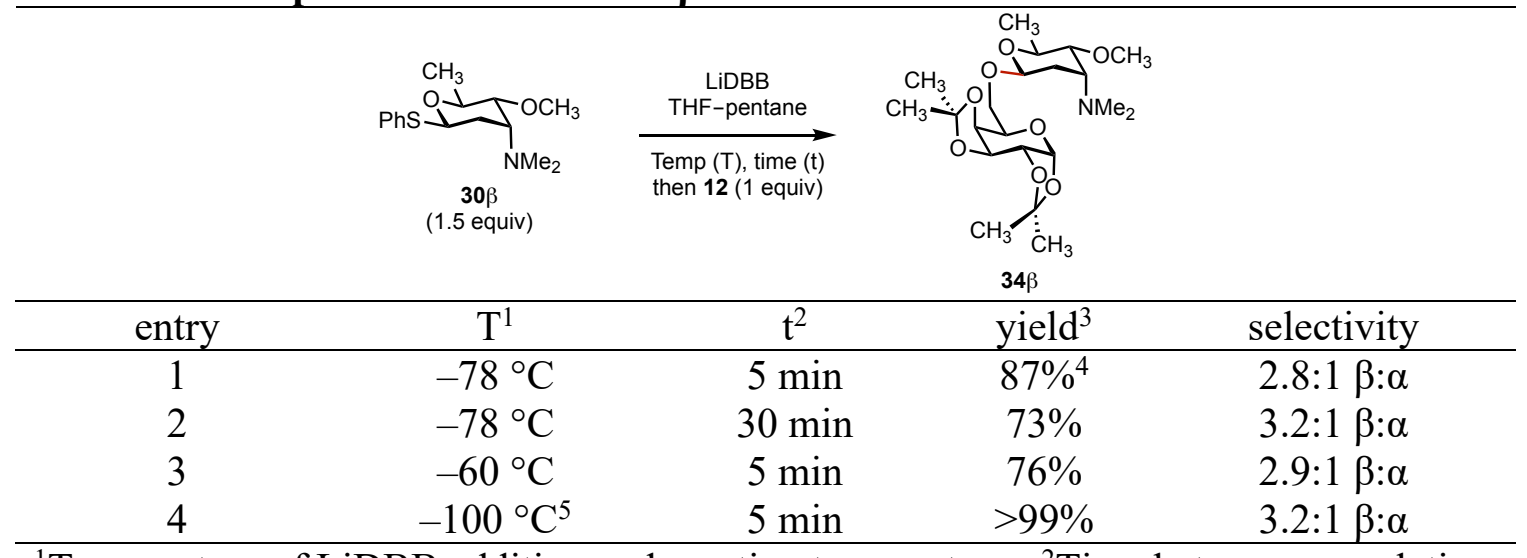

${ }^{1}$ Temperature of LiDBB addition and reaction temperature. ${ }^{2}$ Time between completion of the addition of LiDBB and the addition of the electrophile 12. ${ }^{3}$ Combined yield of both diastereomers as determined by ${ }^{1} \mathrm{H}$ NMR analysis using trimethoxybenzene as an internal standard. ${ }^{4}$ Isolated yields. ${ }^{5}$ Reaction temperature was $-78{ }^{\circ} \mathrm{C}$.

Hoang et al. "General method for the synthesis of $\alpha$ - or $\beta$-deoxyaminoglycosides bearing 
General Experimental Procedures. All reactions were performed in single-neck, flame-dried glassware fitted with rubber septa under a positive pressure of argon, unless otherwise noted. Airand moisture-sensitive liquids were transferred via syringe or stainless steel cannula, or were handled in a nitrogen-filled drybox (working oxygen level $<5 \mathrm{ppm}$ ). Flash-column chromatography was performed as described by Still et al., ${ }^{1}$ employing silica gel (60 A, 40-63 $\mu \mathrm{m}$ particle size) purchased from SiliCycle. Analytical thin-layered chromatography (TLC) was performed using glass plates pre-coated with silica gel $(0.25 \mathrm{~mm}, 60 \AA$ pore size $)$ impregnated with a fluorescent indicator $(254 \mathrm{~nm})$. TLC plates were visualized by exposure to ultraviolet light (UV) and/or submersion in aqueous ceric ammonium molybdate solution (CAM) or aqueous potassium permanganate solution $\left(\mathrm{KMnO}_{4}\right)$, followed by brief heating on a hot plate $\left(120^{\circ} \mathrm{C}, 10-\right.$ $15 \mathrm{~s})$.

Materials. Commercial solvents and reagents were used as received with the following exceptions. Dichloromethane, ether, $N, N$-dimethylformamide, pentane, tetrahydrofuran, and toluene were purified according to the method of Pangborn et al. ${ }^{2}$ Tetrahydrofuran- $d_{8}$ was purchased from Sigma-Aldrich and was dried by refluxing overnight in the presence of benzophenone and sodium metal in a sealed round-bottom flask that had been fused to a Tefloncoated valve under Ar. After refluxing overnight, tetrahydrofuran- $d_{8}$ was vacuum transferred to a flame-dried round-bottom flask that been fused to a Teflon-coated valve under Ar. Pyridine was distilled from calcium hydride under an atmosphere of nitrogen immediately prior to use. The molarity of solutions of methyllithium in ether were determined by titration against a standard solution of menthol and 1,10-phenanthroline in tetrahydrofuran (average of three determinations). ${ }^{3}$ Trifluoromethanesulfonic anhydride was purified by vacuum distillation and stored under argon at $4{ }^{\circ} \mathrm{C}$. Tri- $O$-acetyl-D-glucal and tri- $O$-acetyl D-galactal were purchased from Alfa Aesar. D$(+)$-Galactose, L-rhamnose and trichlorooxobis(triphenylphosphone) rhenium(v) were purchased from Sigma-Aldrich. The intermediates S1, ${ }^{4} \mathbf{S 8},{ }^{5} \mathbf{S 1 0},{ }^{6} \mathbf{1 2},{ }^{5}$ and $\mathbf{1 9 \alpha}{ }^{5}$ and oxotrichlorotriphenylphosphine-dimethylsulphoxide-rhenium $(\mathrm{V})^{7}$ were prepared according to published procedures. 4,4'-Di-tert-butylbiphenyl (DBB) was purchased from Alfa Aesar. Solutions of lithium di-tert-butylbiphenylide (LiDBB) were prepared by a slight modification of the procedure described by Hill et al.: ${ }^{8}$ DBB (3.60 g, 13.5 mmol, 1 equiv) was melted in a flame-dried 50-mL round-bottomed flask that had been fused to a Teflon-coated valve under vacuum. The flask was left to cool under vacuum (200 mTorr) and backfilled with argon. Lithium wire (938 mg, 135 mmol, 10.0 equiv) was added to the flask under a positive pressure of argon. The flask was evacuated and backfilled with argon twice. Tetrahydrofuran $(34 \mathrm{~mL})$ was added and the resulting mixture was cooled to $0{ }^{\circ} \mathrm{C}$. The solution was stirred for $5 \mathrm{~h}$ at $0{ }^{\circ} \mathrm{C}$ before use. The concentration of LiDBB was nominally $0.4 \mathrm{M}{ }^{8}$ The LiDBB solution was stored under argon at $-20{ }^{\circ} \mathrm{C}$ with protection from light when not in use. Solutions of LiDBB prepared in this way were used within two months of preparation.

Instrumentation. Proton nuclear magnetic resonance $\left({ }^{1} \mathrm{H}\right.$ NMR) spectra were recorded at 400 , 500 , or 600 megahertz $(\mathrm{MHz})$ at $23{ }^{\circ} \mathrm{C}$, unless otherwise noted. Chemical shifts are expressed in parts per million (ppm, $\delta$ scale) downfield from tetramethylsilane and are referenced to residual proton in the NMR solvent $\left(\mathrm{CHCl}_{3}, \delta 7.26 ; \mathrm{C}_{6} \mathrm{D}_{5} \mathrm{H}, \delta 7.16\right)$. Data are represented as follows: chemical shift, multiplicity ( $\mathrm{s}=$ singlet, $\mathrm{d}=$ doublet, $\mathrm{t}=$ triplet, $\mathrm{q}=$ quartet, $\mathrm{m}=$ multiplet and/or multiple resonances, $b r=$ broad, app $=$ apparent $)$, coupling constant in Hertz $(\mathrm{Hz})$, integration, and

Hoang et al. "General method for the synthesis of $\alpha$ - or $\beta$-deoxyaminoglycosides bearing S3 basic nitrogen" 
assignment. Proton-decoupled carbon nuclear magnetic resonance spectra $\left({ }^{13} \mathrm{C} \mathrm{NMR}\right)$ were recorded at 101,126 , or $151 \mathrm{MHz}$ at $23{ }^{\circ} \mathrm{C}$, unless otherwise noted. Chemical shifts are expressed in parts per million ( $\mathrm{ppm}, \delta$ scale) downfield from tetramethylsilane and are referenced to the carbon resonances of the solvent $\left(\mathrm{CDCl}_{3}, \delta 77.16 ; \mathrm{C}_{6} \mathrm{D}_{6}, \delta 128.06\right)$. Heteronuclear single quantum coherence (HSQC) spectra were recorded at 400,500 , or $600 \mathrm{MHz}$ at $23{ }^{\circ} \mathrm{C}$, unless otherwise noted. Two-dimensional nuclear Overhauser effect spectroscopy (2D NOESY) experiments were performed at $500 \mathrm{MHz}$ or $600 \mathrm{MHz}$ at $23{ }^{\circ} \mathrm{C}$, unless otherwise noted. ${ }^{13} \mathrm{C}$ NMR and HSQC data are combined and represented as follows: chemical shift, carbon type [obtained from HSQC experiments]. Attenuated total reflectance Fourier transform infrared (ATR-FTIR) spectra were obtained using a Thermo Electron Corporation Nicolet 6700 FTIR spectrometer referenced to a polystyrene standard. Data are represented as follows: frequency of absorption $\left(\mathrm{cm}^{-1}\right)$, intensity of absorption $(\mathrm{s}=$ strong, $\mathrm{m}=$ medium, $\mathrm{w}=$ weak, $\mathrm{br}=$ broad $)$. High-resolution mass spectrometry (HRMS) were obtained on a Waters UPLC/HRMS instrument equipped with a dual API/ESI highresolution mass spectrometry detector and photodiode array detector. Unless otherwise noted, samples were eluted over a reverse-phase C18 column $(1.7 \mu \mathrm{m}$ particle size, $2.1 \times 50 \mathrm{~mm})$ with a linear gradient of $5 \%$ acetonitrile-water containing $0.1 \%$ formic acid $\rightarrow 95 \%$ acetonitrile-water containing $0.1 \%$ formic acid for $1 \mathrm{~min}$, at a flow rate of $600 \mu \mathrm{L} / \mathrm{min}$. Optical rotations were measured on a Rudolph Research Analytical Autopol IV polarimeter equipped with a sodium (589 $\mathrm{nm}, \mathrm{D})$ lamp. Optical rotation data are represented as follows: specific rotation $\left([a]_{\lambda}^{T}\right)$, concentration $(\mathrm{g} / \mathrm{mL})$, and solvent.

Hoang et al. "General method for the synthesis of $\alpha$ - or $\beta$-deoxyaminoglycosides bearing basic nitrogen" 


\section{Synthetic Procedures.}

Synthesis of the thioglycoside $\mathbf{S} 2$.

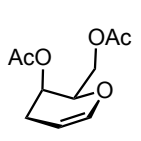

S1

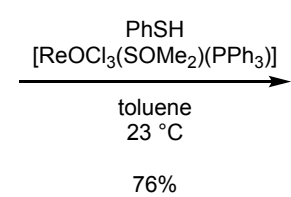

$76 \%$

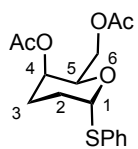

S2

Oxotrichloro-triphenylphosphine-dimethylsulphoxide-rhenium (V) (15.8 mg, $24.3 \mu \mathrm{mol}, 0.01$ equiv) was added in one portion to a solution of 3-deoxy-4,6-di- $O$-acetyl D-galactal (S1, $520 \mathrm{mg}$, $2.43 \mathrm{mmol}, 1$ equiv) and thiophenol $(322 \mu \mathrm{L}, 3.16 \mathrm{mmol}, 1.30$ equiv $)$ in toluene $(12 \mathrm{~mL})$ at $23{ }^{\circ} \mathrm{C}$. The resulting mixture was stirred for $4 \mathrm{~h}$ at $23{ }^{\circ} \mathrm{C}$. The product mixture was transferred directly to a silica gel column and purified by flash-column chromatography (eluting with $10 \%$ ethyl acetate-hexanes initially, grading to $20 \%$ ethyl acetate-hexanes, three steps) to provide the thioglycoside $\mathbf{S} 2$ as a yellow oil [600 $\mathrm{mg}, 76 \%, \alpha$ diastereomer only ( ${ }^{1} \mathrm{H}$ NMR analysis)].

$\mathrm{R}_{f}=0.32\left(20 \%\right.$ ethyl acetate-hexanes; UV, CAM). ${ }^{1} \mathrm{H}$ NMR $\left(600 \mathrm{MHz}, \mathrm{CDCl}_{3}\right) \delta 7.54-7.47(\mathrm{~m}$, $2 \mathrm{H}, \mathrm{SPh}), 7.31-7.28$ (m, 2H, SPh), $7.26-7.21(\mathrm{~m}, 1 \mathrm{H}, \mathrm{SPh}), 5.69\left(\mathrm{~d}, J=5.4 \mathrm{~Hz}, 1 \mathrm{H}, \mathrm{H}_{1}\right), 5.00$ $\left(\mathrm{q}, J=2.6 \mathrm{~Hz}, 1 \mathrm{H}, \mathrm{H}_{4}\right), 4.65\left(\mathrm{ddd}, J=6.9,5.1,1.5 \mathrm{~Hz}, 1 \mathrm{H}, \mathrm{H}_{5}\right), 4.15-4.08\left(\mathrm{~m}, 2 \mathrm{H}, \mathrm{H}_{6}\right), 2.37$ (tt, $\left.J=14.0,5.0 \mathrm{~Hz}, 1 \mathrm{H}, \mathrm{H}_{2}\right), 2.11\left(\mathrm{~s}, 3 \mathrm{H}, \mathrm{CH}_{3}\right), 2.10-2.02\left(\mathrm{~m}, 1 \mathrm{H}, \mathrm{H}_{3}\right), 2.01-1.95\left(\mathrm{~m}, 4 \mathrm{H}, \mathrm{H}_{3}\right.$, $\left.\mathrm{CH}_{3}\right), 1.84\left(\mathrm{dt}, J=14.0,3.6 \mathrm{~Hz}, 1 \mathrm{H}, \mathrm{H}_{2}\right) .{ }^{13} \mathrm{C} \mathrm{NMR}\left(151 \mathrm{MHz}, \mathrm{CDCl}_{3}\right) \delta 170.8(\mathrm{C}), 170.5(\mathrm{C})$, $134.7(\mathrm{C}), 131.5(2 \times \mathrm{CH}), 129.0(2 \times \mathrm{CH}), 127.2(\mathrm{CH}), 84.4(\mathrm{CH}), 67.9(\mathrm{CH}), 66.7(\mathrm{CH}), 63.5$ $\left(\mathrm{CH}_{2}\right), 25.3\left(\mathrm{CH}_{2}\right), 24.2\left(\mathrm{CH}_{2}\right), 21.2\left(\mathrm{CH}_{3}\right), 20.9\left(\mathrm{CH}_{3}\right)$. IR (ATR-FTIR), $\mathrm{cm}^{-1}: 2953(\mathrm{w}), 2356$ $(\mathrm{w}), 1738(\mathrm{~s}), 1584(\mathrm{w})$. HRMS-ESI (m/z): $[\mathrm{M}+\mathrm{Na}]^{+}$calculated for $\left[\mathrm{C}_{16} \mathrm{H}_{20} \mathrm{O}_{5} \mathrm{SNa}\right]^{+} 347.0924$, found 347.0937. $[a]_{D}^{21}=+277.7^{\circ}\left(c=1.0, \mathrm{CHCl}_{3}\right)$. 
Synthesis of the tosylate $\mathbf{S 3}$.

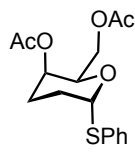

S2

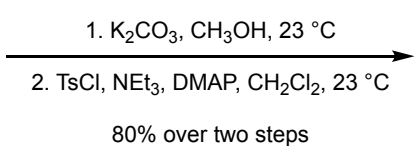

$80 \%$ over two steps

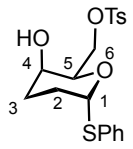

S3

Potassium carbonate $(27.7 \mathrm{mg}, 200 \mu \mathrm{mol}, 0.10$ equiv) was added in one portion to a solution of the thioglycoside $\mathbf{S 2}\left(650 \mathrm{mg}, 2.00 \mathrm{mmol}, 1\right.$ equiv) in methanol $(10 \mathrm{~mL})$ at $23{ }^{\circ} \mathrm{C}$. The reaction mixture was stirred for $18 \mathrm{~h}$ at $23{ }^{\circ} \mathrm{C}$. The product mixture was filtered over a pad of celite and the filter cake was washed with methanol $(3 \times 25 \mathrm{~mL})$. The filtrates were combined and the combined filtrates were concentrated. The residue obtained was used directly in the following step.

Triethylamine (1.10 mL, $7.69 \mathrm{mmol}, 2.20$ equiv), 4-(dimethylamino)pyridine (42.7 $\mathrm{mg}, 350 \mu \mathrm{mol}$, 0.10 equiv), and 4-toluenesulfonyl chloride (1.00 g, $5.24 \mathrm{mmol}, 1.50$ equiv) were added in sequence to a solution of the unpurified diol obtained in the preceding step (nominally $3.50 \mathrm{mmol}$, 1 equiv) in dichloromethane $(12 \mathrm{~mL})$ at $23{ }^{\circ} \mathrm{C}$. The resulting mixture was stirred for $1 \mathrm{~h}$ at $23{ }^{\circ} \mathrm{C}$. The product mixture was diluted sequentially with saturated aqueous sodium hydrogen carbonate solution $(50 \mathrm{~mL})$ and ethyl acetate $(50 \mathrm{~mL})$. The resulting biphasic mixture was transferred to a separatory funnel and the layers that formed were separated. The aqueous layer was extracted with ethyl acetate $(3 \times 50 \mathrm{~mL})$. The organic layers were combined and the combined organic layers were washed with saturated aqueous sodium chloride solution $(2 \times 10 \mathrm{~mL})$. The washed organic layer was dried over sodium sulfate. The dried solution was filtered and the filtrate was concentrated. The residue obtained was purified by flash-column chromatography (eluting with $10 \%$ ethyl acetate-hexanes initially, grading to $50 \%$ ethyl acetate-hexanes, three steps) to provide the tosylate $\mathbf{S 3}$ as a white solid $\left[1.10 \mathrm{~g}, 80 \%\right.$ over two steps, $\alpha$ diastereomer only ( ${ }^{1} \mathrm{H}$ NMR analysis)].

$\mathrm{R}_{f}=0.39$ (50\% ethyl acetate-hexanes; UV, CAM). ${ }^{1} \mathrm{H}$ NMR $\left(500 \mathrm{MHz}, \mathrm{CDCl}_{3}\right) \delta 7.74(\mathrm{~d}, J=8.3$ $\mathrm{Hz}, 2 \mathrm{H}, \mathrm{Ar}), 7.50-7.44$ (m, 2H, SPh), $7.34-7.25$ (m, 5H, Ar, SPh), 5.54 (d, J=5.5 Hz, 1H, H , $^{2}$ $4.59\left(\mathrm{t}, J=6.2 \mathrm{~Hz}, 1 \mathrm{H}, \mathrm{H}_{5}\right), 4.24\left(\mathrm{dd}, J=10.5,5.7 \mathrm{~Hz}, 1 \mathrm{H}, \mathrm{H}_{6}\right), 4.02(\mathrm{dd}, J=10.4,6.8 \mathrm{~Hz}, 1 \mathrm{H}$, $\left.\mathrm{H}_{6}\right), 3.90\left(\mathrm{~d}, J=3.4 \mathrm{~Hz}, 1 \mathrm{H}, \mathrm{H}_{4}\right), 2.44\left(\mathrm{~s}, 3 \mathrm{H}, \mathrm{CH}_{3}\right), 2.39$ (tt, $\left.J=14.2,5.0 \mathrm{~Hz}, 1 \mathrm{H}, \mathrm{H}_{2}\right), 2.02$ (tdd, $\left.J=14.2,4.6,2.8 \mathrm{~Hz}, 1 \mathrm{H}, \mathrm{H}_{3}\right), 1.90-1.76\left(\mathrm{~m}, 2 \mathrm{H}, \mathrm{H}_{2}, \mathrm{H}_{3}\right) .{ }^{13} \mathrm{C} \mathrm{NMR}\left(126 \mathrm{MHz}, \mathrm{CDCl}_{3}\right) \delta 145.1$ (C), $134.5(\mathrm{C}), 132.8(\mathrm{C}), 132.0(2 \times \mathrm{CH}), 130.0(2 \times \mathrm{CH}), 129.1(2 \times \mathrm{CH}), 128.1(2 \times \mathrm{CH}), 127.4$ $(\mathrm{CH}), 85.1(\mathrm{CH}), 69.3\left(\mathrm{CH}_{2}\right), 68.9(\mathrm{CH}), 64.1(\mathrm{CH}), 26.7\left(\mathrm{CH}_{2}\right), 24.7\left(\mathrm{CH}_{2}\right), 21.8\left(\mathrm{CH}_{3}\right)$. IR $(\mathrm{ATR}-$ FTIR), $\mathrm{cm}^{-1}: 3535$ (br w), $2948(\mathrm{w}), 2366(\mathrm{w}), 2331(\mathrm{w}), 1598(\mathrm{~m}) . \operatorname{HRMS}-E S I(\mathrm{~m} / \mathrm{z}):[\mathrm{M}+\mathrm{Na}]^{+}$ calculated for $\left[\mathrm{C}_{19} \mathrm{H}_{22} \mathrm{O}_{5} \mathrm{~S}_{2} \mathrm{Na}\right]^{+} 417.0801$, found 417.0815. $[a]_{D}^{21}=+203.5^{\circ}\left(c=1.0, \mathrm{CHCl}_{3}\right)$. 
Synthesis of the alcohol $\mathbf{S 4}$.

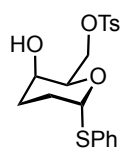

S3

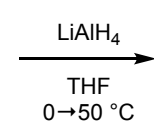

$69 \%$

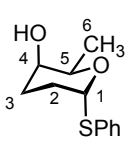

S4

Lithium aluminum hydride ( $127 \mathrm{mg}, 3.35 \mathrm{mmol}, 1.20$ equiv) was added portionwise to a solution of the tosylate $\mathbf{S 3}\left(1.10 \mathrm{~g}, 2.79 \mathrm{mmol}, 1\right.$ equiv) in tetrahydrofuran $(28 \mathrm{~mL})$ at $0{ }^{\circ} \mathrm{C}$. The reaction vessel was fitted with an air condenser and was then placed in an oil bath that had been preheated to $50{ }^{\circ} \mathrm{C}$. The reaction mixture was stirred and heated for $4 \mathrm{~h}$ at $50{ }^{\circ} \mathrm{C}$. The product mixture was cooled to $23{ }^{\circ} \mathrm{C}$ over $10 \mathrm{~min}$ and then cooled to $0{ }^{\circ} \mathrm{C}$ in an ice bath. The cooled product mixture was diluted slowly with ethyl acetate $(2.0 \mathrm{~mL})$. Saturated aqueous potassium sodium tartrate solution $(40 \mathrm{~mL})$ was then added, and the resulting mixture was stirred vigorously for $12 \mathrm{~h}$ at 23 ${ }^{\circ} \mathrm{C}$. The resulting biphasic mixture was transferred to a separatory funnel and the layers that formed were separated. The aqueous layer was extracted with ethyl acetate $(3 \times 30 \mathrm{~mL})$. The organic layers were combined and the combined organic layers were washed with saturated aqueous sodium chloride solution $(20 \mathrm{~mL})$. The washed organic layer was dried over sodium sulfate. The dried solution was filtered and the filtrate was concentrated. The residue obtained was purified by flash-column chromatography (eluting with $5 \%$ acetone-hexanes initially, grading to $20 \%$ acetone-hexanes, three steps) to provide the alcohol $\mathbf{S} 4$ as a white solid [430 $\mathrm{mg}, 69 \%, \alpha$ diastereomer only ( ${ }^{1} \mathrm{H}$ NMR analysis) $]$.

$\mathrm{R}_{f}=0.30\left(20 \%\right.$ acetone-hexanes; UV, CAM). ${ }^{1} \mathrm{H}$ NMR $\left(600 \mathrm{MHz}, \mathrm{CDCl}_{3}\right) \delta 7.48-7.45(\mathrm{~m}, 2 \mathrm{H}$, $\mathrm{SPh}), 7.29(\mathrm{t}, J=7.5 \mathrm{~Hz}, 2 \mathrm{H}, \mathrm{SPh}), 7.25-7.20(\mathrm{~m}, 1 \mathrm{H}, \mathrm{SPh}), 5.61\left(\mathrm{~d}, J=5.6 \mathrm{~Hz}, 1 \mathrm{H}, \mathrm{H}_{1}\right), 4.46$ $\left(\mathrm{q}, J=6.6 \mathrm{~Hz}, 1 \mathrm{H}, \mathrm{H}_{5}\right), 3.71-3.64\left(\mathrm{~m}, 1 \mathrm{H}, \mathrm{H}_{4}\right), 2.38\left(\mathrm{tt}, J=14.2,5.1 \mathrm{~Hz}, 1 \mathrm{H}, \mathrm{H}_{2}\right), 2.02$ (tdd, $J=$ 14.1, 4.7, $\left.2.7 \mathrm{~Hz}, 1 \mathrm{H}, \mathrm{H}_{3}\right), 1.90\left(\mathrm{dq}, J=14.1,3.0 \mathrm{~Hz}, 1 \mathrm{H}, \mathrm{H}_{3}\right), 1.79\left(\mathrm{dt}, J=14.3,3.3 \mathrm{~Hz}, 1 \mathrm{H}, \mathrm{H}_{2}\right)$, $1.20\left(\mathrm{~d}, J=6.6 \mathrm{~Hz}, 3 \mathrm{H}, \mathrm{H}_{6}\right) .{ }^{13} \mathrm{C} \mathrm{NMR}\left(151 \mathrm{MHz}, \mathrm{CDCl}_{3}\right) \delta 135.5(\mathrm{C}), 131.1(2 \times \mathrm{CH}), 129.0(2$ $\times \mathrm{CH}), 126.9(\mathrm{CH}), 85.1(\mathrm{CH}), 67.5(\mathrm{CH}), 67.4(\mathrm{CH}), 27.3\left(\mathrm{CH}_{2}\right), 24.8\left(\mathrm{CH}_{2}\right), 17.1\left(\mathrm{CH}_{3}\right) . \quad \mathrm{IR}$ (ATR-FTIR), $\mathrm{cm}^{-1}: 3414$ (br m), $2976(\mathrm{~m}), 2935$ (m), 2357 (m), $2338(\mathrm{~m}), 1583(\mathrm{~m})$. HRMS-ESI $(\mathrm{m} / \mathrm{z}):[\mathrm{M}+\mathrm{H}]^{+}$calculated for $\left[\mathrm{C}_{12} \mathrm{H}_{17} \mathrm{O}_{2} \mathrm{~S}\right]^{+} 225.0944$, found $225.0960 .[a]_{D}^{21}=+331.7^{\circ}(c=1.0$, $\left.\mathrm{CHCl}_{3}\right)$. 
Synthesis of the azide $\mathbf{S 5}$.
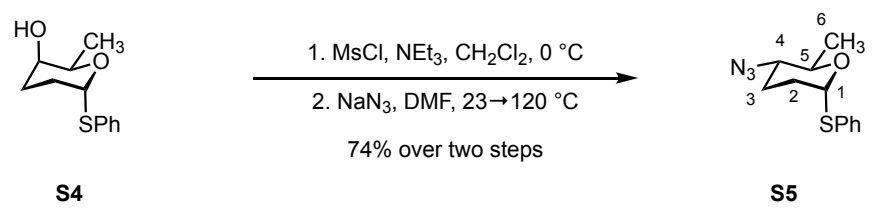

Methanesulfonyl chloride ( $207 \mu \mathrm{L}, 2.68 \mathrm{mmol}, 1.50$ equiv) was added dropwise via syringe to a solution of the alcohol S4 (400 mg, $1.78 \mathrm{mmol}, 1$ equiv) and triethylamine (496 $\mu \mathrm{L}, 3.57 \mathrm{mmol}$, 2.00 equiv) in dichloromethane $(12 \mathrm{~mL})$ at $0{ }^{\circ} \mathrm{C}$. The resulting mixture was stirred for $1 \mathrm{~h}$ at $0{ }^{\circ} \mathrm{C}$. The cold product mixture was diluted sequentially with saturated aqueous sodium hydrogen carbonate solution $(15 \mathrm{~mL})$ and water $(5.0 \mathrm{~mL})$. The resulting biphasic mixture was transferred to a separatory funnel and the layers that formed were separated. The aqueous layer was extracted with dichloromethane $(3 \times 10 \mathrm{~mL})$. The organic layers were combined and the combined organic layers were washed with saturated aqueous sodium chloride solution $(10 \mathrm{~mL})$. The washed organic layer was dried over sodium sulfate. The dried solution was filtered and the filtrate was concentrated. The residue obtained was used directly in the following step.

Sodium azide ( $824 \mathrm{mg}, 12.5 \mathrm{mmol}, 7.00$ equiv) was added in one portion to a solution of the alkyl mesylate obtained in the preceding step (nominally $1.78 \mathrm{mmol}, 1$ equiv) in $N, N$ dimethylformamide $(8.9 \mathrm{~mL})$ at $23{ }^{\circ} \mathrm{C}$. The reaction vessel was placed in an oil bath that had been preheated to $120^{\circ} \mathrm{C}$. The reaction mixture was stirred and heated for $4 \mathrm{~h}$ at $120{ }^{\circ} \mathrm{C}$. The product mixture was cooled to $23{ }^{\circ} \mathrm{C}$ over $10 \mathrm{~min}$. The cooled product mixture was diluted sequentially with ethyl acetate $(30 \mathrm{~mL})$, saturated aqueous sodium hydrogen carbonate solution $(25 \mathrm{~mL})$, and saturated aqueous sodium chloride solution $(25 \mathrm{~mL})$. The resulting biphasic mixture was transferred to a separatory funnel and the layers that formed were separated. The aqueous layer was extracted with ethyl acetate $(3 \times 35 \mathrm{~mL})$. The organic layers were combined and the combined organic layers were washed with saturated aqueous sodium chloride solution $(30 \mathrm{~mL})$. The washed organic layer was dried over sodium sulfate. The dried solution was filtered and the filtrate was concentrated. The residue obtained was purified by flash-column chromatography (eluting with $2 \%$ ether-hexanes initially, grading to $10 \%$ ether-hexanes, five steps) to provide the azide $\mathbf{S 5}$ as a clear, colorless oil [330 mg, 74\% over two steps, $\alpha$ diastereomer only ( ${ }^{1} \mathrm{H}$ NMR analysis)].

$\mathrm{R}_{f}=0.42$ (10\% ether-hexanes; UV, CAM). ${ }^{1} \mathrm{H}$ NMR $\left(600 \mathrm{MHz}, \mathrm{CDCl}_{3}\right) \delta 7.47-7.42(\mathrm{~m}, 2 \mathrm{H}$, $\mathrm{SPh}), 7.32-7.27$ (m, 2H, SPh), $7.25-7.20$ (m, 1H, SPh), 5.53 (d, J=5.0 Hz, 1H, H $), 4.14$ (dq, $\left.J=9.6,6.2 \mathrm{~Hz}, 1 \mathrm{H}, \mathrm{H}_{5}\right), 3.07\left(\mathrm{ddd}, J=11.5,9.7,4.5 \mathrm{~Hz}, 1 \mathrm{H}, \mathrm{H}_{4}\right), 2.22-2.11\left(\mathrm{~m}, 2 \mathrm{H}, \mathrm{H}_{2}\right), 2.08$ $\left(\mathrm{dq}, J=12.1,3.8 \mathrm{~Hz}, 1 \mathrm{H}, \mathrm{H}_{3}\right), 1.90\left(\mathrm{tdd}, J=13.2,11.5,4.7 \mathrm{~Hz}, 1 \mathrm{H}, \mathrm{H}_{3}\right), 1.27(\mathrm{~d}, J=6.2 \mathrm{~Hz}, 3 \mathrm{H}$, $\left.\mathrm{H}_{6}\right) .{ }^{13} \mathrm{C}$ NMR $\left(151 \mathrm{MHz}, \mathrm{CDCl}_{3}\right) \delta 135.0(\mathrm{C}), 131.1(2 \times \mathrm{CH}), 128.9(2 \times \mathrm{CH}), 127.0(\mathrm{CH}), 84.1$ $(\mathrm{CH}), 68.3(\mathrm{CH}), 62.7(\mathrm{CH}), 30.3\left(\mathrm{CH}_{2}\right), 25.4\left(\mathrm{CH}_{2}\right), 18.5\left(\mathrm{CH}_{3}\right)$. IR (ATR-FTIR), $\mathrm{cm}^{-1}: 2933$ (w), 2359 (w), 2098 (s), $1583(\mathrm{w}), 1481(\mathrm{~m}), 1439(\mathrm{~m})$. HRMS-ESI (m/z): $\left[\mathrm{M}-\mathrm{N}_{2}+\mathrm{H}\right]^{+}$ calculated for $\left[\mathrm{C}_{12} \mathrm{H}_{16} \mathrm{NOS}\right]^{+} 222.0952$, found 222.0960. $[a]_{D}^{21}=+482.1^{\circ}\left(c=0.7, \mathrm{CHCl}_{3}\right)$.

Hoang et al. "General method for the synthesis of $\alpha$ - or $\beta$-deoxyaminoglycosides bearing S8 basic nitrogen" 
Synthesis of the amine $11 \alpha$.
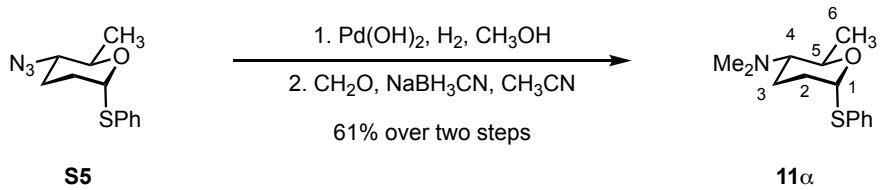

Palladium hydroxide ( $20 \mathrm{wt} \%$ on carbon, $36.6 \mathrm{mg}, 261 \mu \mathrm{mol}, 0.10$ equiv) was added in one portion to a solution of the azide $\mathbf{S 5}\left(650 \mathrm{mg}, 2.61 \mathrm{mmol}, 1\right.$ equiv) in methanol $(26 \mathrm{~mL})$ at $23{ }^{\circ} \mathrm{C}$. The reaction vessel was fitted with a rubber septum and the septum was penetrated with a needle. A balloon of dihydrogen was fixed to the vessel and the solution was sparged with dihydrogen for $10 \mathrm{~min}$. The needle and emptied balloon were removed and the suspension was stirred under a fresh balloon of dihydrogen for $18 \mathrm{~h}$ at $23{ }^{\circ} \mathrm{C}$. The product mixture was filtered through a bed of celite and the filter cake was washed with ethyl acetate $(3 \times 15 \mathrm{~mL})$. The filtrates were combined and the combined filtrates were concentrated. The residue obtained was used directly in the following step.

Aqueous formaldehyde (37 wt \%, $1.94 \mathrm{~mL}, 26.1 \mathrm{mmol}, 10.0$ equiv) and sodium cyanoborohydride ( $1.15 \mathrm{~g}, 18.3 \mathrm{mmol}, 7.00$ equiv) were added in sequence to a solution of unpurified amine obtained in the preceding step (nominally $2.61 \mathrm{mmol}, 1$ equiv) in acetonitrile $(26 \mathrm{~mL})$ at $23{ }^{\circ} \mathrm{C}$. The resulting mixture was stirred for $12 \mathrm{~h}$ at $23{ }^{\circ} \mathrm{C}$. The product mixture was diluted sequentially with saturated aqueous sodium hydrogen carbonate solution $(50 \mathrm{~mL})$ and ethyl acetate $(50 \mathrm{~mL})$. The resulting biphasic mixture was transferred to a separatory funnel and the layers that formed were separated. The aqueous layer was extracted with ethyl acetate $(3 \times 50 \mathrm{~mL})$. The organic layers were combined and the combined organic layers were washed with saturated aqueous sodium chloride solution $(2 \times 20 \mathrm{~mL})$. The washed organic layer was dried over sodium sulfate. The dried solution was filtered and the filtrate was concentrated. The residue obtained was purified by flashcolumn chromatography (eluting with $0.5 \%$ triethylamine- $2 \%$ acetone-hexanes initially, grading to $0.5 \%$ triethylamine- $10 \%$ acetone-hexanes, four steps) to provide the amine $11 \alpha$ as a clear colorless oil [400 mg, 61\% over two steps, $\alpha$ diastereomer only ( ${ }^{1} \mathrm{H}$ NMR analysis)].

$\mathrm{R}_{f}=0.29\left(0.5 \%\right.$ triethylamine- $10 \%$ acetone-hexanes; UV, CAM). ${ }^{1} \mathrm{H}$ NMR $\left(600 \mathrm{MHz}, \mathrm{CDCl}_{3}\right)$ $\delta 7.49-7.44(\mathrm{~m}, 2 \mathrm{H}, \mathrm{SPh}), 7.28(\mathrm{t}, J=7.7 \mathrm{~Hz}, 2 \mathrm{H}, \mathrm{SPh}), 7.24-7.19(\mathrm{~m}, 1 \mathrm{H}, \mathrm{SPh}), 5.52(\mathrm{~d}, J=$ $\left.4.9 \mathrm{~Hz}, 1 \mathrm{H}, \mathrm{H}_{1}\right), 4.32\left(\mathrm{dq}, J=9.6,6.2 \mathrm{~Hz}, 1 \mathrm{H}, \mathrm{H}_{5}\right), 2.35-2.30\left(\mathrm{~m}, 7 \mathrm{H}, \mathrm{H}_{4}, 2 \times \mathrm{NCH}_{3}\right), 2.16-2.07$ $\left(\mathrm{m}, 2 \mathrm{H}, \mathrm{H}_{2}\right), 1.82-1.73\left(\mathrm{~m}, 2 \mathrm{H}, \mathrm{H}_{3}\right), 1.27\left(\mathrm{~d}, J=6.2 \mathrm{~Hz}, 3 \mathrm{H}, \mathrm{H}_{6}\right) .{ }^{13} \mathrm{C} \mathrm{NMR}\left(151 \mathrm{MHz}, \mathrm{CDCl}_{3}\right)$ $\delta 135.9(\mathrm{C}), 131.0(2 \times \mathrm{CH}), 129.0(2 \times \mathrm{CH}), 126.8(\mathrm{CH}), 85.0(\mathrm{CH}), 68.0(\mathrm{CH}), 66.0(\mathrm{CH}), 40.8$ $\left(2 \times \mathrm{CH}_{3}\right), 31.5\left(\mathrm{CH}_{2}\right), 19.0\left(\mathrm{CH}_{2}\right), 16.8\left(\mathrm{CH}_{3}\right)$. IR (ATR-FTIR), $\mathrm{cm}^{-1}: 2968(\mathrm{w}), 2934(\mathrm{~m}), 2891$ $(\mathrm{w}), 2825(\mathrm{w}), 2775(\mathrm{w}), 2358(\mathrm{~m})$. HRMS-ESI $(\mathrm{m} / \mathrm{z}):[\mathrm{M}+\mathrm{H}]^{+}$calculated for $\left[\mathrm{C}_{14} \mathrm{H}_{22} \mathrm{NOS}^{+}\right.$ 252.1417, found 252.1433. $[a]_{D}^{21}=+434.4^{\circ}\left(c=1.0, \mathrm{CHCl}_{3}\right)$.

Hoang et al. "General method for the synthesis of $\alpha$ - or $\beta$-deoxyaminoglycosides bearing basic nitrogen" 
Synthesis of the disaccharide $\mathbf{1 3 \alpha}$.
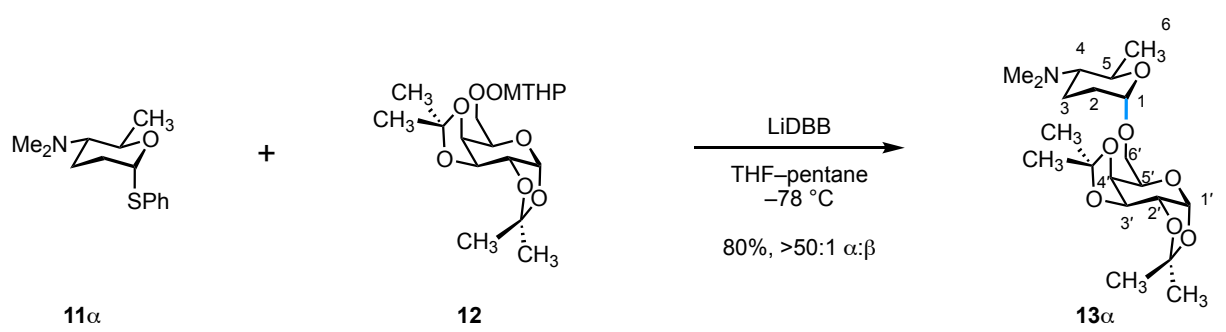

A solution of LiDBB in tetrahydrofuran (nominally $0.4 \mathrm{M}$ ) was added dropwise via syringe to a solution of the amine $11 \alpha(28.3 \mathrm{mg}, 113 \mu \mathrm{mol}, 1.50$ equiv) in tetrahydrofuran-pentane $(1: 1 \mathrm{v} / \mathrm{v}$, $1.8 \mathrm{~mL}$ ) in a $10-\mathrm{mL}$ round-bottomed flask that had been fused to a Teflon-coated valve at $-78^{\circ} \mathrm{C}$. The addition of LiDBB was continued until a green color persisted $(584 \mu \mathrm{L}$, nominally $234 \mu \mathrm{mol}$, 3.10 equiv). The resulting mixture was stirred for $10 \mathrm{~min}$ at $-78{ }^{\circ} \mathrm{C}$. A solution of the MTHP monoperoxy acetal $12(28.1 \mathrm{mg}, 75.0 \mu \mathrm{mol}, 1$ equiv $)$ in tetrahydrofuran $(300 \mu \mathrm{L})$ was then added dropwise via syringe. The resulting mixture was stirred for $3 \mathrm{~h}$ at $-78^{\circ} \mathrm{C}$. The cold product mixture was diluted with saturated aqueous sodium hydrogen carbonate solution $(1.0 \mathrm{~mL})$. The diluted product mixture was allowed to warm to $23{ }^{\circ} \mathrm{C}$ over $15 \mathrm{~min}$. The warmed product mixture was transferred to a $20-\mathrm{mL}$ test tube and the layers that formed were separated. The aqueous layer was extracted with ethyl acetate $(4 \times 5.0 \mathrm{~mL})$. The organic layers were combined and the combined organic layers were dried over sodium sulfate. The dried solution was filtered and the filtrate was concentrated under a stream of nitrogen. The residue obtained was purified by flashcolumn chromatography (eluting with $5 \%$ acetone-hexanes initially, grading to $20 \%$ acetonehexanes, four steps) to provide the disaccharide $\mathbf{1 3} \boldsymbol{\alpha}$ as a clear colorless oil (24.0 $\mathrm{mg}, 80 \%)$.

The diastereoselectivity of the reaction was determined to be $>50: 1 \alpha: \beta$ by ${ }^{1} \mathrm{H}$ NMR analysis of the unpurified product mixture.

$\mathrm{R}_{f}=0.14\left(20 \%\right.$ acetone-hexanes; CAM). ${ }^{1} \mathrm{H}$ NMR $\left(600 \mathrm{MHz}, \mathrm{C}_{6} \mathrm{D}_{6}\right) \delta 5.53(\mathrm{~d}, J=5.0 \mathrm{~Hz}, 1 \mathrm{H}$, $\left.\mathrm{H}_{1^{\prime}}\right), 4.88\left(\mathrm{~d}, J=3.4 \mathrm{~Hz}, 1 \mathrm{H}, \mathrm{H}_{1}\right), 4.54\left(\mathrm{dd}, J=7.9,2.3 \mathrm{~Hz}, 1 \mathrm{H}, \mathrm{H}_{3^{\prime}}\right), 4.27(\mathrm{td}, J=6.4,1.8 \mathrm{~Hz}, 1 \mathrm{H}$, $\left.\mathrm{H}_{5^{\prime}}\right), 4.21-4.15\left(\mathrm{~m}, 3 \mathrm{H}, \mathrm{H}_{2^{\prime}}, \mathrm{H}_{4^{\prime}}, \mathrm{H}_{6^{\prime}}\right), 4.12-4.06\left(\mathrm{~m}, 1 \mathrm{H}, \mathrm{H}_{5}\right), 3.93$ (dd, $J=10.3,6.3 \mathrm{~Hz}, 1 \mathrm{H}$, $\left.\mathrm{H}_{6^{\prime}}\right), 2.18$ (ddd, $\left.J=11.6,9.8,3.7 \mathrm{~Hz}, 1 \mathrm{H}, \mathrm{H}_{4}\right), 2.12\left(\mathrm{~s}, 6 \mathrm{H}, 2 \times \mathrm{NCH}_{3}\right), 1.91-1.83\left(\mathrm{~m}, 2 \mathrm{H}, \mathrm{H}_{2}\right.$, $\left.\mathrm{H}_{3}\right), 1.52-1.47\left(\mathrm{~m}, 1 \mathrm{H}, \mathrm{H}_{2}\right), 1.46\left(\mathrm{~s}, 3 \mathrm{H}, \mathrm{CH}_{3}\right), 1.44\left(\mathrm{~d}, J=6.6 \mathrm{~Hz}, 3 \mathrm{H}, \mathrm{H}_{6}\right), 1.43\left(\mathrm{~s}, 3 \mathrm{H}, \mathrm{CH}_{3}\right)$, $1.43-1.39\left(\mathrm{~m}, 1 \mathrm{H}, \mathrm{H}_{3}\right), 1.17\left(\mathrm{~s}, 3 \mathrm{H}, \mathrm{CH}_{3}\right), 1.04\left(\mathrm{~s}, 3 \mathrm{H}, \mathrm{CH}_{3}\right) .{ }^{13} \mathrm{C} \mathrm{NMR}\left(151 \mathrm{MHz}, \mathrm{C}_{6} \mathrm{D}_{6}\right) \delta 109.3$ (C), $108.4(\mathrm{C}), 97.0(\mathrm{CH}), 96.8(\mathrm{CH}), 71.8(\mathrm{CH}), 71.4(\mathrm{CH}), 71.1(\mathrm{CH}), 67.5(\mathrm{CH}), 67.2(\mathrm{CH})$, $66.0\left(\mathrm{CH}_{2}\right), 65.9(\mathrm{CH}), 40.8\left(2 \times \mathrm{CH}_{3}\right), 30.6\left(\mathrm{CH}_{2}\right), 26.3\left(\mathrm{CH}_{3}\right), 26.2\left(\mathrm{CH}_{3}\right), 24.9\left(\mathrm{CH}_{3}\right), 24.6$ $\left(\mathrm{CH}_{3}\right), 19.4\left(\mathrm{CH}_{3}\right), 14.9\left(\mathrm{CH}_{2}\right)$. IR (ATR-FTIR), $\mathrm{cm}^{-1}: 2935(\mathrm{~m}), 2826(\mathrm{w}), 2780(\mathrm{w}), 1455(\mathrm{~m})$, $1381(\mathrm{~m})$. HRMS-ESI $(\mathrm{m} / \mathrm{z}):[\mathrm{M}+\mathrm{H}]^{+}$calculated for $\left[\mathrm{C}_{20} \mathrm{H}_{36} \mathrm{NO}_{7}\right]^{+} 402.2486$, found 402.2515 . $[a]_{D}^{21}=+32.3^{\circ}\left(c=0.6, \mathrm{CHCl}_{3}\right)$.

Hoang et al. "General method for the synthesis of $\alpha$ - or $\beta$-deoxyaminoglycosides bearing S10 basic nitrogen" 
Synthesis of the disaccharide $\mathbf{1 3 \beta}$.

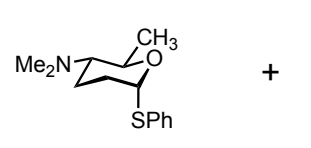

$11 \alpha$

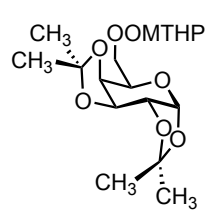

12

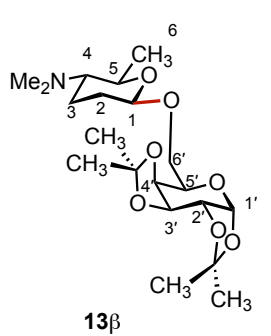

$13 \beta$

A solution of LiDBB in tetrahydrofuran (nominally $0.4 \mathrm{M}$ ) was added dropwise via syringe to a solution of the amine $\mathbf{1 1 \alpha}(94.0 \mathrm{mg}, 375 \mu \mathrm{mol}, 10.00$ equiv) in tetrahydrofuran $(1.3 \mathrm{~mL})$ in a 10 $\mathrm{mL}$ round-bottomed flask that had been fused to a Teflon-coated valve at $-78^{\circ} \mathrm{C}$. The addition of LiDBB was continued until a green color persisted $(1.88 \mathrm{~mL}$, nominally $753 \mu \mathrm{mol}, 20.10$ equiv). The resulting mixture was stirred for $10 \mathrm{~min}$ at $-78^{\circ} \mathrm{C}$. The reaction vessel was then placed in a bath that had been precooled to $-30{ }^{\circ} \mathrm{C}$. The reaction mixture was stirred for $2 \mathrm{~h} 30 \mathrm{~min}$ at $-30{ }^{\circ} \mathrm{C}$ and then cooled to $-78^{\circ} \mathrm{C}$ over $5 \mathrm{~min}$. A solution of the MTHP monoperoxy acetal $12(14.0 \mathrm{mg}$, $37.5 \mu \mathrm{mol}, 1$ equiv) in tetrahydrofuran $(300 \mu \mathrm{L})$ was then added dropwise via syringe. Upon completion of the addition, the reaction vessel was placed in a cryogenic bath that had been precooled to $-65{ }^{\circ} \mathrm{C}$. The mixture was stirred for $6 \mathrm{~h}$ at $-65^{\circ} \mathrm{C}$. The cold product mixture was diluted with saturated aqueous sodium hydrogen carbonate solution $(1.0 \mathrm{~mL})$. The diluted product mixture was allowed to warm to $23{ }^{\circ} \mathrm{C}$ over $15 \mathrm{~min}$. The warmed product mixture was transferred to a $20-\mathrm{mL}$ test tube and the layers that formed were separated. The aqueous layer was extracted with ethyl acetate $(4 \times 5.0 \mathrm{~mL})$. The organic layers were combined and the combined organic layers were dried over sodium sulfate. The dried solution was filtered and the filtrate was concentrated under a stream of nitrogen. The residue obtained was purified by flash-column chromatography (eluting with $0.5 \%$ triethylamine- $5 \%$ acetone-hexanes initially, grading to $0.5 \%$ triethylamine-20\% acetone-hexanes, four steps) to provide the disaccharide $\mathbf{1 3 \beta}$ as a clear colorless oil (25.9 mg, 69\%).

The diastereoselectivity of the reaction was determined to be $5.3: 1 \beta: \alpha$ by ${ }^{1} \mathrm{H}$ NMR analysis of the unpurified product mixture.

$\mathrm{R}_{f}=0.14\left(0.5 \%\right.$ triethylamine-20\% acetone-hexanes; CAM). ${ }^{1} \mathrm{H}$ NMR $\left(600 \mathrm{MHz}, \mathrm{C}_{6} \mathrm{D}_{6}\right) \delta 5.58$ $\left(\mathrm{d}, J=5.0 \mathrm{~Hz}, 1 \mathrm{H}, \mathrm{H}_{1^{\prime}}\right), 4.46\left(\mathrm{dd}, J=8.0,2.3 \mathrm{~Hz}, 1 \mathrm{H}, \mathrm{H}_{3^{\prime}}\right), 4.40-4.36$ (m, 2H, $\left.\mathrm{H}_{6^{\prime}}, \mathrm{H}_{1}\right), 4.26$ (ddd, $\left.J=7.3,4.0,1.8 \mathrm{~Hz}, 1 \mathrm{H}, \mathrm{H}_{5^{\prime}}\right), 4.18\left(\mathrm{dd}, J=5.1,2.3 \mathrm{~Hz}, 1 \mathrm{H}, \mathrm{H}_{2^{\prime}}\right), 4.04(\mathrm{dd}, J=10.9,7.3 \mathrm{~Hz}, 1 \mathrm{H}$, $\left.\mathrm{H}_{6^{\prime}}\right), 3.99\left(\mathrm{dd}, J=7.9,1.8 \mathrm{~Hz}, 1 \mathrm{H}, \mathrm{H}_{4^{\prime}}\right), 3.25$ (dq, $\left.J=9.4,6.1 \mathrm{~Hz}, 1 \mathrm{H}, \mathrm{H}_{5}\right), 2.07$ (ddd, $J=11.9,9.4$, $\left.3.9 \mathrm{~Hz}, 1 \mathrm{H}, \mathrm{H}_{4}\right), 1.95\left(\mathrm{~s}, 6 \mathrm{H}, 2 \times \mathrm{NCH}_{3}\right), 1.88\left(\mathrm{ddt}, J=12.8,4.8,2.6 \mathrm{~Hz}, 1 \mathrm{H}, \mathrm{H}_{2}\right), 1.59(\mathrm{tdd}, J=$ 13.4, 9.5, 4.3 Hz, 1H, H2), 1.48 (s, 3H, $\left.\mathrm{CH}_{3}\right), 1.47$ (s, 3H, $\left.\mathrm{CH}_{3}\right), 1.44-1.40\left(\mathrm{~m}, 4 \mathrm{H}, \mathrm{H}_{3}, \mathrm{H}_{6}\right), 1.12$ (s, 3H, $\left.\mathrm{CH}_{3}\right), 1.07-1.03\left(\mathrm{~m}, 4 \mathrm{H}, \mathrm{H}_{3}, \mathrm{CH}_{3}\right) .{ }^{13} \mathrm{C} \mathrm{NMR}\left(151 \mathrm{MHz}, \mathrm{C}_{6} \mathrm{D}_{6}\right) \delta 109.1$ (C), $108.4(\mathrm{C})$, $102.9(\mathrm{CH}), 96.9(\mathrm{CH}), 73.8(\mathrm{CH}), 71.9(\mathrm{CH}), 71.3(\mathrm{CH}), 71.1(\mathrm{CH}), 68.8\left(\mathrm{CH}_{2}\right), 68.5(\mathrm{CH}), 65.4$ $(\mathrm{CH}), 40.7\left(2 \times \mathrm{CH}_{3}\right), 31.6\left(\mathrm{CH}_{2}\right), 26.3\left(\mathrm{CH}_{3}\right), 26.3\left(\mathrm{CH}_{3}\right), 25.0\left(\mathrm{CH}_{3}\right), 24.3\left(\mathrm{CH}_{3}\right), 19.3\left(\mathrm{CH}_{3}\right)$, $18.2\left(\mathrm{CH}_{2}\right)$. IR (ATR-FTIR), $\mathrm{cm}^{-1}: 3000(\mathrm{w}), 2935(\mathrm{~m}), 2780(\mathrm{w}), 2360(\mathrm{~m}), 2341(\mathrm{~m}), 1454(\mathrm{~m})$, $1381(\mathrm{~m})$. HRMS-ESI $(\mathrm{m} / \mathrm{z}):[\mathrm{M}+\mathrm{H}]^{+}$calculated for $\left[\mathrm{C}_{20} \mathrm{H}_{36} \mathrm{NO}_{7}\right]^{+} 402.2486$, found 402.2515 . $[a]_{D}^{21}=-62.2^{\circ}\left(c=0.5, \mathrm{CHCl}_{3}\right)$.

Hoang et al. "General method for the synthesis of $\alpha$ - or $\beta$-deoxyaminoglycosides bearing S11 basic nitrogen" 
Synthesis of the amide $\mathbf{S 6}$.

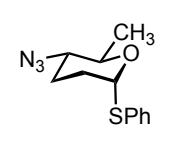

S5

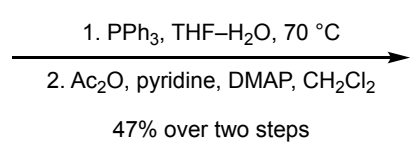

$47 \%$ over two steps

Triphenylphosphine ( $253 \mathrm{mg}, 963 \mu \mathrm{mol}, 2.00$ equiv) and deionized water (3.2 mL) were added in sequence to a solution of the azide $\mathbf{S 5}(120 \mathrm{mg}, 481 \mu \mathrm{mol}, 1$ equiv) in tetrahydrofuran $(8.0 \mathrm{~mL})$ at $23{ }^{\circ} \mathrm{C}$. The reaction vessel was fitted with a reflux condenser and then placed in an oil bath that had been preheated to $70{ }^{\circ} \mathrm{C}$. The reaction mixture was stirred and heated for $18 \mathrm{~h}$ at $70{ }^{\circ} \mathrm{C}$. The product mixture was cooled to $23{ }^{\circ} \mathrm{C}$ over $15 \mathrm{~min}$. The cooled product mixture was diluted sequentially with $1 \mathrm{~N}$ aqueous hydrochloric acid solution $(10 \mathrm{~mL})$ and hexanes-ether $(1: 1 \mathrm{v} / \mathrm{v}, 20$ $\mathrm{mL})$. The resulting mixture was transferred to a separatory funnel and the layers that formed were separated. The aqueous layer was extracted with hexanes-ether $(1: 1 \mathrm{v} / \mathrm{v}, 3 \times 20 \mathrm{~mL})$. The aqueous layer was diluted sequentially with $2 \mathrm{~N}$ aqueous sodium hydroxide solution $(10 \mathrm{~mL})$ and hexanesether $(1: 1 \mathrm{v} / \mathrm{v}, 30 \mathrm{~mL})$. The layers that formed were separated and the aqueous layer was extracted with hexanes-ether $(1: 1 \mathrm{v} / \mathrm{v}, 3 \times 30 \mathrm{~mL})$. Then organic layers were combined and the combined organic layers were dried over sodium sulfate. The dried solution was filtered and the filtrate was concentrated. The residue obtained was used directly in the following step.

Pyridine (580 $\mu \mathrm{L}, 2.13 \mathrm{mmol}, 1.50$ equiv) and 4-(dimethylamino)pyridine (5.90 mg, $48.0 \mu \mathrm{mol}$, 0.10 equiv) were added in sequence to a solution of the unpurified amine obtained in the preceding step (nominally $481 \mu \mathrm{mol}, 1$ equiv) in dichloromethane $(4.8 \mathrm{~mL})$ at $23{ }^{\circ} \mathrm{C}$. The resulting solution was cooled to $0{ }^{\circ} \mathrm{C}$. Acetic anhydride $(59.0 \mu \mathrm{L}, 625 \mu \mathrm{mol}, 1.30$ equiv) was then added dropwise via syringe. Upon completion of the addition, the cooling bath was removed and the reaction mixture was allowed to warm to $23{ }^{\circ} \mathrm{C}$. The reaction mixture was stirred for $2 \mathrm{~h}$ at $23{ }^{\circ} \mathrm{C}$. The product mixture was diluted sequentially with saturated aqueous sodium hydrogen carbonate solution $(50 \mathrm{~mL})$ and ethyl acetate $(50 \mathrm{~mL})$. The resulting biphasic mixture was transferred to a separatory funnel and the layers that formed were separated. The aqueous layer was extracted with ethyl acetate $(3 \times 50 \mathrm{~mL})$. The organic layers were combined and the combined organic layers were washed with saturated aqueous sodium chloride solution $(2 \times 20 \mathrm{~mL})$. The washed organic layer was dried over sodium sulfate. The dried solution was filtered and the filtrate was concentrated. The residue obtained was triturated sequentially with ether-hexanes $(1: 6 \mathrm{v} / \mathrm{v}, 5.0$ $\mathrm{mL})$ and hexanes $(5.0 \mathrm{~mL})$. The washed solids were collected and dried in vacuo to provide the amide S6 as a white solid [60 mg, 47\% over two steps, $\alpha$ diastereomer only ( ${ }^{1} \mathrm{H} \mathrm{NMR}$ analysis)].

$\mathrm{R}_{f}=0.12\left(0.5 \%\right.$ triethylamine-20\% acetone-hexanes; UV, CAM). ${ }^{1} \mathrm{H}$ NMR $\left(400 \mathrm{MHz}, \mathrm{CDCl}_{3}\right)$ $\delta 7.45(\mathrm{dd}, J=8.3,1.4 \mathrm{~Hz}, 2 \mathrm{H}, \mathrm{SPh}), 7.29(\mathrm{t}, J=7.4 \mathrm{~Hz}, 2 \mathrm{H}, \mathrm{SPh}), 7.23$ (t, $J=7.3 \mathrm{~Hz}, 1 \mathrm{H}, \mathrm{SPh})$, $5.54\left(\mathrm{~d}, J=4.7 \mathrm{~Hz}, 1 \mathrm{H}, \mathrm{H}_{1}\right), 5.35(\mathrm{~d}, J=9.5 \mathrm{~Hz}, 1 \mathrm{H}, \mathrm{NH}), 4.06\left(\mathrm{dq}, J=9.6,6.3 \mathrm{~Hz}, 1 \mathrm{H}, \mathrm{H}_{5}\right), 3.81$ (qd, $\left.J=9.7,4.3 \mathrm{~Hz}, 1 \mathrm{H}, \mathrm{H}_{4}\right), 2.19\left(\mathrm{tt}, J=13.4,4.6 \mathrm{~Hz}, 1 \mathrm{H}, \mathrm{H}_{2}\right), 2.08-1.93\left(\mathrm{~m}, 5 \mathrm{H}, \mathrm{H}_{2}, \mathrm{H}_{3}, \mathrm{CH}_{3}\right)$, 1.65 (ddd, $\left.J=24.9,13.0,4.3 \mathrm{~Hz}, 1 \mathrm{H}, \mathrm{H}_{3}\right), 1.21\left(\mathrm{~d}, J=6.3 \mathrm{~Hz}, 3 \mathrm{H}, \mathrm{H}_{6}\right) .{ }^{13} \mathrm{C} \mathrm{NMR}(151 \mathrm{MHz}$, $\left.\mathrm{CDCl}_{3}\right) \delta 169.7(\mathrm{C}), 135.3(\mathrm{C}), 131.0(2 \times \mathrm{CH}), 129.1(2 \times \mathrm{CH}), 127.0(\mathrm{CH}), 84.2(\mathrm{CH}), 69.5(\mathrm{CH})$, $50.7(\mathrm{CH}), 30.7\left(\mathrm{CH}_{2}\right), 27.0\left(\mathrm{CH}_{2}\right), 23.7\left(\mathrm{CH}_{3}\right), 18.3\left(\mathrm{CH}_{3}\right)$. IR (ATR-FTIR), cm ${ }^{-1}: 3271$ (br m), 3077 (m), 2977 (m), 2935 (m), 2866 (m), 2359 (m), 2338 (m), 1652 (s), 1553 (s). HRMS-ESI 
$(\mathrm{m} / \mathrm{z}):[\mathrm{M}+\mathrm{H}]^{+}$calculated for $\left[\mathrm{C}_{14} \mathrm{H}_{20} \mathrm{NO}_{2} \mathrm{~S}\right]^{+}$266.1209, found 266.1210. $[a]_{D}^{21}=+303.9^{\circ}(c=$ $\left.0.5, \mathrm{CHCl}_{3}\right)$.

Hoang et al. "General method for the synthesis of $\alpha$ - or $\beta$-deoxyaminoglycosides bearing 
Synthesis of the disaccharide $\mathbf{S 7}$.
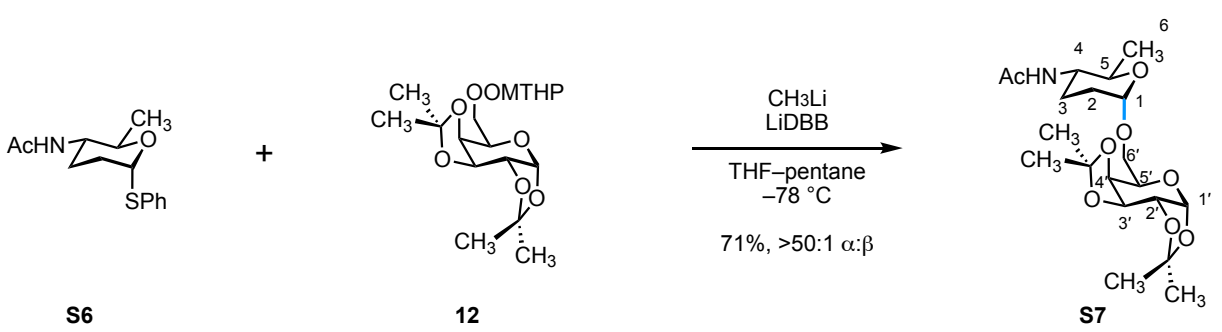

A solution of methyllithium in ether $(1.40 \mathrm{M}, 37.0 \mu \mathrm{L}, 52.1 \mu \mathrm{mol}, 1.50$ equiv) was added dropwise via syringe to a solution of the amide $\mathbf{S 6}(13.8 \mathrm{mg}, 52.1 \mu \mathrm{mol}, 1.50$ equiv) in tetrahydrofuran (830 $\mu \mathrm{L})$ in a $10-\mathrm{mL}$ round-bottomed flask that had been fused to a Teflon-coated valve at $-78^{\circ} \mathrm{C}$. The resulting mixture was stirred for $30 \mathrm{~min}$ at $-78{ }^{\circ} \mathrm{C}$. A solution of $\mathrm{LiDBB}$ in tetrahydrofuran (nominally $0.4 \mathrm{M}$ ) was then added dropwise via syringe. The addition of LiDBB was continued until a green color persisted $(269 \mu \mathrm{L}$, nominally $108 \mu \mathrm{mol}, 3.10$ equiv). The resulting mixture was stirred for $10 \mathrm{~min}$ at $-78^{\circ} \mathrm{C}$. A solution of the MTHP monoperoxy acetal $12(13.0 \mathrm{mg}, 34.7 \mu \mathrm{mol}$, 1 equiv) in tetrahydrofuran $(300 \mu \mathrm{L})$ was then added dropwise via syringe. The resulting mixture was stirred for $3 \mathrm{~h}$ at $-78^{\circ} \mathrm{C}$. The cold product mixture was diluted with saturated aqueous sodium hydrogen carbonate solution $(1.0 \mathrm{~mL})$. The diluted product mixture was allowed to warm to 23 ${ }^{\circ} \mathrm{C}$ over $15 \mathrm{~min}$. The warmed product mixture was transferred to a 20 -mL test tube and the layers that formed were separated. The aqueous layer was extracted with ethyl acetate $(4 \times 5.0 \mathrm{~mL})$. The organic layers were combined and the combined organic layers were dried over sodium sulfate. The dried solution was filtered and the filtrate was concentrated under a stream of nitrogen. The residue obtained was purified by flash-column chromatography (eluting with $0.5 \%$ triethylamine$10 \%$ acetone-hexanes initially, grading to $0.5 \%$ triethylamine $-30 \%$ acetone-hexanes, three steps) to provide the disaccharide $\mathbf{S 7}$ as a clear, colorless oil (10.3 $\mathrm{mg}, 71 \%)$.

The diastereoselectivity of the reaction was determined to be $>50: 1 \alpha: \beta$ by ${ }^{1} \mathrm{H}$ NMR analysis of the unpurified product mixture.

$\mathrm{R}_{f}=0.38\left(0.5 \%\right.$ triethylamine- $40 \%$ acetone-hexanes; CAM). ${ }^{1} \mathrm{H}$ NMR $\left(600 \mathrm{MHz}, \mathrm{C}_{6} \mathrm{D}_{6}\right) \delta 5.54$ $\left(\mathrm{d}, J=5.0 \mathrm{~Hz}, 1 \mathrm{H}, \mathrm{H}_{1^{\prime}}\right), 4.75\left(\mathrm{~d}, J=3.2 \mathrm{~Hz}, 1 \mathrm{H}, \mathrm{H}_{1}\right), 4.53\left(\mathrm{dd}, J=7.9,2.3 \mathrm{~Hz}, 1 \mathrm{H}, \mathrm{H}_{3^{\prime}}\right), 4.28(\mathrm{~d}, J$ $=9.5 \mathrm{~Hz}, 1 \mathrm{H}, \mathrm{NH}), 4.24$ (ddd, $\left.J=7.1,5.3,1.8 \mathrm{~Hz}, 1 \mathrm{H}, \mathrm{H}_{5^{\prime}}\right), 4.19$ (dd, $J=5.1,2.3 \mathrm{~Hz}, 1 \mathrm{H}, \mathrm{H}_{2^{\prime}}$ ), 4.14 (dd, $\left.J=10.5,7.0 \mathrm{~Hz}, 1 \mathrm{H}, \mathrm{H}_{6^{\prime}}\right), 4.08$ (dd, $J=8.0,1.9 \mathrm{~Hz}, 1 \mathrm{H}, \mathrm{H}_{4^{\prime}}$ ), 3.92 (qt, $J=9.4,4.8 \mathrm{~Hz}$, $\left.1 \mathrm{H}, \mathrm{H}_{4}\right), 3.76\left(\mathrm{dd}, J=10.5,5.3 \mathrm{~Hz}, 1 \mathrm{H}, \mathrm{H}_{6^{\prime}}\right), 3.57\left(\mathrm{dq}, J=9.8,6.3 \mathrm{~Hz}, 1 \mathrm{H}, \mathrm{H}_{5}\right), 1.66-1.60(\mathrm{~m}$, $\left.1 \mathrm{H}, \mathrm{H}_{2}\right), 1.59-1.51\left(\mathrm{~m}, 2 \mathrm{H}, \mathrm{H}_{3}\right), 1.48\left(\mathrm{~s}, 4 \mathrm{H}, \mathrm{CH}_{3}, \mathrm{H}_{2}\right), 1.46\left(\mathrm{~d}, J=4.3 \mathrm{~Hz}, 6 \mathrm{H}, 2 \times \mathrm{CH}_{3}\right), 1.23$ $\left(\mathrm{d}, J=6.2 \mathrm{~Hz}, 3 \mathrm{H}, \mathrm{H}_{6}\right), 1.17\left(\mathrm{~s}, 3 \mathrm{H}, \mathrm{CH}_{3}\right), 1.03\left(\mathrm{~s}, 3 \mathrm{H}, \mathrm{CH}_{3}\right) .{ }^{13} \mathrm{C} \mathrm{NMR}\left(151 \mathrm{MHz}, \mathrm{C}_{6} \mathrm{D}_{6}\right) \delta 168.1$ (C), $109.4(\mathrm{C}), 108.4(\mathrm{C}), 96.9(\mathrm{CH}), 96.7(\mathrm{CH}), 71.9(\mathrm{CH}), 71.3(\mathrm{CH}), 71.0(\mathrm{CH}), 68.8(\mathrm{CH}), 67.4$ $(\mathrm{CH}), 66.7\left(\mathrm{CH}_{2}\right), 50.5(\mathrm{CH}), 29.9\left(\mathrm{CH}_{2}\right), 26.3\left(2 \times \mathrm{CH}_{3}\right), 25.7\left(\mathrm{CH}_{2}\right), 24.9\left(\mathrm{CH}_{3}\right), 24.6\left(\mathrm{CH}_{3}\right)$, $23.1\left(\mathrm{CH}_{3}\right), 18.6\left(\mathrm{CH}_{3}\right)$. IR (ATR-FTIR), $\mathrm{cm}^{-1}$ : 3285 (br m), 2985 (m), 2935 (m), 2359 (m), 2338 $(\mathrm{w}), 1655(\mathrm{~m}), 1555(\mathrm{~m})$. HRMS-ESI $(\mathrm{m} / \mathrm{z})$ : $[\mathrm{M}+\mathrm{H}]^{+}$calculated for $\left[\mathrm{C}_{20} \mathrm{H}_{34} \mathrm{NO}_{8}\right]^{+} 416.2279$, found 416.2282. $[a]_{D}^{21}=+16.3^{\circ}\left(c=0.4, \mathrm{CHCl}_{3}\right)$.

Hoang et al. "General method for the synthesis of $\alpha$ - or $\beta$-deoxyaminoglycosides bearing S14 basic nitrogen" 
Synthesis of the disaccharide $\mathbf{S 7}$.

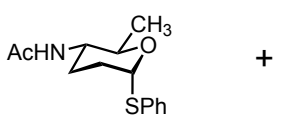

S6

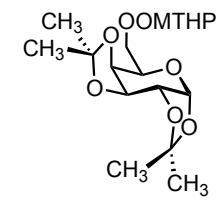

12

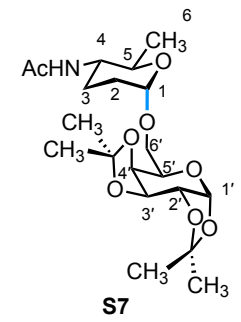

S7

A solution of methyllithium in ether $(1.40 \mathrm{M}, 107 \mu \mathrm{L}, 150 \mu \mathrm{mol}, 2.00$ equiv) was added dropwise via syringe to a solution of the amide $\mathbf{S 6}(39.8 \mathrm{mg}, 150 \mu \mathrm{mol}, 2.00$ equiv) in tetrahydrofuran (1.8 $\mathrm{mL}$ ) in a $10-\mathrm{mL}$ round-bottomed flask that had been fused to a Teflon-coated valve at $-78^{\circ} \mathrm{C}$. The resulting mixture was stirred for $45 \mathrm{~min}$ at $-78{ }^{\circ} \mathrm{C}$. A solution of LiDBB in tetrahydrofuran (nominally $0.4 \mathrm{M}$ ) was then added dropwise via syringe. The addition of LiDBB was continued until a green color persisted ( $769 \mu \mathrm{L}$, nominally $308 \mu \mathrm{mol}, 4.10$ equiv). The resulting mixture was stirred for $10 \mathrm{~min}$ at $-78^{\circ} \mathrm{C}$. The reaction vessel was then placed in a bath that had been precooled to $-20^{\circ} \mathrm{C}$. The reaction mixture was stirred for $1 \mathrm{~h}$ at $-20^{\circ} \mathrm{C}$ and then cooled to $-78{ }^{\circ} \mathrm{C}$ over 10 min. A solution of the MTHP monoperoxy acetal $12(28.1 \mathrm{mg}, 75.0 \mu \mathrm{mol}, 1$ equiv) in tetrahydrofuran $(300 \mu \mathrm{L})$ was then added dropwise via syringe. The reaction vessel was then placed in a cryogenic bath that had been precooled to $-65^{\circ} \mathrm{C}$. The mixture was stirred for $6 \mathrm{~h}$ at $-65^{\circ} \mathrm{C}$. The cold product mixture was diluted with saturated aqueous sodium hydrogen carbonate solution $(1.0 \mathrm{~mL})$. The diluted product mixture was allowed to warm to $23^{\circ} \mathrm{C}$ over $15 \mathrm{~min}$. The warmed product mixture was transferred to a $20-\mathrm{mL}$ test tube and the layers that formed were separated. The aqueous layer was extracted with ethyl acetate $(4 \times 5.0 \mathrm{~mL})$. The organic layers were combined and the combined organic layers were dried over sodium sulfate. The dried solution was filtered and the filtrate was concentrated under a stream of nitrogen. The residue obtained was purified by flash-column chromatography (eluting with $0.5 \%$ triethylamine- $10 \%$ acetone-hexanes initially, grading to $0.5 \%$ triethylamine $-30 \%$ acetone-hexanes, three steps) to provide the disaccharide $\mathbf{S} 7$ as a clear, colorless oil (20.0 $\mathrm{mg}, 64 \%)$.

The diastereoselectivity of the reaction was determined to be $>50: 1 \alpha$ : $\beta$ by ${ }^{1} \mathrm{H}$ NMR analysis of the unpurified product mixture.

The desired $\beta$-disaccharide was not observed under these conditions. We hypothesize that the dianionic intermediate derived from $\mathbf{S 6}$ is stabilized via chelation through a boat intermediate, thereby preventing equilibration to the expected $\beta$-anion (see below). For more substituted donors, such an intermediate would be disfavored due to syn-pentane interactions.

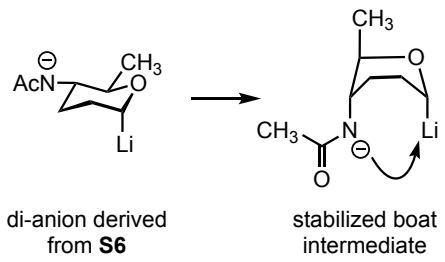

Hoang et al. "General method for the synthesis of $\alpha$ - or $\beta$-deoxyaminoglycosides bearing S15 basic nitrogen" 
Synthesis of the azide $\mathbf{S 9}$.

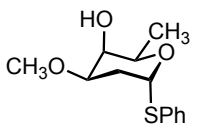

s8

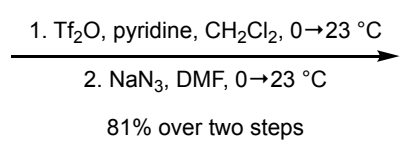

$81 \%$ over two steps

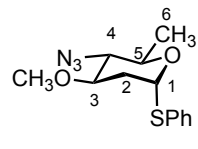

s9

Trifluoromethanesulfonic anhydride $(775 \mu \mathrm{L}, 4.61 \mathrm{mmol}, 1.20$ equiv) was added dropwise via syringe to a solution of the alcohol $\mathbf{S 8}(976 \mathrm{mg}, 3.84 \mathrm{mmol}, 1$ equiv) and pyridine (463 $\mu \mathrm{L}, 5.76$ mmol, 1.50 equiv) in dichloromethane $(23 \mathrm{~mL})$ at $0{ }^{\circ} \mathrm{C}$. The resulting mixture was stirred for $1 \mathrm{~h}$ at $0{ }^{\circ} \mathrm{C}$. The reaction vessel was removed from the cooling bath and the reaction mixture was allowed to warm to $23{ }^{\circ} \mathrm{C}$ over $30 \mathrm{~min}$. The reaction mixture was stirred for $1 \mathrm{~h}$ at $23{ }^{\circ} \mathrm{C}$. The product mixture was diluted with saturated aqueous sodium hydrogen carbonate solution $(10 \mathrm{~mL})$. The resulting biphasic mixture was transferred to a separatory funnel and the layers that formed were separated. The aqueous layer was extracted with ethyl acetate $(4 \times 10 \mathrm{~mL})$. The organic layers were combined and the combined organic layers were washed with saturated aqueous sodium chloride solution $(10 \mathrm{~mL})$. The washed organic layer was dried over sodium sulfate. The dried solution was filtered and the filtrate was concentrated. The residue obtained was eluted over a plug of silica (eluting with $20 \%$ ether-hexanes) to provide the expected alkyl triflate as a colorless oil $(1.20 \mathrm{~g}, 81 \%)$. The alkyl triflate was used in the following step without further purification.

Sodium azide (789 mg, $12.0 \mathrm{mmol}, 7.00$ equiv) was added in one portion to a solution of the alkyl triflate obtained in the preceding step (nominally $1.71 \mathrm{mmol}, 1$ equiv) in $N, N$-dimethylformamide $(4.3 \mathrm{~mL})$ at $23{ }^{\circ} \mathrm{C}$. The resulting mixture was stirred for $2 \mathrm{~h}$ at $23{ }^{\circ} \mathrm{C}$. The product mixture was diluted sequentially with ethyl acetate $(30 \mathrm{~mL})$, saturated aqueous sodium hydrogen carbonate solution $(25 \mathrm{~mL})$, and saturated aqueous sodium chloride solution $(25 \mathrm{~mL})$. The resulting biphasic mixture was transferred to a separatory funnel and the layers that formed were separated. The aqueous layer was extracted with ethyl acetate $(3 \times 35 \mathrm{~mL})$. The organic layers were combined and the combined organic layers were washed with saturated aqueous sodium chloride solution $(30 \mathrm{~mL})$. The washed organic layer was dried over sodium sulfate. The dried solution was filtered and the filtrate was concentrated. The residue obtained was purified by flash-column chromatography (eluting with $5 \%$ ether-hexanes initially, grading to $10 \%$ ether-hexanes, two steps) to provide the azide $\mathbf{S 9}$ as a clear colorless oil [ $475 \mathrm{mg}, 99 \%, \alpha$ diastereomer only $\left({ }^{1} \mathrm{H}\right.$ NMR analysis)].

$\mathrm{R}_{f}=0.42\left(10 \%\right.$ ether-hexanes; UV, CAM). ${ }^{1} \mathrm{H}$ NMR $\left(400 \mathrm{MHz}, \mathrm{CDCl}_{3}\right) \delta 7.45-7.40(\mathrm{~m}, 2 \mathrm{H}$, $\mathrm{SPh}), 7.35-7.28(\mathrm{~m}, 2 \mathrm{H}, \mathrm{SPh}), 7.28-7.23(\mathrm{~m}, 1 \mathrm{H}, \mathrm{SPh}), 5.61$ (d, J=5.6 Hz, 1H, H $), 4.07$ (dq, $\left.J=10.0,6.2 \mathrm{~Hz}, 1 \mathrm{H}, \mathrm{H}_{5}\right), 3.59\left(\mathrm{ddd}, J=11.6,9.3,4.8 \mathrm{~Hz}, 1 \mathrm{H}, \mathrm{H}_{3}\right), 3.47\left(\mathrm{~s}, 3 \mathrm{H}, \mathrm{OCH}_{3}\right), 3.03(\mathrm{t}, J$ $\left.=9.6 \mathrm{~Hz}, 1 \mathrm{H}, \mathrm{H}_{4}\right), 2.49\left(\mathrm{ddd}, J=13.4,4.9,1.2 \mathrm{~Hz}, 1 \mathrm{H}, \mathrm{H}_{2}\right), 1.98(\mathrm{ddd}, J=13.4,11.6,5.7 \mathrm{~Hz}, 1 \mathrm{H}$, $\left.\mathrm{H}_{2}\right), 1.30\left(\mathrm{~d}, J=6.2 \mathrm{~Hz}, 3 \mathrm{H}, \mathrm{H}_{6}\right) .{ }^{13} \mathrm{C} \mathrm{NMR}\left(151 \mathrm{MHz}, \mathrm{CDCl}_{3}\right) \delta 134.9(\mathrm{C}), 131.3(2 \times \mathrm{CH}), 129.2$ $(2 \times \mathrm{CH}), 127.4(\mathrm{CH}), 83.8(\mathrm{CH}), 77.9(\mathrm{CH}), 68.5(\mathrm{CH}), 67.6(\mathrm{CH}), 57.1\left(\mathrm{CH}_{3}\right), 35.8\left(\mathrm{CH}_{2}\right), 18.7$ $\left(\mathrm{CH}_{3}\right)$. IR (ATR-FTIR), $\mathrm{cm}^{-1}: 3000(\mathrm{w}), 2934(\mathrm{w}), 2850(\mathrm{w}), 2358(\mathrm{w}), 2106(\mathrm{~s}), 1584(\mathrm{w}), 1478$ $(\mathrm{m}), 1439(\mathrm{~m})$. HRMS-ESI (m/z): $\left[\mathrm{M}-\mathrm{N}_{2}+\mathrm{H}\right]^{+}$calculated for $\left[\mathrm{C}_{13} \mathrm{H}_{18} \mathrm{NO}_{2} \mathrm{~S}\right]^{+} 252.1058$, found 252.1053. $[a]_{D}^{21}=+402.0^{\circ}\left(c=1.0, \mathrm{CHCl}_{3}\right)$.

Hoang et al. "General method for the synthesis of $\alpha$ - or $\beta$-deoxyaminoglycosides bearing S16 basic nitrogen" 
Synthesis of the amine $14 \alpha$.
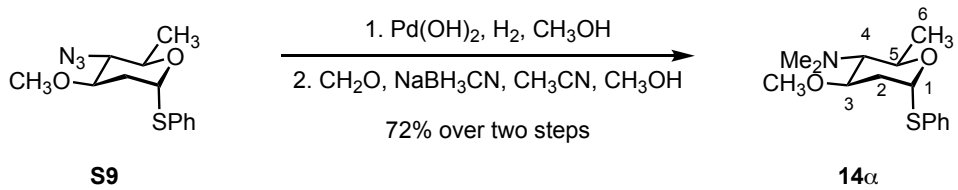

Palladium hydroxide ( $20 \mathrm{wt} \%$ on carbon, $27.2 \mathrm{mg}, 71.7 \mu \mathrm{mol}, 0.10$ equiv) was added in one portion to a solution of the azide $\mathbf{S 9}\left(200 \mathrm{mg}, 716 \mu \mathrm{mol}, 1\right.$ equiv) in methanol $(2.4 \mathrm{~mL})$ at $23{ }^{\circ} \mathrm{C}$. The reaction vessel was fitted with a rubber septum and the septum was penetrated with a needle. A balloon of dihydrogen was fixed to the vessel and the solution was sparged with dihydrogen for $10 \mathrm{~min}$. The needle and emptied balloon were removed and the suspension was stirred under a fresh balloon of dihydrogen for $18 \mathrm{~h}$ at $23{ }^{\circ} \mathrm{C}$. The product mixture was filtered through a bed of celite and the filter cake was washed with ethyl acetate $(3 \times 15 \mathrm{~mL})$. The filtrates were combined and the combined filtrates were concentrated. The residue obtained was used directly in the following step.

An aqueous solution of formaldehyde (37 wt \%, $533 \mu \mathrm{L}, 7.16 \mathrm{mmol}, 10.0$ equiv) and sodium cyanoborohydride (315 mg, $5.01 \mathrm{mmol}, 7.00$ equiv) were added in sequence to a solution of the unpurified amine obtained in the preceding step (nominally $716 \mu \mathrm{mol}, 1$ equiv) in acetonitrile $(7.2$ $\mathrm{mL}$ ) at $23{ }^{\circ} \mathrm{C}$. The resulting mixture was stirred for $2 \mathrm{~h}$ at $23{ }^{\circ} \mathrm{C}$. The product mixture was diluted sequentially with saturated aqueous sodium hydrogen carbonate solution $(50 \mathrm{~mL})$ and ethyl acetate $(50 \mathrm{~mL})$. The resulting biphasic mixture was transferred to a separatory funnel and the layers that formed were separated. The aqueous layer was extracted with ethyl acetate $(3 \times 50 \mathrm{~mL})$. The organic layers were combined and the combined organic layers were washed with saturated aqueous sodium chloride solution $(2 \times 20 \mathrm{~mL})$. The washed organic layer was dried over sodium sulfate. The dried solution was filtered and the filtrate was concentrated. The residue obtained was purified by flash-column chromatography (eluting with $0.5 \%$ triethylamine- $1 \%$ acetonehexanes initially, grading to $0.5 \%$ triethylamine- $5 \%$ acetone-hexanes, three steps) to provide the amine $\mathbf{1 4} \alpha$ as a clear oil [147 mg, 72\% over two steps, $\alpha$ diastereomer only ( ${ }^{1} \mathrm{H}$ NMR analysis)].

$\mathrm{R}_{f}=0.43\left(0.5 \%\right.$ triethylamine- $5 \%$ acetone-hexanes; UV, CAM). ${ }^{1} \mathrm{H} \mathrm{NMR}\left(500 \mathrm{MHz}, \mathrm{CDCl}_{3}\right) \delta$ $7.47-7.41$ (m, 2H, SPh), $7.36-7.27$ (m, 2H, SPh), $7.25-7.18$ (m, 1H, SPh), 5.60 (dd, J= 5.5, $\left.1.7 \mathrm{~Hz}, 1 \mathrm{H}, \mathrm{H}_{1}\right), 4.17\left(\mathrm{dq}, J=12.2,6.3 \mathrm{~Hz}, 1 \mathrm{H}, \mathrm{H}_{5}\right), 3.76\left(\mathrm{td}, J=10.3,4.5 \mathrm{~Hz}, 1 \mathrm{H}, \mathrm{H}_{3}\right), 3.37(\mathrm{~s}$, $\left.3 \mathrm{H}, \mathrm{OCH}_{3}\right), 2.55-2.47\left(\mathrm{~m}, 1 \mathrm{H}, \mathrm{H}_{2}\right), 2.46\left(\mathrm{~s}, 6 \mathrm{H}, 2 \times \mathrm{NCH}_{3}\right), 2.19\left(\mathrm{t}, J=9.7 \mathrm{~Hz}, 1 \mathrm{H}, \mathrm{H}_{4}\right), 1.94$ (ddd, $\left.J=13.0,11.0,5.6 \mathrm{~Hz}, 1 \mathrm{H}, \mathrm{H}_{2}\right), 1.29\left(\mathrm{~d}, J=6.2 \mathrm{~Hz}, 3 \mathrm{H}, \mathrm{H}_{6}\right) .{ }^{13} \mathrm{C}$ NMR $\left(126 \mathrm{MHz}, \mathrm{CDCl}_{3}\right)$ $\delta 135.7(\mathrm{C}), 131.0(2 \times \mathrm{CH}), 129.0(2 \times \mathrm{CH}), 127.0(\mathrm{CH}), 84.0(\mathrm{CH}), 74.7(\mathrm{CH}), 70.7(\mathrm{CH}), 67.7$ $(\mathrm{CH}), 55.4\left(\mathrm{CH}_{3}\right), 42.6\left(2 \times \mathrm{CH}_{3}\right), 36.2\left(\mathrm{CH}_{2}\right), 19.4\left(\mathrm{CH}_{3}\right)$. IR (ATR-FTIR), $\mathrm{cm}^{-1}: 2968(\mathrm{~m}), 2930$ (m), 2829 (m), $2783(\mathrm{~m}), 2358(\mathrm{~m}), 2332$ (m), 1584 (w), 1479 (m), 1439 (m). HRMS-ESI (m/z): $[\mathrm{M}+\mathrm{H}]^{+}$calculated for $\left[\mathrm{C}_{15} \mathrm{H}_{24} \mathrm{NO}_{2} \mathrm{~S}\right]^{+} 282.1522$, found 282.1552. $\quad[a]_{D}^{21}=+336.7^{\circ}(c=1.0$, $\left.\mathrm{CHCl}_{3}\right)$. 
Synthesis of the amide $15 \alpha$.

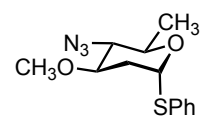

S9

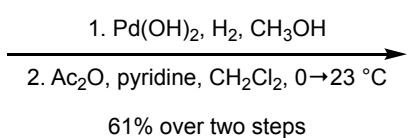

$61 \%$ over two steps

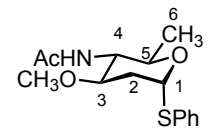

$15 \alpha$

Palladium hydroxide ( $20 \mathrm{wt} \%$ on carbon, $68.0 \mathrm{mg}, 179 \mu \mathrm{mol}, 0.10$ equiv) was added in one portion to a solution of the azide $\mathbf{S 9}\left(500 \mathrm{mg}, 1.79 \mathrm{mmol}, 1\right.$ equiv) in methanol $(2.4 \mathrm{~mL})$ at $23{ }^{\circ} \mathrm{C}$. The reaction vessel was fitted with a rubber septum and the septum was penetrated with a needle. A balloon of dihydrogen was fixed to the vessel and the solution was sparged with dihydrogen for $10 \mathrm{~min}$. The needle and emptied balloon were removed and the suspension was stirred under a fresh balloon of dihydrogen for $18 \mathrm{~h}$ at $23{ }^{\circ} \mathrm{C}$. The product mixture was filtered through a bed of celite and the filter cake was washed with ethyl acetate $(3 \times 15 \mathrm{~mL})$. The filtrates were combined and the combined filtrates were concentrated. The residue obtained was used directly in the following step.

Acetic anhydride (174 $\mu \mathrm{L}, 1.85 \mathrm{mmol}, 1.30$ equiv) was added dropwise via syringe to a solution of pyridine (171 $\mu \mathrm{L}, 2.13 \mathrm{mmol}, 1.50$ equiv) and the unpurified amine obtained in the preceding step (nominally $1.42 \mathrm{mmol}, 1$ equiv) in dichloromethane $(14 \mathrm{~mL})$ at $0{ }^{\circ} \mathrm{C}$. Upon completion of the addition, the cooling bath was removed and the reaction mixture was allowed to warm to $23{ }^{\circ} \mathrm{C}$. The reaction mixture was stirred for $2 \mathrm{~h}$ at $23{ }^{\circ} \mathrm{C}$. The product mixture was diluted sequentially with saturated aqueous sodium hydrogen carbonate solution $(50 \mathrm{~mL})$ and ethyl acetate $(50 \mathrm{~mL})$. The resulting biphasic mixture was transferred to a separatory funnel and the layers that formed were separated. The aqueous layer was extracted with ethyl acetate $(3 \times 50 \mathrm{~mL})$. The organic layers were combined and the combined organic layers were washed with saturated aqueous sodium chloride solution $(2 \times 20 \mathrm{~mL})$. The washed organic layer was dried over sodium sulfate. The dried solution was filtered and the filtrate was concentrated. The residue obtained was purified by flash-column chromatography (eluting with $0.5 \%$ triethylamine- $10 \%$ acetone-hexanes initially, grading to $0.5 \%$ triethylamine- $30 \%$ acetone-hexanes, three steps) to provide the amide $\mathbf{1 5} \boldsymbol{\alpha}$ as a white solid [320 mg, 61\% over two steps, $\alpha$ diastereomer only ( ${ }^{1} \mathrm{H}$ NMR analysis)].

$\mathrm{R}_{f}=0.17\left(0.5 \%\right.$ triethylamine- $-30 \%$ acetone-hexanes, UV, CAM). ${ }^{1} \mathrm{H}$ NMR $\left(600 \mathrm{MHz}, \mathrm{CDCl}_{3}\right)$ $\delta 7.50-7.40$ (m, 2H, SPh), 7.30 (d, $J=7.5 \mathrm{~Hz}, 2 \mathrm{H}, \mathrm{SPh}), 7.24$ (t, $J=7.5 \mathrm{~Hz}, 1 \mathrm{H}, \mathrm{SPh}), 5.64$ (dd, $\left.J=5.5,1.9 \mathrm{~Hz}, 1 \mathrm{H}, \mathrm{H}_{1}\right), 5.44(\mathrm{~d}, J=9.3 \mathrm{~Hz}, 1 \mathrm{H}, \mathrm{NH}), 4.17\left(\mathrm{dq}, J=9.7,6.3 \mathrm{~Hz}, 1 \mathrm{H}, \mathrm{H}_{5}\right), 3.76(\mathrm{q}$, $\left.J=9.5 \mathrm{~Hz}, 1 \mathrm{H}, \mathrm{H}_{4}\right), 3.53\left(\mathrm{ddd}, J=11.0,9.6,4.6 \mathrm{~Hz}, 1 \mathrm{H}, \mathrm{H}_{3}\right), 3.35\left(\mathrm{~s}, 3 \mathrm{H}, \mathrm{OCH}_{3}\right), 2.45(\mathrm{ddd}, J=$ 13.4, 4.6, $\left.1.9 \mathrm{~Hz}, 1 \mathrm{H}, \mathrm{H}_{2}\right), 2.07-2.00\left(\mathrm{~m}, 4 \mathrm{H}, \mathrm{H}_{2}, \mathrm{CH}_{3}\right), 1.25\left(\mathrm{~d}, J=6.3 \mathrm{~Hz}, 3 \mathrm{H}, \mathrm{H}_{6}\right)$. ${ }^{13} \mathrm{C} \mathrm{NMR}$ $\left(151 \mathrm{MHz}, \mathrm{CDCl}_{3}\right) \delta 170.3(\mathrm{C}), 135.1(\mathrm{C}), 131.1(2 \times \mathrm{CH}), 129.1(2 \times \mathrm{CH}), 127.3(\mathrm{CH}), 83.5(\mathrm{CH})$, $76.3(\mathrm{CH}), 69.0(\mathrm{CH}), 56.3\left(\mathrm{CH}_{3}\right), 56.1(\mathrm{CH}), 35.5\left(\mathrm{CH}_{2}\right), 23.7\left(\mathrm{CH}_{3}\right), 18.1\left(\mathrm{CH}_{3}\right)$. IR $(\mathrm{ATR}-$ FTIR), $\mathrm{cm}^{-1}$ : 3270 (br m), 3078 (w), 2978 (m), 2935 (m), 1654 (s), 1555 (s), 1479 (m), 1439 (m). HRMS-ESI $(\mathrm{m} / \mathrm{z}):[\mathrm{M}+\mathrm{H}]^{+}$calculated for $\left[\mathrm{C}_{15} \mathrm{H}_{22} \mathrm{NO}_{3} \mathrm{~S}\right]^{+} 296.1315$, found 296.1326. $[a]_{D}^{21}=$ $+266.8^{\circ}\left(c=1.0, \mathrm{CHCl}_{3}\right)$.

Hoang et al. "General method for the synthesis of $\alpha$ - or $\beta$-deoxyaminoglycosides bearing S18 basic nitrogen" 
Synthesis of the thioglycoside $\mathbf{S 1 1 .}$

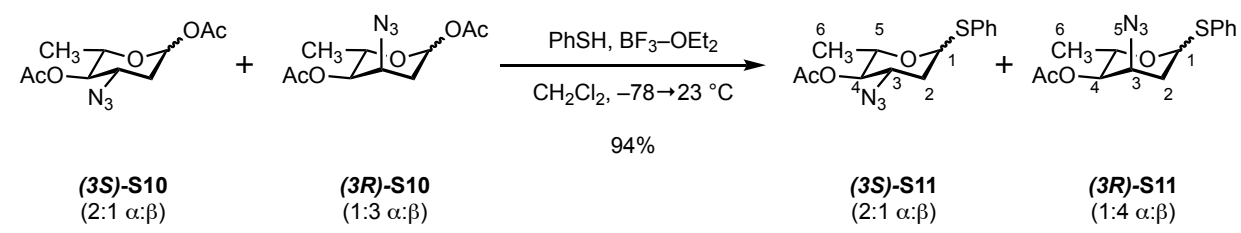

Thiophenol (5.10 mL, $49.6 \mathrm{mmol}, 1.50$ equiv) and boron trifluoride etherate complex $(5.30 \mathrm{~mL}$, $43.0 \mathrm{mmol}, 1.30$ equiv) were added in sequence to a solution of the azides S10 (3:1 (3S)-S10:(3R)S10, $8.50 \mathrm{~g}, 33.0 \mathrm{mmol}, 1$ equiv) in dichloromethane $(160 \mathrm{~mL})$ at $-78{ }^{\circ} \mathrm{C}$. The reaction mixture was stirred for $1 \mathrm{~h}$ at $-78{ }^{\circ} \mathrm{C}$. The reaction mixture was warmed to $23{ }^{\circ} \mathrm{C}$ over $30 \mathrm{~min}$ and then stirred for $1 \mathrm{~h}$ at $23^{\circ} \mathrm{C}$. The product mixture was diluted with saturated aqueous sodium hydrogen carbonate solution $(200 \mathrm{~mL})$. The resulting biphasic mixture was transferred to a separatory funnel and the layers that formed were separated. The aqueous layer was extracted with ethyl acetate (3 $\times 100 \mathrm{~mL}$ ). The organic layers were combined and the combined organic layers were washed with saturated aqueous sodium chloride solution $(2 \times 30 \mathrm{~mL})$. The washed organic layer was dried over sodium sulfate. The dried solution was filtered and the filtrate was concentrated. The residue obtained was purified by flash-column chromatography (eluting with 5\% ether-hexanes initially, grading to $10 \%$ ether-hexanes, three steps) to provide a 3:1 mixture of the thioglycosides (3S)S11 $(2: 1 \alpha: \beta)$ and (3R)-S11 (1:4 $\alpha: \beta)$ as a colorless oil (9.50 g, 94\%).

The diastereomeric mixture of the acetates S11 could not be fully resolved by flash-column chromatography. To facilitate characterization of each diastereomer, the alcohols S12 prepared in the experimental that follows were individually acylated (acetic anhydride, pyridine, dichloromethane, $0{ }^{\circ} \mathrm{C}$ ). Characterization data for the acetates $\mathbf{S 1 1}$ obtained in this way are shown below.

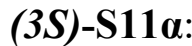

$\mathrm{R}_{f}=0.39\left(10 \%\right.$ ether-hexanes; UV, CAM). ${ }^{1} \mathrm{H}$ NMR $\left(400 \mathrm{MHz}, \mathrm{CDCl}_{3}\right) \delta 7.46-7.41(\mathrm{~m}, 2 \mathrm{H}$, $\mathrm{SPh}), 7.35-7.24(\mathrm{~m}, 3 \mathrm{H}, \mathrm{SPh}), 5.58\left(\mathrm{~d}, J=5.6 \mathrm{~Hz}, 1 \mathrm{H}, \mathrm{H}_{1}\right), 4.72\left(\mathrm{t}, J=9.7 \mathrm{~Hz}, 1 \mathrm{H}, \mathrm{H}_{4}\right), 4.31(\mathrm{dq}$, $J=9.6,6.3 \mathrm{~Hz}, 1 \mathrm{H}, \mathrm{H}_{5}$ ), 3.88 (ddd, $J=12.5,9.7,4.9 \mathrm{~Hz}, 1 \mathrm{H}, \mathrm{H}_{3}$ ), 2.38 (ddd, $J=13.6,4.9,1.2 \mathrm{~Hz}$, $\left.1 \mathrm{H}, \mathrm{H}_{2}\right), 2.19-2.06\left(\mathrm{~m}, 4 \mathrm{H}, \mathrm{H}_{2}, \mathrm{CH}_{3}\right), 1.17\left(\mathrm{~d}, J=6.3 \mathrm{~Hz}, 3 \mathrm{H}, \mathrm{H}_{6}\right) .{ }^{13} \mathrm{C} \mathrm{NMR}\left(151 \mathrm{MHz}, \mathrm{CDCl}_{3}\right)$ $\delta 170.2(\mathrm{C}), 134.3(\mathrm{C}), 131.5(2 \times \mathrm{CH}), 129.2(2 \times \mathrm{CH}), 127.6(\mathrm{CH}), 83.2(\mathrm{CH}), 75.8(\mathrm{CH}), 67.0$ $(\mathrm{CH}), 58.5(\mathrm{CH}), 36.2\left(\mathrm{CH}_{2}\right), 21.0\left(\mathrm{CH}_{3}\right), 17.5\left(\mathrm{CH}_{3}\right)$. IR (ATR-FTIR), $\mathrm{cm}^{-1}: 2985(\mathrm{~m}), 2358(\mathrm{w})$, $2102(\mathrm{~s}), 1746(\mathrm{~s}), 1584(\mathrm{~m}), 1480(\mathrm{~m})$. HRMS-ESI (m/z): $[\mathrm{M}+\mathrm{H}]^{+}$calculated for $\left[\mathrm{C}_{14} \mathrm{H}_{18} \mathrm{~N}_{3} \mathrm{O}_{3} \mathrm{~S}\right]^{+}$ 308.1063, found 308.1088. $[a]_{D}^{21}=-307.8^{\circ}\left(c=1.0, \mathrm{CHCl}_{3}\right)$.

\section{(3S)-S11ß:}

$\mathrm{R}_{f}=0.33\left(10 \%\right.$ ether-hexanes; UV, CAM). ${ }^{1} \mathrm{H}$ NMR $\left(400 \mathrm{MHz}, \mathrm{CDCl}_{3}\right) \delta 7.54-7.47(\mathrm{~m}, 2 \mathrm{H}$, $\mathrm{SPh}), 7.36-7.27(\mathrm{~m}, 3 \mathrm{H}, \mathrm{SPh}), 4.77$ (dd, $\left.J=11.7,2.0 \mathrm{~Hz}, 1 \mathrm{H}, \mathrm{H}_{1}\right), 4.66\left(\mathrm{t}, J=9.6 \mathrm{~Hz}, 1 \mathrm{H}, \mathrm{H}_{4}\right)$, 3.57 (ddd, $\left.J=12.1,9.7,5.1 \mathrm{~Hz}, 1 \mathrm{H}, \mathrm{H}_{3}\right), 3.48$ (dq, $J=9.6,6.2 \mathrm{~Hz}, 1 \mathrm{H}, \mathrm{H}_{5}$ ), 2.36 (ddd, $J=13.2$, 5.1, $\left.2.0 \mathrm{~Hz}, 1 \mathrm{H}, \mathrm{H}_{2}\right), 2.12\left(\mathrm{~s}, 3 \mathrm{H}, \mathrm{CH}_{3}\right), 1.80\left(\mathrm{dt}, J=13.3,11.9 \mathrm{~Hz}, 1 \mathrm{H}, \mathrm{H}_{2}\right), 1.24(\mathrm{~d}, J=6.2 \mathrm{~Hz}$,

Hoang et al. "General method for the synthesis of $\alpha$ - or $\beta$-deoxyaminoglycosides bearing S19 basic nitrogen" 
3H, $\left.\mathrm{H}_{6}\right) .{ }^{13} \mathrm{C}$ NMR $\left(101 \mathrm{MHz}, \mathrm{CDCl}_{3}\right) \delta 170.1(\mathrm{C}), 132.9(\mathrm{C}), 132.4(2 \times \mathrm{CH}), 129.1(2 \times \mathrm{CH})$, 128.1 (CH), 82.1 (CH), 75.0 (CH), 74.8 (CH), $61.4(\mathrm{CH}), 36.6\left(\mathrm{CH}_{2}\right), 21.0\left(\mathrm{CH}_{3}\right), 18.0\left(\mathrm{CH}_{3}\right) . \mathrm{IR}$ (ATR-FTIR), $\mathrm{cm}^{-1}: 3050$ (w), 2983 (w), 2864 (w), 2100 (s), 1746 (s), 1583 (w). HRMS-ESI (m/z): $[\mathrm{M}+\mathrm{H}]^{+}$calculated for $\left[\mathrm{C}_{14} \mathrm{H}_{18} \mathrm{~N}_{3} \mathrm{OS}\right]^{+} 308.1063$, found 308.1071. $[a]_{D}^{21}=+54.2^{\circ}(c=1.0$, $\left.\mathrm{CHCl}_{3}\right)$.

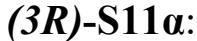

$\mathrm{R}_{f}=0.21\left(10 \%\right.$ ether-hexanes; UV, CAM). ${ }^{1} \mathrm{H}$ NMR $\left(600 \mathrm{MHz}, \mathrm{CDCl}_{3}\right) \delta 7.47(\mathrm{~d}, J=7.3 \mathrm{~Hz}$, 2H, SPh), 7.29 (t, $J=7.7 \mathrm{~Hz}, 2 \mathrm{H}, \mathrm{SPh}), 7.24(\mathrm{t}, J=7.3 \mathrm{~Hz}, 1 \mathrm{H}, \mathrm{SPh}), 5.42$ (dd, $J=6.3,1.9 \mathrm{~Hz}$, $\left.1 \mathrm{H}, \mathrm{H}_{1}\right), 4.72\left(\mathrm{dd}, J=9.3,3.4 \mathrm{~Hz}, 1 \mathrm{H}, \mathrm{H}_{4}\right), 4.60\left(\mathrm{dq}, J=9.2,6.3 \mathrm{~Hz}, 1 \mathrm{H}, \mathrm{H}_{5}\right), 4.17(\mathrm{q}, J=3.7 \mathrm{~Hz}$, $1 \mathrm{H}, \mathrm{H}_{3}$ ), 2.44 (ddd, $J=14.8,6.4,3.7 \mathrm{~Hz}, 1 \mathrm{H}, \mathrm{H}_{2}$ ), 2.31 (ddd, $J=14.8,4.1,1.9 \mathrm{~Hz}, 1 \mathrm{H}, \mathrm{H}_{2}$ ), 2.16 (s, $\left.3 \mathrm{H}, \mathrm{CH}_{3}\right), 1.23\left(\mathrm{~d}, J=6.3 \mathrm{~Hz}, 3 \mathrm{H}, \mathrm{H}_{6}\right) .{ }^{13} \mathrm{C} \mathrm{NMR}\left(151 \mathrm{MHz}, \mathrm{CDCl}_{3}\right) \delta 170.4(\mathrm{C}), 136.9(\mathrm{C})$, $130.8(2 \times \mathrm{CH}), 129.1(2 \times \mathrm{CH}), 127.2(\mathrm{CH}), 82.5(\mathrm{CH}), 74.3(\mathrm{CH}), 63.7(\mathrm{CH}), 56.7(\mathrm{CH}), 35.2$ $\left(\mathrm{CH}_{2}\right), 20.9\left(\mathrm{CH}_{3}\right), 17.3\left(\mathrm{CH}_{3}\right)$. IR (ATR-FTIR), cm ${ }^{-1}: 2978(\mathrm{w}), 2935(\mathrm{w}), 2359(\mathrm{~m}), 2337(\mathrm{~m})$, $2107(\mathrm{~s}), 1740(\mathrm{~s}), 1584(\mathrm{~m}), 1481(\mathrm{~m})$. HRMS-ESI (m/z): $[\mathrm{M}+\mathrm{H}]^{+}$calculated for $\left[\mathrm{C}_{14} \mathrm{H}_{18} \mathrm{~N}_{3} \mathrm{O}_{3} \mathrm{~S}\right]^{+}$ 308.1063, found 308.1074. $[a]_{D}^{21}=-337.0^{\circ}\left(c=1.0, \mathrm{CHCl}_{3}\right)$.

\section{(3R)-S11ß:}

$\mathrm{R}_{f}=0.33\left(10 \%\right.$ ether-hexanes; UV, CAM). ${ }^{1} \mathrm{H}$ NMR $\left(400 \mathrm{MHz}, \mathrm{CDCl}_{3}\right) \delta 7.53-7.42(\mathrm{~m}, 2 \mathrm{H}$, $\mathrm{SPh}), 7.34-7.28(\mathrm{~m}, 3 \mathrm{H}, \mathrm{SPh}), 5.02\left(\mathrm{dd}, J=11.6,2.1 \mathrm{~Hz}, 1 \mathrm{H}, \mathrm{H}_{1}\right), 4.64(\mathrm{dd}, J=9.8,3.4 \mathrm{~Hz}, 1 \mathrm{H}$, $\left.\mathrm{H}_{4}\right), 4.19\left(\mathrm{q}, J=3.3 \mathrm{~Hz}, 1 \mathrm{H}, \mathrm{H}_{3}\right), 3.98\left(\mathrm{dq}, J=10.0,6.2 \mathrm{~Hz}, 1 \mathrm{H}, \mathrm{H}_{5}\right), 2.17-2.09\left(\mathrm{~m}, 4 \mathrm{H}, \mathrm{H}_{2}, \mathrm{CH}_{3}\right)$, 2.00 (ddd, $\left.J=14.4,11.5,3.3 \mathrm{~Hz}, 1 \mathrm{H}, \mathrm{H}_{2}\right), 1.24\left(\mathrm{~d}, J=6.2 \mathrm{~Hz}, 3 \mathrm{H}, \mathrm{H}_{6}\right) .{ }^{13} \mathrm{C} \mathrm{NMR}(101 \mathrm{MHz}$, $\left.\mathrm{CDCl}_{3}\right) \delta 170.2(\mathrm{C}), 133.4(\mathrm{C}), 132.0(2 \times \mathrm{CH}), 129.0(2 \times \mathrm{CH}), 127.8(\mathrm{CH}), 79.6(\mathrm{CH}), 74.4(\mathrm{CH})$, $70.8(\mathrm{CH}), 58.8(\mathrm{CH}), 36.4\left(\mathrm{CH}_{2}\right), 20.8\left(\mathrm{CH}_{3}\right), 18.1\left(\mathrm{CH}_{3}\right)$. IR (ATR-FTIR), $\mathrm{cm}^{-1}: 2980(\mathrm{w}), 2935$ (w), $2880(\mathrm{w}), 2115(\mathrm{~s}), 1742(\mathrm{~s}), 1584(\mathrm{w})$. HRMS-ESI $(\mathrm{m} / \mathrm{z})$ : $[\mathrm{M}+\mathrm{H}]^{+}$calculated for $\left[\mathrm{C}_{14} \mathrm{H}_{18} \mathrm{~N}_{3} \mathrm{O}_{3} \mathrm{~S}\right]^{+} 308.1063$, found 308.1050. $[a]_{D}^{21}=-43.0^{\circ}\left(c=1.0, \mathrm{CHCl}_{3}\right)$. 
Synthesis of the alcohol $\mathbf{S 1 2 .}$

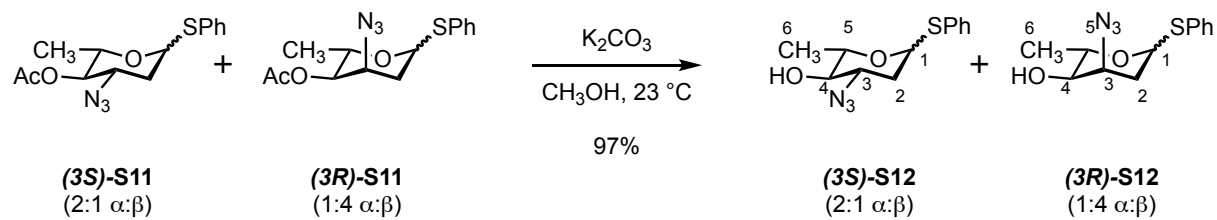

Potassium carbonate ( $854 \mathrm{mg}, 6.18 \mathrm{mmol}, 0.20$ equiv) was added in one portion to a 3:1 mixture of the thioglycosides S11 $\left(9.50 \mathrm{~g}, 30.9 \mathrm{mmol}, 1\right.$ equiv) in methanol $(150 \mathrm{~mL})$ at $23{ }^{\circ} \mathrm{C}$. The reaction mixture was stirred at $23^{\circ} \mathrm{C}$ for $3 \mathrm{~h}$. The product mixture was filtered through a bed of celite and the filter cake was washed with methanol $(3 \times 25 \mathrm{~mL})$. The filtrates were combined and the combined filtrates were concentrated. The residue obtained was purified by flash-column chromatography (eluting with $2 \%$ ethyl acetate-hexanes initially, grading to $15 \%$ ethyl acetatehexanes, 10 steps) to provide separately the alcohols (3S)-S12 $\alpha$ (yellow oil, $3.82 \mathrm{~g}, 47 \%$ ), (3S)-

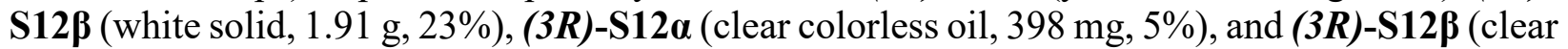
colorless oil, $1.51 \mathrm{~g}, 18 \%)$.

(3S)-S12a:

$\mathrm{R}_{f}=0.40$ (15\% ethyl acetate-hexanes; UV, CAM). ${ }^{1} \mathrm{H}$ NMR $\left(400 \mathrm{MHz}, \mathrm{CDCl}_{3}\right) \delta 7.49-7.41(\mathrm{~m}$, $2 \mathrm{H}, \mathrm{SPh}), 7.34-7.27(\mathrm{~m}, 3 \mathrm{H}, \mathrm{SPh}), 5.57\left(\mathrm{~d}, J=5.6 \mathrm{~Hz}, 1 \mathrm{H}, \mathrm{H}_{1}\right), 4.21(\mathrm{dq}, J=9.3,6.2 \mathrm{~Hz}, 1 \mathrm{H}$, $\mathrm{H}_{5}$ ), 3.77 (ddd, $\left.J=12.5,9.4,4.8 \mathrm{~Hz}, 1 \mathrm{H}, \mathrm{H}_{3}\right), 3.19\left(\mathrm{t}, J=9.3 \mathrm{~Hz}, 1 \mathrm{H}, \mathrm{H}_{4}\right), 2.38$ (ddd, $J=13.6,4.8$, $\left.1.2 \mathrm{~Hz}, 1 \mathrm{H}, \mathrm{H}_{2}\right), 2.13\left(\mathrm{td}, J=13.0,5.7 \mathrm{~Hz}, 1 \mathrm{H}, \mathrm{H}_{2}\right), 1.30\left(\mathrm{~d}, J=6.2 \mathrm{~Hz}, 3 \mathrm{H}, \mathrm{H}_{6}\right) .{ }^{13} \mathrm{C}$ NMR $(151$ $\left.\mathrm{MHz}, \mathrm{CDCl}_{3}\right) \delta 134.5(\mathrm{C}), 131.5(2 \times \mathrm{CH}), 129.2(2 \times \mathrm{CH}), 127.5(\mathrm{CH}), 83.4(\mathrm{CH}), 76.5(\mathrm{CH})$, $68.8(\mathrm{CH}), 61.2(\mathrm{CH}), 36.0\left(\mathrm{CH}_{2}\right), 17.7\left(\mathrm{CH}_{3}\right)$. IR (ATR-FTIR), $\mathrm{cm}^{-1}: 3437$ (br m), $2976(\mathrm{~m})$, $2932(\mathrm{~m}), 2358(\mathrm{~m}), 2224(\mathrm{w}), 2105(\mathrm{~s}), 1583(\mathrm{~m})$. HRMS-ESI $(\mathrm{m} / \mathrm{z}):[\mathrm{M}+\mathrm{H}]^{+}$calculated for $\left[\mathrm{C}_{12} \mathrm{H}_{16} \mathrm{~N}_{3} \mathrm{O}_{2} \mathrm{~S}\right]^{+}$266.0968, found 266.0980. [a $]_{D}^{21}=-274.1^{\circ}\left(c=1.0, \mathrm{CHCl}_{3}\right)$.

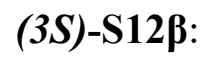

$\mathrm{R}_{f}=0.29$ (15\% ethyl acetate-hexanes; UV, CAM). ${ }^{1} \mathrm{H}$ NMR $\left(400 \mathrm{MHz}, \mathrm{CDCl}_{3}\right) \delta 7.55-7.47(\mathrm{~m}$, 2H, SPh), $7.36-7.27$ (m, 3H, SPh), $4.80\left(\mathrm{dd}, J=11.8,2.0 \mathrm{~Hz}, 1 \mathrm{H}, \mathrm{H}_{1}\right), 3.48$ (ddd, $J=11.9$, 9.3, $\left.5.0 \mathrm{~Hz}, 1 \mathrm{H}, \mathrm{H}_{3}\right), 3.38\left(\mathrm{dq}, J=9.1,6.1 \mathrm{~Hz}, 1 \mathrm{H}, \mathrm{H}_{5}\right), 3.16\left(\mathrm{t}, J=9.2 \mathrm{~Hz}, 1 \mathrm{H}, \mathrm{H}_{4}\right), 2.37$ (ddd, $J=$ 13.0, 5.0, 2.0 Hz, $\left.1 \mathrm{H}, \mathrm{H}_{2}\right), 1.80\left(\mathrm{dt}, J=12.9,11.9 \mathrm{~Hz}, 1 \mathrm{H}, \mathrm{H}_{2}\right), 1.37\left(\mathrm{~d}, J=6.1 \mathrm{~Hz}, 3 \mathrm{H}, \mathrm{H}_{6}\right) .{ }^{13} \mathrm{C}$ NMR $\left(151 \mathrm{MHz}, \mathrm{CDCl}_{3}\right) \delta 133.5(\mathrm{C}), 131.9(2 \times \mathrm{CH}), 129.1(2 \times \mathrm{CH}), 127.8(\mathrm{CH}), 82.2(\mathrm{CH})$, $76.5(\mathrm{CH}), 75.3(\mathrm{CH}), 64.1(\mathrm{CH}), 36.4\left(\mathrm{CH}_{2}\right), 18.2\left(\mathrm{CH}_{3}\right)$. IR (ATR-FTIR), cm ${ }^{-1}: 3437$ (br m), $2978(\mathrm{~m}), 2874(\mathrm{~m}), 2358(\mathrm{~m}), 2331$ (m), 2218 (m), 2100 (s), 1584 (m). HRMS-ESI (m/z): [M + $\mathrm{H}]^{+}$calculated for $\left[\mathrm{C}_{12} \mathrm{H}_{16} \mathrm{~N}_{3} \mathrm{O}_{2} \mathrm{~S}\right]^{+} 266.0968$, found 266.0967. $[a]_{D}^{21}=+0.92 .9^{\circ}\left(c=1.0, \mathrm{CHCl}_{3}\right)$.

Hoang et al. "General method for the synthesis of $\alpha$ - or $\beta$-deoxyaminoglycosides bearing $\mathrm{S} 21$ basic nitrogen" 


\section{(3R)-S12 $\alpha$ :}

$\mathrm{R}_{f}=0.14\left(15 \%\right.$ ethyl acetate-hexanes; UV, CAM). ${ }^{1} \mathrm{H}$ NMR $\left(500 \mathrm{MHz}, \mathrm{CDCl}_{3}\right) \delta 7.52-7.45(\mathrm{~m}$, 2H, SPh), 7.30 (td, $J=7.1,6.1,1.3 \mathrm{~Hz}, 2 \mathrm{H}, \mathrm{SPh}), 7.26-7.19(\mathrm{~m}, 1 \mathrm{H}, \mathrm{SPh}), 5.42$ (dd, $J=5.6,2.6$ $\left.\mathrm{Hz}, 1 \mathrm{H}, \mathrm{H}_{1}\right), 4.27\left(\mathrm{dq}, J=8.9,6.3 \mathrm{~Hz}, 1 \mathrm{H}, \mathrm{H}_{5}\right), 4.10\left(\mathrm{q}, J=3.7 \mathrm{~Hz}, 1 \mathrm{H}, \mathrm{H}_{3}\right), 3.41(\mathrm{dd}, J=9.0,3.8$ $\left.\mathrm{Hz}, 1 \mathrm{H}, \mathrm{H}_{4}\right), 2.43\left(\mathrm{dt}, J=6.8,3.5 \mathrm{~Hz}, 2 \mathrm{H}, \mathrm{H}_{2}\right), 1.30\left(\mathrm{~d}, J=6.3 \mathrm{~Hz}, 3 \mathrm{H}, \mathrm{H}_{6}\right) .{ }^{13} \mathrm{C} \mathrm{NMR}(101 \mathrm{MHz}$, $\left.\mathrm{CDCl}_{3}\right) \delta 136.8(\mathrm{C}), 130.9(2 \times \mathrm{CH}), 129.1(2 \times \mathrm{CH}), 127.2(\mathrm{CH}), 82.3(\mathrm{CH}), 72.4(\mathrm{CH}), 66.2$ $(\mathrm{CH}), 59.7(\mathrm{CH}), 35.0\left(\mathrm{CH}_{2}\right), 17.5\left(\mathrm{CH}_{3}\right)$. IR (ATR-FTIR), $\mathrm{cm}^{-1}: 3420$ (br m), $2990(\mathrm{w}), 2930$ (w), $2359(\mathrm{~m}), 2338(\mathrm{~m}), 2110(\mathrm{~s})$. HRMS-ESI (m/z): $[\mathrm{M}+\mathrm{H}]^{+}$calculated for $\left[\mathrm{C}_{12} \mathrm{H}_{16} \mathrm{~N}_{3} \mathrm{O}_{2} \mathrm{~S}^{+}\right.$ 266.0968, found 266.0946. $[a]_{D}^{21}=-402.3^{\circ}\left(c=1.0, \mathrm{CHCl}_{3}\right)$.

\section{(3R)-S12B:}

$\mathrm{R}_{f}=0.20$ (15\% ethyl acetate-hexanes; UV, CAM). ${ }^{1} \mathrm{H} \mathrm{NMR}\left(400 \mathrm{MHz}, \mathrm{CDCl}_{3}\right) \delta 7.49(\mathrm{dd}, J=$ 8.1, 1.6 Hz, 2H, SPh), $7.34-7.26$ (m, 3H, SPh), 5.03 (dd, $\left.J=11.7,2.0 \mathrm{~Hz}, 1 \mathrm{H}, \mathrm{H}_{1}\right), 4.10$ (q, $J=$ $\left.3.3 \mathrm{~Hz}, 1 \mathrm{H}, \mathrm{H}_{3}\right), 3.66\left(\mathrm{dq}, J=9.4,6.2 \mathrm{~Hz}, 1 \mathrm{H}, \mathrm{H}_{5}\right), 3.39$ (dd, $\left.J=9.4,3.7 \mathrm{~Hz}, 1 \mathrm{H}, \mathrm{H}_{4}\right), 2.27$ (ddd, $\left.J=14.2,3.3,2.1 \mathrm{~Hz}, 1 \mathrm{H}, \mathrm{H}_{2}\right), 2.03\left(\mathrm{ddd}, J=14.5,11.7,3.1 \mathrm{~Hz}, 1 \mathrm{H}, \mathrm{H}_{2}\right), 1.32(\mathrm{~d}, J=6.2 \mathrm{~Hz}, 3 \mathrm{H}$, $\left.\mathrm{H}_{6}\right) .{ }^{13} \mathrm{C} \mathrm{NMR}\left(151 \mathrm{MHz}, \mathrm{CDCl}_{3}\right) \delta 133.8(\mathrm{C}), 131.6(2 \times \mathrm{CH}), 129.0(2 \times \mathrm{CH}), 127.6(\mathrm{CH}), 79.5$ $(\mathrm{CH}), 73.4(\mathrm{CH}), 72.5(\mathrm{CH}), 61.9(\mathrm{CH}), 36.2\left(\mathrm{CH}_{2}\right), 18.2\left(\mathrm{CH}_{3}\right)$. IR (ATR-FTIR), cm ${ }^{-1}: 3464$ (br m), $2359(\mathrm{~m}), 2332(\mathrm{~m}), 2117(\mathrm{~s}), 1480(\mathrm{~m})$. HRMS-ESI $(\mathrm{m} / \mathrm{z}):[\mathrm{M}+\mathrm{H}]^{+}$calculated for $\left[\mathrm{C}_{12} \mathrm{H}_{16} \mathrm{~N}_{3} \mathrm{O}_{2} \mathrm{~S}\right]^{+}$266.0968, found 266.0969. $[a]_{D}^{21}=-99.8^{\circ}\left(c=1.0, \mathrm{CHCl}_{3}\right)$. 
Synthesis of the ether $\mathbf{S 1 3 .}$

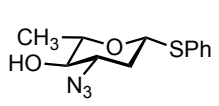

(3S)-S12 $\beta$

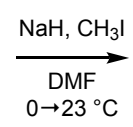

$95 \%$

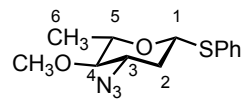

S13

Sodium hydride ( $60 \%$ dispersion in mineral oil, $109 \mathrm{mg}, 2.71 \mathrm{mmol}, 1.20$ equiv) was added in one portion to a solution of the alcohol (3S)-S12及 $(600 \mathrm{mg}, 2.26 \mathrm{mmol}, 1$ equiv) in $N, N$ dimethylformamide $(23 \mathrm{~mL})$ at $0{ }^{\circ} \mathrm{C}$. Upon completion of the addition, the cooling bath was removed and the mixture was allowed to warm to $23^{\circ} \mathrm{C}$. The mixture was stirred for $30 \mathrm{~min}$ at 23 ${ }^{\circ} \mathrm{C}$ and then was cooled to $0{ }^{\circ} \mathrm{C}$. Methyl iodide $(183 \mu \mathrm{L}, 2.94 \mathrm{mmol}, 1.30$ equiv) was added dropwise to the cold mixture. Upon completion of the addition, the cooling bath was removed and the reaction mixture was allowed to warm to $23{ }^{\circ} \mathrm{C}$. The reaction mixture was stirred for $2 \mathrm{~h}$ at 23 ${ }^{\circ} \mathrm{C}$. The product mixture was diluted sequentially with saturated aqueous ammonium chloride solution $(100 \mathrm{~mL})$ and ethyl acetate $(50 \mathrm{~mL})$. The resulting mixture was transferred to a separatory funnel and the layers that formed were separated. The aqueous layer was extracted with ethyl acetate $(3 \times 50 \mathrm{~mL})$. The organic layers were combined and the combined organic layers were washed sequentially with saturated aqueous sodium chloride solution $(20 \mathrm{~mL})$ and saturated aqueous sodium thiosulfate solution $(20 \mathrm{~mL})$. The washed organic layer was dried over sodium sulfate. The dried solution was filtered and the filtrate was concentrated. The residue obtained was purified by flash-column chromatography (eluting with $2 \%$ ether-hexanes initially, grading to $10 \%$ ether-hexanes, two steps) to provide the ether $\mathbf{S 1 3}$ as a white solid [600 $\mathrm{mg}, 95 \%, \beta$ diastereomer only $\left({ }^{1} \mathrm{H}\right.$ NMR analysis) $]$.

$\mathrm{R}_{f}=0.39\left(10 \%\right.$ ether-hexanes; UV, CAM). ${ }^{1} \mathrm{H}$ NMR $\left(600 \mathrm{MHz}, \mathrm{CDCl}_{3}\right) \delta 7.50-7.45(\mathrm{~m}, 2 \mathrm{H}$, $\mathrm{SPh}), 7.34-7.27(\mathrm{~m}, 3 \mathrm{H}, \mathrm{SPh}), 4.75\left(\mathrm{dd}, J=11.8,2.0 \mathrm{~Hz}, 1 \mathrm{H}, \mathrm{H}_{1}\right), 3.58\left(\mathrm{~s}, 3 \mathrm{H}, \mathrm{OCH}_{3}\right), 3.49$ (ddd, $\left.J=12.1,9.2,5.1 \mathrm{~Hz}, 1 \mathrm{H}, \mathrm{H}_{3}\right), 3.34\left(\mathrm{dq}, J=9.2,6.1 \mathrm{~Hz}, 1 \mathrm{H}, \mathrm{H}_{5}\right), 2.75\left(\mathrm{t}, J=9.2 \mathrm{~Hz}, 1 \mathrm{H}, \mathrm{H}_{4}\right), 2.29$ (ddd, $\left.J=13.1,5.1,2.0 \mathrm{~Hz}, 1 \mathrm{H}, \mathrm{H}_{2}\right), 1.71\left(\mathrm{q}, J=12.2 \mathrm{~Hz}, 1 \mathrm{H}, \mathrm{H}_{2}\right), 1.37\left(\mathrm{~d}, J=6.2 \mathrm{~Hz}, 3 \mathrm{H}, \mathrm{H}_{6}\right)$. ${ }^{13} \mathrm{C} \mathrm{NMR}\left(151 \mathrm{MHz}, \mathrm{CDCl}_{3}\right) \delta 133.6(\mathrm{C}), 131.9(2 \times \mathrm{CH}), 129.1(2 \times \mathrm{CH}), 127.8(\mathrm{CH}), 85.4(\mathrm{CH})$, $82.1(\mathrm{CH}), 76.4(\mathrm{CH}), 63.3(\mathrm{CH}), 60.9\left(\mathrm{CH}_{3}\right), 37.0\left(\mathrm{CH}_{2}\right), 18.4\left(\mathrm{CH}_{3}\right)$. IR (ATR-FTIR), $\mathrm{cm}^{-1}$ : $3063(\mathrm{w}), 2986(\mathrm{~m}), 2939(\mathrm{~m}), 2831(\mathrm{~m}), 2358$ (m), $2332(\mathrm{~m}), 2099$ (s), $1583(\mathrm{~m})$. HRMS-ESI $(\mathrm{m} / \mathrm{z}):[\mathrm{M}+\mathrm{H}]^{+}$calculated for $\left[\mathrm{C}_{13} \mathrm{H}_{18} \mathrm{~N}_{3} \mathrm{O}_{2} \mathrm{~S}\right]^{+} 280.1114$, found 280.1126. $[a]_{D}^{21}=+37.0^{\circ}(c=$ $\left.1.0, \mathrm{CHCl}_{3}\right)$.

Hoang et al. "General method for the synthesis of $\alpha$ - or $\beta$-deoxyaminoglycosides bearing S23 basic nitrogen" 
Synthesis of the amine $\mathbf{1 6 \beta}$.

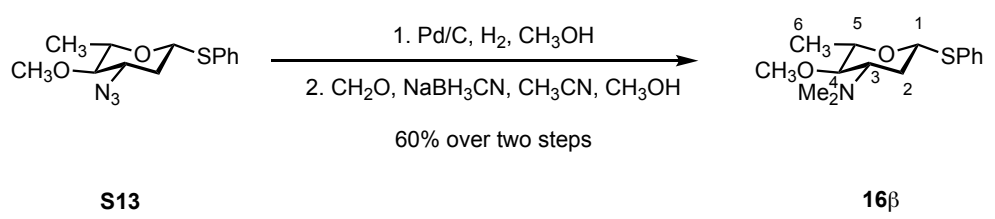

Palladium (10 wt \% on carbon, $45.7 \mathrm{mg}, 430 \mu \mathrm{mol}, 0.20$ equiv) was added in one portion to a solution of the ether $\mathbf{S 1 3}\left(600 \mathrm{mg}, 2.15 \mathrm{mmol}, 1\right.$ equiv) in methanol $(22 \mathrm{~mL})$ at $23^{\circ} \mathrm{C}$. The reaction vessel was fitted with a rubber septum and the septum was penetrated with a needle. A balloon of dihydrogen was fixed to the vessel and the solution was sparged with dihydrogen for $10 \mathrm{~min}$. The needle and emptied balloon were removed and the suspension was stirred under a fresh balloon of dihydrogen for $18 \mathrm{~h}$ at $23{ }^{\circ} \mathrm{C}$. The product mixture was filtered through a bed of celite and the filter cake was washed with ethyl acetate $(3 \times 25 \mathrm{~mL})$. The filtrates were combined and the combined filtrates were concentrated. The residue obtained was used directly in the following step.

Aqueous formaldehyde ( $37 \mathrm{wt} \%, 592 \mu \mathrm{L}, 21.5 \mathrm{mmol}, 10.0$ equiv), sodium cyanoborohydride (946 $\mathrm{mg}, 15.1 \mathrm{mmol}, 7.00$ equiv), and methanol $(2.0 \mathrm{~mL})$ added in sequence to a solution of the unpurified amine obtained in the preceding step (nominally $2.15 \mathrm{mmol}, 1$ equiv) in acetonitrile (22 $\mathrm{mL}$ ) at $23{ }^{\circ} \mathrm{C}$. The resulting mixture was stirred for $18 \mathrm{~h}$ at $23^{\circ} \mathrm{C}$. The product mixture was diluted sequentially with saturated aqueous sodium hydrogen carbonate solution $(100 \mathrm{~mL})$ and ethyl acetate $(100 \mathrm{~mL})$. The resulting biphasic mixture was transferred to a separatory funnel and the layers that formed were separated. The aqueous layer was extracted with ethyl acetate $(4 \times 50$ $\mathrm{mL}$ ). The organic layers were combined and the combined organic layers were washed with saturated aqueous sodium chloride solution $(2 \times 20 \mathrm{~mL})$. The washed organic layer was dried over sodium sulfate. The dried solution was filtered and the filtrate was concentrated. The residue obtained was purified by flash-column chromatography (eluting with $0.5 \%$ triethylamine $-5 \%$ acetone-hexanes initially, grading to $0.5 \%$ triethylamine $-15 \%$ acetone-hexanes, three steps) to provide the amine $\mathbf{1 6 \beta}$ as a clear, colorless oil $[380 \mathrm{mg}, 60 \%$ over two steps, $\beta$ diastereomer only $\left({ }^{1} \mathrm{H}\right.$ NMR analysis) $]$.

$\mathrm{R}_{f}=0.21(0.5 \%$ triethylamine- $20 \%$ acetone-hexanes; $\mathrm{UV}, \mathrm{CAM}) .{ }^{1} \mathrm{H} \mathrm{NMR}\left(500 \mathrm{MHz}, \mathrm{CDCl}_{3}\right)$ $\delta 7.50-7.44(\mathrm{~m}, 2 \mathrm{H}, \mathrm{SPh}), 7.29$ (t, $J=7.3 \mathrm{~Hz}, 2 \mathrm{H}, \mathrm{SPh}), 7.25-7.22(\mathrm{~m}, 1 \mathrm{H}, \mathrm{SPh}), 4.76$ (dd, $J=$ 11.6, $\left.2.0 \mathrm{~Hz}, 1 \mathrm{H}, \mathrm{H}_{1}\right), 3.54\left(\mathrm{~s}, 3 \mathrm{H}, \mathrm{OCH}_{3}\right), 3.33\left(\mathrm{dq}, J=8.5,6.2 \mathrm{~Hz}, 1 \mathrm{H}, \mathrm{H}_{5}\right), 2.87(\mathrm{t}, J=9.3 \mathrm{~Hz}$, $\left.1 \mathrm{H}, \mathrm{H}_{4}\right), 2.72$ (ddd, $\left.J=12.1,9.9,4.4 \mathrm{~Hz}, 1 \mathrm{H}, \mathrm{H}_{3}\right), 2.35\left(\mathrm{~s}, 6 \mathrm{H}, 2 \times \mathrm{NCH}_{3}\right), 2.12$ (dd, $J=12.1,3.2$ $\left.\mathrm{Hz}, 1 \mathrm{H}, \mathrm{H}_{2}\right), 1.70\left(\mathrm{q}, J=12.1 \mathrm{~Hz}, 1 \mathrm{H}, \mathrm{H}_{2}\right), 1.37\left(\mathrm{~d}, J=6.1 \mathrm{~Hz}, 3 \mathrm{H}, \mathrm{H}_{6}\right) .{ }^{13} \mathrm{C}$ NMR $(126 \mathrm{MHz}$, $\left.\mathrm{CDCl}_{3}\right) \delta 134.7(\mathrm{C}), 131.1(2 \times \mathrm{CH}), 129.0(2 \times \mathrm{CH}), 127.3(\mathrm{CH}), 83.5(\mathrm{CH}), 81.4(\mathrm{CH}), 77.1$ $(\mathrm{CH}), 66.2(\mathrm{CH}), 60.1\left(\mathrm{CH}_{3}\right), 40.9\left(2 \times \mathrm{CH}_{3}\right), 29.6\left(\mathrm{CH}_{2}\right), 18.9\left(\mathrm{CH}_{3}\right)$. IR (ATR-FTIR), $\mathrm{cm}^{-1}$ : $2969(\mathrm{~m}), 2933(\mathrm{~m}), 2827$ (m), $2778(\mathrm{~m}), 2360$ (s), 2337 (m), 2157 (m), 1479 (m). HRMS-ESI $(\mathrm{m} / \mathrm{z}):[\mathrm{M}+\mathrm{H}]^{+}$calculated for $\left[\mathrm{C}_{15} \mathrm{H}_{24} \mathrm{NO}_{2} \mathrm{~S}\right]^{+} 282.1522$, found 282.1545. $[a]_{D}^{21}=-190.6^{\circ}(c=$ $\left.1.0, \mathrm{CHCl}_{3}\right)$.

Hoang et al. "General method for the synthesis of $\alpha$ - or $\beta$-deoxyaminoglycosides bearing S24 basic nitrogen" 
Synthesis of the ether $\mathbf{S 1 4 .}$

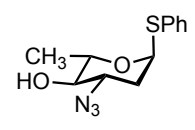

(3S)-S12 $\alpha$

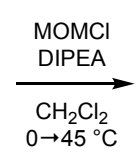

$96 \%$

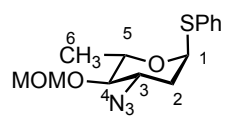

S14

$N, N$-Di-iso-propylethylamine $(4.90 \mathrm{~mL}, 28.3 \mathrm{mmol}, 7.50$ equiv) was added dropwise via syringe to a solution of the alcohol (3S)-S12 $\alpha(1.00 \mathrm{~g}, 3.77 \mathrm{mmol}, 1$ equiv) in dichloromethane $(9.4 \mathrm{~mL})$ at $0{ }^{\circ} \mathrm{C}$ in a $50-\mathrm{mL}$ round-bottomed flask that had been fused to a Teflon-coated valve. Chloromethyl methyl ether $(860 \mu \mathrm{L}, 11.3 \mathrm{mmol}, 3.00$ equiv $)$ was then added in one portion. The reaction vessel was sealed and the sealed reaction vessel was warmed to $23{ }^{\circ} \mathrm{C}$. The reaction vessel was then placed in an oil bath that had been preheated to $45^{\circ} \mathrm{C}$. The reaction mixture was stirred and heated for $18 \mathrm{~h}$ at $45^{\circ} \mathrm{C}$. The product mixture was cooled to $23{ }^{\circ} \mathrm{C}$ over $10 \mathrm{~min}$. The cooled product mixture was transferred to a $100-\mathrm{mL}$ beaker and diluted sequentially with water $(25 \mathrm{~mL})$, saturated aqueous sodium hydrogen carbonate solution $(25 \mathrm{~mL})$ and ethyl acetate $(50 \mathrm{~mL})$. The resulting biphasic mixture was transferred to a separatory funnel and the layers that formed were separated. The aqueous layer was extracted with ethyl acetate $(3 \times 25 \mathrm{~mL})$. The organic layers were combined and the combined organic layers were washed with saturated aqueous sodium chloride solution $(2 \times 20 \mathrm{~mL})$. The washed organic layer was dried over sodium sulfate. The dried solution was filtered and the filtrate was concentrated. The residue obtained was purified by flashcolumn chromatography (eluting with $5 \%$ ethyl acetate-hexanes initially, grading to $10 \%$ ethyl acetate-hexanes, two steps) to provide the ether S14 as a clear, colorless oil [1.12 g, 96\%, $\alpha$ diastereomer only ( ${ }^{1} \mathrm{H}$ NMR analysis)].

$\mathrm{R}_{f}=0.50$ (10\% ethyl acetate-hexanes; UV, CAM). ${ }^{1} \mathrm{H}$ NMR $\left(600 \mathrm{MHz}, \mathrm{CDCl}_{3}\right) \delta 7.46-7.43(\mathrm{~m}$, 2H, SPh), $7.34-7.28$ (m, 2H, SPh), $7.27-7.26(\mathrm{~m}, 1 \mathrm{H}, \mathrm{SPh}), 5.56\left(\mathrm{~d}, J=5.6 \mathrm{~Hz}, 1 \mathrm{H}, \mathrm{H}_{1}\right), 4.88$ $\left(\mathrm{d}, J=6.7 \mathrm{~Hz}, 1 \mathrm{H}, \mathrm{CH}_{2}\right), 4.77\left(\mathrm{~d}, J=6.7 \mathrm{~Hz}, 1 \mathrm{H}, \mathrm{CH}_{2}\right), 4.23\left(\mathrm{dq}, J=8.9,6.3 \mathrm{~Hz}, 1 \mathrm{H}, \mathrm{H}_{5}\right), 3.79$ (ddd, $\left.J=12.5,9.3,4.8 \mathrm{~Hz}, 1 \mathrm{H}, \mathrm{H}_{3}\right), 3.47\left(\mathrm{~s}, 3 \mathrm{H}, \mathrm{OCH}_{3}\right), 3.12\left(\mathrm{t}, J=9.3 \mathrm{~Hz}, 1 \mathrm{H}, \mathrm{H}_{4}\right), 2.37$ (ddd, $J$ $\left.=13.6,4.9,1.3 \mathrm{~Hz}, 1 \mathrm{H}, \mathrm{H}_{2}\right), 2.11\left(\mathrm{td}, J=13.1,5.7 \mathrm{~Hz}, 1 \mathrm{H}, \mathrm{H}_{2}\right), 1.30\left(\mathrm{~d}, J=6.3 \mathrm{~Hz}, 3 \mathrm{H}, \mathrm{H}_{6}\right) .{ }^{13} \mathrm{C}$ NMR $\left(151 \mathrm{MHz}, \mathrm{CDCl}_{3}\right) \delta 134.6(\mathrm{C}), 131.5(2 \times \mathrm{CH}), 129.2(2 \times \mathrm{CH}), 127.5(\mathrm{CH}), 98.3\left(\mathrm{CH}_{2}\right)$, $83.3(\mathrm{CH}), 82.0(\mathrm{CH}), 68.3(\mathrm{CH}), 60.7(\mathrm{CH}), 56.7\left(\mathrm{CH}_{3}\right), 36.5\left(\mathrm{CH}_{2}\right), 18.1\left(\mathrm{CH}_{3}\right)$. IR (ATR-FTIR), $\mathrm{cm}^{-1}: 2896(\mathrm{br} \mathrm{m}), 2358(\mathrm{~m}), 2102(\mathrm{~s}), 1584(\mathrm{~m})$. HRMS-ESI $(\mathrm{m} / \mathrm{z}):[\mathrm{M}+\mathrm{H}]^{+}$calculated for $\left[\mathrm{C}_{14} \mathrm{H}_{20} \mathrm{~N}_{3} \mathrm{O}_{3} \mathrm{~S}\right]^{+} 310.1220$, found 310.1235. $[a]_{D}^{21}=-321.1^{\circ}\left(c=1.0, \mathrm{CHCl}_{3}\right)$. 
Synthesis of the amine $\mathbf{1 7 \alpha}$.

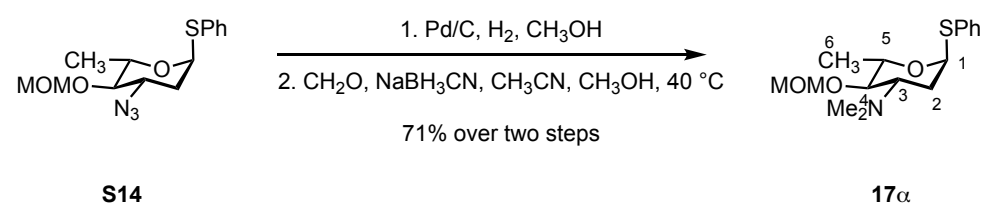

Palladium ( $10 \mathrm{wt} \%$ on carbon, $77.1 \mathrm{mg}, 724 \mu \mathrm{mol}, 0.20$ equiv) was added in one portion to a solution of the ether $\mathbf{S 1 4}\left(1.12 \mathrm{~g}, 3.62 \mathrm{mmol}, 1\right.$ equiv) in methanol $(18 \mathrm{~mL})$ at $23^{\circ} \mathrm{C}$. The reaction vessel was fitted with a rubber septum and the septum was penetrated with a needle. A balloon of dihydrogen was fixed to the vessel and the solution was sparged with dihydrogen for $10 \mathrm{~min}$. The needle and emptied balloon were removed and the suspension was stirred under a fresh balloon of dihydrogen for $18 \mathrm{~h}$ at $23{ }^{\circ} \mathrm{C}$. The product mixture was filtered through a bed of celite and the filter cake was washed with ethyl acetate $(3 \times 25 \mathrm{~mL})$. The filtrates were combined and the combined filtrates were concentrated. The residue obtained was used directly in the following step.

Aqueous formaldehyde ( $37 \mathrm{wt} \%, 2.70 \mathrm{~mL}, 36.2 \mathrm{mmol}, 10.0$ equiv), sodium cyanoborohydride $(1.59 \mathrm{~g}, 25.3 \mathrm{mmol}, 7.00$ equiv), and methanol $(3.2 \mathrm{~mL})$ were added in sequence to a solution of the unpurified amine obtained in the preceding step (nominally $3.62 \mathrm{mmol}, 1$ equiv) in acetonitrile $(35 \mathrm{~mL})$ at $23{ }^{\circ} \mathrm{C}$. The reaction vessel was placed in an oil bath that had been preheated to $40{ }^{\circ} \mathrm{C}$. The reaction mixture was stirred and heated for $16 \mathrm{~h}$ at $40^{\circ} \mathrm{C}$. The product mixture was cooled to $23{ }^{\circ} \mathrm{C}$ and diluted sequentially with saturated aqueous sodium hydrogen carbonate solution (150 $\mathrm{mL})$ and ethyl acetate $(150 \mathrm{~mL})$. The resulting biphasic mixture was transferred to a separatory funnel and the layers that formed were separated. The aqueous layer was extracted with ethyl acetate $(4 \times 50 \mathrm{~mL})$. The organic layers were combined and the combined organic layers were washed with saturated aqueous sodium chloride solution $(2 \times 20 \mathrm{~mL})$. The washed organic layer was dried over sodium sulfate. The dried solution was filtered and the filtrate was concentrated. The residue obtained was purified by flash-column chromatography (eluting with $0.5 \%$ triethylamine $-5 \%$ acetone-hexanes initially, grading to $0.5 \%$ triethylamine- $-15 \%$ acetonehexanes, three steps) to provide the amine $\mathbf{1 7} \boldsymbol{\alpha}$ as a clear, colorless solid [ $800 \mathrm{mg}, 71 \%$ over two steps, $\alpha$ diastereomer only ( ${ }^{1} \mathrm{H}$ NMR analysis)].

$\mathrm{R}_{f}=0.46\left(20 \%\right.$ acetone-hexanes, $\left.0.5 \% \mathrm{NEt}_{3} ; \mathrm{UV}, \mathrm{CAM}\right) .{ }^{1} \mathrm{H} \mathrm{NMR}\left(600 \mathrm{MHz}, \mathrm{CDCl}_{3}\right) \delta 7.47-$ $7.44(\mathrm{~m}, 2 \mathrm{H}, \mathrm{SPh}), 7.32-7.27(\mathrm{~m}, 2 \mathrm{H}, \mathrm{SPh}), 7.25-7.21(\mathrm{~m}, 1 \mathrm{H}, \mathrm{SPh}), 5.62(\mathrm{~d}, J=5.5 \mathrm{~Hz}, 1 \mathrm{H}$, $\left.\mathrm{H}_{1}\right), 4.94\left(\mathrm{~d}, J=6.7 \mathrm{~Hz}, 1 \mathrm{H}, \mathrm{CH}_{2}\right), 4.72\left(\mathrm{~d}, J=6.7 \mathrm{~Hz}, 1 \mathrm{H}, \mathrm{CH}_{2}\right), 4.21(\mathrm{dq}, J=12.5,6.3 \mathrm{~Hz}, 1 \mathrm{H}$, $\left.\mathrm{H}_{5}\right), 3.44\left(\mathrm{~s}, 3 \mathrm{H}, \mathrm{OCH}_{3}\right), 3.26\left(\mathrm{t}, J=9.3 \mathrm{~Hz}, 1 \mathrm{H}, \mathrm{H}_{4}\right), 2.99$ (ddd, $\left.J=13.2,9.9,4.0 \mathrm{~Hz}, 1 \mathrm{H}, \mathrm{H}_{3}\right)$, $2.29\left(\mathrm{~s}, 6 \mathrm{H}, 2 \times \mathrm{NCH}_{3}\right), 2.13\left(\mathrm{ddd}, J=13.5,4.0,1.8 \mathrm{~Hz}, 1 \mathrm{H}, \mathrm{H}_{2}\right), 2.01(\mathrm{td}, J=13.0,5.5 \mathrm{~Hz}, 1 \mathrm{H}$, $\left.\mathrm{H}_{2}\right), 1.31\left(\mathrm{~d}, J=6.3 \mathrm{~Hz}, 3 \mathrm{H}, \mathrm{H}_{6}\right) .{ }^{13} \mathrm{C} \mathrm{NMR}\left(151 \mathrm{MHz}, \mathrm{CDCl}_{3}\right) \delta 135.7(\mathrm{C}), 131.2(2 \times \mathrm{CH}), 129.0$ $(2 \times \mathrm{CH}), 127.0(\mathrm{CH}), 97.7\left(\mathrm{CH}_{2}\right), 84.8(\mathrm{CH}), 77.1(\mathrm{CH}), 69.1(\mathrm{CH}), 62.6(\mathrm{CH}), 56.3\left(\mathrm{CH}_{3}\right), 40.5$ $\left(2 \times \mathrm{CH}_{3}\right), 27.8\left(\mathrm{CH}_{2}\right), 18.8\left(\mathrm{CH}_{3}\right)$. IR (ATR-FTIR), $\mathrm{cm}^{-1}: 2934(\mathrm{~m}), 2828(\mathrm{~m}), 2779(\mathrm{~m}), 2357$ (m), $2344(\mathrm{~m}), 1584(\mathrm{~m})$. HRMS-ESI (m/z): $[\mathrm{M}+\mathrm{Na}]^{+}$calculated for $\left[\mathrm{C}_{16} \mathrm{H}_{25} \mathrm{NO}_{3} \mathrm{SNa}\right]^{+} 334.1447$, found 334.1435. $[a]_{D}^{21}=-272.2^{\circ}\left(c=1.0, \mathrm{CHCl}_{3}\right)$.

Hoang et al. "General method for the synthesis of $\alpha$ - or $\beta$-deoxyaminoglycosides bearing S26 basic nitrogen" 
Synthesis of the ether $\mathbf{S 1 5}$.

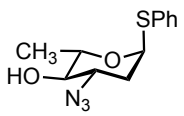

(3S)-S12 $\alpha$

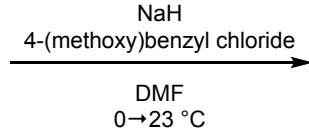

$94 \%$

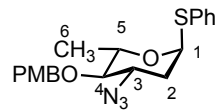

S15

Sodium hydride (60\% dispersion in mineral oil, $181 \mathrm{mg}, 4.52 \mathrm{mmol}, 1.20$ equiv) was added

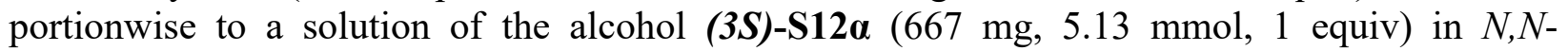
dimethylformamide $(38 \mathrm{~mL})$ at $0{ }^{\circ} \mathrm{C}$. The resulting mixture was stirred for $30 \mathrm{~min}$ at $0{ }^{\circ} \mathrm{C}$. 4(Methoxy)benzyl chloride ( $692 \mu \mathrm{L}, 4.90 \mathrm{mmol}, 1.30$ equiv) was then added dropwise via syringe. The reaction vessel was removed from the cooling bath, and the reaction mixture was allowed to warm to $23{ }^{\circ} \mathrm{C}$. The reaction mixture was stirred for $3 \mathrm{~h}$ at $23{ }^{\circ} \mathrm{C}$. The product mixture was cooled to $0^{\circ} \mathrm{C}$ and the cooled product mixture was diluted sequentially with water $(150 \mathrm{~mL})$ and ethyl acetate $(150 \mathrm{~mL})$. The resulting biphasic mixture was transferred to a separatory funnel and the layers that formed were separated. The aqueous layer was extracted with ethyl acetate $(4 \times 35$ $\mathrm{mL}$ ). The organic layers were combined and the combined organic layers were washed with saturated aqueous sodium chloride solution $(2 \times 20 \mathrm{~mL})$. The washed organic layer was dried over sodium sulfate. The dried solution was filtered and the filtrate was concentrated. The residue obtained was purified by flash-column chromatography (eluting with 5\% ethyl acetate-hexanes initially, grading to $15 \%$ ethyl acetate-hexanes, three steps) to provide the ether $\mathbf{S 1 5}$ as a white solid $\left[1.36 \mathrm{~g}, 94 \%, \alpha\right.$ diastereomer only ( ${ }^{1} \mathrm{H}$ NMR analysis)].

$\mathrm{R}_{f}=0.46\left(15 \%\right.$ ethyl acetate-hexanes; UV, CAM). ${ }^{1} \mathrm{H}$ NMR $\left(600 \mathrm{MHz}, \mathrm{CDCl}_{3}\right) \delta 7.44-7.40(\mathrm{~m}$, 2H, PMB), 7.33 (d, $J=8.3 \mathrm{~Hz}, 2 \mathrm{H}, \mathrm{SPh}), 7.30$ (ddd, $J=7.6,6.4,1.3 \mathrm{~Hz}, 2 \mathrm{H}, \mathrm{SPh}), 7.24(\mathrm{~d}, J=$ $7.7 \mathrm{~Hz}, 1 \mathrm{H}, \mathrm{SPh}), 6.91(\mathrm{~d}, J=8.3 \mathrm{~Hz}, 2 \mathrm{H}, \mathrm{PMB}), 5.54$ (d, $\left.J=5.6 \mathrm{~Hz}, 1 \mathrm{H}, \mathrm{H}_{1}\right), 4.82(\mathrm{~d}, J=10.3$ $\mathrm{Hz}, 1 \mathrm{H}, \mathrm{CH}_{2} \mathrm{Ar}$ ), 4.59 (d, $J=10.3 \mathrm{~Hz}, 1 \mathrm{H}, \mathrm{CH}_{2} \mathrm{Ar}$ ), 4.24 (dq, $J=9.1,6.3 \mathrm{~Hz}, 1 \mathrm{H}, \mathrm{H}_{5}$ ), 3.87 (ddd, $\left.J=12.3,9.2,4.9 \mathrm{~Hz}, 1 \mathrm{H}, \mathrm{H}_{3}\right), 3.81\left(\mathrm{~s}, 3 \mathrm{H}, \mathrm{OCH}_{3}\right), 3.04\left(\mathrm{t}, J=9.3 \mathrm{~Hz}, 1 \mathrm{H}, \mathrm{H}_{4}\right), 2.35(\mathrm{dd}, J=13.6$, $\left.4.8 \mathrm{~Hz}, 1 \mathrm{H}, \mathrm{H}_{2}\right), 2.07\left(\mathrm{td}, J=13.1,5.7 \mathrm{~Hz}, 1 \mathrm{H}, \mathrm{H}_{2}\right), 1.29\left(\mathrm{~d}, J=6.0 \mathrm{~Hz}, 3 \mathrm{H}, \mathrm{H}_{6}\right) .{ }^{13} \mathrm{C} \mathrm{NMR}(151$ $\left.\mathrm{MHz}, \mathrm{CDCl}_{3}\right) \delta 159.7(\mathrm{C}), 134.7(\mathrm{C}), 131.6(2 \times \mathrm{CH}), 130.1(2 \times \mathrm{CH}), 129.8(\mathrm{C}), 129.1(2 \times \mathrm{CH})$, 127.4 $(\mathrm{CH}), 114.1(2 \times \mathrm{CH}), 84.0(\mathrm{CH}), 83.4(\mathrm{CH}), 75.0\left(\mathrm{CH}_{2}\right), 68.5(\mathrm{CH}), 60.8(\mathrm{CH}), 55.5\left(\mathrm{CH}_{3}\right)$, $36.7\left(\mathrm{CH}_{2}\right), 18.1\left(\mathrm{CH}_{3}\right)$. IR (ATR-FTIR), $\mathrm{cm}^{-1}: 2933$ (br m), $2358(\mathrm{~m}), 2332(\mathrm{~m}), 2103$ (s), 1613 $(\mathrm{m}), 1585(\mathrm{~m}), 1514(\mathrm{~s})$. HRMS-ESI (m/z): $[\mathrm{M}+\mathrm{Na}]^{+}$calculated for $\left[\mathrm{C}_{20} \mathrm{H}_{23} \mathrm{~N}_{3} \mathrm{O}_{3} \mathrm{SNa}\right]^{+} 408.1352$, found 408.1340. $[a]_{D}^{21}=-300.6^{\circ}\left(c=1.0, \mathrm{CHCl}_{3}\right)$. 
Synthesis of the amine $18 \alpha$.

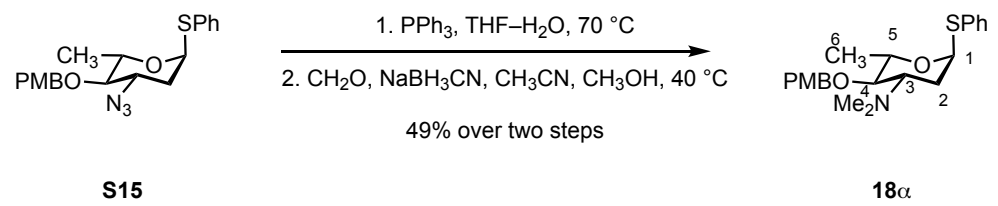

Triphenylphosphine ( $1.85 \mathrm{~g}, 7.06 \mathrm{mmol}, 2.00$ equiv) and deionized water $(23 \mathrm{~mL})$ were added in sequence to a solution of the azide $\mathbf{S 1 5}(1.36 \mathrm{~g}, 3.53 \mathrm{mmol}, 1$ equiv) in tetrahydrofuran $(56 \mathrm{~mL})$ at $23{ }^{\circ} \mathrm{C}$. The reaction vessel was fitted with a reflux condenser and then placed in an oil bath that had been preheated to $70^{\circ} \mathrm{C}$. The reaction mixture was stirred and heated for $3 \mathrm{~h}$ at $70{ }^{\circ} \mathrm{C}$. The reaction mixture was cooled to $23^{\circ} \mathrm{C}$ over $20 \mathrm{~min}$. The cooled mixture was concentrated and the residue obtained was employed directly in the following step.

Aqueous formaldehyde ( $37 \mathrm{wt} \%, 972 \mu \mathrm{L}, 35.3 \mathrm{mmol}, 10.0$ equiv), sodium cyanoborohydride $(1.55 \mathrm{~g}, 24.7 \mathrm{mmol}, 7.00$ equiv) and methanol $(3.0 \mathrm{~mL})$ were added in sequence to a solution of the unpurified amine obtained in the preceding step (nominally $3.53 \mathrm{mmol}, 1$ equiv) in acetonitrile $(17 \mathrm{~mL})$ at $23{ }^{\circ} \mathrm{C}$. The resulting mixture was heated to $40{ }^{\circ} \mathrm{C}$ for $16 \mathrm{~h}$. The product mixture was cooled to $23{ }^{\circ} \mathrm{C}$ over $10 \mathrm{~min}$. The cooled product mixture was diluted sequentially with saturated aqueous sodium hydrogen carbonate solution $(150 \mathrm{~mL})$ and ethyl acetate $(150 \mathrm{~mL})$. The resulting biphasic mixture was transferred to a separatory funnel and the layers that formed were separated. The aqueous layer was extracted with ethyl acetate $(4 \times 35 \mathrm{~mL})$. The organic layers were combined and the combined organic layers were washed with saturated aqueous sodium chloride solution (2 $\times 20 \mathrm{~mL}$ ). The washed organic layer was dried over sodium sulfate. The dried solution was filtered and the filtrate was concentrated. The residue obtained was purified by flash-column chromatography (eluting with $0.5 \%$ triethylamine- $5 \%$ acetone-hexanes initially, grading to $0.5 \%$ triethylamine- $15 \%$ acetone-hexanes, five steps) to provide the amine $\mathbf{1 8 \alpha}$ as a white solid [660 $\mathrm{mg}, 49 \%$ over two steps, $\alpha$ diastereomer only ( ${ }^{1} \mathrm{H}$ NMR analysis)].

$\mathrm{R}_{f}=0.40\left(0.5 \%\right.$ triethylamine $-20 \%$ acetone-hexanes; UV, CAM. ${ }^{1} \mathrm{H}$ NMR $\left(600 \mathrm{MHz}, \mathrm{CDCl}_{3}\right) \delta$ $7.44(\mathrm{~d}, J=7.2 \mathrm{~Hz}, 2 \mathrm{H}, \mathrm{PMB}), 7.31$ (d, $J=8.3 \mathrm{~Hz}, 2 \mathrm{H}, \mathrm{SPh}), 7.28$ (t, $J=7.8 \mathrm{~Hz}, 2 \mathrm{H}, \mathrm{SPh}), 7.22$ (t, $J=7.7 \mathrm{~Hz}, 1 \mathrm{H}, \mathrm{SPh}), 6.88(\mathrm{~d}, J=8.2 \mathrm{~Hz}, 2 \mathrm{H}, \mathrm{PMB}), 5.60\left(\mathrm{~d}, J=5.4 \mathrm{~Hz}, 1 \mathrm{H}, \mathrm{H}_{1}\right), 4.87(\mathrm{~d}, J=$ $10.4 \mathrm{~Hz}, 1 \mathrm{H}, \mathrm{CH}_{2} \mathrm{Ar}$ ), 4.56 (d, $J=10.4 \mathrm{~Hz}, 1 \mathrm{H}, \mathrm{CH}_{2} \mathrm{Ar}$ ), 4.23 (dq, $\left.J=9.2,6.3 \mathrm{~Hz}, 1 \mathrm{H}, \mathrm{H}_{5}\right), 3.81$ (s, $\left.3 \mathrm{H}, \mathrm{OCH}_{3}\right), 3.12$ (t, $\left.J=9.2 \mathrm{~Hz}, 1 \mathrm{H}, \mathrm{H}_{4}\right), 3.08$ (td, $\left.J=10.8,9.8,3.8 \mathrm{~Hz}, 1 \mathrm{H}, \mathrm{H}_{3}\right), 2.37(\mathrm{~s}, 6 \mathrm{H}, 2$ $\left.\times \mathrm{NCH}_{3}\right), 2.13\left(\mathrm{ddd}, J=13.4,3.9,1.6 \mathrm{~Hz}, 1 \mathrm{H}, \mathrm{H}_{2}\right), 2.04\left(\mathrm{td}, J=12.7,5.5 \mathrm{~Hz}, 1 \mathrm{H}, \mathrm{H}_{2}\right), 1.28(\mathrm{~d}, J$ $\left.=6.2 \mathrm{~Hz}, 3 \mathrm{H}, \mathrm{H}_{6}\right) .{ }^{13} \mathrm{C} \mathrm{NMR}\left(151 \mathrm{MHz}, \mathrm{CDCl}_{3}\right) \delta 159.3(\mathrm{C}), 135.7(\mathrm{C}), 131.3(2 \times \mathrm{CH}), 131.1$ $(\mathrm{C}), 129.7(2 \times \mathrm{CH}), 129.0(2 \times \mathrm{CH}), 127.0(\mathrm{CH}), 113.9(2 \times \mathrm{CH}), 84.9(\mathrm{CH}), 80.1(\mathrm{CH}), 73.7$ $\left(\mathrm{CH}_{2}\right), 69.1(\mathrm{CH}), 62.4(\mathrm{CH}), 55.5\left(\mathrm{CH}_{3}\right), 40.9\left(2 \times \mathrm{CH}_{3}\right), 29.3\left(\mathrm{CH}_{2}\right), 18.7\left(\mathrm{CH}_{3}\right)$. IR (ATRFTIR), $\mathrm{cm}^{-1}: 2933$ (m), $2832(\mathrm{~m}), 2777(\mathrm{~m}), 2331$ (w), $1612(\mathrm{~m}), 1585(\mathrm{~m}), 1513(\mathrm{~s})$. HRMS-ESI $(\mathrm{m} / \mathrm{z}):[\mathrm{M}+\mathrm{Na}]^{+}$calculated for $\left[\mathrm{C}_{22} \mathrm{H}_{29} \mathrm{NO}_{3} \mathrm{SNa}\right]^{+} 410.1760$, found $410.1767 .[a]_{D}^{21}=-269.2^{\circ}(c$ $\left.=1.0, \mathrm{CHCl}_{3}\right)$.

Hoang et al. "General method for the synthesis of $\alpha$ - or $\beta$-deoxyaminoglycosides bearing S28 basic nitrogen" 
Synthesis of the disaccharide $\mathbf{2 0 \alpha}$.

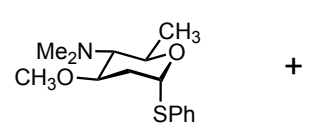

$14 \alpha$

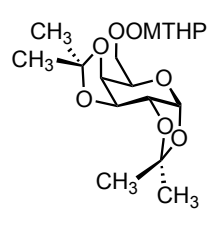

12

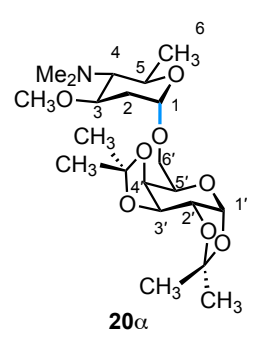

$20 \alpha$

A solution of LiDBB in tetrahydrofuran (nominally $0.4 \mathrm{M}$ ) was added dropwise via syringe to a solution of the amine $\mathbf{1 4 \alpha}(31.7 \mathrm{mg}, 113 \mu \mathrm{mol}, 1.50$ equiv) in tetrahydrofuran-pentane $(1: 1 \mathrm{v} / \mathrm{v}$, $1.8 \mathrm{~mL}$ ) in a $10-\mathrm{mL}$ round-bottomed flask that had been fused to a Teflon-coated valve at $-78^{\circ} \mathrm{C}$. The addition of LiDBB was continued until a green color persisted $(584 \mu \mathrm{L}$, nominally $234 \mu \mathrm{mol}$, 3.10 equiv). The resulting mixture was stirred for $10 \mathrm{~min}$ at $-78{ }^{\circ} \mathrm{C}$. A solution of the MTHP monoperoxy acetal $12(28.1 \mathrm{mg}, 75.0 \mu \mathrm{mol}, 1$ equiv $)$ in tetrahydrofuran $(300 \mu \mathrm{L})$ was then added dropwise via syringe. The resulting mixture was stirred for $3 \mathrm{~h}$ at $-78{ }^{\circ} \mathrm{C}$. The cold product mixture was diluted with saturated aqueous sodium hydrogen carbonate solution $(1.0 \mathrm{~mL})$. The diluted product mixture was allowed to warm to $23{ }^{\circ} \mathrm{C}$ over $15 \mathrm{~min}$. The warmed product mixture was transferred to a $20-\mathrm{mL}$ test tube and the layers that formed were separated. The aqueous layer was extracted with ethyl acetate $(4 \times 5.0 \mathrm{~mL})$. The organic layers were combined and the combined organic layers were dried over sodium sulfate. The dried solution was filtered and the filtrate was concentrated under a stream of nitrogen. The residue obtained was purified by flashcolumn chromatography (eluting with $0.5 \%$ triethylamine- $2 \%$ acetone-hexanes initially, grading to $0.5 \%$ triethylamine- $10 \%$ acetone-hexanes, four steps) to provide the disaccharide $\mathbf{2 0 \alpha}$ as a colorless oil (30.0 mg, 93\%).

The diastereoselectivity of the reaction was determined to be $>50: 1 \alpha: \beta$ by ${ }^{1} \mathrm{H}$ NMR analysis of the unpurified product mixture.

$\mathrm{R}_{f}=0.28\left(0.5 \%\right.$ triethylamine-10\% acetone-hexanes; CAM). ${ }^{1} \mathrm{H}$ NMR $\left(600 \mathrm{MHz}, \mathrm{CDCl}_{3}\right) \delta 5.52$ $\left(\mathrm{d}, J=5.0 \mathrm{~Hz}, 1 \mathrm{H}, \mathrm{H}_{1^{\prime}}\right), 4.89\left(\mathrm{dd}, J=3.7,1.6 \mathrm{~Hz}, 1 \mathrm{H}, \mathrm{H}_{1}\right), 4.61\left(\mathrm{dd}, J=7.9,2.5 \mathrm{~Hz}, 1 \mathrm{H}, \mathrm{H}_{3^{\prime}}\right), 4.31$ $\left(\mathrm{dd}, J=5.0,2.4 \mathrm{~Hz}, 1 \mathrm{H}, \mathrm{H}_{2^{\prime}}\right), 4.23\left(\mathrm{dd}, J=7.9,1.9 \mathrm{~Hz}, 1 \mathrm{H}, \mathrm{H}_{4^{\prime}}\right), 3.96\left(\mathrm{td}, J=6.5,1.9 \mathrm{~Hz}, 1 \mathrm{H}, \mathrm{H}_{5^{\prime}}\right)$, 3.78 (ddd, $\left.J=10.9,9.7,4.8 \mathrm{~Hz}, 1 \mathrm{H}, \mathrm{H}_{3}\right), 3.74-3.68\left(\mathrm{~m}, 2 \mathrm{H}, \mathrm{H}_{5}, \mathrm{H}_{6^{\prime}}\right), 3.65$ (dd, $J=10.8,6.3 \mathrm{~Hz}$, $\left.1 \mathrm{H}, \mathrm{H}_{6^{\prime}}\right), 3.32\left(\mathrm{~s}, 3 \mathrm{H}, \mathrm{OCH}_{3}\right), 2.40\left(\mathrm{~s}, 6 \mathrm{H}, 2 \times \mathrm{NCH}_{3}\right), 2.30\left(\mathrm{ddd}, J=12.8,4.9,1.7 \mathrm{~Hz}, 1 \mathrm{H}, \mathrm{H}_{2}\right)$, $2.12\left(\mathrm{t}, J=9.8 \mathrm{~Hz}, 1 \mathrm{H}, \mathrm{H}_{4}\right), 1.53\left(\mathrm{~s}, 3 \mathrm{H}, \mathrm{CH}_{3}\right), 1.52-1.49\left(\mathrm{~m}, 1 \mathrm{H}, \mathrm{H}_{2}\right), 1.43\left(\mathrm{~s}, 3 \mathrm{H}, \mathrm{CH}_{3}\right), 1.33(\mathrm{~s}$, $\left.3 \mathrm{H}, \mathrm{CH}_{3}\right), 1.33\left(\mathrm{~s}, 3 \mathrm{H}, \mathrm{CH}_{3}\right), 1.24\left(\mathrm{~d}, J=6.2 \mathrm{~Hz}, 3 \mathrm{H}, \mathrm{H}_{6}\right) .{ }^{13} \mathrm{C} \mathrm{NMR}\left(151 \mathrm{MHz}, \mathrm{CDCl}_{3}\right) \delta 109.5$ (C), $108.7(\mathrm{C}), 96.8(\mathrm{CH}), 96.5(\mathrm{CH}), 73.8(\mathrm{CH}), 71.3(\mathrm{CH}), 70.8(\mathrm{CH}), 70.7(\mathrm{CH}), 70.2(\mathrm{CH})$, $66.7(\mathrm{CH}), 66.1(\mathrm{CH}), 65.2\left(\mathrm{CH}_{2}\right), 55.2\left(\mathrm{CH}_{3}\right), 42.6\left(2 \times \mathrm{CH}_{3}\right), 35.1\left(\mathrm{CH}_{2}\right), 26.2\left(\mathrm{CH}_{3}\right), 26.1\left(\mathrm{CH}_{3}\right)$, $25.1\left(\mathrm{CH}_{3}\right), 24.7\left(\mathrm{CH}_{3}\right), 19.5\left(\mathrm{CH}_{3}\right)$. IR (ATR-FTIR), $\mathrm{cm}^{-1}: 2977(\mathrm{~m}), 2933(\mathrm{~m}), 2830(\mathrm{w}), 2361$ $(\mathrm{w}), 1452(\mathrm{~m})$. HRMS-ESI $(\mathrm{m} / \mathrm{z}):[\mathrm{M}+\mathrm{Na}]^{+}$calculated for $\left[\mathrm{C}_{21} \mathrm{H}_{37} \mathrm{NO}_{8} \mathrm{Na}\right]^{+} 454.2411$, found 454.2413. $[a]_{D}^{21}=+18.5^{\circ}\left(c=1.0, \mathrm{CHCl}_{3}\right)$.

Hoang et al. "General method for the synthesis of $\alpha$ - or $\beta$-deoxyaminoglycosides bearing S29 basic nitrogen" 
Synthesis of the disaccharide $\mathbf{2 0 \boldsymbol { \beta }}$.

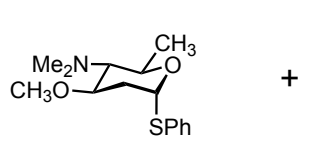

$14 \alpha$

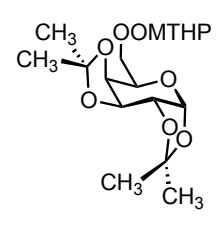

12

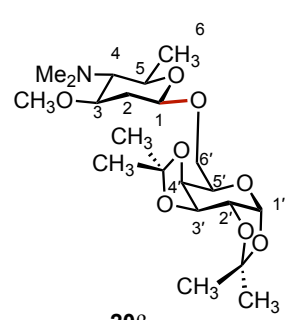

$20 \beta$

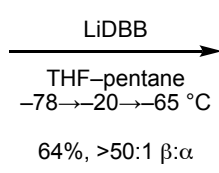

$64 \%,>50: 1 \beta: \alpha$

A solution of LiDBB in tetrahydrofuran (nominally $0.4 \mathrm{M}$ ) was added dropwise via syringe to a solution of the amine $14 \alpha(56.3 \mathrm{mg}, 200 \mu \mathrm{mol}, 2.00$ equiv) in tetrahydrofuran-pentane $(1: 1 \mathrm{v} / \mathrm{v}$, $2.6 \mathrm{~mL}$ ) in a $10-\mathrm{mL}$ round-bottomed flask that had been fused to a Teflon-coated valve at $-78^{\circ} \mathrm{C}$. The addition of LiDBB was continued until a green color persisted $(1.03 \mathrm{~mL}$, nominally $410 \mu \mathrm{mol}$, 4.10 equiv). The resulting mixture was stirred for $10 \mathrm{~min}$ at $-78^{\circ} \mathrm{C}$. The reaction vessel was then placed in a bath that had been precooled to $-20^{\circ} \mathrm{C}$. The reaction mixture was stirred for $1 \mathrm{~h}$ at $20^{\circ} \mathrm{C}$ and then cooled to $-78{ }^{\circ} \mathrm{C}$ over $10 \mathrm{~min}$. A solution of the MTHP monoperoxy acetal $\mathbf{1 2}$ (37.4 mg, $100 \mu \mathrm{mol}, 1$ equiv) in tetrahydrofuran $(300 \mu \mathrm{L})$ was then added dropwise via syringe. The reaction vessel was then placed in a cryogenic bath that had been precooled to $-65^{\circ} \mathrm{C}$. The mixture was stirred for $6 \mathrm{~h}$ at $-65^{\circ} \mathrm{C}$. The cold product mixture was diluted with saturated aqueous sodium hydrogen carbonate solution $(1.0 \mathrm{~mL})$. The diluted product mixture was allowed to warm to $23{ }^{\circ} \mathrm{C}$ over $15 \mathrm{~min}$. The warmed product mixture was transferred to a $20-\mathrm{mL}$ test tube and the layers that formed were separated. The aqueous layer was extracted with ethyl acetate $(4 \times 5.0$ $\mathrm{mL}$ ). The organic layers were combined and the combined organic layers were dried over sodium sulfate. The dried solution was filtered and the filtrate was concentrated under a stream of nitrogen. The residue obtained was purified by flash-column chromatography (eluting with $5 \%$ acetonehexanes initially, grading to $25 \%$ acetone-hexanes, four steps) to provide the disaccharide $\mathbf{2 0 \beta}$ as a colorless oil $(27.6 \mathrm{mg}, 64 \%)$.

The diastereoselectivity of the reaction was determined to be $>50: 1 \beta: \alpha$ by ${ }^{1} \mathrm{H}$ NMR analysis of the unpurified product mixture.

$\mathrm{R}_{f}=0.27\left(25 \%\right.$ acetone-hexanes; CAM). ${ }^{1} \mathrm{H}$ NMR $\left(500 \mathrm{MHz}, \mathrm{CDCl}_{3}\right) \delta 5.55(\mathrm{~d}, J=5.0 \mathrm{~Hz}, 1 \mathrm{H}$, $\mathrm{H}_{1^{\prime}}$ ), 4.59 (dd, $\left.J=7.9,2.4 \mathrm{~Hz}, 1 \mathrm{H}, \mathrm{H}_{3^{\prime}}\right), 4.40$ (dd, $\left.J=9.8,1.9 \mathrm{~Hz}, 1 \mathrm{H}, \mathrm{H}_{1}\right), 4.31$ (dd, $J=5.0,2.4$ $\left.\mathrm{Hz}, 1 \mathrm{H}, \mathrm{H}_{2^{\prime}}\right), 4.22\left(\mathrm{dd}, J=7.9,1.9 \mathrm{~Hz}, 1 \mathrm{H}, \mathrm{H}_{4^{\prime}}\right), 4.04\left(\mathrm{dd}, J=11.0,3.2 \mathrm{~Hz}, 1 \mathrm{H}, \mathrm{H}_{6^{\prime}}\right), 4.00(\mathrm{dt}, J=$ 7.6, $\left.2.5 \mathrm{~Hz}, 1 \mathrm{H}, \mathrm{H}_{5^{\prime}}\right), 3.64\left(\mathrm{dd}, J=10.9,7.6 \mathrm{~Hz}, 1 \mathrm{H}, \mathrm{H}_{6^{\prime}}\right), 3.48$ (ddd, $\left.J=11.3,9.4,4.6 \mathrm{~Hz}, 1 \mathrm{H}, \mathrm{H}_{3}\right)$, $3.33-3.28\left(\mathrm{~m}, 4 \mathrm{H}, \mathrm{H}_{5}, \mathrm{OCH}_{3}\right), 2.46$ (ddd, $\left.J=11.9,4.4,1.2 \mathrm{~Hz}, 1 \mathrm{H}, \mathrm{H}_{2}\right), 2.39\left(\mathrm{~s}, 6 \mathrm{H}, 2 \times \mathrm{NCH}_{3}\right)$, $2.13\left(\mathrm{t}, J=10.0 \mathrm{~Hz}, 1 \mathrm{H}, \mathrm{H}_{4}\right), 1.56\left(\mathrm{~s}, 3 \mathrm{H}, \mathrm{CH}_{3}\right), 1.54\left(\mathrm{~s}, 3 \mathrm{H}, \mathrm{CH}_{3}\right), 1.45\left(\mathrm{~s}, 3 \mathrm{H}, \mathrm{CH}_{3}\right), 1.44-1.39$ $\left(\mathrm{m}, 1 \mathrm{H}, \mathrm{H}_{2}\right), 1.33\left(\mathrm{~s}, 6 \mathrm{H}, 2 \times \mathrm{CH}_{3}\right), 1.30\left(\mathrm{~d}, J=6.2 \mathrm{~Hz}, 3 \mathrm{H}, \mathrm{H}_{6}\right) .{ }^{13} \mathrm{C} \mathrm{NMR}\left(151 \mathrm{MHz}, \mathrm{CDCl}_{3}\right) \delta$ $109.5(\mathrm{C}), 108.8(\mathrm{C}), 100.2(\mathrm{CH}), 96.5(\mathrm{CH}), 76.3(\mathrm{CH}), 71.7(\mathrm{CH}), 70.8(\mathrm{CH}), 70.7(\mathrm{CH}), 70.5$ $(\mathrm{CH}), 69.8(\mathrm{CH}), 68.8\left(\mathrm{CH}_{2}\right), 68.0(\mathrm{CH}), 55.0\left(\mathrm{CH}_{3}\right), 42.5\left(2 \times \mathrm{CH}_{3}\right), 36.5\left(\mathrm{CH}_{2}\right), 26.2\left(\mathrm{CH}_{3}\right), 26.1$ $\left(\mathrm{CH}_{3}\right), 25.1\left(\mathrm{CH}_{3}\right), 24.5\left(\mathrm{CH}_{3}\right), 19.5\left(\mathrm{CH}_{3}\right)$. IR (ATR-FTIR), $\mathrm{cm}^{-1}: 2976(\mathrm{~m}), 2933(\mathrm{~m}), 1452(\mathrm{w})$, $1281(\mathrm{~m}), 1255(\mathrm{~m})$. HRMS-ESI $(\mathrm{m} / \mathrm{z}):[\mathrm{M}+\mathrm{H}]^{+}$calculated for $\left[\mathrm{C}_{21} \mathrm{H}_{38} \mathrm{NO}_{8}\right]^{+} 432.2592$, found 432.2569. $[a]_{D}^{21}=-85.8^{\circ}\left(c=1.0, \mathrm{CHCl}_{3}\right)$.

Hoang et al. "General method for the synthesis of $\alpha$ - or $\beta$-deoxyaminoglycosides bearing S30 basic nitrogen" 
Synthesis of the disaccharide $\mathbf{2 1 \alpha}$.

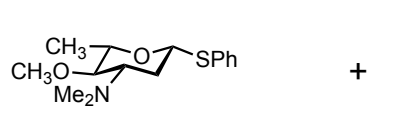

$16 \beta$

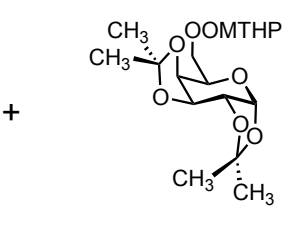

12

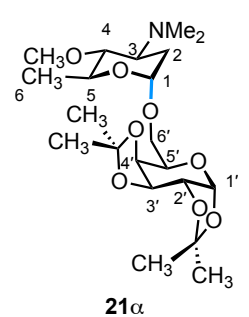

$21 \alpha$

A solution of LiDBB in tetrahydrofuran (nominally $0.4 \mathrm{M}$ ) was added dropwise via syringe to a solution of the amine $\mathbf{1 6 \beta}(31.7 \mathrm{mg}, 113 \mu \mathrm{mol}, 1.50$ equiv) in tetrahydrofuran-pentane $(1: 1 \mathrm{v} / \mathrm{v}$, $1.8 \mathrm{~mL}$ ) in a $10-\mathrm{mL}$ round-bottomed flask that had been fused to a Teflon-coated valve at $-78^{\circ} \mathrm{C}$. The addition of LiDBB was continued until a green color persisted $(584 \mu \mathrm{L}$, nominally $234 \mu \mathrm{mol}$, 3.10 equiv). The resulting mixture was stirred for $10 \mathrm{~min}$ at $-78{ }^{\circ} \mathrm{C}$. A solution of the MTHP monoperoxy acetal $12(28.1 \mathrm{mg}, 75.0 \mu \mathrm{mol}, 1$ equiv $)$ in tetrahydrofuran $(300 \mu \mathrm{L})$ was then added dropwise via syringe. The resulting mixture was stirred for $3 \mathrm{~h}$ at $-78^{\circ} \mathrm{C}$. The cold product mixture was diluted with saturated aqueous sodium hydrogen carbonate solution $(1.0 \mathrm{~mL})$. The diluted product mixture was allowed to warm to $23{ }^{\circ} \mathrm{C}$ over $15 \mathrm{~min}$. The warmed product mixture was transferred to a $20-\mathrm{mL}$ test tube and the layers that formed were separated. The aqueous layer was extracted with ethyl acetate $(4 \times 5.0 \mathrm{~mL})$. The organic layers were combined and the combined organic layers were dried over sodium sulfate. The dried solution was filtered and the filtrate was concentrated under a stream of nitrogen. The residue obtained was purified by flashcolumn chromatography (eluting with $1 \%$ methanol-dichloromethane initially, grading to $5 \%$ methanol-dichloromethane, three steps) to provide the disaccharide $\mathbf{2 1} \boldsymbol{\alpha}$ as a colorless oil (31.0 mg, 96\%).

The diastereoselectivity of the reaction was determined to be $>50: 1 \alpha$ : $\beta$ by ${ }^{1} \mathrm{H}$ NMR analysis of the unpurified product mixture.

$\mathrm{R}_{f}=0.16$ (5\% methanol-dichloromethane; CAM). ${ }^{1} \mathrm{H}$ NMR $\left(600 \mathrm{MHz}, \mathrm{CDCl}_{3}\right) \delta 5.51(\mathrm{~d}, J=5.0$ $\left.\mathrm{Hz}, 1 \mathrm{H}, \mathrm{H}_{1^{\prime}}\right), 4.90\left(\mathrm{~d}, J=3.5 \mathrm{~Hz}, 1 \mathrm{H}, \mathrm{H}_{1}\right), 4.59$ (dd, $\left.J=7.9,2.3 \mathrm{~Hz}, 1 \mathrm{H}, \mathrm{H}_{3^{\prime}}\right), 4.30$ (dd, $J=5.1,2.3$ $\left.\mathrm{Hz}, 1 \mathrm{H}, \mathrm{H}_{2^{\prime}}\right), 4.24\left(\mathrm{dd}, J=7.8,1.9 \mathrm{~Hz}, 1 \mathrm{H}, \mathrm{H}_{4^{\prime}}\right), 3.94\left(\mathrm{td}, J=6.3,1.8 \mathrm{~Hz}, 1 \mathrm{H}, \mathrm{H}_{5^{\prime}}\right), 3.81-3.73(\mathrm{~m}$, $\left.1 \mathrm{H}, \mathrm{H}_{5}, \mathrm{H}_{6^{\prime}}\right), 3.54-3.51\left(\mathrm{~m}, 1 \mathrm{H}, \mathrm{H}_{6^{\prime}}\right), 3.51\left(\mathrm{~s}, 3 \mathrm{H}, \mathrm{OCH}_{3}\right), 3.09$ (td, $\left.J=13.0,4.2 \mathrm{~Hz}, 1 \mathrm{H}, \mathrm{H}_{3}\right), 2.89$ $\left(\mathrm{t}, J=9.6 \mathrm{~Hz}, 1 \mathrm{H}, \mathrm{H}_{4}\right), 2.40\left(\mathrm{~s}, 6 \mathrm{H}, 2 \times \mathrm{NCH}_{3}\right), 1.99\left(\mathrm{dd}, J=13.0,4.2 \mathrm{~Hz}, 1 \mathrm{H}, \mathrm{H}_{2}\right), 1.60(\mathrm{td}, J=$ $\left.12.8,3.8 \mathrm{~Hz}, 1 \mathrm{H}, \mathrm{H}_{2}\right), 1.53\left(\mathrm{~s}, 3 \mathrm{H}, \mathrm{CH}_{3}\right), 1.43\left(\mathrm{~s}, 3 \mathrm{H}, \mathrm{CH}_{3}\right), 1.32\left(\mathrm{~s}, 6 \mathrm{H}, 2 \times \mathrm{CH}_{3}\right), 1.27(\mathrm{~d}, J=6.2$ $\left.\mathrm{Hz}, 3 \mathrm{H}, \mathrm{H}_{6}\right) .{ }^{13} \mathrm{C} \mathrm{NMR}\left(151 \mathrm{MHz}, \mathrm{CDCl}_{3}\right) \delta 109.3(\mathrm{C}), 108.7(\mathrm{C}), 96.9(\mathrm{CH}), 96.4(\mathrm{CH}), 81.9$ $(\mathrm{CH}), 71.2(\mathrm{CH}), 70.7(2 \times \mathrm{CH}), 67.9(\mathrm{CH}), 67.1(\mathrm{CH}), 65.4\left(\mathrm{CH}_{2}\right), 60.5(\mathrm{CH}), 59.3\left(\mathrm{CH}_{3}\right), 40.8$ $\left(2 \times \mathrm{CH}_{3}\right), 28.3\left(\mathrm{CH}_{2}\right), 26.2\left(\mathrm{CH}_{3}\right), 26.1\left(\mathrm{CH}_{3}\right), 25.1\left(\mathrm{CH}_{3}\right), 24.6\left(\mathrm{CH}_{3}\right), 18.4\left(\mathrm{CH}_{3}\right)$. IR (ATRFTIR), $\mathrm{cm}^{-1}: 2977(\mathrm{~m}), 2935(\mathrm{~m}), 2827(\mathrm{w}), 2360(\mathrm{w}), 1456(\mathrm{~m})$. HRMS-ESI (m/z): $[\mathrm{M}+\mathrm{H}]^{+}$ calculated for $\left[\mathrm{C}_{21} \mathrm{H}_{38} \mathrm{NO}_{8}\right]^{+} 432.2592$, found 432.2564. $[a]_{D}^{21}=-97.8^{\circ}\left(c=1.0, \mathrm{CHCl}_{3}\right)$.

Hoang et al. "General method for the synthesis of $\alpha$ - or $\beta$-deoxyaminoglycosides bearing S31 basic nitrogen" 
Synthesis of the disaccharide $\mathbf{2 1 \boldsymbol { \beta } .}$

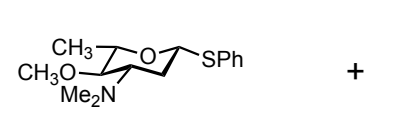

$16 \beta$

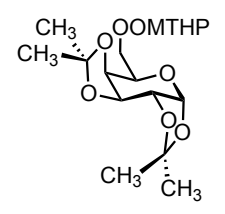

12

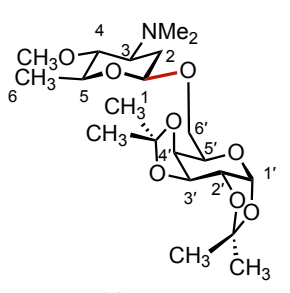

$21 \beta$

A solution of LiDBB in tetrahydrofuran (nominally $0.4 \mathrm{M}$ ) was added dropwise via syringe to a solution of the amine $\mathbf{1 6 \beta}(42.2 \mathrm{mg}, 150 \mu \mathrm{mol}, 2.00$ equiv) in tetrahydrofuran $(1.8 \mathrm{~mL})$ in a 10 $\mathrm{mL}$ round-bottomed flask that had been fused to a Teflon-coated valve at $-78^{\circ} \mathrm{C}$. The addition of LiDBB was continued until a green color persisted (769 $\mu \mathrm{L}$, nominally $308 \mu$ mol, 4.10 equiv). The resulting mixture was stirred for $10 \mathrm{~min}$ at $-78^{\circ} \mathrm{C}$. The reaction vessel was then placed in a bath that had been precooled to $-20{ }^{\circ} \mathrm{C}$. The reaction mixture was stirred for $1 \mathrm{~h}$ at $-20{ }^{\circ} \mathrm{C}$ and then cooled to $-78^{\circ} \mathrm{C}$ over $10 \mathrm{~min}$. A solution of the MTHP monoperoxy acetal $12(28.1 \mathrm{mg}, 75.0$ $\mu \mathrm{mol}, 1$ equiv) in tetrahydrofuran $(300 \mu \mathrm{L})$ was then added dropwise via syringe. The reaction vessel was then placed in a cryogenic bath that had been precooled to $-65^{\circ} \mathrm{C}$. The mixture was stirred for $6 \mathrm{~h}$ at $-65^{\circ} \mathrm{C}$. The cold product mixture was diluted with saturated aqueous sodium hydrogen carbonate solution $(1.0 \mathrm{~mL})$. The diluted product mixture was allowed to warm to 23 ${ }^{\circ} \mathrm{C}$ over $15 \mathrm{~min}$. The warmed product mixture was transferred to a 20 -mL test tube and the layers that formed were separated. The aqueous layer was extracted with ethyl acetate $(4 \times 5.0 \mathrm{~mL})$. The organic layers were combined and the combined organic layers were dried over sodium sulfate. The dried solution was filtered and the filtrate was concentrated under a stream of nitrogen. The residue obtained was purified by flash-column chromatography (eluting with $0.5 \%$ triethylamine$5 \%$ acetone-hexanes initially, grading to $0.5 \%$ triethylamine- $20 \%$ acetone-hexanes, four steps) to provide the disaccharide $\mathbf{2 1 \beta}$ as a colorless oil (25.9 $\mathrm{mg}, 80 \%)$.

The diastereoselectivity of the reaction was determined to be $16: 1 \beta: \alpha$ by ${ }^{1} \mathrm{H}$ NMR analysis of the unpurified product mixture.

$\mathrm{R}_{f}=0.10\left(0.5 \%\right.$ triethylamine- $20 \%$ acetone-hexanes; CAM). ${ }^{1} \mathrm{H}$ NMR $\left(600 \mathrm{MHz}, \mathrm{CDCl}_{3}\right) \delta 5.51$ $\left(\mathrm{d}, J=5.0 \mathrm{~Hz}, 1 \mathrm{H}, \mathrm{H}_{1^{\prime}}\right), 4.60\left(\mathrm{dd}, J=7.9,2.4 \mathrm{~Hz}, 1 \mathrm{H}, \mathrm{H}_{3^{\prime}}\right), 4.47\left(\mathrm{dd}, J=9.5,2.0 \mathrm{~Hz}, 1 \mathrm{H}, \mathrm{H}_{1}\right), 4.32$ $-4.29\left(\mathrm{~m}, 2 \mathrm{H}, \mathrm{H}_{2^{\prime}}, \mathrm{H}_{4^{\prime}}\right), 4.02\left(\mathrm{ddd}, J=7.9,5.9,1.9 \mathrm{~Hz}, 1 \mathrm{H}, \mathrm{H}_{5^{\prime}}\right), 3.86(\mathrm{dd}, J=10.1,6.0 \mathrm{~Hz}, 1 \mathrm{H}$, $\left.\mathrm{H}_{6^{\prime}}\right), 3.75\left(\mathrm{dd}, J=10.1,8.2 \mathrm{~Hz}, 1 \mathrm{H}, \mathrm{H}_{6^{\prime}}\right), 3.52\left(\mathrm{~s}, 3 \mathrm{H}, \mathrm{OCH}_{3}\right), 3.26\left(\mathrm{dq}, J=8.8,6.2 \mathrm{~Hz}, 1 \mathrm{H}, \mathrm{H}_{5}\right)$, $2.80\left(\mathrm{t}, J=9.3 \mathrm{~Hz}, 1 \mathrm{H}, \mathrm{H}_{4}\right), 2.65\left(\mathrm{ddd}, J=13.7,9.9,4.2 \mathrm{~Hz}, 1 \mathrm{H}, \mathrm{H}_{3}\right), 2.32\left(\mathrm{~s}, 6 \mathrm{H}, 2 \times \mathrm{NCH}_{3}\right), 1.99$ (ddd, $\left.J=12.7,4.4,2.0 \mathrm{~Hz}, 1 \mathrm{H}, \mathrm{H}_{2}\right), 1.52\left(\mathrm{~s}, 3 \mathrm{H}, \mathrm{CH}_{3}\right), 1.50\left(\mathrm{dd}, J=13.0,2.9 \mathrm{~Hz}, 1 \mathrm{H}, \mathrm{H}_{2}\right), 1.44$ $\left(\mathrm{s}, 3 \mathrm{H}, \mathrm{CH}_{3}\right), 1.35\left(\mathrm{~s}, 3 \mathrm{H}, \mathrm{CH}_{3}\right), 1.32\left(\mathrm{~s}, 3 \mathrm{H}, \mathrm{CH}_{3}\right), 1.31\left(\mathrm{~d}, J=4.5 \mathrm{~Hz}, 3 \mathrm{H}, \mathrm{H}_{6}\right) .{ }^{13} \mathrm{C} \mathrm{NMR}(151$ $\left.\mathrm{MHz}, \mathrm{CDCl}_{3}\right) \delta 109.3(\mathrm{C}), 108.7(\mathrm{C}), 101.5(\mathrm{CH}), 96.5(\mathrm{CH}), 81.6(\mathrm{CH}), 73.0(\mathrm{CH}), 70.9(\mathrm{CH})$, $70.8(\mathrm{CH}), 70.7(\mathrm{CH}), 67.6\left(\mathrm{CH}_{2}\right), 66.1(\mathrm{CH}), 64.3(\mathrm{CH}), 60.1\left(\mathrm{CH}_{3}\right), 40.9\left(2 \times \mathrm{CH}_{3}\right), 29.0\left(\mathrm{CH}_{2}\right)$, $26.3\left(\mathrm{CH}_{3}\right), 26.1\left(\mathrm{CH}_{3}\right), 25.1\left(\mathrm{CH}_{3}\right), 24.6\left(\mathrm{CH}_{3}\right), 18.6\left(\mathrm{CH}_{3}\right)$. IR (ATR-FTIR), cm ${ }^{-1}: 2977(\mathrm{~m})$, $2935(\mathrm{~m}), 1456(\mathrm{w}), 1376(\mathrm{~m}), 1309(\mathrm{w})$. HRMS-ESI (m/z): $[\mathrm{M}+\mathrm{H}]^{+}$calculated for $\left[\mathrm{C}_{21} \mathrm{H}_{38} \mathrm{NO}_{8}\right]^{+}$ 432.2592, found 432.2570. $[a]_{D}^{21}=-28.8^{\circ}\left(c=0.9, \mathrm{CHCl}_{3}\right)$.

Hoang et al. "General method for the synthesis of $\alpha$ - or $\beta$-deoxyaminoglycosides bearing S32 basic nitrogen" 
Synthesis of the disaccharide $\mathbf{2 2 \alpha}$.
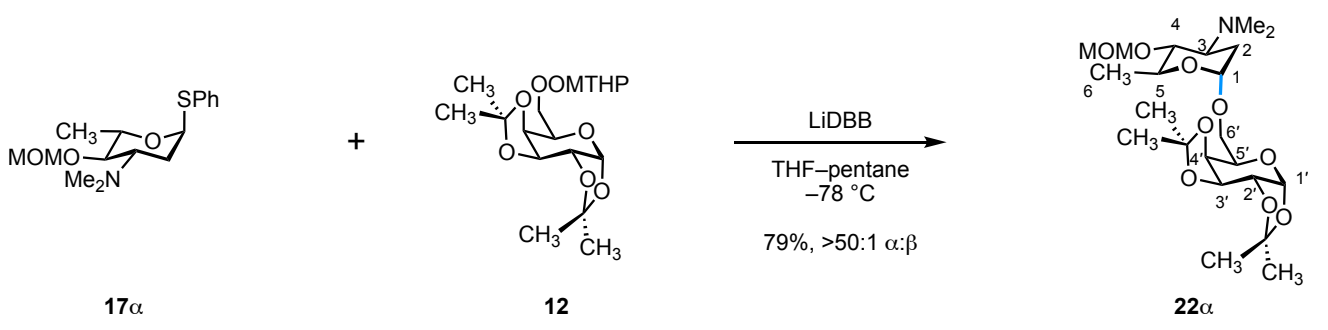

A solution of LiDBB in tetrahydrofuran (nominally $0.4 \mathrm{M}$ ) was added dropwise via syringe to a solution of the amine $17 \boldsymbol{\alpha}(35.1 \mathrm{mg}, 113 \mu \mathrm{mol}, 1.50$ equiv) in tetrahydrofuran-pentane $(1: 1 \mathrm{v} / \mathrm{v}$, $1.8 \mathrm{~mL}$ ) in a 10 - $\mathrm{mL}$ round-bottomed flask that had been fused to a Teflon-coated valve at $-78^{\circ} \mathrm{C}$. The addition of LiDBB was continued until a green color persisted $(584 \mu \mathrm{L}$, nominally $234 \mu \mathrm{mol}$, 3.10 equiv). The resulting mixture was stirred for $10 \mathrm{~min}$ at $-78{ }^{\circ} \mathrm{C}$. A solution of the MTHP monoperoxy acetal $12(28.1 \mathrm{mg}, 75.0 \mu \mathrm{mol}, 1$ equiv $)$ in tetrahydrofuran $(300 \mu \mathrm{L})$ was then added dropwise via syringe. The resulting mixture was stirred for $3 \mathrm{~h}$ at $-78{ }^{\circ} \mathrm{C}$. The cold product mixture was diluted with saturated aqueous sodium hydrogen carbonate solution $(1.0 \mathrm{~mL})$. The diluted product mixture was allowed to warm to $23{ }^{\circ} \mathrm{C}$ over $15 \mathrm{~min}$. The warmed product mixture was transferred to a 20 - $\mathrm{mL}$ test tube and the layers that formed were separated. The aqueous layer was extracted with ethyl acetate $(4 \times 5.0 \mathrm{~mL})$. The organic layers were combined and the combined organic layers were dried over sodium sulfate. The dried solution was filtered and the filtrate was concentrated under a stream of nitrogen. The residue obtained was purified by flashcolumn chromatography (eluting with $0.5 \%$ triethylamine- $5 \%$ acetone-hexanes initially, grading to $0.5 \%$ triethylamine- $25 \%$ acetone-hexanes, five steps) to provide the disaccharide $22 \alpha$ as a colorless oil ( $27.4 \mathrm{mg}, 79 \%)$.

The diastereoselectivity of the reaction was determined to be $>50: 1 \alpha$ : $\beta$ by ${ }^{1} \mathrm{H}$ NMR analysis of the unpurified product mixture.

$\mathrm{R}_{f}=0.32\left(0.5 \%\right.$ triethylamine- $25 \%$ acetone-hexanes; CAM). ${ }^{1} \mathrm{H}$ NMR $\left(600 \mathrm{MHz}, \mathrm{CDCl}_{3}\right) \delta 5.52$ $\left(\mathrm{d}, J=4.9 \mathrm{~Hz}, 1 \mathrm{H}, \mathrm{H}_{1^{\prime}}\right), 4.92\left(\mathrm{~d}, J=3.5 \mathrm{~Hz}, 1 \mathrm{H}, \mathrm{H}_{1}\right), 4.89\left(\mathrm{dd}, J=6.7,1.2 \mathrm{~Hz}, 1 \mathrm{H}, \mathrm{CH}_{2}\right), 4.70$ (dd, $\left.J=6.7,1.2 \mathrm{~Hz}, 1 \mathrm{H}, \mathrm{CH}_{2}\right), 4.59\left(\mathrm{dd}, J=8.3,2.3 \mathrm{~Hz}, 1 \mathrm{H}, \mathrm{H}_{3^{\prime}}\right), 4.30\left(\mathrm{dd}, J=4.9,2.3 \mathrm{~Hz}, 1 \mathrm{H}, \mathrm{H}_{2^{\prime}}\right)$, $4.24\left(\mathrm{dd}, J=8.0,1.7 \mathrm{~Hz}, 1 \mathrm{H}, \mathrm{H}_{4^{\prime}}\right), 3.95\left(\mathrm{td}, J=6.3,1.9 \mathrm{~Hz}, 1 \mathrm{H}, \mathrm{H}_{5^{\prime}}\right), 3.80(\mathrm{dd}, J=10.3,6.0 \mathrm{~Hz}$, $\left.1 \mathrm{H}, \mathrm{H}_{6^{\prime}}\right), 3.76\left(\mathrm{dq}, J=12.6,6.3 \mathrm{~Hz}, 1 \mathrm{H}, \mathrm{H}_{5}\right), 3.52\left(\mathrm{dd}, J=10.1,6.7 \mathrm{~Hz}, 1 \mathrm{H}, \mathrm{H}_{6^{\prime}}\right), 3.41(\mathrm{~s}, 3 \mathrm{H}$, $\left.\mathrm{OCH}_{3}\right), 3.19\left(\mathrm{t}, J=9.5 \mathrm{~Hz}, 1 \mathrm{H}, \mathrm{H}_{4}\right), 2.99\left(\mathrm{td}, J=12.5,9.5,4.4 \mathrm{~Hz}, 1 \mathrm{H}, \mathrm{H}_{3}\right), 2.25\left(\mathrm{~s}, 6 \mathrm{H}, 2 \times \mathrm{NCH}_{3}\right)$, 1.91 (dd, $\left.J=12.7,4.4 \mathrm{~Hz}, 1 \mathrm{H}, \mathrm{H}_{2}\right), 1.57\left(\mathrm{td}, J=12.5,3.5 \mathrm{~Hz}, 1 \mathrm{H}, \mathrm{H}_{2}\right), 1.54\left(\mathrm{~s}, 3 \mathrm{H}, \mathrm{CH}_{3}\right), 1.43(\mathrm{~s}$, $\left.3 \mathrm{H}, \mathrm{CH}_{3}\right), 1.33\left(\mathrm{~s}, 6 \mathrm{H}, 2 \times \mathrm{CH}_{3}\right), 1.27\left(\mathrm{~d}, J=6.2 \mathrm{~Hz}, 3 \mathrm{H}, \mathrm{H}_{6}\right) .{ }^{13} \mathrm{C} \mathrm{NMR}\left(151 \mathrm{MHz}, \mathrm{CDCl}_{3}\right) \delta$ 109.3 (C), 108.7 (C), $97.7\left(\mathrm{CH}_{2}\right), 97.3(\mathrm{CH}), 96.4(\mathrm{CH}), 77.1(\mathrm{CH}), 71.3(\mathrm{CH}), 70.8(\mathrm{CH}), 70.7$ $(\mathrm{CH}), 68.0(\mathrm{CH}), 67.2(\mathrm{CH}), 65.5\left(\mathrm{CH}_{3}\right), 61.2(\mathrm{CH}), 56.2\left(\mathrm{CH}_{3}\right), 40.4\left(2 \times \mathrm{CH}_{3}\right), 26.4\left(\mathrm{CH}_{2}\right), 26.2$ $\left(\mathrm{CH}_{3}\right), 26.1\left(\mathrm{CH}_{3}\right), 25.1\left(\mathrm{CH}_{3}\right), 24.6\left(\mathrm{CH}_{3}\right), 18.7\left(\mathrm{CH}_{3}\right)$. IR (ATR-FTIR), $\mathrm{cm}^{-1}: 2977(\mathrm{~m}), 2935$ (m), $2827(\mathrm{w}), 2779(\mathrm{w}), 2361(\mathrm{w}), 1256(\mathrm{w})$. HRMS-ESI (m/z): $[\mathrm{M}+\mathrm{Na}]^{+}$calculated for $\left[\mathrm{C}_{22} \mathrm{H}_{39} \mathrm{NO}_{9} \mathrm{Na}\right]^{+} 484.2517$, found 484.2547. $[a]_{D}^{21}=-115.5^{\circ}\left(c=1.0, \mathrm{CHCl}_{3}\right)$.

Hoang et al. "General method for the synthesis of $\alpha$ - or $\beta$-deoxyaminoglycosides bearing S33 basic nitrogen" 
Synthesis of the disaccharide $\mathbf{2 2 \boldsymbol { \beta }}$.
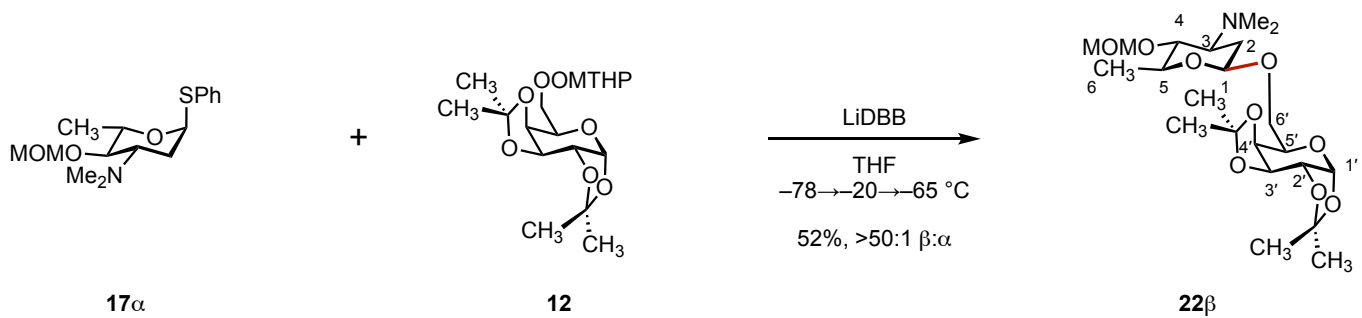

A solution of LiDBB in tetrahydrofuran (nominally $0.4 \mathrm{M}$ ) was added dropwise via syringe to a solution of the amine $17 \boldsymbol{\alpha}(35.1 \mathrm{mg}, 113 \mu \mathrm{mol}, 1.50$ equiv) in tetrahydrofuran-pentane $(1: 1 \mathrm{v} / \mathrm{v}$, $1.8 \mathrm{~mL}$ ) in a $10-\mathrm{mL}$ round-bottomed flask that had been fused to a Teflon-coated valve at $-78^{\circ} \mathrm{C}$. The addition of LiDBB was continued until a green color persisted $(584 \mu \mathrm{L}$, nominally $234 \mu \mathrm{mol}$, 3.10 equiv). The resulting mixture was stirred for $10 \mathrm{~min}$ at $-78^{\circ} \mathrm{C}$. The reaction vessel was then placed in a bath that had been precooled to $-20^{\circ} \mathrm{C}$. The reaction mixture was stirred for $1 \mathrm{~h}$ at $20^{\circ} \mathrm{C}$ and then cooled to $-78^{\circ} \mathrm{C}$ over $10 \mathrm{~min}$. A solution of the MTHP monoperoxy acetal 12 (28.1 mg, $75.0 \mu \mathrm{mol}, 1$ equiv) in tetrahydrofuran $(300 \mu \mathrm{L})$ was then added dropwise via syringe. The reaction vessel was then placed in a cryogenic bath that had been precooled to $-65^{\circ} \mathrm{C}$. The mixture was stirred for $6 \mathrm{~h}$ at $-65^{\circ} \mathrm{C}$. The cold product mixture was diluted with saturated aqueous sodium hydrogen carbonate solution $(1.0 \mathrm{~mL})$. The diluted product mixture was allowed to warm to $23{ }^{\circ} \mathrm{C}$ over $15 \mathrm{~min}$. The warmed product mixture was transferred to a 20 -mL test tube and the layers that formed were separated. The aqueous layer was extracted with ethyl acetate $(4 \times 5.0$ $\mathrm{mL}$ ). The organic layers were combined and the combined organic layers were dried over sodium sulfate. The dried solution was filtered and the filtrate was concentrated under a stream of nitrogen. The residue obtained was purified by flash-column chromatography (eluting with $0.5 \%$ triethylamine- $10 \%$ ethyl acetate-hexanes initially, grading to $0.5 \%$ triethylamine- $40 \%$ ethyl acetate-hexanes, four steps) to provide the disaccharide $\mathbf{2 2} \boldsymbol{\beta}$ as a colorless oil (18.0 $\mathrm{mg}, 52 \%)$.

The diastereoselectivity of the reaction was determined to be $>50: 1 \beta: \alpha$ by ${ }^{1} \mathrm{H}$ NMR analysis of the unpurified product mixture.

$\mathrm{R}_{f}=0.10$ (0.5\% triethylamine- $40 \%$ ethyl acetate-hexanes; CAM). ${ }^{1} \mathrm{H}$ NMR $\left(600 \mathrm{MHz}, \mathrm{CDCl}_{3}\right)$ $\delta 5.51\left(\mathrm{~d}, J=5.0 \mathrm{~Hz}, 1 \mathrm{H}, \mathrm{H}_{1^{\prime}}\right), 4.91\left(\mathrm{~d}, J=6.6 \mathrm{~Hz}, 1 \mathrm{H}, \mathrm{CH}_{2}\right), 4.69\left(\mathrm{~d}, J=6.6 \mathrm{~Hz}, 1 \mathrm{H}, \mathrm{CH}_{2}\right), 4.61$ $\left(\mathrm{dd}, J=7.9,2.4 \mathrm{~Hz}, 1 \mathrm{H}, \mathrm{H}_{3^{\prime}}\right), 4.49\left(\mathrm{dd}, J=9.5,2.0 \mathrm{~Hz}, 1 \mathrm{H}, \mathrm{H}_{1}\right), 4.34-4.29\left(\mathrm{~m}, 2 \mathrm{H}, \mathrm{H}_{2^{\prime}}, \mathrm{H}_{4^{\prime}}\right), 4.02$ (ddd, $\left.J=8.1,5.9,1.9 \mathrm{~Hz}, 1 \mathrm{H}, \mathrm{H}_{5^{\prime}}\right), 3.87$ (dd, $\left.J=10.1,6.0 \mathrm{~Hz}, 1 \mathrm{H}, \mathrm{H}_{6^{\prime}}\right), 3.76(\mathrm{dd}, J=10.1,8.2 \mathrm{~Hz}$, $\left.1 \mathrm{H}, \mathrm{H}_{6^{\prime}}\right), 3.41\left(\mathrm{~s}, 3 \mathrm{H}, \mathrm{OCH}_{3}\right), 3.30\left(\mathrm{dq}, J=8.9,6.2 \mathrm{~Hz}, 1 \mathrm{H}, \mathrm{H}_{5}\right), 3.17\left(\mathrm{t}, J=9.3 \mathrm{~Hz}, 1 \mathrm{H}, \mathrm{H}_{4}\right), 2.70$ $-2.60\left(\mathrm{~m}, 1 \mathrm{H}, \mathrm{H}_{3}\right), 2.25\left(\mathrm{~s}, 6 \mathrm{H}, 2 \times \mathrm{NCH}_{3}\right), 1.99\left(\mathrm{~d}, J=12.5 \mathrm{~Hz}, 1 \mathrm{H}, \mathrm{H}_{2}\right), 1.53\left(\mathrm{~s}, 3 \mathrm{H}, \mathrm{CH}_{3}\right), 1.52$ $-1.48\left(\mathrm{~m}, 1 \mathrm{H}, \mathrm{H}_{2}\right), 1.45\left(\mathrm{~s}, 3 \mathrm{H}, \mathrm{CH}_{3}\right), 1.35\left(\mathrm{~s}, 3 \mathrm{H}, \mathrm{CH}_{3}\right), 1.33\left(\mathrm{~d}, J=6.4 \mathrm{~Hz}, 3 \mathrm{H}, \mathrm{H}_{6}\right), 1.32(\mathrm{~s}, 3 \mathrm{H}$, $\left.\mathrm{CH}_{3}\right) .{ }^{13} \mathrm{C} \mathrm{NMR}\left(151 \mathrm{MHz}, \mathrm{CDCl}_{3}\right) \delta 109.3(\mathrm{C}), 108.7(\mathrm{C}), 101.7(\mathrm{CH}), 97.7\left(\mathrm{CH}_{2}\right), 96.5(\mathrm{CH})$, $76.3(\mathrm{CH}), 72.9(\mathrm{CH}), 70.9(\mathrm{CH}), 70.8(\mathrm{CH}), 70.7(\mathrm{CH}), 67.6\left(\mathrm{CH}_{2}\right), 66.1(\mathrm{CH}), 65.0(\mathrm{CH}), 56.3$ $\left(\mathrm{CH}_{3}\right), 40.5\left(2 \times \mathrm{CH}_{3}\right), 27.8\left(\mathrm{CH}_{2}\right), 26.3\left(\mathrm{CH}_{3}\right), 26.1\left(\mathrm{CH}_{3}\right), 25.1\left(\mathrm{CH}_{3}\right), 24.7\left(\mathrm{CH}_{3}\right), 18.9\left(\mathrm{CH}_{3}\right)$. IR (ATR-FTIR), $\mathrm{cm}^{-1}: 2978(\mathrm{~m}), 2935$ (m), 2360 (m), 1256 (m), 1279 (m). HRMS-ESI (m/z): [M $+\mathrm{H}]^{+}$calculated for $\left[\mathrm{C}_{22} \mathrm{H}_{40} \mathrm{NO}_{9}\right]^{+} 462.2698$, found 462.2727. $[a]_{D}^{21}=-54.1^{\circ}\left(c=0.6, \mathrm{CHCl}_{3}\right)$.

Hoang et al. "General method for the synthesis of $\alpha$ - or $\beta$-deoxyaminoglycosides bearing S34 basic nitrogen" 
Synthesis of the disaccharide $\mathbf{2 3 \alpha}$.

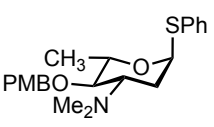

$18 \alpha$

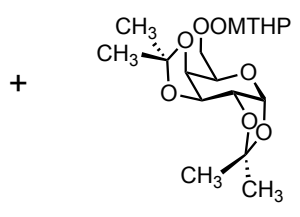

12

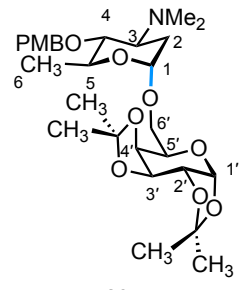

$23 \alpha$

A solution of LiDBB in tetrahydrofuran (nominally $0.4 \mathrm{M}$ ) was added dropwise via syringe to a solution of the amine $\mathbf{1 8 \alpha}$ (43.6 $\mathrm{mg}, 113 \mu \mathrm{mol}, 1.50$ equiv) in tetrahydrofuran-pentane $(1: 1 \mathrm{v} / \mathrm{v}$, $1.8 \mathrm{~mL}$ ) in a $10-\mathrm{mL}$ round-bottomed flask that had been fused to a Teflon-coated valve at $-78^{\circ} \mathrm{C}$. The addition of LiDBB was continued until a green color persisted $(584 \mu \mathrm{L}$, nominally $234 \mu \mathrm{mol}$, 3.10 equiv). The resulting mixture was stirred for $10 \mathrm{~min}$ at $-78{ }^{\circ} \mathrm{C}$. A solution of the MTHP monoperoxy acetal $12(28.1 \mathrm{mg}, 75.0 \mu \mathrm{mol}, 1$ equiv $)$ in tetrahydrofuran $(300 \mu \mathrm{L})$ was then added dropwise via syringe. The resulting mixture was stirred for $3 \mathrm{~h}$ at $-78^{\circ} \mathrm{C}$. The cold product mixture was diluted with saturated aqueous sodium hydrogen carbonate solution $(1.0 \mathrm{~mL})$. The diluted product mixture was allowed to warm to $23{ }^{\circ} \mathrm{C}$ over $15 \mathrm{~min}$. The warmed product mixture was transferred to a 20 - $\mathrm{mL}$ test tube and the layers that formed were separated. The aqueous layer was extracted with ethyl acetate $(4 \times 5.0 \mathrm{~mL})$. The organic layers were combined and the combined organic layers were dried over sodium sulfate. The dried solution was filtered and the filtrate was concentrated under a stream of nitrogen. The residue obtained was purified by flashcolumn chromatography (eluting with $1 \%$ methanol-dichloromethane initially, grading to $5 \%$ methanol-dichloromethane, three steps) to provide the disaccharide $\mathbf{2 3 \alpha}$ as a colorless oil (35.0 $\mathrm{mg}, 87 \%)$.

The diastereoselectivity of the reaction was determined to be $>50: 1 \alpha$ : $\beta$ by ${ }^{1} \mathrm{H}$ NMR analysis of the unpurified product mixture.

$\mathrm{R}_{f}=0.25\left(5 \%\right.$ methanol-dichloromethane; UV, CAM). ${ }^{1} \mathrm{H}$ NMR $\left(600 \mathrm{MHz}, \mathrm{CDCl}_{3}\right) \delta 7.29(\mathrm{~d}, J$ $=8.0 \mathrm{~Hz}, 2 \mathrm{H}, \mathrm{PMB}), 6.86(\mathrm{~d}, J=8.0 \mathrm{~Hz}, 2 \mathrm{H}, \mathrm{PMB}), 5.52\left(\mathrm{~d}, J=4.2 \mathrm{~Hz}, 1 \mathrm{H}, \mathrm{H}_{1^{\prime}}\right), 4.91(\mathrm{~d}, J=3.4$ $\left.\mathrm{Hz}, 1 \mathrm{H}, \mathrm{H}_{1}\right), 4.82\left(\mathrm{~d}, J=10.6 \mathrm{~Hz}, 1 \mathrm{H}, \mathrm{CH}_{2} \mathrm{Ar}\right), 4.59\left(\mathrm{dd}, J=7.9,2.4 \mathrm{~Hz}, 1 \mathrm{H}, \mathrm{H}_{3^{\prime}}\right), 4.54(\mathrm{~d}, J=$ $\left.10.6 \mathrm{~Hz}, 1 \mathrm{H}, \mathrm{CH}_{2} \mathrm{Ar}\right), 4.29\left(\mathrm{dd}, J=5.1,2.4 \mathrm{~Hz}, 1 \mathrm{H}, \mathrm{H}_{2^{\prime}}\right), 4.23\left(\mathrm{dd}, J=8.0,1.9 \mathrm{~Hz}, 1 \mathrm{H}, \mathrm{H}_{4^{\prime}}\right), 3.94$ (td, $\left.J=6.2,1.9 \mathrm{~Hz}, 1 \mathrm{H}, \mathrm{H}_{5^{\prime}}\right), 3.83-3.73\left(\mathrm{~m}, 5 \mathrm{H}, \mathrm{H}_{5}, \mathrm{H}_{6^{\prime}}, \mathrm{OCH}_{3}\right), 3.52(\mathrm{dd}, J=10.3,6.6 \mathrm{~Hz}, 1 \mathrm{H}$, $\left.\mathrm{H}_{6^{\prime}}\right), 3.12-3.03\left(\mathrm{~m}, 2 \mathrm{H}, \mathrm{H}_{3}, \mathrm{H}_{4}\right), 2.33\left(\mathrm{~s}, 6 \mathrm{H}, 2 \times \mathrm{NCH}_{3}\right), 1.92\left(\mathrm{~d}, J=13.1 \mathrm{~Hz}, 1 \mathrm{H}, \mathrm{H}_{2}\right), 1.60(\mathrm{t}, J$ $\left.=12.2 \mathrm{~Hz}, 1 \mathrm{H}, \mathrm{H}_{2}\right), 1.53\left(\mathrm{~s}, 3 \mathrm{H}, \mathrm{CH}_{3}\right), 1.43\left(\mathrm{~s}, 3 \mathrm{H}, \mathrm{CH}_{3}\right), 1.33\left(\mathrm{~s}, 3 \mathrm{H}, \mathrm{CH}_{3}\right), 1.32\left(\mathrm{~s}, 3 \mathrm{H}, \mathrm{CH}_{3}\right)$, $1.25\left(\mathrm{~d}, J=4.9 \mathrm{~Hz}, 3 \mathrm{H}, \mathrm{H}_{6}\right) .{ }^{13} \mathrm{C} \mathrm{NMR}\left(151 \mathrm{MHz}, \mathrm{CDCl}_{3}\right) \delta 159.2(\mathrm{C}), 131.3(\mathrm{C}), 129.6(2 \times \mathrm{CH})$, $113.8(2 \times \mathrm{CH}), 109.3(\mathrm{C}), 108.7(\mathrm{C}), 97.4(\mathrm{CH}), 96.4(\mathrm{CH}), 79.9(\mathrm{CH}), 73.4\left(\mathrm{CH}_{2}\right), 71.3(\mathrm{CH})$, $70.8(2 \times \mathrm{CH}), 68.0(\mathrm{CH}), 67.3(\mathrm{CH}), 65.5\left(\mathrm{CH}_{2}\right), 61.0(\mathrm{CH}), 55.4\left(\mathrm{CH}_{3}\right), 40.9\left(2 \times \mathrm{CH}_{3}\right), 27.9$ $\left(\mathrm{CH}_{2}\right), 26.3\left(\mathrm{CH}_{3}\right), 26.1\left(\mathrm{CH}_{3}\right), 25.1\left(\mathrm{CH}_{3}\right), 24.6\left(\mathrm{CH}_{3}\right), 18.7\left(\mathrm{CH}_{3}\right)$. IR (ATR-FTIR), cm ${ }^{-1}: 2934$ (m), $2359(\mathrm{w}), 1613(\mathrm{~m}), 1514(\mathrm{~m}), 1456(\mathrm{~m})$. HRMS-ESI $(\mathrm{m} / \mathrm{z})$ : $[\mathrm{M}+\mathrm{Na}]^{+}$calculated for $\left[\mathrm{C}_{28} \mathrm{H}_{43} \mathrm{NO}_{9} \mathrm{Na}\right]^{+}$560.2830, found 560.2853. $[a]_{D}^{21}=-83.2^{\circ}\left(c=1.0, \mathrm{CHCl}_{3}\right)$.

Hoang et al. "General method for the synthesis of $\alpha$ - or $\beta$-deoxyaminoglycosides bearing S35 basic nitrogen" 
Synthesis of the disaccharide $\mathbf{2 4 \alpha}$.

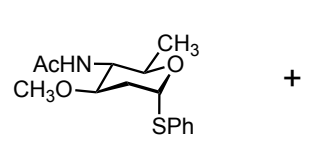

$15 \alpha$

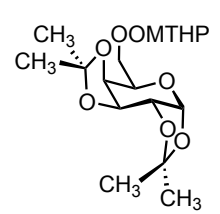

12

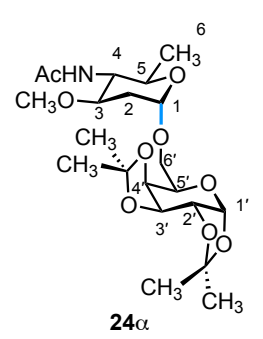

$24 \alpha$

A solution of methyllithium in ether $(1.40 \mathrm{M}, 80.0 \mu \mathrm{L}, 113 \mu \mathrm{mol}, 1.50$ equiv $)$ was added dropwise via syringe to a solution of the amide $15 \boldsymbol{\alpha}(33.2 \mathrm{mg}, 113 \mu \mathrm{mol}, 1.50$ equiv) in tetrahydrofuranpentane $(1: 1 \mathrm{v} / \mathrm{v}, 1.8 \mathrm{~mL})$ in a $10-\mathrm{mL}$ round-bottomed flask that had been fused to a Teflon-coated valve at $-78^{\circ} \mathrm{C}$. The resulting mixture was stirred for $30 \mathrm{~min}$ at $-78^{\circ} \mathrm{C}$. A solution of LiDBB in tetrahydrofuran (nominally $0.4 \mathrm{M}$ ) was then added dropwise via syringe. The addition of LiDBB was continued until a green color persisted $(584 \mu \mathrm{L}$, nominally $234 \mu \mathrm{mol}, 3.10$ equiv). The resulting mixture was stirred for $10 \mathrm{~min}$ at $-78{ }^{\circ} \mathrm{C}$. A solution of the MTHP monoperoxy acetal $12(28.1 \mathrm{mg}, 75.0 \mu \mathrm{mol}, 1$ equiv $)$ in tetrahydrofuran $(300 \mu \mathrm{L})$ was then added dropwise via syringe. The resulting mixture was stirred for $3 \mathrm{~h}$ at $-78^{\circ} \mathrm{C}$. The cold product mixture was diluted with saturated aqueous sodium hydrogen carbonate solution $(1.0 \mathrm{~mL})$. The diluted product mixture was allowed to warm to $23{ }^{\circ} \mathrm{C}$ over $15 \mathrm{~min}$. The warmed product mixture was transferred to a $20-\mathrm{mL}$ test tube and the layers that formed were separated. The aqueous layer was extracted with ethyl acetate $(4 \times 5.0 \mathrm{~mL})$. The organic layers were combined and the combined organic layers were dried over sodium sulfate. The dried solution was filtered and the filtrate was concentrated under a stream of nitrogen. The residue obtained was purified by flash-column chromatography (eluting with $0.5 \%$ triethylamine- $10 \%$ acetone-hexanes initially, grading to $0.5 \%$ triethylamine $-30 \%$ acetone-hexanes, five steps) to provide the disaccharide $\mathbf{2 4 \alpha}$ as a colorless oil $(20.0 \mathrm{mg}, 60 \%$ ).

The diastereoselectivity of the reaction was determined to be $>50: 1 \alpha: \beta$ by ${ }^{1} \mathrm{H}$ NMR analysis of the unpurified product mixture.

$\mathrm{R}_{f}=0.13\left(0.5 \%\right.$ triethylamine-30\% acetone-hexanes; CAM). ${ }^{1} \mathrm{H}$ NMR $\left(400 \mathrm{MHz}, \mathrm{CDCl}_{3}\right) \delta 5.53$ $\left(\mathrm{d}, J=5.1 \mathrm{~Hz}, 1 \mathrm{H}, \mathrm{H}_{1^{\prime}}\right), 5.38(\mathrm{~d}, J=8.4 \mathrm{~Hz}, 1 \mathrm{H}, \mathrm{NH}), 4.96\left(\mathrm{dd}, J=3.7,1.5 \mathrm{~Hz}, 1 \mathrm{H}, \mathrm{H}_{1}\right), 4.61(\mathrm{dd}$, $\left.J=7.9,2.5 \mathrm{~Hz}, 1 \mathrm{H}, \mathrm{H}_{3^{\prime}}\right), 4.32\left(\mathrm{dd}, J=5.0,2.4 \mathrm{~Hz}, 1 \mathrm{H}, \mathrm{H}_{2^{\prime}}\right), 4.22\left(\mathrm{dd}, J=7.9,2.0 \mathrm{~Hz}, 1 \mathrm{H}, \mathrm{H}_{4^{\prime}}\right)$, 3.95 (ddd, $\left.J=7.3,5.6,1.9 \mathrm{~Hz}, 1 \mathrm{H}, \mathrm{H}_{5^{\prime}}\right), 3.76-3.67$ (m, $3 \mathrm{H}, \mathrm{H}_{4}, \mathrm{H}_{5}, \mathrm{H}_{6^{\prime}}$ ), 3.62 (dd, $J=10.8,5.6$ $\left.\mathrm{Hz}, 1 \mathrm{H}, \mathrm{H}_{6^{\prime}}\right), 3.53\left(\mathrm{ddd}, J=6.8,5.4,3.2 \mathrm{~Hz}, 1 \mathrm{H}, \mathrm{H}_{3}\right), 3.29\left(\mathrm{~s}, 3 \mathrm{H}, \mathrm{OCH}_{3}\right), 2.26(\mathrm{ddd}, J=12.9,4.8$, $\left.1.6 \mathrm{~Hz}, 1 \mathrm{H}, \mathrm{H}_{2}\right), 2.01\left(\mathrm{~s}, 3 \mathrm{H}, \mathrm{CH}_{3}\right), 1.62\left(\mathrm{ddd}, J=13.0,11.1,3.7 \mathrm{~Hz}, 1 \mathrm{H}, \mathrm{H}_{2}\right), 1.54\left(\mathrm{~s}, 3 \mathrm{H}, \mathrm{CH}_{3}\right)$, $1.43\left(\mathrm{~s}, 3 \mathrm{H}, \mathrm{CH}_{3}\right), 1.33\left(\mathrm{~s}, 6 \mathrm{H}, 2 \times \mathrm{CH}_{3}\right), 1.20\left(\mathrm{~d}, J=5.7 \mathrm{~Hz}, 3 \mathrm{H}, \mathrm{H}_{6}\right) .{ }^{13} \mathrm{C} \mathrm{NMR}(151 \mathrm{MHz}$, $\left.\mathrm{CDCl}_{3}\right) \delta 170.4(\mathrm{C}), 109.6(\mathrm{C}), 108.7(\mathrm{C}), 96.9(\mathrm{CH}), 96.5(\mathrm{CH}), 75.5(\mathrm{CH}), 71.3(\mathrm{CH}), 70.8(\mathrm{CH})$, $70.7(\mathrm{CH}), 67.9(\mathrm{CH}), 66.2(\mathrm{CH}), 65.7\left(\mathrm{CH}_{2}\right), 55.9(\mathrm{CH}), 55.8\left(\mathrm{CH}_{3}\right), 34.6\left(\mathrm{CH}_{2}\right), 26.2\left(\mathrm{CH}_{3}\right), 26.1$ $\left(\mathrm{CH}_{3}\right), 25.1\left(\mathrm{CH}_{3}\right), 24.7\left(\mathrm{CH}_{3}\right), 23.7\left(\mathrm{CH}_{3}\right), 18.2\left(\mathrm{CH}_{3}\right)$. IR (ATR-FTIR), $\mathrm{cm}^{-1}: 3272$ (br w), 2986 (m), $2936(\mathrm{~m}), 1656(\mathrm{~m}), 1556(\mathrm{~m}), 1455(\mathrm{w})$. HRMS-ESI $(\mathrm{m} / \mathrm{z}):[\mathrm{M}+\mathrm{H}]^{+}$calculated for $\left[\mathrm{C}_{21} \mathrm{H}_{36} \mathrm{NO}_{9}\right]^{+} 446.2385$, found 446.2363. $[a]_{D}^{21}=+13.6^{\circ}\left(c=0.8, \mathrm{CHCl}_{3}\right)$.

Hoang et al. "General method for the synthesis of $\alpha$ - or $\beta$-deoxyaminoglycosides bearing S36 basic nitrogen" 


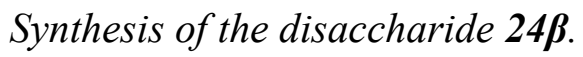

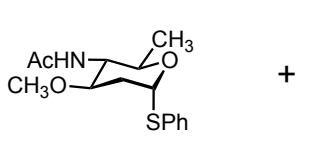

$15 \alpha$

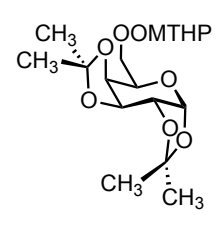

12

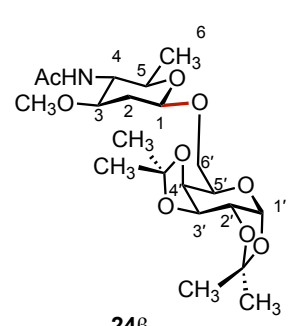

$24 \beta$

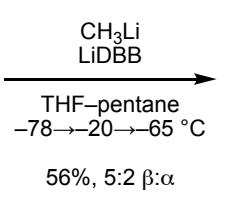

$56 \%, 5: 2 \beta: \alpha$

A solution of methyllithium in ether $(1.40 \mathrm{M}, 107 \mu \mathrm{L}, 150 \mu \mathrm{mol}, 2.00$ equiv) was added dropwise via syringe to a solution of the amide $15 \boldsymbol{\alpha}(44.3 \mathrm{mg}, 150 \mu \mathrm{mol}, 2.00$ equiv) in tetrahydrofuranpentane $(1: 1 \mathrm{v} / \mathrm{v}, 1.8 \mathrm{~mL})$ in a $10-\mathrm{mL}$ round-bottomed flask that had been fused to a Teflon-coated valve at $-78^{\circ} \mathrm{C}$. The resulting mixture was stirred for $45 \mathrm{~min}$ at $-78^{\circ} \mathrm{C}$. A solution of $\mathrm{LiDBB}$ in tetrahydrofuran (nominally $0.4 \mathrm{M}$ ) was then added dropwise via syringe. The addition of LiDBB was continued until a green color persisted $(769 \mu \mathrm{L}$, nominally $308 \mu$ mol, 4.10 equiv). The resulting mixture was stirred for $10 \mathrm{~min}$ at $-78{ }^{\circ} \mathrm{C}$. The reaction vessel was then placed in a bath that had been precooled to $-20{ }^{\circ} \mathrm{C}$. The reaction mixture was stirred for $1 \mathrm{~h}$ at $-20{ }^{\circ} \mathrm{C}$ and then cooled to $-78{ }^{\circ} \mathrm{C}$ over $10 \mathrm{~min}$. A solution of the MTHP monoperoxy acetal $12(28.1 \mathrm{mg}, 75.0$ $\mu \mathrm{mol}, 1$ equiv) in tetrahydrofuran $(300 \mu \mathrm{L})$ was then added dropwise via syringe. The reaction vessel was then placed in a cryogenic bath that had been precooled to $-65^{\circ} \mathrm{C}$. The mixture was stirred for $6 \mathrm{~h}$ at $-65^{\circ} \mathrm{C}$. The cold product mixture was diluted with saturated aqueous sodium hydrogen carbonate solution $(1.0 \mathrm{~mL})$. The diluted product mixture was allowed to warm to 23 ${ }^{\circ} \mathrm{C}$ over $15 \mathrm{~min}$. The warmed product mixture was transferred to a 20 -mL test tube and the layers that formed were separated. The aqueous layer was extracted with ethyl acetate $(4 \times 5.0 \mathrm{~mL})$. The organic layers were combined and the combined organic layers were dried over sodium sulfate. The dried solution was filtered and the filtrate was concentrated under a stream of nitrogen. The residue obtained was purified by flash-column chromatography (eluting with $0.5 \%$ triethylamine$5 \%$ acetone-hexanes initially, grading to $0.5 \%$ triethylamine- $30 \%$ acetone-hexanes, five steps) to provide the disaccharide $\mathbf{2 4 \boldsymbol { \beta }}$ as a colorless oil (18.6 $\mathrm{mg}, 56 \%)$.

The diastereoselectivity of the reaction was determined to be $2.6: 1 \beta: \alpha$ by ${ }^{1} \mathrm{H}$ NMR analysis of the unpurified product mixture.

$\mathrm{R}_{f}=0.11\left(0.5 \%\right.$ triethylamine- $30 \%$ acetone-hexanes; CAM). ${ }^{1} \mathrm{H}$ NMR $\left(600 \mathrm{MHz}, \mathrm{C}_{6} \mathrm{D}_{6}\right) \delta 5.58$ $\left(\mathrm{d}, J=5.0 \mathrm{~Hz}, 1 \mathrm{H}, \mathrm{H}_{1^{\prime}}\right), 4.46\left(\mathrm{~d}, J=8.1 \mathrm{~Hz}, 1 \mathrm{H}, \mathrm{H}_{3^{\prime}}\right), 4.43\left(\mathrm{~d}, J=9.7 \mathrm{~Hz}, 1 \mathrm{H}, \mathrm{H}_{1}\right), 4.35(\mathrm{dd}, J=$ 10.9, $3.4 \mathrm{~Hz}, 1 \mathrm{H}, \mathrm{H}_{6^{\prime}}$ ), 4.27 (d, $\left.J=8.6 \mathrm{~Hz}, 1 \mathrm{H}, \mathrm{NH}\right), 4.24$ (dd, $J=6.6,2.3 \mathrm{~Hz}, 1 \mathrm{H}, \mathrm{H}_{5^{\prime}}$ ), 4.18 (dd, $\left.J=5.3,2.2 \mathrm{~Hz}, 1 \mathrm{H}, \mathrm{H}_{2^{\prime}}\right), 4.02\left(\mathrm{dd}, J=10.8,7.6 \mathrm{~Hz}, 1 \mathrm{H}, \mathrm{H}_{6^{\prime}}\right), 3.93\left(\mathrm{~d}, J=8.0 \mathrm{~Hz}, 1 \mathrm{H}, \mathrm{H}_{4^{\prime}}\right), 3.49$ $\left(\mathrm{q}, J=9.4 \mathrm{~Hz}, 1 \mathrm{H}, \mathrm{H}_{4}\right), 3.25\left(\mathrm{dq}, J=12.9,6.5 \mathrm{~Hz}, 1 \mathrm{H}, \mathrm{H}_{5}\right), 3.04\left(\mathrm{td}, J=10.8,4.7 \mathrm{~Hz}, 1 \mathrm{H}, \mathrm{H}_{3}\right)$, $2.96\left(\mathrm{~s}, 3 \mathrm{H}, \mathrm{OCH}_{3}\right), 2.24\left(\mathrm{dd}, J=12.2,4.7 \mathrm{~Hz}, 1 \mathrm{H}, \mathrm{H}_{2}\right), 1.62\left(\mathrm{q}, J=11.2 \mathrm{~Hz}, 1 \mathrm{H}, \mathrm{H}_{2}\right), 1.49(\mathrm{~s}, 3 \mathrm{H}$, $\left.\mathrm{CH}_{3}\right), 1.48\left(\mathrm{~s}, 6 \mathrm{H}, 2 \times \mathrm{CH}_{3}\right), 1.29\left(\mathrm{~d}, J=6.1 \mathrm{~Hz}, 3 \mathrm{H}, \mathrm{H}_{6}\right), 1.13\left(\mathrm{~s}, 3 \mathrm{H}, \mathrm{CH}_{3}\right), 1.05\left(\mathrm{~s}, 3 \mathrm{H}, \mathrm{CH}_{3}\right)$. ${ }^{13} \mathrm{C}$ NMR (151 MHz, C6 $\left.\mathrm{D}_{6}\right) \delta 168.9(\mathrm{C}), 109.2(\mathrm{C}), 108.5(\mathrm{C}), 100.8(\mathrm{CH}), 96.9(\mathrm{CH}), 76.9(\mathrm{CH})$, $71.8(\mathrm{CH}), 71.3(2 \times \mathrm{CH}), 71.0(\mathrm{CH}), 69.4\left(\mathrm{CH}_{2}\right), 68.5(\mathrm{CH}), 57.1(\mathrm{CH}), 55.0\left(\mathrm{CH}_{3}\right), 36.7\left(\mathrm{CH}_{2}\right)$, $26.3\left(\mathrm{CH}_{3}\right), 26.3\left(\mathrm{CH}_{3}\right), 25.0\left(\mathrm{CH}_{3}\right), 24.3\left(\mathrm{CH}_{3}\right), 23.3\left(\mathrm{CH}_{3}\right), 18.6\left(\mathrm{CH}_{3}\right)$. IR (ATR-FTIR), $\mathrm{cm}^{-1}$ :

Hoang et al. "General method for the synthesis of $\alpha$ - or $\beta$-deoxyaminoglycosides bearing 
3275 (br w), 2985 (m), 2936 (m), 2359 (m), 2341 (m), 1656 (m), 1556 (m). HRMS-ESI (m/z): [M

$+\mathrm{H}]^{+}$calculated for $\left[\mathrm{C}_{21} \mathrm{H}_{36} \mathrm{NO}_{9}\right]^{+} 446.2385$, found 446.2404. $[a]_{D}^{21}=-89.2^{\circ}\left(c=0.3, \mathrm{CHCl}_{3}\right)$. 
Synthesis of the disaccharide $\mathbf{2 5 \alpha}$.

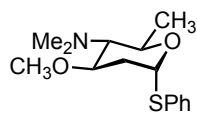

$14 \alpha$

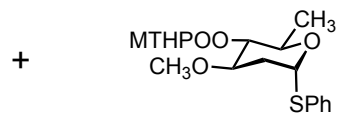

$19 \alpha$

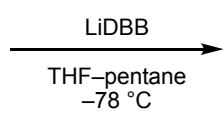

$88 \%,>50: 1 \alpha: \beta$

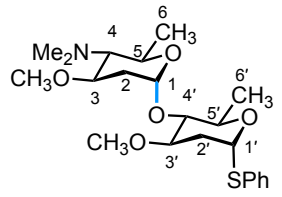

$25 \alpha$

A solution of LiDBB in tetrahydrofuran (nominally $0.4 \mathrm{M}$ ) was added dropwise via syringe to a solution of the amine $\mathbf{1 4 \alpha}(31.7 \mathrm{mg}, 113 \mu \mathrm{mol}, 1.50$ equiv) in tetrahydrofuran-pentane $(1: 1 \mathrm{v} / \mathrm{v}$, $1.8 \mathrm{~mL}$ ) in a $10-\mathrm{mL}$ round-bottomed flask that had been fused to a Teflon-coated valve at $-78^{\circ} \mathrm{C}$. The addition of LiDBB was continued until a green color persisted $(584 \mu \mathrm{L}$, nominally $234 \mu \mathrm{mol}$, 3.10 equiv). The resulting mixture was stirred for $10 \mathrm{~min}$ at $-78{ }^{\circ} \mathrm{C}$. A solution of the MTHP monoperoxy acetal $19 \alpha(27.6 \mathrm{mg}, 75.0 \mu \mathrm{mol}, 1$ equiv $)$ in tetrahydrofuran $(300 \mu \mathrm{L})$ was then added dropwise via syringe. The resulting mixture was stirred for $3 \mathrm{~h}$ at $-78{ }^{\circ} \mathrm{C}$. The cold product mixture was diluted with saturated aqueous sodium hydrogen carbonate solution $(1.0 \mathrm{~mL})$. The diluted product mixture was allowed to warm to $23{ }^{\circ} \mathrm{C}$ over $15 \mathrm{~min}$. The warmed product mixture was transferred to a $20-\mathrm{mL}$ test tube and the layers that formed were separated. The aqueous layer was extracted with ethyl acetate $(4 \times 5.0 \mathrm{~mL})$. The organic layers were combined and the combined organic layers were dried over sodium sulfate. The dried solution was filtered and the filtrate was concentrated under a stream of nitrogen. The residue obtained was purified by flashcolumn chromatography (eluting with $0.5 \%$ triethylamine- $2 \%$ acetone-hexanes initially, grading to $0.5 \%$ triethylamine- $10 \%$ acetone-hexanes, four steps) to provide the disaccharide $\mathbf{2 5} \boldsymbol{\alpha}$ as a colorless oil (28.1 mg, 88\%).

The diastereoselectivity of the reaction was determined to be $>50: 1 \alpha: \beta$ by ${ }^{1} \mathrm{H}$ NMR analysis of the unpurified product mixture.

$\mathrm{R}_{f}=0.30$ (0.5\% triethylamine-10\% acetone-hexanes; UV, CAM). ${ }^{1} \mathrm{H} \mathrm{NMR}\left(500 \mathrm{MHz}, \mathrm{CDCl}_{3}\right)$ $\delta 7.47-7.44(\mathrm{~m}, 2 \mathrm{H}, \mathrm{SPh}), 7.33-7.28(\mathrm{~m}, 2 \mathrm{H}, \mathrm{SPh}), 7.25-7.22(\mathrm{~m}, 1 \mathrm{H}, \mathrm{SPh}), 5.59$ (dd, J= 5.8, $\left.1.5 \mathrm{~Hz}, 1 \mathrm{H}, \mathrm{H}_{1^{\prime}}\right), 5.34\left(\mathrm{dd}, J=4.0,1.9 \mathrm{~Hz}, 1 \mathrm{H}, \mathrm{H}_{1}\right), 4.17\left(\mathrm{dq}, J=9.2,6.2 \mathrm{~Hz}, 1 \mathrm{H}, \mathrm{H}_{5^{\prime}}\right), 3.81-3.71$ $\left(\mathrm{m}, 2 \mathrm{H}, \mathrm{H}_{3}, \mathrm{H}_{5}\right), 3.58$ (ddd, $\left.J=11.4,8.4,4.7 \mathrm{~Hz}, 1 \mathrm{H}, \mathrm{H}_{3^{\prime}}\right), 3.38\left(\mathrm{~s}, 3 \mathrm{H}, \mathrm{OCH}_{3}\right), 3.36\left(\mathrm{~s}, 3 \mathrm{H}, \mathrm{OCH}_{3}\right)$, $3.28\left(\mathrm{t}, J=8.9 \mathrm{~Hz}, 1 \mathrm{H}, \mathrm{H}_{4^{\prime}}\right), 2.44\left(\mathrm{ddd}, J=13.3,4.8,1.6 \mathrm{~Hz}, 1 \mathrm{H}, \mathrm{H}_{2^{\prime}}\right), 2.42\left(\mathrm{~s}, 6 \mathrm{H}, 2 \times \mathrm{NCH}_{3}\right)$, 2.29 (ddd, $\left.J=12.8,4.6,2.0 \mathrm{~Hz}, 1 \mathrm{H}, \mathrm{H}_{2}\right), 2.15\left(\mathrm{t}, J=9.6 \mathrm{~Hz}, 1 \mathrm{H}, \mathrm{H}_{4}\right), 1.96(\mathrm{ddd}, J=13.4,11.4$, $\left.5.7 \mathrm{~Hz}, 1 \mathrm{H}, \mathrm{H}_{2^{\prime}}\right), 1.57$ (td, $\left.J=12.7,10.6,4.0 \mathrm{~Hz}, 1 \mathrm{H}, \mathrm{H}_{2}\right), 1.29$ (d, $\left.J=6.3 \mathrm{~Hz}, 3 \mathrm{H}, \mathrm{H}_{6^{\prime}}\right), 1.25(\mathrm{~d}, J$ $\left.=6.2 \mathrm{~Hz}, 3 \mathrm{H}, \mathrm{H}_{6}\right) .{ }^{13} \mathrm{C} \mathrm{NMR}\left(126 \mathrm{MHz}, \mathrm{CDCl}_{3}\right) \delta 135.3(\mathrm{C}), 131.3(2 \times \mathrm{CH}), 129.1(2 \times \mathrm{CH})$, $127.2(\mathrm{CH}), 98.4(\mathrm{CH}), 83.9(\mathrm{CH}), 80.4(\mathrm{CH}), 80.0(\mathrm{CH}), 73.9(\mathrm{CH}), 70.3(\mathrm{CH}), 68.0(\mathrm{CH}), 67.1$ $(\mathrm{CH}), 56.7\left(\mathrm{CH}_{3}\right), 55.2\left(\mathrm{CH}_{3}\right), 42.6\left(2 \times \mathrm{CH}_{3}\right), 35.5\left(2 \times \mathrm{CH}_{2}\right), 19.4\left(\mathrm{CH}_{3}\right), 18.6\left(\mathrm{CH}_{3}\right)$. IR $(\mathrm{ATR}-$ FTIR), $\mathrm{cm}^{-1}: 2969(\mathrm{~m}), 2930$ (m), 2828 (m), 2359 (m), 2341 (m), $1584(\mathrm{w})$. HRMS-ESI (m/z): $[\mathrm{M}+\mathrm{Na}]^{+}$calculated for $\left[\mathrm{C}_{22} \mathrm{H}_{35} \mathrm{NO}_{5} \mathrm{SNa}\right]^{+} 448.2128$, found $448.2150 . \quad[a]_{D}^{21}=+290.5^{\circ}(c=1.0$, $\left.\mathrm{CHCl}_{3}\right)$.

Hoang et al. "General method for the synthesis of $\alpha$ - or $\beta$-deoxyaminoglycosides bearing 
Synthesis of the disaccharide $\mathbf{2 5 \boldsymbol { \beta }}$.

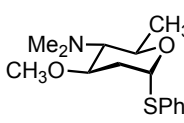

$14 \alpha$

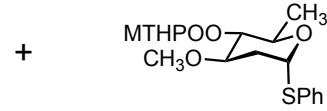

$19 \alpha$

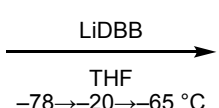

$44 \%,>50: 1 \beta: \alpha$

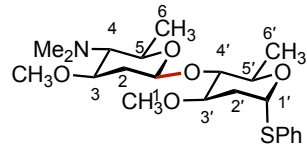

$25 \beta$

A solution of LiDBB in tetrahydrofuran (nominally $0.4 \mathrm{M}$ ) was added dropwise via syringe to a solution of the amine $\mathbf{1 4 \alpha}(42.2 \mathrm{mg}, 150 \mu \mathrm{mol}, 2.00$ equiv) in tetrahydrofuran $(1.8 \mathrm{~mL})$ in a 10 $\mathrm{mL}$ round-bottomed flask that had been fused to a Teflon-coated valve at $-78^{\circ} \mathrm{C}$. The addition of LiDBB was continued until a green color persisted ( $769 \mu \mathrm{L}$, nominally $308 \mu \mathrm{mol}, 4.10$ equiv). The resulting mixture was stirred for $10 \mathrm{~min}$ at $-78{ }^{\circ} \mathrm{C}$. The reaction vessel was then placed in a bath that had been precooled to $-20^{\circ} \mathrm{C}$. The reaction mixture was stirred for $1 \mathrm{~h}$ at $-20{ }^{\circ} \mathrm{C}$ and then cooled to $-78^{\circ} \mathrm{C}$ over $10 \mathrm{~min}$. A solution of the MTHP monoperoxy acetal 19a $(27.6 \mathrm{mg}$, $75.0 \mu \mathrm{mol}, 1$ equiv) in tetrahydrofuran $(300 \mu \mathrm{L})$ was then added dropwise via syringe. The reaction vessel was then placed in a cryogenic bath that had been precooled to $-65^{\circ} \mathrm{C}$. The mixture was stirred for $6 \mathrm{~h}$ at $-65^{\circ} \mathrm{C}$. The cold product mixture was diluted with saturated aqueous sodium hydrogen carbonate solution $(1.0 \mathrm{~mL})$. The diluted product mixture was allowed to warm to 23 ${ }^{\circ} \mathrm{C}$ over $15 \mathrm{~min}$. The warmed product mixture was transferred to a $20-\mathrm{mL}$ test tube and the layers that formed were separated. The aqueous layer was extracted with ethyl acetate $(4 \times 5.0 \mathrm{~mL})$. The organic layers were combined and the combined organic layers were dried over sodium sulfate. The dried solution was filtered and the filtrate was concentrated under a stream of nitrogen. The residue obtained was purified by flash-column chromatography (eluting with $0.5 \%$ triethylamine$5 \%$ acetone-hexanes initially, grading to $0.5 \%$ triethylamine- $20 \%$ acetone-hexanes, four steps) to provide the disaccharide $\mathbf{2 5 \beta}$ as a colorless oil (14.0 $\mathrm{mg}, 44 \%$ ).

The diastereoselectivity of the reaction was determined to be $>50: 1 \beta: \alpha$ by ${ }^{1} \mathrm{H}$ NMR analysis of the unpurified product mixture.

$\mathrm{R}_{f}=0.44(0.5 \%$ triethylamine- $20 \%$ acetone-hexanes; UV, CAM $) .{ }^{1} \mathrm{H}$ NMR $\left(600 \mathrm{MHz}, \mathrm{CDCl}_{3}\right)$ $\delta 7.45-7.41$ (m, 2H, SPh), $7.29-7.26$ (m, 2H, SPh), $7.23-7.20$ (m, 1H, SPh), 5.55 (dd, $J=5.8$, $2.7 \mathrm{~Hz}, 1 \mathrm{H}, \mathrm{H}_{1^{\prime}}$ ), $4.56\left(\mathrm{dd}, J=9.8,2.0 \mathrm{~Hz}, 1 \mathrm{H}, \mathrm{H}_{1}\right), 4.17$ (dq, $J=8.9,6.2 \mathrm{~Hz}, 1 \mathrm{H}, \mathrm{H}_{5^{\prime}}$ ), 3.66 (ddd, $\left.J=10.3,7.5,4.6 \mathrm{~Hz}, 1 \mathrm{H}, \mathrm{H}_{3^{\prime}}\right), 3.47$ (td, $\left.J=10.7,4.8 \mathrm{~Hz}, 1 \mathrm{H}, \mathrm{H}_{3}\right), 3.44\left(\mathrm{~s}, 3 \mathrm{H}, \mathrm{OCH}_{3}\right), 3.34(\mathrm{~s}, 3 \mathrm{H}$, $\left.\mathrm{OCH}_{3}\right), 3.33-3.29\left(\mathrm{~m}, 1 \mathrm{H}, \mathrm{H}_{5}\right), 3.23\left(\mathrm{t}, J=8.4 \mathrm{~Hz}, 1 \mathrm{H}, \mathrm{H}_{4}\right), 2.39\left(\mathrm{~s}, 6 \mathrm{H}, 2 \times \mathrm{NCH}_{3}\right), 2.39-2.37$ $\left(\mathrm{m}, 1 \mathrm{H}, \mathrm{H}_{2}\right), 2.36-2.34\left(\mathrm{~m}, 1 \mathrm{H}, \mathrm{H}_{2^{\prime}}\right), 2.14\left(\mathrm{t}, J=9.8 \mathrm{~Hz}, 1 \mathrm{H}, \mathrm{H}_{4}\right), 2.00(\mathrm{ddd}, J=13.6,10.4,5.7$ $\left.\mathrm{Hz}, 1 \mathrm{H}, \mathrm{H}_{2^{\prime}}\right), 1.43\left(\mathrm{q}, J=11.8,10.0 \mathrm{~Hz}, 1 \mathrm{H}, \mathrm{H}_{2}\right), 1.32\left(\mathrm{~d}, J=6.1 \mathrm{~Hz}, 3 \mathrm{H}, \mathrm{H}_{6}\right), 1.27(\mathrm{~d}, J=6.3 \mathrm{~Hz}$, $\left.3 \mathrm{H}, \mathrm{H}_{6^{\prime}}\right) .{ }^{13} \mathrm{C} \mathrm{NMR}\left(151 \mathrm{MHz}, \mathrm{CDCl}_{3}\right) \delta 135.4(\mathrm{C}), 131.2(2 \times \mathrm{CH}), 129.0(2 \times \mathrm{CH}), 127.1(\mathrm{CH})$, 100.5 (CH), 83.4 (CH), 83.2 (CH), 77.9 (CH), 76.3 (CH), 70.9 (CH), 69.6 (CH), 67.9 (CH), 57.5 $\left(\mathrm{CH}_{3}\right), 55.1\left(\mathrm{CH}_{3}\right), 42.5\left(2 \times \mathrm{CH}_{3}\right), 36.9\left(\mathrm{CH}_{2}\right), 35.2\left(\mathrm{CH}_{2}\right), 19.7\left(\mathrm{CH}_{3}\right), 18.4\left(\mathrm{CH}_{3}\right)$. IR (ATRFTIR), $\mathrm{cm}^{-1}: 2930(\mathrm{~m}), 2829(\mathrm{~m}), 2360(\mathrm{~m}), 1740(\mathrm{w}), 1583(\mathrm{w})$. HRMS-ESI (m/z): $[\mathrm{M}+\mathrm{H}]^{+}$ calculated for $\left[\mathrm{C}_{22} \mathrm{H}_{36} \mathrm{NO}_{5} \mathrm{~S}\right]^{+} 426.2309$, found 426.2328. $[a]_{D}^{21}=+146.4^{\circ}\left(c=0.7, \mathrm{CHCl}_{3}\right)$. 
Synthesis of the disaccharide $\mathbf{2 6 \alpha}$.

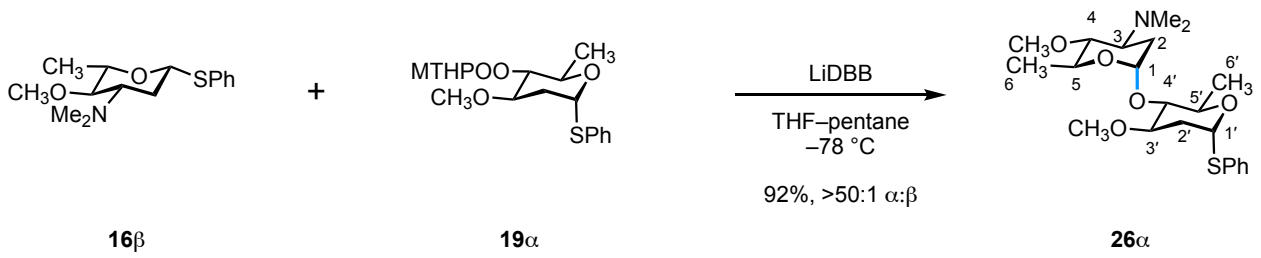

A solution of LiDBB in tetrahydrofuran (nominally $0.4 \mathrm{M}$ ) was added dropwise via syringe to a solution of the amine $\mathbf{1 6 \beta}(31.7 \mathrm{mg}, 113 \mu \mathrm{mol}, 1.50$ equiv) in tetrahydrofuran-pentane $(1: 1 \mathrm{v} / \mathrm{v}$, $1.8 \mathrm{~mL}$ ) in a $10-\mathrm{mL}$ round-bottomed flask that had been fused to a Teflon-coated valve at $-78^{\circ} \mathrm{C}$. The addition of LiDBB was continued until a green color persisted $(584 \mu \mathrm{L}$, nominally $234 \mu \mathrm{mol}$, 3.10 equiv). The resulting mixture was stirred for $10 \mathrm{~min}$ at $-78{ }^{\circ} \mathrm{C}$. A solution of the MTHP monoperoxy acetal $19 \alpha(27.6 \mathrm{mg}, 75.0 \mu \mathrm{mol}, 1$ equiv) in tetrahydrofuran $(300 \mu \mathrm{L})$ was then added dropwise via syringe. The resulting mixture was stirred for $3 \mathrm{~h}$ at $-78^{\circ} \mathrm{C}$. The cold product mixture was diluted with saturated aqueous sodium hydrogen carbonate solution $(1.0 \mathrm{~mL})$. The diluted product mixture was allowed to warm to $23{ }^{\circ} \mathrm{C}$ over $15 \mathrm{~min}$. The warmed product mixture was transferred to a $20-\mathrm{mL}$ test tube and the layers that formed were separated. The aqueous layer was extracted with ethyl acetate $(4 \times 5.0 \mathrm{~mL})$. The organic layers were combined and the combined organic layers were dried over sodium sulfate. The dried solution was filtered and the filtrate was concentrated under a stream of nitrogen. The residue obtained was purified by flashcolumn chromatography (eluting with $2 \%$ methanol-dichloromethane initially, grading to $5 \%$ methanol-dichloromethane, three steps) to provide the disaccharide $\mathbf{2 6} \boldsymbol{\alpha}$ as a colorless oil (29.5 mg, $92 \%)$.

The diastereoselectivity of the reaction was determined to be $>50: 1 \alpha$ : $\beta$ by ${ }^{1} \mathrm{H}$ NMR analysis of the unpurified product mixture.

$\mathrm{R}_{f}=0.29\left(5 \%\right.$ methanol-dichloromethane; UV, CAM). ${ }^{1} \mathrm{H}$ NMR (400 MHz, $\left.\mathrm{CDCl}_{3}\right) \delta 7.48-7.41$ (m, 2H, SPh), 7.29 (t, $J=7.3 \mathrm{~Hz}, 2 \mathrm{H}, \mathrm{SPh}), 7.25-7.20(\mathrm{~m}, 1 \mathrm{H}, \mathrm{SPh}), 5.59$ (dd, $J=5.8,1.7 \mathrm{~Hz}$, $\left.1 \mathrm{H}, \mathrm{H}_{1^{\prime}}\right), 4.96\left(\mathrm{~d}, J=3.6 \mathrm{~Hz}, 1 \mathrm{H}, \mathrm{H}_{1}\right), 4.17\left(\mathrm{dq}, J=9.2,6.3 \mathrm{~Hz}, 1 \mathrm{H}, \mathrm{H}_{5^{\prime}}\right), 3.98(\mathrm{dq}, J=9.2,6.2 \mathrm{~Hz}$, $\left.1 \mathrm{H}, \mathrm{H}_{5}\right), 3.53\left(\mathrm{~s}, 3 \mathrm{H}, \mathrm{OCH}_{3}\right), 3.52-3.45\left(\mathrm{~m}, 1 \mathrm{H}, \mathrm{H}_{3^{\prime}}\right), 3.37\left(\mathrm{~s}, 3 \mathrm{H}, \mathrm{OCH}_{3}\right), 3.19(\mathrm{t}, J=8.9 \mathrm{~Hz}, 1 \mathrm{H}$, $\mathrm{H}_{4^{\prime}}$ ), 3.05 (ddd, $\left.J=12.6,10.0,4.1 \mathrm{~Hz}, 1 \mathrm{H}, \mathrm{H}_{3}\right), 2.87$ (t, $\left.J=9.6 \mathrm{~Hz}, 1 \mathrm{H}, \mathrm{H}_{4}\right), 2.48$ (ddd, $J=13.5$, 4.9, $\left.1.7 \mathrm{~Hz}, 1 \mathrm{H}, \mathrm{H}_{2^{\prime}}\right), 2.36\left(\mathrm{~s}, 6 \mathrm{H}, 2 \times \mathrm{NCH}_{3}\right), 2.01-1.88\left(\mathrm{~m}, 2 \mathrm{H}, \mathrm{H}_{2}, \mathrm{H}_{2^{\prime}}\right), 1.62(\mathrm{td}, J=12.7,3.9$ $\left.\left.\mathrm{Hz}, 1 \mathrm{H}, \mathrm{H}_{2}\right), 1.27\left(\mathrm{~d}, J=6.2 \mathrm{~Hz}, 3 \mathrm{H}, \mathrm{H}_{6}\right), 1.24\left(\mathrm{~d}, J=6.3 \mathrm{~Hz}, 3 \mathrm{H}, \mathrm{H}_{6}\right)^{\prime}\right) .{ }^{13} \mathrm{C}$ NMR $(151 \mathrm{MHz}$, $\left.\mathrm{CDCl}_{3}\right) \delta 135.3(\mathrm{C}), 131.1(2 \times \mathrm{CH}), 129.0(2 \times \mathrm{CH}), 127.1(\mathrm{CH}), 98.6(\mathrm{CH}), 83.6(\mathrm{CH}), 82.3$ $(\mathrm{CH}), 82.2(\mathrm{CH}), 77.3(\mathrm{CH}), 68.6(\mathrm{CH}), 68.4(\mathrm{CH}), 60.4(\mathrm{CH}), 59.4\left(\mathrm{CH}_{3}\right), 56.6\left(\mathrm{CH}_{3}\right), 40.8(2 \times$ $\left.\mathrm{CH}_{3}\right), 35.4\left(\mathrm{CH}_{2}\right), 28.6\left(\mathrm{CH}_{2}\right), 18.2\left(\mathrm{CH}_{3}\right), 18.2\left(\mathrm{CH}_{3}\right)$. IR (ATR-FTIR), $\mathrm{cm}^{-1}: 2971(\mathrm{~m}), 2933$ (m), $2825(\mathrm{~m}), 2778(\mathrm{~m}), 2359(\mathrm{~m}), 2342(\mathrm{~m})$. HRMS-ESI $(\mathrm{m} / \mathrm{z}):[\mathrm{M}+\mathrm{Na}]^{+}$calculated for $\left[\mathrm{C}_{22} \mathrm{H}_{35} \mathrm{NO}_{5} \mathrm{SNa}\right]^{+} 448.2128$, found 448.2156. $[a]_{D}^{21}=+151.8^{\circ}\left(c=1.0, \mathrm{CHCl}_{3}\right)$.

Hoang et al. "General method for the synthesis of $\alpha$ - or $\beta$-deoxyaminoglycosides bearing S41 basic nitrogen" 
Synthesis of the disaccharide $\mathbf{2 6 \boldsymbol { \beta }}$.

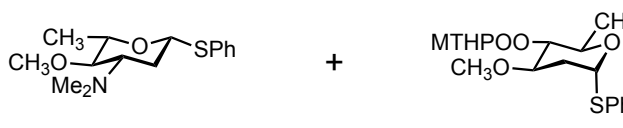

$16 \beta$

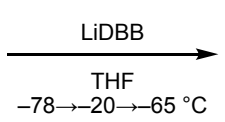

$45 \%,>50: 1 \beta: \alpha$

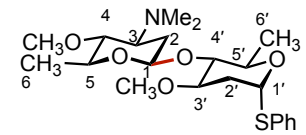

$26 \beta$

A solution of LiDBB in tetrahydrofuran (nominally $0.4 \mathrm{M}$ ) was added dropwise via syringe to a solution of the amine $\mathbf{1 6 \beta}(42.2 \mathrm{mg}, 150 \mu \mathrm{mol}, 2.00$ equiv) in tetrahydrofuran $(1.8 \mathrm{~mL})$ in a 10 $\mathrm{mL}$ round-bottomed flask that had been fused to a Teflon-coated valve at $-78^{\circ} \mathrm{C}$. The addition of LiDBB was continued until a green color persisted (769 $\mu \mathrm{L}$, nominally $308 \mu$ mol, 4.10 equiv). The resulting mixture was stirred for $10 \mathrm{~min}$ at $-78^{\circ} \mathrm{C}$. The reaction vessel was then placed in a bath that had been precooled to $-20{ }^{\circ} \mathrm{C}$. The reaction mixture was stirred for $1 \mathrm{~h}$ at $-20{ }^{\circ} \mathrm{C}$ and then cooled to $-78{ }^{\circ} \mathrm{C}$ over $10 \mathrm{~min}$. A solution of the MTHP monoperoxy acetal $19 \alpha(27.6 \mathrm{mg}$, $75.0 \mu \mathrm{mol}, 1$ equiv) in tetrahydrofuran $(300 \mu \mathrm{L})$ was then added dropwise via syringe. The reaction vessel was then placed in a cryogenic bath that had been precooled to $-65^{\circ} \mathrm{C}$. The mixture was stirred for $6 \mathrm{~h}$ at $-65^{\circ} \mathrm{C}$. The cold product mixture was diluted with saturated aqueous sodium hydrogen carbonate solution $(1.0 \mathrm{~mL})$. The diluted product mixture was allowed to warm to 23 ${ }^{\circ} \mathrm{C}$ over $15 \mathrm{~min}$. The warmed product mixture was transferred to a $20-\mathrm{mL}$ test tube and the layers that formed were separated. The aqueous layer was extracted with ethyl acetate $(4 \times 5.0 \mathrm{~mL})$. The organic layers were combined and the combined organic layers were dried over sodium sulfate. The dried solution was filtered and the filtrate was concentrated under a stream of nitrogen. The residue obtained was purified by flash-column chromatography (eluting with $2 \%$ methanoldichloromethane initially, grading to $5 \%$ methanol-dichloromethane, three steps) to provide the disaccharide $\mathbf{2 6 \beta}$ as a colorless oil (14.5 $\mathrm{mg}, 45 \%)$.

The diastereoselectivity of the reaction was determined to be $>50: 1 \beta: \alpha$ by ${ }^{1} \mathrm{H}$ NMR analysis of the unpurified product mixture.

$\mathrm{R}_{f}=0.33$ (5\% methanol-dichloromethane; UV, CAM). ${ }^{1} \mathrm{H}$ NMR $\left(500 \mathrm{MHz}, \mathrm{CDCl}_{3}\right) \delta 7.46-7.42$ (m, 2H, SPh), $7.31-7.27$ (m, 2H, SPh), $7.25-7.21(\mathrm{~m}, 1 \mathrm{H}, \mathrm{SPh}), 5.58\left(\mathrm{~d}, J=5.5 \mathrm{~Hz}, 1 \mathrm{H}, \mathrm{H}_{1^{\prime}}\right)$, $4.72\left(\mathrm{dd}, J=9.5,2.0 \mathrm{~Hz}, 1 \mathrm{H}, \mathrm{H}_{1}\right), 4.14\left(\mathrm{dq}, J=9.2,6.2 \mathrm{~Hz}, 1 \mathrm{H}, \mathrm{H}_{5^{\prime}}\right), 3.57(\mathrm{ddd}, J=11.5,8.8,4.7$ $\left.\left.\mathrm{Hz}, 1 \mathrm{H}, \mathrm{H}_{3^{\prime}}\right), 3.53\left(\mathrm{~s}, 3 \mathrm{H}, \mathrm{OCH}_{3}\right), 3.42\left(\mathrm{~s}, 3 \mathrm{H}, \mathrm{OCH}_{3}\right), 3.31\left(\mathrm{t}, J=9.1 \mathrm{~Hz}, 1 \mathrm{H}, \mathrm{H}_{4}\right)^{\prime}\right), 3.25(\mathrm{dq}, J=$ 8.5, 6.1 Hz, 1H, H5), $2.82\left(\mathrm{t}, J=9.3 \mathrm{~Hz}, 1 \mathrm{H}, \mathrm{H}_{4}\right), 2.72-2.64\left(\mathrm{~m}, 1 \mathrm{H}, \mathrm{H}_{3}\right), 2.45$ (ddd, $J=13.4,4.9$, $\left.1.4 \mathrm{~Hz}, 1 \mathrm{H}, \mathrm{H}_{2^{\prime}}\right), 2.36\left(\mathrm{~s}, 6 \mathrm{H}, 2 \times \mathrm{NCH}_{3}\right), 2.01\left(\mathrm{~d}, J=12.6 \mathrm{~Hz}, 1 \mathrm{H}, \mathrm{H}_{2}\right), 1.93(\mathrm{ddd}, J=13.2,11.7$, $\left.5.7 \mathrm{~Hz}, 1 \mathrm{H}, \mathrm{H}_{2^{\prime}}\right), 1.46\left(\mathrm{td}, J=12.5,9.5 \mathrm{~Hz}, 1 \mathrm{H}, \mathrm{H}_{2}\right), 1.31\left(\mathrm{~d}, J=5.7 \mathrm{~Hz}, 3 \mathrm{H}, \mathrm{H}_{6}\right), 1.30(\mathrm{~d}, J=5.9$ $\left.\mathrm{Hz}, 3 \mathrm{H}, \mathrm{H}_{6^{\prime}}\right) .{ }^{13} \mathrm{C}$ NMR $\left(126 \mathrm{MHz}, \mathrm{CDCl}_{3}\right) \delta 135.4(\mathrm{C}), 131.4(2 \times \mathrm{CH}), 129.1(2 \times \mathrm{CH}), 127.2$ $(\mathrm{CH}), 101.7(\mathrm{CH}), 84.0(\mathrm{CH}), 81.9(\mathrm{CH}), 81.8(\mathrm{CH}), 79.4(\mathrm{CH}), 72.7(\mathrm{CH}), 68.2(\mathrm{CH}), 64.3(\mathrm{CH})$, $59.9\left(\mathrm{CH}_{3}\right), 57.3\left(\mathrm{CH}_{3}\right), 41.0\left(2 \times \mathrm{CH}_{3}\right), 35.8\left(\mathrm{CH}_{2}\right), 29.7\left(\mathrm{CH}_{2}\right), 18.6\left(\mathrm{CH}_{3}\right), 18.1\left(\mathrm{CH}_{3}\right)$. IR $(\mathrm{ATR}-$ FTIR), $\mathrm{cm}^{-1}$ : 2932 (m), 2829 (m), 2779 (m), 2360 (m), 2342 (m), 1480 (w). HRMS-ESI (m/z): $[\mathrm{M}+\mathrm{Na}]^{+}$calculated for $\left[\mathrm{C}_{22} \mathrm{H}_{35} \mathrm{NO}_{5} \mathrm{SNa}\right]^{+} 448.2128$, found $448.2156 . \quad[a]_{D}^{21}=+140.2^{\circ}(c=0.3$, $\left.\mathrm{CHCl}_{3}\right)$.

Hoang et al. "General method for the synthesis of $\alpha$ - or $\beta$-deoxyaminoglycosides bearing S42 basic nitrogen" 
Synthesis of the disaccharide $\mathbf{2 7 \alpha}$.

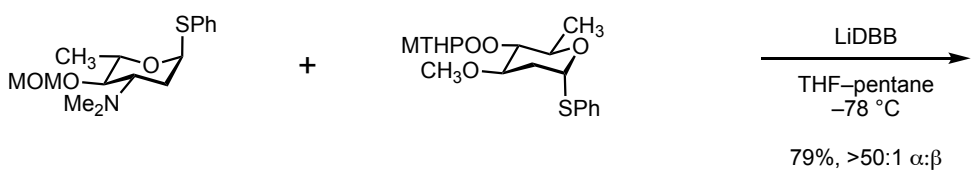

$17 \alpha$

$19 \alpha$

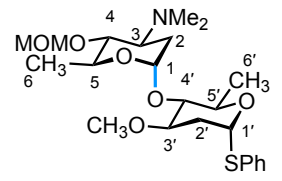

$27 \alpha$

A solution of LiDBB in tetrahydrofuran (nominally $0.4 \mathrm{M}$ ) was added dropwise via syringe to a solution of the amine $17 \alpha(35.0 \mathrm{mg}, 113 \mu \mathrm{mol}, 1.50$ equiv) in tetrahydrofuran-pentane $(1: 1 \mathrm{v} / \mathrm{v}$, $1.8 \mathrm{~mL}$ ) in a $10-\mathrm{mL}$ round-bottomed flask that had been fused to a Teflon-coated valve at $-78^{\circ} \mathrm{C}$. The addition of LiDBB was continued until a green color persisted $(584 \mu \mathrm{L}$, nominally $234 \mu \mathrm{mol}$, 3.10 equiv). The resulting mixture was stirred for $10 \mathrm{~min}$ at $-78{ }^{\circ} \mathrm{C}$. A solution of the MTHP monoperoxy acetal $19 \boldsymbol{\alpha}(27.6 \mathrm{mg}, 75.0 \mu \mathrm{mol}, 1$ equiv) in tetrahydrofuran $(300 \mu \mathrm{L})$ was then added dropwise via syringe. The resulting mixture was stirred for $3 \mathrm{~h}$ at $-78^{\circ} \mathrm{C}$. The cold product mixture was diluted with saturated aqueous sodium hydrogen carbonate solution $(1.0 \mathrm{~mL})$. The diluted product mixture was allowed to warm to $23{ }^{\circ} \mathrm{C}$ over $15 \mathrm{~min}$. The warmed product mixture was transferred to a $20-\mathrm{mL}$ test tube and the layers that formed were separated. The aqueous layer was extracted with ethyl acetate $(4 \times 5.0 \mathrm{~mL})$. The organic layers were combined and the combined organic layers were dried over sodium sulfate. The dried solution was filtered and the filtrate was concentrated under a stream of nitrogen. The residue obtained was purified by flashcolumn chromatography (eluting with $0.5 \%$ triethylamine- $5 \%$ acetone-hexanes initially, grading to $0.5 \%$ triethylamine $-20 \%$ acetone-hexanes, four steps) to provide the disaccharide $\mathbf{2 7} \boldsymbol{\alpha}$ as a colorless oil ( $27.0 \mathrm{mg}, 79 \%)$.

The diastereoselectivity of the reaction was determined to be $>50: 1 \alpha$ : $\beta$ by ${ }^{1} \mathrm{H}$ NMR analysis of the unpurified product mixture.

$\mathrm{R}_{f}=0.35\left(0.5 \%\right.$ triethylamine- $25 \%$ acetone-hexanes; UV, CAM). ${ }^{1} \mathrm{H}$ NMR (400 MHz, $\left.\mathrm{CDCl}_{3}\right)$ $\delta 7.45$ (dt, $J=6.3,1.3 \mathrm{~Hz}, 2 \mathrm{H}, \mathrm{SPh}), 7.29$ (t, $J=7.3 \mathrm{~Hz}, 2 \mathrm{H}, \mathrm{SPh}), 7.25-7.20$ (m, 1H, SPh), 5.59 (dd, $\left.J=5.7,1.8 \mathrm{~Hz}, 1 \mathrm{H}, \mathrm{H}_{1^{\prime}}\right), 4.99\left(\mathrm{~d}, J=3.6 \mathrm{~Hz}, 1 \mathrm{H}, \mathrm{H}_{1}\right), 4.92\left(\mathrm{~d}, J=6.7 \mathrm{~Hz}, 1 \mathrm{H}, \mathrm{CH}_{2}\right), 4.73(\mathrm{~d}$, $\left.J=6.7 \mathrm{~Hz}, 1 \mathrm{H}, \mathrm{CH}_{2}\right), 4.17\left(\mathrm{dq}, J=9.3,6.3 \mathrm{~Hz}, 1 \mathrm{H}, \mathrm{H}_{5^{\prime}}\right), 4.00\left(\mathrm{dq}, J=9.3,6.2 \mathrm{~Hz}, 1 \mathrm{H}, \mathrm{H}_{5}\right), 3.51$ (ddd, $\left.J=11.1,8.5,4.8 \mathrm{~Hz}, 1 \mathrm{H}, \mathrm{H}_{3^{\prime}}\right), 3.44\left(\mathrm{~s}, 3 \mathrm{H}, \mathrm{OCH}_{3}\right), 3.38\left(\mathrm{~s}, 3 \mathrm{H}, \mathrm{OCH}_{3}\right), 3.28-3.15(\mathrm{~m}, 2 \mathrm{H}$, $\left.\mathrm{H}_{4}, \mathrm{H}_{4^{\prime}}\right), 3.08-2.93\left(\mathrm{~m}, 1 \mathrm{H}, \mathrm{H}_{3}\right), 2.48$ (ddd, $\left.J=13.5,4.8,1.8 \mathrm{~Hz}, 1 \mathrm{H}, \mathrm{H}_{2^{\prime}}\right), 2.28\left(\mathrm{~s}, 6 \mathrm{H}, 2 \times \mathrm{NCH}_{3}\right)$, $2.05-1.84\left(\mathrm{~m}, 2 \mathrm{H}, \mathrm{H}_{2}, \mathrm{H}_{2^{\prime}}\right), 1.60\left(\mathrm{td}, J=12.7,3.8 \mathrm{~Hz}, 1 \mathrm{H}, \mathrm{H}_{2}\right), 1.28\left(\mathrm{~d}, J=6.2 \mathrm{~Hz}, 3 \mathrm{H}, \mathrm{H}_{6}\right), 1.24$ $\left(\mathrm{d}, J=6.3 \mathrm{~Hz}, 3 \mathrm{H}, \mathrm{H}_{6^{\prime}}\right) .{ }^{13} \mathrm{C} \mathrm{NMR}\left(151 \mathrm{MHz}, \mathrm{CDCl}_{3}\right) \delta 135.3(\mathrm{C}), 131.1(2 \times \mathrm{CH}), 129.0(2 \times$ $\mathrm{CH}), 127.1(\mathrm{CH}), 98.6(\mathrm{CH}), 97.7\left(\mathrm{CH}_{2}\right), 83.6(\mathrm{CH}), 82.3(\mathrm{CH}), 77.3(\mathrm{CH}), 77.0(\mathrm{CH}), 68.6(\mathrm{CH})$, $68.4(\mathrm{CH}), 61.2(\mathrm{CH}), 56.6\left(\mathrm{CH}_{3}\right), 56.3\left(\mathrm{CH}_{3}\right), 40.4\left(2 \times \mathrm{CH}_{3}\right), 35.4\left(\mathrm{CH}_{2}\right), 26.7\left(\mathrm{CH}_{2}\right), 18.5\left(\mathrm{CH}_{3}\right)$, $18.2\left(\mathrm{CH}_{3}\right)$. IR (ATR-FTIR), cm ${ }^{-1}: 2932(\mathrm{~m}), 2826(\mathrm{~m}), 2778(\mathrm{~m}), 2360(\mathrm{~m}), 1584(\mathrm{w}), 1479(\mathrm{~m})$. HRMS-ESI $(\mathrm{m} / \mathrm{z}):[\mathrm{M}+\mathrm{Na}]^{+}$calculated for $\left[\mathrm{C}_{23} \mathrm{H}_{37} \mathrm{NO}_{6} \mathrm{SNa}\right]^{+} 478.2234$, found 478.2231. [a $]_{D}^{21}$ $=+130.2^{\circ}\left(c=1.0, \mathrm{CHCl}_{3}\right)$.

Hoang et al. "General method for the synthesis of $\alpha$ - or $\beta$-deoxyaminoglycosides bearing 
Synthesis of the disaccharide $\mathbf{2 8 \alpha}$.

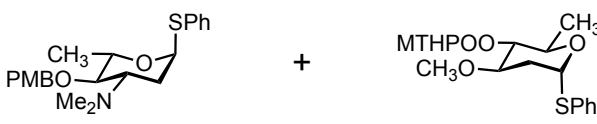

$18 \alpha$

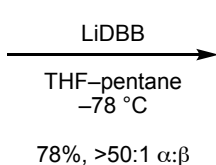

$19 \alpha$

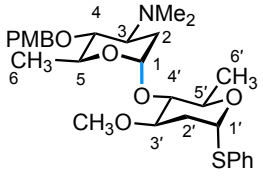

$28 \alpha$

A solution of LiDBB in tetrahydrofuran (nominally $0.4 \mathrm{M}$ ) was added dropwise via syringe to a solution of the amine $\mathbf{1 8 \alpha}(43.6 \mathrm{mg}, 113 \mu \mathrm{mol}, 1.50$ equiv) in tetrahydrofuran-pentane $(1: 1 \mathrm{v} / \mathrm{v}$, $1.8 \mathrm{~mL}$ ) in a $10-\mathrm{mL}$ round-bottomed flask that had been fused to a Teflon-coated valve at $-78{ }^{\circ} \mathrm{C}$. The addition of LiDBB was continued until a green color persisted $(584 \mu \mathrm{L}$, nominally $234 \mu \mathrm{mol}$, 3.10 equiv). The resulting mixture was stirred for $10 \mathrm{~min}$ at $-78{ }^{\circ} \mathrm{C}$. A solution of the MTHP monoperoxy acetal $19 \alpha(27.6 \mathrm{mg}, 75.0 \mu \mathrm{mol}, 1$ equiv $)$ in tetrahydrofuran $(300 \mu \mathrm{L})$ was then added dropwise via syringe. The resulting mixture was stirred for $3 \mathrm{~h}$ at $-78{ }^{\circ} \mathrm{C}$. The cold product mixture was diluted with saturated aqueous sodium hydrogen carbonate solution $(1.0 \mathrm{~mL})$. The diluted product mixture was allowed to warm to $23{ }^{\circ} \mathrm{C}$ over $15 \mathrm{~min}$. The warmed product mixture was transferred to a $20-\mathrm{mL}$ test tube and the layers that formed were separated. The aqueous layer was extracted with ethyl acetate $(4 \times 5.0 \mathrm{~mL})$. The organic layers were combined and the combined organic layers were dried over sodium sulfate. The dried solution was filtered and the filtrate was concentrated under a stream of nitrogen. The residue obtained was purified by flashcolumn chromatography (eluting with $2 \%$ methanol-dichloromethane initially, grading to $5 \%$ methanol-dichloromethane, three steps) to provide the disaccharide $\mathbf{2 8 \alpha}$ as a colorless oil (31.0 $\mathrm{mg}, 78 \%$ ).

The diastereoselectivity of the reaction was determined to be $>50: 1 \alpha: \beta$ by ${ }^{1} \mathrm{H}$ NMR analysis of the unpurified product mixture.

$\mathrm{R}_{f}=0.38$ (5\% methanol-dichloromethane; UV, CAM). ${ }^{1} \mathrm{H}$ NMR (600 MHz, $\left.\mathrm{C}_{6} \mathrm{D}_{6}\right) \delta 7.51-7.46$ (m, 2H, SPh), 7.40 (d, J=8.1 Hz, 2H, PMB), $7.07-7.00$ (m, 2H, SPh), $7.00-6.94$ (m, 1H, SPh), $6.89-6.80(\mathrm{~m}, 2 \mathrm{H}, \mathrm{PMB}), 5.43\left(\mathrm{~d}, J=5.6 \mathrm{~Hz}, 1 \mathrm{H}, \mathrm{H}_{1^{\prime}}\right), 5.05\left(\mathrm{~d}, J=10.6 \mathrm{~Hz}, 1 \mathrm{H}, \mathrm{CH}_{2} \mathrm{Ar}\right), 5.02$ $\left(\mathrm{d}, J=3.5 \mathrm{~Hz}, 1 \mathrm{H}, \mathrm{H}_{1}\right), 4.63\left(\mathrm{~d}, J=10.6 \mathrm{~Hz}, 1 \mathrm{H}, \mathrm{CH}_{2} \mathrm{Ar}\right), 4.39\left(\mathrm{p}, J=10.3,6.6 \mathrm{~Hz}, 1 \mathrm{H}, \mathrm{H}_{5}\right), 4.35$ $\left(\mathrm{p}, J=9.0,6.5 \mathrm{~Hz}, 1 \mathrm{H}, \mathrm{H}_{5^{\prime}}\right), 3.61\left(\mathrm{ddd}, J=11.1,8.5,4.8 \mathrm{~Hz}, 1 \mathrm{H}, \mathrm{H}_{3^{\prime}}\right), 3.40(\mathrm{td}, J=13.1,11.6,4.0$ $\left.\mathrm{Hz}, 1 \mathrm{H}, \mathrm{H}_{3}\right), 3.35\left(\mathrm{t}, J=9.0 \mathrm{~Hz}, 1 \mathrm{H}, \mathrm{H}_{4}{ }^{\prime}\right), 3.31\left(\mathrm{~s}, 3 \mathrm{H}, \mathrm{OCH}_{3}\right), 3.11\left(\mathrm{t}, J=9.6 \mathrm{~Hz}, 1 \mathrm{H}, \mathrm{H}_{4}\right), 3.05(\mathrm{~s}$, $\left.3 \mathrm{H}, \mathrm{OCH}_{3}\right), 2.26-2.23\left(\mathrm{~m}, 7 \mathrm{H}, \mathrm{H}_{2}, 2 \times \mathrm{NCH}_{3}\right), 1.85\left(\mathrm{dd}, J=12.9,4.1 \mathrm{~Hz}, 1 \mathrm{H}, \mathrm{H}_{2}\right), 1.74(\mathrm{td}, J=$ $\left.12.8,12.3,5.8 \mathrm{~Hz}, 1 \mathrm{H}, \mathrm{H}_{2^{\prime}}\right), 1.54\left(\mathrm{~d}, J=6.3 \mathrm{~Hz}, 3 \mathrm{H}, \mathrm{H}_{6}\right), 1.47\left(\mathrm{td}, J=12.8,3.8 \mathrm{~Hz}, 1 \mathrm{H}, \mathrm{H}_{2}\right), 1.19$ $\left(\mathrm{d}, J=6.2 \mathrm{~Hz}, 3 \mathrm{H}, \mathrm{H}_{6^{\prime}}\right) .{ }^{13} \mathrm{C} \mathrm{NMR}\left(151 \mathrm{MHz}, \mathrm{C}_{6} \mathrm{D}_{6}\right) \delta 159.7(\mathrm{C}), 136.3(\mathrm{C}), 132.2(\mathrm{C}), 131.2(2 \times$ $\mathrm{CH}), 129.8(2 \times \mathrm{CH}), 129.1(2 \times \mathrm{CH}), 127.0(\mathrm{CH}), 114.0(2 \times \mathrm{CH}), 98.6(\mathrm{CH}), 83.8(\mathrm{CH}), 82.1$ $(\mathrm{CH}), 80.2(\mathrm{CH}), 77.8(\mathrm{CH}), 74.0\left(\mathrm{CH}_{2}\right), 69.1(\mathrm{CH}), 68.8(\mathrm{CH}), 61.8(\mathrm{CH}), 56.2\left(\mathrm{CH}_{3}\right), 54.8\left(\mathrm{CH}_{3}\right)$, $40.7\left(2 \times \mathrm{CH}_{3}\right), 35.8\left(\mathrm{CH}_{2}\right), 28.1\left(\mathrm{CH}_{2}\right), 18.9\left(\mathrm{CH}_{3}\right), 18.4\left(\mathrm{CH}_{3}\right)$. IR (ATR-FTIR), $\mathrm{cm}^{-1}: 2933(\mathrm{~m})$, $2830(\mathrm{~m}), 2777(\mathrm{~m}), 2359(\mathrm{~m}), 2340(\mathrm{~m}), 1612(\mathrm{~m})$. HRMS-ESI (m/z): $[\mathrm{M}+\mathrm{Na}]^{+}$calculated for $\left[\mathrm{C}_{29} \mathrm{H}_{41} \mathrm{NO}_{6} \mathrm{SNa}\right]^{+}$554.2547, found 554.2568. $[a]_{D}^{21}=+132.4^{\circ}\left(c=1.0, \mathrm{CHCl}_{3}\right)$.

Hoang et al. "General method for the synthesis of $\alpha$ - or $\beta$-deoxyaminoglycosides bearing S44 basic nitrogen" 
Synthesis of the disaccharide $\mathbf{2 9 \alpha}$.

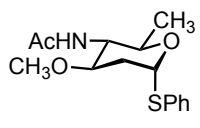

$15 \alpha$

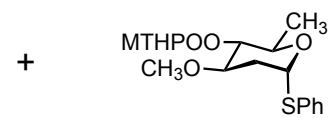

$19 \alpha$

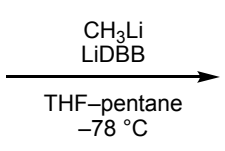

$80 \%,>50: 1 \alpha: \beta$

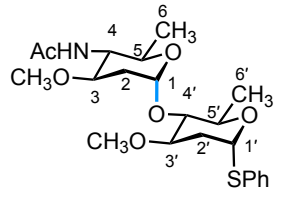

$29 \alpha$

A solution of methyllithium in ether $(1.40 \mathrm{M}, 80.0 \mu \mathrm{L}, 113 \mu \mathrm{mol}, 1.50$ equiv $)$ was added dropwise via syringe to a solution of the amine $15 \boldsymbol{\alpha}(33.2 \mathrm{mg}, 113 \mu \mathrm{mol}, 1.50$ equiv) in tetrahydrofuranpentane $(1: 1 \mathrm{v} / \mathrm{v}, 1.8 \mathrm{~mL})$ in a $10-\mathrm{mL}$ round-bottomed flask that had been fused to a Teflon-coated valve at $-78^{\circ} \mathrm{C}$. The resulting mixture was stirred for $30 \mathrm{~min}$ at $-78^{\circ} \mathrm{C}$. A solution of $\mathrm{LiDBB}$ in tetrahydrofuran (nominally $0.4 \mathrm{M}$ ) was then added dropwise via syringe. The addition of LiDBB was continued until a green color persisted $(584 \mu \mathrm{L}$, nominally $234 \mu \mathrm{mol}, 3.10$ equiv). The resulting mixture was stirred for $10 \mathrm{~min}$ at $-78{ }^{\circ} \mathrm{C}$. A solution of the MTHP monoperoxy acetal $19 \alpha(27.6 \mathrm{mg}, 75.0 \mu \mathrm{mol}, 1$ equiv) in tetrahydrofuran $(300 \mu \mathrm{L})$ was then added dropwise via syringe. The resulting mixture was stirred for $3 \mathrm{~h}$ at $-78^{\circ} \mathrm{C}$. The cold product mixture was diluted with saturated aqueous sodium hydrogen carbonate solution $(1.0 \mathrm{~mL})$. The diluted product mixture was allowed to warm to $23{ }^{\circ} \mathrm{C}$ over $15 \mathrm{~min}$. The warmed product mixture was transferred to a 20 $\mathrm{mL}$ test tube and the layers that formed were separated. The aqueous layer was extracted with ethyl acetate $(4 \times 5.0 \mathrm{~mL})$. The organic layers were combined and the combined organic layers were dried over sodium sulfate. The dried solution was filtered and the filtrate was concentrated under a stream of nitrogen. The residue obtained was purified by flash-column chromatography (eluting with $0.5 \%$ triethylamine-10\% ethyl acetate-dichloromethane initially, grading to $0.5 \%$ triethylamine- $50 \%$ ethyl acetate-dichloromethane, five steps) to provide the disaccharide $\mathbf{2 9 \alpha}$ as a colorless oil $(26.4 \mathrm{mg}, 80 \%)$.

The diastereoselectivity of the reaction was determined to be $>50: 1 \alpha: \beta$ by ${ }^{1} \mathrm{H}$ NMR analysis of the unpurified product mixture.

$\mathrm{R}_{f}=0.27\left(0.5 \%\right.$ triethylamine- $60 \%$ ethyl acetate-dichloromethane; UV, CAM). ${ }^{1} \mathrm{H}$ NMR (600 $\left.\mathrm{MHz}, \mathrm{C}_{6} \mathrm{D}_{6}\right) \delta 7.52(\mathrm{dd}, J=8.2,1.3 \mathrm{~Hz}, 2 \mathrm{H}, \mathrm{SPh}), 7.05(\mathrm{t}, J=7.7 \mathrm{~Hz}, 2 \mathrm{H}, \mathrm{SPh}), 7.01-6.94(\mathrm{~m}$, $1 \mathrm{H}, \mathrm{SPh}), 5.54\left(\mathrm{dd}, J=4.1,1.8 \mathrm{~Hz}, 1 \mathrm{H}, \mathrm{H}_{1}\right), 5.46\left(\mathrm{dd}, J=5.6,1.5 \mathrm{~Hz}, 1 \mathrm{H}, \mathrm{H}_{1^{\prime}}\right), 4.89(\mathrm{~d}, J=8.8$ $\mathrm{Hz}, 1 \mathrm{H}, \mathrm{NH}), 4.47\left(\mathrm{dq}, J=9.4,6.2 \mathrm{~Hz}, 1 \mathrm{H}, \mathrm{H}_{5}\right), 3.95\left(\mathrm{dq}, J=9.9,6.2 \mathrm{~Hz}, 1 \mathrm{H}, \mathrm{H}_{5^{\prime}}\right), 3.85(\mathrm{q}, J=$ $\left.9.5 \mathrm{~Hz}, 1 \mathrm{H}, \mathrm{H}_{4}\right), 3.73-3.59\left(\mathrm{~m}, 2 \mathrm{H}, \mathrm{H}_{3}, \mathrm{H}_{3^{\prime}}\right), 3.42\left(\mathrm{t}, J=8.9 \mathrm{~Hz}, 1 \mathrm{H}, \mathrm{H}_{4}{ }^{\prime}\right), 3.17\left(\mathrm{~s}, 3 \mathrm{H}, \mathrm{OCH}_{3}\right)$, $3.00\left(\mathrm{~s}, 3 \mathrm{H}, \mathrm{OCH}_{3}\right), 2.33\left(\mathrm{ddd}, J=12.7,4.7,1.8 \mathrm{~Hz}, 1 \mathrm{H}, \mathrm{H}_{2}\right), 2.23(\mathrm{ddd}, J=13.4,4.8,1.5 \mathrm{~Hz}, 1 \mathrm{H}$, $\mathrm{H}_{2^{\prime}}$ ), 1.71 (ddd, $J=13.4,11.6,5.7 \mathrm{~Hz}, 1 \mathrm{H}, \mathrm{H}_{2^{\prime}}$ ), 1.64 (ddd, $\left.J=12.8,11.0,4.0 \mathrm{~Hz}, 1 \mathrm{H}, \mathrm{H}_{2}\right), 1.61$ (s, $\left.3 \mathrm{H}, \mathrm{CH}_{3}\right), 1.53\left(\mathrm{~d}, J=6.2 \mathrm{~Hz}, 3 \mathrm{H}, \mathrm{H}_{6^{\prime}}\right), 1.34\left(\mathrm{~d}, J=6.3 \mathrm{~Hz}, 3 \mathrm{H}, \mathrm{H}_{6}\right) .{ }^{13} \mathrm{C} \mathrm{NMR}\left(151 \mathrm{MHz}, \mathrm{C}_{6} \mathrm{D}_{6}\right)$ $\delta 169.2(\mathrm{C}), 136.2(\mathrm{C}), 131.1(2 \times \mathrm{CH}), 129.2(2 \times \mathrm{CH}), 127.1(\mathrm{CH}), 99.2(\mathrm{CH}), 84.0(\mathrm{CH}), 81.8$ $(\mathrm{CH}), 80.2(\mathrm{CH}), 75.1(\mathrm{CH}), 68.7(\mathrm{CH}), 68.4(\mathrm{CH}), 56.8(\mathrm{CH}), 56.1\left(\mathrm{CH}_{3}\right), 55.4\left(\mathrm{CH}_{3}\right), 35.7\left(\mathrm{CH}_{2}\right)$, $35.6\left(\mathrm{CH}_{2}\right), 23.3\left(\mathrm{CH}_{3}\right), 18.9\left(\mathrm{CH}_{3}\right), 18.4\left(\mathrm{CH}_{3}\right)$. IR (ATR-FTIR), $\mathrm{cm}^{-1}: 3273$ (br w), $2975(\mathrm{~m})$, $2934(\mathrm{~m}), 2828(\mathrm{w}), 2359(\mathrm{~m}), 2342(\mathrm{~m}), 1655(\mathrm{~s})$. HRMS-ESI $(\mathrm{m} / \mathrm{z}):[\mathrm{M}+\mathrm{H}]^{+}$calculated for $\left[\mathrm{C}_{22} \mathrm{H}_{34} \mathrm{NO}_{6} \mathrm{~S}\right]^{+} 440.2101$, found $440.2098 .[a]_{D}^{21}=+271.8^{\circ}\left(c=1.0, \mathrm{CHCl}_{3}\right)$.

Hoang et al. "General method for the synthesis of $\alpha$ - or $\beta$-deoxyaminoglycosides bearing S45 basic nitrogen" 
Synthesis of the ether $\mathbf{S 1 6 .}$

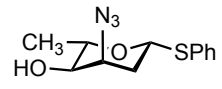

(3R)-S12 $\beta$

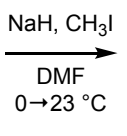

$99 \%$

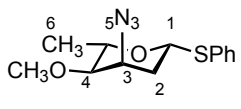

S16

Sodium hydride (60\% dispersion in mineral oil, $72.4 \mathrm{mg}, 1.81 \mathrm{mmol}, 1.20$ equiv) was added in one portion to a solution of the alcohol (3R)-S12 $\beta$ (400 mg, $1.51 \mathrm{mmol}$, 1 equiv) in $N, N$ dimethylformamide $(15 \mathrm{~mL})$ at $0{ }^{\circ} \mathrm{C}$. The resulting mixture was warmed to $23{ }^{\circ} \mathrm{C}$. The mixture was stirred for $30 \mathrm{~min}$ at $23{ }^{\circ} \mathrm{C}$ and then was cooled to $0{ }^{\circ} \mathrm{C}$. Methyl iodide $(122 \mu \mathrm{L}, 1.96 \mathrm{mmol}$, 1.30 equiv) was added dropwise to the mixture. Upon completion of the addition, the cooling bath was removed and the reaction mixture was allowed to warm to $23{ }^{\circ} \mathrm{C}$. The reaction mixture was stirred for $2 \mathrm{~h}$ at $23{ }^{\circ} \mathrm{C}$. The product mixture was diluted sequentially with saturated aqueous ammonium chloride solution $(100 \mathrm{~mL})$ and ethyl acetate $(50 \mathrm{~mL})$. The resulting mixture was transferred to a separatory funnel and the layers that formed were separated. The aqueous layer was extracted with ethyl acetate $(3 \times 50 \mathrm{~mL})$. The organic layers were combined and the combined organic layers were washed sequentially with saturated aqueous sodium chloride solution $(20 \mathrm{~mL})$ and saturated aqueous sodium thiosulfate solution $(20 \mathrm{~mL})$. The washed organic layer was dried over sodium sulfate. The dried solution was filtered and the filtrate was concentrated. The residue obtained was purified by flash-column chromatography (eluting with 5\% ether-hexanes initially, grading to $15 \%$ ether-hexanes, three steps) to provide the ether $\mathbf{S 1 6}$ as a clear, colorless oil [420 $\mathrm{mg}, 99 \%, \beta$ diastereomer only ( ${ }^{1} \mathrm{H}$ NMR analysis)].

$\mathrm{R}_{f}=0.26\left(10 \%\right.$ ether-hexanes; UV, CAM). ${ }^{1} \mathrm{H}$ NMR $\left(400 \mathrm{MHz}, \mathrm{CDCl}_{3}\right) \delta 7.50-7.46(\mathrm{~m}, 2 \mathrm{H}$, $\mathrm{SPh}), 7.36-7.27(\mathrm{~m}, 3 \mathrm{H}, \mathrm{SPh}), 5.02\left(\mathrm{dd}, J=11.6,2.0 \mathrm{~Hz}, 1 \mathrm{H}, \mathrm{H}_{1}\right), 4.26\left(\mathrm{q}, J=3.3 \mathrm{~Hz}, 1 \mathrm{H}, \mathrm{H}_{3}\right)$, $3.83\left(\mathrm{dq}, J=9.3,6.2 \mathrm{~Hz}, 1 \mathrm{H}, \mathrm{H}_{5}\right), 3.45\left(\mathrm{~s}, 3 \mathrm{H}, \mathrm{OCH}_{3}\right), 3.03\left(\mathrm{dd}, J=9.3,3.2 \mathrm{~Hz}, 1 \mathrm{H}, \mathrm{H}_{4}\right), 2.17$ $\left(\mathrm{ddd}, J=13.9,3.4,2.0 \mathrm{~Hz}, 1 \mathrm{H}, \mathrm{H}_{2}\right), 1.90\left(\mathrm{ddd}, J=14.0,11.6,3.2 \mathrm{~Hz}, 1 \mathrm{H}, \mathrm{H}_{2}\right), 1.32(\mathrm{~d}, J=6.2 \mathrm{~Hz}$, $\left.3 \mathrm{H}, \mathrm{H}_{6}\right) .{ }^{13} \mathrm{C} \mathrm{NMR}\left(151 \mathrm{MHz}, \mathrm{CDCl}_{3}\right) \delta 133.9(\mathrm{C}), 131.5(2 \times \mathrm{CH}), 129.0(2 \times \mathrm{CH}), 127.5(\mathrm{CH})$, $82.8(\mathrm{CH}), 79.6(\mathrm{CH}), 72.1(\mathrm{CH}), 57.6\left(\mathrm{CH}_{3}\right), 57.0(\mathrm{CH}), 36.3\left(\mathrm{CH}_{2}\right), 18.4\left(\mathrm{CH}_{3}\right)$. IR (ATR-FTIR), $\mathrm{cm}^{-1}: 2976(\mathrm{w}), 2934(\mathrm{~m}), 2884(\mathrm{~m}), 2830(\mathrm{w}), 2362(\mathrm{~m}), 2114(\mathrm{~s}), 1584(\mathrm{~m})$. HRMS-ESI (m/z): $[\mathrm{M}+\mathrm{H}]^{+}$calculated for $\left[\mathrm{C}_{13} \mathrm{H}_{18} \mathrm{~N}_{3} \mathrm{O}_{2} \mathrm{~S}\right]^{+} 280.1114$, found $280.1120 . \quad[a]_{D}^{21}=-52.2^{\circ}(c=1.0$, $\left.\mathrm{CHCl}_{3}\right)$. 
Synthesis of the amine $30 \boldsymbol{\beta}$.

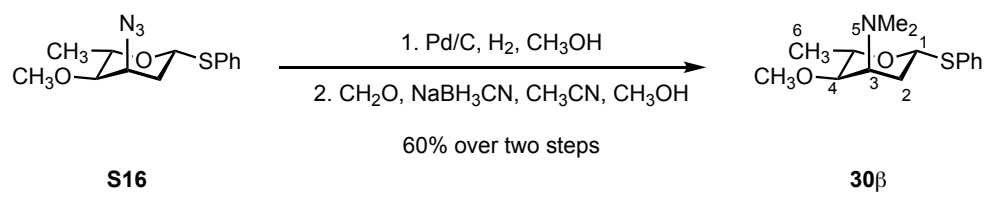

Palladium ( $10 \mathrm{wt} \%$ on carbon, $45.7 \mathrm{mg}, 430 \mu \mathrm{mol}, 0.20$ equiv) was added in one portion to a solution of the ether $\mathbf{S 1 6}\left(600 \mathrm{mg}, 2.15 \mathrm{mmol}, 1\right.$ equiv) in methanol $(22 \mathrm{~mL})$ at $23^{\circ} \mathrm{C}$. The reaction vessel was fitted with a rubber septum and the septum was penetrated with a needle. A balloon of dihydrogen was fixed to the vessel and the solution was sparged with dihydrogen for $10 \mathrm{~min}$. The needle and emptied balloon were removed and the suspension was stirred under a fresh balloon of dihydrogen for $18 \mathrm{~h}$ at $23{ }^{\circ} \mathrm{C}$. The product mixture was filtered through a bed of celite and the filter cake was washed with ethyl acetate $(3 \times 25 \mathrm{~mL})$. The filtrates were combined and the combined filtrates were concentrated. The residue obtained was employed directly in the following step.

Aqueous formaldehyde ( $37 \mathrm{wt} \%, 1.60 \mathrm{~mL}, 21.5 \mathrm{mmol}, 10.0$ equiv), sodium cyanoborohydride (946 mg, $15.1 \mathrm{mmol}, 7.00$ equiv), and methanol $(2.0 \mathrm{~mL})$ were added in sequence to a solution of the unpurified amine prepared in the preceding step (nominally $2.15 \mathrm{mmol}, 1$ equiv) in acetonitrile $(22 \mathrm{~mL})$ at $23{ }^{\circ} \mathrm{C}$. The resulting mixture was stirred for $18 \mathrm{~h}$ at $23{ }^{\circ} \mathrm{C}$. The product mixture was diluted sequentially with saturated aqueous sodium hydrogen carbonate solution $(100 \mathrm{~mL})$ and ethyl acetate $(100 \mathrm{~mL})$. The resulting biphasic mixture was transferred to a separatory funnel and the layers that formed were separated. The aqueous layer was extracted with ethyl acetate $(4 \times 50$ $\mathrm{mL}$ ). The organic layers were combined and the combined organic layers were washed with saturated aqueous sodium chloride solution $(2 \times 20 \mathrm{~mL})$. The washed organic layer was dried over sodium sulfate. The dried solution was filtered and the filtrate was concentrated. The residue obtained was purified by flash-column chromatography (eluting with $0.5 \%$ triethylamine- $5 \%$ acetone-hexanes initially, grading to $0.5 \%$ triethylamine $-15 \%$ acetone-hexanes, four steps) to provide the amine $\mathbf{3 0} \boldsymbol{\beta}$ as a clear oil $\left[120 \mathrm{mg}, 25 \%\right.$ over two steps, $\beta$ diastereomer only $\left({ }^{1} \mathrm{H}\right.$ NMR analysis)].

$\mathrm{R}_{f}=0.41(0.5 \%$ triethylamine- $20 \%$ acetone-hexanes; UV, CAM $) .{ }^{1} \mathrm{H}$ NMR $\left(600 \mathrm{MHz}, \mathrm{CDCl}_{3}\right)$ $\delta 7.50-7.44$ (m, 2H, SPh), 7.29 (t, $J=7.6 \mathrm{~Hz}, 2 \mathrm{H}, \mathrm{SPh}), 7.25-7.21$ (m, $1 \mathrm{H}, \mathrm{SPh}), 5.33$ (dd, $J=$ 9.2, $\left.4.1 \mathrm{~Hz}, 1 \mathrm{H}, \mathrm{H}_{1}\right), 4.14$ (qd, $\left.J=6.6,4.7 \mathrm{~Hz}, 1 \mathrm{H}, \mathrm{H}_{5}\right), 3.36\left(\mathrm{~s}, 3 \mathrm{H}, \mathrm{OCH}_{3}\right), 3.20$ (br s, $\left.1 \mathrm{H}, \mathrm{H}_{4}\right)$, 2.61 (br s, $1 \mathrm{H}, \mathrm{H}_{3}$ ), 2.33 (s, $6 \mathrm{H}, 2 \times \mathrm{NCH}_{3}$ ), 2.26 (ddd, $J=13.6,7.6,4.2 \mathrm{~Hz}, 1 \mathrm{H}, \mathrm{H}_{2}$ ), 1.89 (ddd, $J$ $\left.=13.8,9.2,4.9 \mathrm{~Hz}, 1 \mathrm{H}, \mathrm{H}_{2}\right), 1.33\left(\mathrm{~d}, J=6.6 \mathrm{~Hz}, 3 \mathrm{H}, \mathrm{H}_{6}\right) .{ }^{13} \mathrm{C} \mathrm{NMR}\left(151 \mathrm{MHz}, \mathrm{CDCl}_{3}\right) \delta 135.4$ (C), $130.7(2 \times \mathrm{CH}), 128.9(2 \times \mathrm{CH}), 126.9(\mathrm{CH}), 82.9(\mathrm{CH}), 80.3(\mathrm{CH}), 73.2(\mathrm{CH}), 58.6(\mathrm{CH})$, $57.2\left(\mathrm{CH}_{3}\right), 44.1\left(2 \times \mathrm{CH}_{3}\right), 33.1\left(\mathrm{CH}_{2}\right), 19.7\left(\mathrm{CH}_{3}\right)$. IR (ATR-FTIR), $\mathrm{cm}^{-1}: 2975(\mathrm{~m}), 2932(\mathrm{~m})$, $2886(\mathrm{~m}), 2820(\mathrm{~m}), 2774(\mathrm{~m}), 2359(\mathrm{~m}), 2338(\mathrm{~m}), 1584(\mathrm{~m})$. HRMS-ESI (m/z): $[\mathrm{M}+\mathrm{H}]^{+}$ calculated for $\left[\mathrm{C}_{15} \mathrm{H}_{24} \mathrm{NO}_{2} \mathrm{~S}\right]^{+} 282.1522$, found 282.1533. $[a]_{D}^{21}=+67.9^{\circ}\left(c=1.0, \mathrm{CHCl}_{3}\right)$.

Hoang et al. "General method for the synthesis of $\alpha$ - or $\beta$-deoxyaminoglycosides bearing S47 basic nitrogen" 
Synthesis of the ether $\mathbf{S 1 7 .}$

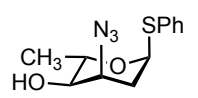

(3R)-S12 $\alpha$

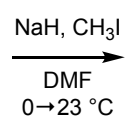

$86 \%$

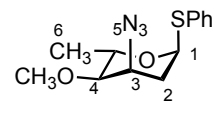

S17

Sodium hydride (60\% dispersion in mineral oil, $199 \mathrm{mg}, 4.98 \mathrm{mmol}, 1.20$ equiv) was added in one portion to a solution of the alcohol (3R)-S12a (1.10 g, $4.15 \mathrm{mmol}, 1$ equiv) in $N, N$ dimethylformamide $(42 \mathrm{~mL})$ at $0{ }^{\circ} \mathrm{C}$. The resulting mixture was warmed to $23{ }^{\circ} \mathrm{C}$. The mixture was stirred for $30 \mathrm{~min}$ at $23^{\circ} \mathrm{C}$ and then was cooled to $0{ }^{\circ} \mathrm{C}$. Methyl iodide $(336 \mu \mathrm{L}, 5.39 \mathrm{mmol}$, 1.30 equiv) was added dropwise to the mixture. Upon completion of the addition, the cooling bath was removed and the reaction mixture was allowed to warm to $23{ }^{\circ} \mathrm{C}$. The reaction mixture was stirred for $2 \mathrm{~h}$ at $23{ }^{\circ} \mathrm{C}$. The product mixture was diluted sequentially with saturated aqueous ammonium chloride solution $(400 \mathrm{~mL})$ and ethyl acetate $(75 \mathrm{~mL})$. The resulting mixture was transferred to a separatory funnel and the layers that formed were separated. The aqueous layer was extracted with ethyl acetate $(3 \times 75 \mathrm{~mL})$. The organic layers were combined and the combined organic layers were washed sequentially with saturated aqueous sodium chloride solution $(50 \mathrm{~mL})$ and saturated aqueous sodium thiosulfate solution $(100 \mathrm{~mL})$. The washed organic layer was dried over sodium sulfate. The dried solution was filtered and the filtrate was concentrated. The residue obtained was purified by flash-column chromatography (eluting with 5\% ether-hexanes initially, grading to $15 \%$ ether-hexanes, three steps) to provide the ether $\mathbf{S 1 7}$ as a yellow oil [1.00 g, 86\%, $\alpha$ diastereomer only ( ${ }^{1} \mathrm{H}$ NMR analysis)].

$\mathrm{R}_{f}=0.21\left(20 \%\right.$ ether-hexanes; UV, CAM). ${ }^{1} \mathrm{H}$ NMR $\left(400 \mathrm{MHz}, \mathrm{CDCl}_{3}\right) \delta 7.49-7.44(\mathrm{~m}, 2 \mathrm{H}$, $\mathrm{SPh}), 7.31-7.26(\mathrm{~m}, 2 \mathrm{H}, \mathrm{SPh}), 7.24-7.17(\mathrm{~m}, 1 \mathrm{H}, \mathrm{SPh}), 5.40\left(\mathrm{dd}, J=4.7,3.4 \mathrm{~Hz}, 1 \mathrm{H}, \mathrm{H}_{1}\right), 4.45$ $\left(\mathrm{dq}, J=8.9,6.3 \mathrm{~Hz}, 1 \mathrm{H}, \mathrm{H}_{5}\right), 4.22\left(\mathrm{q}, J=3.6 \mathrm{~Hz}, 1 \mathrm{H}, \mathrm{H}_{3}\right), 3.49\left(\mathrm{~s}, 3 \mathrm{H}, \mathrm{OCH}_{3}\right), 3.08(\mathrm{dd}, J=8.9$, $\left.3.4 \mathrm{~Hz}, 1 \mathrm{H}, \mathrm{H}_{4}\right), 2.35-2.31\left(\mathrm{~m}, 2 \mathrm{H}, \mathrm{H}_{2}\right), 1.30\left(\mathrm{~d}, J=6.3 \mathrm{~Hz}, 3 \mathrm{H}, \mathrm{H}_{6}\right) .{ }^{13} \mathrm{C}$ NMR $(151 \mathrm{MHz}$, $\left.\mathrm{CDCl}_{3}\right) \delta 137.4(\mathrm{C}), 130.7(2 \times \mathrm{CH}), 129.0(2 \times \mathrm{CH}), 127.0(\mathrm{CH}), 82.8(\mathrm{CH}), 82.7(\mathrm{CH}), 64.7$ $(\mathrm{CH}), 57.6\left(\mathrm{CH}_{3}\right), 55.1(\mathrm{CH}), 35.2\left(\mathrm{CH}_{2}\right), 17.8\left(\mathrm{CH}_{3}\right)$. IR (ATR-FTIR), $\mathrm{cm}^{-1}: 2933(\mathrm{~m}), 2830(\mathrm{~m})$, $2359(\mathrm{~m}), 2339(\mathrm{~m}), 2102(\mathrm{~s}), 1584(\mathrm{~m})$. HRMS-ESI $(\mathrm{m} / \mathrm{z}):[\mathrm{M}+\mathrm{H}]^{+}$calculated for $\left[\mathrm{C}_{13} \mathrm{H}_{18} \mathrm{~N}_{3} \mathrm{O}_{2} \mathrm{~S}\right]^{+} 280.1114$, found 280.1133. $[a]_{D}^{21}=-407.8^{\circ}\left(c=1.0, \mathrm{CHCl}_{3}\right)$. 
Synthesis of the amine $\mathbf{3 0 \alpha}$.

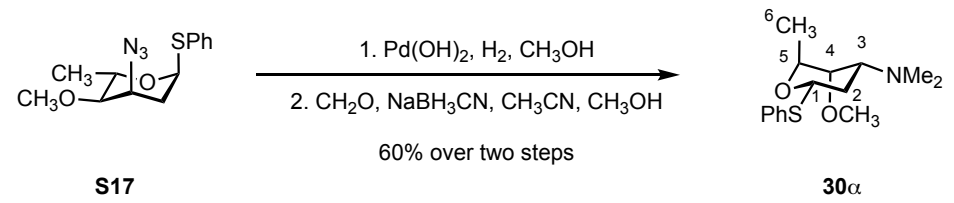

Palladium hydroxide ( $20 \mathrm{wt} \%$ on carbon, $60.3 \mathrm{mg}, 430 \mu \mathrm{mol}, 0.20$ equiv) was added in one portion to a solution of the ether $\mathbf{S 1 7}\left(600 \mathrm{mg}, 2.15 \mathrm{mmol}, 1\right.$ equiv) in methanol $(11 \mathrm{~mL})$ at $23{ }^{\circ} \mathrm{C}$. The reaction vessel was fitted with a rubber septum and the septum was penetrated with a needle. A balloon of dihydrogen was fixed to the vessel and the solution was sparged with dihydrogen for 10 min. The needle and emptied balloon were removed and the suspension was stirred under a fresh balloon of dihydrogen for $18 \mathrm{~h}$ at $23{ }^{\circ} \mathrm{C}$. The product mixture was filtered through a bed of celite and the filter cake was washed with methanol $(3 \times 25 \mathrm{~mL})$. The filtrates were combined and the combined filtrates were concentrated. The residue obtained was employed directly in the following step.

Aqueous formaldehyde ( $37 \mathrm{wt} \%, 1.60 \mathrm{~mL}, 21.5 \mathrm{mmol}, 10.0$ equiv), sodium cyanoborohydride (946 mg, $15.1 \mathrm{mmol}, 7.00$ equiv), and methanol $(1.8 \mathrm{~mL})$ were added in sequence to a solution of the unpurified amine obtained in the preceding step (nominally $2.15 \mathrm{mmol}, 1$ equiv) in acetonitrile $(21 \mathrm{~mL})$ at $23{ }^{\circ} \mathrm{C}$. The reaction vessel was placed in an oil bath that had been preheated to $35^{\circ} \mathrm{C}$. The resulting mixture was stirred and heated for $18 \mathrm{~h}$ at $35^{\circ} \mathrm{C}$. The product mixture cooled to 23 ${ }^{\circ} \mathrm{C}$ over $10 \mathrm{~min}$. The cooled solution was diluted sequentially with saturated aqueous sodium hydrogen carbonate solution $(200 \mathrm{~mL})$ and ethyl acetate $(100 \mathrm{~mL})$. The resulting biphasic mixture was transferred to a separatory funnel and the layers that formed were separated. The aqueous layer was extracted with ethyl acetate $(4 \times 75 \mathrm{~mL})$. The organic layers were combined and the combined organic layers were washed with saturated aqueous sodium chloride solution $(2 \times 30$ $\mathrm{mL}$ ). The washed organic layer was dried over sodium sulfate. The dried solution was filtered and the filtrate was concentrated. The residue obtained was purified by flash-column chromatography (eluting with $0.5 \%$ triethylamine $-5 \%$ acetone-hexanes initially, grading to $0.5 \%$ triethylamine- $15 \%$ acetone-hexanes, four steps) to provide the amine $\mathbf{3 0 \alpha}$ as a yellow oil [ 310 $\mathrm{mg}, 51 \%$ over two steps, $\alpha$ diastereomer only ( ${ }^{1} \mathrm{H}$ NMR analysis)].

$\mathrm{R}_{f}=0.13(0.5 \%$ triethylamine- $20 \%$ acetone-hexanes; $\mathrm{UV}, \mathrm{CAM}) .{ }^{1} \mathrm{H} \mathrm{NMR}\left(400 \mathrm{MHz}, \mathrm{CDCl}_{3}\right)$ $\delta 7.52-7.47$ (m, 2H, SPh), 7.29 (d, $J=7.0 \mathrm{~Hz}, 2 \mathrm{H}, \mathrm{SPh}), 7.24-7.18(\mathrm{~m}, 1 \mathrm{H}, \mathrm{SPh}), 5.18$ (dd, $J=$ 10.7, $\left.4.1 \mathrm{~Hz}, 1 \mathrm{H}, \mathrm{H}_{1}\right), 4.44\left(\mathrm{qd}, J=7.0,2.5 \mathrm{~Hz}, 1 \mathrm{H}, \mathrm{H}_{5}\right), 3.42\left(\mathrm{~s}, 3 \mathrm{H}, \mathrm{OCH}_{3}\right), 3.25\left(\mathrm{~s}, 1 \mathrm{H}, \mathrm{H}_{4}\right)$, $2.43\left(\mathrm{ddd}, J=11.5,4.4,3.0 \mathrm{~Hz}, 1 \mathrm{H}, \mathrm{H}_{3}\right), 2.32\left(\mathrm{~s}, 6 \mathrm{H}, 2 \times \mathrm{NCH}_{3}\right), 2.11-1.94\left(\mathrm{~m}, 2 \mathrm{H}, \mathrm{H}_{2}\right), 1.29(\mathrm{~d}$, $\left.J=7.0 \mathrm{~Hz}, 3 \mathrm{H}, \mathrm{H}_{6}\right) .{ }^{13} \mathrm{C} \mathrm{NMR}\left(151 \mathrm{MHz}, \mathrm{CDCl}_{3}\right) \delta 135.4(\mathrm{C}), 130.8(2 \times \mathrm{CH}), 128.9(2 \times \mathrm{CH})$,

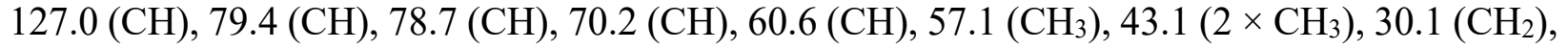
$16.8\left(\mathrm{CH}_{3}\right)$. IR (ATR-FTIR), $\mathrm{cm}^{-1}: 3057(\mathrm{w}), 2974(\mathrm{~m}), 2932(\mathrm{~m}), 2823(\mathrm{~m}), 2775(\mathrm{~m}), 2359(\mathrm{~m})$, $2331(\mathrm{~m}), 1584(\mathrm{~m})$. HRMS-ESI $(\mathrm{m} / \mathrm{z}):[\mathrm{M}+\mathrm{Na}]^{+}$calculated for $\left[\mathrm{C}_{15} \mathrm{H}_{23} \mathrm{NO}_{2} \mathrm{SNa}\right]^{+}$304.1342, found 304.1345. $[a]_{D}^{21}=-80.4^{\circ}\left(c=1.0, \mathrm{CHCl}_{3}\right)$.

Hoang et al. "General method for the synthesis of $\alpha$ - or $\beta$-deoxyaminoglycosides bearing S49 basic nitrogen" 
Synthesis of the ether $\mathbf{S 1 8 .}$

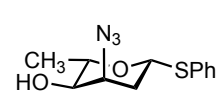

(3R)-S12 $\beta$

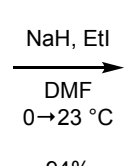

$94 \%$

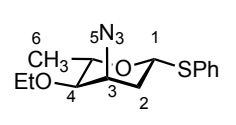

$\mathbf{S 1 8}$

Sodium hydride (60\% dispersion in mineral oil, $36.2 \mathrm{mg}, 905 \mu \mathrm{mol}, 1.20$ equiv) was added in one portion to a solution of the alcohol (3R)-S12及 (200 mg, $754 \mu \mathrm{mol}, 1$ equiv) in $N, N-$ dimethylformamide $(7.5 \mathrm{~mL})$ at $0{ }^{\circ} \mathrm{C}$. Upon completion of the addition, the cooling bath was removed and the reaction mixture was allowed to warm to $23{ }^{\circ} \mathrm{C}$. The mixture was stirred for 30 min at $23{ }^{\circ} \mathrm{C}$ and then was cooled to $0{ }^{\circ} \mathrm{C}$. Ethyl iodide $(79.0 \mu \mathrm{L}, 980 \mu \mathrm{mol}, 1.30$ equiv) was then added dropwise via syringe to the cooled solution. Upon completion of the addition, the cooling bath was removed and the reaction mixture was allowed to warm to $23{ }^{\circ} \mathrm{C}$. The reaction mixture was stirred for $2 \mathrm{~h}$ at $23{ }^{\circ} \mathrm{C}$. The product mixture was diluted sequentially with saturated aqueous ammonium chloride solution $(100 \mathrm{~mL})$ and ethyl acetate $(50 \mathrm{~mL})$. The resulting mixture was transferred to a separatory funnel and the layers that formed were separated. The aqueous layer was extracted with ethyl acetate $(3 \times 50 \mathrm{~mL})$. The organic layers were combined and the combined organic layers were washed sequentially with saturated aqueous sodium chloride solution $(20 \mathrm{~mL})$ and saturated aqueous sodium thiosulfate solution $(20 \mathrm{~mL})$. The washed organic layer was dried over sodium sulfate. The dried solution was filtered and the filtrate was concentrated. The residue obtained was purified by flash-column chromatography (eluting with $2 \%$ ether-hexanes initially, grading to $10 \%$ ether-hexanes, three steps) to provide the ether $\mathbf{S 1 8}$ as a yellow oil [207 $\mathrm{mg}, 94 \%$, $\beta$ diastereomer only ( ${ }^{1} \mathrm{H}$ NMR analysis)].

$\mathrm{R}_{f}=0.33$ (10\% ether-hexanes; UV, CAM). ${ }^{1} \mathrm{H}$ NMR $\left(600 \mathrm{MHz}, \mathrm{CDCl}_{3}\right) \delta 7.51-7.44(\mathrm{~m}, 2 \mathrm{H}$, $\mathrm{SPh}), 7.32-7.27(\mathrm{~m}, 2 \mathrm{H}, \mathrm{SPh}), 7.27-7.24(\mathrm{~m}, 1 \mathrm{H}, \mathrm{SPh}), 5.01\left(\mathrm{dd}, J=11.7,1.9 \mathrm{~Hz}, 1 \mathrm{H}, \mathrm{H}_{1}\right), 4.19$ $\left(\mathrm{q}, J=3.3 \mathrm{~Hz}, 1 \mathrm{H}, \mathrm{H}_{3}\right), 3.84\left(\mathrm{dq}, J=9.4,6.3 \mathrm{~Hz}, 1 \mathrm{H}, \mathrm{H}_{5}\right), 3.71\left(\mathrm{dq}, J=9.1,7.0 \mathrm{~Hz}, 1 \mathrm{H}, \mathrm{CH}_{2}\right)$, $3.50\left(\mathrm{dq}, J=9.1,7.0 \mathrm{~Hz}, 1 \mathrm{H}, \mathrm{CH}_{2}\right), 3.13\left(\mathrm{dd}, J=9.3,3.3 \mathrm{~Hz}, 1 \mathrm{H}, \mathrm{H}_{4}\right), 2.14(\mathrm{ddd}, J=13.9,3.4,2.0$ $\left.\mathrm{Hz}, 1 \mathrm{H}, \mathrm{H}_{2}\right), 1.89$ (ddd, $\left.J=13.9,11.6,3.2 \mathrm{~Hz}, 1 \mathrm{H}, \mathrm{H}_{2}\right), 1.31\left(\mathrm{~d}, J=6.2 \mathrm{~Hz}, 3 \mathrm{H}, \mathrm{H}_{6}\right), 1.23(\mathrm{t}, J=$ $\left.7.0 \mathrm{~Hz}, 3 \mathrm{H}, \mathrm{CH}_{3}\right) .{ }^{13} \mathrm{C} \mathrm{NMR}\left(151 \mathrm{MHz}, \mathrm{CDCl}_{3}\right) \delta 134.0(\mathrm{C}), 131.5(2 \times \mathrm{CH}), 129.0(2 \times \mathrm{CH})$, $127.5(\mathrm{CH}), 81.0(\mathrm{CH}), 79.6(\mathrm{CH}), 72.2(\mathrm{CH}), 65.5\left(\mathrm{CH}_{2}\right), 57.8(\mathrm{CH}), 36.4\left(\mathrm{CH}_{2}\right), 18.4\left(\mathrm{CH}_{3}\right), 15.5$ $\left(\mathrm{CH}_{3}\right)$. IR (ATR-FTIR), $\mathrm{cm}^{-1}: 2976(\mathrm{~m}), 2931(\mathrm{~m}), 2884(\mathrm{~m}), 2359(\mathrm{~m}), 2337(\mathrm{~m}), 2117(\mathrm{~s}), 1584$ (m). HRMS-ESI (m/z): $[\mathrm{M}+\mathrm{H}]^{+}$calculated for $\left[\mathrm{C}_{14} \mathrm{H}_{20} \mathrm{~N}_{3} \mathrm{O}_{2} \mathrm{~S}\right]^{+}$294.1271, found 294.1286. [a $]_{D}^{21}$ $=-22.2^{\circ}\left(c=1.0, \mathrm{CHCl}_{3}\right)$. 
Synthesis of the amine $\mathbf{3 1 \beta}$.

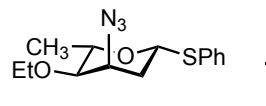

S18

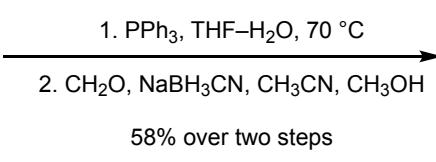

$58 \%$ over two steps

Triphenylphosphine (160 mg, $1.36 \mathrm{mmol}, 2.50$ equiv) and deionized water (3.6 mL) were added in sequence to a solution of the ether $\mathbf{S 1 8}(160 \mathrm{mg}, 545 \mu \mathrm{mol}, 1$ equiv) in tetrahydrofuran $(11 \mathrm{~mL})$ at $23{ }^{\circ} \mathrm{C}$. The reaction vessel was fitted with a reflux condenser and then placed in an oil bath that had been preheated to $70{ }^{\circ} \mathrm{C}$. The reaction mixture was stirred and heated for $18 \mathrm{~h}$ at $70{ }^{\circ} \mathrm{C}$. The product mixture was cooled to $23{ }^{\circ} \mathrm{C}$. The cooled product mixture was diluted sequentially with $1 \mathrm{~N}$ aqueous hydrochloric acid solution $(10 \mathrm{~mL})$ and hexanes-ether $(1: 1 \mathrm{v} / \mathrm{v}, 20 \mathrm{~mL})$. The resulting mixture was transferred to a separatory funnel and the layers that formed were separated. The aqueous layer was extracted with hexanes-ether $(1: 1 \mathrm{v} / \mathrm{v}, 3 \times 20 \mathrm{~mL})$. The aqueous layer was then diluted sequentially with $2 \mathrm{~N}$ aqueous sodium hydroxide solution $(10 \mathrm{~mL})$ and hexanes-ether $(1: 1$ $\mathrm{v} / \mathrm{v}, 30 \mathrm{~mL})$. The layers that formed were separated and the aqueous layer was extracted with hexanes-ether $(1: 1 \mathrm{v} / \mathrm{v}, 3 \times 30 \mathrm{~mL})$. The organic layers were combined and the combined organic layers were dried over sodium sulfate. The dried solution was filtered and the filtrate was concentrated. The residue obtained was employed directly in the following step.

Aqueous formaldehyde ( $37 \mathrm{wt} \%, 406 \mu \mathrm{L}, 5.45 \mathrm{mmol}, 10.0$ equiv), sodium cyanoborohydride (240 $\mathrm{mg}, 3.82 \mathrm{mmol}, 7.00$ equiv), and methanol $(1.0 \mathrm{~mL})$ were added in sequence to a solution of unpurified amine obtained in the preceding step (nominally $545 \mu \mathrm{mol}, 1$ equiv) in acetonitrile (5.5 $\mathrm{mL}$ ) at $23{ }^{\circ} \mathrm{C}$. The reaction vessel was placed in an oil bath that had been preheated to $35^{\circ} \mathrm{C}$. The reaction mixture was stirred and heated for $72 \mathrm{~h}$ at $35^{\circ} \mathrm{C}$. The product mixture was cooled to 23 ${ }^{\circ} \mathrm{C}$ over $10 \mathrm{~min}$. The cooled product mixture was diluted sequentially with saturated aqueous sodium hydrogen carbonate solution $(100 \mathrm{~mL})$ and ethyl acetate $(100 \mathrm{~mL})$. The resulting biphasic mixture was transferred to a separatory funnel and the layers that formed were separated. The aqueous layer was extracted with ethyl acetate $(4 \times 35 \mathrm{~mL})$. The organic layers were combined and the combined organic layers were washed with saturated aqueous sodium chloride solution (2 $\times 20 \mathrm{~mL}$ ). The washed organic layer was dried over sodium sulfate. The dried solution was filtered and the filtrate was concentrated. The residue obtained was purified by flash-column chromatography (eluting with $0.5 \%$ triethylamine- $5 \%$ acetone-hexanes initially, grading to $0.5 \%$ triethylamine- $15 \%$ acetone-hexanes, four steps) to provide the amine $\mathbf{3 1 \beta}$ as a clear oil [93.6 $\mathrm{mg}$, $58 \%$ over two steps, $\beta$ diastereomer only $\left({ }^{1} \mathrm{H}\right.$ NMR analysis)].

$\mathrm{R}_{f}=0.33\left(0.5 \%\right.$ triethylamine-20\% acetone-hexanes; UV, CAM). ${ }^{1} \mathrm{H}$ NMR $\left(600 \mathrm{MHz}, \mathrm{C}_{6} \mathrm{D}_{6}\right) \delta$ $7.71-7.60(\mathrm{~m}, 2 \mathrm{H}, \mathrm{SPh}), 7.05(\mathrm{t}, J=7.7 \mathrm{~Hz}, 2 \mathrm{H}, \mathrm{SPh}), 7.00-6.93(\mathrm{~m}, 1 \mathrm{H}, \mathrm{SPh}), 5.53(\mathrm{dd}, J=$ $\left.10.7,2.6 \mathrm{~Hz}, 1 \mathrm{H}, \mathrm{H}_{1}\right), 4.21\left(\mathrm{p}, J=6.4 \mathrm{~Hz}, 1 \mathrm{H}, \mathrm{H}_{5}\right), 3.29\left(\mathrm{dq}, J=8.9,7.0 \mathrm{~Hz}, 1 \mathrm{H}, \mathrm{CH}_{2}\right), 3.03-2.95$ $\left(\mathrm{m}, 2 \mathrm{H}, \mathrm{CH}_{2}, \mathrm{H}_{4}\right), 2.36$ (dt, $\left.J=5.6,2.9 \mathrm{~Hz}, 1 \mathrm{H}, \mathrm{H}_{3}\right), 2.26$ (ddd, $\left.J=13.9,5.3,2.7 \mathrm{~Hz}, 1 \mathrm{H}, \mathrm{H}_{2}\right), 2.16$ (s, 6H, $2 \times \mathrm{NCH}_{3}$ ), 1.72 (ddd, $\left.J=14.0,10.7,3.4 \mathrm{~Hz}, 1 \mathrm{H}, \mathrm{H}_{2}\right), 1.32$ (d, $\left.J=6.3 \mathrm{~Hz}, 3 \mathrm{H}, \mathrm{H}_{6}\right), 0.96$ $\left(\mathrm{t}, J=7.0 \mathrm{~Hz}, 3 \mathrm{H}, \mathrm{CH}_{3}\right) .{ }^{13} \mathrm{C} \mathrm{NMR}\left(151 \mathrm{MHz}, \mathrm{C}_{6} \mathrm{D}_{6}\right) \delta 136.0(\mathrm{C}), 131.5(2 \times \mathrm{CH}), 129.0(2 \times \mathrm{CH})$, $127.0(\mathrm{CH}), 84.0(\mathrm{CH}), 80.1(\mathrm{CH}), 72.9(\mathrm{CH}), 65.0\left(\mathrm{CH}_{2}\right), 59.3(\mathrm{CH}), 44.5\left(2 \times \mathrm{CH}_{3}\right), 35.5\left(\mathrm{CH}_{2}\right)$, $19.2\left(\mathrm{CH}_{3}\right), 15.5\left(\mathrm{CH}_{3}\right)$. IR (ATR-FTIR), $\mathrm{cm}^{-1}: 2975(\mathrm{~m}), 2932(\mathrm{~m}), 2873(\mathrm{~m}), 2919(\mathrm{~m}), 2774$

Hoang et al. "General method for the synthesis of $\alpha$ - or $\beta$-deoxyaminoglycosides bearing S51 basic nitrogen" 
(m), 2359 (s), $2331(\mathrm{~s}), 1584(\mathrm{~m})$. HRMS-ESI (m/z): $[\mathrm{M}+\mathrm{H}]^{+}$calculated for $\left[\mathrm{C}_{16} \mathrm{H}_{26} \mathrm{NO}_{2} \mathrm{~S}\right]^{+}$ 296.1679, found 296.1701. $[a]_{D}^{21}=+40.2^{\circ}\left(c=1.0, \mathrm{CHCl}_{3}\right)$. 
Synthesis of the silyl ether $\mathbf{S 1 9 .}$

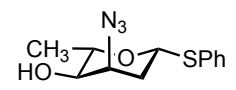

$(3 R)-S 12 \beta$

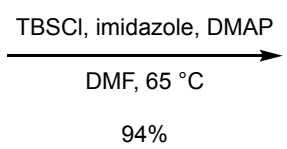

$94 \%$

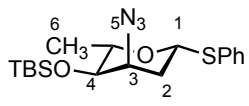

S19

tert-Butyldimethylsilyl chloride (432 mg, $2.86 \mathrm{mmol}, 4.00$ equiv) was added to a solution of imidazole (488 mg, $7.16 \mathrm{mmol}, 10.0$ equiv), 4-(dimethylamino)pyridine (17.5 mg, $143 \mu \mathrm{mol}, 0.20$ equiv), and the alcohol (3R)-S12及 (190 mg, $716 \mu \mathrm{mol}, 1.00$ equiv) in $N, N$-dimethylformamide $(3.6 \mathrm{~mL})$ at $23^{\circ} \mathrm{C}$. The reaction vessel was fitted with a reflux condenser and then placed in an oil bath that had been preheated to $65^{\circ} \mathrm{C}$. The reaction mixture was stirred and heated for $18 \mathrm{~h}$ at 65 ${ }^{\circ} \mathrm{C}$. The product mixture was cooled to $23{ }^{\circ} \mathrm{C}$ over $15 \mathrm{~min}$. The cooled product mixture was diluted sequentially with saturated aqueous sodium hydrogen carbonate solution $(100 \mathrm{~mL})$ and ethyl acetate $(50 \mathrm{~mL})$. The resulting mixture was transferred to a separatory funnel and the layers that formed were separated. The aqueous layer was extracted with ethyl acetate $(3 \times 50 \mathrm{~mL})$. The organic layers were combined and the combined organic layers were washed with saturated aqueous sodium chloride solution $(30 \mathrm{~mL})$. The washed organic layer was dried over sodium sulfate. The dried solution was filtered and the filtrate was concentrated. The residue obtained was purified by flash-column chromatography (eluting with 1\% ethyl acetate-hexanes initially, grading to 3\% ethyl acetate-hexanes, three steps) to provide the silyl ether S19 as a clear oil [220 $\mathrm{mg}, 81 \%, \beta$ diastereomer only ( ${ }^{1} \mathrm{H}$ NMR analysis)].

$\mathrm{R}_{f}=0.30$ (3\% ethyl acetate-hexanes; UV, CAM). ${ }^{1} \mathrm{H}$ NMR $\left(500 \mathrm{MHz}, \mathrm{CDCl}_{3}\right) \delta 7.52-7.44(\mathrm{~m}$, 2H, SPh), 7.30 (t, J=7.3 Hz, 2H, SPh), $7.27-7.23(\mathrm{~m}, 1 \mathrm{H}, \mathrm{SPh}), 5.03$ (dd, $J=11.6,2.0 \mathrm{~Hz}, 1 \mathrm{H}$, $\left.\mathrm{H}_{1}\right), 3.92\left(\mathrm{q}, J=3.3 \mathrm{~Hz}, 1 \mathrm{H}, \mathrm{H}_{3}\right), 3.84\left(\mathrm{dq}, J=8.6,6.2 \mathrm{~Hz}, 1 \mathrm{H}, \mathrm{H}_{5}\right), 3.52(\mathrm{dd}, J=9.1,3.2 \mathrm{~Hz}, 1 \mathrm{H}$, $\left.\mathrm{H}_{4}\right), 2.12\left(\mathrm{dt}, J=13.6,2.3 \mathrm{~Hz}, 1 \mathrm{H}, \mathrm{H}_{2}\right), 1.93$ (ddd, $\left.J=14.1,11.5,3.2 \mathrm{~Hz}, 1 \mathrm{H}, \mathrm{H}_{2}\right), 1.26(\mathrm{~d}, J=6.2$ $\left.\mathrm{Hz}, 3 \mathrm{H}, \mathrm{H}_{6}\right), 0.93(\mathrm{~s}, 9 \mathrm{H}, t \mathrm{Bu}), 0.12\left(\mathrm{~s}, 3 \mathrm{H}, \mathrm{CH}_{3}\right), 0.12\left(\mathrm{~s}, 3 \mathrm{H}, \mathrm{CH}_{3}\right) .{ }^{13} \mathrm{C} \mathrm{NMR}\left(126 \mathrm{MHz}, \mathrm{CDCl}_{3}\right)$ $\delta 134.2(\mathrm{C}), 131.4(2 \times \mathrm{CH}), 129.0(2 \times \mathrm{CH}), 127.4(\mathrm{CH}), 79.6(\mathrm{CH}), 75.0(\mathrm{CH}), 73.3(\mathrm{CH}), 61.9$ $(\mathrm{CH}), 37.0\left(\mathrm{CH}_{2}\right), 25.9\left(3 \times \mathrm{CH}_{3}\right), 18.6\left(\mathrm{CH}_{3}\right), 18.1(\mathrm{C}),-3.5\left(\mathrm{CH}_{3}\right),-4.7\left(\mathrm{CH}_{3}\right)$. IR (ATR-FTIR), $\mathrm{cm}^{-1}: 2957(\mathrm{~m}), 2930(\mathrm{~m}), 2885(\mathrm{~m}), 2858(\mathrm{~m}), 2358(\mathrm{~m}), 2338(\mathrm{~m}), 2118(\mathrm{~m}), 1479(\mathrm{~m})$. HRMS$\operatorname{ESI}(\mathrm{m} / \mathrm{z}):[\mathrm{M}+\mathrm{H}]^{+}$calculated for $\left[\mathrm{C}_{18} \mathrm{H}_{30} \mathrm{~N}_{3} \mathrm{O}_{2} \mathrm{SSi}\right]^{+}$380.1823, found 380.1815. $[a]_{D}^{21}=-2.7^{\circ}$ $\left(c=1.0, \mathrm{CHCl}_{3}\right)$. 
Synthesis of the amine $32 \beta$.

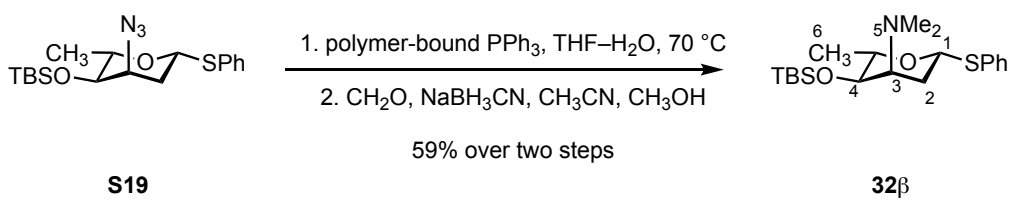

Polymer-bound triphenylphosphine (483 mg, $1.45 \mathrm{mmol}, 2.50$ equiv) and deionized water (3.9 $\mathrm{mL}$ ) were added in sequence to a solution of the silyl ether $\mathbf{S 1 9}(220 \mathrm{mg}, 580 \mu \mathrm{mol}, 1$ equiv) in tetrahydrofuran $(17 \mathrm{~mL})$ at $23{ }^{\circ} \mathrm{C}$. The reaction vessel was fitted with a reflux condenser and then placed in an oil bath that had been preheated to $70{ }^{\circ} \mathrm{C}$. The reaction mixture was stirred and heated for $48 \mathrm{~h}$ at $70{ }^{\circ} \mathrm{C}$. The product mixture was cooled to $23{ }^{\circ} \mathrm{C}$ over $15 \mathrm{~min}$. The cooled product mixture was filtered through a pad of celite. The celite pad was washed with hexanes-ether (1:1 $\mathrm{v} / \mathrm{v}, 20 \mathrm{~mL}$ ). The filtrates were combined and the combined filtrates were transferred to a separatory funnel. The layers that formed were separated and the aqueous layer was extracted with hexanes-ether $(1: 1 \mathrm{v} / \mathrm{v}, 3 \times 10 \mathrm{~mL})$. The organic layers were combined and the combined organic layers were dried over sodium sulfate. The dried solution was filtered and the filtrate was concentrated. The residue obtained was employed directly in the following step.

Aqueous formaldehyde ( $37 \mathrm{wt} \%, 471 \mathrm{mg}, 5.80 \mathrm{mmol}, 10.0$ equiv), sodium cyanoborohydride (255 mg, $4.06 \mathrm{mmol}, 7.00$ equiv), and methanol $(1.0 \mathrm{~mL}$ ) were added in sequence to a solution of the unpurified amine obtained in the preceding step (nominally $580 \mu \mathrm{mol}, 1$ equiv) in acetonitrile $(5.8 \mathrm{~mL})$ at $23{ }^{\circ} \mathrm{C}$. The reaction vessel was placed in an oil bath that had been preheated to $35^{\circ} \mathrm{C}$. The reaction mixture was stirred and heated for $48 \mathrm{~h}$ at $35^{\circ} \mathrm{C}$. The product mixture was cooled to $23{ }^{\circ} \mathrm{C}$ over $15 \mathrm{~min}$. The cooled product mixture was diluted sequentially with saturated aqueous sodium hydrogen carbonate solution $(100 \mathrm{~mL})$ and ethyl acetate $(100 \mathrm{~mL})$. The resulting biphasic mixture was transferred to a separatory funnel and the layers that formed were separated. The aqueous layer was extracted with ethyl acetate $(4 \times 35 \mathrm{~mL})$. The organic layers were combined and the combined organic layers were washed with saturated aqueous sodium chloride solution (2 $\times 20 \mathrm{~mL}$ ). The washed organic layer was dried over sodium sulfate. The dried solution was filtered and the filtrate was concentrated. The residue obtained was purified by flash-column chromatography (eluting with $0.5 \%$ triethylamine $-1 \%$ acetone-hexanes initially, grading to $0.5 \%$ triethylamine- $5 \%$ acetone-hexanes, five steps) to provide the amine $\mathbf{3 2} \beta$ as a clear colorless oil [130 mg, 59\% over two steps, $\beta$ diastereomer only ( ${ }^{1} \mathrm{H}$ NMR analysis)].

$\mathrm{R}_{f}=0.48\left(0.5 \%\right.$ triethylamine- $10 \%$ acetone-hexanes; UV, CAM). ${ }^{1} \mathrm{H}$ NMR $\left(600 \mathrm{MHz}, \mathrm{C}_{6} \mathrm{D}_{6}\right) \delta$ $7.72-7.64$ (m, 2H, SPh), $7.05(\mathrm{t}, J=7.7 \mathrm{~Hz}, 2 \mathrm{H}, \mathrm{SPh}), 6.98-6.91(\mathrm{~m}, 1 \mathrm{H}, \mathrm{SPh}), 5.59$ (dd, $J=$ 10.7, $\left.2.4 \mathrm{~Hz}, 1 \mathrm{H}, \mathrm{H}_{1}\right), 4.22\left(\mathrm{p}, J=6.5 \mathrm{~Hz}, 1 \mathrm{H}, \mathrm{H}_{5}\right), 3.54\left(\mathrm{dd}, J=7.8,2.3 \mathrm{~Hz}, 1 \mathrm{H}, \mathrm{H}_{4}\right), 2.32-2.23$ $\left(\mathrm{m}, 2 \mathrm{H}, \mathrm{H}_{2}, \mathrm{H}_{3}\right), 2.17$ (s, $\left.6 \mathrm{H}, 2 \times \mathrm{NCH}_{3}\right), 1.78$ (ddd, $\left.J=13.6,10.7,2.9 \mathrm{~Hz}, 1 \mathrm{H}, \mathrm{H}_{2}\right), 1.28(\mathrm{~d}, J=$ $\left.6.4 \mathrm{~Hz}, 3 \mathrm{H}, \mathrm{H}_{6}\right), 0.90(\mathrm{~s}, 9 \mathrm{H}, t \mathrm{Bu}),-0.01\left(\mathrm{~s}, 3 \mathrm{H}, \mathrm{CH}_{3}\right),-0.05\left(\mathrm{~s}, 3 \mathrm{H}, \mathrm{CH}_{3}\right) .{ }^{13} \mathrm{C} \mathrm{NMR}(151 \mathrm{MHz}$, $\left.\mathrm{C}_{6} \mathrm{D}_{6}\right) \delta 136.2(\mathrm{C}), 131.3(2 \times \mathrm{CH}), 129.1(2 \times \mathrm{CH}), 127.0(\mathrm{CH}), 80.2(\mathrm{CH}), 77.5(\mathrm{CH}), 74.1(\mathrm{CH})$, $63.3(\mathrm{CH}), 45.0\left(2 \times \mathrm{CH}_{3}\right), 36.1\left(\mathrm{CH}_{2}\right), 26.1\left(3 \times \mathrm{CH}_{3}\right), 19.3\left(\mathrm{CH}_{3}\right), 18.2(\mathrm{C}),-3.6\left(\mathrm{CH}_{3}\right),-4.9$ $\left(\mathrm{CH}_{3}\right)$. IR (ATR-FTIR), $\mathrm{cm}^{-1}: 2953(\mathrm{~m}), 2930(\mathrm{~m}), 2887(\mathrm{~m}), 2857(\mathrm{~m}), 2820(\mathrm{~m}), 2775(\mathrm{~m}), 2359$ $(\mathrm{m}), 1585(\mathrm{~m})$. HRMS-ESI $(\mathrm{m} / \mathrm{z}):[\mathrm{M}+\mathrm{H}]^{+}$calculated for $\left[\mathrm{C}_{20} \mathrm{H}_{36} \mathrm{NO}_{2} \mathrm{SSi}\right]^{+}$382.2231, found 382.2261. $[a]_{D}^{21}=+29.8^{\circ}\left(c=1.0, \mathrm{CHCl}_{3}\right)$.

Hoang et al. "General method for the synthesis of $\alpha$ - or $\beta$-deoxyaminoglycosides bearing S54 basic nitrogen" 
Synthesis of the amine $\mathbf{3 3 \beta}$.

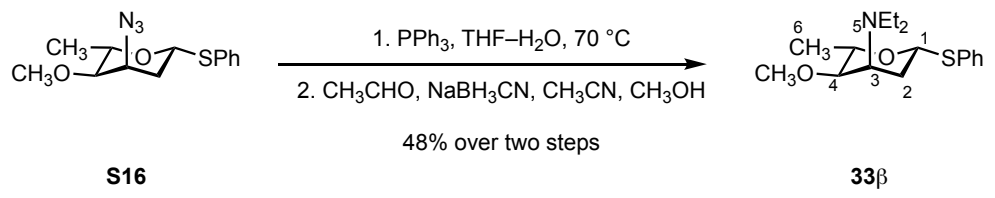

Triphenylphosphine (399 mg, $1.52 \mathrm{mmol}, 2.50$ equiv) and deionized water $(4.1 \mathrm{~mL})$ were added in sequence to a solution of the ether $\mathbf{S 1 6}(170 \mathrm{mg}, 609 \mu \mathrm{mol}, 1$ equiv) in tetrahydrofuran $(17 \mathrm{~mL})$ at $23^{\circ} \mathrm{C}$. The reaction vessel was fitted with a reflux condenser and then placed in an oil bath that had been preheated to $70^{\circ} \mathrm{C}$. The reaction mixture was stirred and heated for $18 \mathrm{~h}$ at $70{ }^{\circ} \mathrm{C}$. The product mixture was allowed to cool to $23^{\circ} \mathrm{C}$ over $15 \mathrm{~min}$. The cooled product mixture was diluted sequentially with $1 \mathrm{~N}$ aqueous hydrochloric acid solution $(10 \mathrm{~mL})$ and hexanes-ether $(1: 1 \mathrm{v} / \mathrm{v}, 20$ $\mathrm{mL}$ ). The resulting mixture was transferred to a separatory funnel and the layers that formed were separated. The aqueous layer was extracted with hexanes-ether $(1: 1 \mathrm{v} / \mathrm{v}, 3 \times 20 \mathrm{~mL})$. The aqueous layer was then basified with $2 \mathrm{~N}$ aqueous sodium hydroxide solution $(10 \mathrm{~mL})$. The basified aqueous layer was diluted with hexanes-ether $(1: 1 \mathrm{v} / \mathrm{v}, 30 \mathrm{~mL})$. The layers that formed were separated, and the aqueous layer was extracted with hexanes-ether $(1: 1 \mathrm{v} / \mathrm{v}, 3 \times 30 \mathrm{~mL})$. The organic layers were combined and the combined organic layers were dried over sodium sulfate. The dried solution was filtered and the filtrate was concentrated. The residue obtained was employed directly in the following step.

A solution of acetaldehyde in tetrahydrofuran $(5.0 \mathrm{M}, 1.22 \mathrm{~mL}, 6.09 \mathrm{mmol}, 10.0$ equiv) and sodium cyanoborohydride ( $268 \mathrm{mg}, 4.26 \mathrm{mmol}, 7.00$ equiv) were added in sequence to a solution of unpurified amine obtained in the preceding step (nominally $609 \mu \mathrm{mol}, 1$ equiv) in methanol (6.1 $\mathrm{mL}$ ) at $23{ }^{\circ} \mathrm{C}$. The reaction vessel was placed in an oil bath that had been preheated to $35^{\circ} \mathrm{C}$. The reaction mixture was stirred and heated for $144 \mathrm{~h}$ at $35^{\circ} \mathrm{C}$. The product mixture was cooled to 23 ${ }^{\circ} \mathrm{C}$ over $15 \mathrm{~min}$. The cooled product mixture was diluted sequentially with saturated aqueous sodium hydrogen carbonate solution $(100 \mathrm{~mL})$ and ethyl acetate $(100 \mathrm{~mL})$. The resulting biphasic mixture was transferred to a separatory funnel and the layers that formed were separated. The aqueous layer was extracted with ethyl acetate $(4 \times 35 \mathrm{~mL})$. The organic layers were combined and the combined organic layers were washed with saturated aqueous sodium chloride solution (2 $\times 20 \mathrm{~mL}$ ). The washed organic layer was dried over sodium sulfate. The dried solution was filtered and the filtrate was concentrated. The residue obtained was purified by flash-column chromatography (eluting with $0.5 \%$ triethylamine- $2 \%$ acetone-hexanes initially, grading to $0.5 \%$ triethylamine- $10 \%$ acetone-hexanes, five steps) to provide the amine $\mathbf{3 3 \beta}$ as a clear colorless oil [ $90.0 \mathrm{mg}, 48 \%$ over two steps, $\beta$ diastereomer only $\left({ }^{1} \mathrm{H}\right.$ NMR analysis)].

$\mathrm{R}_{f}=0.16(0.5 \%$ triethylamine- $10 \%$ acetone-hexanes; UV, CAM $) .{ }^{1} \mathrm{H}$ NMR $\left(500 \mathrm{MHz}, \mathrm{C}_{6} \mathrm{D}_{6}\right) \delta$ $7.69-7.62$ (m, 2H, SPh), 7.05 (t, $J=7.7 \mathrm{~Hz}, 2 \mathrm{H}, \mathrm{SPh}), 6.96$ (td, $J=7.2,1.3 \mathrm{~Hz}, 1 \mathrm{H}, \mathrm{SPh}), 5.53$ (dd, $\left.J=8.8,4.3 \mathrm{~Hz}, 1 \mathrm{H}, \mathrm{H}_{1}\right), 4.07$ (qd, $J=6.6,4.7 \mathrm{~Hz}, 1 \mathrm{H}, \mathrm{H}_{5}$ ), 3.05 (ddd, $J=7.8,4.8,2.3 \mathrm{~Hz}$, $\left.1 \mathrm{H}, \mathrm{H}_{3}\right), 2.99\left(\mathrm{~s}, 3 \mathrm{H}, \mathrm{OCH}_{3}\right), 2.97\left(\mathrm{dd}, J=4.6,2.3 \mathrm{~Hz}, 1 \mathrm{H}, \mathrm{H}_{4}\right), 2.67-2.54\left(\mathrm{~m}, 4 \mathrm{H}, 2 \times \mathrm{CH}_{2}\right), 2.36$ (ddd, $\left.J=13.1,8.2,4.4 \mathrm{~Hz}, 1 \mathrm{H}, \mathrm{H}_{2}\right), 1.85\left(\mathrm{ddd}, J=13.5,8.8,4.7 \mathrm{~Hz}, 1 \mathrm{H}, \mathrm{H}_{2}\right), 1.27$ (d, $J=6.6 \mathrm{~Hz}$, $\left.3 \mathrm{H}, \mathrm{H}_{6}\right), 0.92\left(\mathrm{t}, J=7.1 \mathrm{~Hz}, 6 \mathrm{H}, 2 \times \mathrm{CH}_{3}\right) .{ }^{13} \mathrm{C}$ NMR $\left(126 \mathrm{MHz}, \mathrm{C}_{6} \mathrm{D}_{6}\right) \delta 136.4(\mathrm{C}), 131.4(2 \times$ $\mathrm{CH}), 129.0(2 \times \mathrm{CH}), 127.0(\mathrm{CH}), 84.8(\mathrm{CH}), 81.3(\mathrm{CH}), 73.9(\mathrm{CH}), 57.0\left(\mathrm{CH}_{3}\right), 53.2(\mathrm{CH}), 44.2$

Hoang et al. "General method for the synthesis of $\alpha$ - or $\beta$-deoxyaminoglycosides bearing S55 basic nitrogen" 
$\left(2 \times \mathrm{CH}_{2}\right), 32.8\left(\mathrm{CH}_{2}\right), 19.8\left(\mathrm{CH}_{3}\right), 13.1\left(2 \times \mathrm{CH}_{3}\right)$. IR (ATR-FTIR), $\mathrm{cm}^{-1}: 2968(\mathrm{~m}), 2930(\mathrm{~m})$, $2821(\mathrm{~m}), 2362(\mathrm{~m}), 2343(\mathrm{~m}), 1585(\mathrm{~m})$. HRMS-ESI $(\mathrm{m} / \mathrm{z}):[\mathrm{M}+\mathrm{H}]^{+}$calculated for $\left[\mathrm{C}_{17} \mathrm{H}_{28} \mathrm{NO}_{2} \mathrm{~S}\right]^{+} 310.1835$, found 310.1859. $[a]_{D}^{21}=+85.5^{\circ}\left(c=1.0, \mathrm{CHCl}_{3}\right)$. 
Synthesis of the disaccharide $\mathbf{3 5 \boldsymbol { \beta }}$.

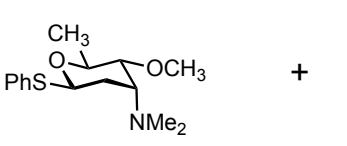

$30 \beta$

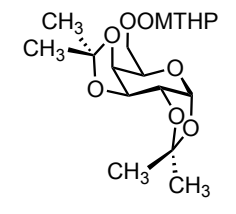

12

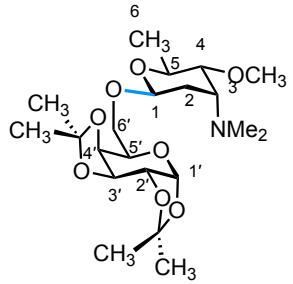

$35 \beta$

A solution of LiDBB in tetrahydrofuran (nominally $0.4 \mathrm{M}$ ) was added dropwise via syringe to a solution of the amine $\mathbf{3 0 \beta}(31.6 \mathrm{mg}, 113 \mu \mathrm{mol}, 1.50$ equiv) in tetrahydrofuran-pentane $(1: 1 \mathrm{v} / \mathrm{v}$, $1.8 \mathrm{~mL}$ ) in a $10-\mathrm{mL}$ round-bottomed flask that had been fused to a Teflon-coated valve at $-78{ }^{\circ} \mathrm{C}$. The addition of LiDBB was continued until a green color persisted $(584 \mu \mathrm{L}$, nominally $234 \mu \mathrm{mol}$, 3.10 equiv). The resulting mixture was stirred for $10 \mathrm{~min}$ at $-78{ }^{\circ} \mathrm{C}$. A solution of the MTHP monoperoxy acetal $12(28.1 \mathrm{mg}, 75.0 \mu \mathrm{mol}, 1$ equiv $)$ in tetrahydrofuran $(300 \mu \mathrm{L})$ was then added dropwise via syringe. The resulting mixture was stirred for $3 \mathrm{~h}$ at $-78{ }^{\circ} \mathrm{C}$. The cold product mixture was diluted with saturated aqueous sodium hydrogen carbonate solution $(1.0 \mathrm{~mL})$. The diluted product mixture was allowed to warm to $23{ }^{\circ} \mathrm{C}$ over $15 \mathrm{~min}$. The warmed product mixture was transferred to a $20-\mathrm{mL}$ test tube and the layers that formed were separated. The aqueous layer was extracted with ethyl acetate $(4 \times 5.0 \mathrm{~mL})$. The organic layers were combined and the combined organic layers were dried over sodium sulfate. The dried solution was filtered and the filtrate was concentrated under a stream of nitrogen. The residue obtained was purified by flashcolumn chromatography (eluting with $0.5 \%$ triethylamine- $5 \%$ acetone-hexanes initially, grading to $0.5 \%$ triethylamine $-25 \%$ acetone-hexanes, five steps) to provide the disaccharide $\mathbf{3 5 \beta}$ as a colorless oil (28.0 mg, 87\%).

The diastereoselectivity of the reaction was determined to be $2.8: 1 \beta: \alpha$ by ${ }^{1} \mathrm{H}$ NMR analysis of the unpurified product mixture.

$\beta$-anomer:

$\mathrm{R}_{f}=0.15\left(0.5 \%\right.$ triethylamine $-25 \%$ acetone-hexanes; CAM). ${ }^{1} \mathrm{H}$ NMR $\left(600 \mathrm{MHz}, \mathrm{CDCl}_{3}\right) \delta 5.51$ $\left(\mathrm{d}, J=5.0 \mathrm{~Hz}, 1 \mathrm{H}, \mathrm{H}_{1^{\prime}}\right), 4.97\left(\mathrm{t}, J=3.4 \mathrm{~Hz}, 1 \mathrm{H}, \mathrm{H}_{1}\right), 4.60\left(\mathrm{dd}, J=8.0,2.4 \mathrm{~Hz}, 1 \mathrm{H}, \mathrm{H}_{3^{\prime}}\right), 4.30$ (dd, $\left.J=5.1,2.3 \mathrm{~Hz}, 1 \mathrm{H}, \mathrm{H}_{2^{\prime}}\right), 4.25\left(\mathrm{dd}, J=8.0,1.9 \mathrm{~Hz}, 1 \mathrm{H}, \mathrm{H}_{4^{\prime}}\right), 4.19\left(\mathrm{qd}, J=7.0,2.2 \mathrm{~Hz}, 1 \mathrm{H}, \mathrm{H}_{5}\right)$, $3.94\left(\mathrm{td}, J=6.8,1.8 \mathrm{~Hz}, 1 \mathrm{H}, \mathrm{H}_{5^{\prime}}\right), 3.82\left(\mathrm{dd}, J=10.3,6.4 \mathrm{~Hz}, 1 \mathrm{H}, \mathrm{H}_{6^{\prime}}\right), 3.69$ (dd, $J=10.3,7.1 \mathrm{~Hz}$, $\left.1 \mathrm{H}, \mathrm{H}_{6^{\prime}}\right), 3.39\left(\mathrm{~s}, 3 \mathrm{H}, \mathrm{OCH}_{3}\right), 3.29\left(\mathrm{~s}, 1 \mathrm{H}, \mathrm{H}_{4}\right), 2.69\left(\mathrm{~d}, J=8.3 \mathrm{~Hz}, 1 \mathrm{H}, \mathrm{H}_{3}\right), 2.33\left(\mathrm{~s}, 6 \mathrm{H}, 2 \times \mathrm{NCH}_{3}\right)$, $2.05\left(\mathrm{td}, J=12.3,4.0 \mathrm{~Hz}, 1 \mathrm{H}, \mathrm{H}_{2}\right), 1.83\left(\mathrm{dt}, J=13.0,3.7 \mathrm{~Hz}, 1 \mathrm{H}, \mathrm{H}_{2}\right), 1.52\left(\mathrm{~s}, 3 \mathrm{H}, \mathrm{CH}_{3}\right), 1.43(\mathrm{~s}$, $\left.3 \mathrm{H}, \mathrm{CH}_{3}\right), 1.35-1.32\left(\mathrm{~m}, 9 \mathrm{H}, \mathrm{H}_{6}, 2 \times \mathrm{CH}_{3}\right) .{ }^{13} \mathrm{C} \mathrm{NMR}\left(151 \mathrm{MHz}, \mathrm{CDCl}_{3}\right) \delta 109.2(\mathrm{C}), 108.5(\mathrm{C})$, $98.1(\mathrm{CH}), 96.3(\mathrm{CH}), 79.7(\mathrm{CH}), 70.9(\mathrm{CH}), 70.7(\mathrm{CH}), 70.6(\mathrm{CH}), 69.7(\mathrm{CH}), 65.9(\mathrm{CH}), 65.6$ $\left(\mathrm{CH}_{2}\right), 56.7\left(\mathrm{CH}_{3}\right), 55.3(\mathrm{CH}), 42.9\left(2 \times \mathrm{CH}_{3}\right), 29.4\left(\mathrm{CH}_{2}\right), 26.0\left(\mathrm{CH}_{3}\right), 26.0\left(\mathrm{CH}_{3}\right), 24.9\left(\mathrm{CH}_{3}\right)$, $24.5\left(\mathrm{CH}_{3}\right), 19.9\left(\mathrm{CH}_{3}\right)$. IR (ATR-FTIR), $\mathrm{cm}^{-1}: 2984(\mathrm{~m}), 2935(\mathrm{~m}), 2822(\mathrm{w}), 2360(\mathrm{w}), 1371$ (m). HRMS-ESI $(\mathrm{m} / \mathrm{z}):[\mathrm{M}+\mathrm{H}]^{+}$calculated for $\left[\mathrm{C}_{21} \mathrm{H}_{38} \mathrm{NO}_{8}\right]^{+} 432.2592$, found 432.2574. $[a]_{D}^{21}$ $=+17.0^{\circ}\left(c=0.8, \mathrm{CHCl}_{3}\right)$. 
$\alpha$-anomer:

$\mathrm{R}_{f}=0.09$ (0.5\% triethylamine-25\% acetone-hexanes; CAM). ${ }^{1} \mathrm{H}$ NMR $\left(400 \mathrm{MHz}, \mathrm{CDCl}_{3}\right) \delta 5.54$ $\left(\mathrm{d}, J=5.0 \mathrm{~Hz}, 1 \mathrm{H}, \mathrm{H}_{1^{\prime}}\right), 4.81\left(\mathrm{dd}, J=8.8,3.7 \mathrm{~Hz}, 1 \mathrm{H}, \mathrm{H}_{1}\right), 4.59\left(\mathrm{dd}, J=7.9,2.4 \mathrm{~Hz}, 1 \mathrm{H}, \mathrm{H}_{3^{\prime}}\right), 4.30$ $\left(\mathrm{dd}, J=5.0,2.4 \mathrm{~Hz}, 1 \mathrm{H}, \mathrm{H}_{2^{\prime}}\right), 4.27\left(\mathrm{dd}, J=6.9,2.6 \mathrm{~Hz}, 1 \mathrm{H}, \mathrm{H}_{5}\right), 4.23\left(\mathrm{dd}, J=8.0,1.6 \mathrm{~Hz}, 1 \mathrm{H}, \mathrm{H}_{4^{\prime}}\right)$, $4.03-3.97\left(\mathrm{~m}, 2 \mathrm{H}, \mathrm{H}_{5^{\prime}}, \mathrm{H}_{6^{\prime}}\right), 3.60$ (dd, $\left.J=12.0,8.6 \mathrm{~Hz}, 1 \mathrm{H}, \mathrm{H}_{6^{\prime}}\right), 3.41$ (s, $\left.3 \mathrm{H}, \mathrm{OCH}_{3}\right), 3.23$ (br s, $\left.1 \mathrm{H}, \mathrm{H}_{4}\right), 2.43-2.37\left(\mathrm{~m}, 1 \mathrm{H}, \mathrm{H}_{3}\right), 2.34\left(\mathrm{~s}, 6 \mathrm{H}, 2 \times \mathrm{NCH}_{3}\right), 2.00\left(\mathrm{dt}, J=12.6,3.9 \mathrm{~Hz}, 1 \mathrm{H}, \mathrm{H}_{2}\right), 1.82$ $\left(\mathrm{td}, J=12.5,8.7 \mathrm{~Hz}, 1 \mathrm{H}, \mathrm{H}_{2}\right), 1.53\left(\mathrm{~s}, 3 \mathrm{H}, \mathrm{CH}_{3}\right), 1.44\left(\mathrm{~s}, 3 \mathrm{H}, \mathrm{CH}_{3}\right), 1.32\left(\mathrm{~s}, 6 \mathrm{H}, 2 \times \mathrm{CH}_{3}\right), 1.26(\mathrm{~d}$, $\left.J=6.9 \mathrm{~Hz}, 3 \mathrm{H}, \mathrm{H}_{6}\right) .{ }^{13} \mathrm{C} \mathrm{NMR}\left(151 \mathrm{MHz}, \mathrm{CDCl}_{3}\right) \delta 109.2(\mathrm{C}), 108.6(\mathrm{C}), 96.7(\mathrm{CH}), 96.3(\mathrm{CH})$, $79.3(\mathrm{CH}), 71.4(\mathrm{CH}), 70.7(\mathrm{CH}), 70.5(\mathrm{CH}), 68.8(\mathrm{CH}), 67.5(\mathrm{CH}), 67.4\left(\mathrm{CH}_{2}\right), 59.5(\mathrm{CH}), 57.3$ $\left(\mathrm{CH}_{3}\right), 43.0\left(2 \times \mathrm{CH}_{3}\right), 29.2\left(\mathrm{CH}_{2}\right), 26.0\left(\mathrm{CH}_{3}\right), 26.0\left(\mathrm{CH}_{3}\right), 25.0\left(\mathrm{CH}_{3}\right), 24.4\left(\mathrm{CH}_{3}\right), 17.7\left(\mathrm{CH}_{3}\right)$. IR (ATR-FTIR), $\mathrm{cm}^{-1}$ : 2980 (m), 2935 (m), 1645 (w), 1459 (m), 1380 (m). HRMS-ESI (m/z): [M $+\mathrm{Na}]^{+}$calculated for $\left[\mathrm{C}_{21} \mathrm{H}_{37} \mathrm{NO}_{8} \mathrm{Na}\right]^{+} 454.2411$, found $454.2439 .[a]_{D}^{21}=-73.5^{\circ}\left(c=0.3, \mathrm{CHCl}_{3}\right)$. 
Synthesis of the disaccharide $\mathbf{3 6 \boldsymbol { \beta }}$.
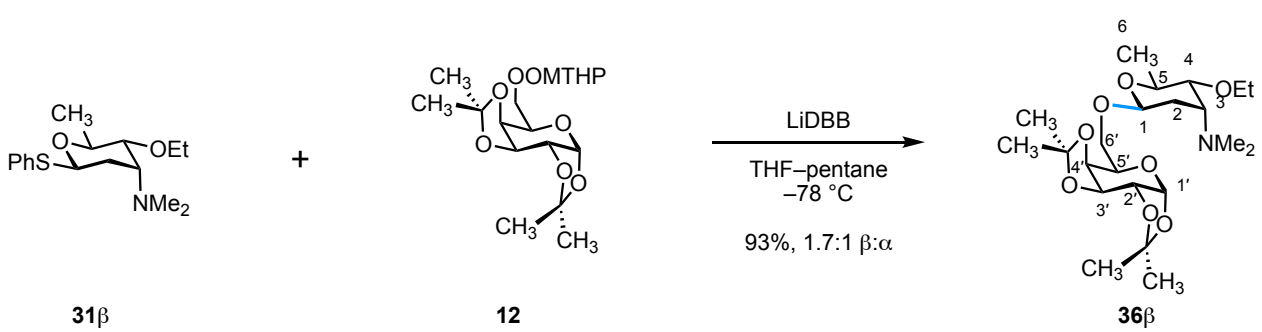

A solution of LiDBB in tetrahydrofuran (nominally $0.4 \mathrm{M}$ ) was added dropwise via syringe to a solution of the amine $31 \boldsymbol{\beta}(33.3 \mathrm{mg}, 113 \mu \mathrm{mol}, 1.50$ equiv) in tetrahydrofuran-pentane $(1: 1 \mathrm{v} / \mathrm{v}$, $1.8 \mathrm{~mL}$ ) in a $10-\mathrm{mL}$ round-bottomed flask that had been fused to a Teflon-coated valve at $-78^{\circ} \mathrm{C}$. The addition of LiDBB was continued until a green color persisted $(584 \mu \mathrm{L}$, nominally $234 \mu \mathrm{mol}$, 3.10 equiv). The resulting mixture was stirred for $10 \mathrm{~min}$ at $-78{ }^{\circ} \mathrm{C}$. A solution of the MTHP monoperoxy acetal $12(28.1 \mathrm{mg}, 75.0 \mu \mathrm{mol}, 1$ equiv $)$ in tetrahydrofuran $(300 \mu \mathrm{L})$ was then added dropwise via syringe. The resulting mixture was stirred for $3 \mathrm{~h}$ at $-78^{\circ} \mathrm{C}$. The cold product mixture was diluted with saturated aqueous sodium hydrogen carbonate solution $(1.0 \mathrm{~mL})$. The diluted product mixture was allowed to warm to $23{ }^{\circ} \mathrm{C}$ over $15 \mathrm{~min}$. The warmed product mixture was transferred to a $20-\mathrm{mL}$ test tube and the layers that formed were separated. The aqueous layer was extracted with ethyl acetate $(4 \times 5.0 \mathrm{~mL})$. The organic layers were combined and the combined organic layers were dried over sodium sulfate. The dried solution was filtered and the filtrate was concentrated under a stream of nitrogen. The residue obtained was purified by flashcolumn chromatography (eluting with $1 \%$ methanol-dichloromethane initially, grading to $10 \%$ methanol-dichloromethane, five steps) to provide the disaccharide $\mathbf{3 6} \boldsymbol{\beta}$ as a colorless oil (31.0 $\mathrm{mg}$, $93 \%)$.

The diastereoselectivity of the reaction was determined to be $1.7: 1 \beta: \alpha$ by ${ }^{1} \mathrm{H}$ NMR analysis of the unpurified product mixture.

$\beta$-anomer:

$\mathrm{R}_{f}=0.50$ (10\% methanol-dichloromethane; CAM). ${ }^{1} \mathrm{H}$ NMR $\left(600 \mathrm{MHz}, \mathrm{C}_{6} \mathrm{D}_{6}\right) \delta 5.52(\mathrm{~d}, J=5.0$ $\left.\mathrm{Hz}, 1 \mathrm{H}, \mathrm{H}_{1^{\prime}}\right), 5.06\left(\mathrm{t}, J=3.6 \mathrm{~Hz}, 1 \mathrm{H}, \mathrm{H}_{1}\right), 4.56\left(\mathrm{dd}, J=7.8,2.3 \mathrm{~Hz}, 1 \mathrm{H}, \mathrm{H}_{3^{\prime}}\right), 4.27-4.22(\mathrm{~m}, 2 \mathrm{H}$, $\left.\mathrm{H}_{4^{\prime}}, \mathrm{H}_{5^{\prime}}\right), 4.22$ - $4.18\left(\mathrm{~m}, 2 \mathrm{H}, \mathrm{H}_{2^{\prime}}, \mathrm{H}_{6^{\prime}}\right), 4.10\left(\mathrm{qd}, J=6.9,3.1 \mathrm{~Hz}, 1 \mathrm{H}, \mathrm{H}_{5}\right), 3.95(\mathrm{dd}, J=9.9,7.0 \mathrm{~Hz}$, $\left.1 \mathrm{H}, \mathrm{H}_{6^{\prime}}\right), 3.50\left(\mathrm{~d}, J=4.4 \mathrm{~Hz}, 1 \mathrm{H}, \mathrm{H}_{4}\right), 3.35-3.21\left(\mathrm{~m}, 2 \mathrm{H}, \mathrm{CH}_{2}\right), 3.11\left(\mathrm{~d}, J=10.6 \mathrm{~Hz}, 1 \mathrm{H}, \mathrm{H}_{3}\right)$, $2.25\left(\mathrm{~s}, 6 \mathrm{H}, 2 \times \mathrm{NCH}_{3}\right), 2.16\left(\mathrm{td}, J=12.1,3.6 \mathrm{~Hz}, 1 \mathrm{H}, \mathrm{H}_{2}\right), 1.66\left(\mathrm{dt}, J=12.6,3.7 \mathrm{~Hz}, 1 \mathrm{H}, \mathrm{H}_{2}\right)$, $1.46\left(\mathrm{~s}, 6 \mathrm{H}, 2 \times \mathrm{CH}_{3}\right), 1.33\left(\mathrm{~d}, J=7.0 \mathrm{~Hz}, 3 \mathrm{H}, \mathrm{H}_{6}\right), 1.18\left(\mathrm{~s}, 3 \mathrm{H}, \mathrm{CH}_{3}\right), 1.08-1.04(\mathrm{~m}, 6 \mathrm{H}, 2 \times$ $\left.\mathrm{CH}_{3}\right) .{ }^{13} \mathrm{C} \mathrm{NMR}\left(126 \mathrm{MHz}, \mathrm{C}_{6} \mathrm{D}_{6}\right) \delta 109.3(\mathrm{C}), 108.5(\mathrm{C}), 98.5(\mathrm{CH}), 96.9(\mathrm{CH}), 79.3(\mathrm{CH}), 71.6$ $(\mathrm{CH}), 71.3(\mathrm{CH}), 71.2(\mathrm{CH}), 71.0(\mathrm{CH}), 66.9\left(\mathrm{CH}_{2}\right), 66.7(\mathrm{CH}), 64.7\left(\mathrm{CH}_{2}\right), 56.3(\mathrm{CH}), 42.3(2 \times$ $\left.\mathrm{CH}_{3}\right), 28.9\left(\mathrm{CH}_{2}\right), 26.3\left(\mathrm{CH}_{3}\right), 26.3\left(\mathrm{CH}_{3}\right), 24.9\left(\mathrm{CH}_{3}\right), 24.6\left(\mathrm{CH}_{3}\right), 20.0\left(\mathrm{CH}_{3}\right), 15.7\left(\mathrm{CH}_{3}\right)$. IR (ATR-FTIR), $\mathrm{cm}^{-1}: 2979(\mathrm{~m}), 2936(\mathrm{~m}), 2360$ (m), 1459 (m), $1373(\mathrm{~m})$. HRMS-ESI (m/z): [M + $\mathrm{H}]^{+}$calculated for $\left[\mathrm{C}_{22} \mathrm{H}_{40} \mathrm{NO}_{8}\right]^{+} 446.2748$, found 446.2778 . $[a]_{D}^{21}=+15.8^{\circ}\left(c=1.0, \mathrm{CHCl}_{3}\right)$.

Hoang et al. "General method for the synthesis of $\alpha$ - or $\beta$-deoxyaminoglycosides bearing S59 basic nitrogen" 
$\alpha$-anomer:

$\mathrm{R}_{f}=0.40$ (10\% methanol-dichloromethane; CAM). ${ }^{1} \mathrm{H}$ NMR $\left(500 \mathrm{MHz}, \mathrm{C}_{6} \mathrm{D}_{6}\right) \delta 5.55(\mathrm{~d}, J=5.0$ $\left.\mathrm{Hz}, 1 \mathrm{H}, \mathrm{H}_{1^{\prime}}\right), 4.78\left(\mathrm{dd}, J=7.3,4.8 \mathrm{~Hz}, 1 \mathrm{H}, \mathrm{H}_{1}\right), 4.49$ (dd, $\left.J=8.0,2.3 \mathrm{~Hz}, 1 \mathrm{H}, \mathrm{H}_{3^{\prime}}\right), 4.34-4.30$ (m, $\left.1 \mathrm{H}, \mathrm{H}_{6^{\prime}}\right), 4.26\left(\mathrm{t}, J=6.0 \mathrm{~Hz}, 1 \mathrm{H}, \mathrm{H}_{5^{\prime}}\right), 4.22-4.16\left(\mathrm{~m}, 2 \mathrm{H}, \mathrm{H}_{5}, \mathrm{H}_{2^{\prime}}\right), 4.11(\mathrm{dd}, J=8.0,1.9 \mathrm{~Hz}, 1 \mathrm{H}$, $\mathrm{H}_{4^{\prime}}$ ), 3.89 (dd, $\left.J=10.0,6.6 \mathrm{~Hz}, 1 \mathrm{H}, \mathrm{H}_{6^{\prime}}\right), 3.45$ (p, $\left.J=8.9,7.2 \mathrm{~Hz}, 1 \mathrm{H}, \mathrm{CH}_{2}\right), 3.36$ (p, $J=8.9,7.2$ $\left.\mathrm{Hz}, 1 \mathrm{H}, \mathrm{CH}_{2}\right), 3.19$ (t, $\left.J=4.4 \mathrm{~Hz}, 1 \mathrm{H}, \mathrm{H}_{4}\right), 2.47$ (dt, $\left.J=11.9,3.7 \mathrm{~Hz}, 1 \mathrm{H}, \mathrm{H}_{3}\right), 2.29(\mathrm{~s}, 6 \mathrm{H}, 2 \times$ $\left.\mathrm{NCH}_{3}\right), 2.14\left(\mathrm{td}, J=12.4,7.5 \mathrm{~Hz}, 1 \mathrm{H}, \mathrm{H}_{2}\right), 1.82\left(\mathrm{dt}, J=12.9,4.2 \mathrm{~Hz}, 1 \mathrm{H}, \mathrm{H}_{2}\right), 1.47\left(\mathrm{~s}, 3 \mathrm{H}, \mathrm{CH}_{3}\right)$, $1.45\left(\mathrm{~s}, 3 \mathrm{H}, \mathrm{CH}_{3}\right), 1.16\left(\mathrm{~d}, J=6.9 \mathrm{~Hz}, 3 \mathrm{H}, \mathrm{H}_{6}\right), 1.15\left(\mathrm{~s}, 3 \mathrm{H}, \mathrm{CH}_{3}\right), 1.08\left(\mathrm{t}, J=7.0 \mathrm{~Hz}, 3 \mathrm{H}, \mathrm{CH}_{3}\right)$, $1.05\left(\mathrm{~s}, 3 \mathrm{H}, \mathrm{CH}_{3}\right) .{ }^{13} \mathrm{C} \mathrm{NMR}\left(126 \mathrm{MHz}, \mathrm{C}_{6} \mathrm{D}_{6}\right) \delta 109.1(\mathrm{C}), 108.4(\mathrm{C}), 98.4(\mathrm{CH}), 96.9(\mathrm{CH}), 81.7$ $(\mathrm{CH}), 71.8(\mathrm{CH}), 71.3(\mathrm{CH}), 71.2(\mathrm{CH}), 69.1(\mathrm{CH}), 68.0(\mathrm{CH}), 67.2\left(\mathrm{CH}_{2}\right), 65.8\left(\mathrm{CH}_{2}\right), 58.9(\mathrm{CH})$, $43.3\left(2 \times \mathrm{CH}_{3}\right), 28.1\left(\mathrm{CH}_{2}\right), 26.3\left(\mathrm{CH}_{3}\right), 26.3\left(\mathrm{CH}_{3}\right), 25.0\left(\mathrm{CH}_{3}\right), 24.4\left(\mathrm{CH}_{3}\right), 18.8\left(\mathrm{CH}_{3}\right), 16.0$ $\left(\mathrm{CH}_{3}\right)$. IR (ATR-FTIR), $\mathrm{cm}^{-1}: 2979(\mathrm{~m}), 2936(\mathrm{~m}), 2897(\mathrm{~m}), 2778(\mathrm{w}), 2360(\mathrm{~m}), 2337(\mathrm{~m}), 1459$ (m). HRMS-ESI $(\mathrm{m} / \mathrm{z}):[\mathrm{M}+\mathrm{H}]^{+}$calculated for $\left[\mathrm{C}_{22} \mathrm{H}_{40} \mathrm{NO}_{8}\right]^{+} 446.2748$, found 446.2778. [a $]_{D}^{21}$ $=-38.7^{\circ}\left(c=0.3, \mathrm{CHCl}_{3}\right)$. 
Synthesis of the disaccharide $\mathbf{3 7 \boldsymbol { \beta }}$.
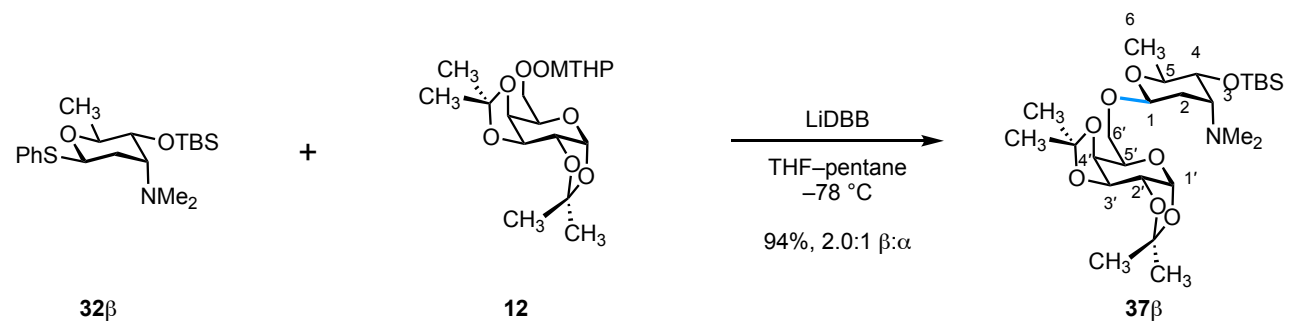

A solution of LiDBB in tetrahydrofuran (nominally $0.4 \mathrm{M}$ ) was added dropwise via syringe to a solution of the amine $32 \beta(43.0 \mathrm{mg}, 113 \mu \mathrm{mol}, 1.50$ equiv) in tetrahydrofuran-pentane $(1: 1 \mathrm{v} / \mathrm{v}$, $1.8 \mathrm{~mL}$ ) in a $10-\mathrm{mL}$ round-bottomed flask that had been fused to a Teflon-coated valve at $-78^{\circ} \mathrm{C}$. The addition of LiDBB was continued until a green color persisted $(584 \mu \mathrm{L}$, nominally $234 \mu \mathrm{mol}$, 3.10 equiv). The resulting mixture was stirred for $10 \mathrm{~min}$ at $-78{ }^{\circ} \mathrm{C}$. A solution of the MTHP monoperoxy acetal $12(28.1 \mathrm{mg}, 75.0 \mu \mathrm{mol}, 1$ equiv $)$ in tetrahydrofuran $(300 \mu \mathrm{L})$ was then added dropwise via syringe. The resulting mixture was stirred for $3 \mathrm{~h}$ at $-78^{\circ} \mathrm{C}$. The cold product mixture was diluted with saturated aqueous sodium hydrogen carbonate solution $(1.0 \mathrm{~mL})$. The diluted product mixture was allowed to warm to $23{ }^{\circ} \mathrm{C}$ over $15 \mathrm{~min}$. The warmed product mixture was transferred to a $20-\mathrm{mL}$ test tube and the layers that formed were separated. The aqueous layer was extracted with ethyl acetate $(4 \times 5.0 \mathrm{~mL})$. The organic layers were combined and the combined organic layers were dried over sodium sulfate. The dried solution was filtered and the filtrate was concentrated under a stream of nitrogen. The residue obtained was purified by flashcolumn chromatography (eluting with $1 \%$ methanol-dichloromethane initially, grading to $5 \%$ methanol-dichloromethane, five steps) to provide the disaccharide $\mathbf{3 7 \beta}$ as a colorless oil (31.4 mg, $94 \%)$.

The diastereoselectivity of the reaction was determined to be $2.0: 1 \beta: \alpha$ by ${ }^{1} \mathrm{H}$ NMR analysis of the unpurified product mixture.

$\beta$-anomer:

$\mathrm{R}_{f}=0.35$ (5\% methanol-dichloromethane; CAM). ${ }^{1} \mathrm{H}$ NMR (600 MHz, $\left.\mathrm{C}_{6} \mathrm{D}_{6}\right) \delta 5.53(\mathrm{~d}, J=5.1$ $\left.\mathrm{Hz}, 1 \mathrm{H}, \mathrm{H}_{1^{\prime}}\right), 5.16\left(\mathrm{dd}, J=5.1,3.4 \mathrm{~Hz}, 1 \mathrm{H}, \mathrm{H}_{1}\right), 4.55\left(\mathrm{dd}, J=7.9,2.3 \mathrm{~Hz}, 1 \mathrm{H}, \mathrm{H}_{3^{\prime}}\right), 4.34-4.28(\mathrm{~m}$, $\left.2 \mathrm{H}, \mathrm{H}_{4^{\prime}}, \mathrm{H}_{5^{\prime}}\right), 4.25\left(\mathrm{dd}, J=9.9,5.9 \mathrm{~Hz}, 1 \mathrm{H}, \mathrm{H}_{6^{\prime}}\right), 4.20\left(\mathrm{dd}, J=5.1,2.3 \mathrm{~Hz}, 1 \mathrm{H}, \mathrm{H}_{2^{\prime}}\right), 4.13(\mathrm{qd}, J=$ 6.8, $\left.4.7 \mathrm{~Hz}, 1 \mathrm{H}, \mathrm{H}_{5}\right), 4.07$ (dd, $\left.J=10.0,7.8 \mathrm{~Hz}, 1 \mathrm{H}, \mathrm{H}_{6^{\prime}}\right), 3.70$ (dd, $\left.J=4.6,2.3 \mathrm{~Hz}, 1 \mathrm{H}, \mathrm{H}_{4}\right), 2.65$ $-2.56\left(\mathrm{~m}, 1 \mathrm{H}, \mathrm{H}_{3}\right), 2.26-2.21\left(\mathrm{~m}, 1 \mathrm{H}, \mathrm{H}_{2}\right), 2.20\left(\mathrm{~s}, 6 \mathrm{H}, 2 \times \mathrm{NCH}_{3}\right), 1.77(\mathrm{dt}, J=13.2,4.6 \mathrm{~Hz}$, $\left.1 \mathrm{H}, \mathrm{H}_{2}\right), 1.46\left(\mathrm{~s}, 3 \mathrm{H}, \mathrm{CH}_{3}\right), 1.45\left(\mathrm{~s}, 3 \mathrm{H}, \mathrm{CH}_{3}\right), 1.32\left(\mathrm{~d}, J=6.8 \mathrm{~Hz}, 3 \mathrm{H}, \mathrm{H}_{6}\right), 1.16\left(\mathrm{~s}, 3 \mathrm{H}, \mathrm{CH}_{3}\right), 1.05$ $\left(\mathrm{s}, 3 \mathrm{H}, \mathrm{CH}_{3}\right), 0.97\left(\mathrm{~s}, 9 \mathrm{H}, 3 \times \mathrm{CH}_{3}\right), 0.07\left(\mathrm{~s}, 3 \mathrm{H}, \mathrm{CH}_{3}\right), 0.02\left(\mathrm{~s}, 3 \mathrm{H}, \mathrm{CH}_{3}\right) .{ }^{13} \mathrm{C} \mathrm{NMR}(151 \mathrm{MHz}$, $\left.\mathrm{C}_{6} \mathrm{D}_{6}\right) \delta 109.2(\mathrm{C}), 108.4(\mathrm{C}), 99.0(\mathrm{CH}), 96.9(\mathrm{CH}), 74.9(\mathrm{CH}), 74.0(\mathrm{CH}), 71.6(\mathrm{CH}), 71.3(\mathrm{CH})$, $71.3(\mathrm{CH}), 67.0\left(\mathrm{CH}_{2}\right), 66.8(\mathrm{CH}), 58.8(\mathrm{CH}), 43.9\left(2 \times \mathrm{CH}_{3}\right), 31.7\left(\mathrm{CH}_{2}\right), 26.3\left(\mathrm{CH}_{3}\right), 26.3\left(\mathrm{CH}_{3}\right)$, $26.2\left(3 \times \mathrm{CH}_{3}\right), 24.9\left(\mathrm{CH}_{3}\right), 24.6\left(\mathrm{CH}_{3}\right), 19.8\left(\mathrm{CH}_{3}\right), 18.4(\mathrm{C}),-3.8\left(\mathrm{CH}_{3}\right),-4.7\left(\mathrm{CH}_{3}\right)$. IR $(\mathrm{ATR}-$ FTIR), $\mathrm{cm}^{-1}: 2925(\mathrm{~m}), 2896(\mathrm{~m}), 2857(\mathrm{~m}), 2820(\mathrm{w}), 2773(\mathrm{w}), 2361(\mathrm{~m}), 2341(\mathrm{~m}), 1462(\mathrm{~m})$. HRMS-ESI $(\mathrm{m} / \mathrm{z}):[\mathrm{M}+\mathrm{H}]^{+}$calculated for $\left[\mathrm{C}_{26} \mathrm{H}_{50} \mathrm{NO}_{8} \mathrm{Si}\right]^{+}$532.3300, found 532.3330. $[a]_{D}^{21}=-$ $10.5^{\circ}\left(c=0.9, \mathrm{CHCl}_{3}\right)$.

Hoang et al. "General method for the synthesis of $\alpha$ - or $\beta$-deoxyaminoglycosides bearing S61 basic nitrogen" 
$\alpha$-anomer:

$\mathrm{R}_{f}=0.29$ (5\% methanol-dichloromethane; CAM). ${ }^{1} \mathrm{H}$ NMR $\left(600 \mathrm{MHz}, \mathrm{C}_{6} \mathrm{D}_{6}\right) \delta 5.56(\mathrm{~d}, J=5.0$ $\left.\mathrm{Hz}, 1 \mathrm{H}, \mathrm{H}_{1^{\prime}}\right), 4.77\left(\mathrm{dd}, J=7.3,4.5 \mathrm{~Hz}, 1 \mathrm{H}, \mathrm{H}_{1}\right), 4.48\left(\mathrm{dd}, J=8.0,2.3 \mathrm{~Hz}, 1 \mathrm{H}, \mathrm{H}_{3^{\prime}}\right), 4.31$ (dd, $J=$ 10.2, $\left.4.9 \mathrm{~Hz}, 1 \mathrm{H}, \mathrm{H}_{6^{\prime}}\right), 4.24\left(\mathrm{td}, J=5.8,4.8,1.7 \mathrm{~Hz}, 1 \mathrm{H}, \mathrm{H}_{5^{\prime}}\right), 4.19-4.14\left(\mathrm{~m}, 2 \mathrm{H}, \mathrm{H}_{5}, \mathrm{H}_{2^{\prime}}\right), 4.07$ $\left(\mathrm{dd}, J=8.0,1.8 \mathrm{~Hz}, 1 \mathrm{H}, \mathrm{H}_{4^{\prime}}\right), 3.91\left(\mathrm{dd}, J=10.2,6.9 \mathrm{~Hz}, 1 \mathrm{H}, \mathrm{H}_{6^{\prime}}\right), 3.62\left(\mathrm{t}, J=3.9 \mathrm{~Hz}, 1 \mathrm{H}, \mathrm{H}_{4}\right), 2.28$ $\left(\mathrm{dt}, J=11.4,3.5 \mathrm{~Hz}, 1 \mathrm{H}, \mathrm{H}_{3}\right), 2.20\left(\mathrm{~s}, 6 \mathrm{H}, 2 \times \mathrm{NCH}_{3}\right), 2.08\left(\mathrm{td}, J=12.1,11.7,7.3 \mathrm{~Hz}, 1 \mathrm{H}, \mathrm{H}_{2}\right)$, $1.77\left(\mathrm{dt}, J=12.9,4.1 \mathrm{~Hz}, 1 \mathrm{H}, \mathrm{H}_{2}\right), 1.47\left(\mathrm{~s}, 3 \mathrm{H}, \mathrm{CH}_{3}\right), 1.46\left(\mathrm{~s}, 3 \mathrm{H}, \mathrm{CH}_{3}\right), 1.16\left(\mathrm{~s}, 3 \mathrm{H}, \mathrm{CH}_{3}\right), 1.13$ $\left(\mathrm{d}, J=6.8 \mathrm{~Hz}, 3 \mathrm{H}, \mathrm{H}_{6}\right), 1.05\left(\mathrm{~s}, 3 \mathrm{H}, \mathrm{CH}_{3}\right), 1.00\left(\mathrm{~s}, 9 \mathrm{H}, 3 \times \mathrm{CH}_{3}\right), 0.14\left(\mathrm{~s}, 3 \mathrm{H}, \mathrm{CH}_{3}\right), 0.06(\mathrm{~s}, 3 \mathrm{H}$, $\left.\mathrm{CH}_{3}\right) .{ }^{13} \mathrm{C}$ NMR $\left(151 \mathrm{MHz}, \mathrm{C}_{6} \mathrm{D}_{6}\right) \delta 109.1(\mathrm{C}), 108.4(\mathrm{C}), 98.2(\mathrm{CH}), 96.9(\mathrm{CH}), 74.4(\mathrm{CH}), 72.2$ $(\mathrm{CH}), 71.8(\mathrm{CH}), 71.3(\mathrm{CH}), 71.1(\mathrm{CH}), 68.1(\mathrm{CH}), 67.5\left(\mathrm{CH}_{2}\right), 60.4(\mathrm{CH}), 43.9\left(2 \times \mathrm{CH}_{3}\right), 28.5$ $\left(\mathrm{CH}_{2}\right), 26.3\left(\mathrm{CH}_{3}\right), 26.3\left(\mathrm{CH}_{3}\right), 26.2\left(3 \times \mathrm{CH}_{3}\right), 25.0\left(\mathrm{CH}_{3}\right), 24.4\left(\mathrm{CH}_{3}\right), 18.5(\mathrm{C}), 18.1\left(\mathrm{CH}_{3}\right),-3.8$ $\left(\mathrm{CH}_{3}\right),-4.4\left(\mathrm{CH}_{3}\right)$. IR (ATR-FTIR), $\mathrm{cm}^{-1}: 2934(\mathrm{~m}), 2897(\mathrm{~m}), 2857(\mathrm{~m}), 2770(\mathrm{w}), 2360(\mathrm{~m})$, $2343(\mathrm{~m}), 1461(\mathrm{~m})$. HRMS-ESI $(\mathrm{m} / \mathrm{z}):[\mathrm{M}+\mathrm{H}]^{+}$calculated for $\left[\mathrm{C}_{26} \mathrm{H}_{50} \mathrm{NO}_{8} \mathrm{Si}\right]^{+}$532.3300, found 532.3321. $[a]_{D}^{21}=-86.2^{\circ}\left(c=0.3, \mathrm{CHCl}_{3}\right)$. 
Synthesis of the disaccharide $\mathbf{3 8 \boldsymbol { \beta }}$.

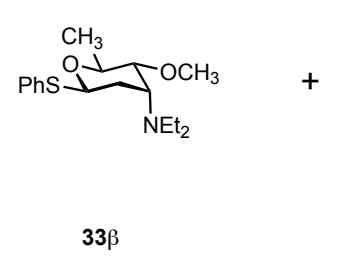

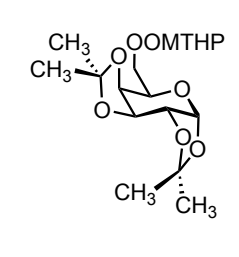

12

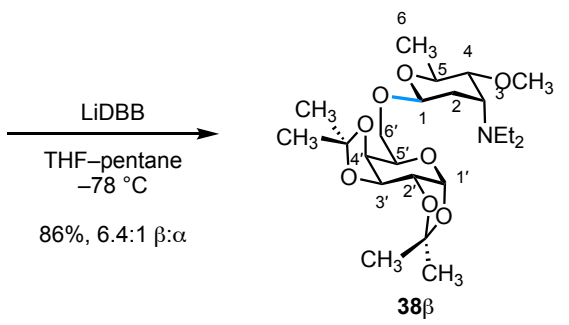

$38 \beta$

A solution of LiDBB in tetrahydrofuran (nominally $0.4 \mathrm{M}$ ) was added dropwise via syringe to a solution of the amine $\mathbf{3 3 \beta}(34.8 \mathrm{mg}, 113 \mu \mathrm{mol}, 1.50$ equiv) in tetrahydrofuran-pentane $(1: 1 \mathrm{v} / \mathrm{v}$, $1.8 \mathrm{~mL}$ ) in a $10-\mathrm{mL}$ round-bottomed flask that had been fused to a Teflon-coated valve at $-78^{\circ} \mathrm{C}$. The addition of LiDBB was continued until a green color persisted $(584 \mu \mathrm{L}$, nominally $234 \mu \mathrm{mol}$, 3.10 equiv). The resulting mixture was stirred for $10 \mathrm{~min}$ at $-78{ }^{\circ} \mathrm{C}$. A solution of the MTHP monoperoxy acetal $12(28.1 \mathrm{mg}, 75.0 \mu \mathrm{mol}, 1$ equiv $)$ in tetrahydrofuran $(300 \mu \mathrm{L})$ was then added dropwise via syringe. The resulting mixture was stirred for $3 \mathrm{~h}$ at $-78{ }^{\circ} \mathrm{C}$. The cold product mixture was diluted with saturated aqueous sodium hydrogen carbonate solution $(1.0 \mathrm{~mL})$. The diluted product mixture was allowed to warm to $23^{\circ} \mathrm{C}$ over $15 \mathrm{~min}$. The warmed product mixture was transferred to a $20-\mathrm{mL}$ test tube and the layers that formed were separated. The aqueous layer was extracted with ethyl acetate $(4 \times 5.0 \mathrm{~mL})$. The organic layers were combined and the combined organic layers were dried over sodium sulfate. The dried solution was filtered and the filtrate was concentrated under a stream of nitrogen. The residue obtained was purified by flashcolumn chromatography (eluting with 1\% methanol-dichloromethane initially, grading to 5\% methanol-dichloromethane, five steps) to provide the disaccharide $\mathbf{3 8 \beta}$ as a colorless oil (29.6 $\mathrm{mg}$, $86 \%$, inseparable mixture of $\alpha$ - and $\beta$-anomers).

The diastereoselectivity of the reaction was determined to be $6.4: 1 \beta: \alpha$ by ${ }^{1} \mathrm{H}$ NMR analysis of the unpurified product mixture.

The diastereomers were not separable by flash-column chromatography; consequently, the optical rotation of $\mathbf{3 8 \beta}$ was not determined.

$\mathrm{R}_{f}=0.18$ (5\% methanol-dichloromethane; CAM). ${ }^{1} \mathrm{H}$ NMR $\left(600 \mathrm{MHz}, \mathrm{C}_{6} \mathrm{D}_{6}\right) \delta 5.53(\mathrm{~d}, J=5.0$ $\mathrm{Hz}, 1 \mathrm{H}, \mathrm{H}_{1^{\prime}}$ ), 5.14 (t, $\left.J=3.3 \mathrm{~Hz}, 1 \mathrm{H} \mathrm{H}_{1}\right), 4.53$ (dd, $\left.J=7.9,2.3 \mathrm{~Hz}, 1 \mathrm{H} \mathrm{H}_{3^{\prime}}\right), 4.28-4.23(\mathrm{~m}, 2 \mathrm{H}$, $\left.\mathrm{H}_{5^{\prime}}, \mathrm{H}_{6^{\prime}}\right), 4.21\left(\mathrm{dd}, J=8.0,1.6 \mathrm{~Hz}, 1 \mathrm{H}, \mathrm{H}_{4^{\prime}}\right), 4.19\left(\mathrm{dd}, J=5.1,2.4 \mathrm{~Hz}, 1 \mathrm{H}, \mathrm{H}_{2^{\prime}}\right), 4.13(\mathrm{qd}, J=6.9$, $\left.2.3 \mathrm{~Hz}, 1 \mathrm{H}, \mathrm{H}_{5}\right), 4.00-3.96\left(\mathrm{~m}, 1 \mathrm{H}, \mathrm{H}_{6^{\prime}}\right), 3.42\left(\mathrm{dt}, J=11.4,3.2 \mathrm{~Hz}, 1 \mathrm{H}, \mathrm{H}_{3}\right), 3.12\left(\mathrm{br} \mathrm{s}, 1 \mathrm{H}, \mathrm{H}_{4}\right)$, $3.09\left(\mathrm{~s}, 3 \mathrm{H}, \mathrm{OCH}_{3}\right), 2.66\left(\mathrm{q}, J=6.8 \mathrm{~Hz}, 4 \mathrm{H}, \mathrm{NCH}_{2}\right), 2.35\left(\mathrm{td}, J=12.3,3.9 \mathrm{~Hz}, 1 \mathrm{H}, \mathrm{H}_{2}\right), 1.78(\mathrm{dt}$, $\left.J=12.7,3.4 \mathrm{~Hz}, 1 \mathrm{H}, \mathrm{H}_{2}\right), 1.46\left(\mathrm{~s}, 3 \mathrm{H}, \mathrm{CH}_{3}\right), 1.43\left(\mathrm{~s}, 3 \mathrm{H}, \mathrm{CH}_{3}\right), 1.34\left(\mathrm{~d}, J=7.0 \mathrm{~Hz}, 3 \mathrm{H}, \mathrm{H}_{6}\right), 1.15$ $\left(\mathrm{s}, 3 \mathrm{H}, \mathrm{CH}_{3}\right), 1.04\left(\mathrm{~s}, 3 \mathrm{H}, \mathrm{CH}_{3}\right), 1.02\left(\mathrm{t}, J=7.1 \mathrm{~Hz}, 6 \mathrm{H}, 2 \times \mathrm{CH}_{3}\right) .{ }^{13} \mathrm{C} \mathrm{NMR}\left(151 \mathrm{MHz}, \mathrm{C}_{6} \mathrm{D}_{6}\right) \delta$ $109.2(\mathrm{C}), 108.4(\mathrm{C}), 99.7(\mathrm{CH}), 96.9(\mathrm{CH}), 82.8(\mathrm{CH}), 71.6(\mathrm{CH}), 71.3(\mathrm{CH}), 71.2(2 \times \mathrm{CH}), 67.0$ $(\mathrm{CH}), 66.7\left(\mathrm{CH}_{2}\right), 56.5\left(\mathrm{CH}_{3}\right), 50.1(\mathrm{CH}), 44.5\left(2 \times \mathrm{CH}_{2}\right), 29.7\left(\mathrm{CH}_{2}\right), 26.3\left(\mathrm{CH}_{3}\right), 26.2\left(\mathrm{CH}_{3}\right)$, $24.9\left(\mathrm{CH}_{3}\right), 24.6\left(\mathrm{CH}_{3}\right), 20.5\left(\mathrm{CH}_{3}\right), 14.4\left(2 \times \mathrm{CH}_{3}\right)$. IR (ATR-FTIR), $\mathrm{cm}^{-1}: 2975(\mathrm{~m}), 2935(\mathrm{~m})$, $2821(\mathrm{~m}), 2359(\mathrm{~m}), 1458(\mathrm{~m})$. HRMS-ESI $(\mathrm{m} / \mathrm{z}):[\mathrm{M}+\mathrm{H}]^{+}$calculated for $\left[\mathrm{C}_{23} \mathrm{H}_{42} \mathrm{NO}_{8}\right]^{+} 460.2905$, found 460.2931 .

Hoang et al. "General method for the synthesis of $\alpha$ - or $\beta$-deoxyaminoglycosides bearing S63 basic nitrogen" 


\section{Catalog of NMR Spectra.}

${ }^{1} \mathrm{H} \mathrm{NMR}, 600 \mathrm{MHz}, \mathrm{CDCl}_{3}$
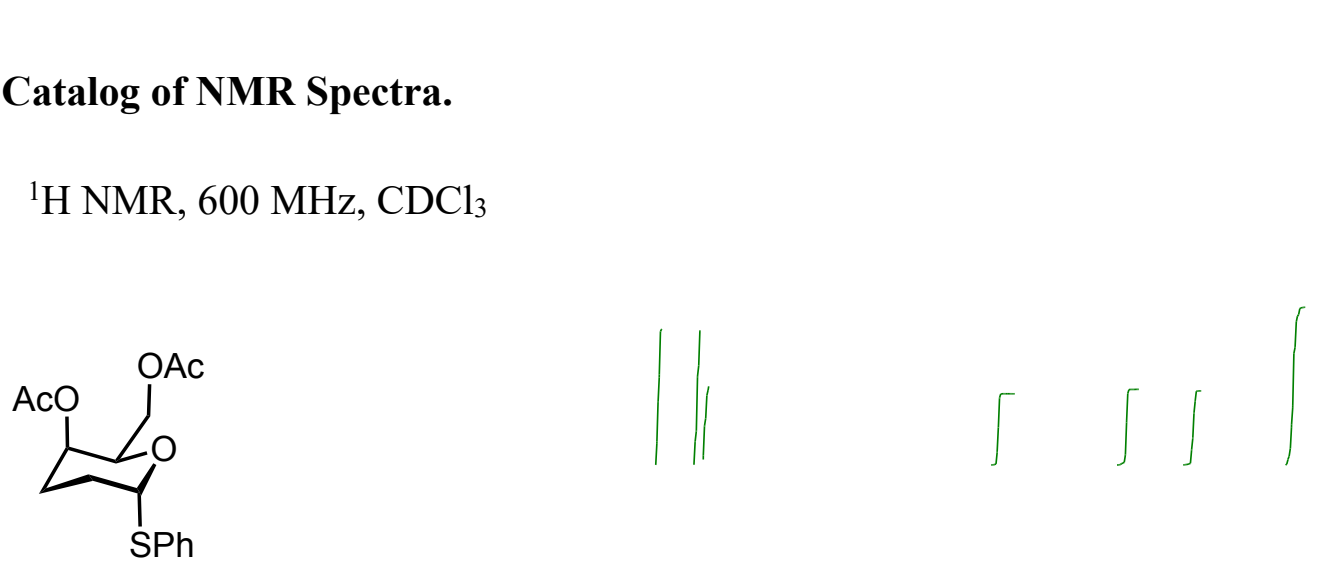

s2

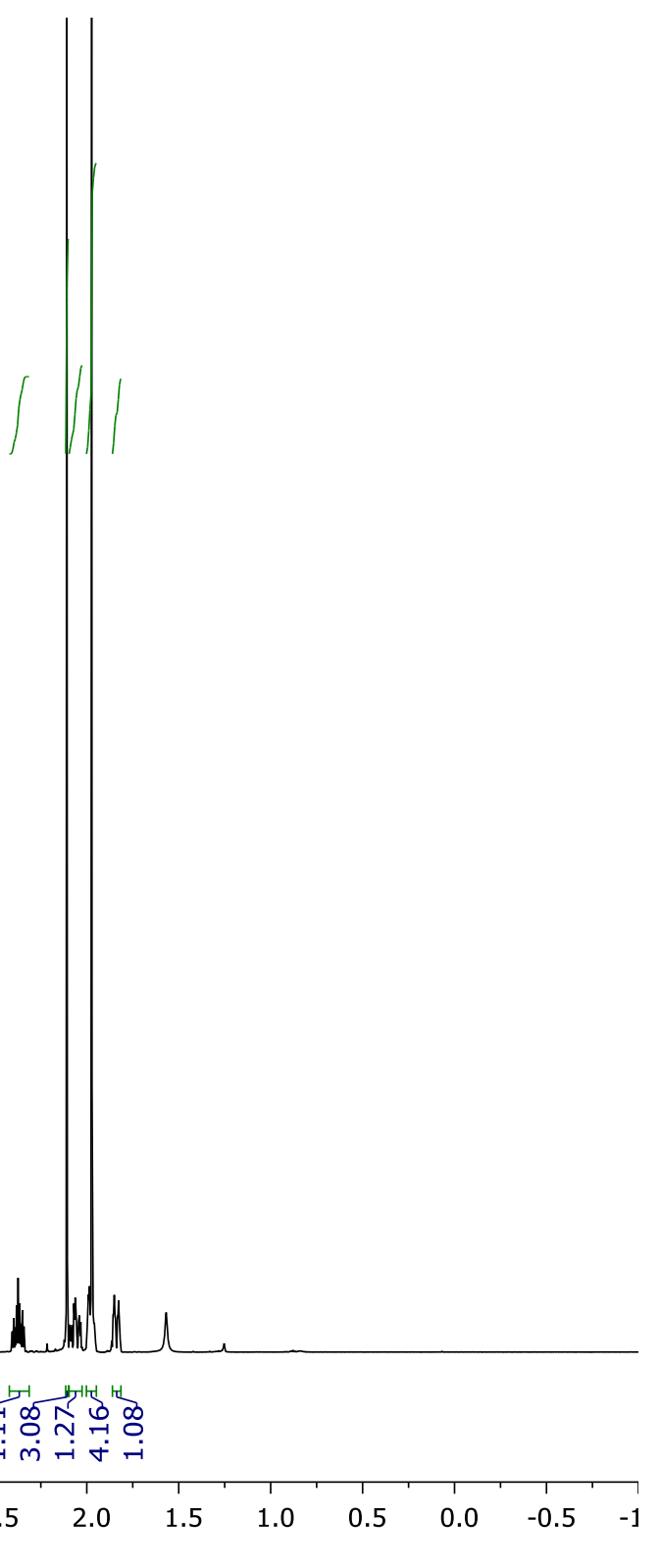

$\begin{array}{lll}.0 & 10.5 \quad 10.0\end{array}$

Hoang et al. "General method for the synthesis of $\alpha$ - or $\beta$-deoxyaminoglycosides bearing S64 basic nitrogen" 


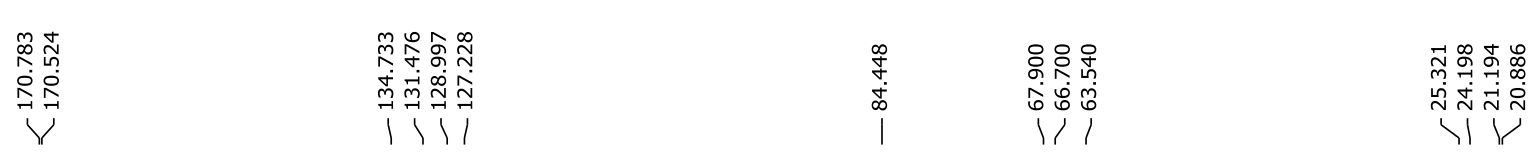

${ }^{13} \mathrm{C} \mathrm{NMR}, 151 \mathrm{MHz}, \mathrm{CDCl}_{3}$

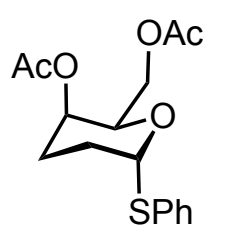

S2

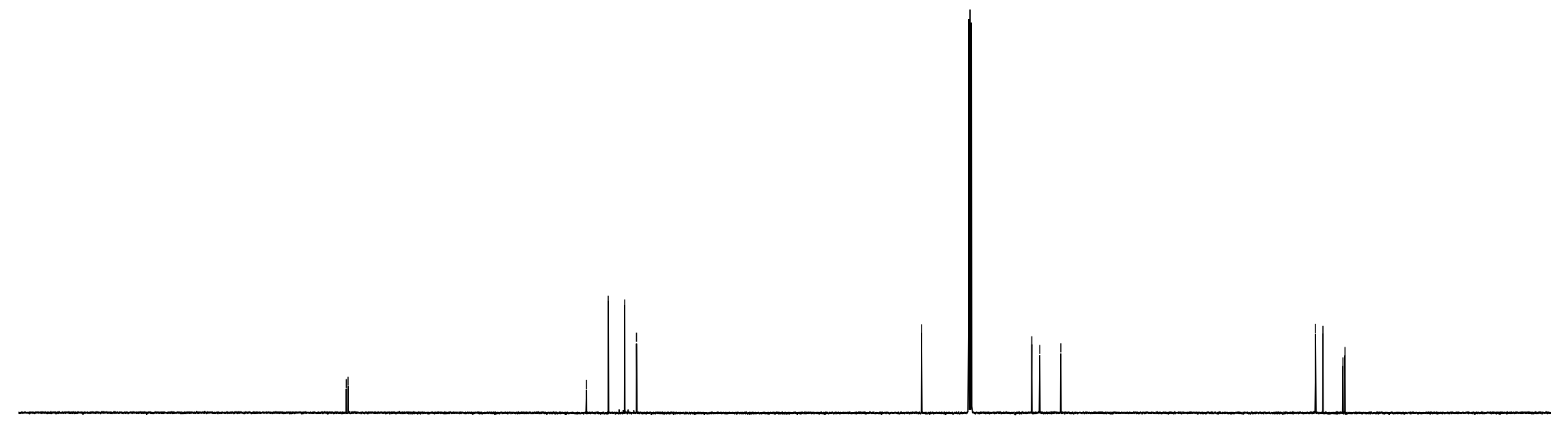

\begin{tabular}{|c|c|c|c|c|c|c|c|c|c|c|c|c|c|c|c|c|c|c|c|c|c|}
\hline \multicolumn{2}{|r|}{210} & 200 & $\begin{array}{c}1 \\
190\end{array}$ & 180 & 170 & 160 & $\begin{array}{c}1 \\
150\end{array}$ & & 130 & 120 & $110 \quad 100$ & 90 & 80 & 70 & 60 & 50 & 40 & & 20 & 10 & 0 \\
\hline
\end{tabular}

Hoang et al. "General method for the synthesis of $\alpha$ - or $\beta$-deoxyaminoglycosides bearing S65 basic nitrogen" 
HSQC NMR, $600 \mathrm{MHz}, \mathrm{CDCl}_{3}$
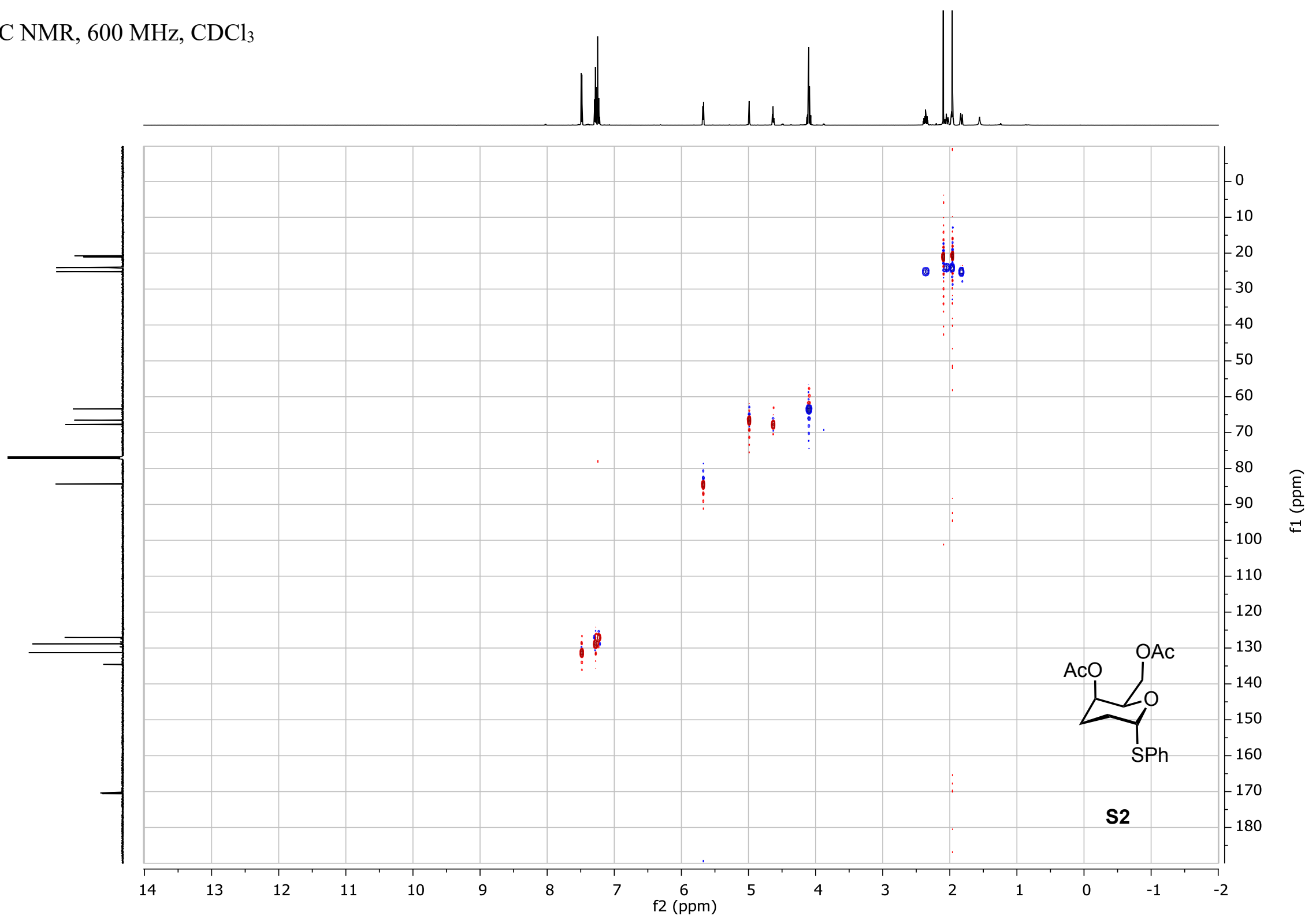

Hoang et al. "General method for the synthesis of $\alpha$ - or $\beta$-deoxyaminoglycosides bearing S66 basic nitrogen" 
${ }^{1} \mathrm{H} \mathrm{NMR}, 500 \mathrm{MHz}, \mathrm{CDCl}_{3}$
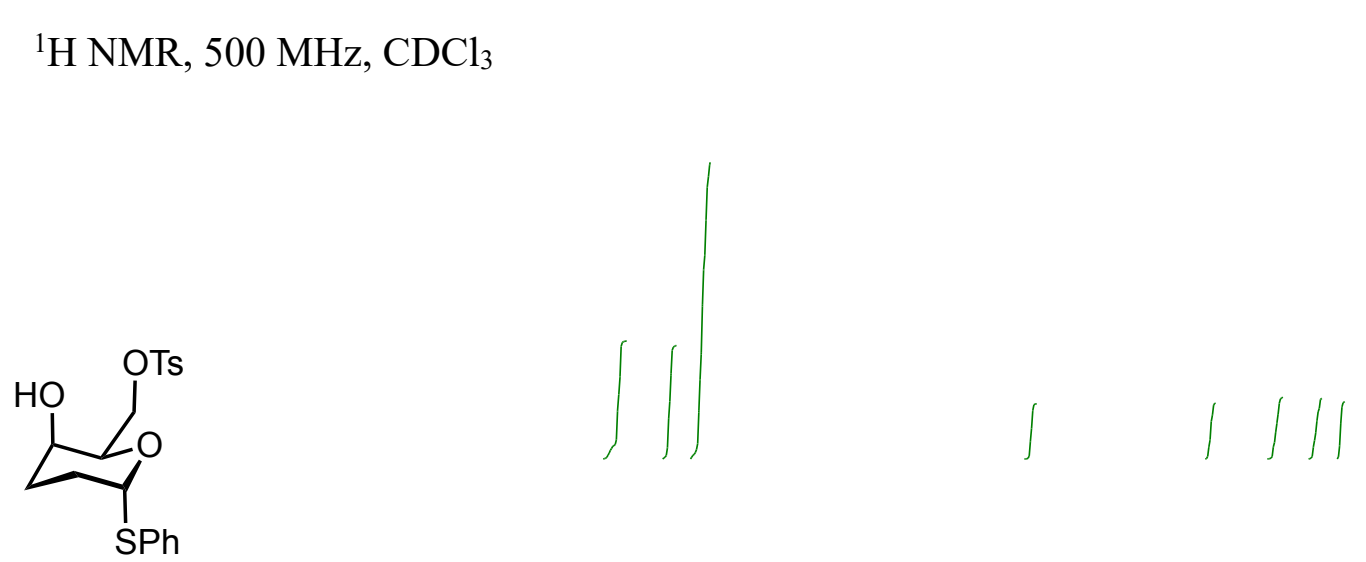

S3

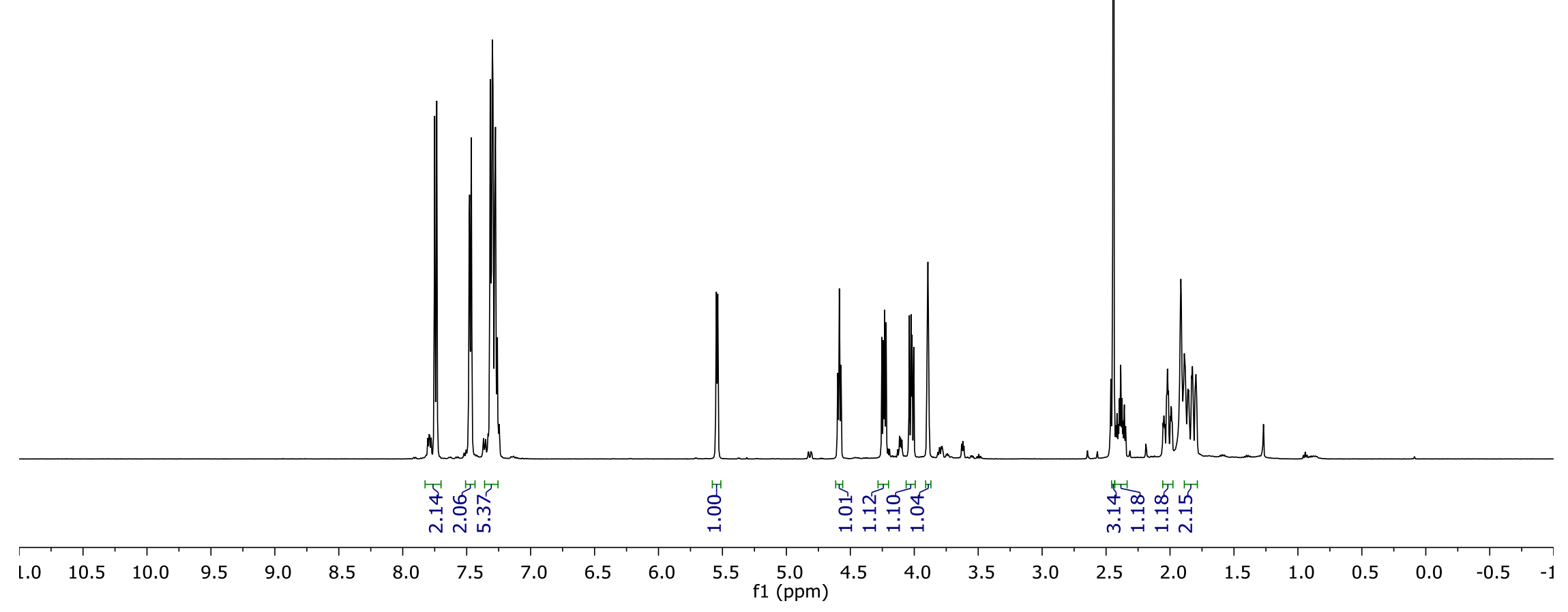

Hoang et al. "General method for the synthesis of $\alpha$ - or $\beta$-deoxyaminoglycosides bearing S67 basic nitrogen" 
${ }^{13} \mathrm{C} \mathrm{NMR}, 126 \mathrm{MHz}, \mathrm{CDCl}_{3}$

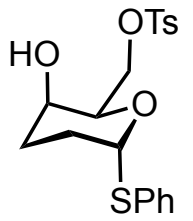

S3

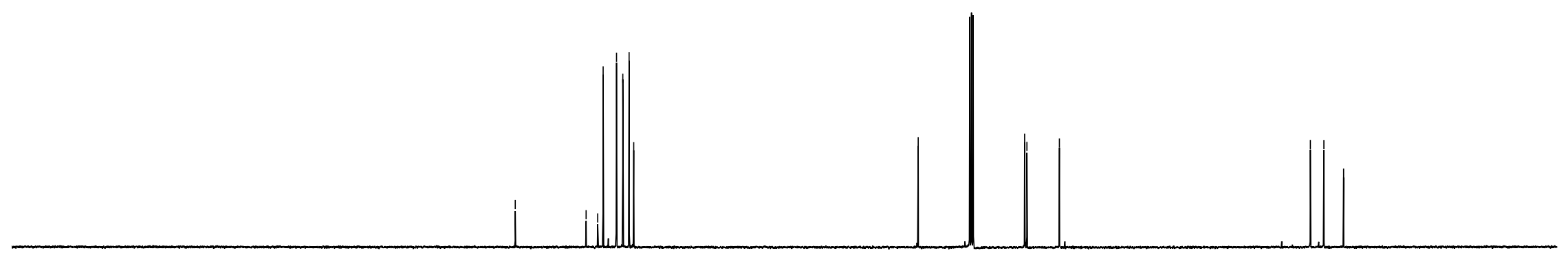

$20 \quad 210 \quad 200 \quad 190 \quad 180 \quad 170$

$110 \quad 100$

90

80

70

60

40

$30 \quad 20$

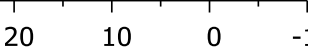

Hoang et al. "General method for the synthesis of $\alpha$ - or $\beta$-deoxyaminoglycosides bearing S68 basic nitrogen" 
HSQC NMR, $500 \mathrm{MHz}, \mathrm{CDCl}_{3}$

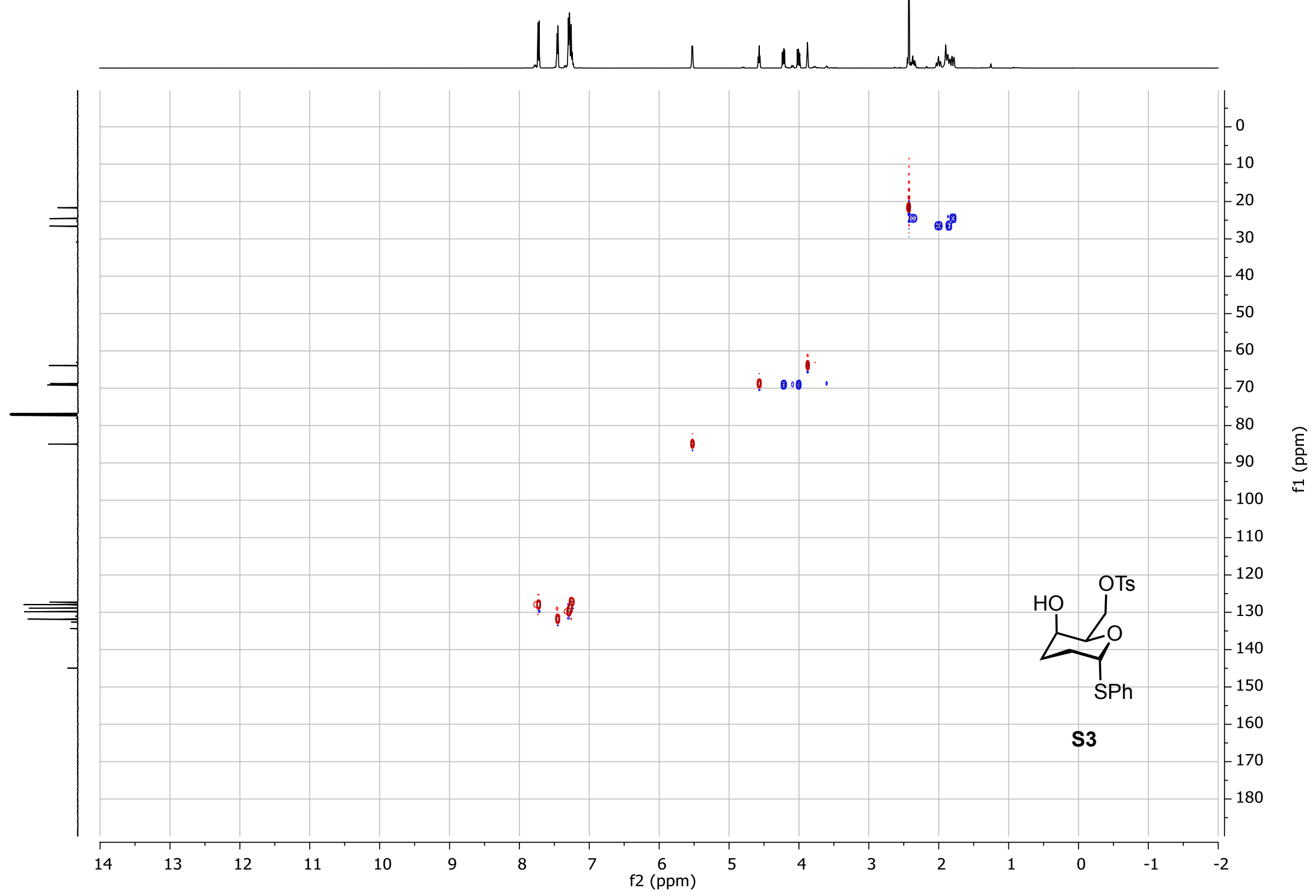

Hoang et al. "General method for the synthesis of $\alpha$ - or $\beta$-deoxyaminoglycosides bearing S69 basic nitrogen" 


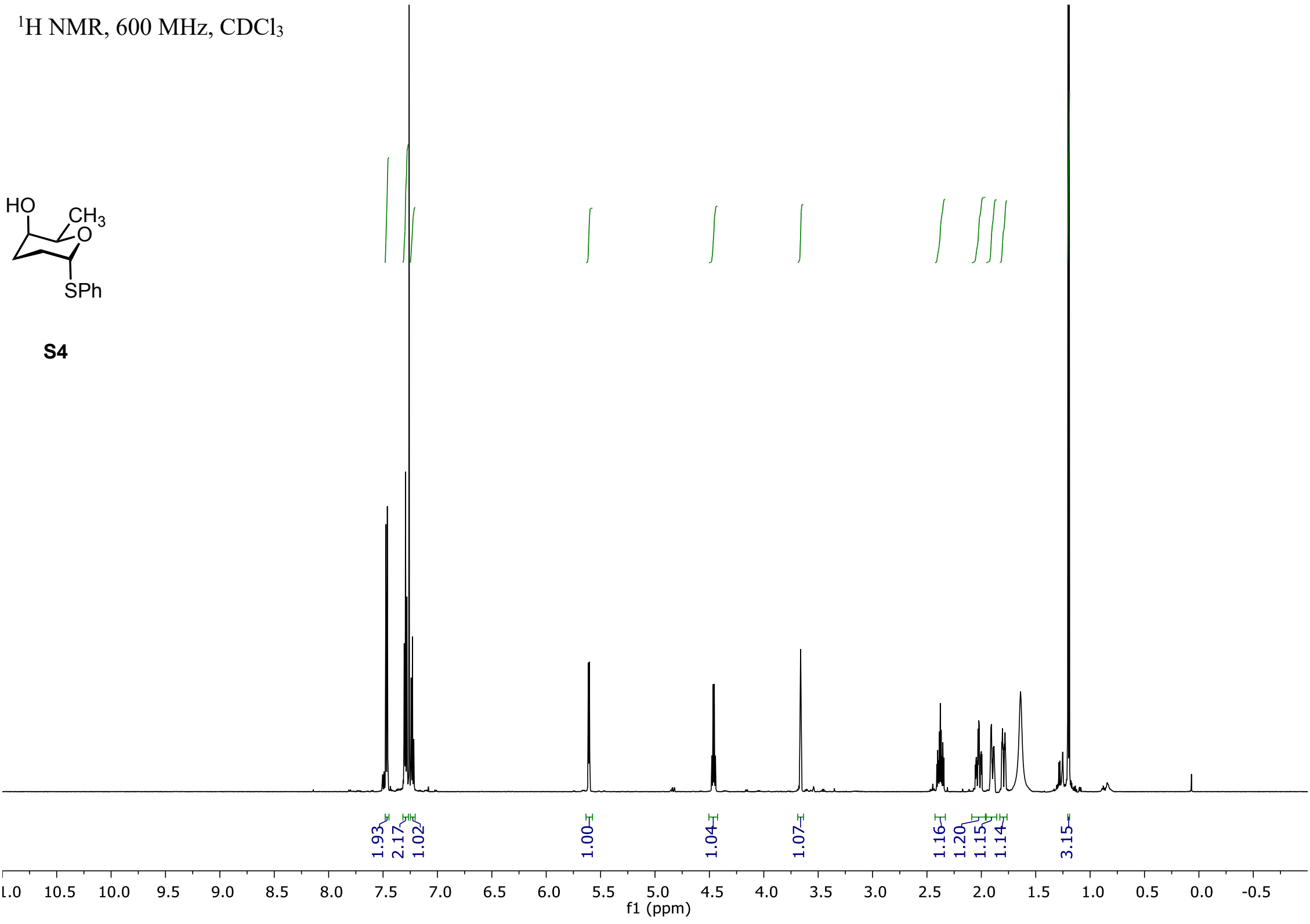

Hoang et al. "General method for the synthesis of $\alpha$ - or $\beta$-deoxyaminoglycosides bearing S70 basic nitrogen" 
${ }^{13} \mathrm{C} \mathrm{NMR}, 151 \mathrm{MHz}, \mathrm{CDCl}_{3}$

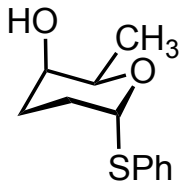

S4

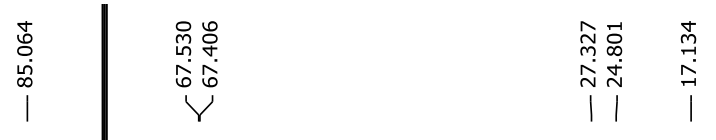

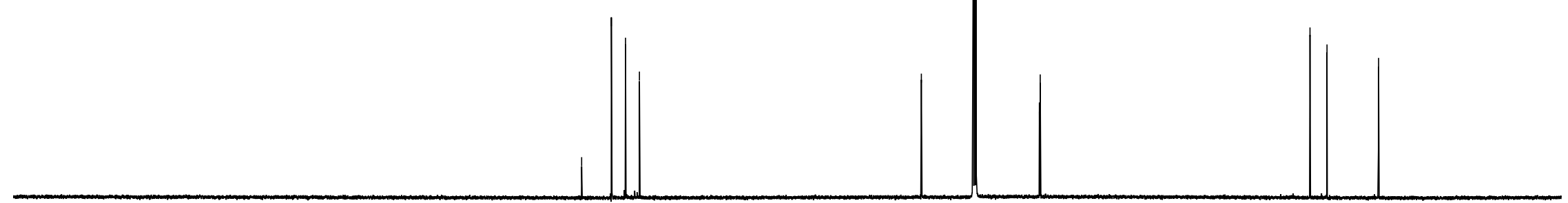

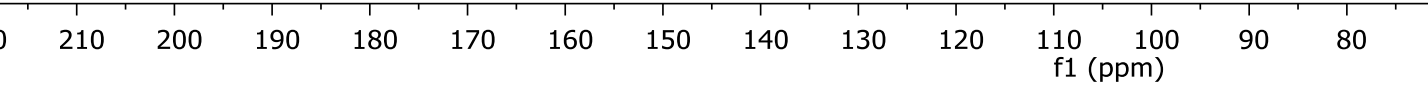

Hoang et al. "General method for the synthesis of $\alpha$ - or $\beta$-deoxyaminoglycosides bearing

S71

basic nitrogen" 
HSQC NMR, $600 \mathrm{MHz}, \mathrm{CDCl}_{3}$
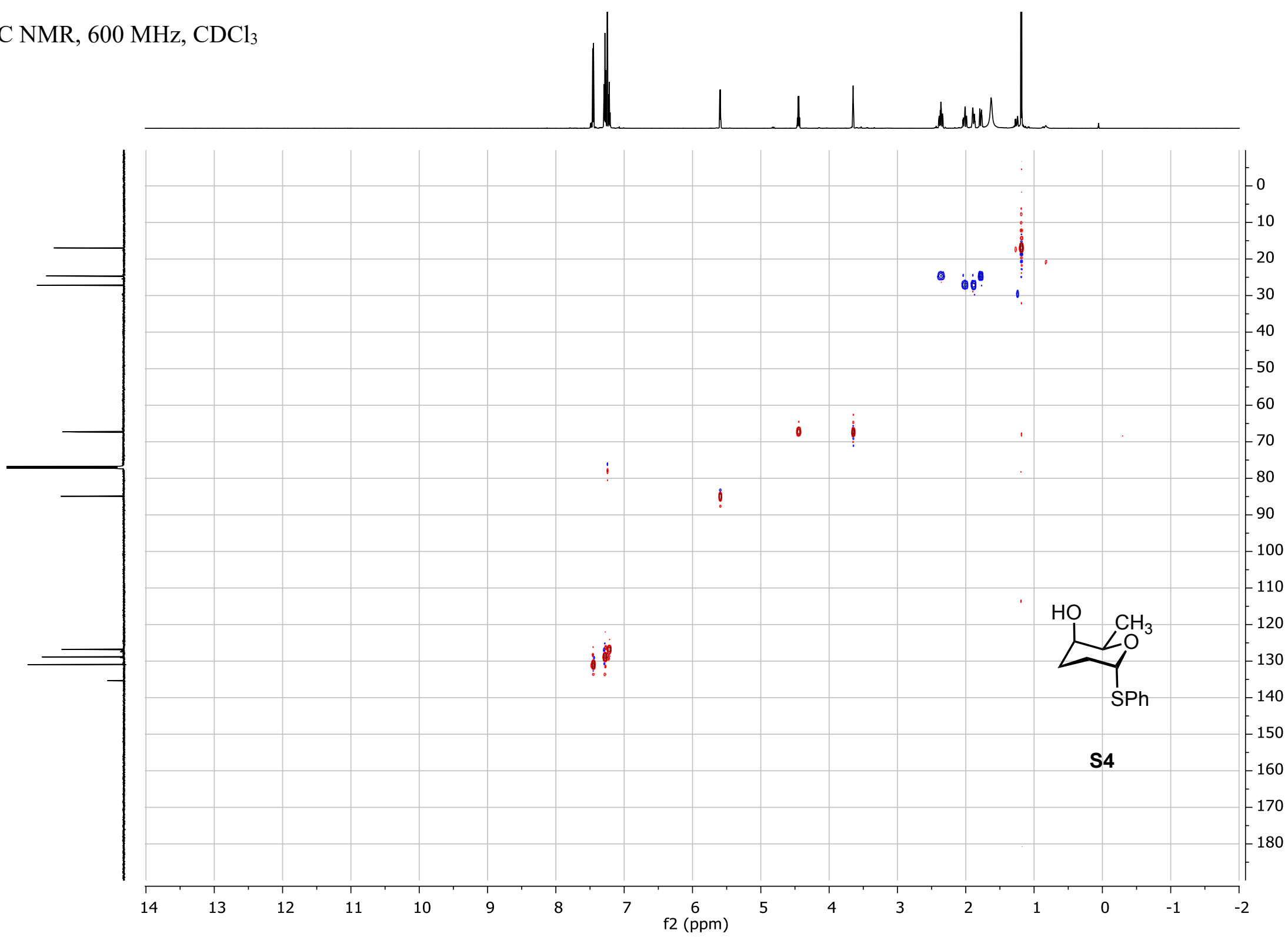

Hoang et al. "General method for the synthesis of $\alpha$ - or $\beta$-deoxyaminoglycosides bearing

$\mathrm{S} 72$ basic nitrogen" 
${ }^{1} \mathrm{H} \mathrm{NMR}, 600 \mathrm{MHz}, \mathrm{CDCl}_{3}$
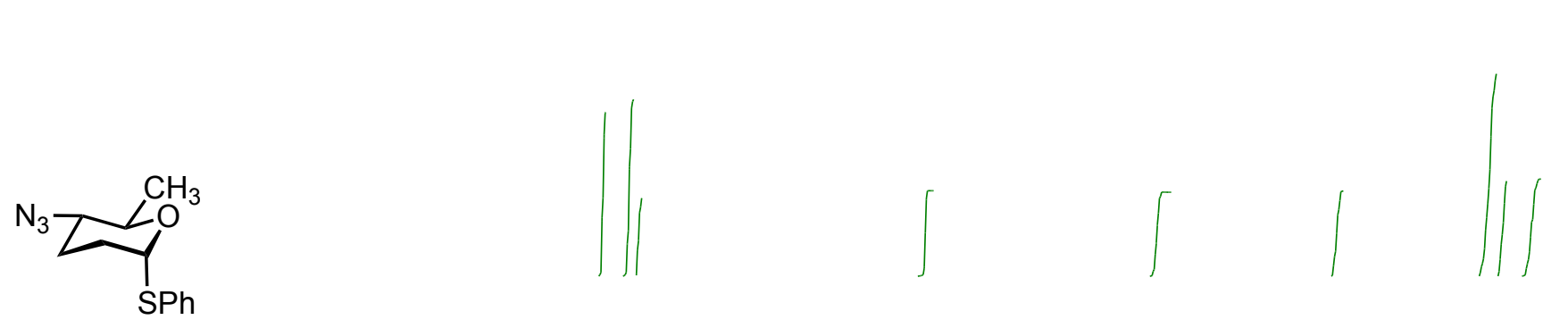

S5

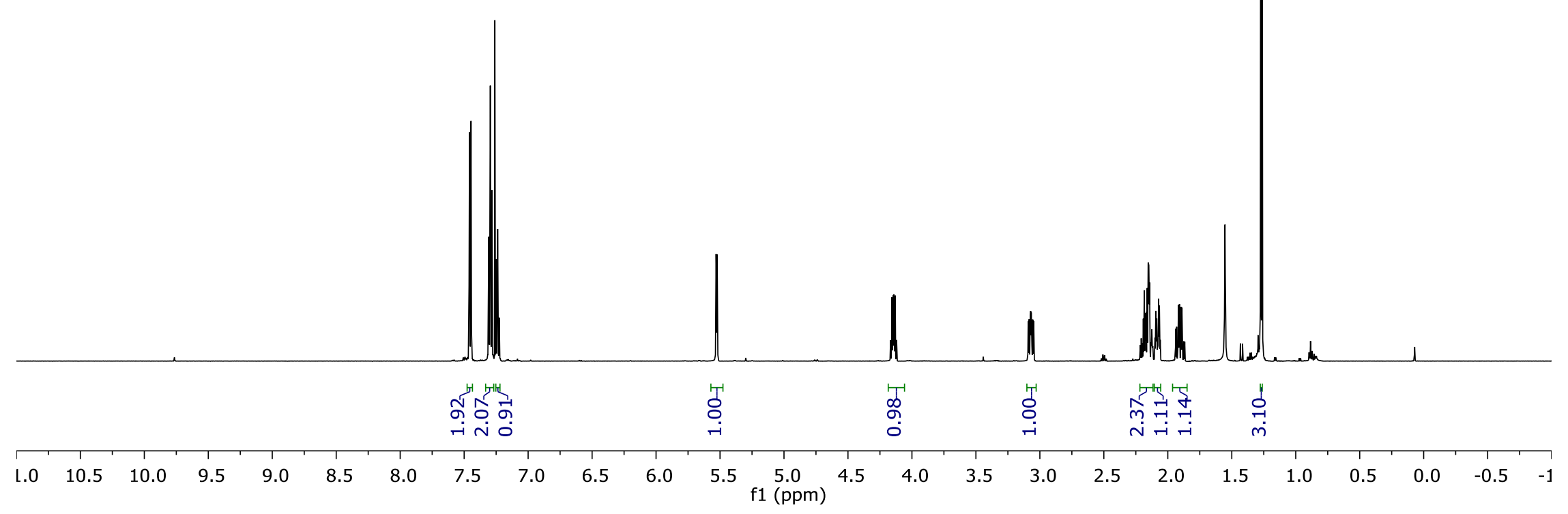

Hoang et al. "General method for the synthesis of $\alpha$ - or $\beta$-deoxyaminoglycosides bearing S73 basic nitrogen" 
${ }^{13} \mathrm{C} \mathrm{NMR}, 151 \mathrm{MHz}, \mathrm{CDCl}_{3}$

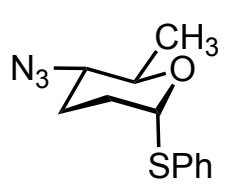

S5

SPh

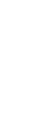

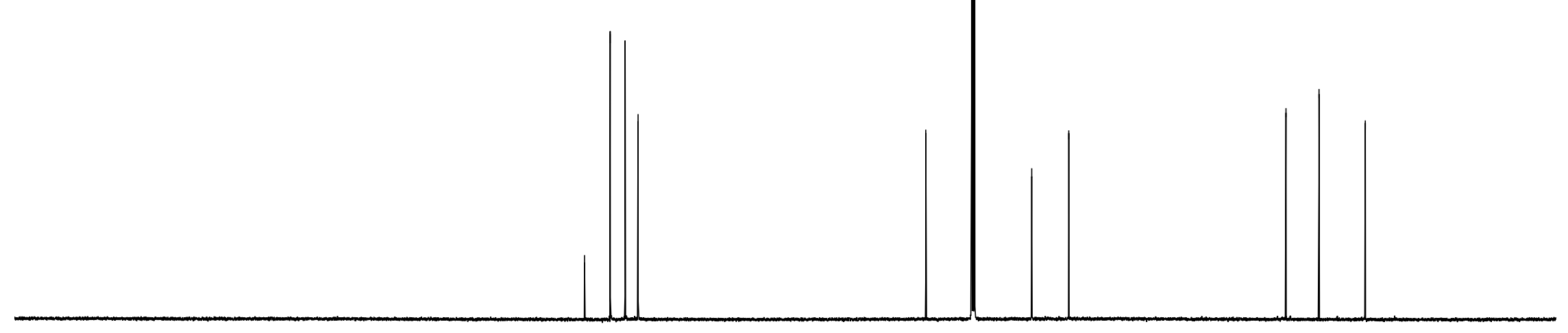

20 ' $210 \quad 200$ 
HSQC NMR, $600 \mathrm{MHz}, \mathrm{CDCl}_{3}$
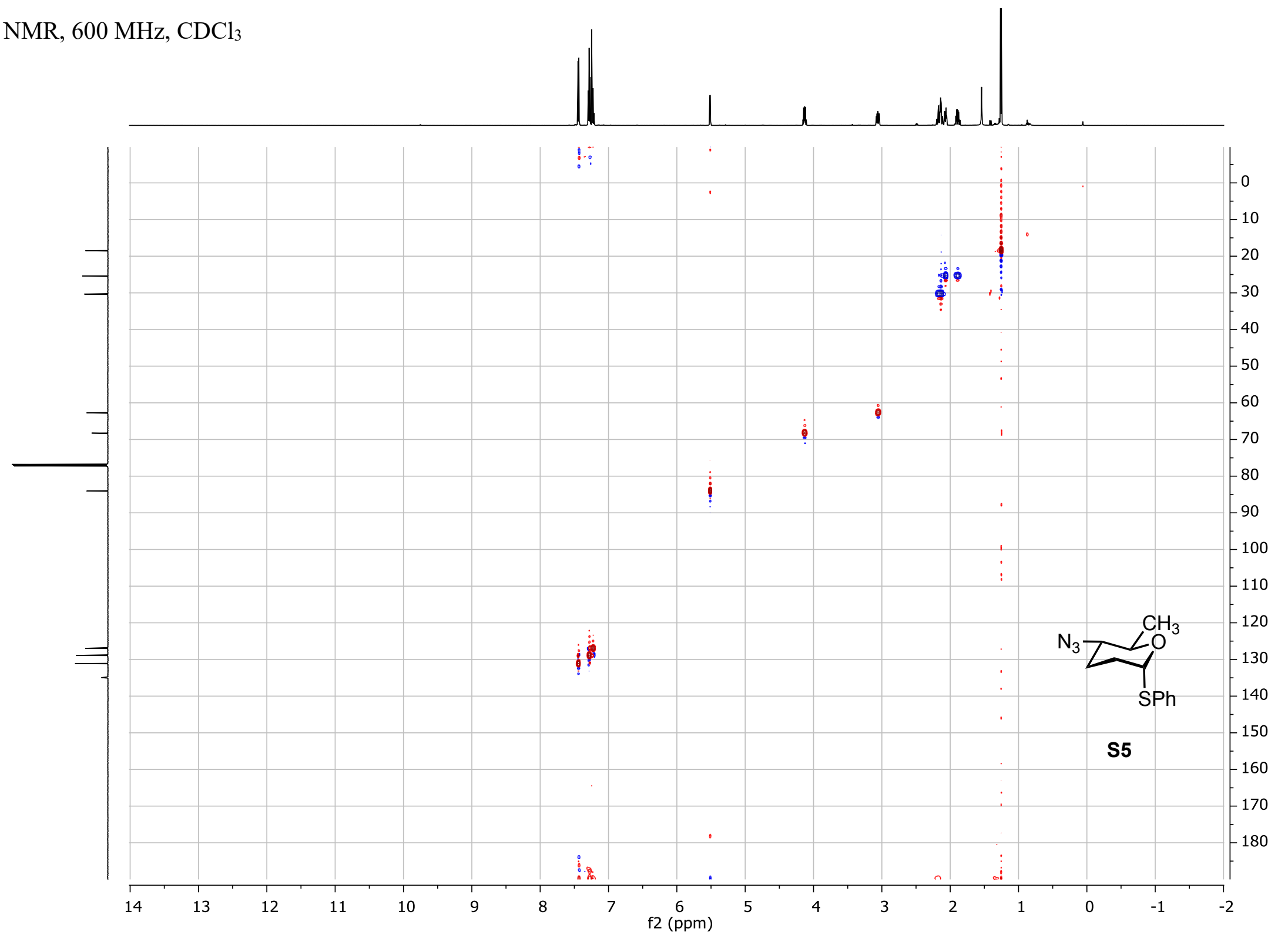

Hoang et al. "General method for the synthesis of $\alpha$ - or $\beta$-deoxyaminoglycosides bearing S75 basic nitrogen" 
${ }^{1} \mathrm{H} \mathrm{NMR}, 600 \mathrm{MHz}, \mathrm{CDCl}_{3}$
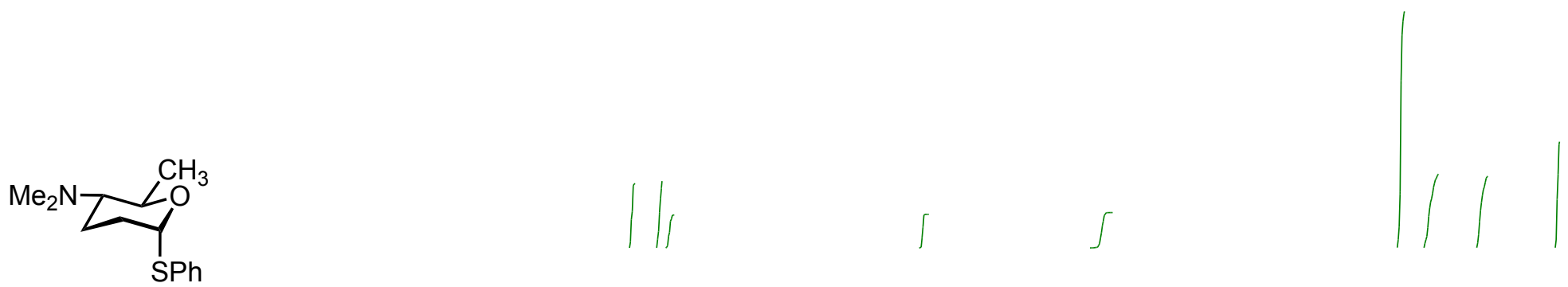

$11 \alpha$

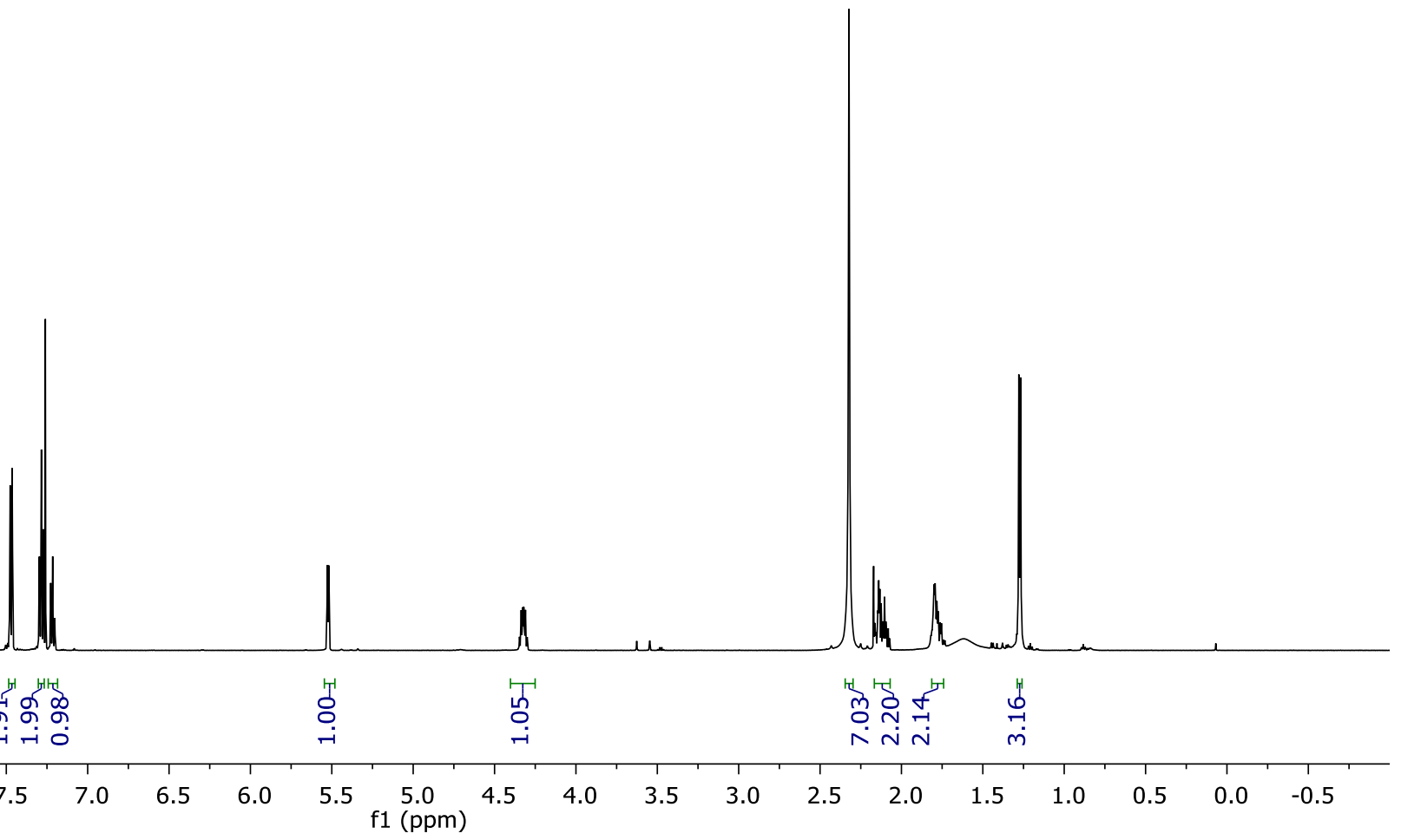

Hoang et al. "General method for the synthesis of $\alpha$ - or $\beta$-deoxyaminoglycosides bearing S76 basic nitrogen" 
${ }^{13} \mathrm{C} \mathrm{NMR,} 151 \mathrm{MHz}, \mathrm{CDCl}_{3}$

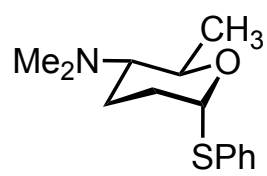

$11 \alpha$

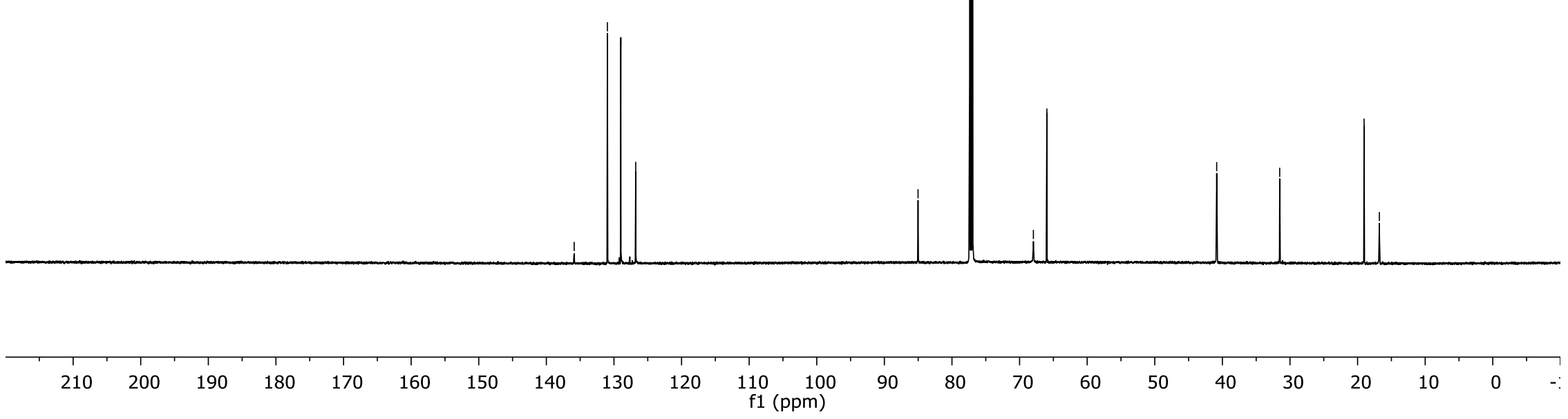

Hoang et al. "General method for the synthesis of $\alpha$ - or $\beta$-deoxyaminoglycosides bearing S77 basic nitrogen" 


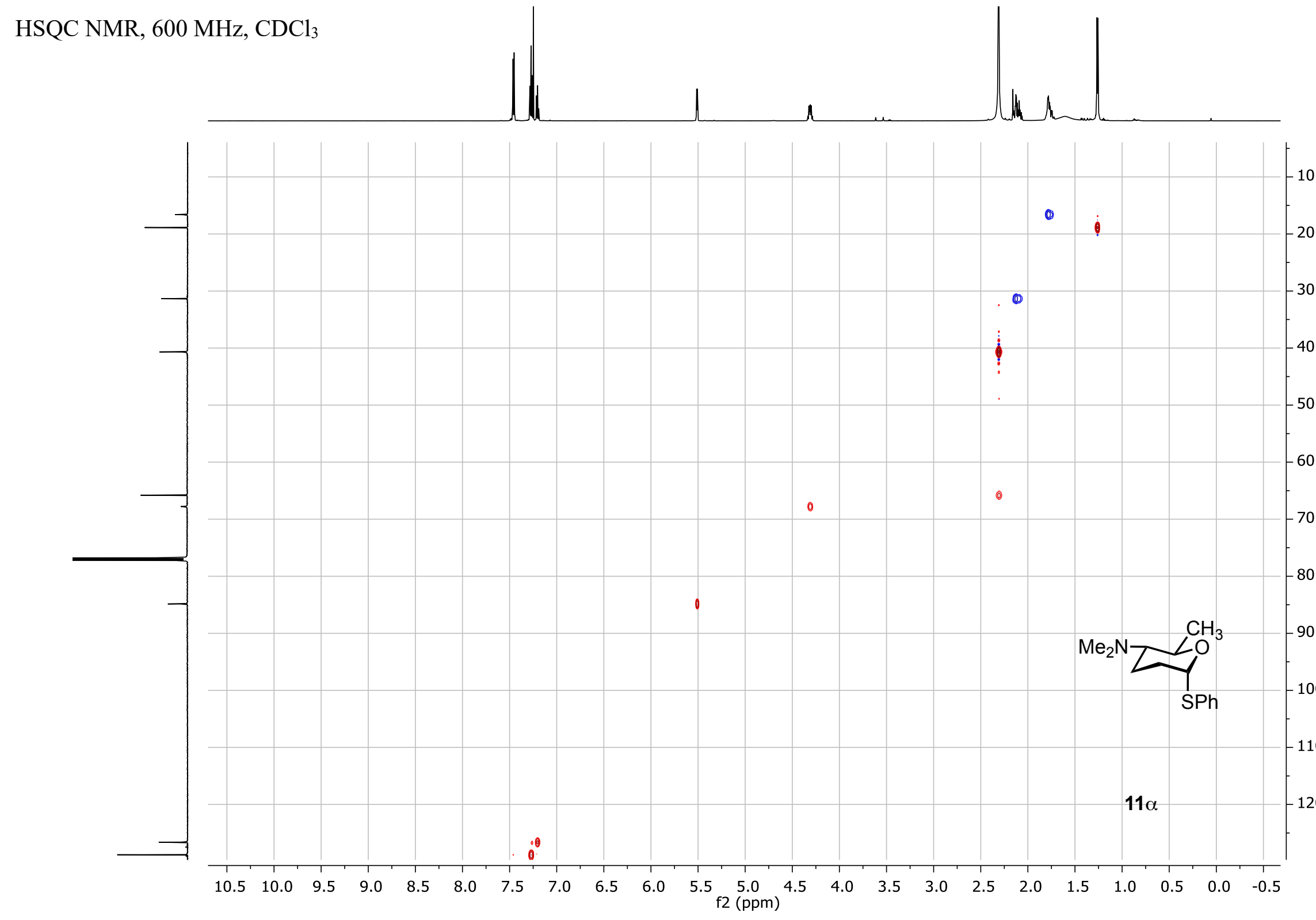

Hoang et al. "General method for the synthesis of $\alpha$ - or $\beta$-deoxyaminoglycosides bearing S78 basic nitrogen" 
${ }^{1} \mathrm{H}$ NMR, $600 \mathrm{MHz}, \mathrm{C}_{6} \mathrm{D}_{6}$
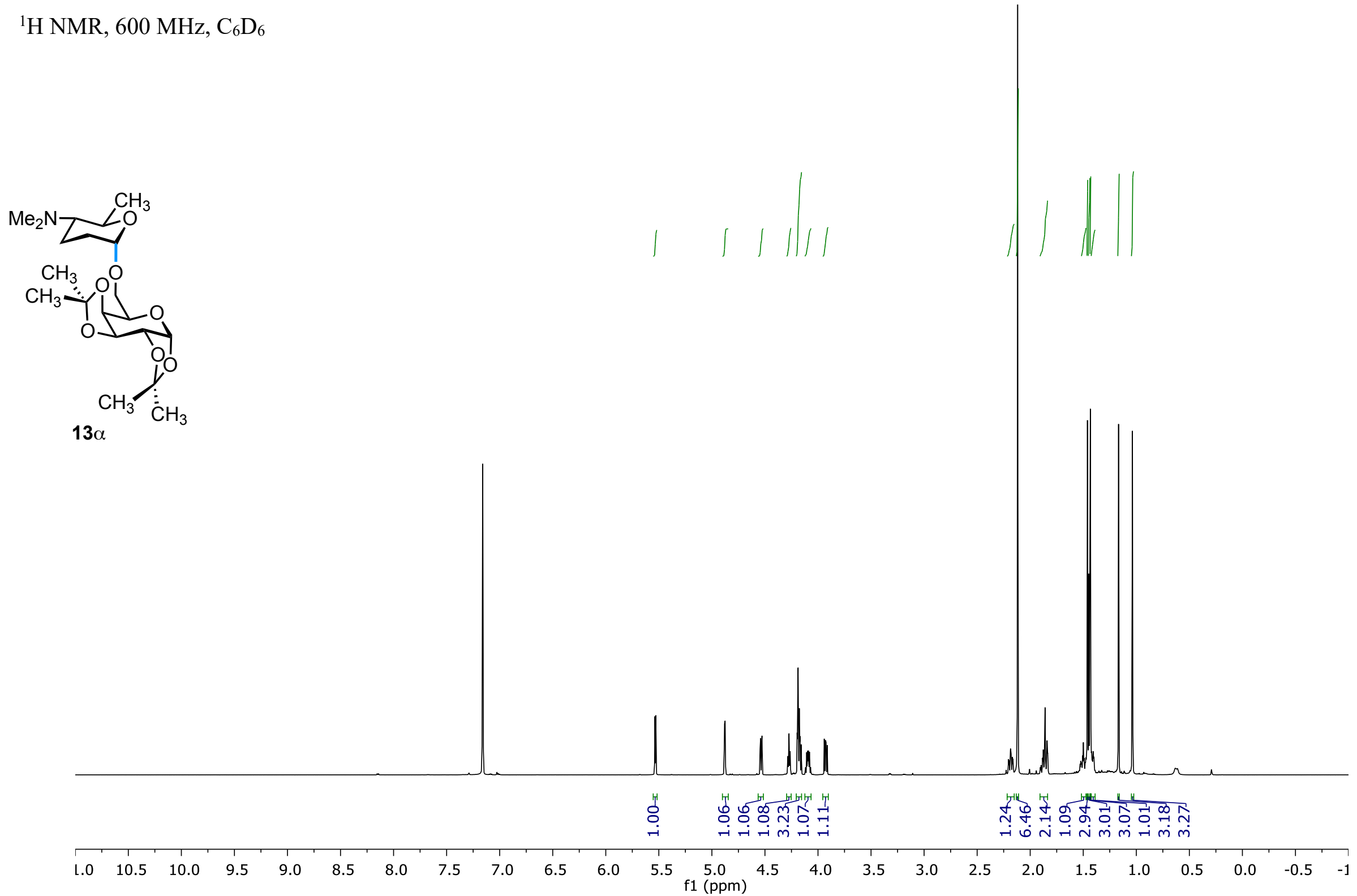

Hoang et al. "General method for the synthesis of $\alpha$ - or $\beta$-deoxyaminoglycosides bearing S79 basic nitrogen" 
${ }^{13} \mathrm{C}$ NMR, $151 \mathrm{MHz}, \mathrm{C}_{6} \mathrm{D}_{6}$

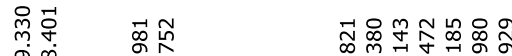

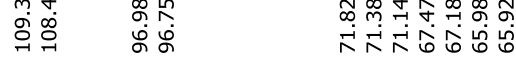

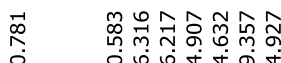

4 近

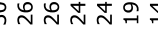

| Vए।
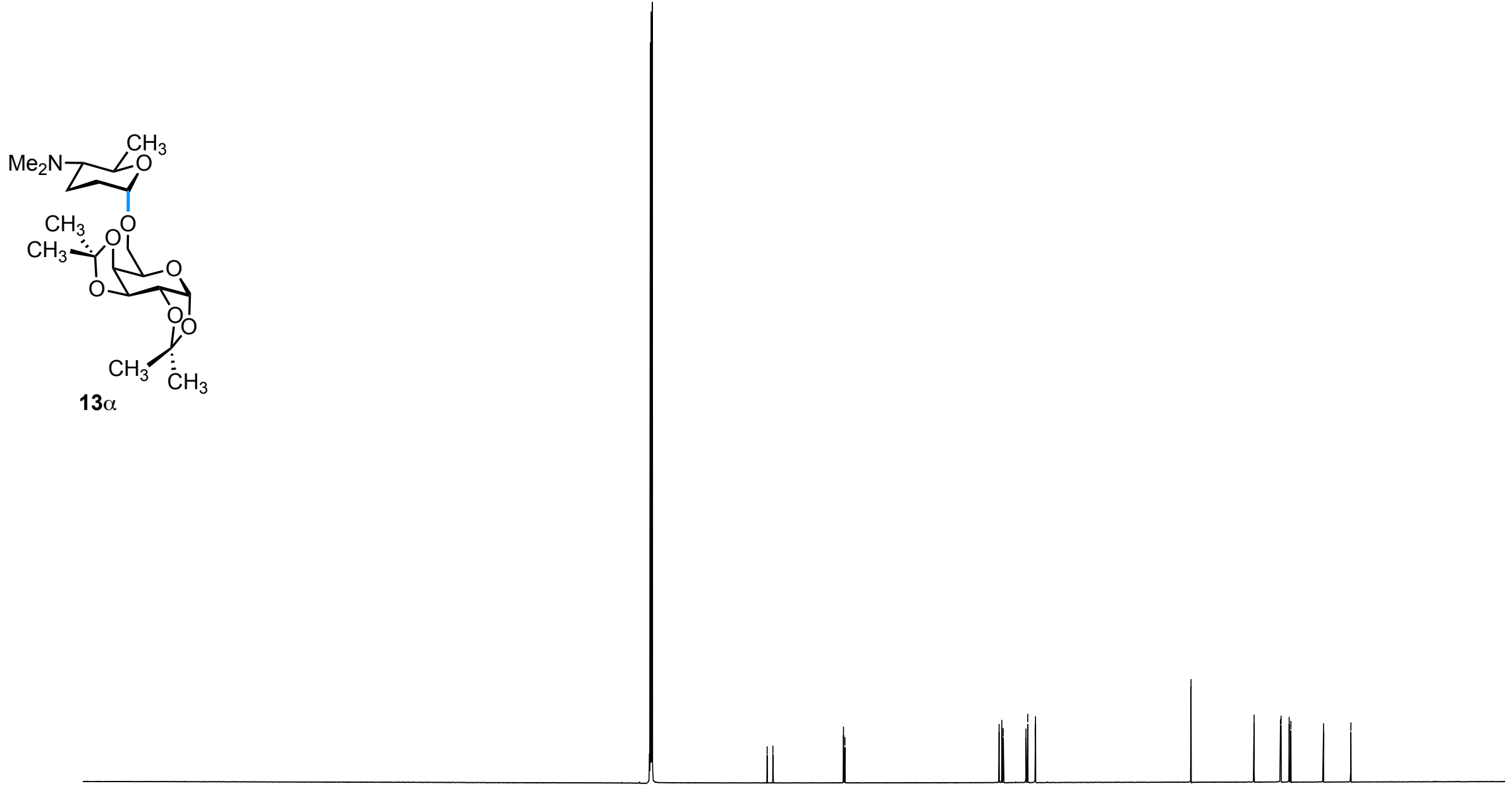

$20 \quad 210$

200

190

180

$170 \quad 160$

$150 \quad 140$

130

120

$110 \quad 100$

Hoang et al. "General method for the synthesis of $\alpha$ - or $\beta$-deoxyaminoglycosides bearing

basic nitrogen" 
HSQC NMR, $600 \mathrm{MHz}, \mathrm{C}_{6} \mathrm{D}_{6}$

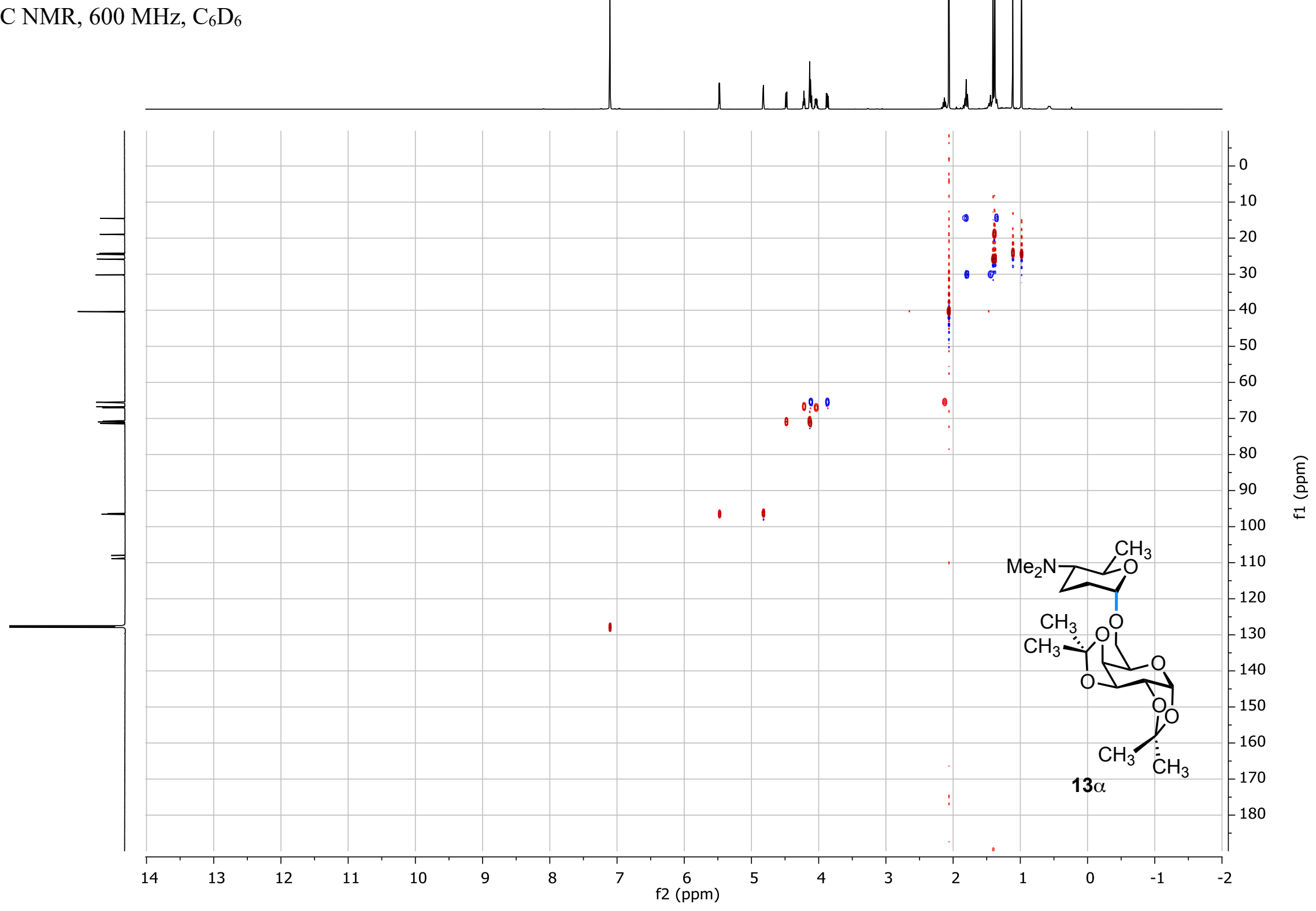

Hoang et al. "General method for the synthesis of $\alpha$ - or $\beta$-deoxyaminoglycosides bearing 
${ }^{1} \mathrm{H}$ NMR, $600 \mathrm{MHz}, \mathrm{C}_{6} \mathrm{D}_{6}$
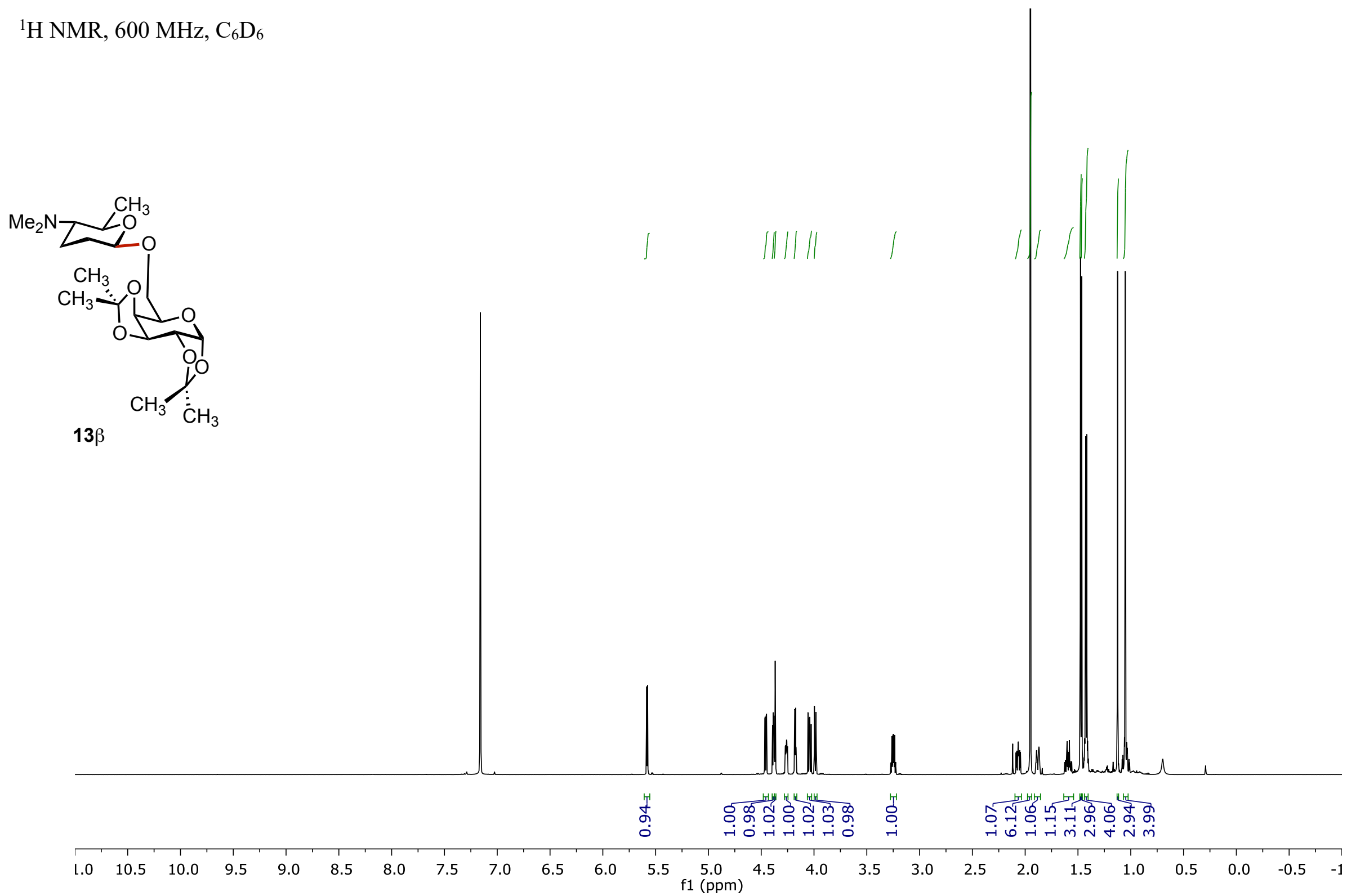

Hoang et al. "General method for the synthesis of $\alpha$ - or $\beta$-deoxyaminoglycosides bearing S82 basic nitrogen" 
${ }^{13} \mathrm{C}$ NMR, $151 \mathrm{MHz}, \mathrm{C}_{6} \mathrm{D}_{6}$

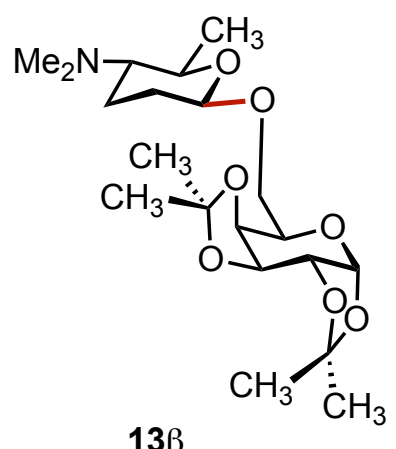

$13 \beta$

$\mathrm{CH}_{3}$

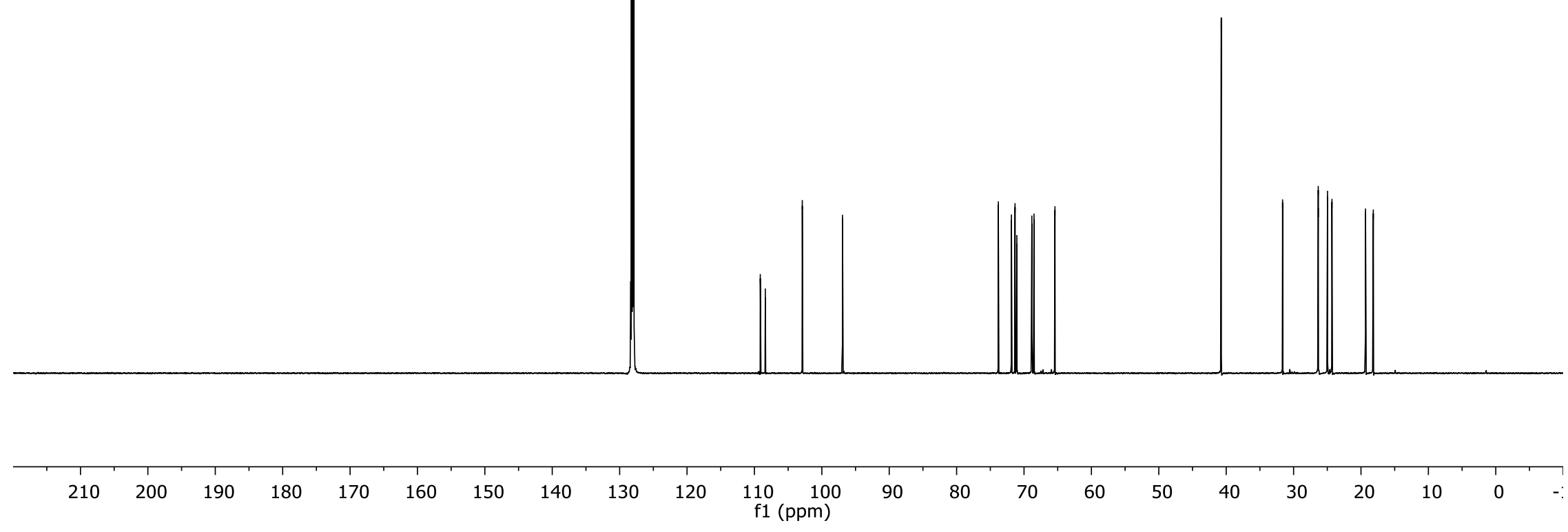

Hoang et al. "General method for the synthesis of $\alpha$ - or $\beta$-deoxyaminoglycosides bearing $\mathrm{S} 83$ basic nitrogen" 
HSQC NMR, $600 \mathrm{MHz}, \mathrm{C}_{6} \mathrm{D}_{6}$

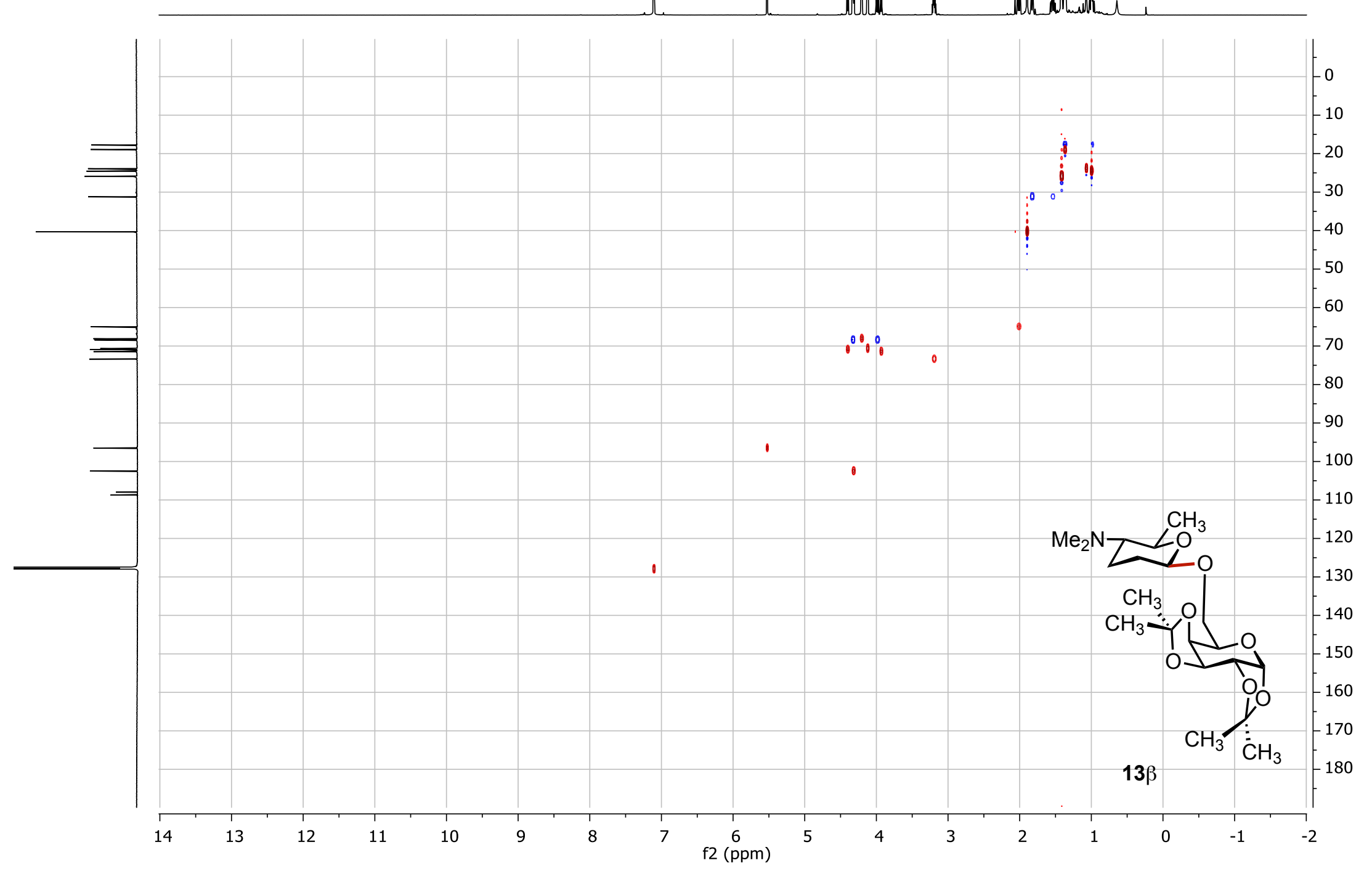

Hoang et al. "General method for the synthesis of $\alpha$ - or $\beta$-deoxyaminoglycosides bearing S84 basic nitrogen" 
${ }^{1} \mathrm{H} \mathrm{NMR}, 400 \mathrm{MHz}, \mathrm{CDCl}_{3}$
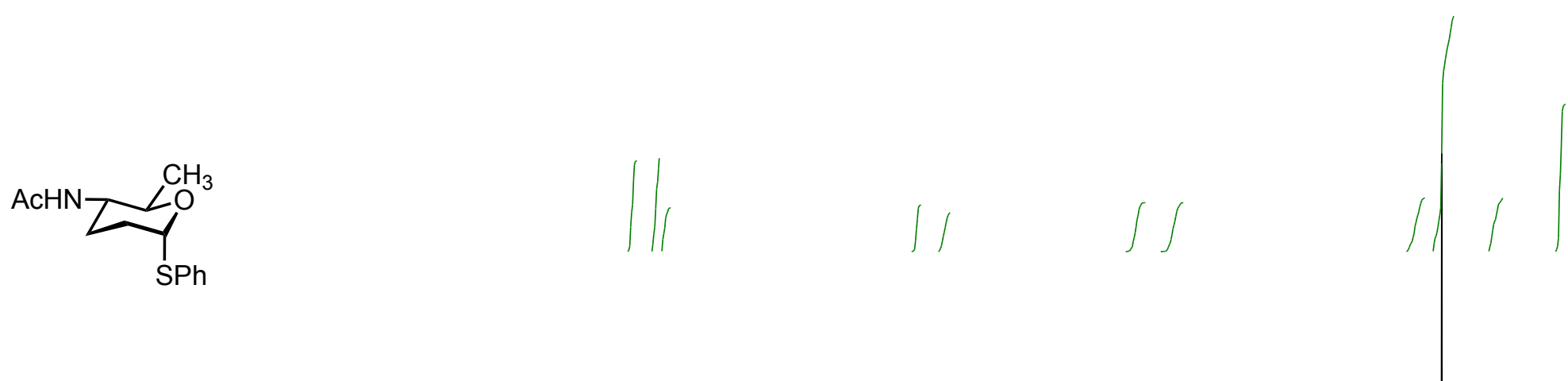

S6

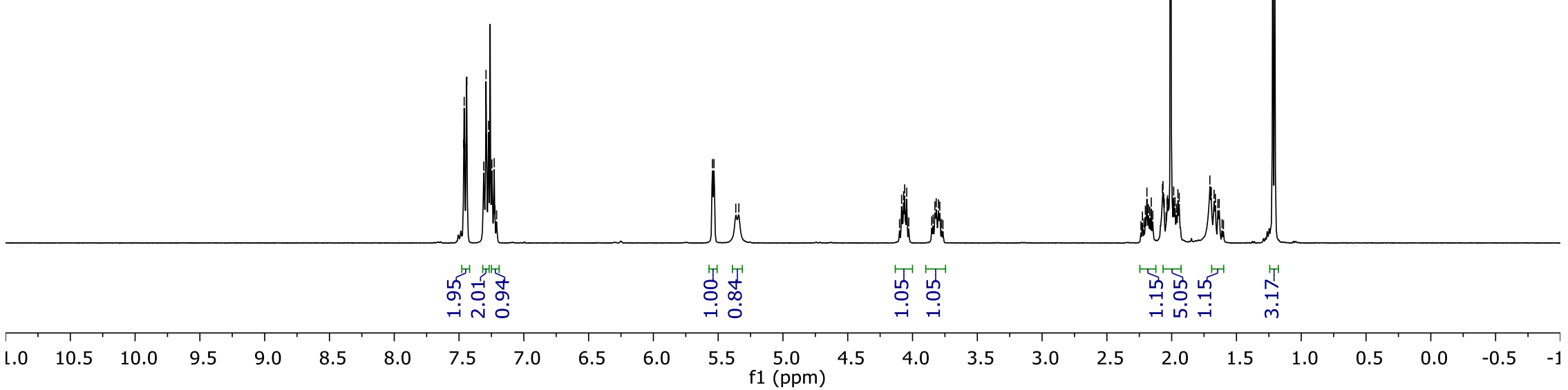

Hoang et al. "General method for the synthesis of $\alpha$ - or $\beta$-deoxyaminoglycosides bearing $\mathrm{S} 85$ basic nitrogen" 
${ }^{13} \mathrm{C} \mathrm{NMR}, 151 \mathrm{MHz}, \mathrm{CDCl}_{3}$

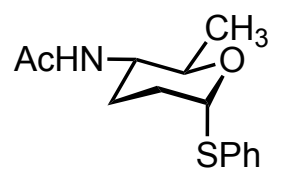

S6

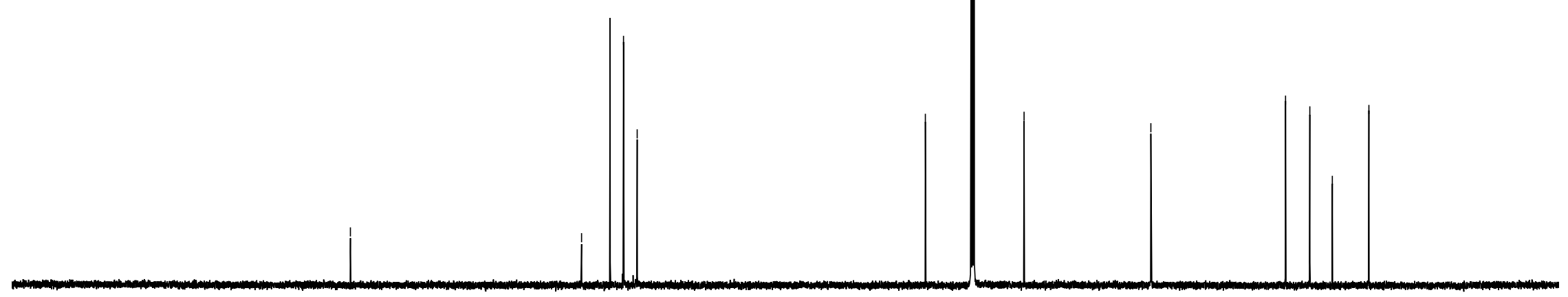

$\begin{array}{llllllllllll}210 & 200 & 190 & 180 & 170 & 160 & 150 & 140 & 130 & 120 & 110 & 100\end{array}$

Hoang et al. "General method for the synthesis of $\alpha$ - or $\beta$-deoxyaminoglycosides bearing basic nitrogen" 
HSQC NMR, $600 \mathrm{MHz}, \mathrm{CDCl}_{3}$

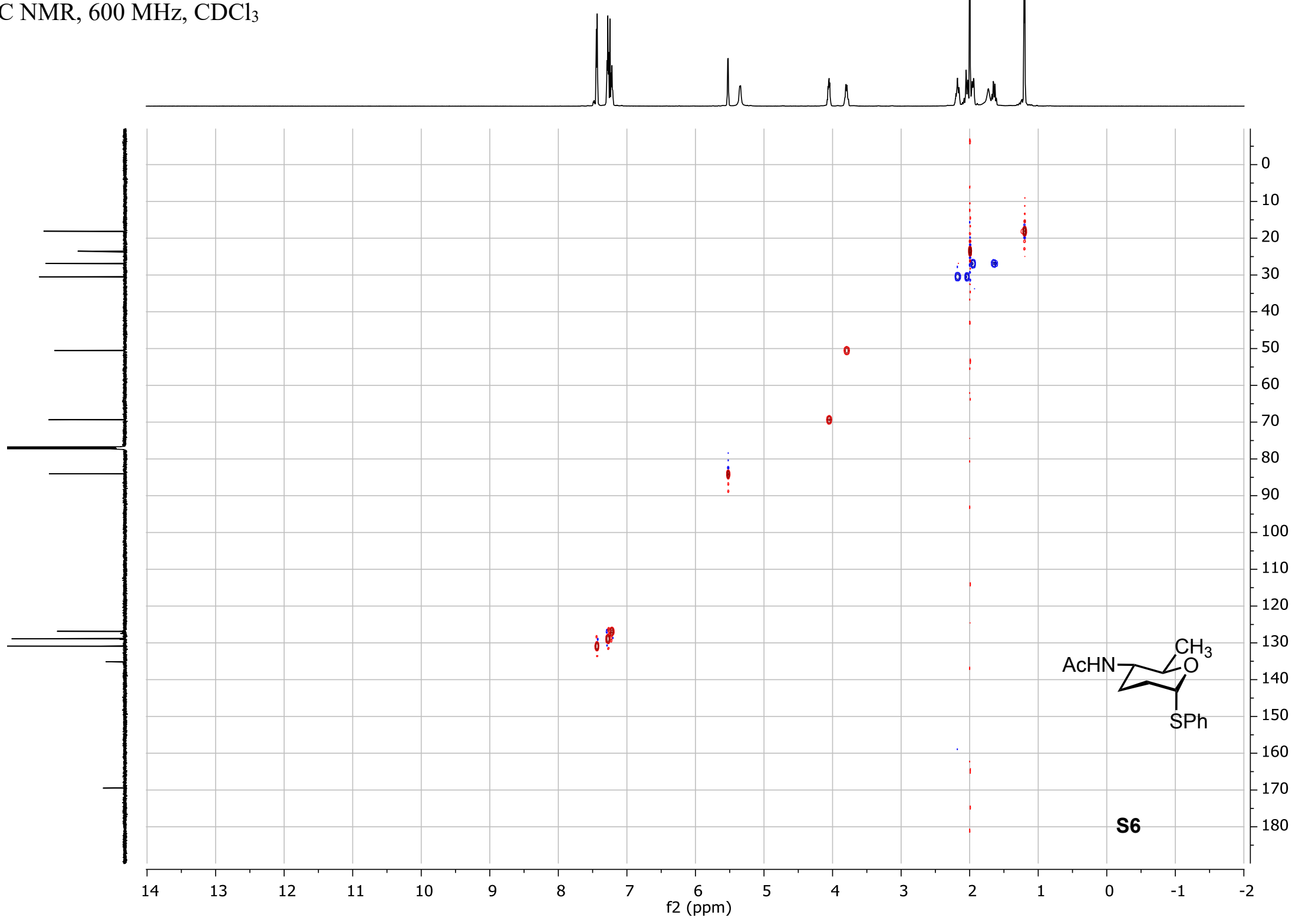

Hoang et al. "General method for the synthesis of $\alpha$ - or $\beta$-deoxyaminoglycosides bearing 
${ }^{1} \mathrm{H}$ NMR, $600 \mathrm{MHz}, \mathrm{C}_{6} \mathrm{D}_{6}$
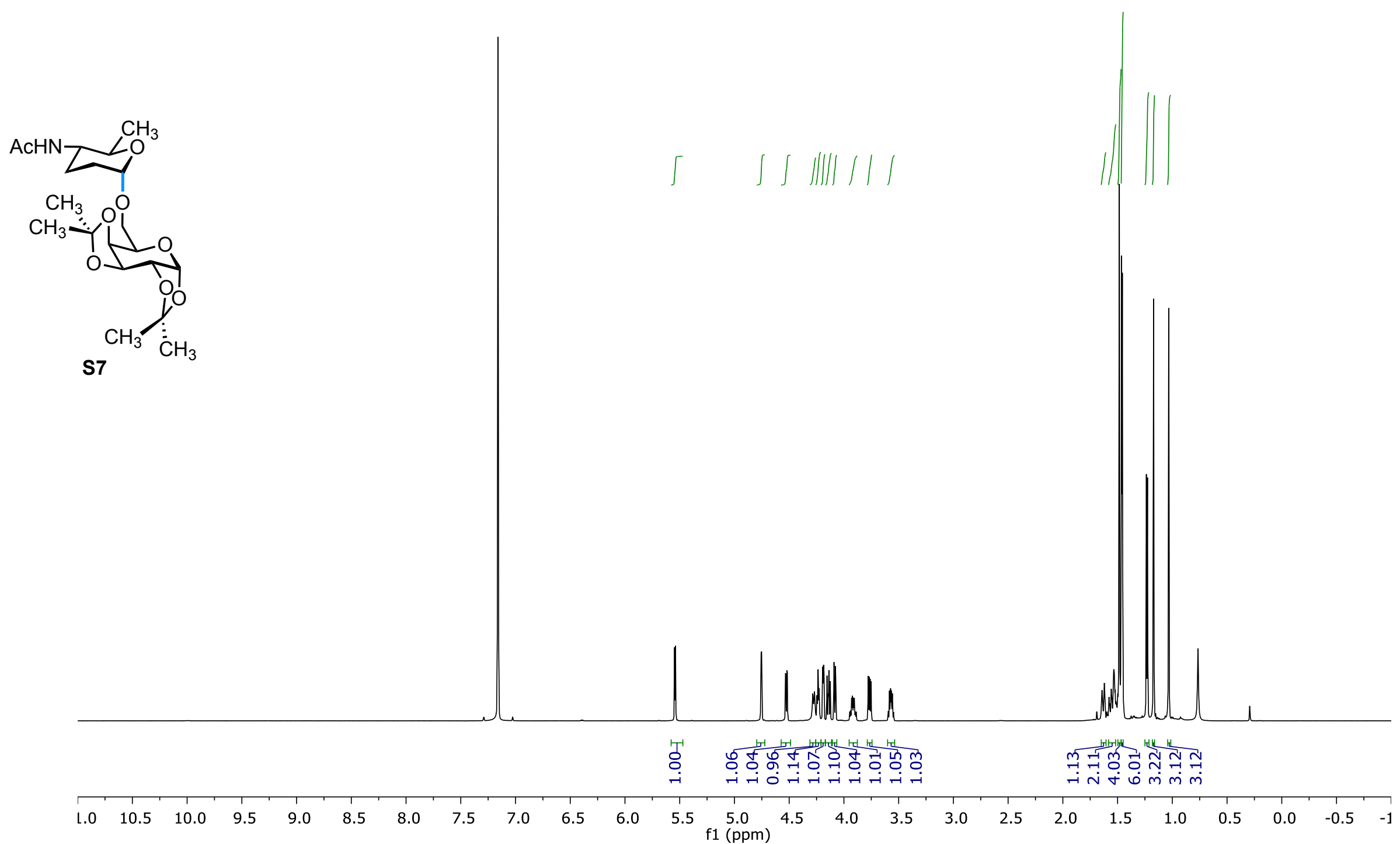

Hoang et al. "General method for the synthesis of $\alpha$ - or $\beta$-deoxyaminoglycosides bearing S88 basic nitrogen" 
${ }^{13} \mathrm{C}$ NMR, $151 \mathrm{MHz}, \mathrm{C}_{6} \mathrm{D}_{6}$
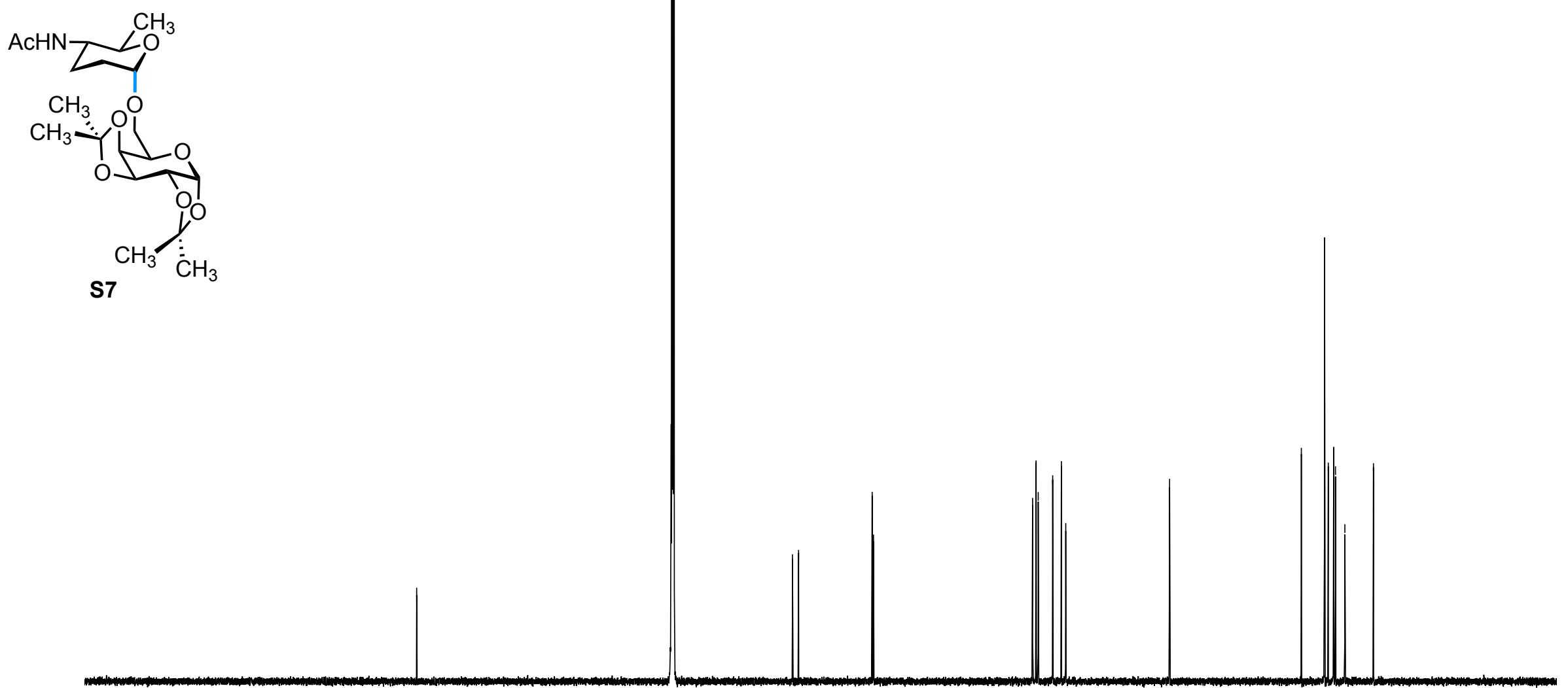

21

200 
HSQC NMR, $600 \mathrm{MHz}, \mathrm{C}_{6} \mathrm{D}_{6}$

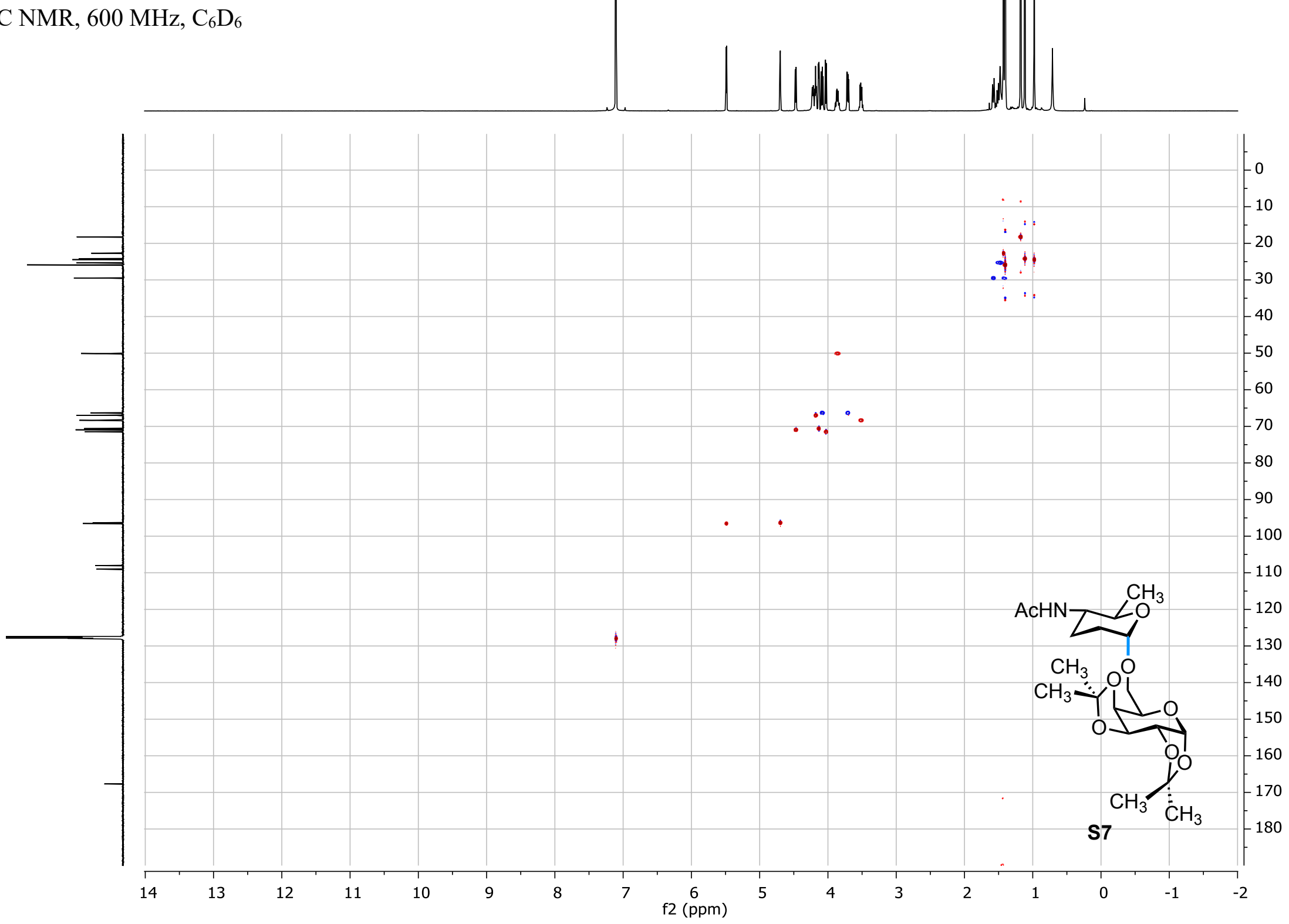

Hoang et al. "General method for the synthesis of $\alpha$ - or $\beta$-deoxyaminoglycosides bearing S90 basic nitrogen" 

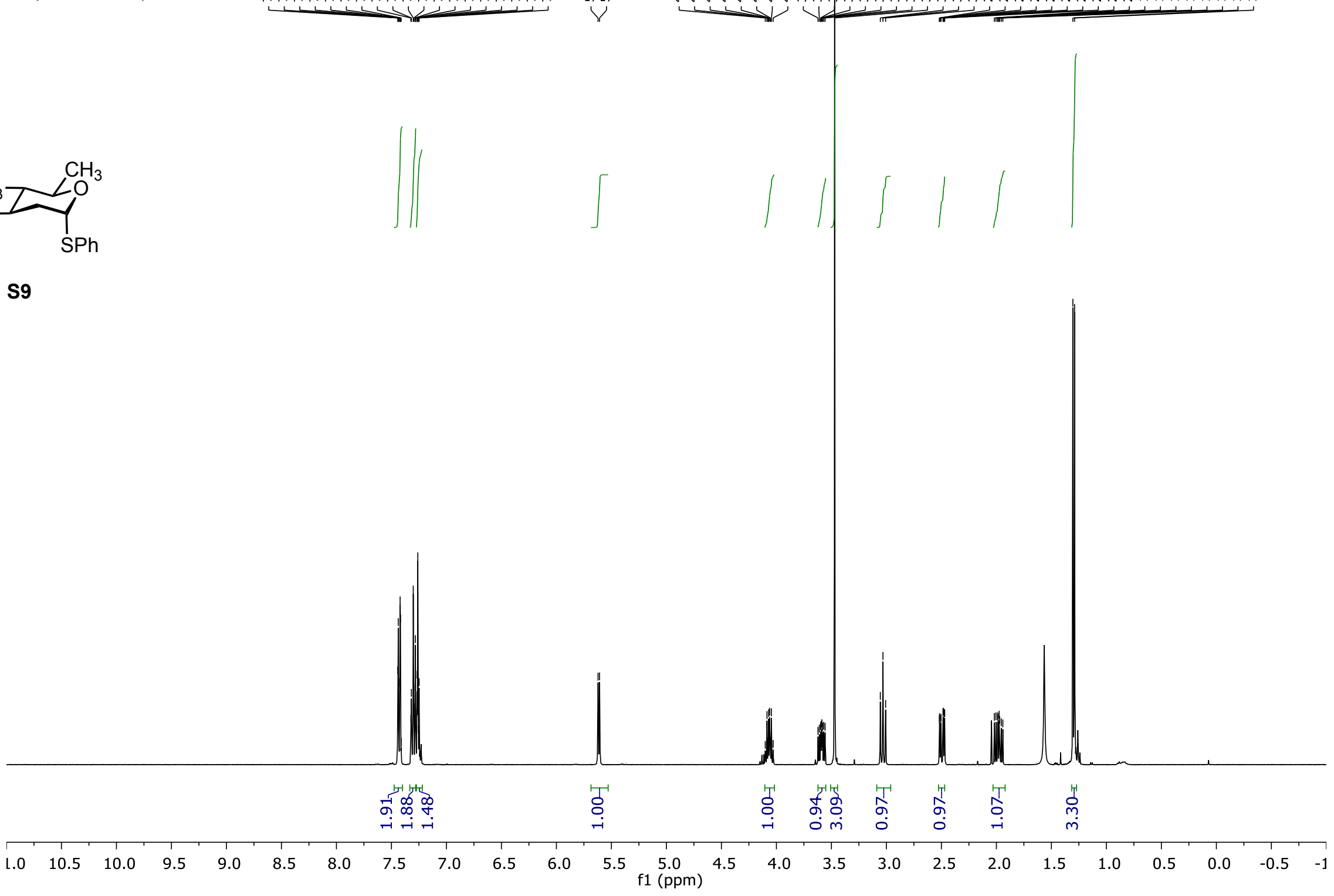

Hoang et al. "General method for the synthesis of $\alpha$ - or $\beta$-deoxyaminoglycosides bearing S91 basic nitrogen" 
${ }^{13} \mathrm{C} \mathrm{NMR,} 151 \mathrm{MHz}, \mathrm{CDCl}_{3}$

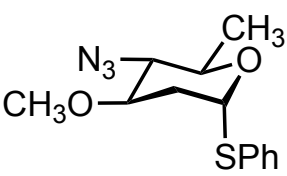

S9

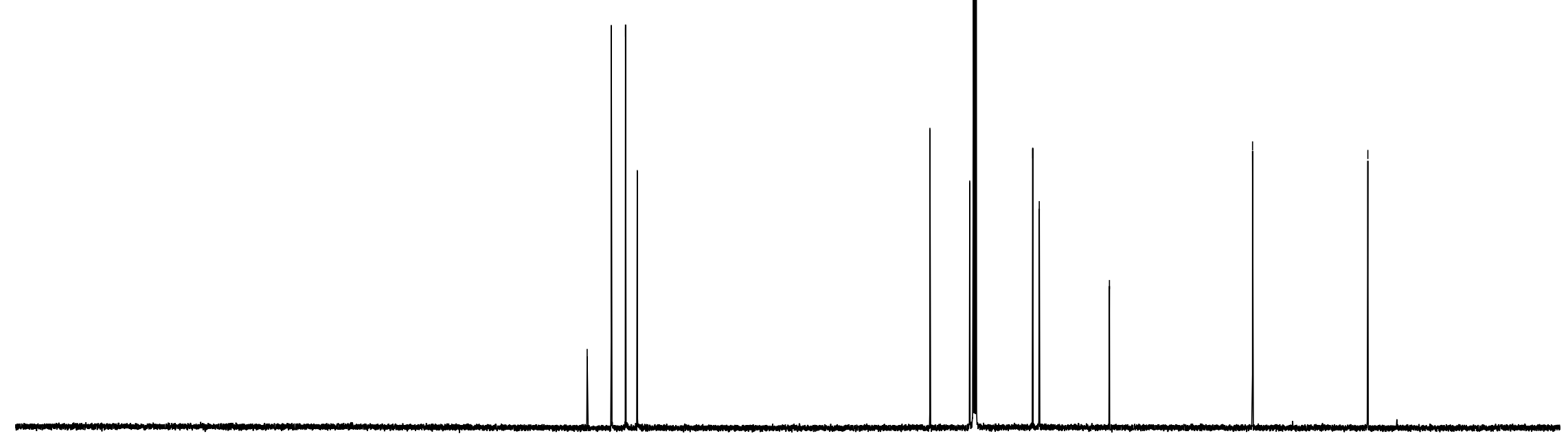

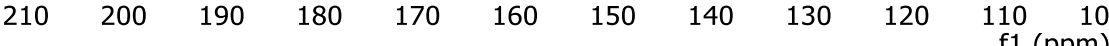

Hoang et al. "General method for the synthesis of $\alpha$ - or $\beta$-deoxyaminoglycosides bearing

S92

basic nitrogen" 
HSQC NMR, $600 \mathrm{MHz}, \mathrm{CDCl}_{3}$
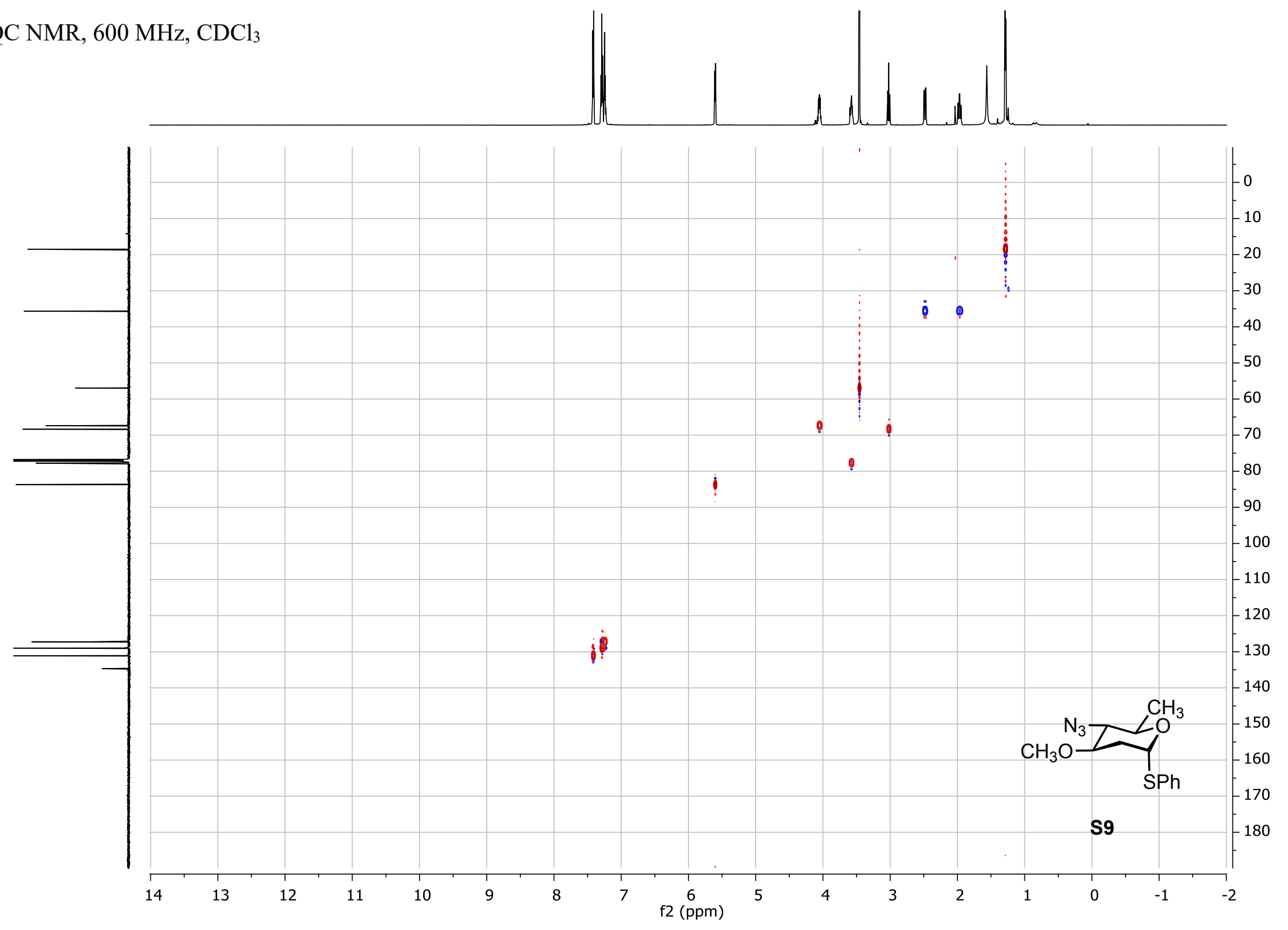

Hoang et al. "General method for the synthesis of $\alpha$ - or $\beta$-deoxyaminoglycosides bearing

S93 basic nitrogen" 
${ }^{1} \mathrm{H} \mathrm{NMR}, 500 \mathrm{MHz}, \mathrm{CDCl}_{3}$
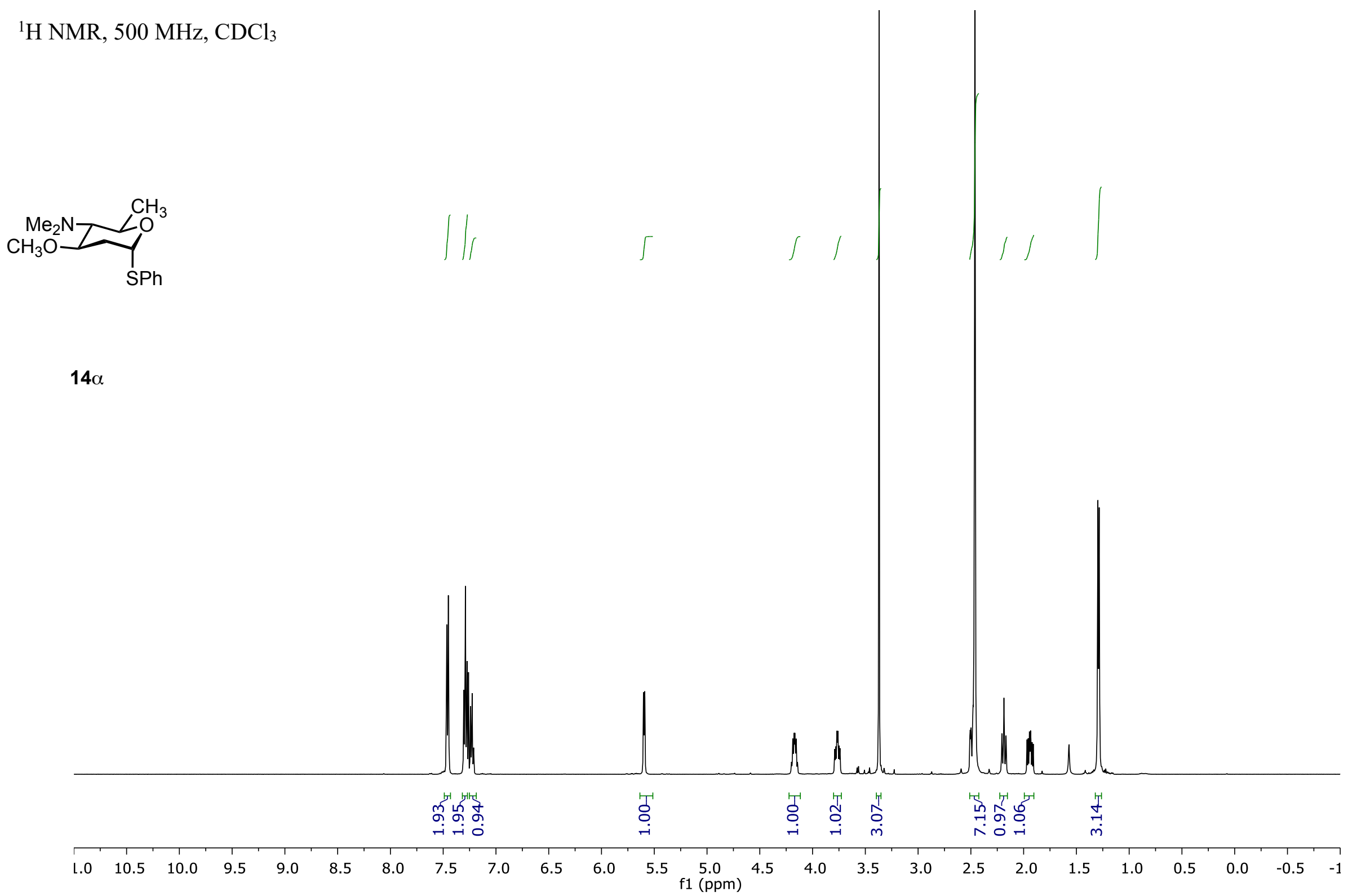

$14 \alpha$

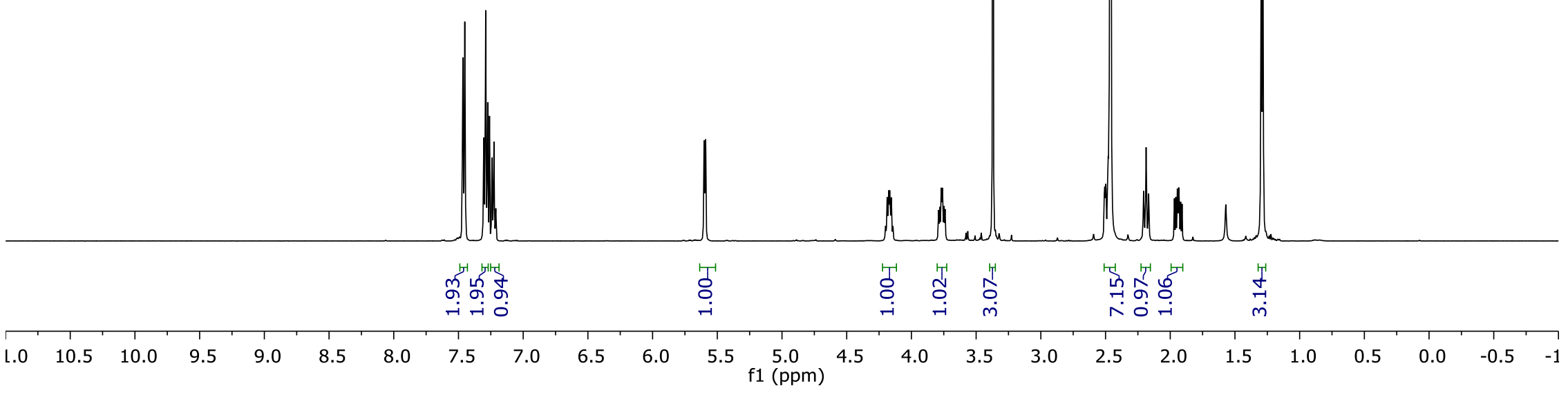

Hoang et al. "General method for the synthesis of $\alpha$ - or $\beta$-deoxyaminoglycosides bearing S94 basic nitrogen" 
${ }^{13} \mathrm{C} \mathrm{NMR,} 126 \mathrm{MHz}, \mathrm{CDCl}_{3}$

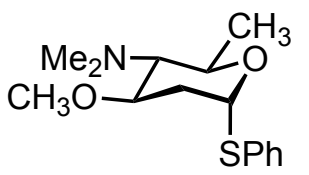

$14 \alpha$

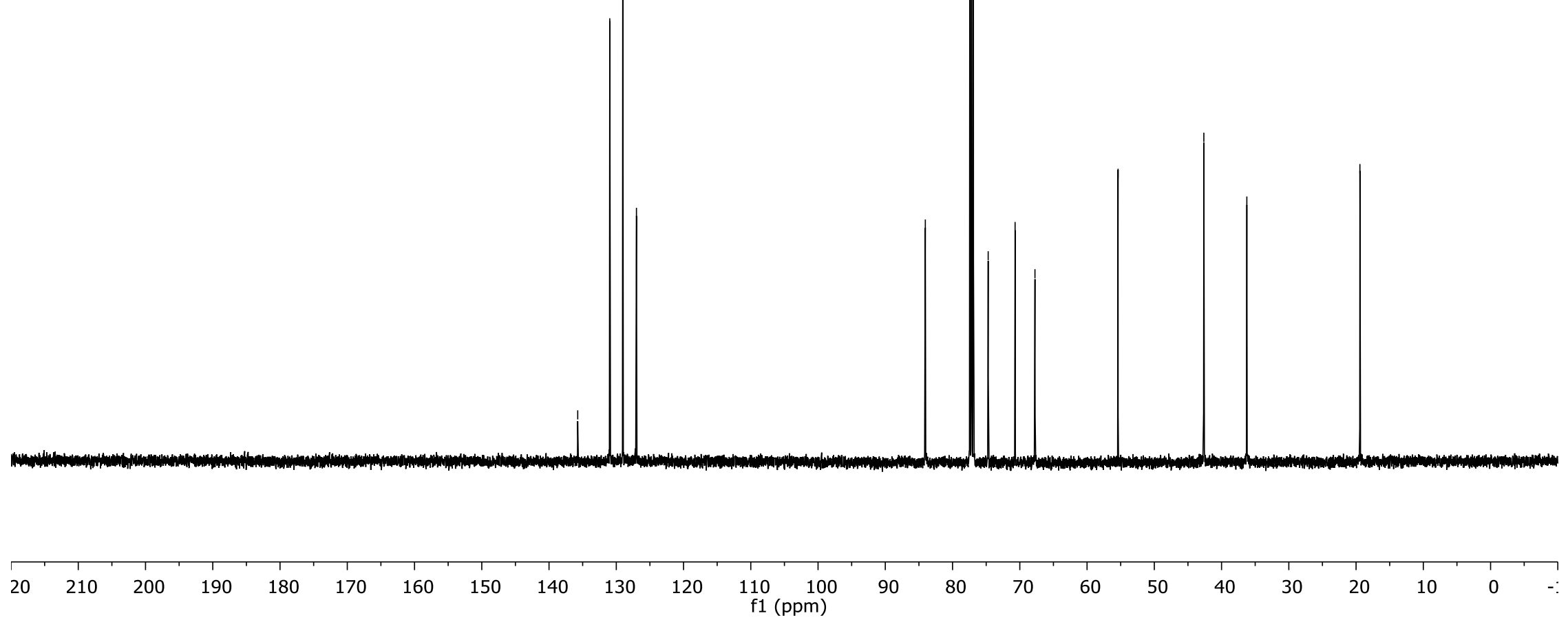

Hoang et al. "General method for the synthesis of $\alpha$ - or $\beta$-deoxyaminoglycosides bearing S95 basic nitrogen" 
HSQC NMR, $500 \mathrm{MHz}, \mathrm{CDCl}_{3}$
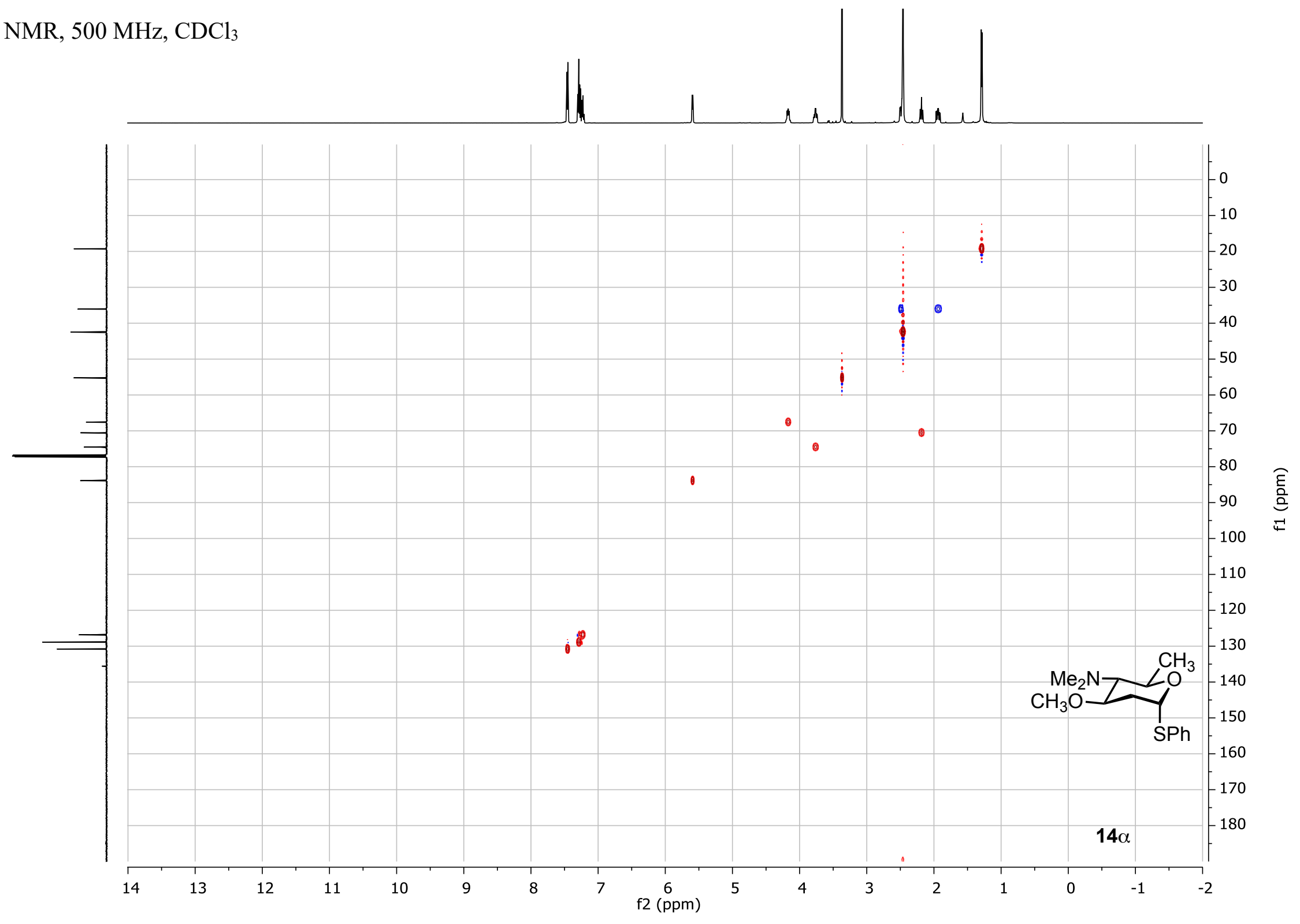

Hoang et al. "General method for the synthesis of $\alpha$ - or $\beta$-deoxyaminoglycosides bearing

S96 basic nitrogen" 
${ }^{1} \mathrm{H} \mathrm{NMR}, 600 \mathrm{MHz}, \mathrm{CDCl}_{3}$

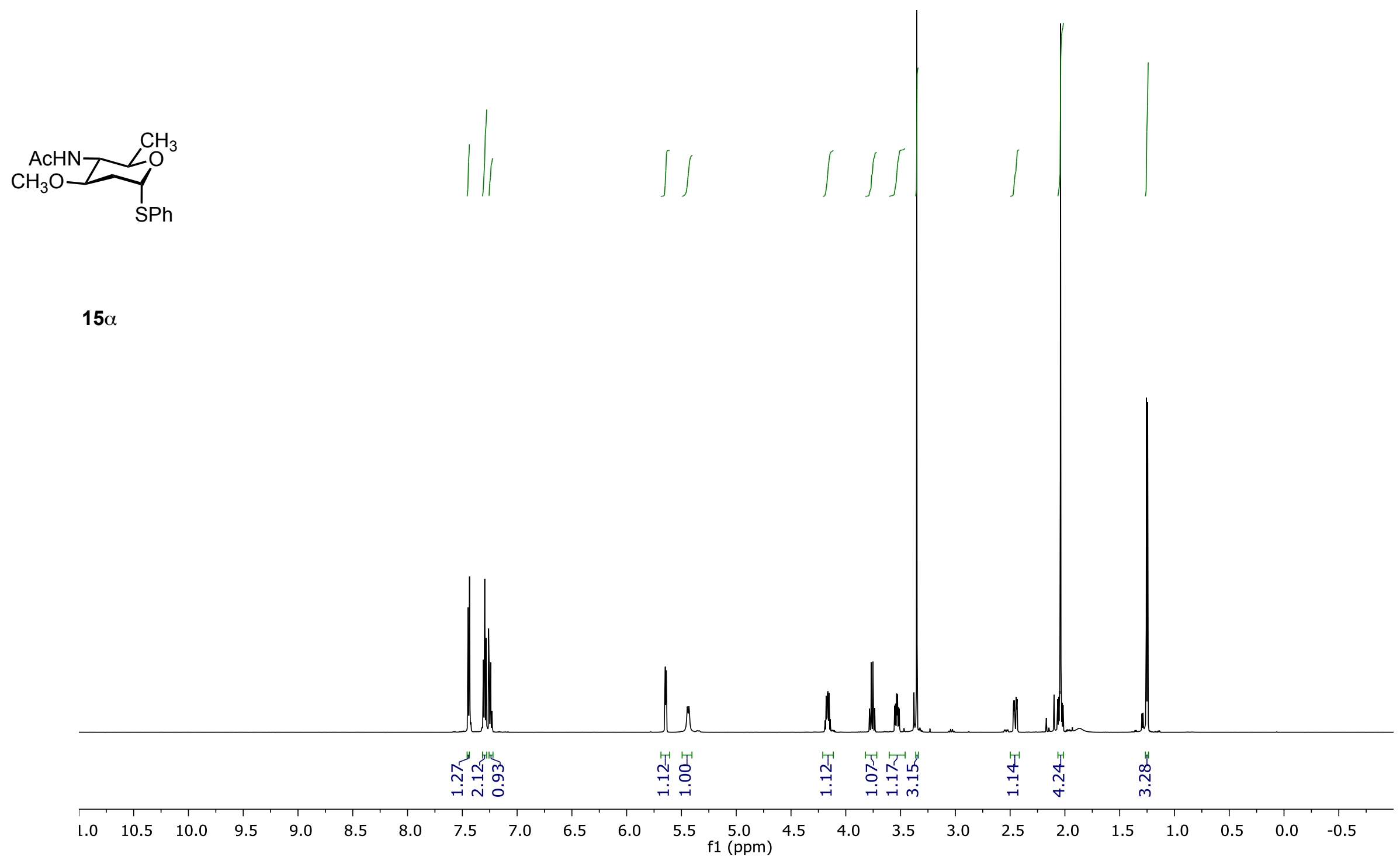

Hoang et al. "General method for the synthesis of $\alpha$ - or $\beta$-deoxyaminoglycosides bearing S97 basic nitrogen" 


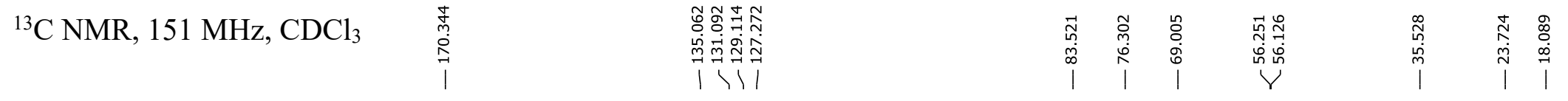

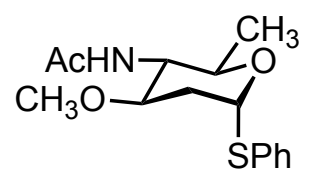

$15 \alpha$

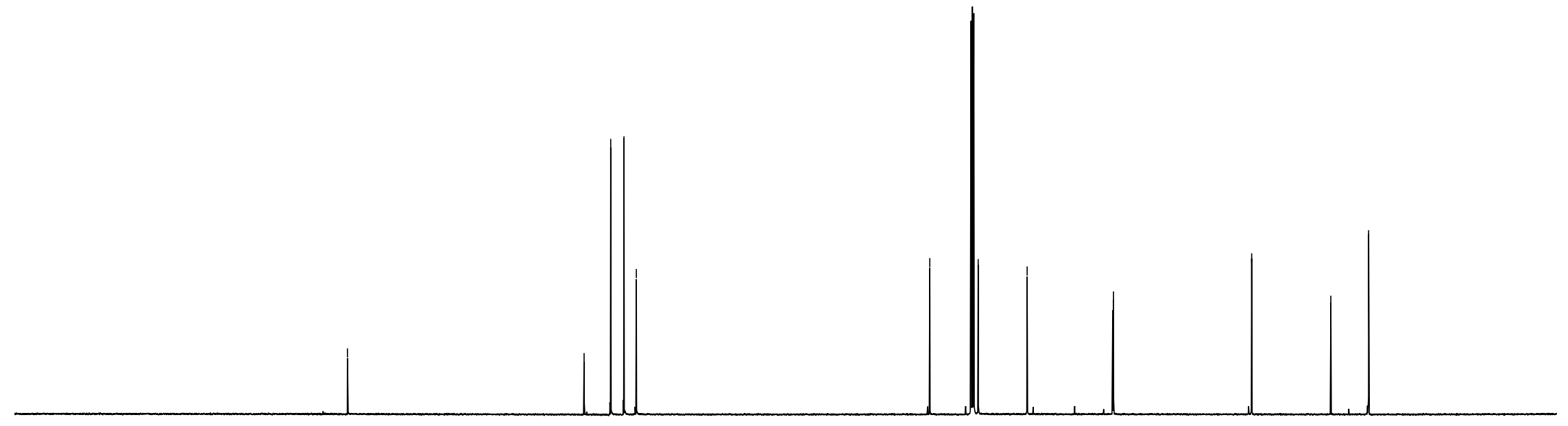

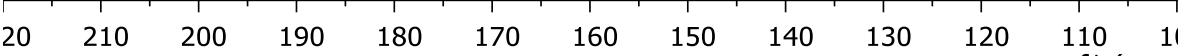

Hoang et al. "General method for the synthesis of $\alpha$ - or $\beta$-deoxyaminoglycosides bearing

basic nitrogen" 
HSQC NMR, $600 \mathrm{MHz}, \mathrm{CDCl}_{3}$
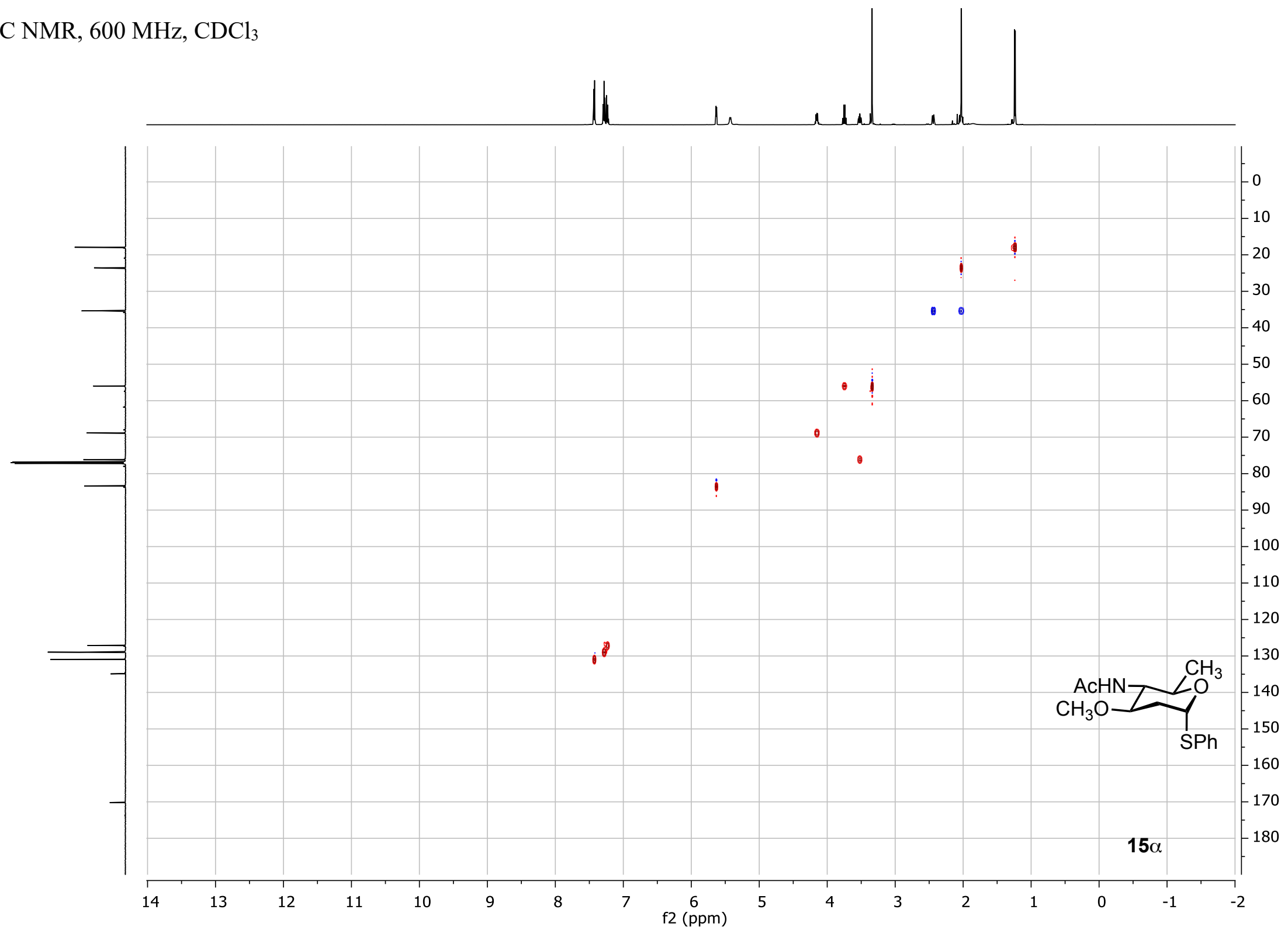

Hoang et al. "General method for the synthesis of $\alpha$ - or $\beta$-deoxyaminoglycosides bearing S99 basic nitrogen" 
${ }^{1} \mathrm{H} \mathrm{NMR}, 400 \mathrm{MHz}, \mathrm{CDCl}_{3}$
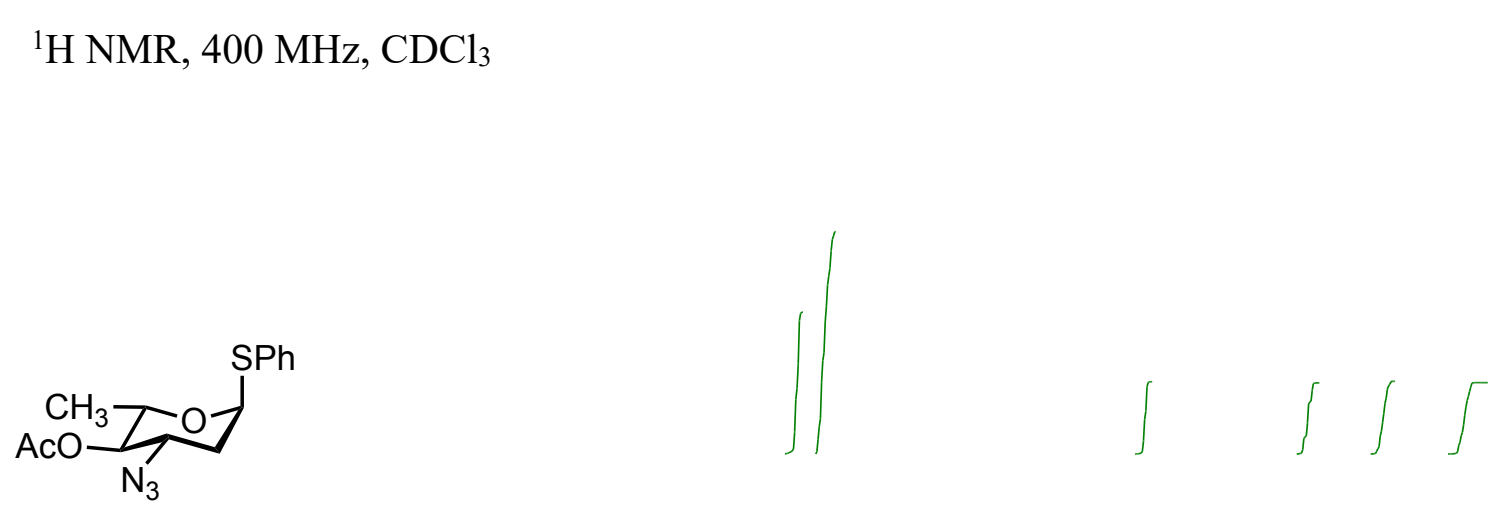

(3S)-S11

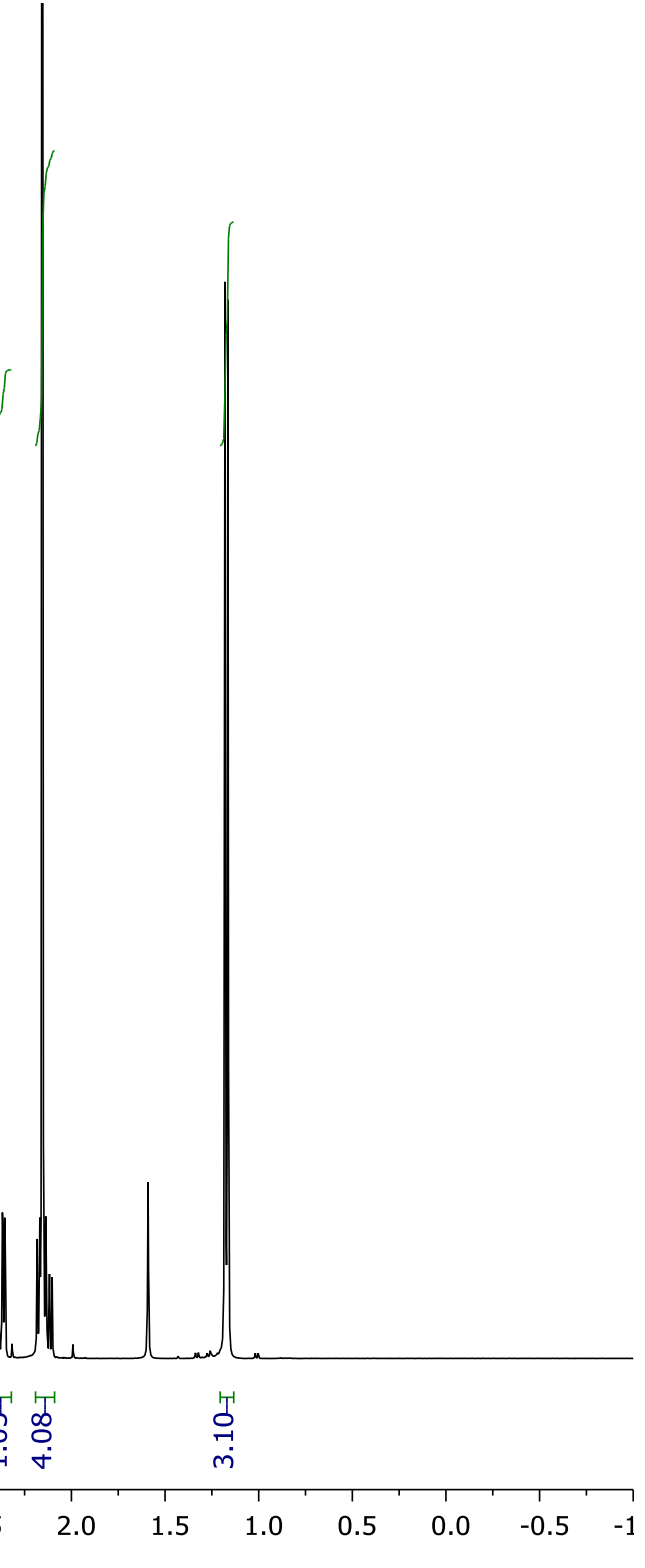

Hoang et al. "General method for the synthesis of $\alpha$ - or $\beta$-deoxyaminoglycosides bearing S100 basic nitrogen" 


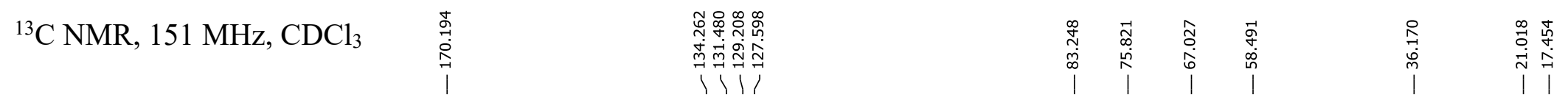

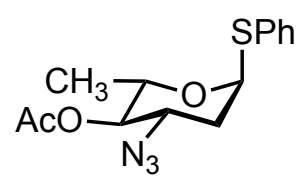

(3S)-S11 $\alpha$

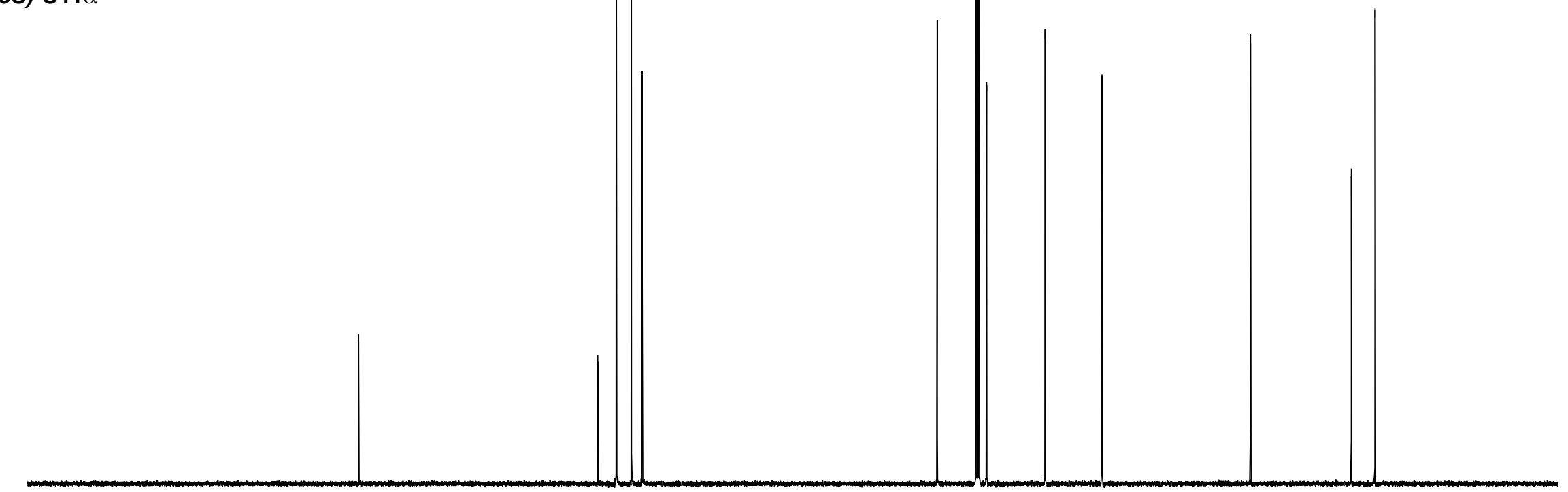


HSQC NMR, $600 \mathrm{MHz}, \mathrm{CDCl}_{3}$
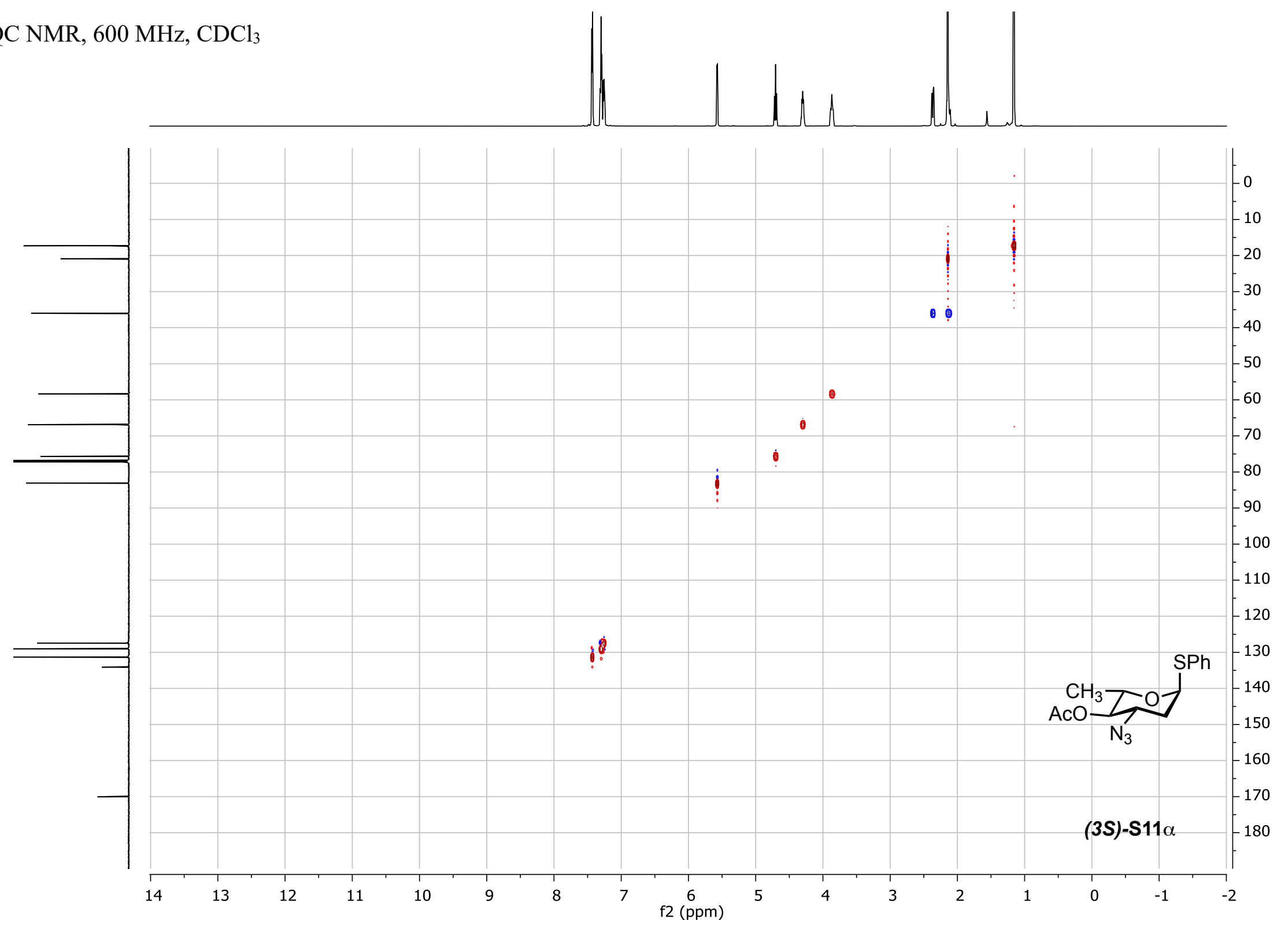

Hoang et al. "General method for the synthesis of $\alpha$ - or $\beta$-deoxyaminoglycosides bearing

S102 basic nitrogen" 
${ }^{1} \mathrm{H} \mathrm{NMR}, 400 \mathrm{MHz}, \mathrm{CDCl}_{3}$
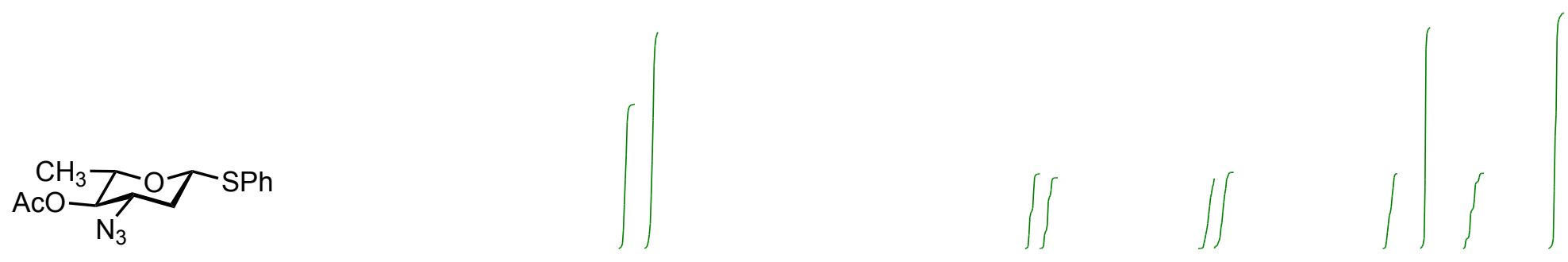

(3S)-S11 $\beta$

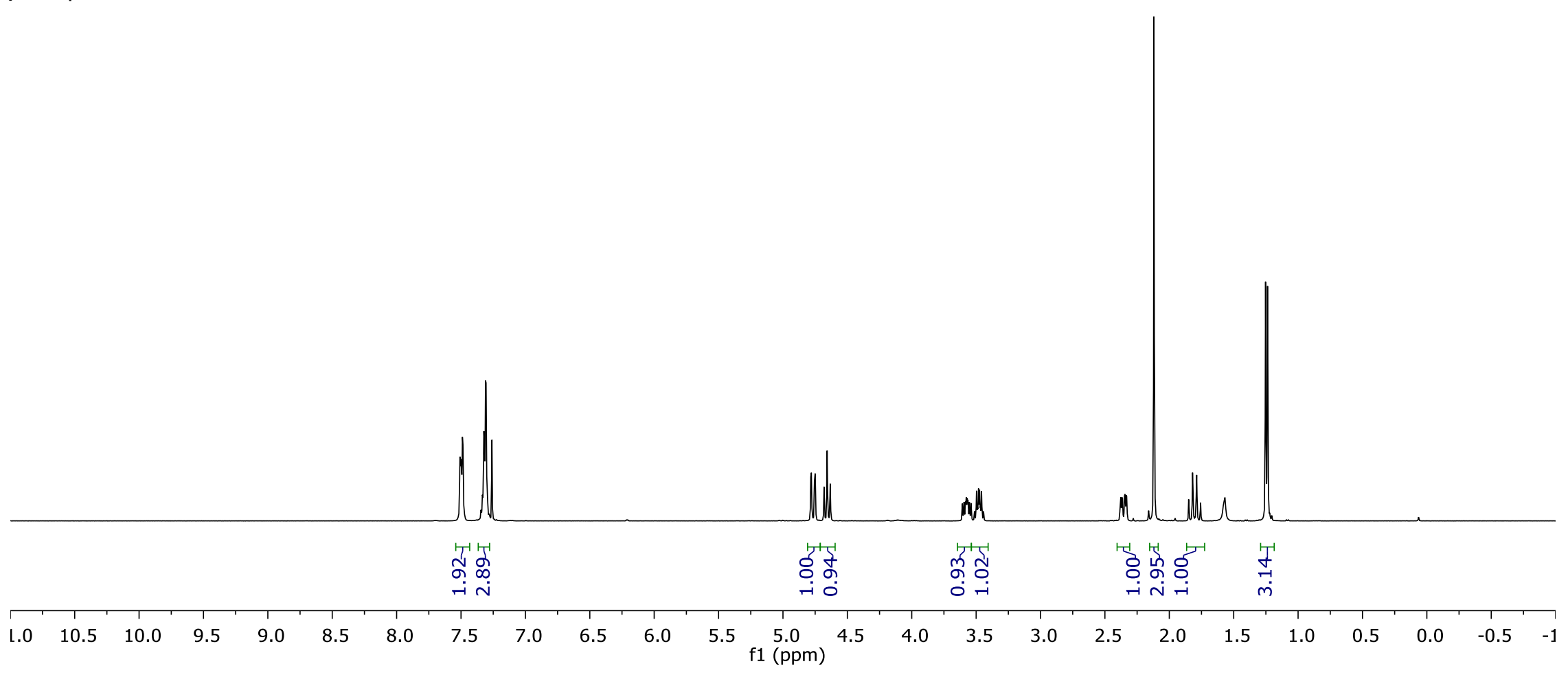

Hoang et al. "General method for the synthesis of $\alpha$ - or $\beta$-deoxyaminoglycosides bearing

S103

basic nitrogen" 
${ }^{13} \mathrm{C} \mathrm{NMR}, 151 \mathrm{MHz}, \mathrm{CDCl}_{3}$

$\mathrm{AcO}_{\mathrm{N}_{3}}^{\mathrm{CH}_{3}} \mathrm{TPh}$

(3S)-S11 $\beta$

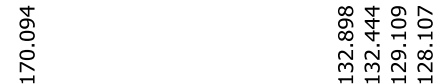

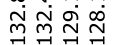

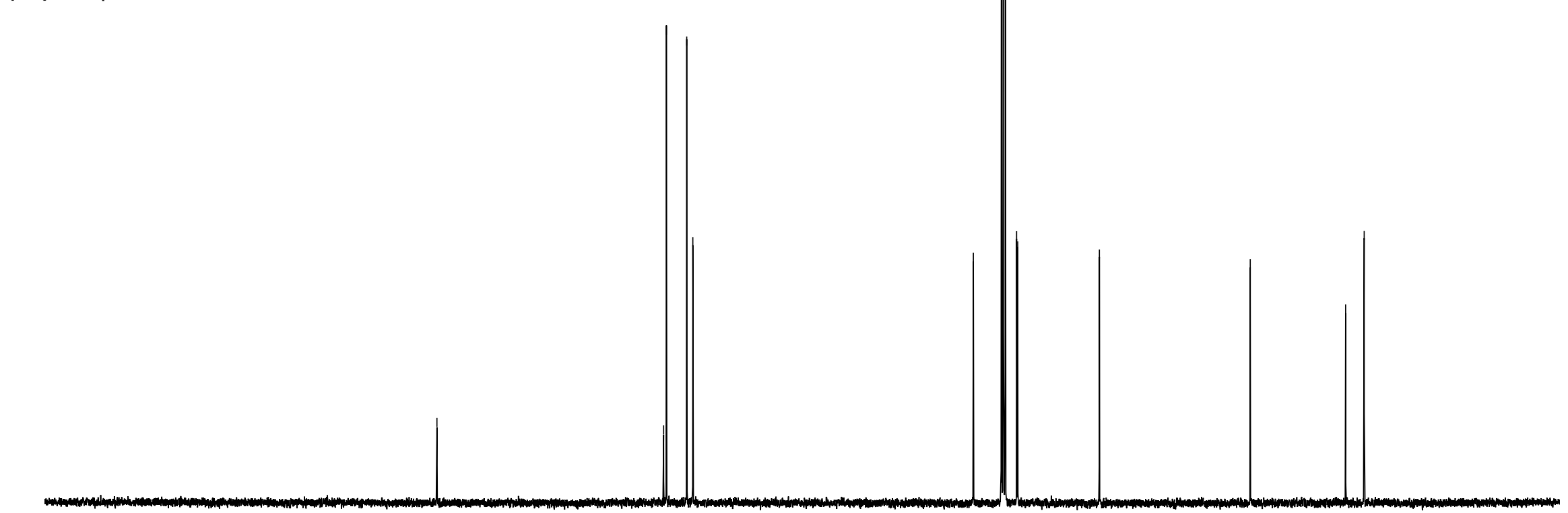

$230 \quad 220-210 \quad 200-190 \quad 180$

150

140

130

$120 \quad 110$ $1(\mathrm{ppm})$

Hoang et al. "General method for the synthesis of $\alpha$ - or $\beta$-deoxyaminoglycosides bearing

S104

basic nitrogen" 
HSQC NMR, $400 \mathrm{MHz}, \mathrm{CDCl}_{3}$
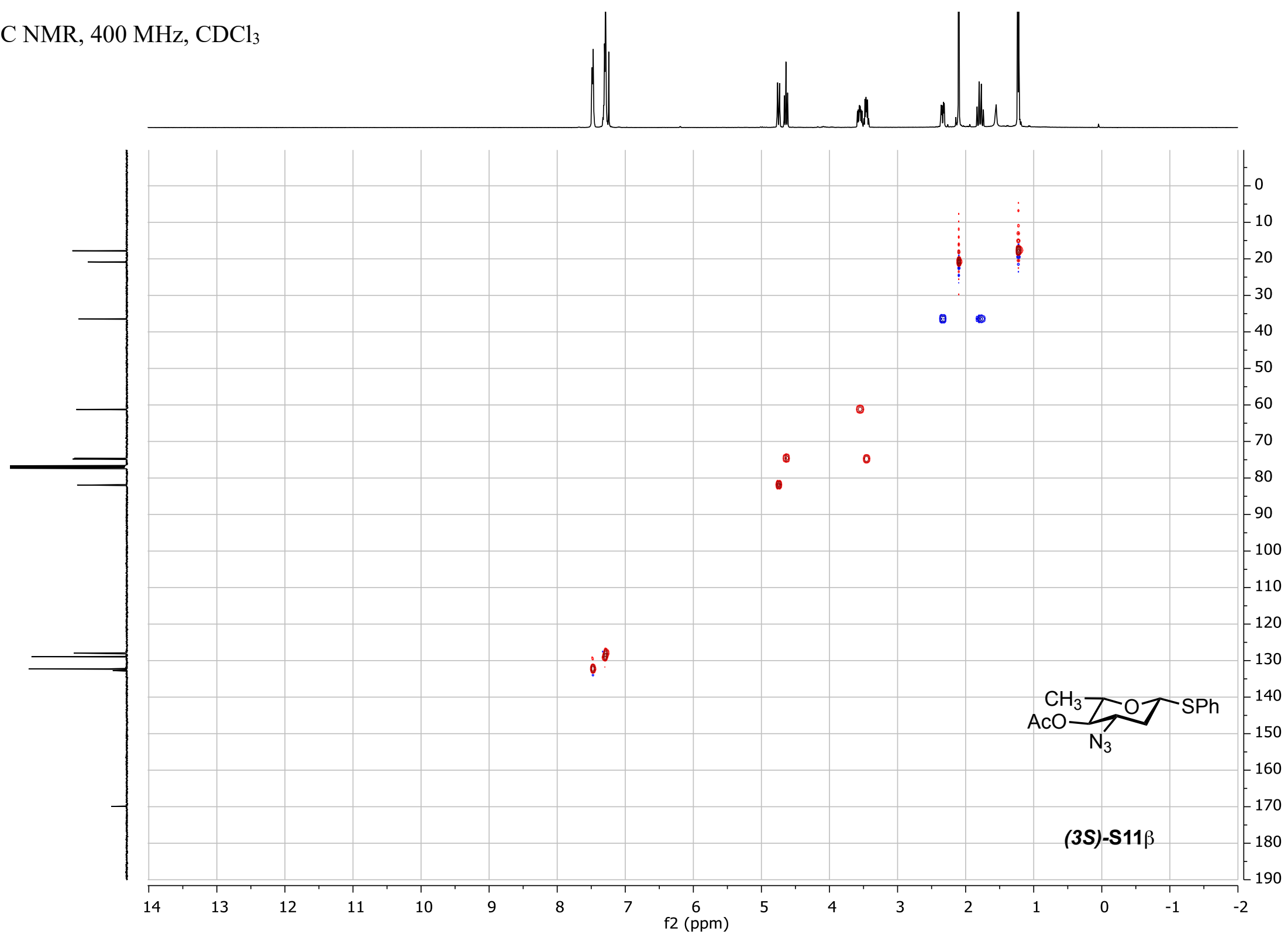

Hoang et al. "General method for the synthesis of $\alpha$ - or $\beta$-deoxyaminoglycosides bearing $\quad$ S105 basic nitrogen" 
${ }^{1} \mathrm{H} \mathrm{NMR}, 600 \mathrm{MHz}, \mathrm{CDCl}_{3}$
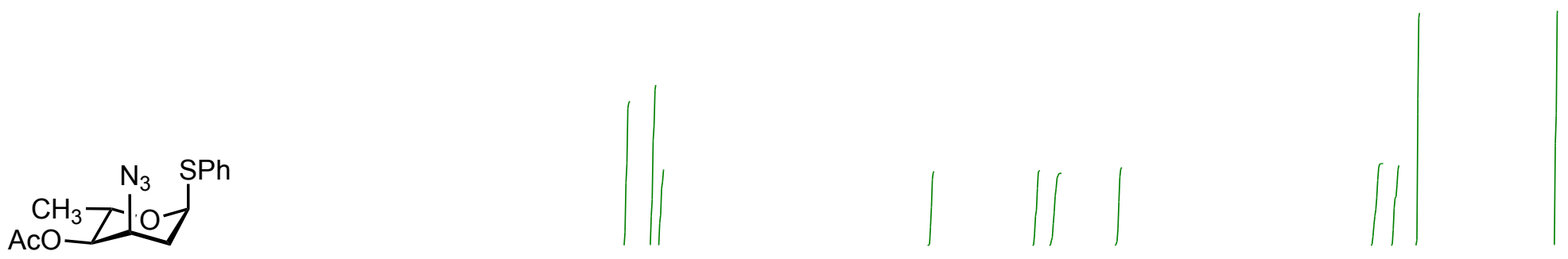

$(3 R)-S 11 \alpha$

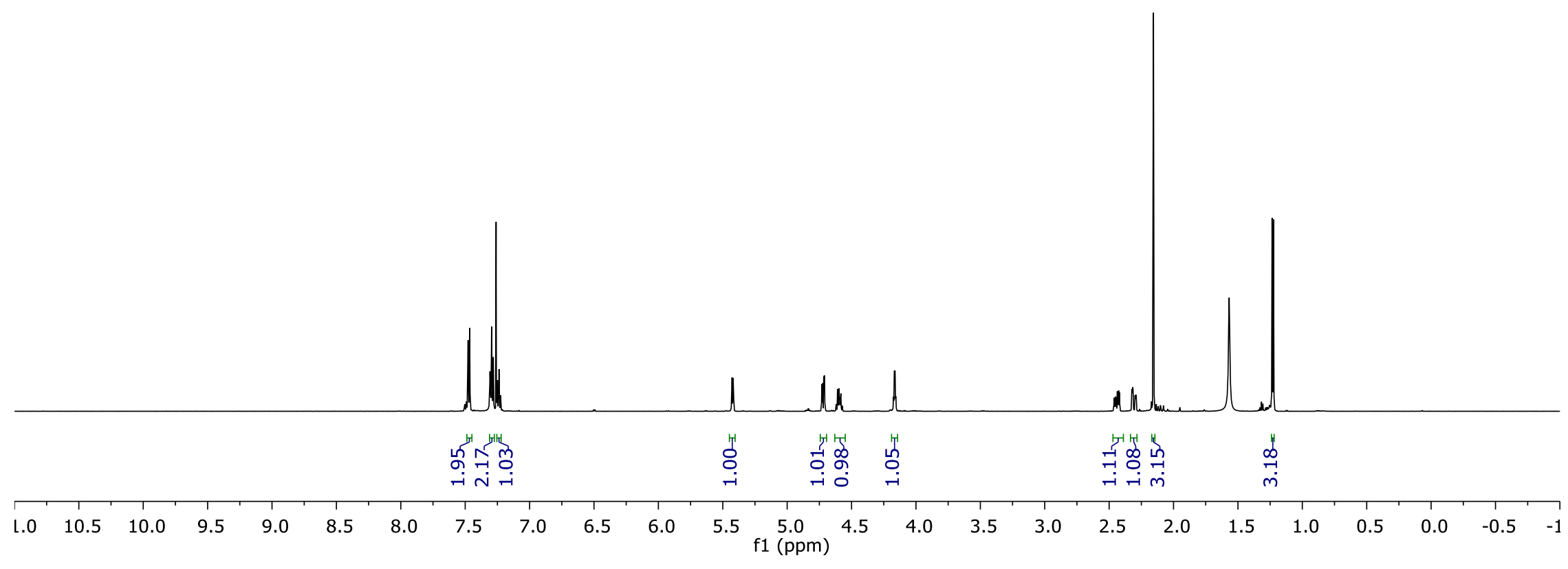

Hoang et al. "General method for the synthesis of $\alpha$ - or $\beta$-deoxyaminoglycosides bearing

S106

basic nitrogen" 


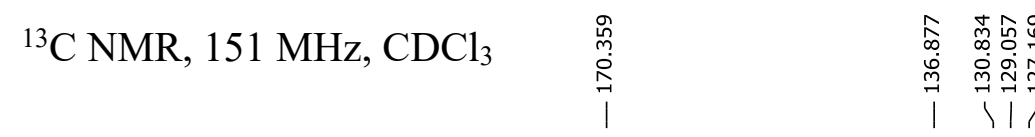

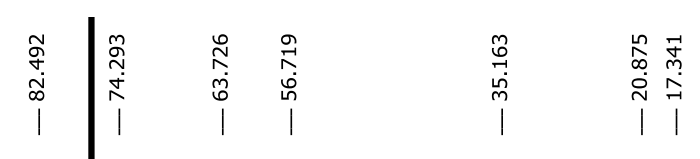

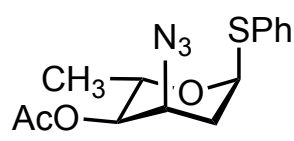

(3R)-S11 $\alpha$

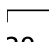

20

$210 \quad 200$

190

180

$170 \quad 160$

$150 \quad 140$

130

120

$110 \quad 100$

$90 \quad 80$

$70 \quad 60$

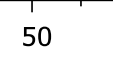

$40 \quad 30 \quad 20$

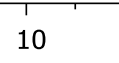

Hoang et al. "General method for the synthesis of $\alpha$ - or $\beta$-deoxyaminoglycosides bearing

S107

basic nitrogen" 
HSQC NMR, $600 \mathrm{MHz}, \mathrm{CDCl}_{3}$
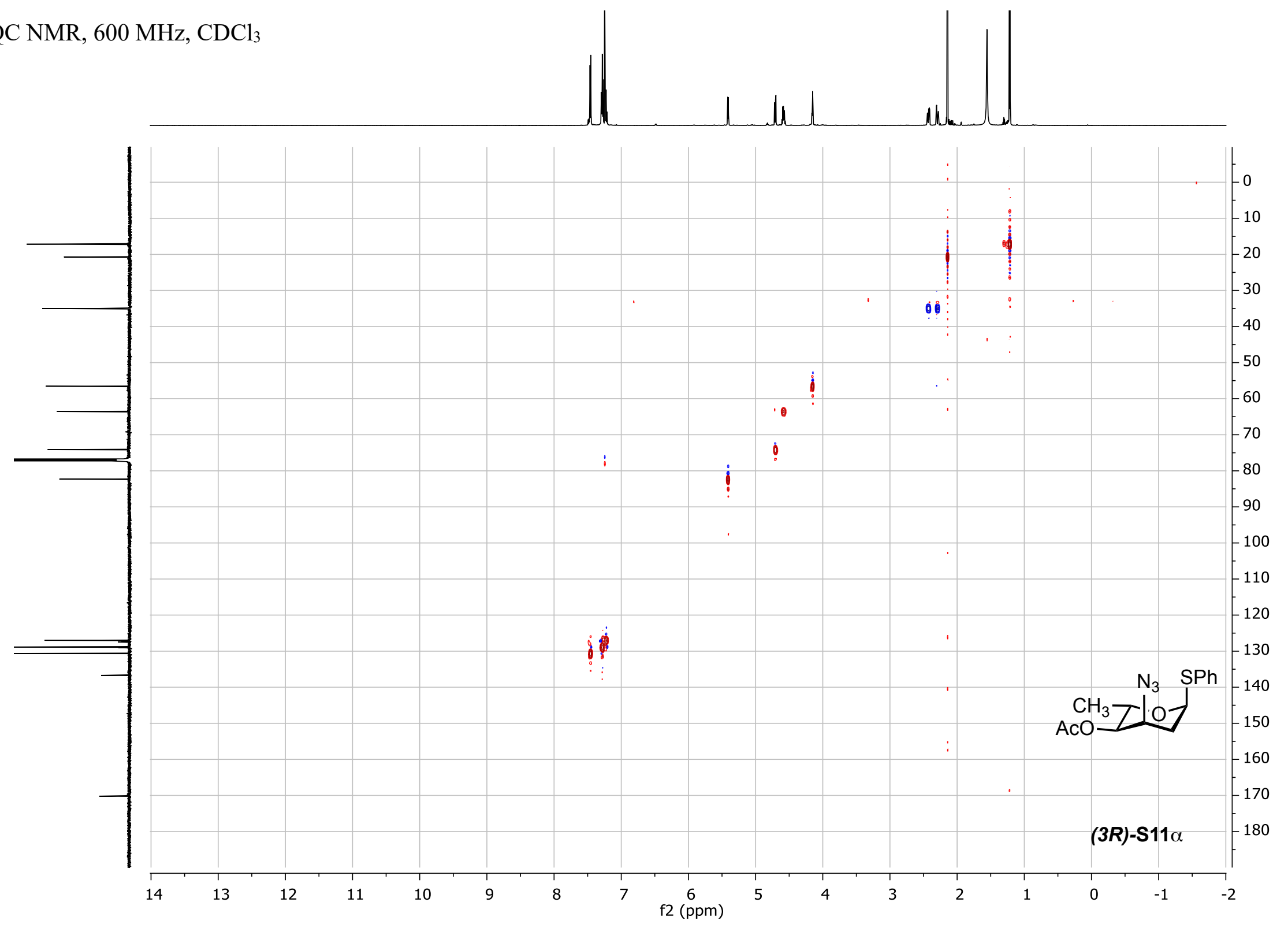

Hoang et al. "General method for the synthesis of $\alpha$ - or $\beta$-deoxyaminoglycosides bearing $\quad$ S108 basic nitrogen" 
${ }^{1} \mathrm{H} \mathrm{NMR}, 400 \mathrm{MHz}, \mathrm{CDCl}_{3}$
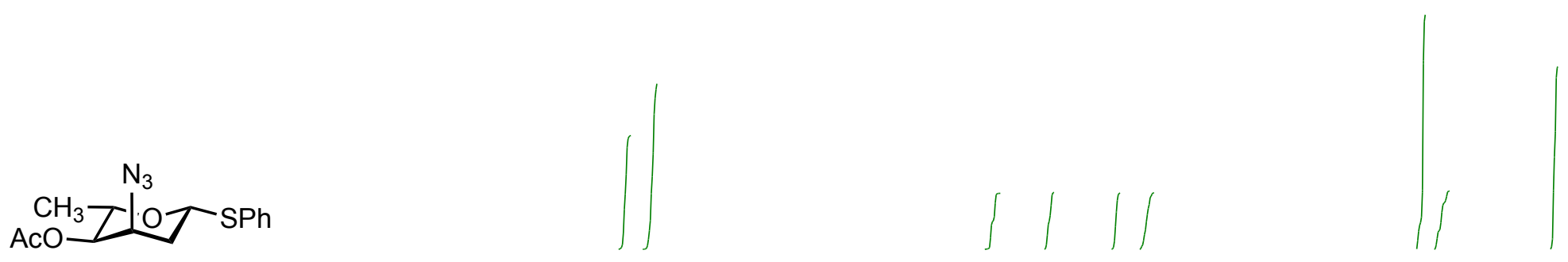

$(3 R)-\mathrm{S} 11 \beta$

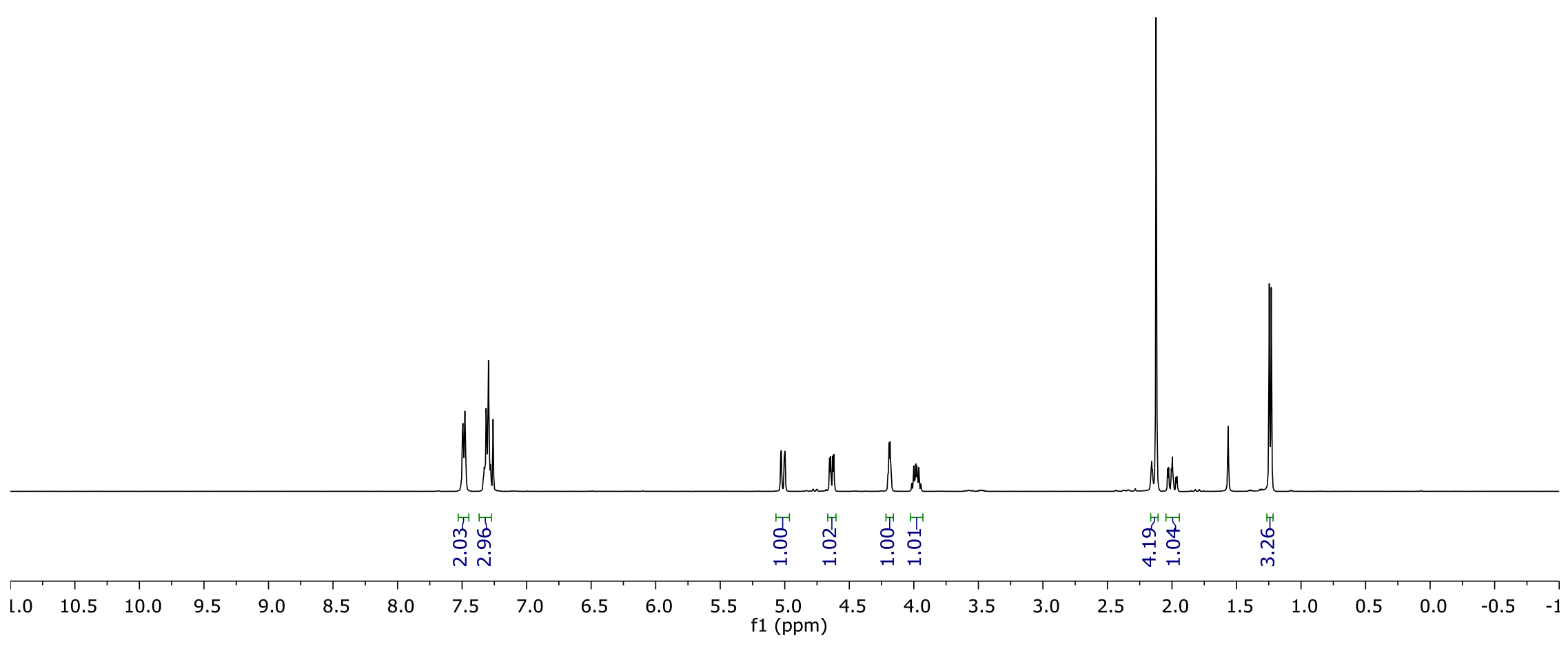

Hoang et al. "General method for the synthesis of $\alpha$ - or $\beta$-deoxyaminoglycosides bearing

S109

basic nitrogen" 
${ }^{13} \mathrm{C} \mathrm{NMR}, 101 \mathrm{MHz}, \mathrm{CDCl}_{3}$

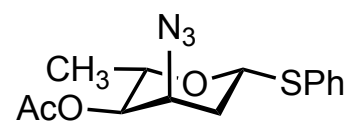

(3R)-S11 $\beta$
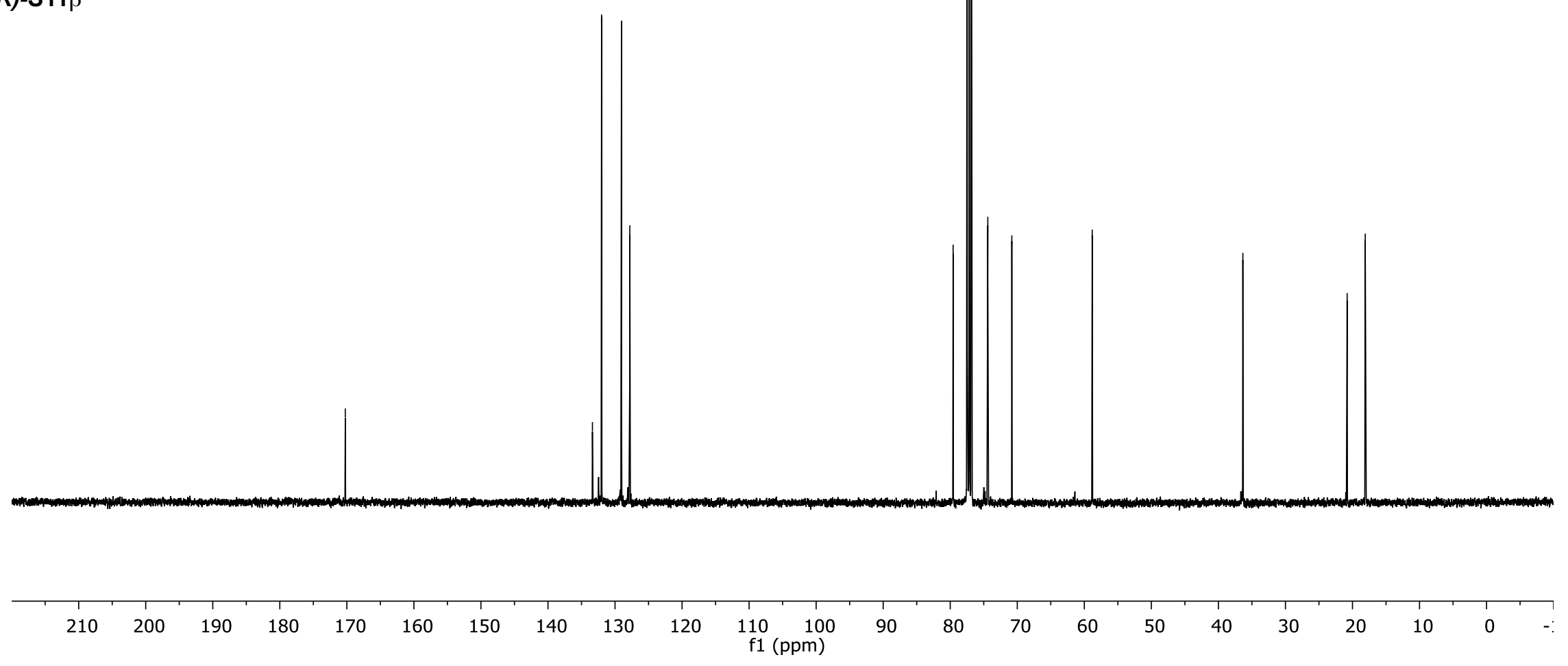

Hoang et al. "General method for the synthesis of $\alpha$ - or $\beta$-deoxyaminoglycosides bearing basic nitrogen"

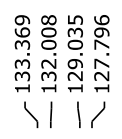

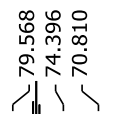

$\underset{\substack{n \\ \infty}}{\substack{\infty \\ \infty}}$

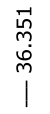

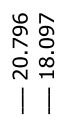

S110 


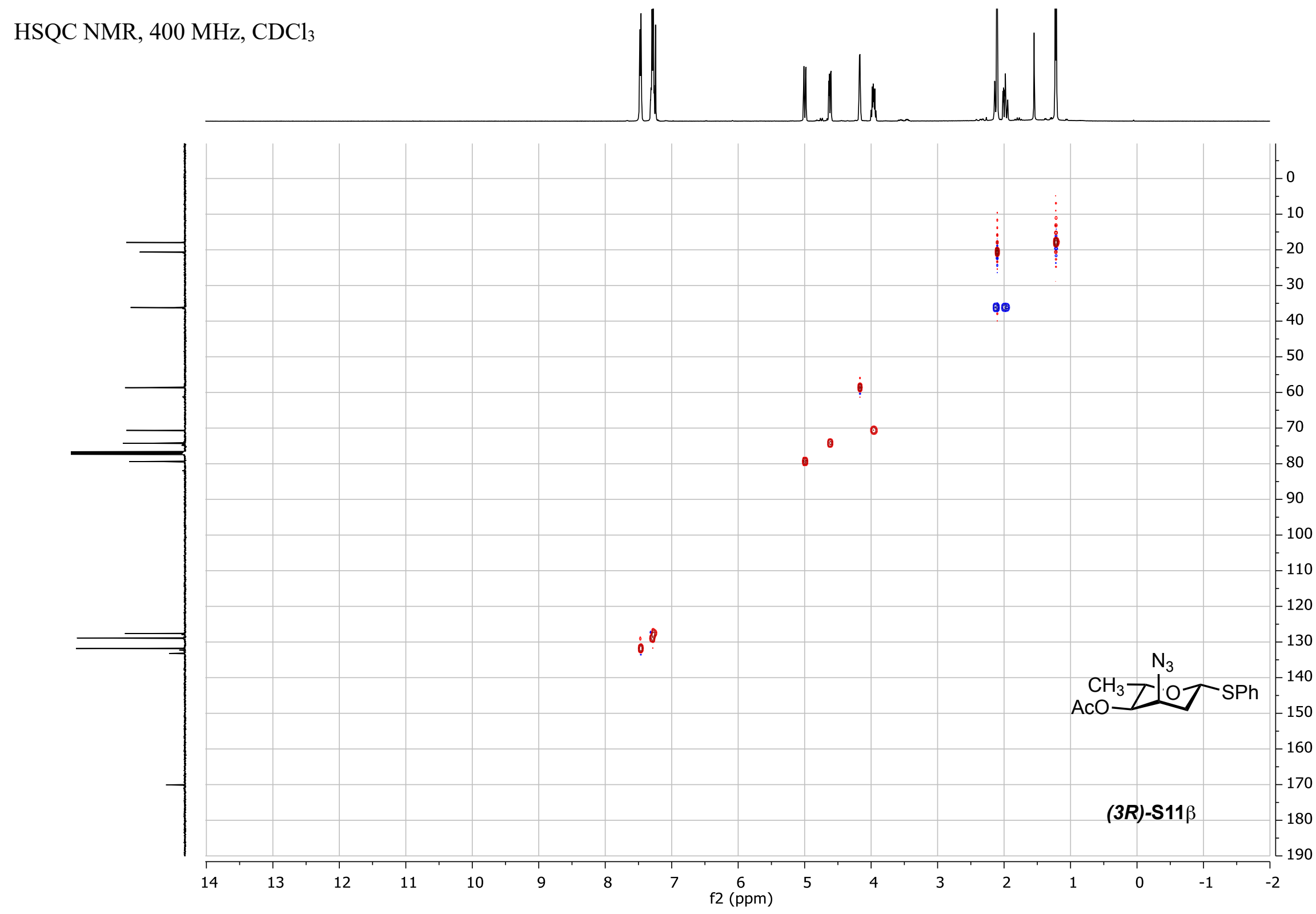

Hoang et al. "General method for the synthesis of $\alpha$ - or $\beta$-deoxyaminoglycosides bearing

S111 basic nitrogen" 
${ }^{1} \mathrm{H} \mathrm{NMR}, 400 \mathrm{MHz}, \mathrm{CDCl}_{3}$
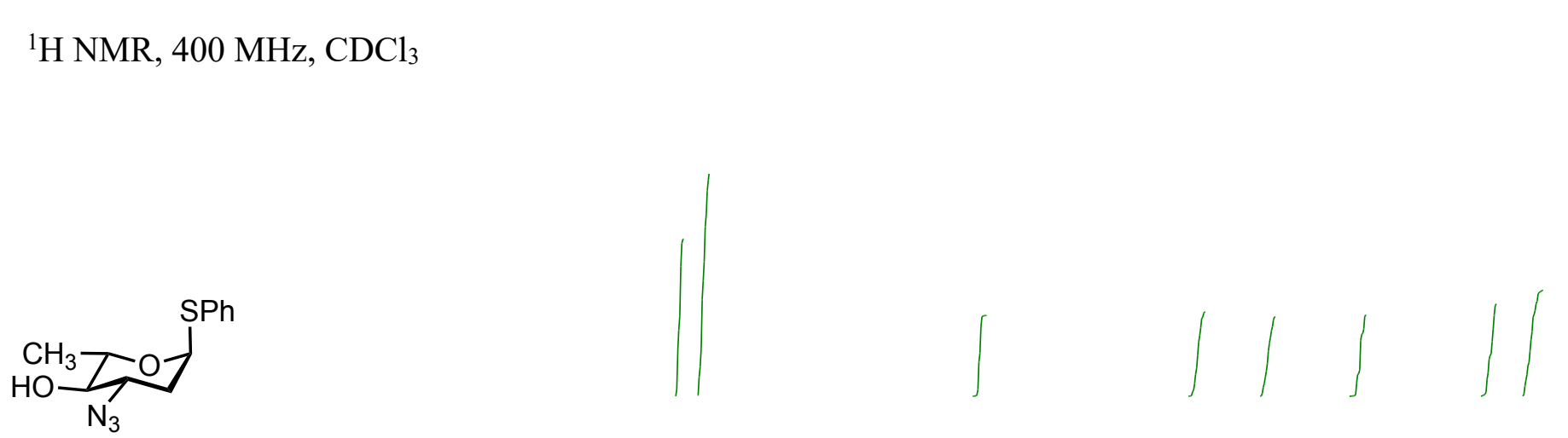

\section{(3S)-S12 $\alpha$}

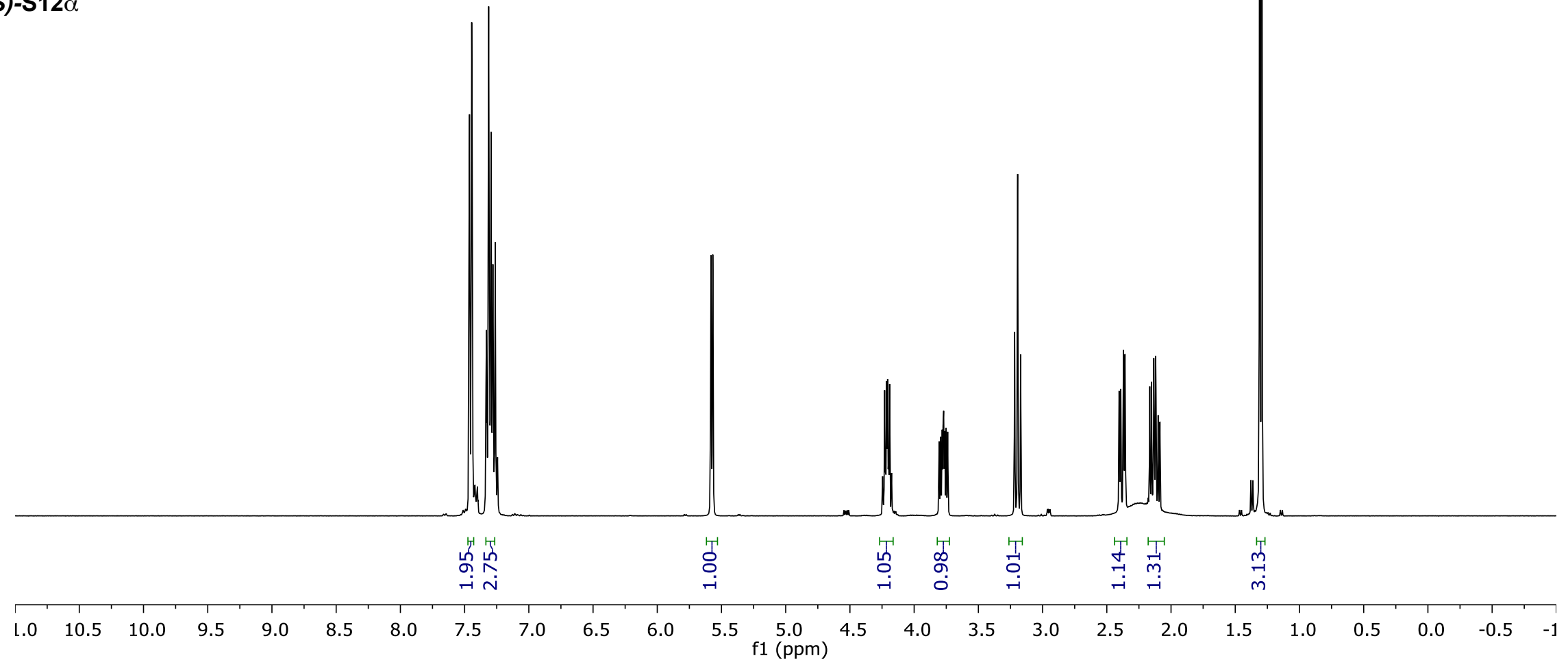

Hoang et al. "General method for the synthesis of $\alpha$ - or $\beta$-deoxyaminoglycosides bearing $\quad$ S112 basic nitrogen" 
${ }^{13} \mathrm{C} \mathrm{NMR,} 151 \mathrm{MHz}, \mathrm{CDCl}_{3}$

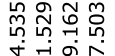

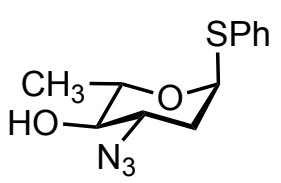

(3S)-S12 $\alpha$

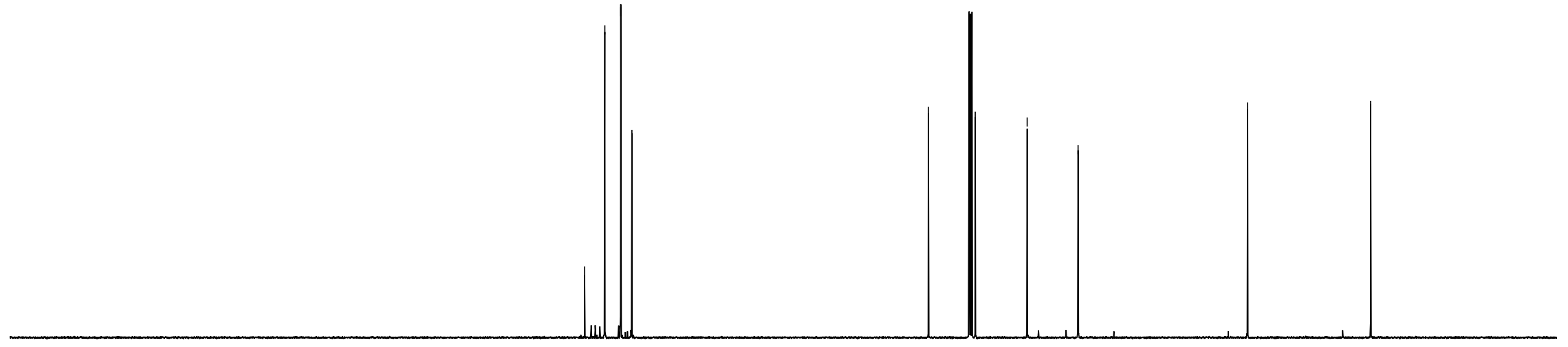


HSQC NMR, $600 \mathrm{MHz}, \mathrm{CDCl}_{3}$
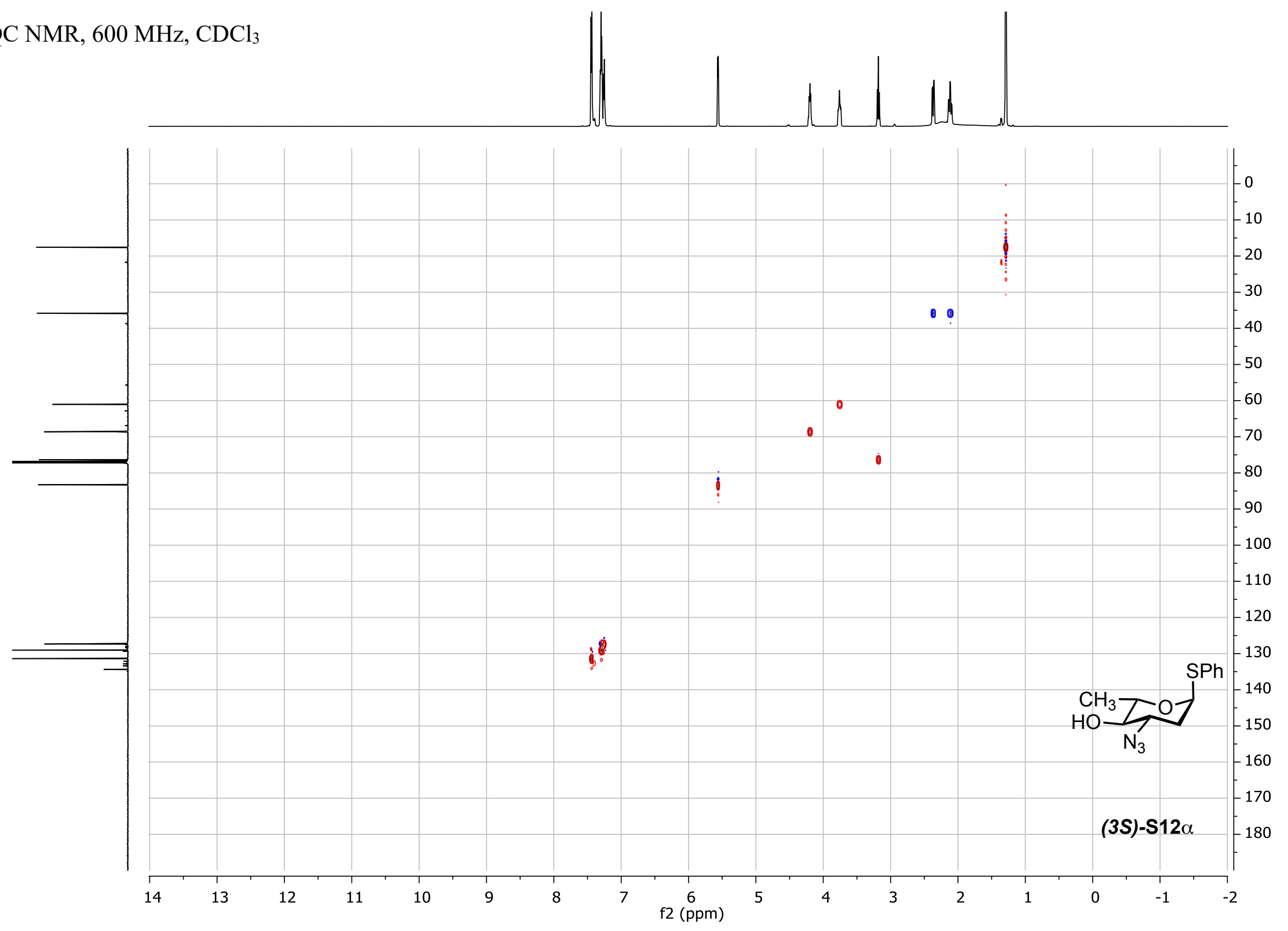

Hoang et al. "General method for the synthesis of $\alpha$ - or $\beta$-deoxyaminoglycosides bearing $\quad$ S114 basic nitrogen" 
${ }^{1} \mathrm{H} \mathrm{NMR}, 400 \mathrm{MHz}, \mathrm{CDCl}_{3}$

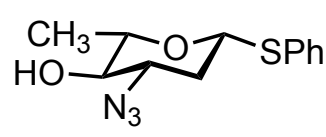

(3S)-S12 $\beta$
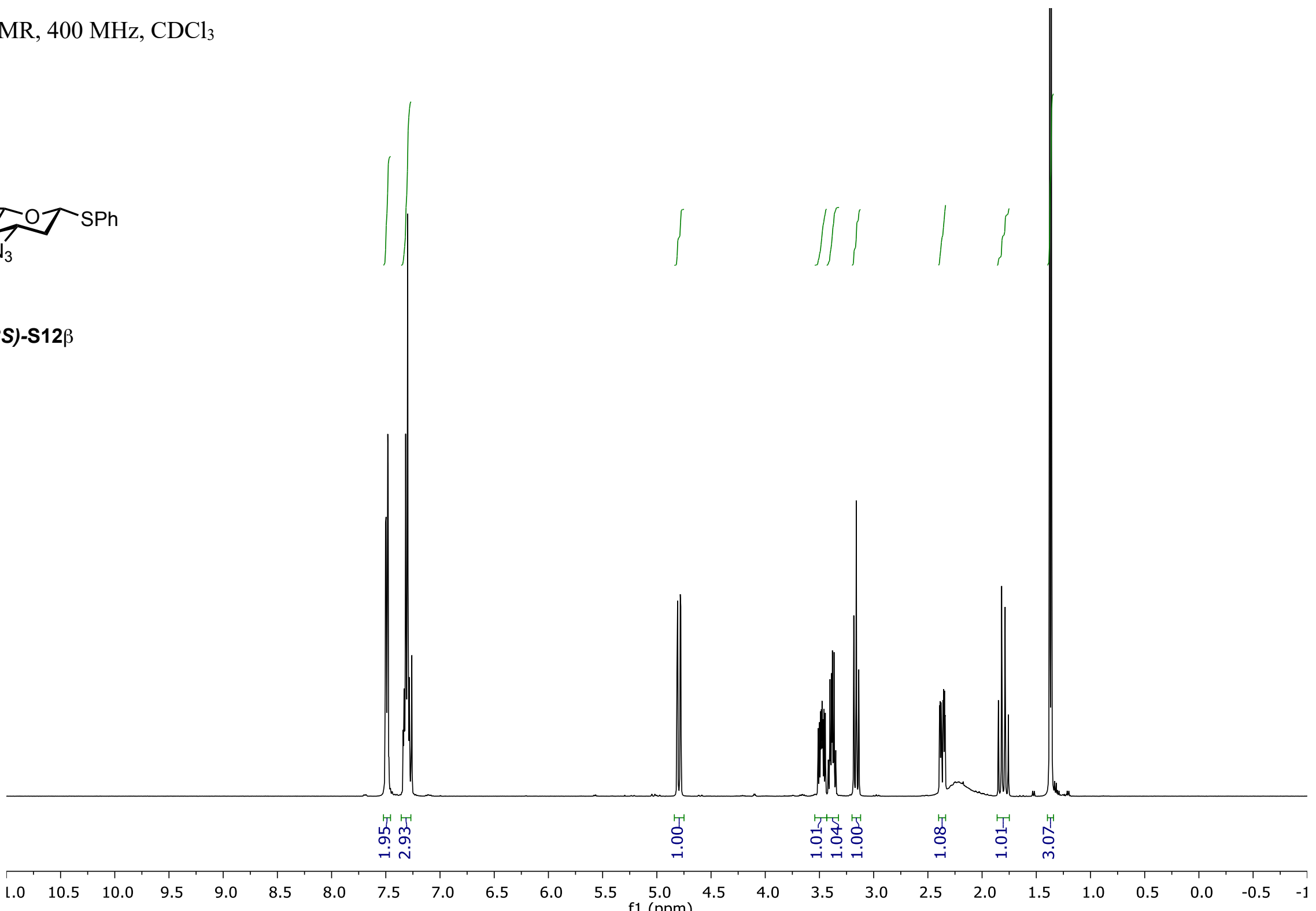

Hoang et al. "General method for the synthesis of $\alpha$ - or $\beta$-deoxyaminoglycosides bearing

S115

basic nitrogen" 
${ }^{13} \mathrm{C} \mathrm{NMR,} 151 \mathrm{MHz}, \mathrm{CDCl}_{3}$

$\mathrm{HO}_{\mathrm{N}_{3}}^{\mathrm{CH}_{3}} \mathrm{O} \mathrm{SPh}$

(3S)-S12 $\beta$

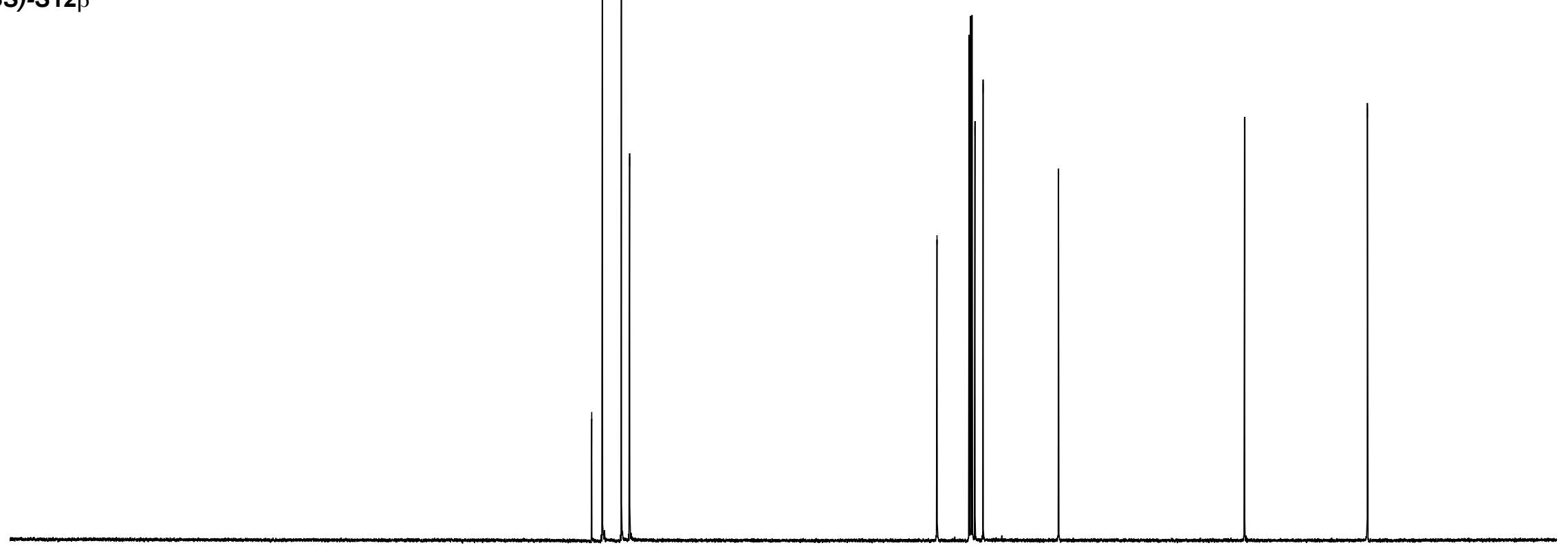


HSQC NMR, $600 \mathrm{MHz}, \mathrm{CDCl}_{3}$
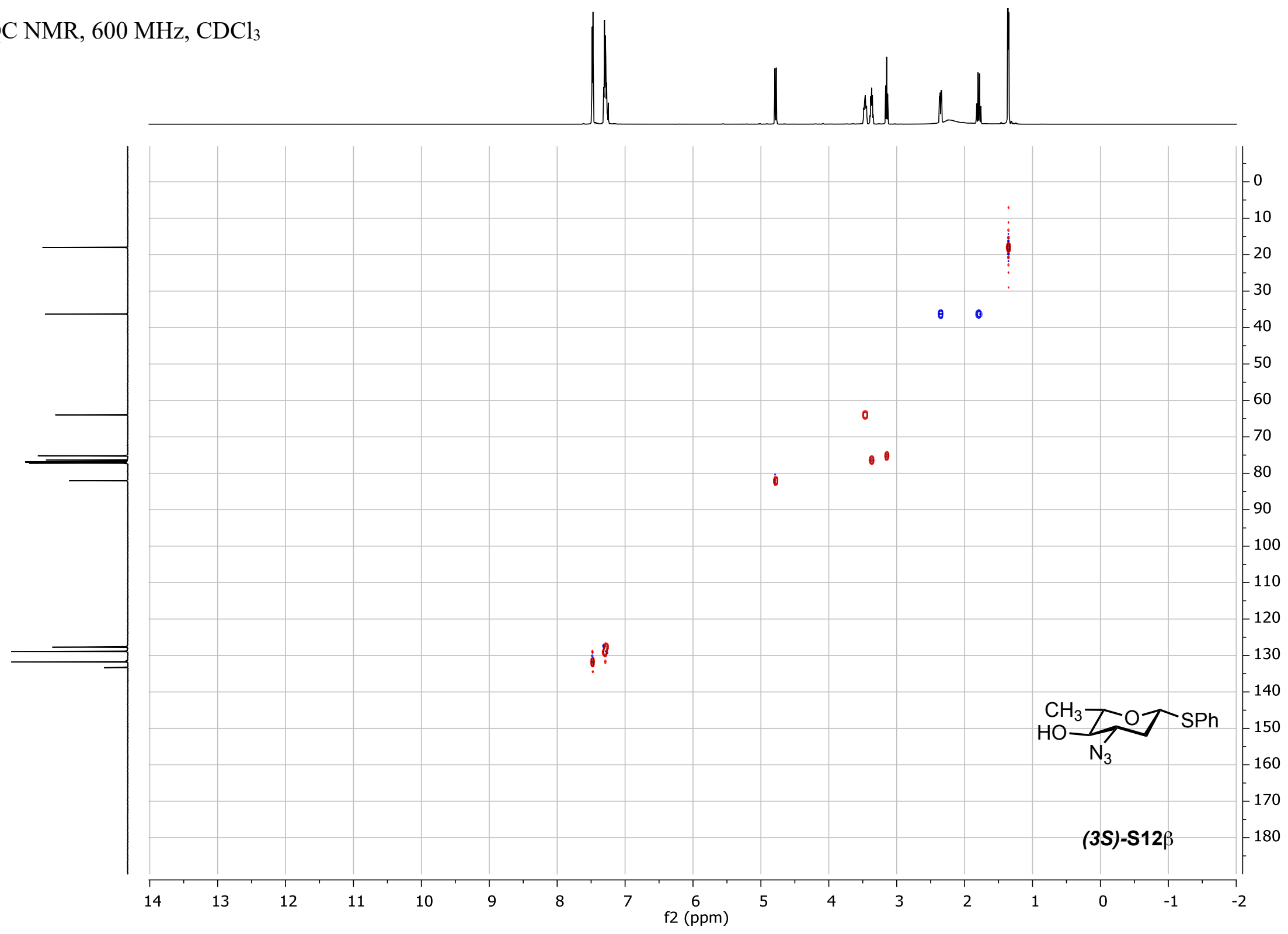

Hoang et al. "General method for the synthesis of $\alpha$ - or $\beta$-deoxyaminoglycosides bearing

S117

basic nitrogen" 
${ }^{1} \mathrm{H} \mathrm{NMR}, 500 \mathrm{MHz}, \mathrm{CDCl}_{3}$
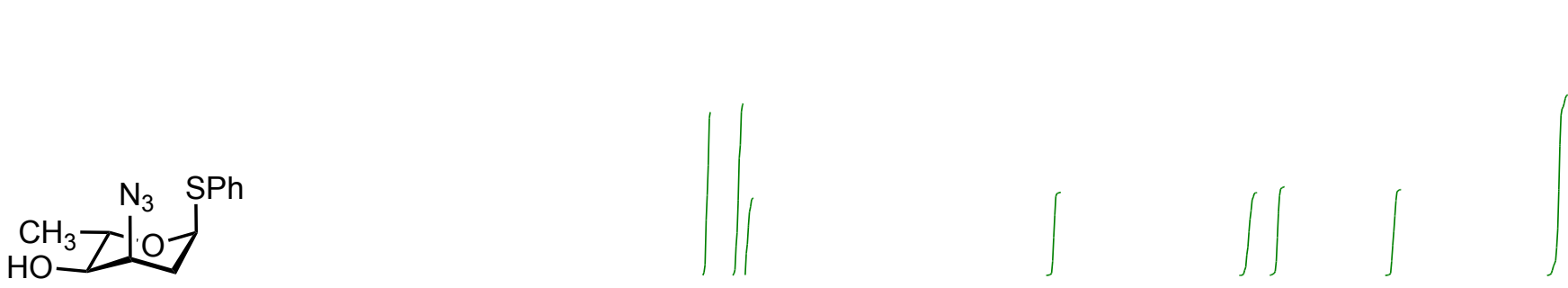

(3R)-S12 $\alpha$

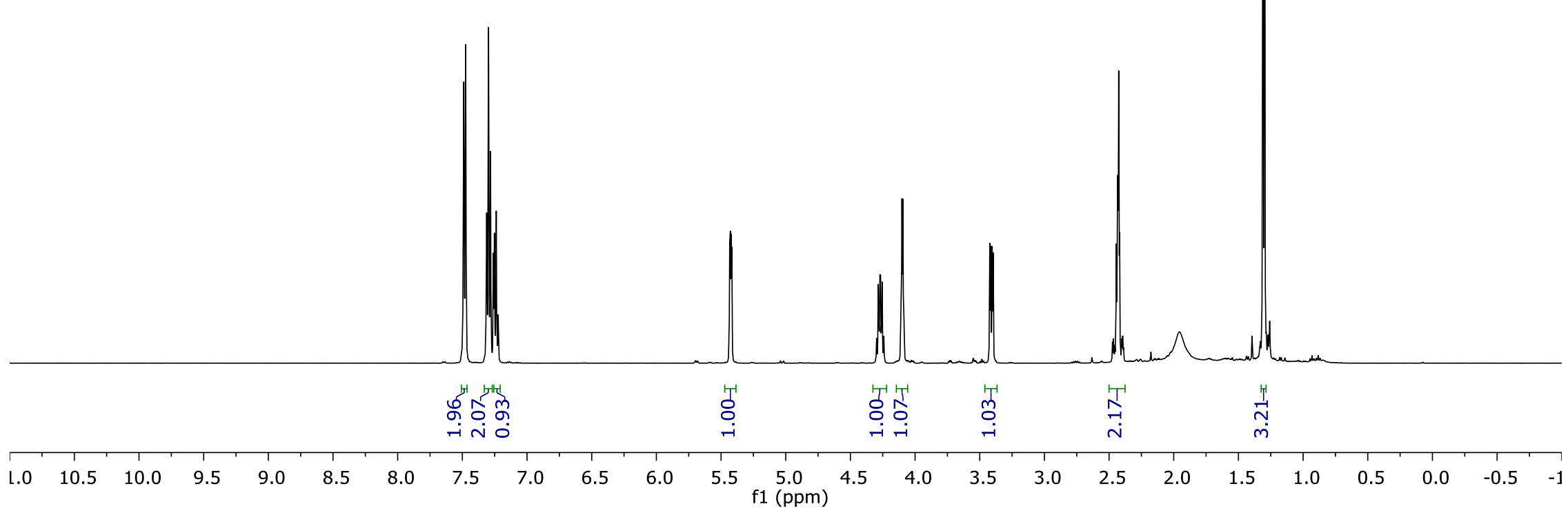

Hoang et al. "General method for the synthesis of $\alpha$ - or $\beta$-deoxyaminoglycosides bearing $\quad$ S118 basic nitrogen" 
${ }^{13} \mathrm{C} \mathrm{NMR,} 101 \mathrm{MHz}, \mathrm{CDCl}_{3}$

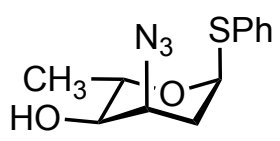

(3R)-S12 $\alpha$

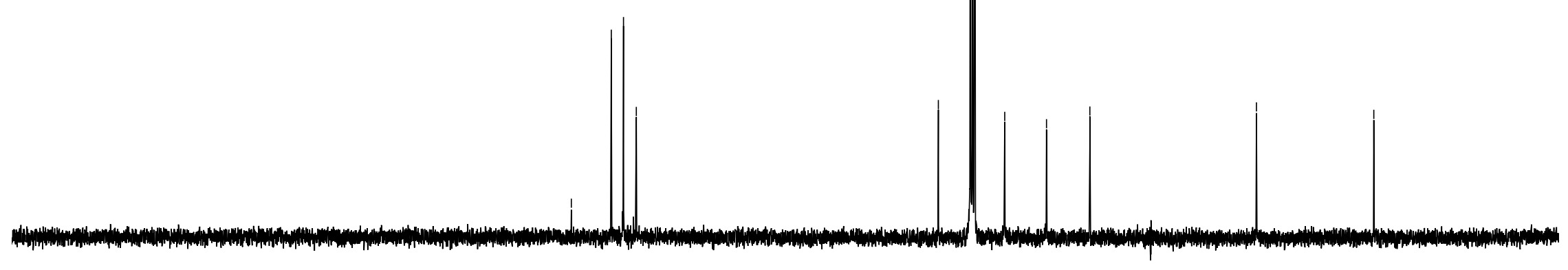

Hoang et al. "General method for the synthesis of $\alpha$ - or $\beta$-deoxyaminoglycosides bearing basic nitrogen" 
HSQC NMR, $500 \mathrm{MHz}, \mathrm{CDCl}_{3}$

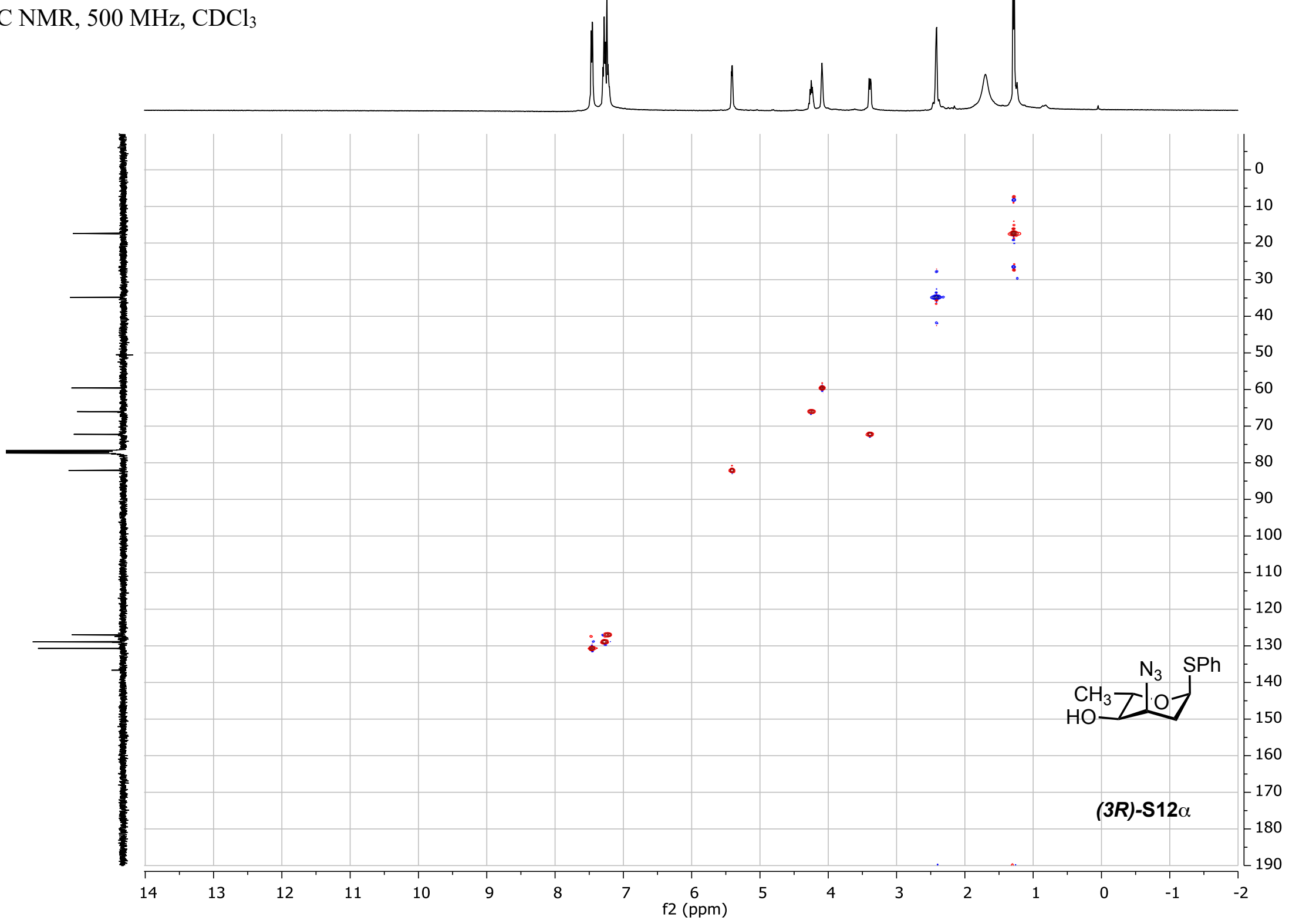

Hoang et al. "General method for the synthesis of $\alpha$ - or $\beta$-deoxyaminoglycosides bearing

S120 basic nitrogen" 
${ }^{1} \mathrm{H} \mathrm{NMR}, 400 \mathrm{MHz}, \mathrm{CDCl}_{3}$
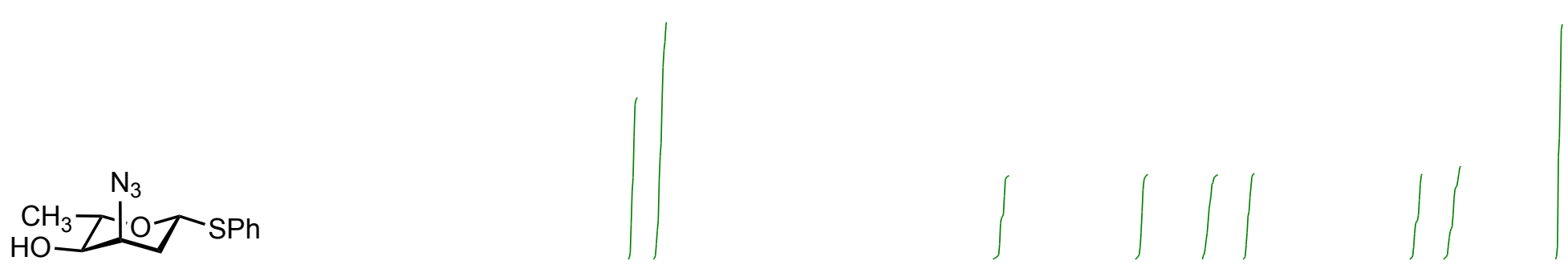

(3R)-S12 $\beta$

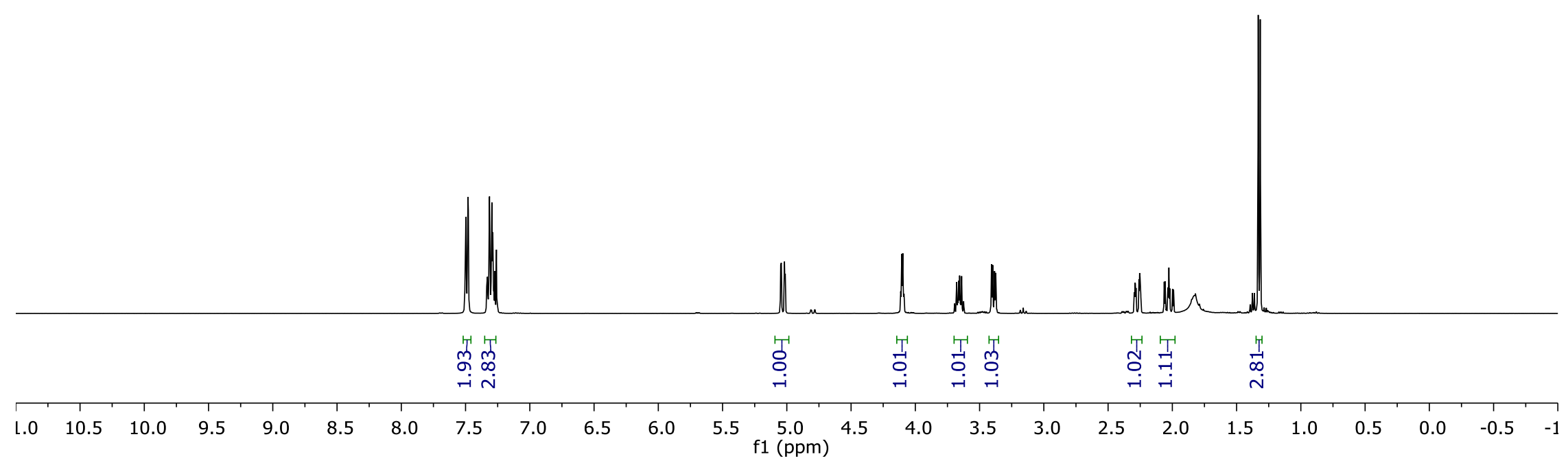

Hoang et al. "General method for the synthesis of $\alpha$ - or $\beta$-deoxyaminoglycosides bearing $\quad$ S121 basic nitrogen" 
${ }^{13} \mathrm{C} \mathrm{NMR,} 151 \mathrm{MHz}, \mathrm{CDCl}_{3}$

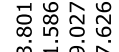

$\mathrm{CH}_{3}$ 工四 $\mathrm{SPh}$

(3R)-S12 $\beta$

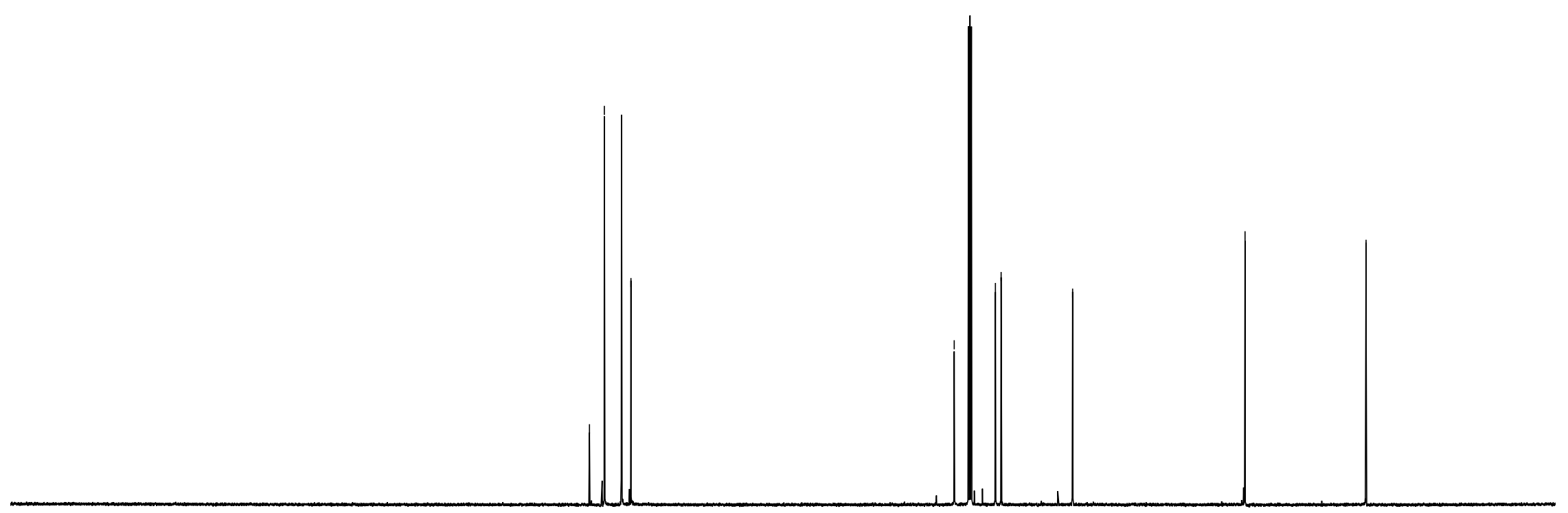

210

190

180

$170 \quad 160$

150140

130

120

$110 \quad 100$

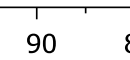

80

Hoang et al. "General method for the synthesis of $\alpha$ - or $\beta$-deoxyaminoglycosides bearing

$\mathrm{S} 122$

basic nitrogen" 
HSQC NMR, $600 \mathrm{MHz}, \mathrm{CDCl}_{3}$

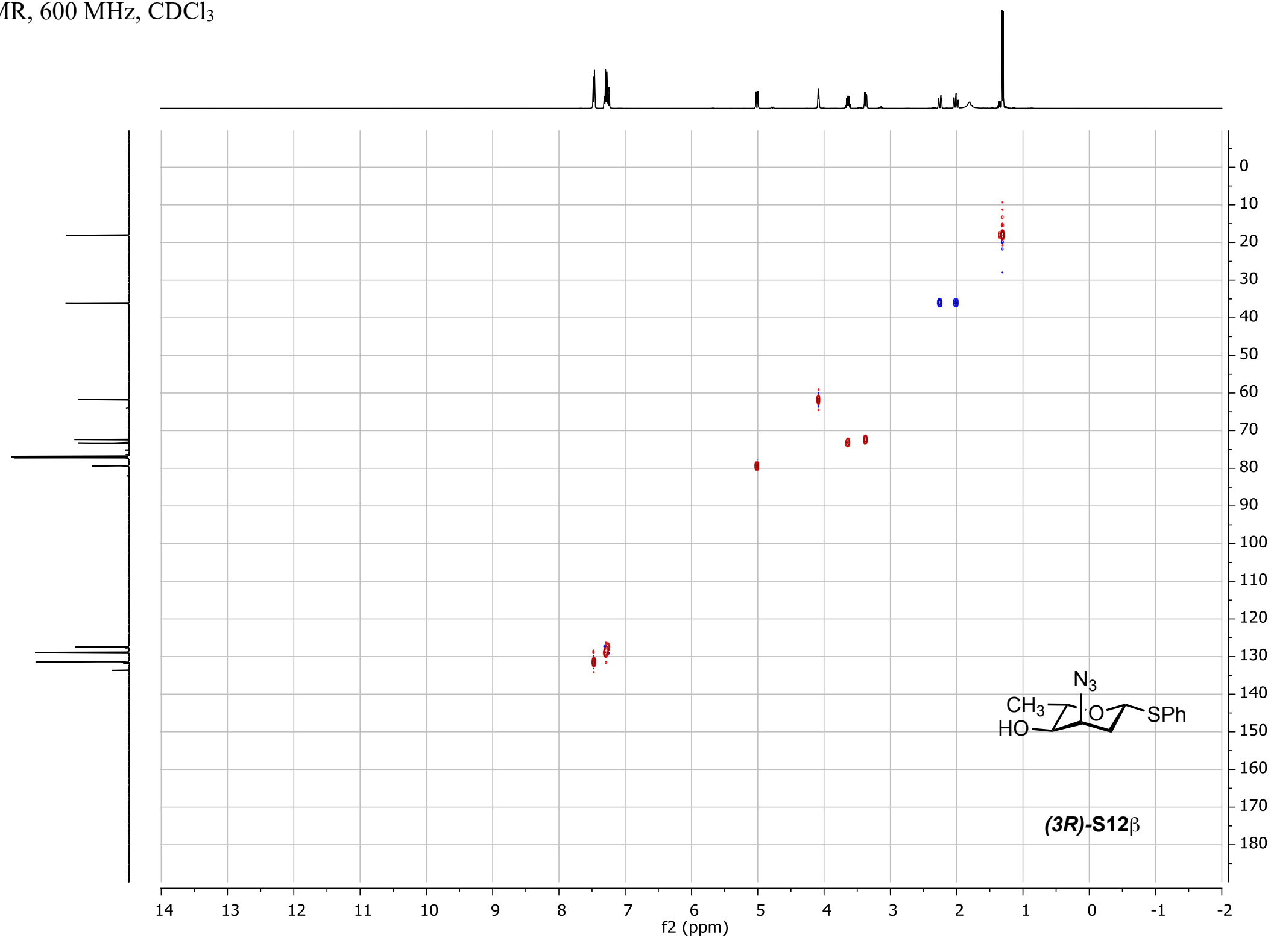

Hoang et al. "General method for the synthesis of $\alpha$ - or $\beta$-deoxyaminoglycosides bearing

S 123 basic nitrogen" 


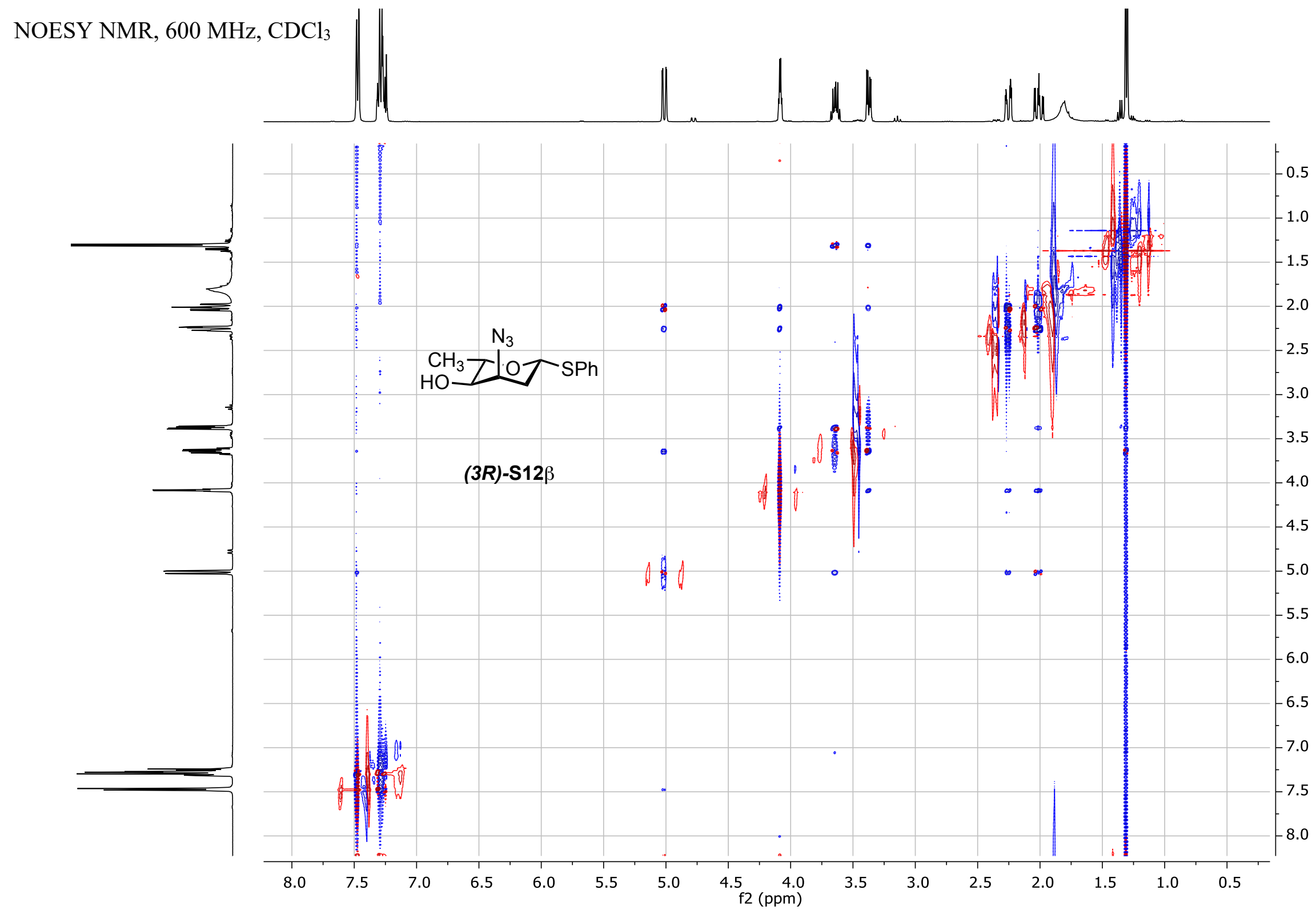

Hoang et al. "General method for the synthesis of $\alpha$ - or $\beta$-deoxyaminoglycosides bearing

S124 basic nitrogen" 
${ }^{1} \mathrm{H} \mathrm{NMR}, 600 \mathrm{MHz}, \mathrm{CDCl}_{3}$
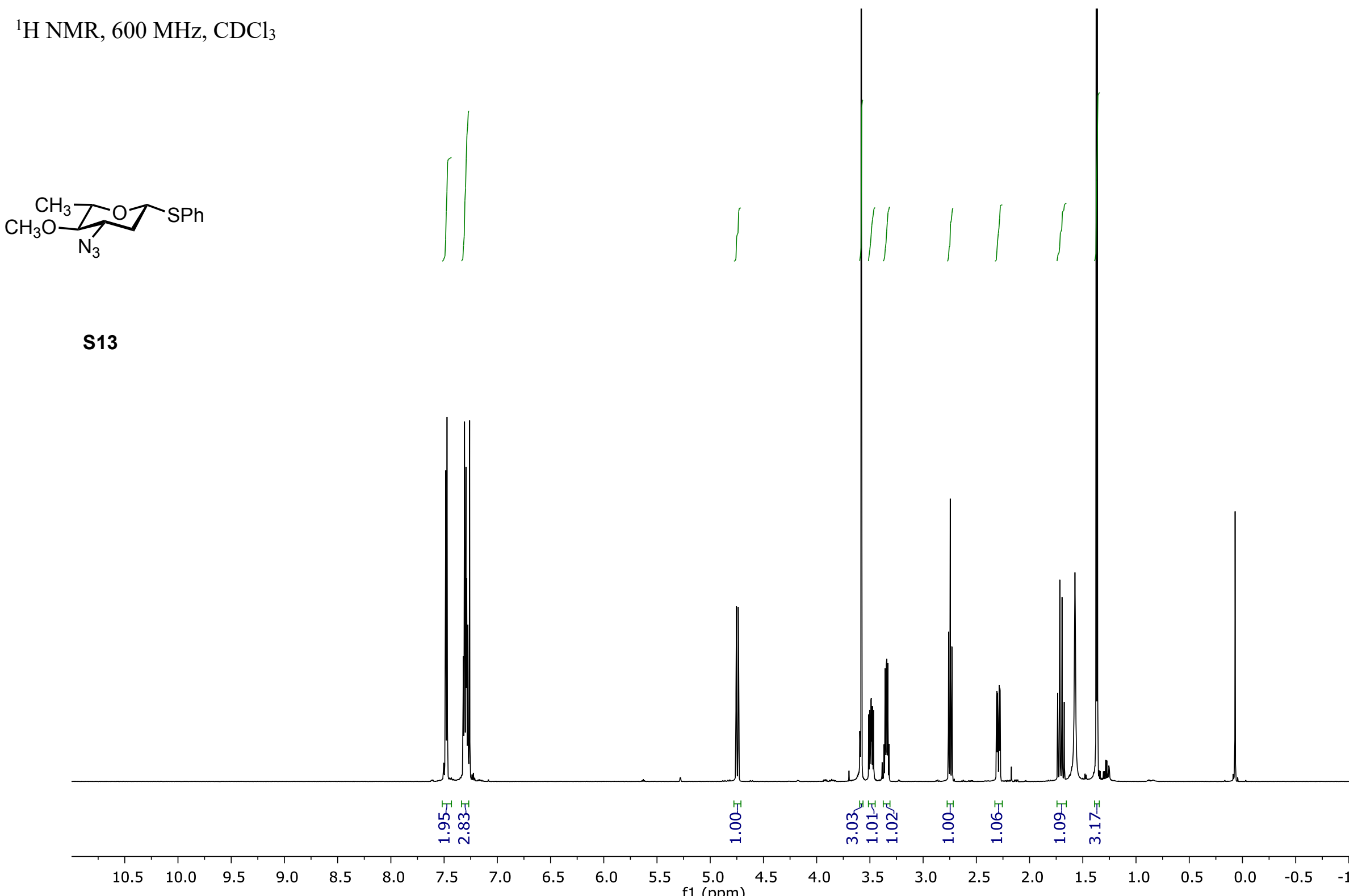

Hoang et al. "General method for the synthesis of $\alpha$ - or $\beta$-deoxyaminoglycosides bearing

S125 basic nitrogen" 
${ }^{13} \mathrm{C} \mathrm{NMR}, 151 \mathrm{MHz}, \mathrm{CDCl}_{3}$

$\mathrm{CH}_{3} \mathrm{O} \underset{\mathrm{N}_{3}}{\mathrm{~T}_{\mathrm{SPh}}} \mathrm{O}$

S13

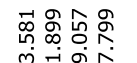

लำ 퍽

111

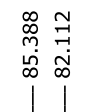

mo mo

11

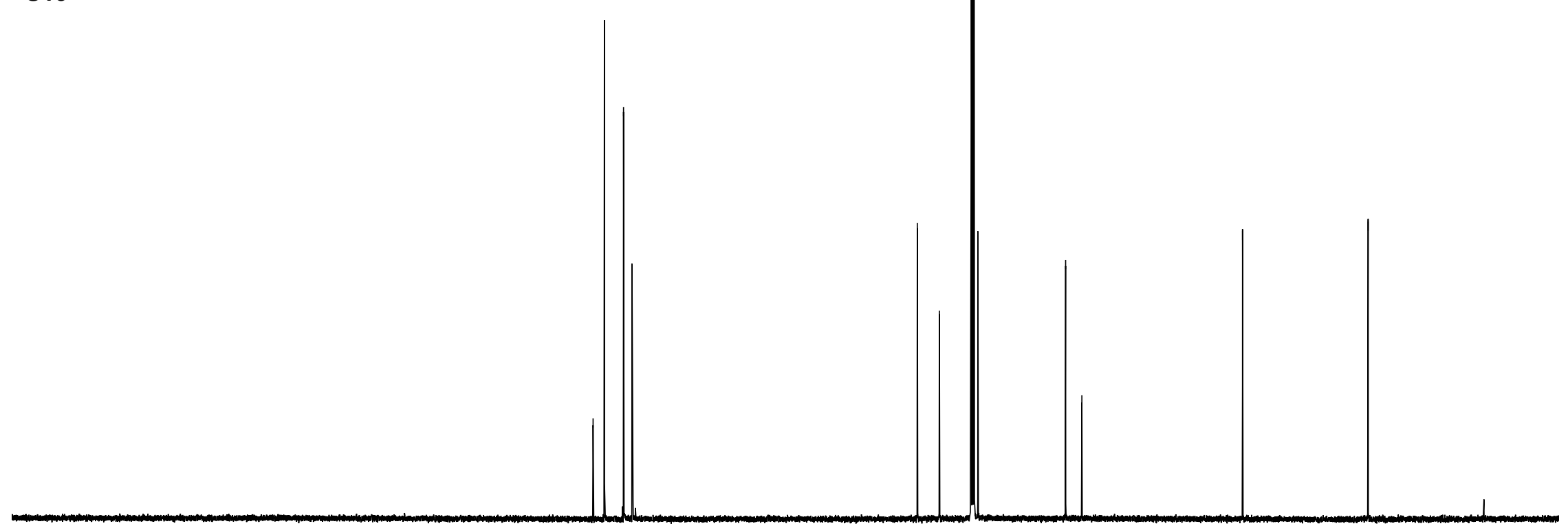

$\begin{array}{llllllllllll}210 & 200 & 190 & 180 & 170 & 160 & 150 & 140 & 130 & 120 & 110 & 100 \\ \text { f1(ppm) }\end{array}$

Hoang et al. "General method for the synthesis of $\alpha$ - or $\beta$-deoxyaminoglycosides bearing basic nitrogen" 
HSQC NMR, $600 \mathrm{MHz}, \mathrm{CDCl}_{3}$
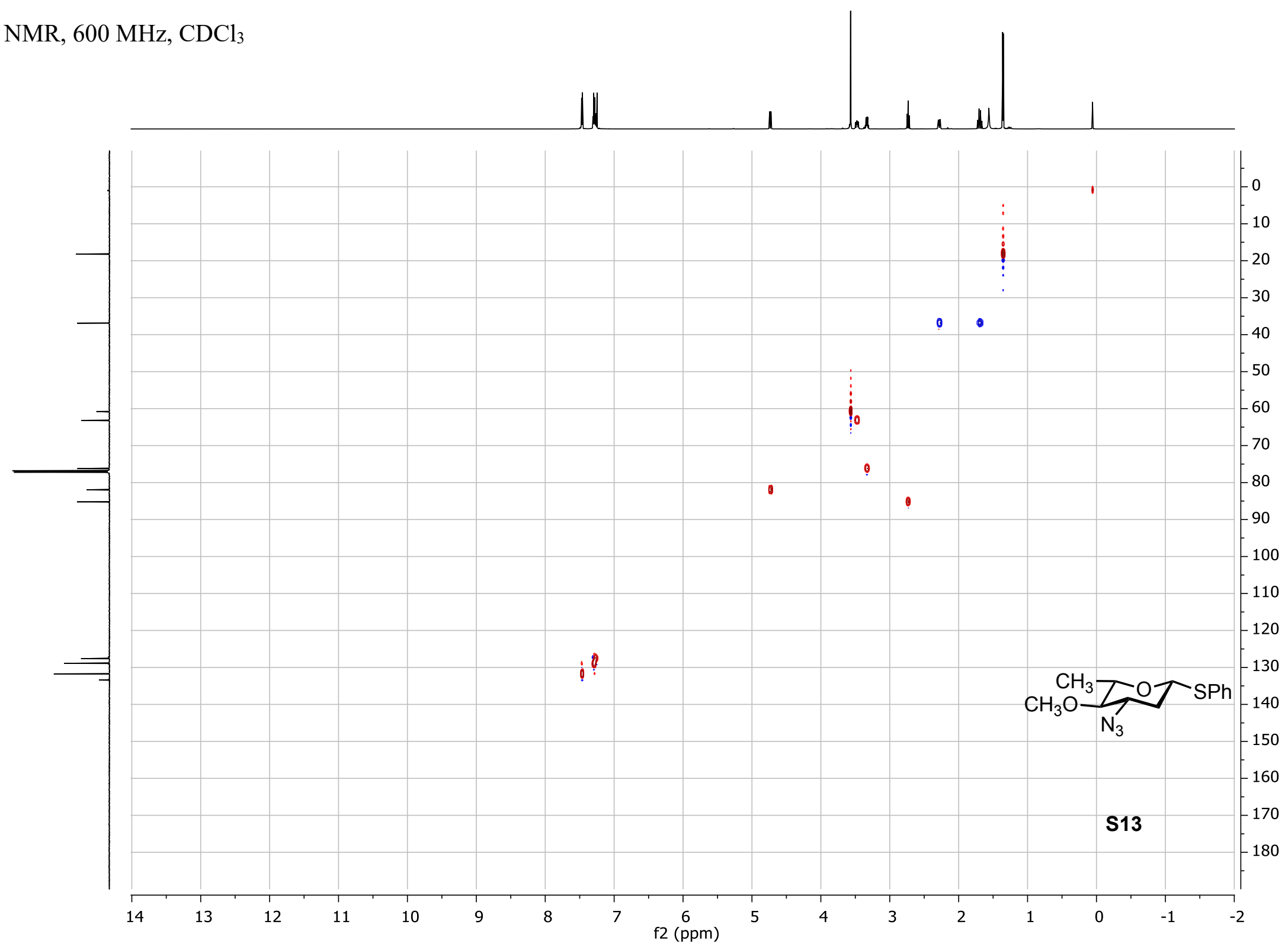

Hoang et al. "General method for the synthesis of $\alpha$ - or $\beta$-deoxyaminoglycosides bearing

S127

basic nitrogen" 
${ }^{1} \mathrm{H} \mathrm{NMR}, 500 \mathrm{MHz}, \mathrm{CDCl}_{3}$
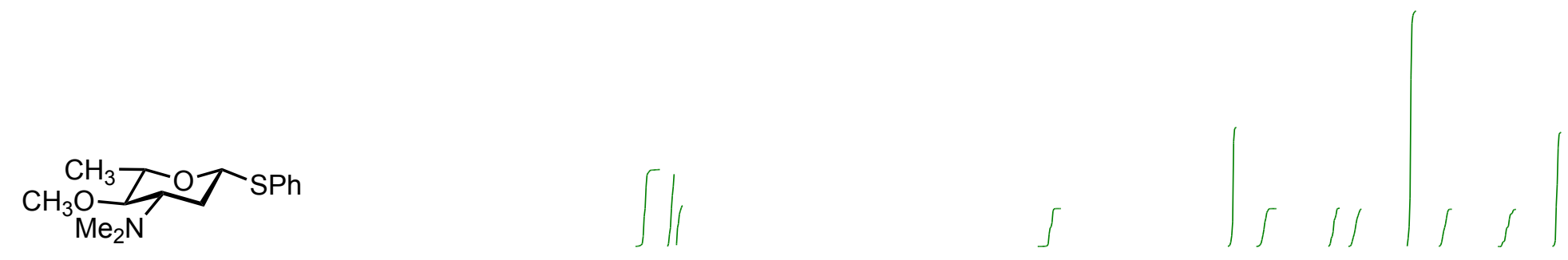

$16 \beta$

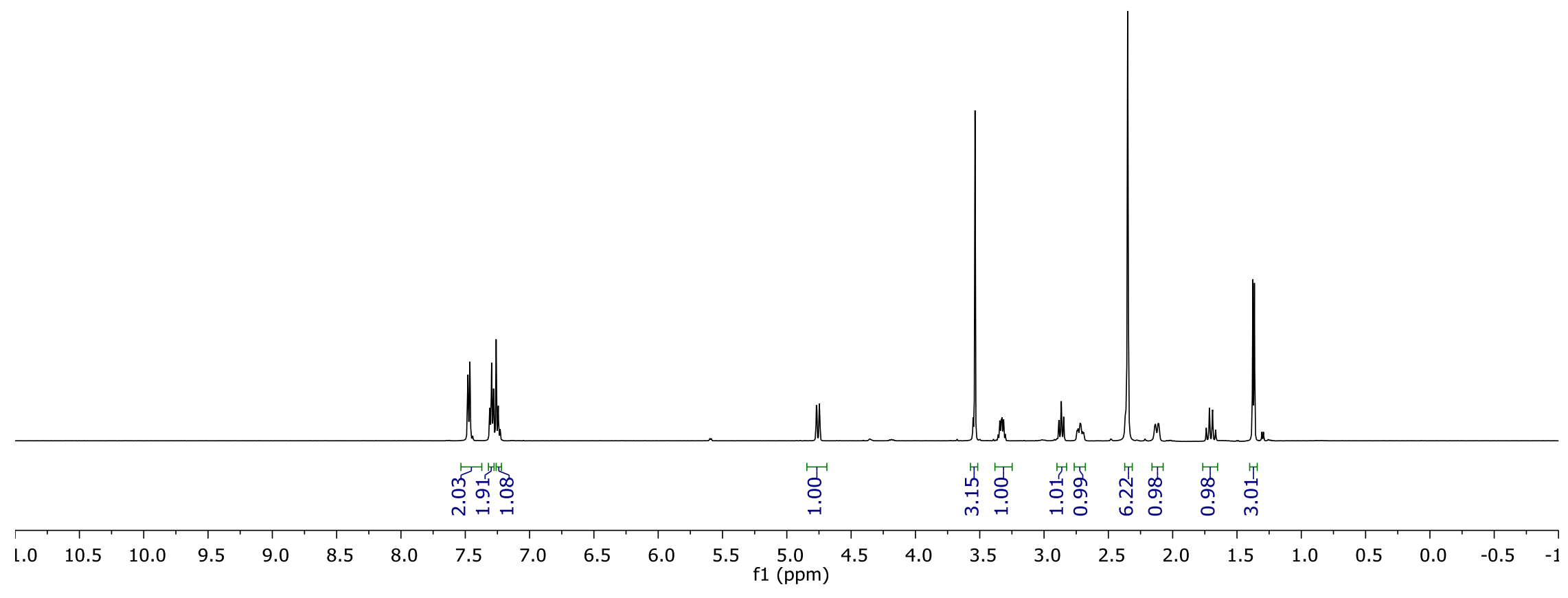

Hoang et al. "General method for the synthesis of $\alpha$ - or $\beta$-deoxyaminoglycosides bearing $\quad$ S128 basic nitrogen" 
${ }^{13} \mathrm{C} \mathrm{NMR,} 126 \mathrm{MHz}, \mathrm{CDCl}_{3}$

$16 \beta$
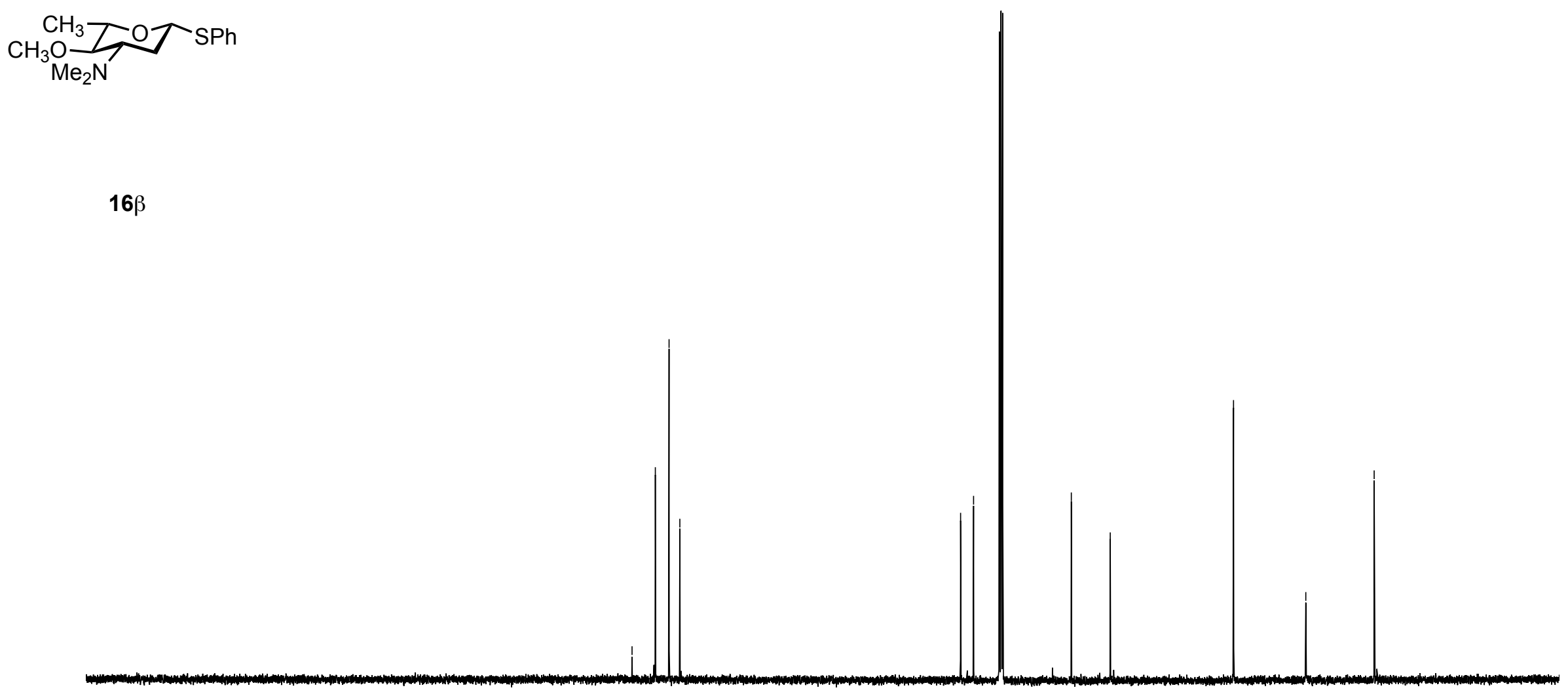

20

210200

190

170

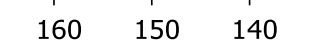

130

120

$110 \quad 100$

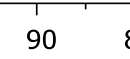

80

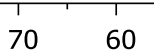

50
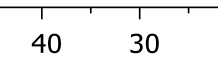

Hoang et al. "General method for the synthesis of $\alpha$ - or $\beta$-deoxyaminoglycosides bearing

S129

basic nitrogen" 
HSQC NMR, $500 \mathrm{MHz}, \mathrm{CDCl}_{3}$
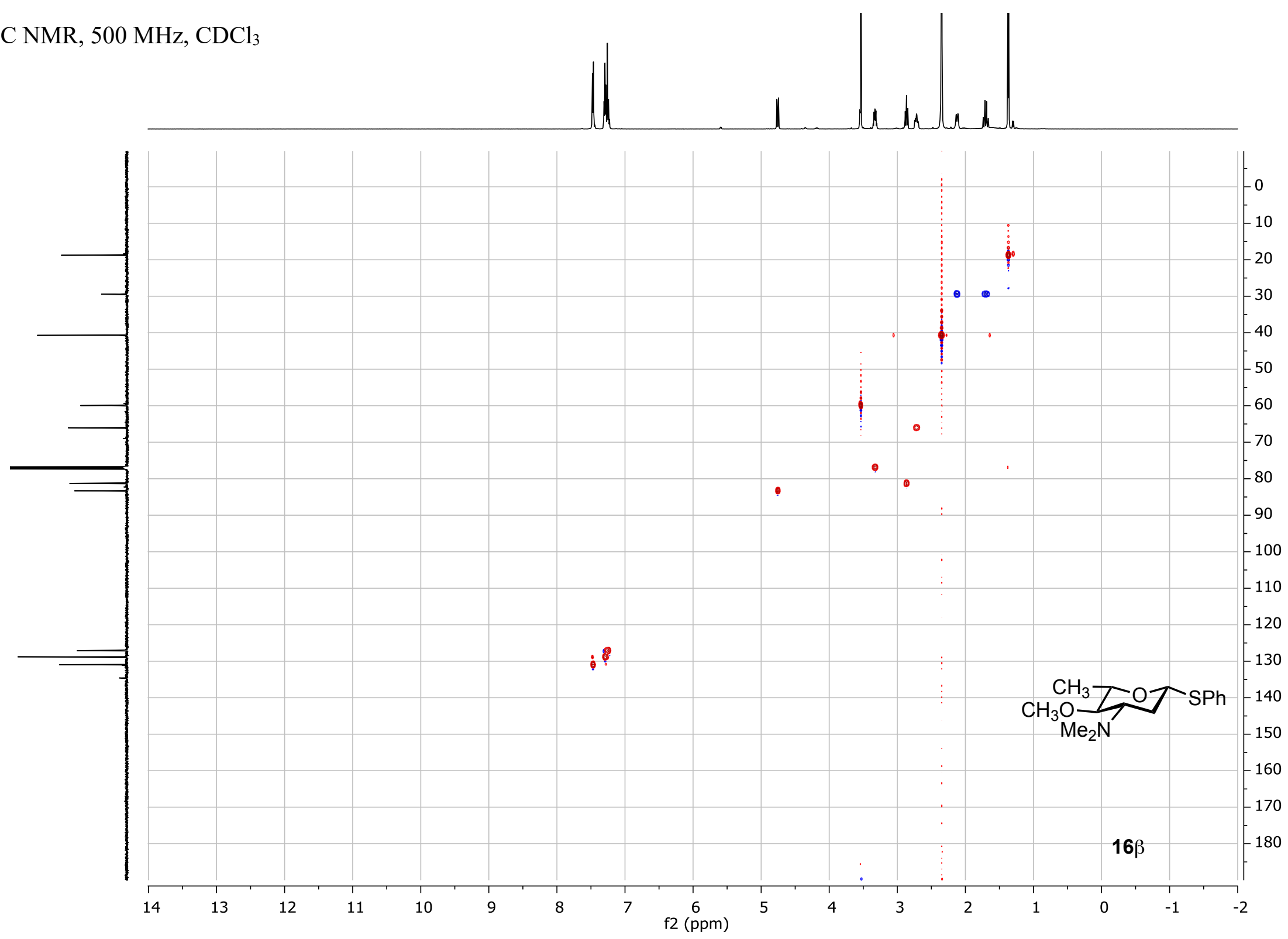

Hoang et al. "General method for the synthesis of $\alpha$ - or $\beta$-deoxyaminoglycosides bearing $\quad$ S130 basic nitrogen" 
${ }^{1} \mathrm{H} \mathrm{NMR}, 500 \mathrm{MHz}, \mathrm{CDCl}_{3}$
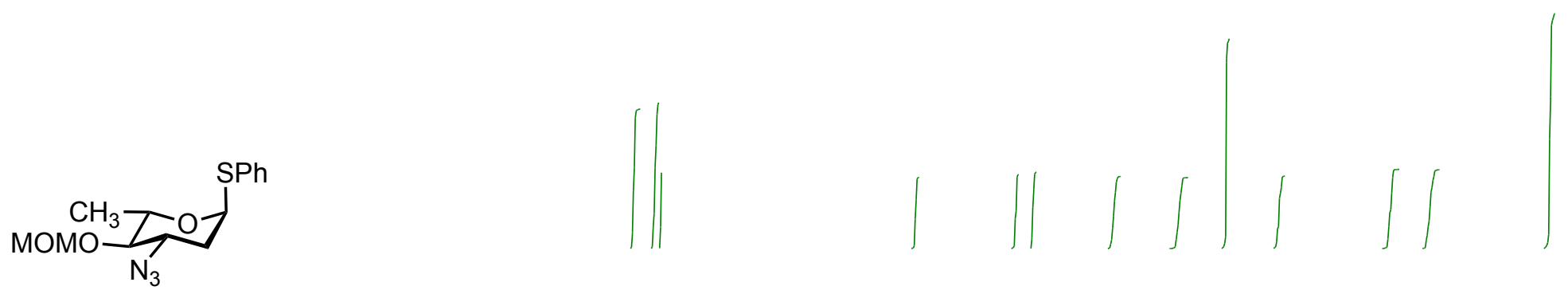

S14

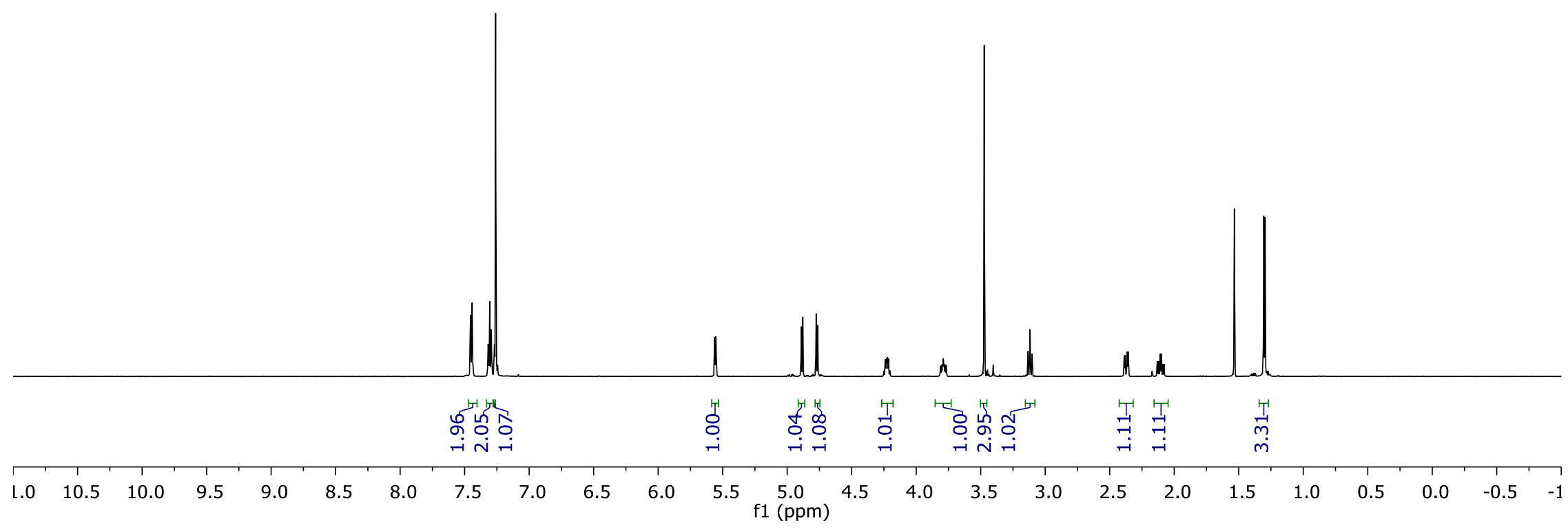

Hoang et al. "General method for the synthesis of $\alpha$ - or $\beta$-deoxyaminoglycosides bearing $\quad$ S131 basic nitrogen" 
${ }^{13} \mathrm{C} \mathrm{NMR,} 126 \mathrm{MHz}, \mathrm{CDCl}_{3}$

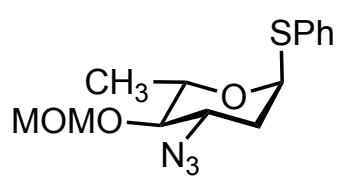

S14

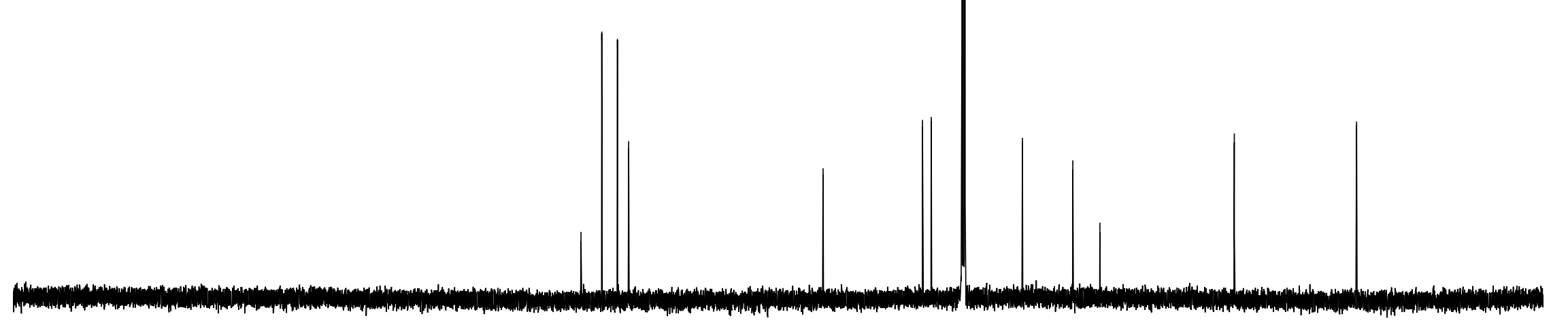




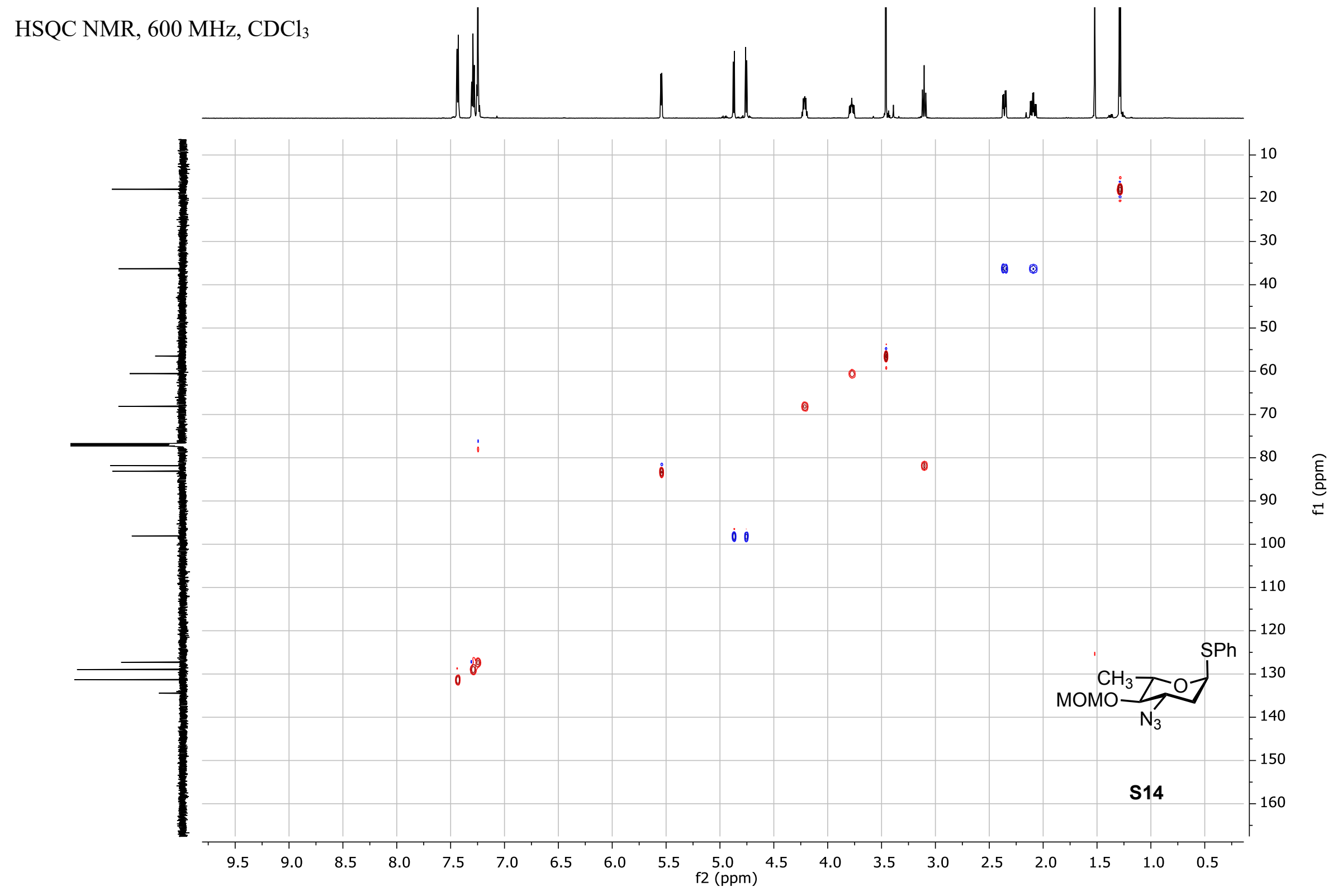

Hoang et al. "General method for the synthesis of $\alpha$ - or $\beta$-deoxyaminoglycosides bearing $\quad$ S133 basic nitrogen" 
${ }^{1} \mathrm{H} \mathrm{NMR}, 600 \mathrm{MHz}, \mathrm{CDCl}_{3}$
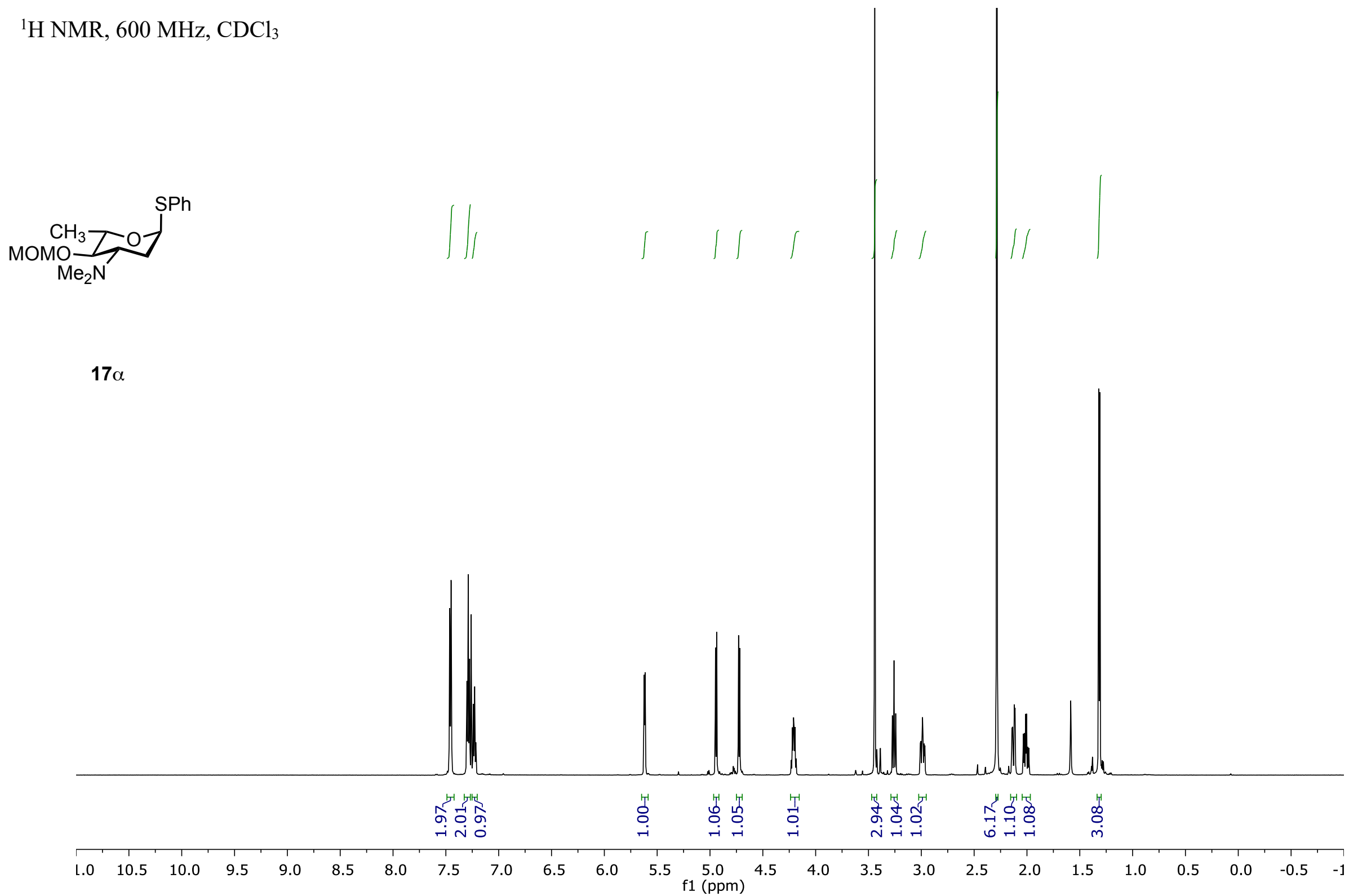

$17 \alpha$

Hoang et al. "General method for the synthesis of $\alpha$ - or $\beta$-deoxyaminoglycosides bearing

S134

basic nitrogen" 
${ }^{13} \mathrm{C} \mathrm{NMR,} 151 \mathrm{MHz}, \mathrm{CDCl}_{3}$

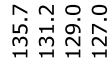

$\underset{\mathrm{Me}_{2} \mathrm{~N}}{\mathrm{MOMO}_{3} \text { Trof }}$

$17 \alpha$

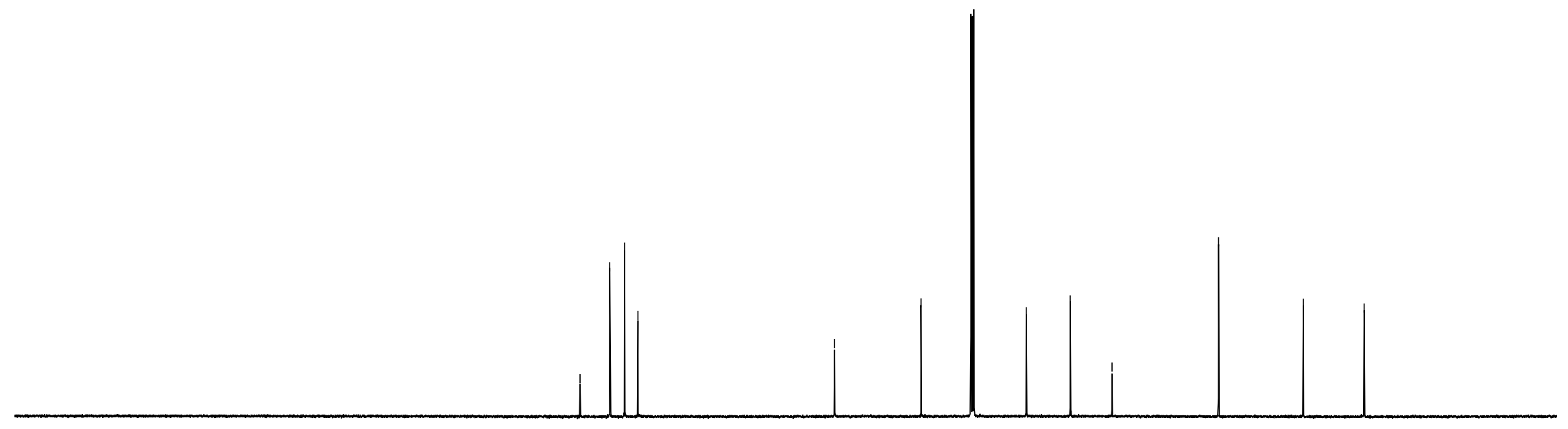

210 
HSQC NMR, $600 \mathrm{MHz}, \mathrm{CDCl}_{3}$
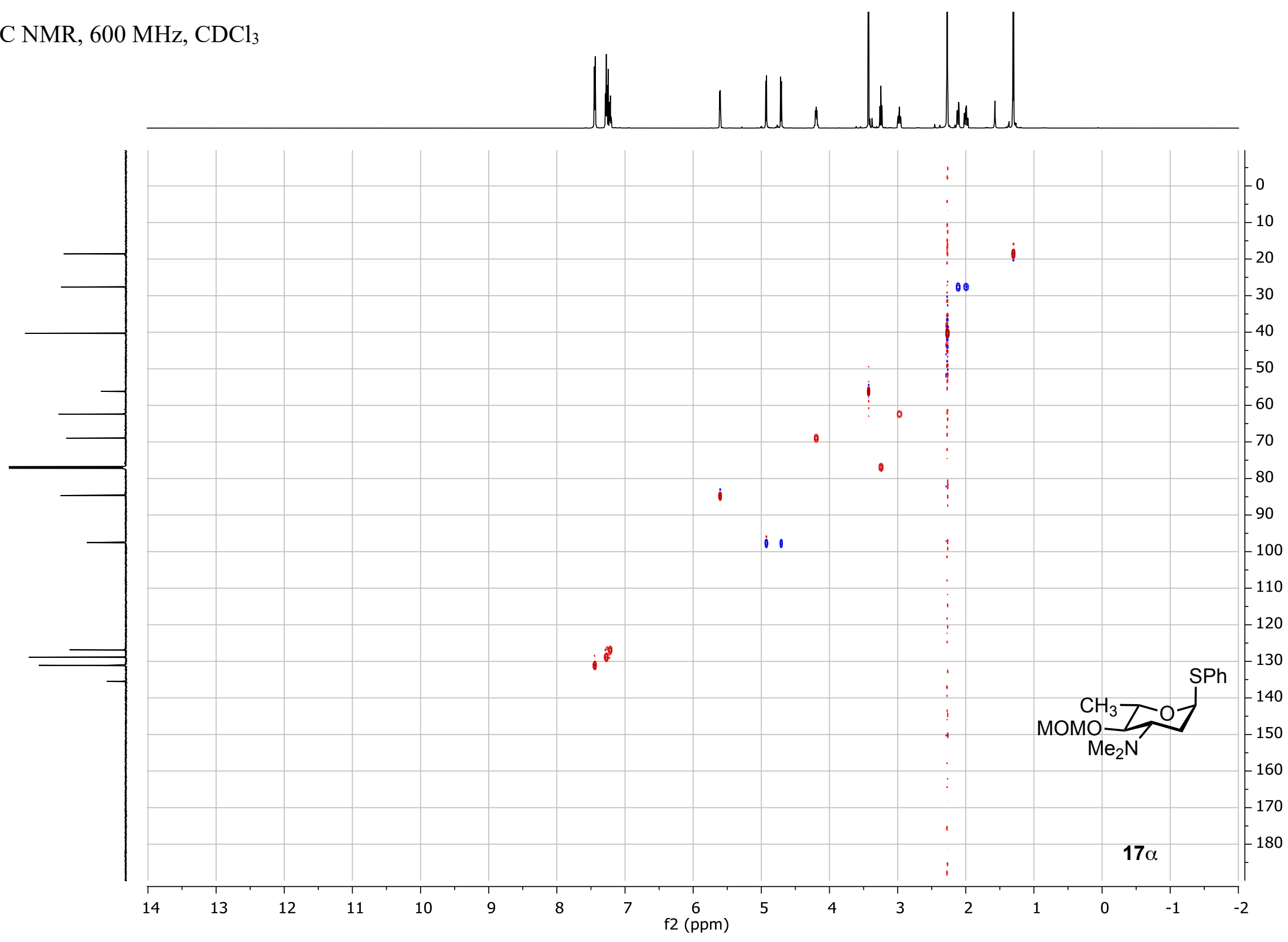

Hoang et al. "General method for the synthesis of $\alpha$ - or $\beta$-deoxyaminoglycosides bearing

S136

basic nitrogen" 
${ }^{1} \mathrm{H} \mathrm{NMR}, 600 \mathrm{MHz}, \mathrm{CDCl}_{3}$

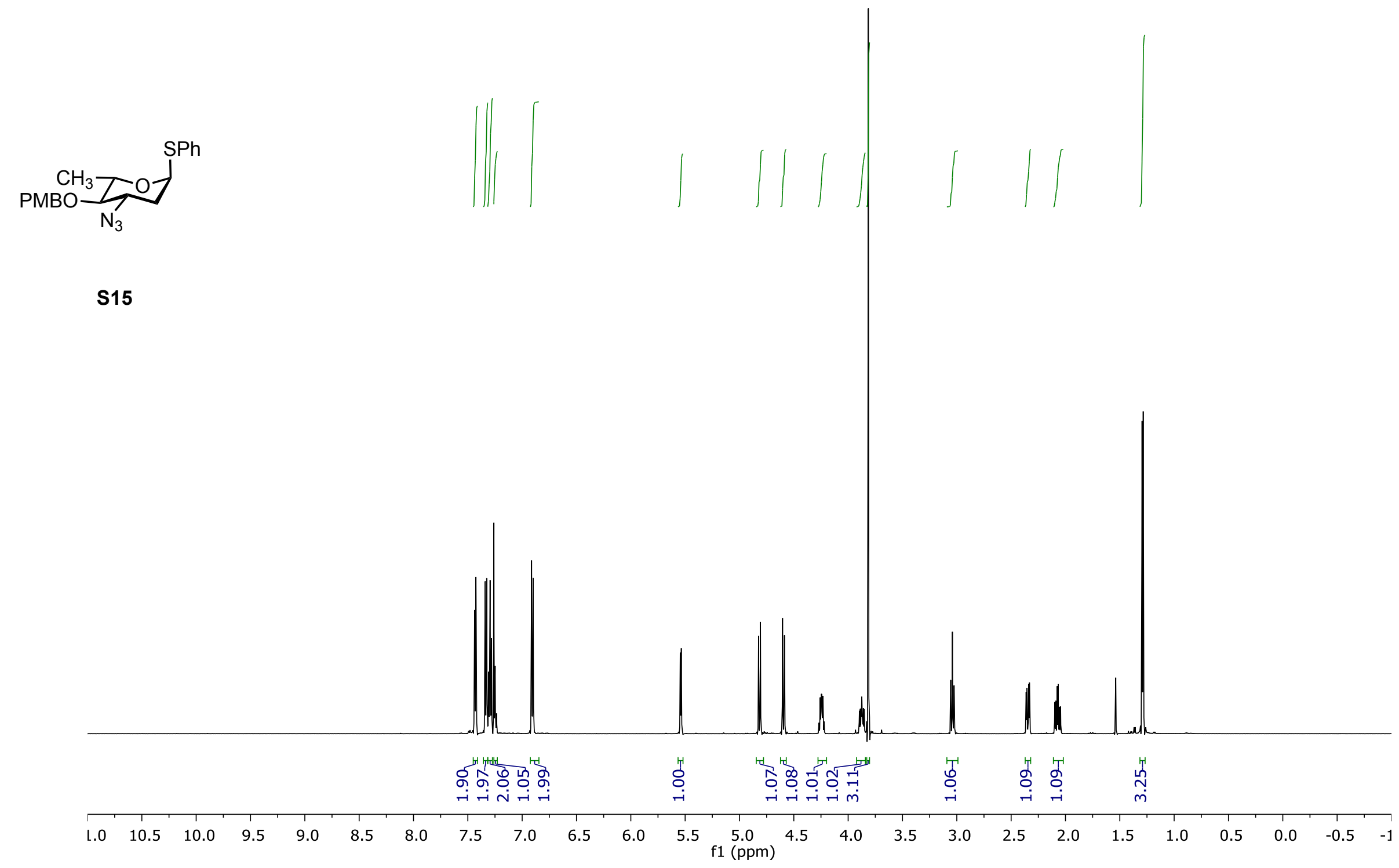

Hoang et al. "General method for the synthesis of $\alpha$ - or $\beta$-deoxyaminoglycosides bearing

S137

basic nitrogen" 
${ }^{13} \mathrm{C} \mathrm{NMR,} 151 \mathrm{MHz}, \mathrm{CDCl}_{3}$

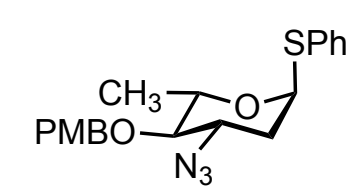

S15

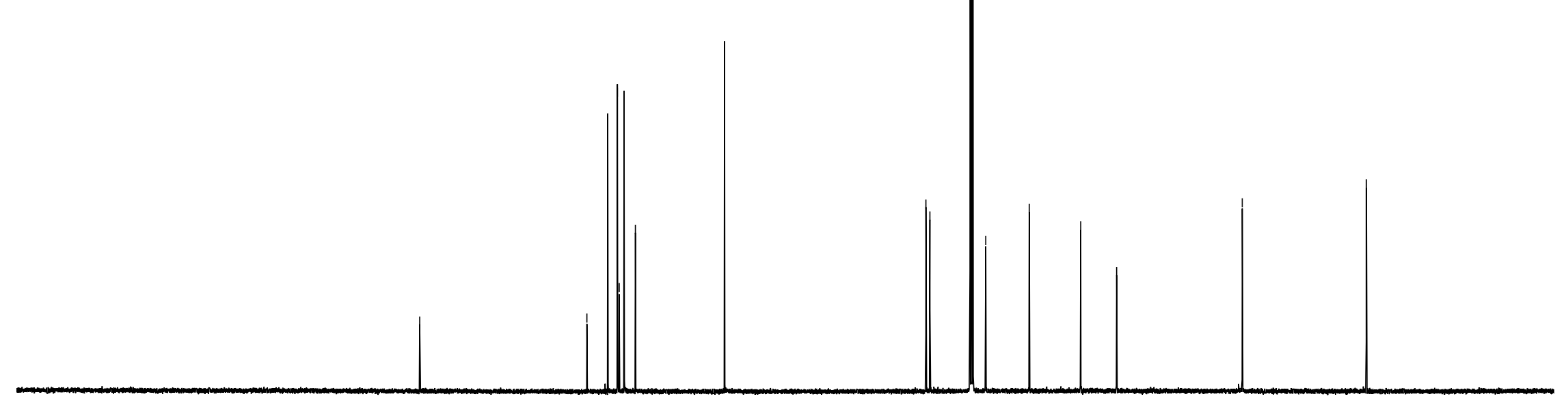

20

190

180

$170 \quad 160$

$150 \quad 140$

$\begin{array}{llll}130 & 120 & 110 & 100\end{array}$

f1 (ppm)

Hoang et al. "General method for the synthesis of $\alpha$ - or $\beta$-deoxyaminoglycosides bearing

basic nitrogen" 
HSQC NMR, $600 \mathrm{MHz}, \mathrm{CDCl}_{3}$
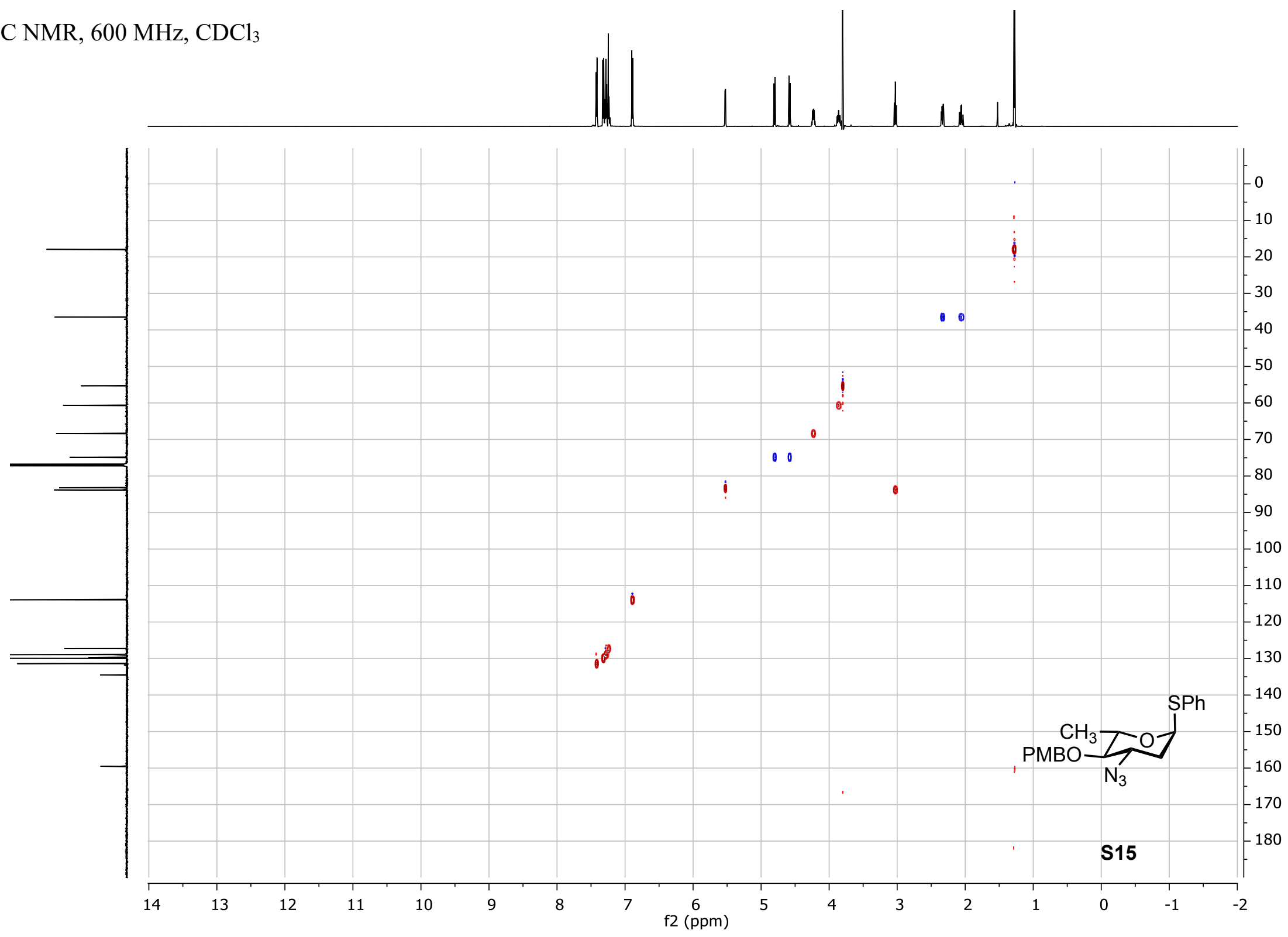

Hoang et al. "General method for the synthesis of $\alpha$ - or $\beta$-deoxyaminoglycosides bearing

S139 basic nitrogen" 
${ }^{1} \mathrm{H} \mathrm{NMR}, 600 \mathrm{MHz}, \mathrm{CDCl}_{3}$

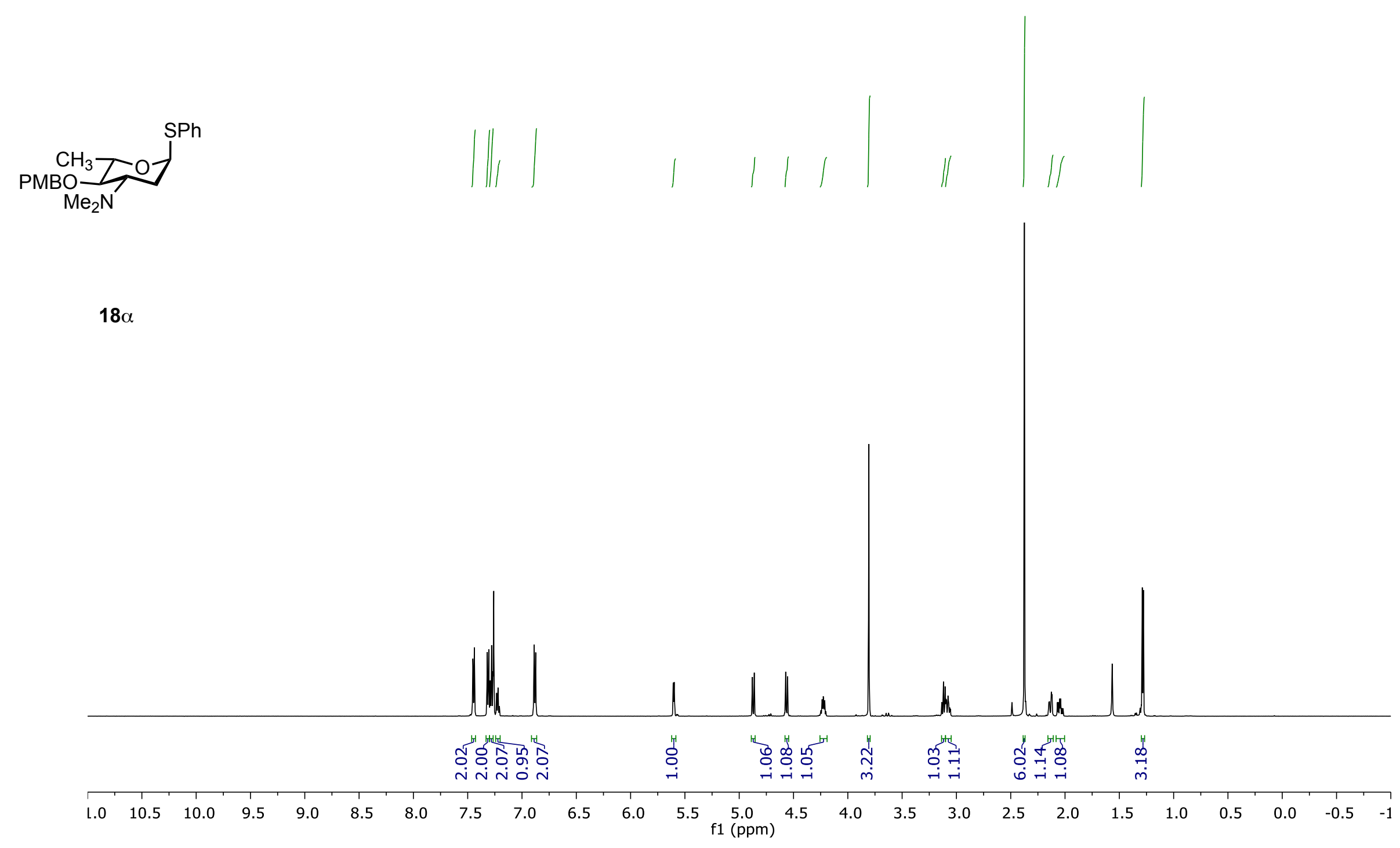

Hoang et al. "General method for the synthesis of $\alpha$ - or $\beta$-deoxyaminoglycosides bearing $\quad$ S140

basic nitrogen" 
${ }^{13} \mathrm{C} \mathrm{NMR,} 151 \mathrm{MHz}, \mathrm{CDCl}_{3}$

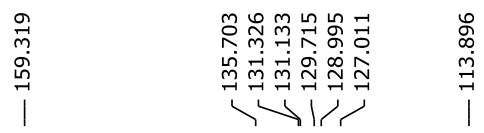

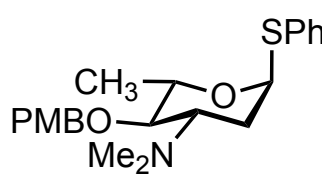

$18 \alpha$

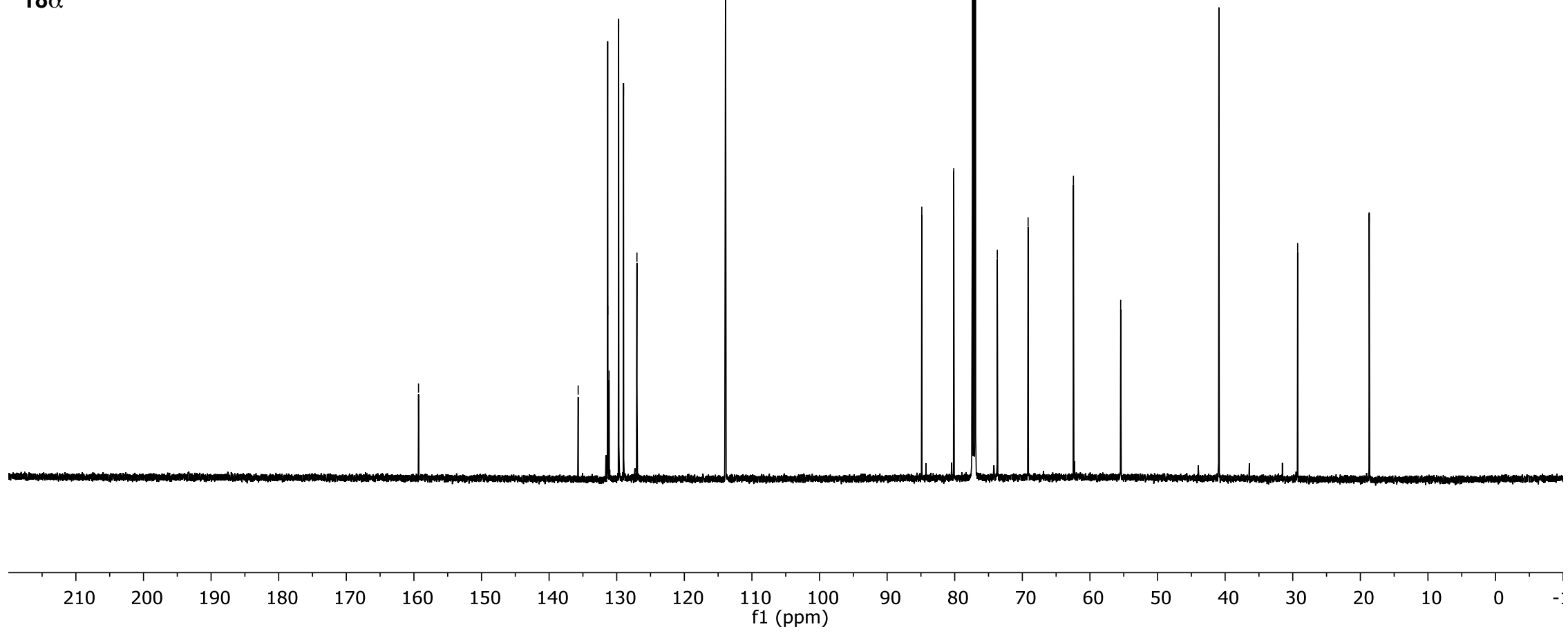

Hoang et al. "General method for the synthesis of $\alpha$ - or $\beta$-deoxyaminoglycosides bearing

S141

basic nitrogen" 
HSQC NMR, $600 \mathrm{MHz}, \mathrm{CDCl}_{3}$
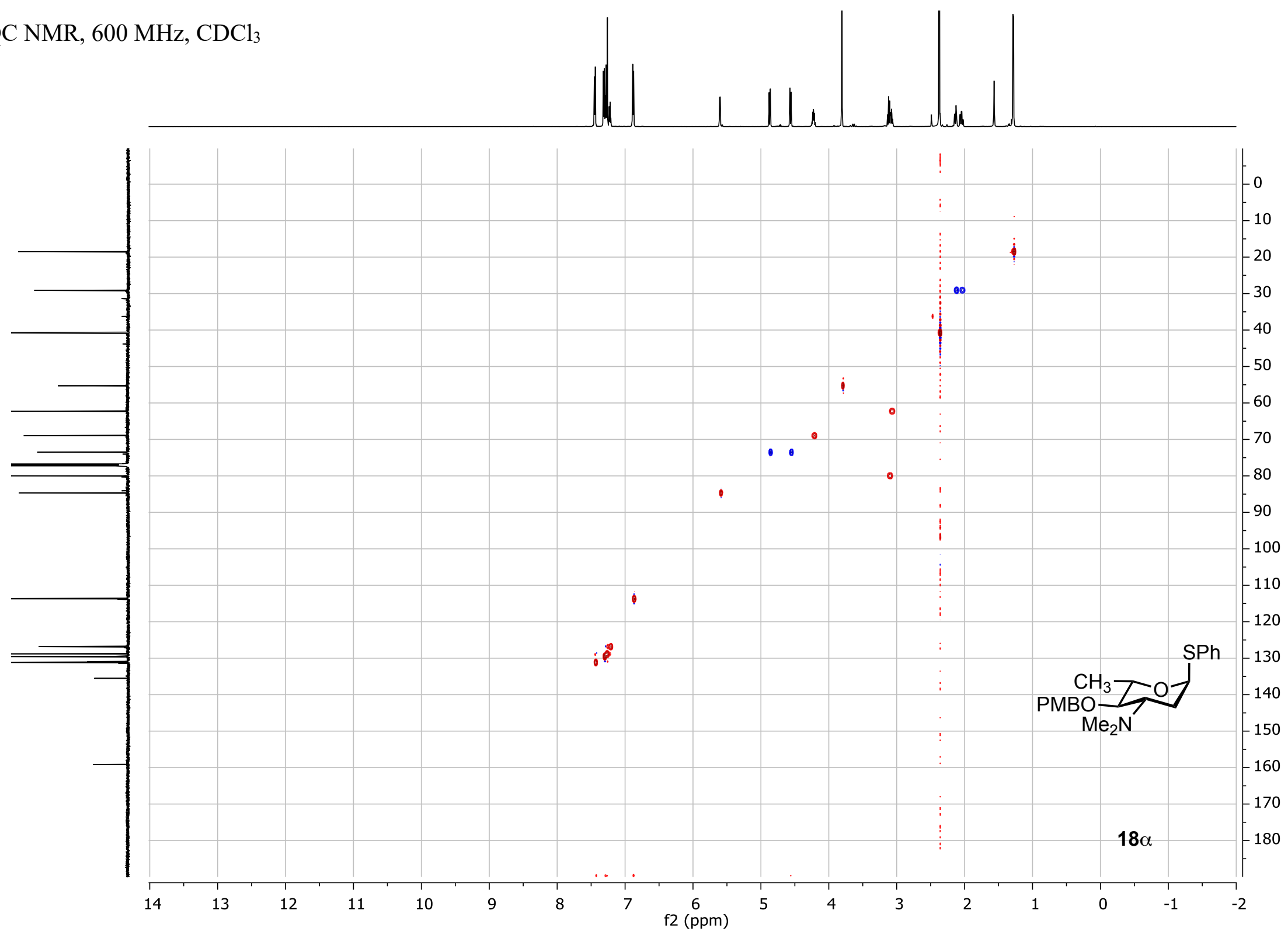

Hoang et al. "General method for the synthesis of $\alpha$ - or $\beta$-deoxyaminoglycosides bearing $\quad$ S142 basic nitrogen" 
${ }^{1} \mathrm{H} \mathrm{NMR}, 600 \mathrm{MHz}, \mathrm{CDCl}_{3}$
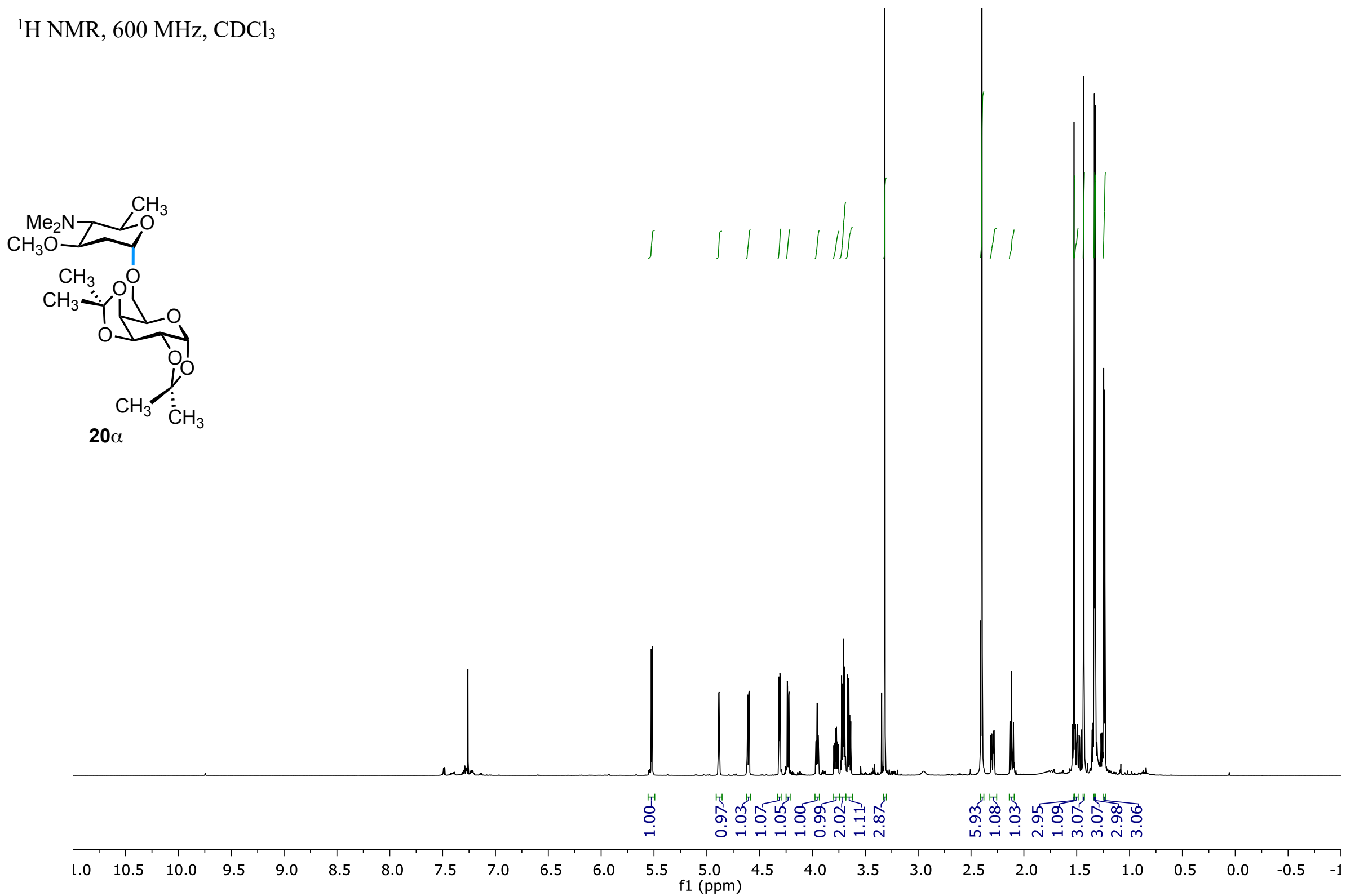

Hoang et al. "General method for the synthesis of $\alpha$ - or $\beta$-deoxyaminoglycosides bearing

S143

basic nitrogen" 
${ }^{13} \mathrm{C} \mathrm{NMR,} 151 \mathrm{MHz}, \mathrm{CDCl}_{3}$

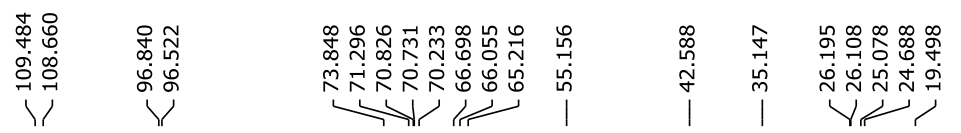

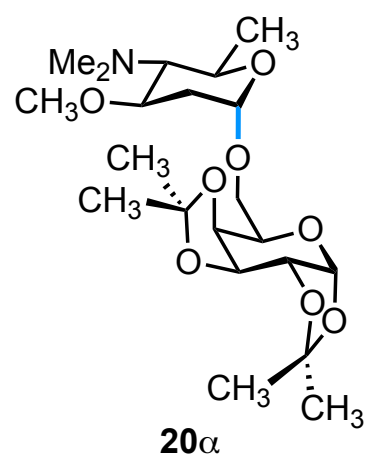

$\mathrm{H}_{3}$

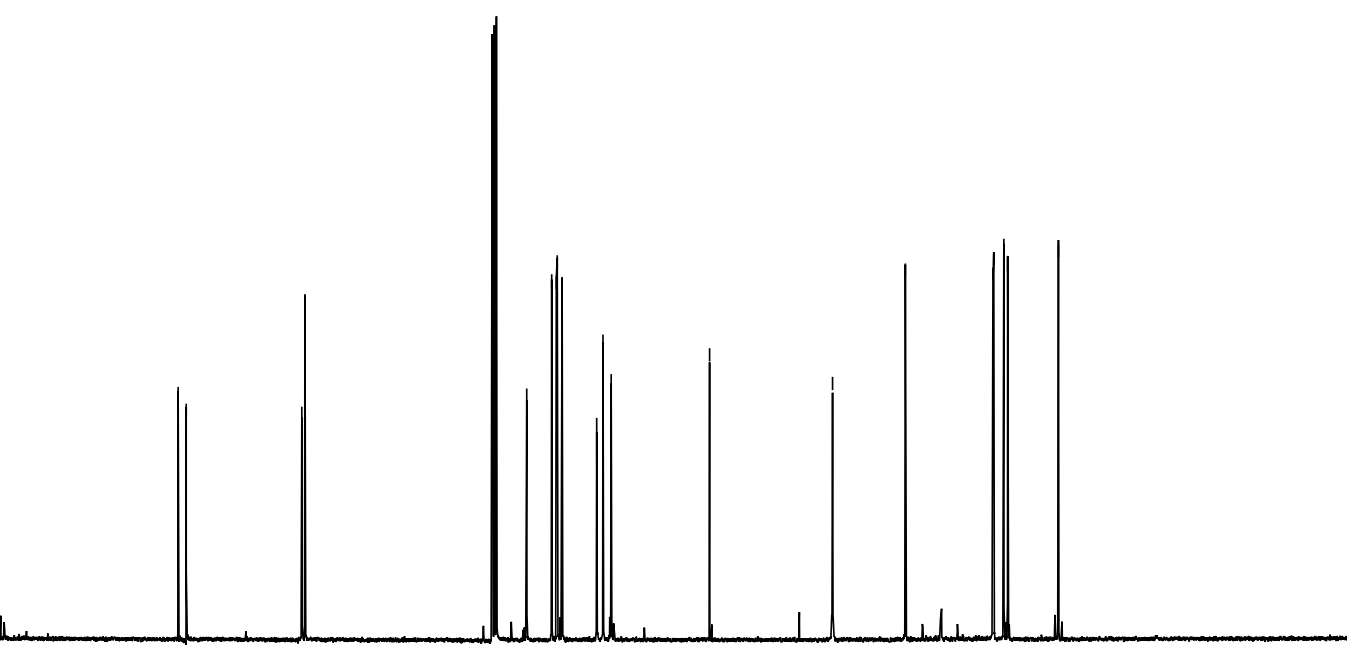

20

$210 \quad 200$

$190 \quad 180$

170160

$150 \quad 140$

130

Hoang et al. "General method for the synthesis of $\alpha$ - or $\beta$-deoxyaminoglycosides bearing

S144

basic nitrogen" 
HSQC NMR, $600 \mathrm{MHz}, \mathrm{CDCl}_{3}$

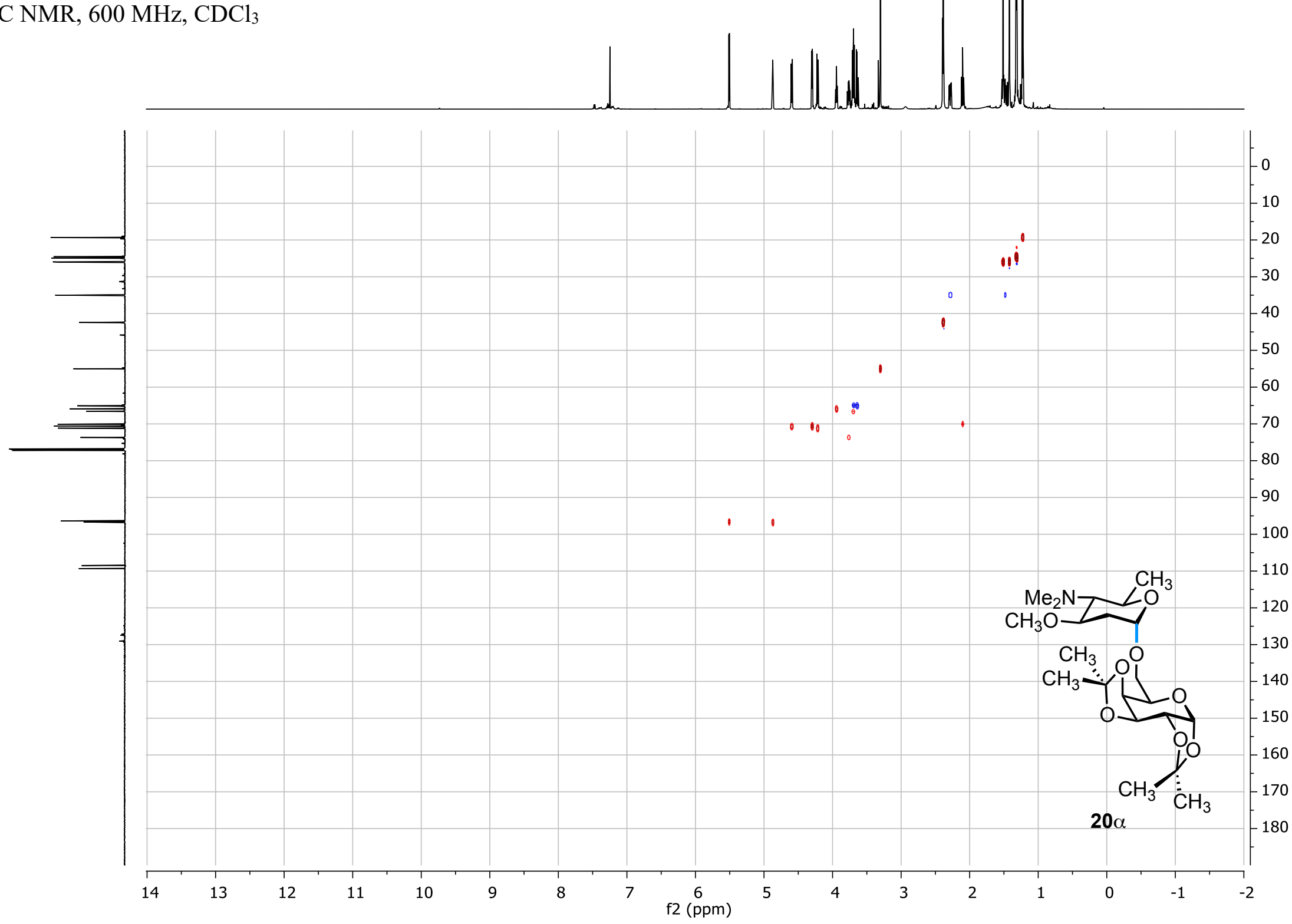

Hoang et al. "General method for the synthesis of $\alpha$ - or $\beta$-deoxyaminoglycosides bearing $\quad$ S145 basic nitrogen" 


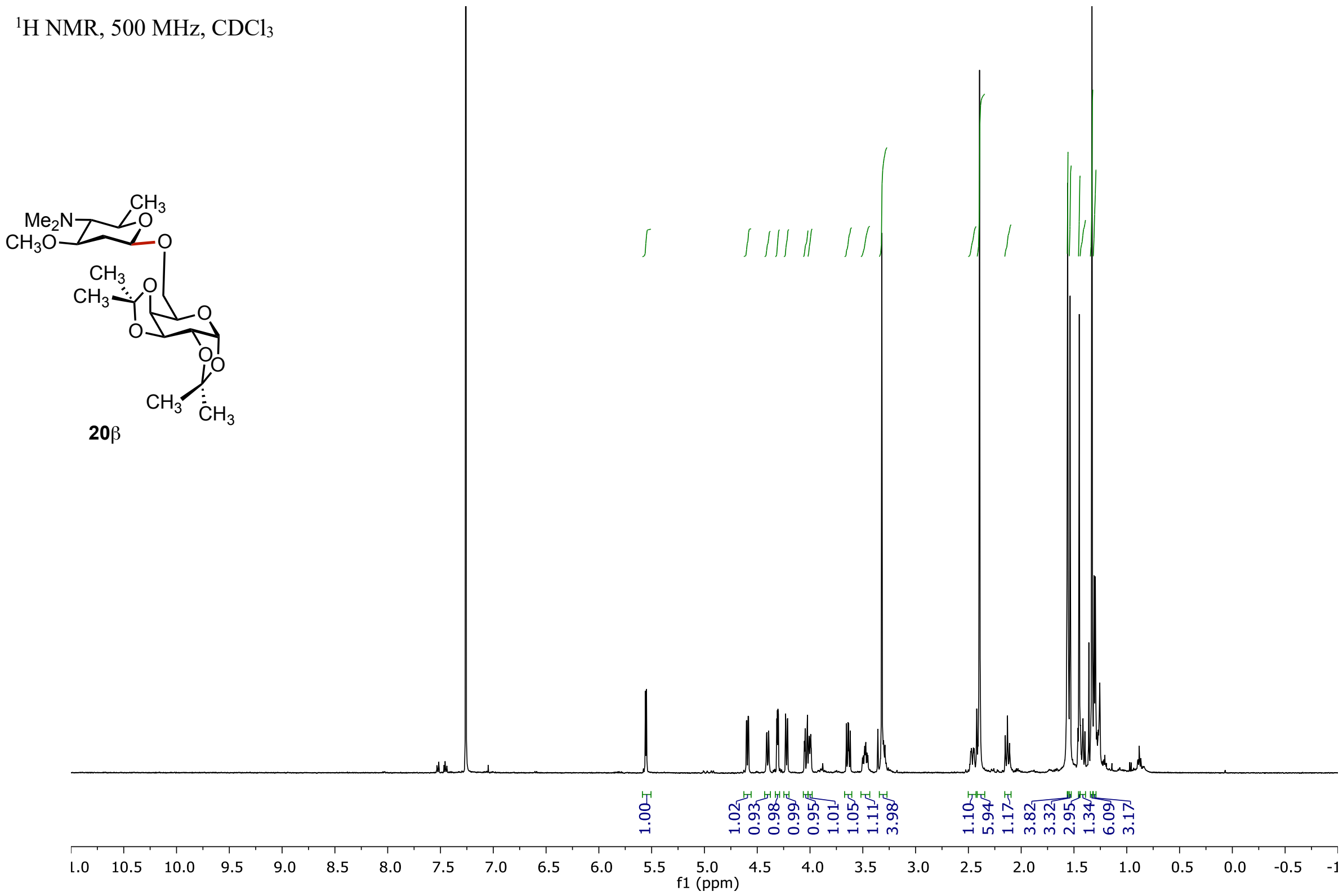

Hoang et al. "General method for the synthesis of $\alpha$ - or $\beta$-deoxyaminoglycosides bearing $\quad$ S146 basic nitrogen" 
${ }^{13} \mathrm{C} \mathrm{NMR,} 151 \mathrm{MHz}, \mathrm{CDCl}_{3}$
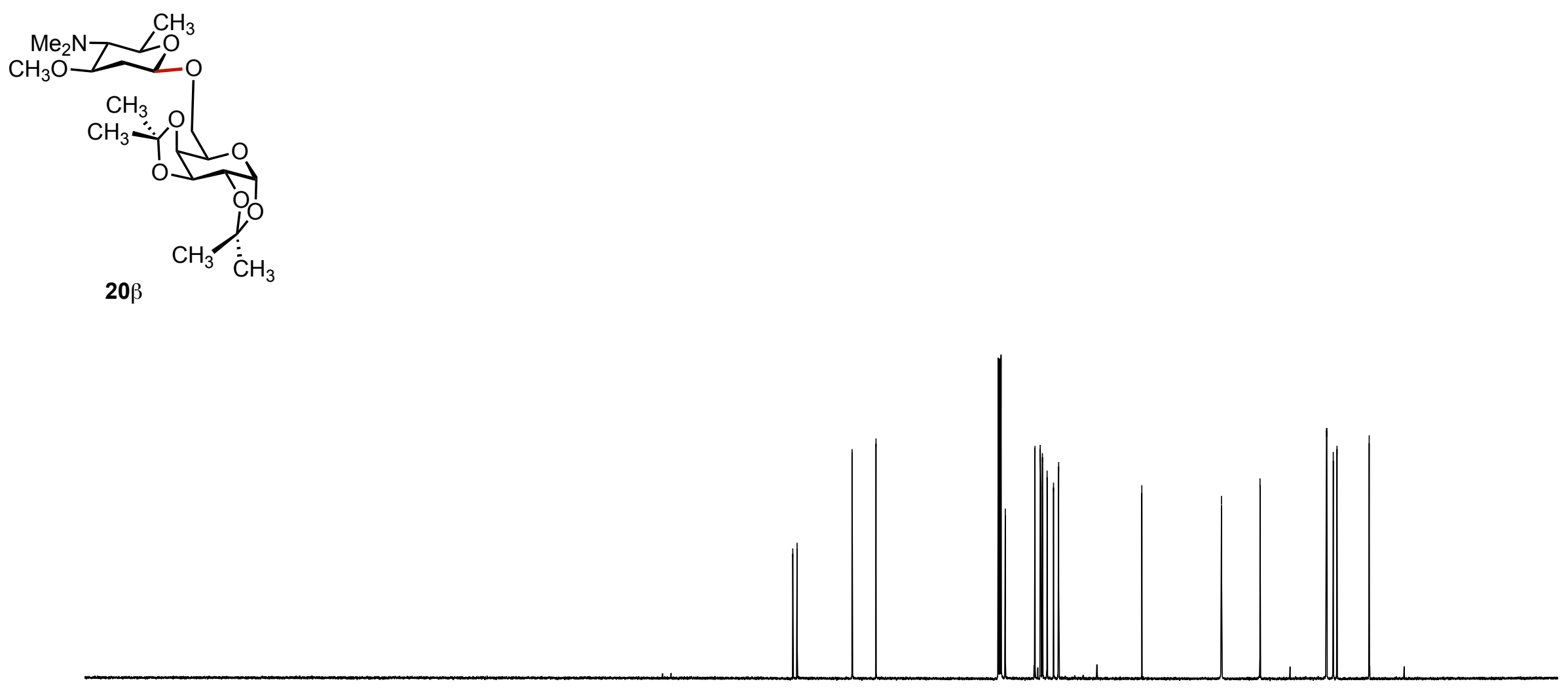

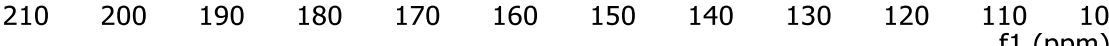

Hoang et al. "General method for the synthesis of $\alpha$ - or $\beta$-deoxyaminoglycosides bearing $\quad$ S147 basic nitrogen" 
HSQC NMR, $600 \mathrm{MHz}, \mathrm{CDCl}_{3}$

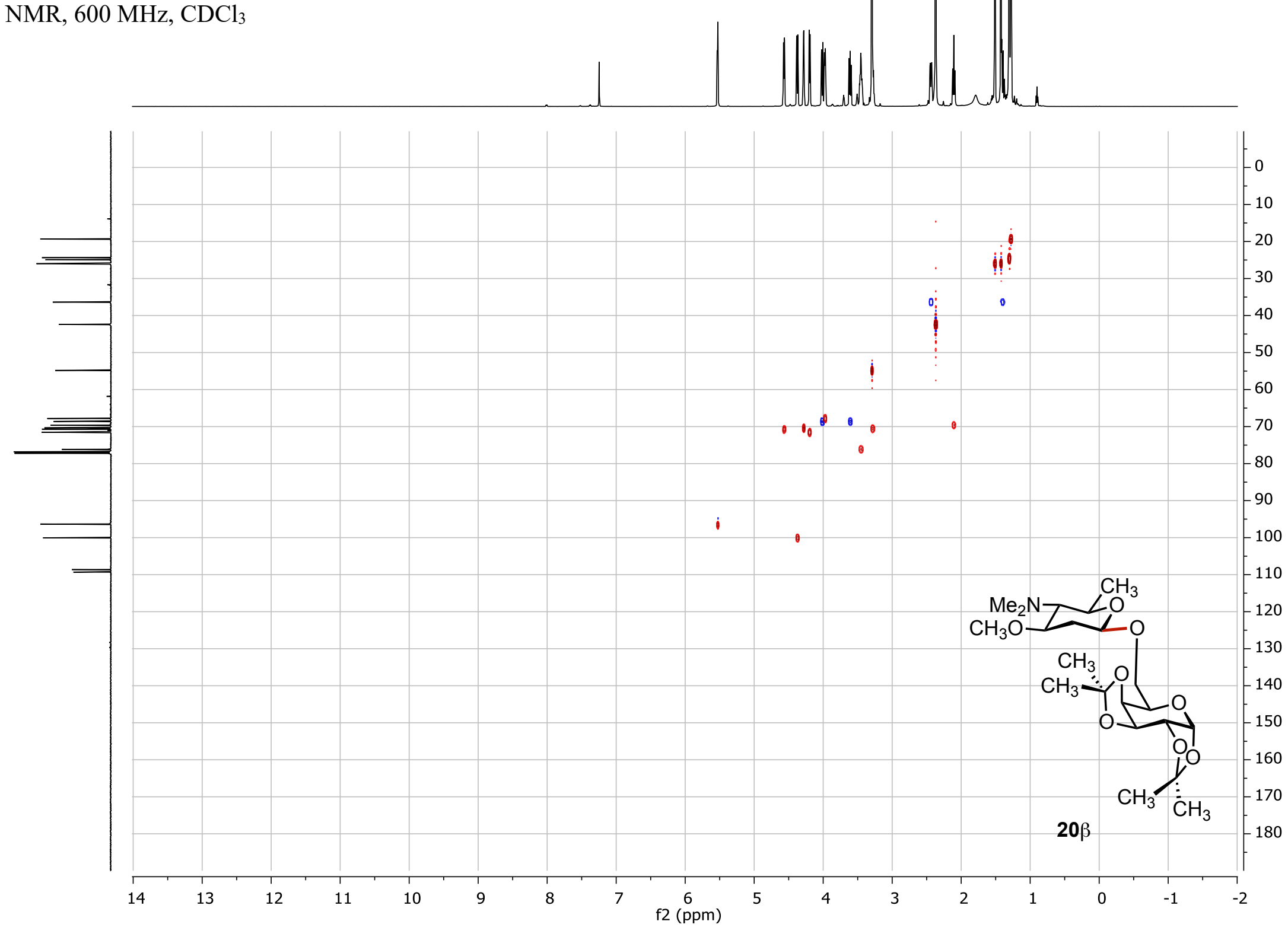

Hoang et al. "General method for the synthesis of $\alpha$ - or $\beta$-deoxyaminoglycosides bearing $\quad$ S148 basic nitrogen" 
${ }^{1} \mathrm{H} \mathrm{NMR}, 600 \mathrm{MHz}, \mathrm{CDCl}_{3}$

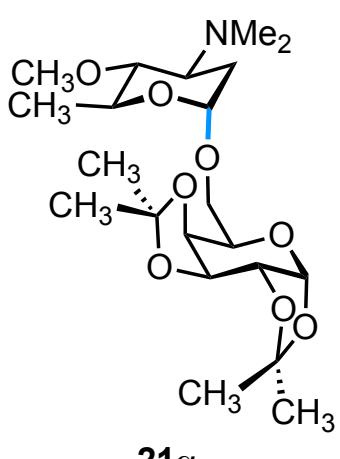

$21 \alpha$

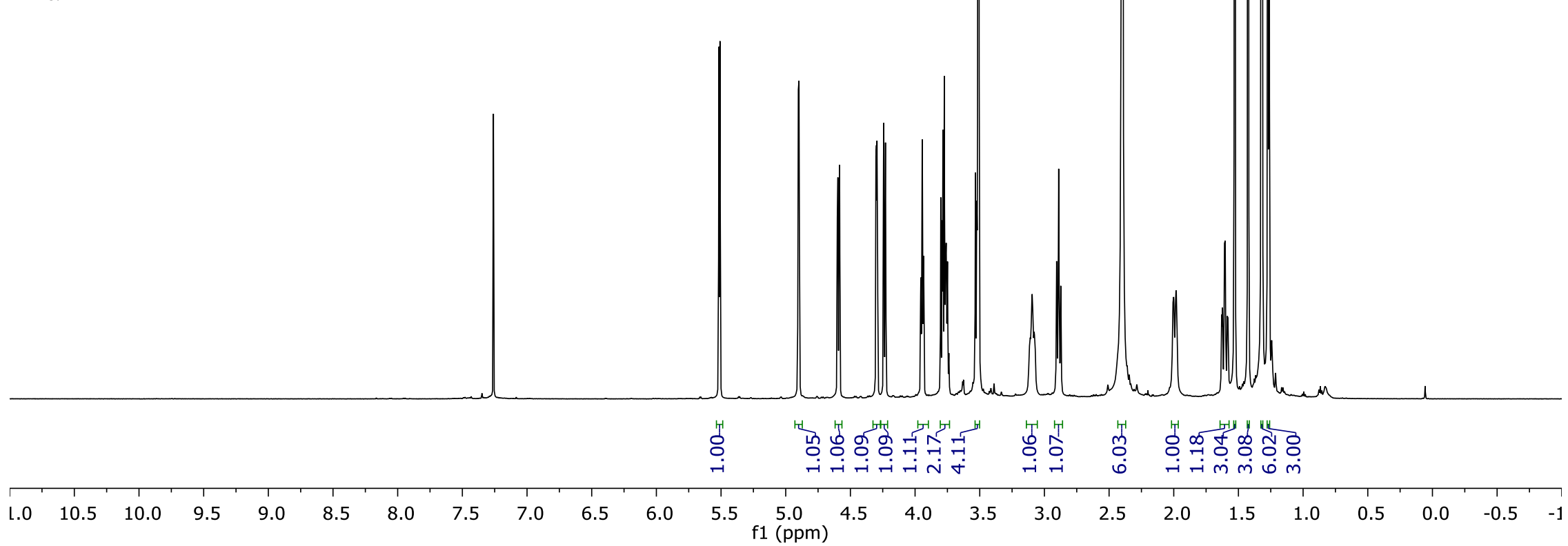

Hoang et al. "General method for the synthesis of $\alpha$ - or $\beta$-deoxyaminoglycosides bearing

S149

basic nitrogen" 
${ }^{13} \mathrm{C} \mathrm{NMR,} 151 \mathrm{MHz}, \mathrm{CDCl}_{3}$

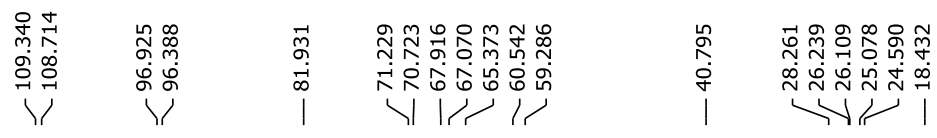

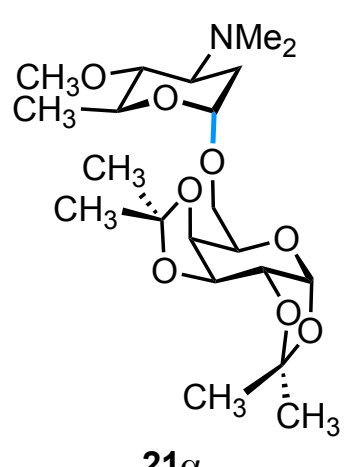

$21 \alpha$

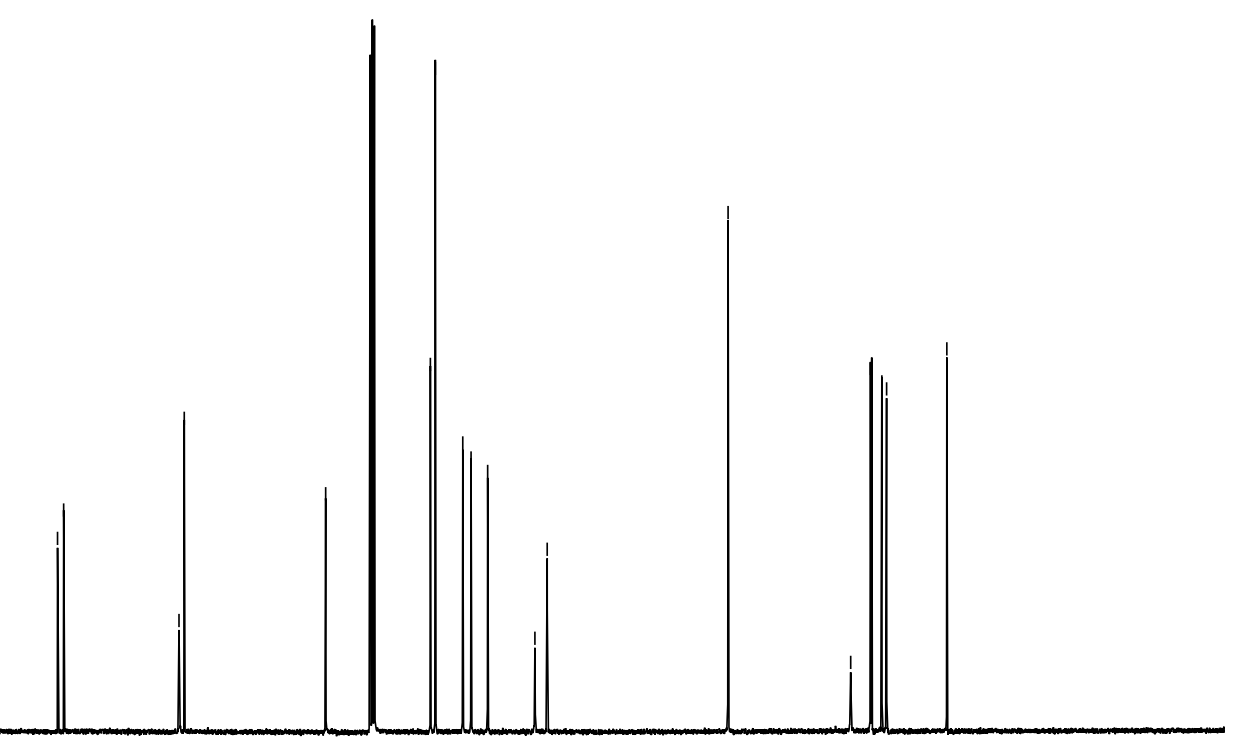

20

210200

$190 \quad 180$

170160

$150 \quad 140$

130

120

$110 \quad 100$

Hoang et al. "General method for the synthesis of $\alpha$ - or $\beta$-deoxyaminoglycosides bearing

basic nitrogen" 
HSQC NMR, $600 \mathrm{MHz}, \mathrm{CDCl}_{3}$

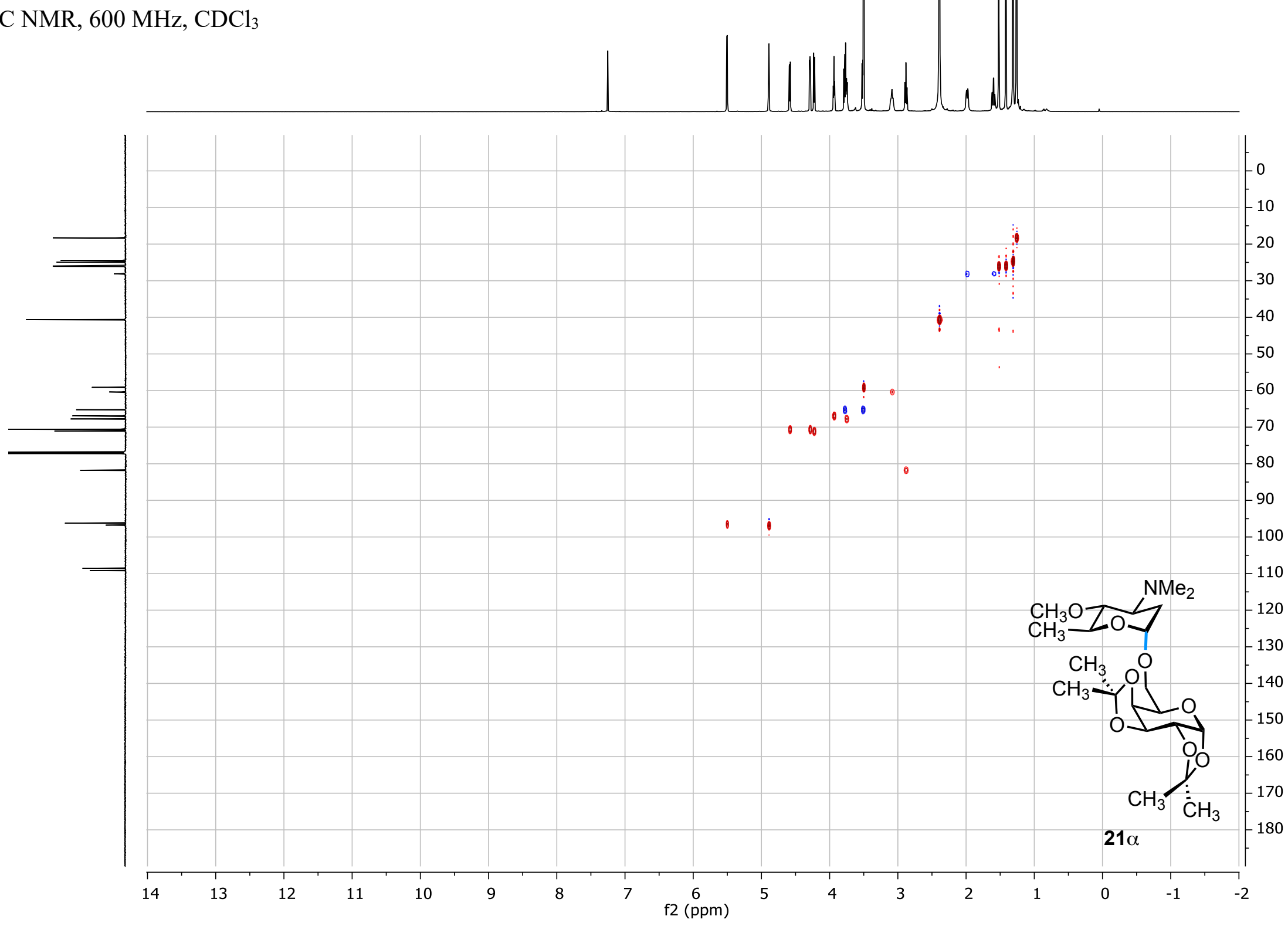

Hoang et al. "General method for the synthesis of $\alpha$ - or $\beta$-deoxyaminoglycosides bearing $\quad$ S151 basic nitrogen" 
${ }^{1} \mathrm{H} \mathrm{NMR}, 600 \mathrm{MHz}, \mathrm{CDCl}_{3}$

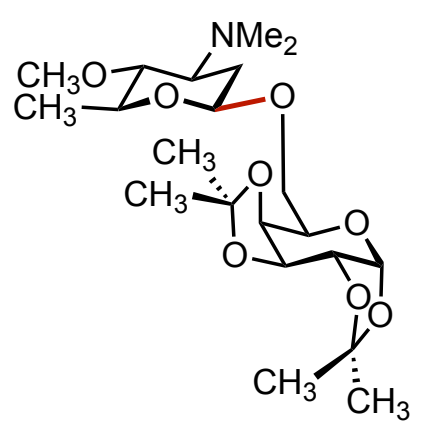

$21 \beta$

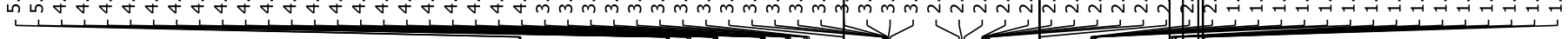

$$
\text { 西 }
$$
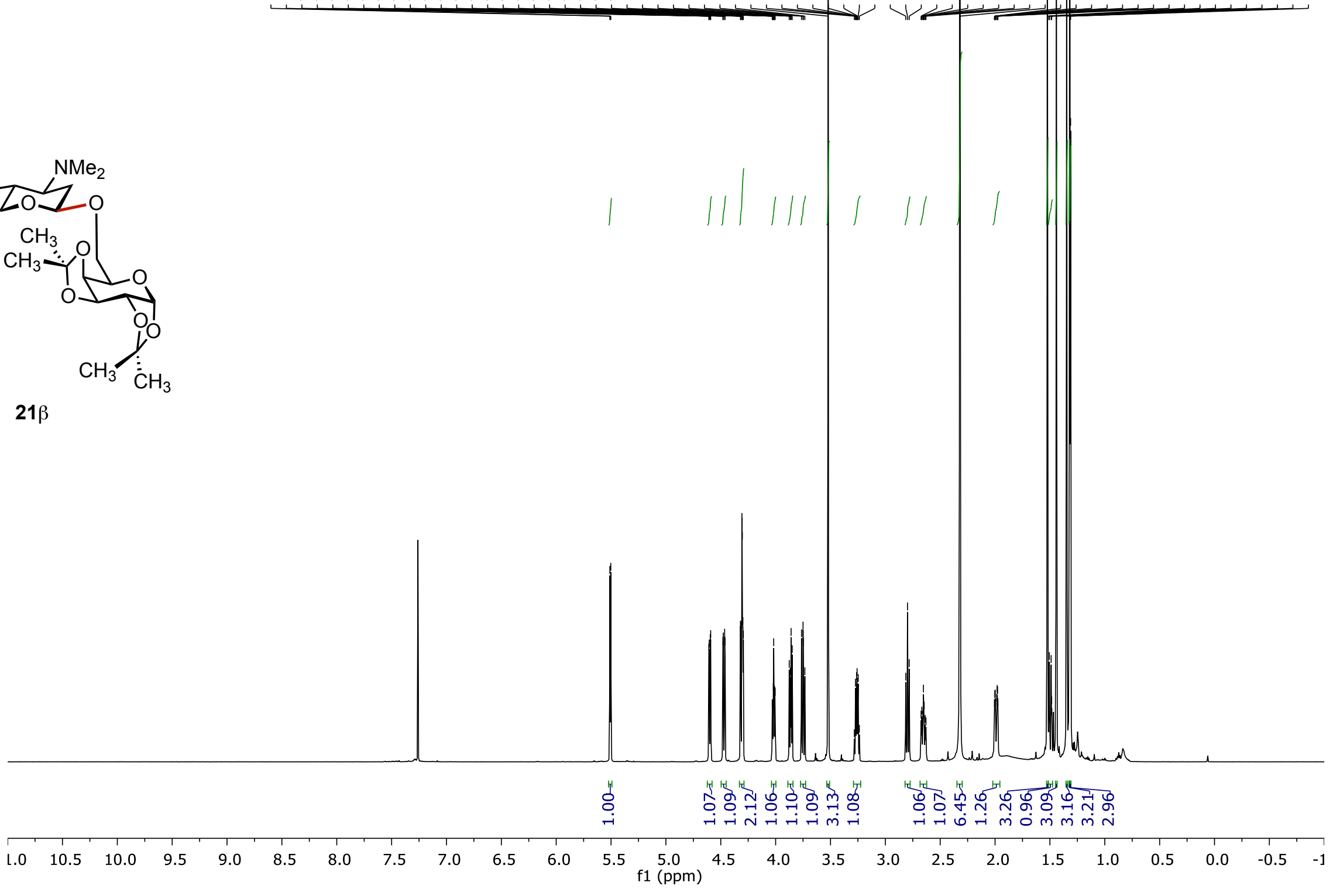

Hoang et al. "General method for the synthesis of $\alpha$ - or $\beta$-deoxyaminoglycosides bearing $\quad$ S152 basic nitrogen" 
${ }^{13} \mathrm{C} \mathrm{NMR,} 151 \mathrm{MHz}, \mathrm{CDCl}_{3}$

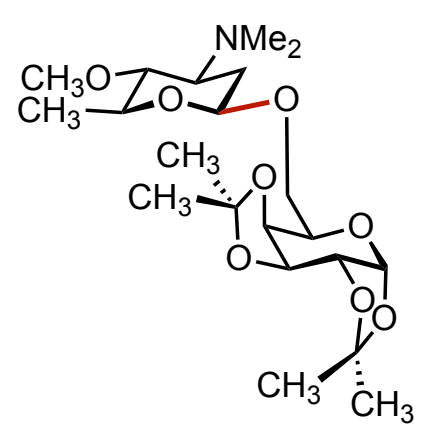

$21 \beta$

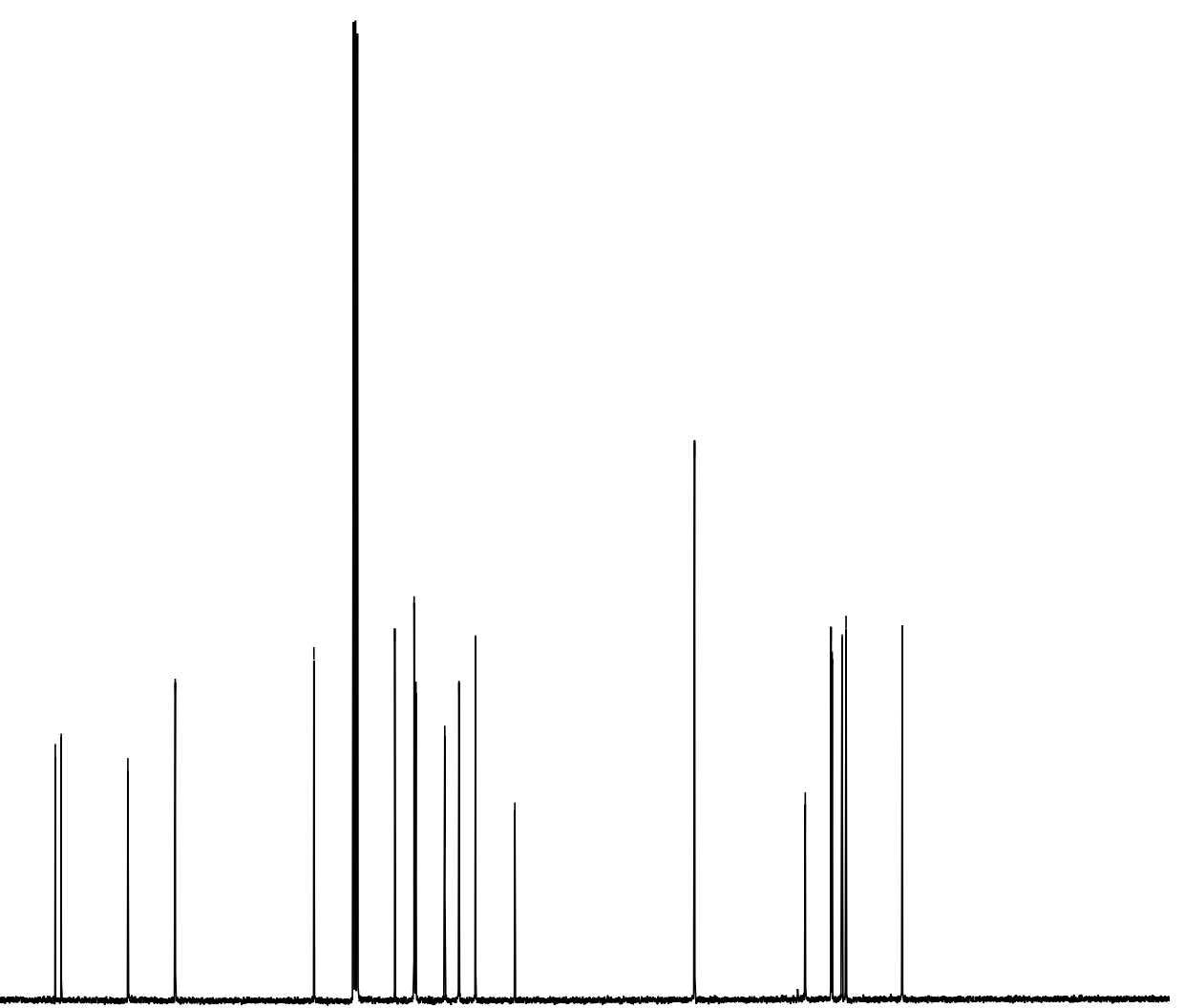

$\begin{array}{llllllllllll}210 & 200 & 190 & 180 & 170 & 160 & 150 & 140 & 130 & 120 & 110 & 100\end{array}$

Hoang et al. "General method for the synthesis of $\alpha$ - or $\beta$-deoxyaminoglycosides bearing basic nitrogen" 
HSQC NMR, $600 \mathrm{MHz}, \mathrm{CDCl}_{3}$

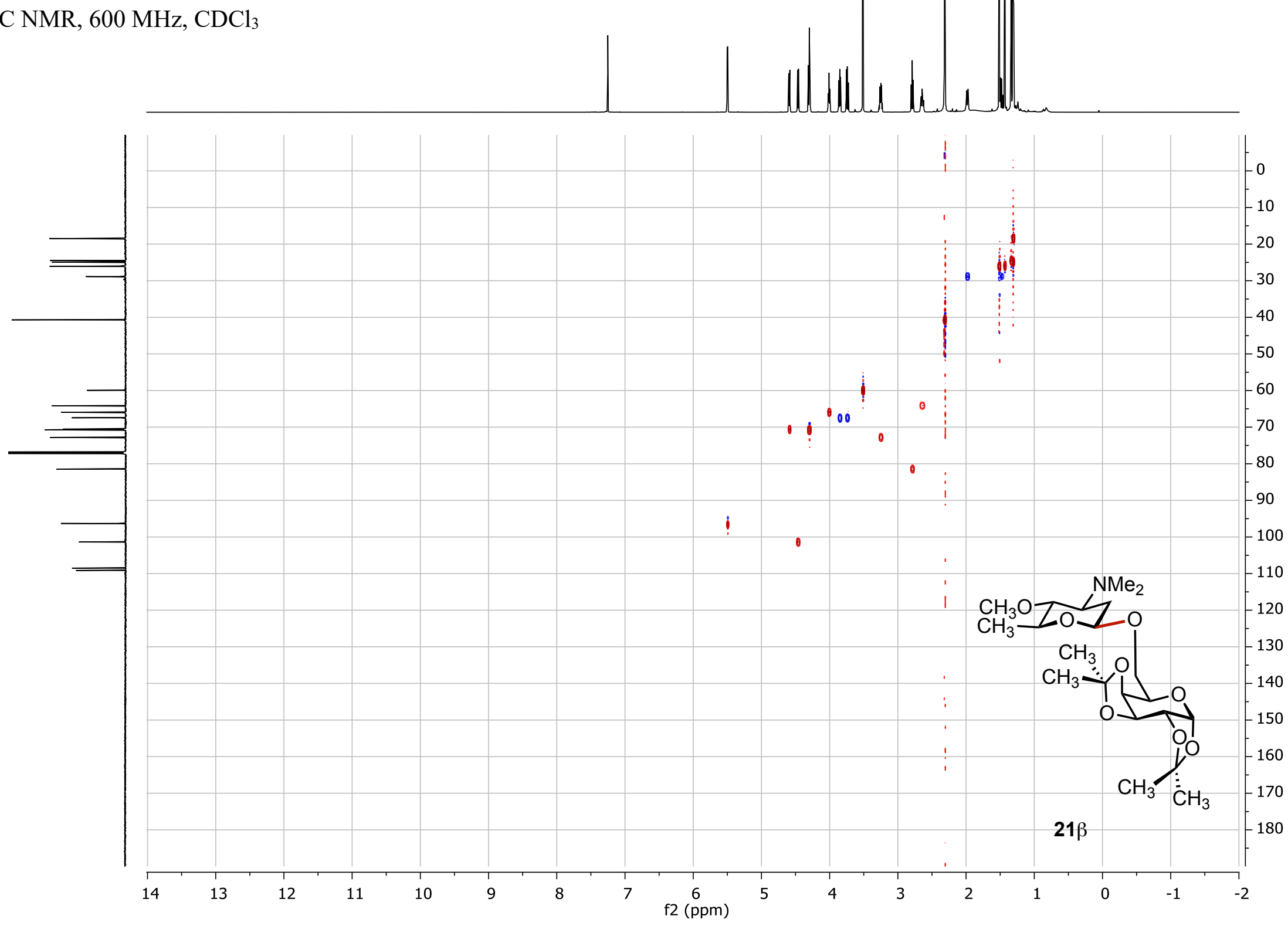

Hoang et al. "General method for the synthesis of $\alpha$ - or $\beta$-deoxyaminoglycosides bearing $\quad$ S154 basic nitrogen" 
${ }^{1} \mathrm{H} \mathrm{NMR}, 600 \mathrm{MHz}, \mathrm{CDCl}_{3}$
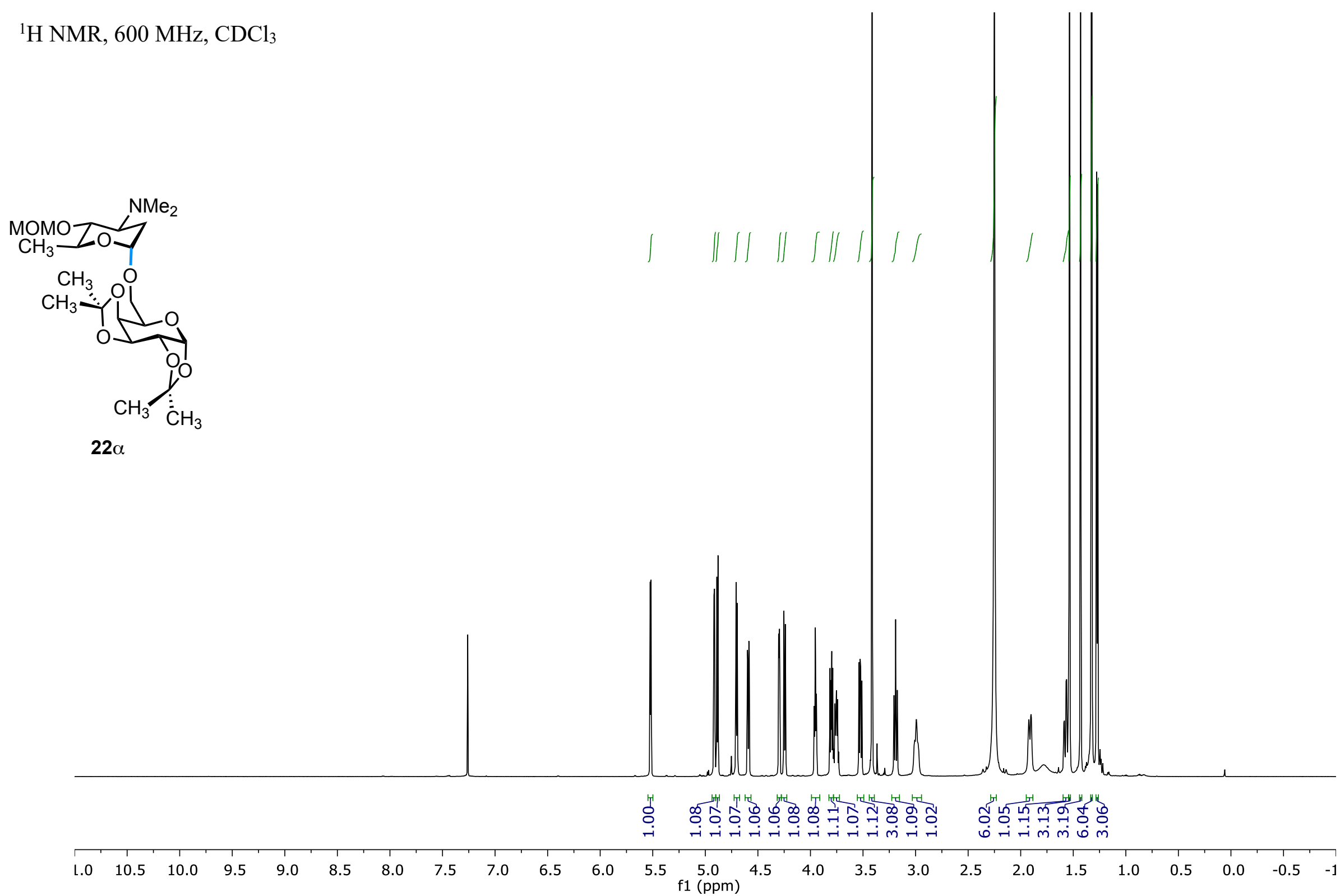

Hoang et al. "General method for the synthesis of $\alpha$ - or $\beta$-deoxyaminoglycosides bearing S155 basic nitrogen" 
${ }^{13} \mathrm{C} \mathrm{NMR}, 151 \mathrm{MHz}, \mathrm{CDCl}_{3}$

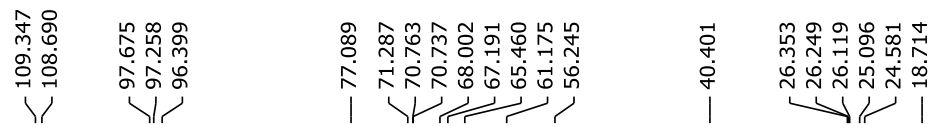

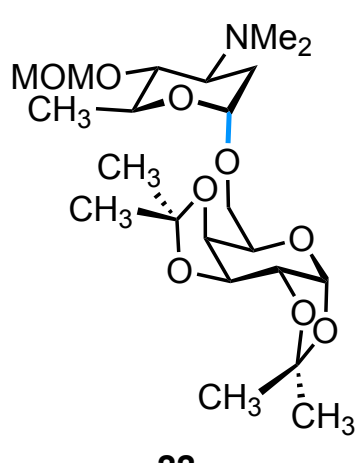

$22 \alpha$

$\mathrm{H}_{3}$
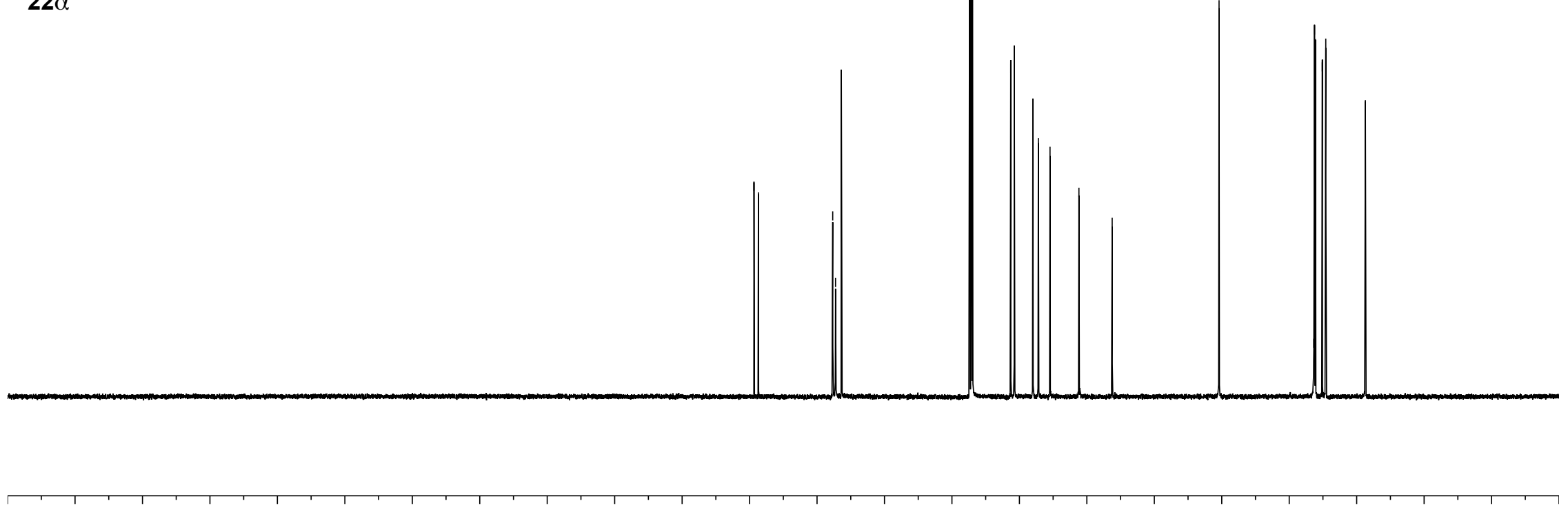

$20 \quad 210+200$

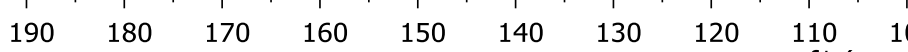

110100

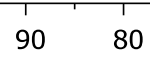

70

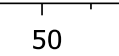

Hoang et al. "General method for the synthesis of $\alpha$ - or $\beta$-deoxyaminoglycosides bearing

S 156

basic nitrogen" 
HSQC NMR, $600 \mathrm{MHz}, \mathrm{CDCl}_{3}$

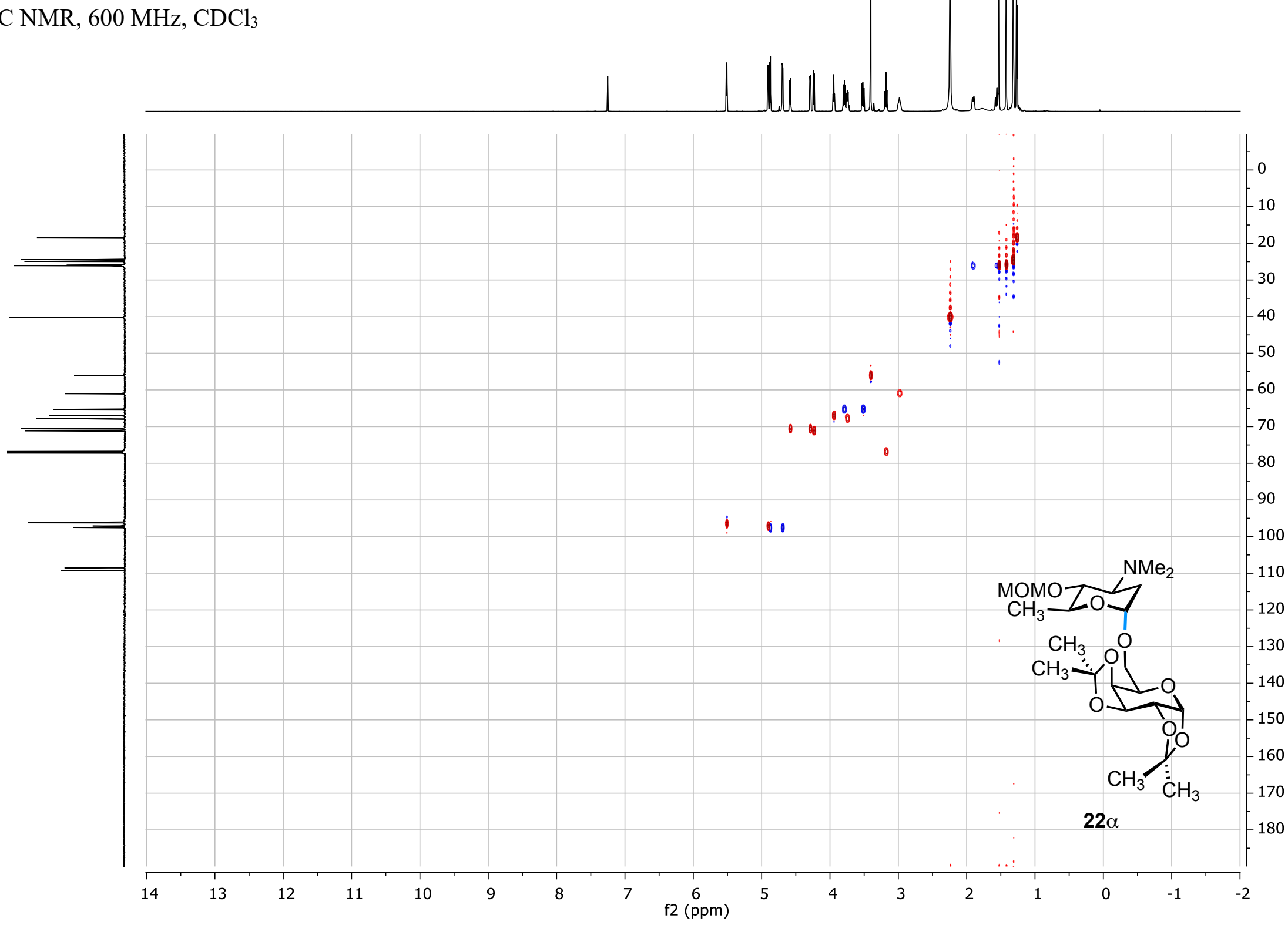

Hoang et al. "General method for the synthesis of $\alpha$ - or $\beta$-deoxyaminoglycosides bearing

S157

basic nitrogen" 
${ }^{1} \mathrm{H} \mathrm{NMR}, 600 \mathrm{MHz}, \mathrm{CDCl}_{3}$
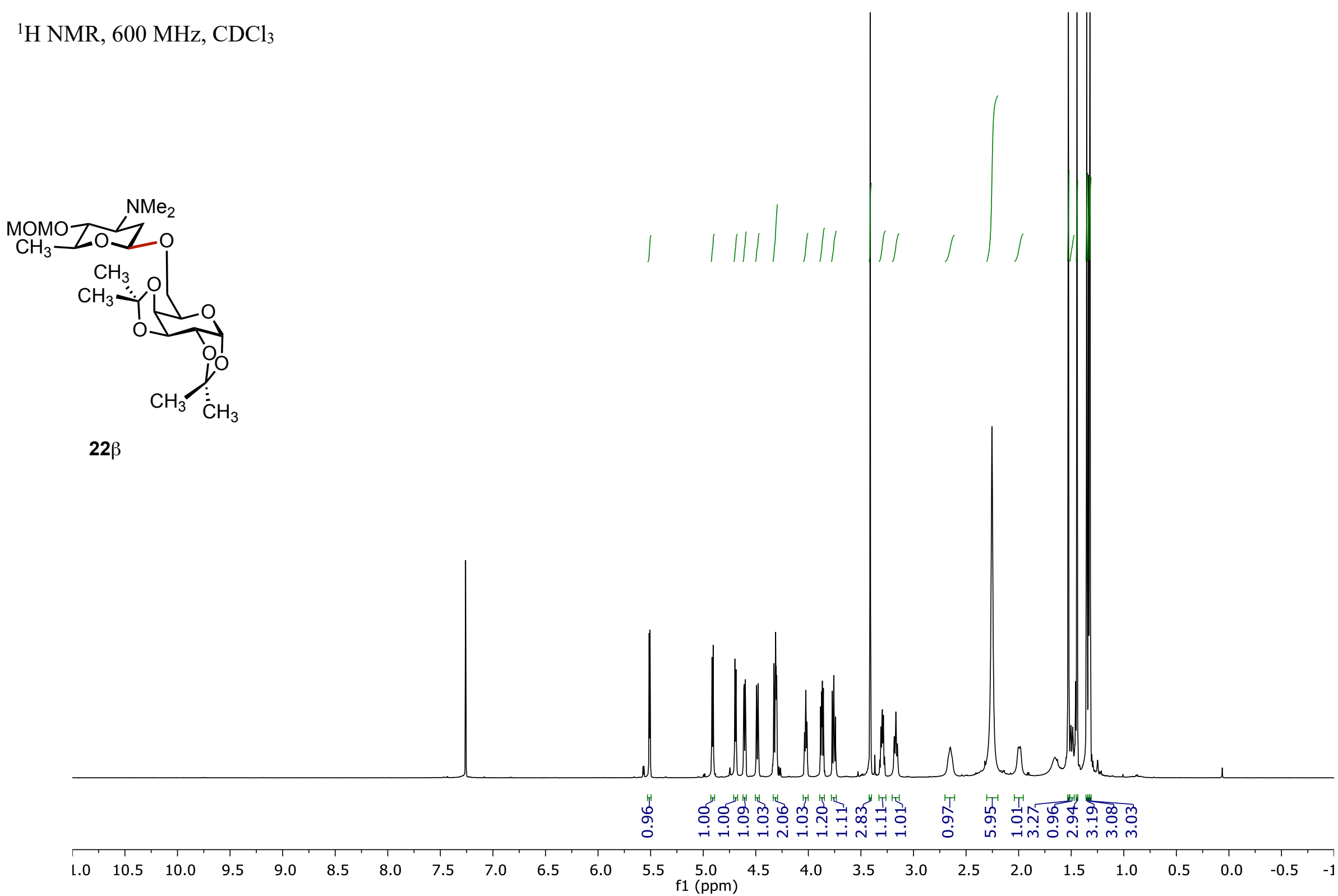

$22 \beta$

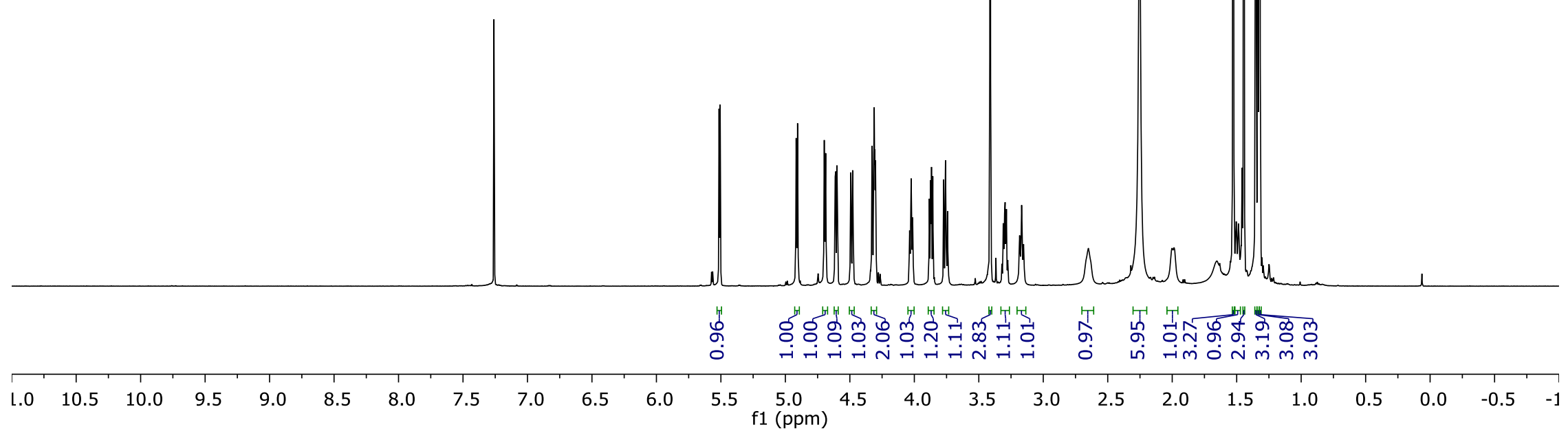

Hoang et al. "General method for the synthesis of $\alpha$ - or $\beta$-deoxyaminoglycosides bearing $\quad$ S158 basic nitrogen" 
${ }^{13} \mathrm{C} \mathrm{NMR}, 151 \mathrm{MHz}, \mathrm{CDCl}_{3}$

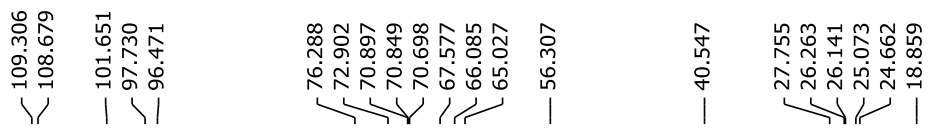

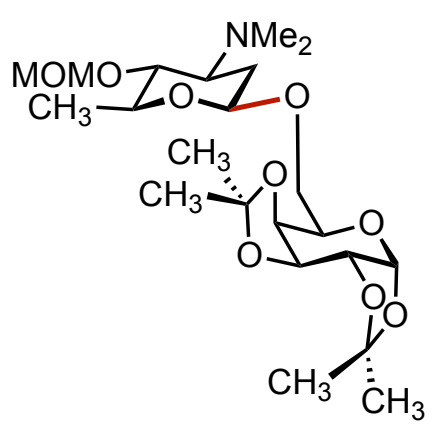

$22 \beta$

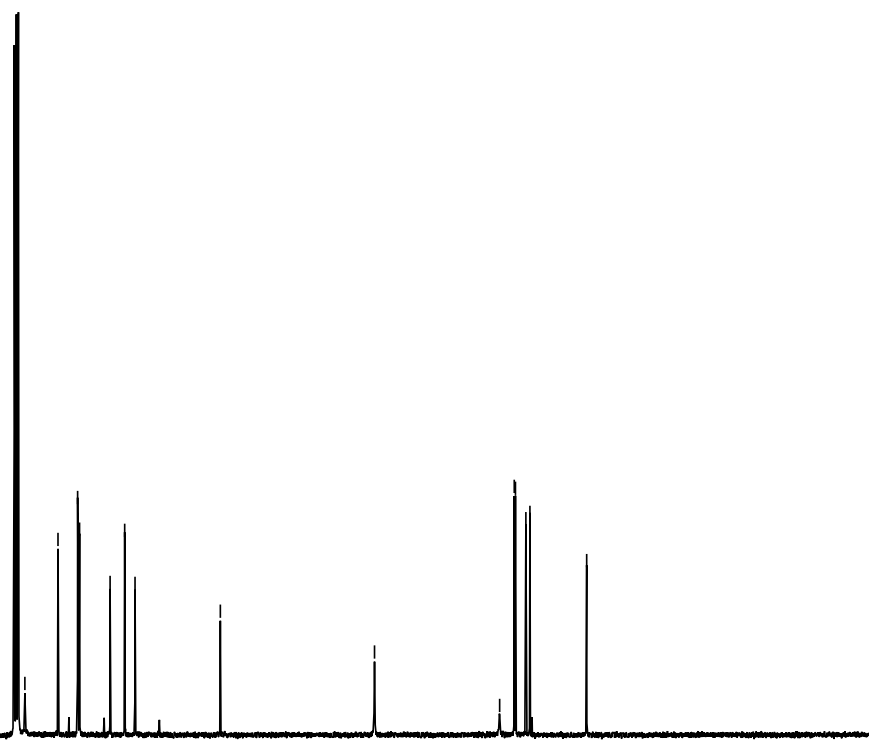

190

170

Hoang et al. "General method for the synthesis of $\alpha$ - or $\beta$-deoxyaminoglycosides bearing

basic nitrogen" 
HSQC NMR, $600 \mathrm{MHz}, \mathrm{CDCl}_{3}$

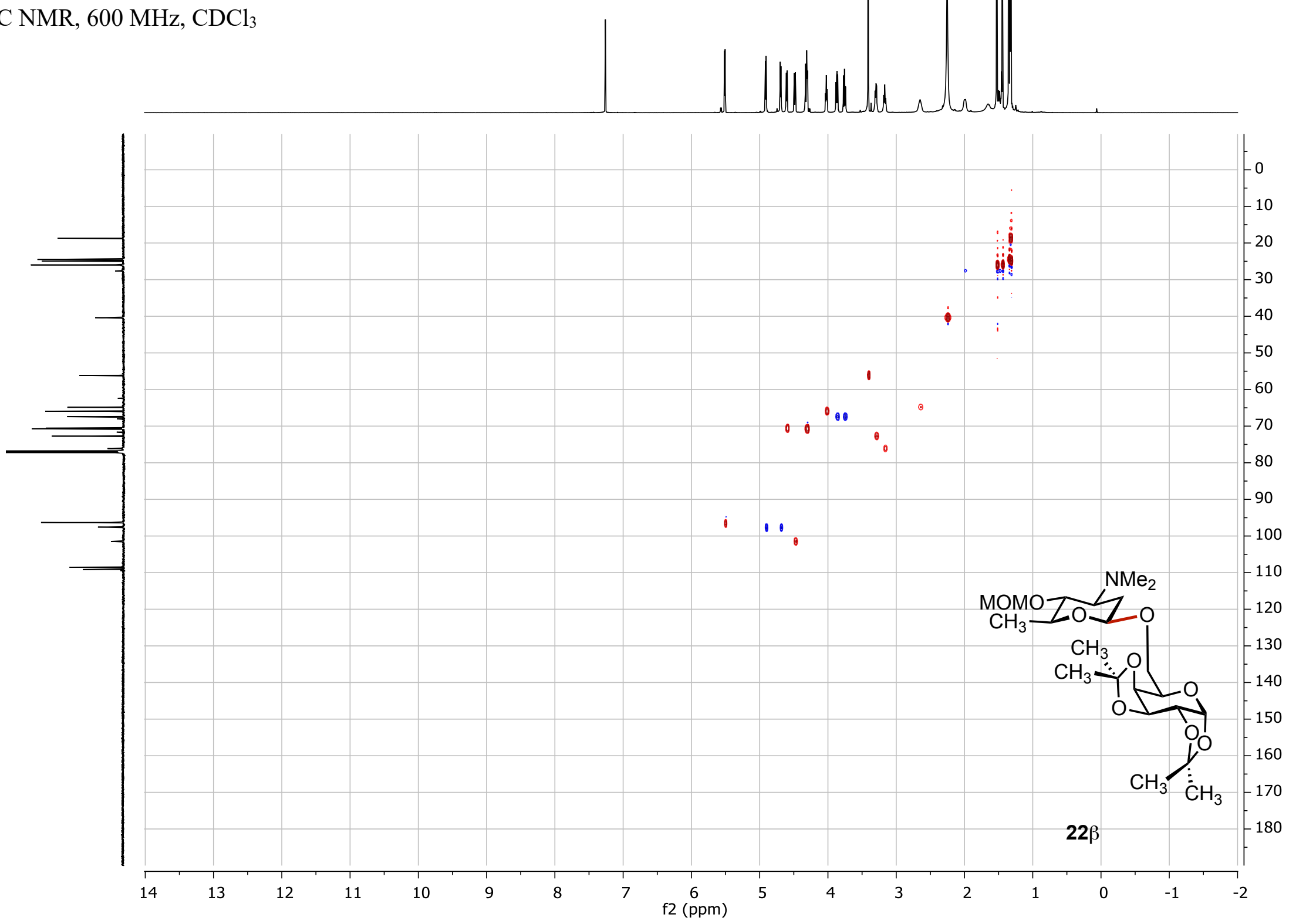

Hoang et al. "General method for the synthesis of $\alpha$ - or $\beta$-deoxyaminoglycosides bearing $\quad$ S160 basic nitrogen" 
${ }^{1} \mathrm{H} \mathrm{NMR}, 600 \mathrm{MHz}, \mathrm{CDCl}_{3}$
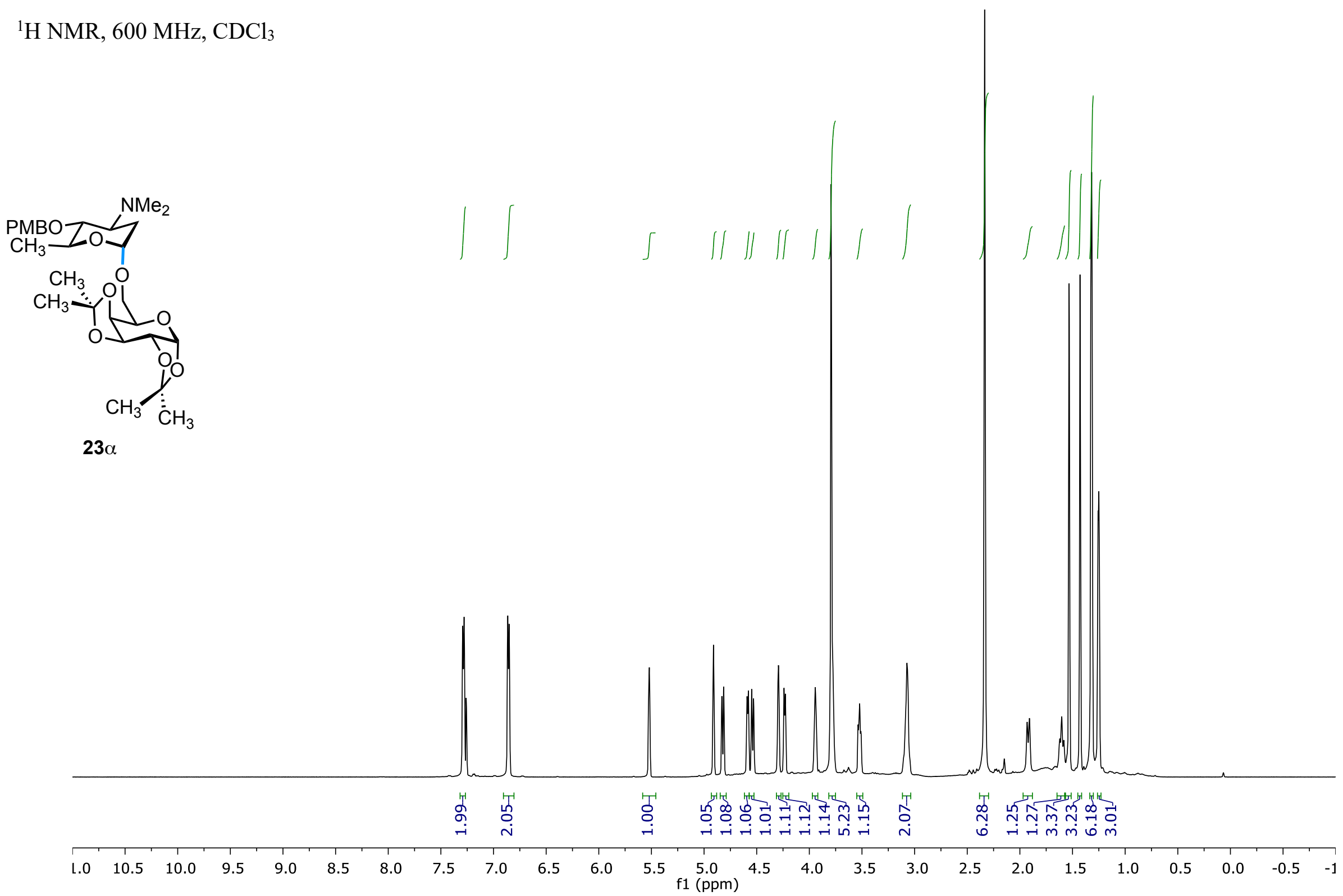

Hoang et al. "General method for the synthesis of $\alpha$ - or $\beta$-deoxyaminoglycosides bearing $\quad$ S161 basic nitrogen" 
${ }^{13} \mathrm{C} \mathrm{NMR,} 151 \mathrm{MHz}, \mathrm{CDCl}_{3}$

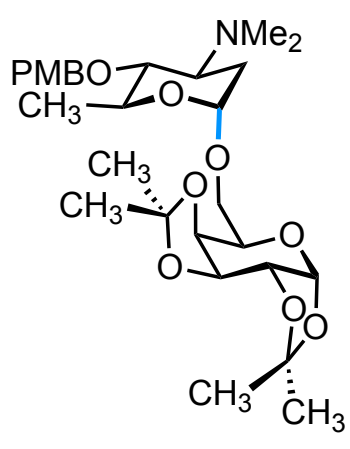

$23 \alpha$

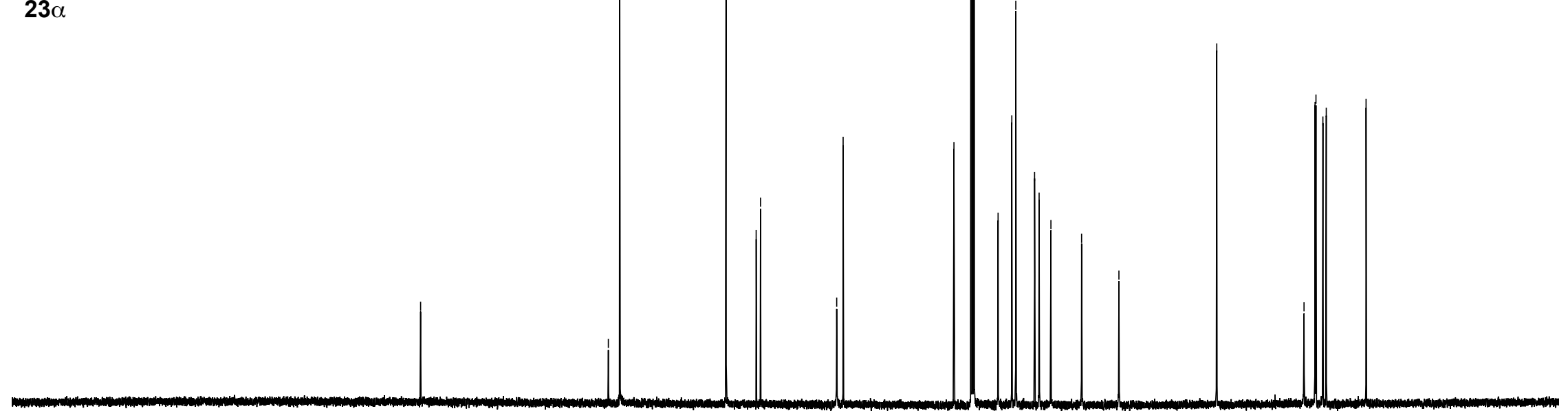


HSQC NMR, $600 \mathrm{MHz}, \mathrm{CDCl}_{3}$
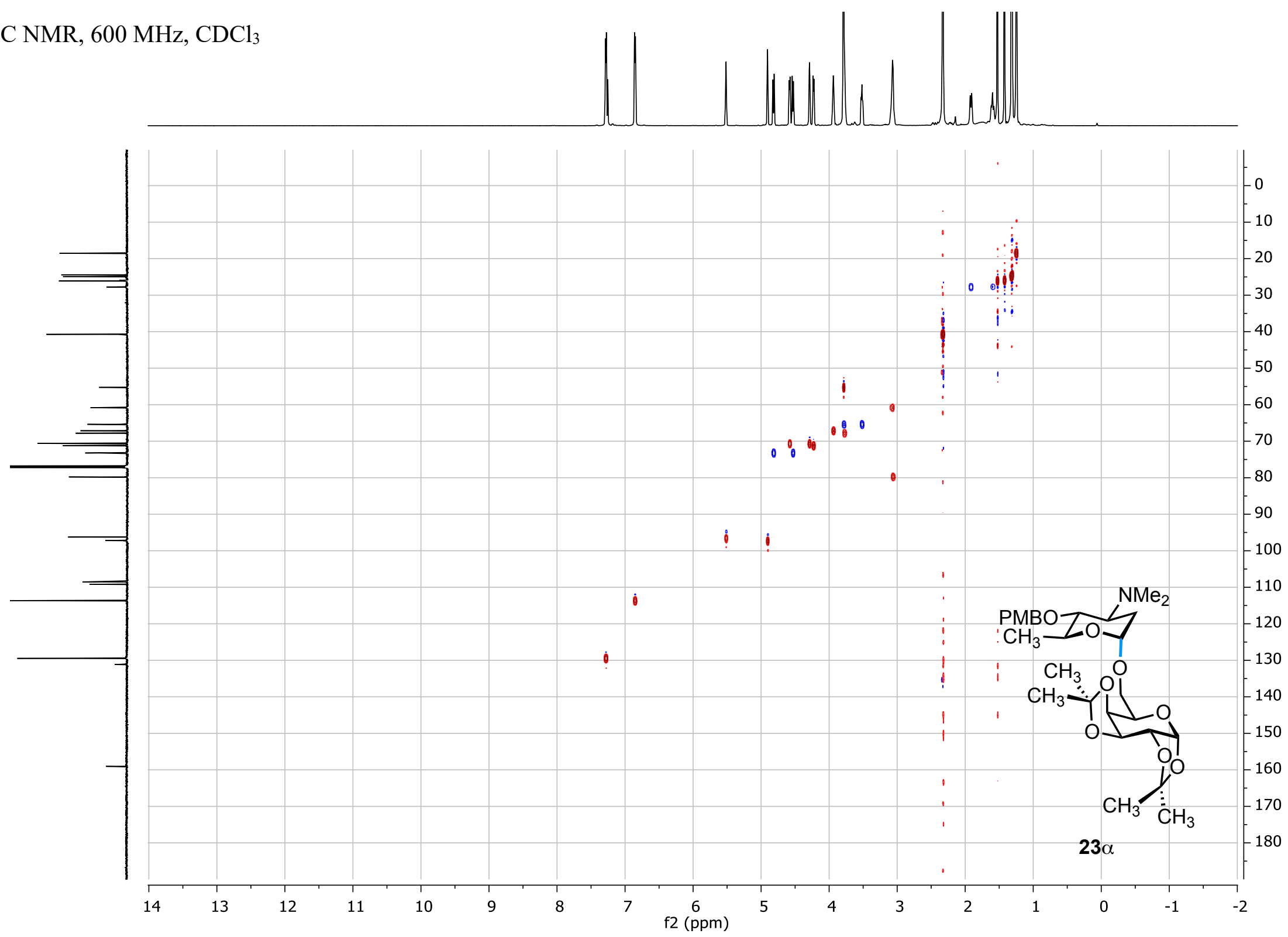

Hoang et al. "General method for the synthesis of $\alpha$ - or $\beta$-deoxyaminoglycosides bearing $\quad$ S163 basic nitrogen" 
${ }^{1} \mathrm{H} \mathrm{NMR}, 400 \mathrm{MHz}, \mathrm{CDCl}_{3}$
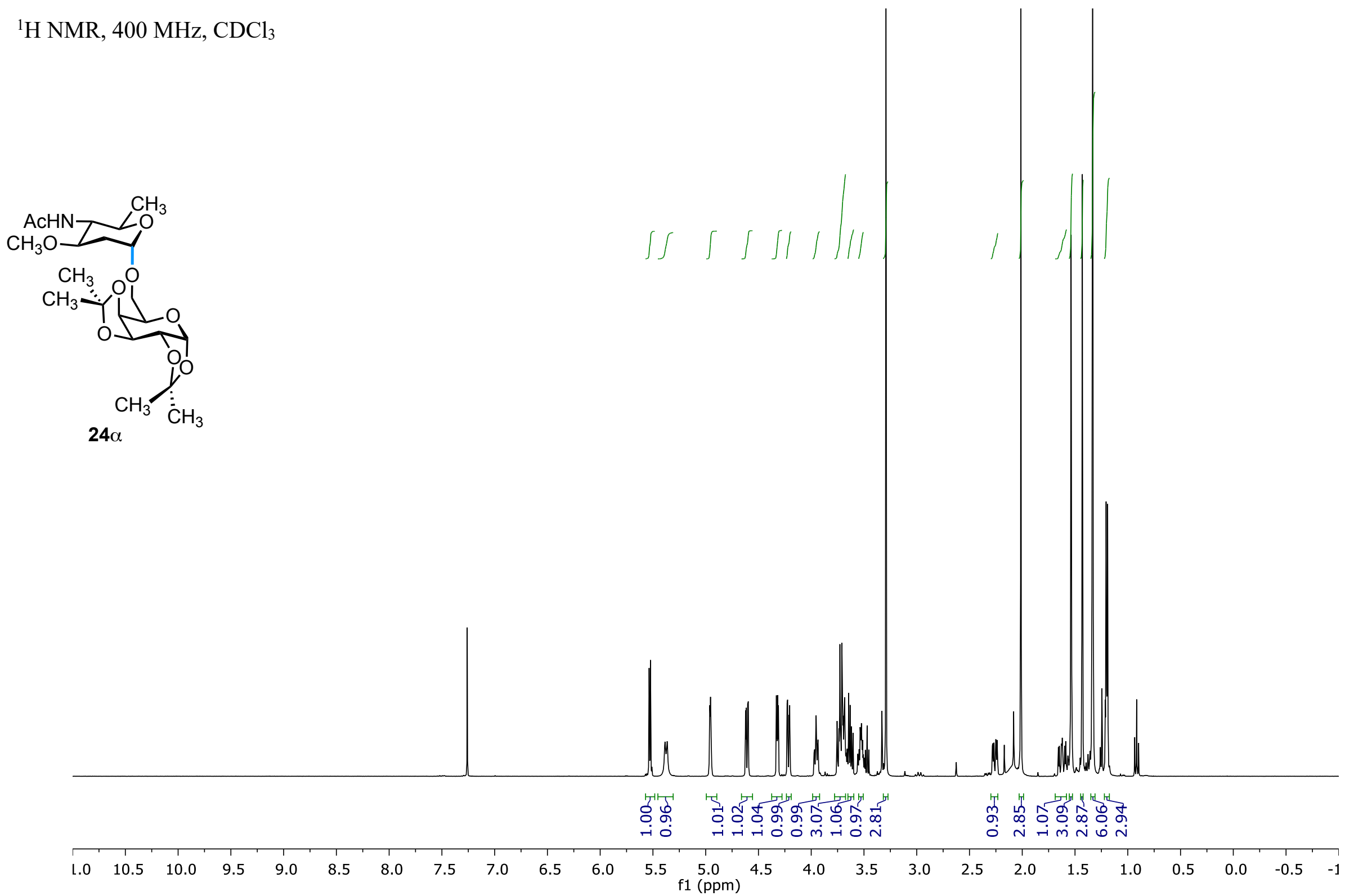

Hoang et al. "General method for the synthesis of $\alpha$ - or $\beta$-deoxyaminoglycosides bearing S164 basic nitrogen" 


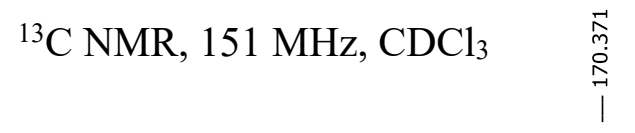
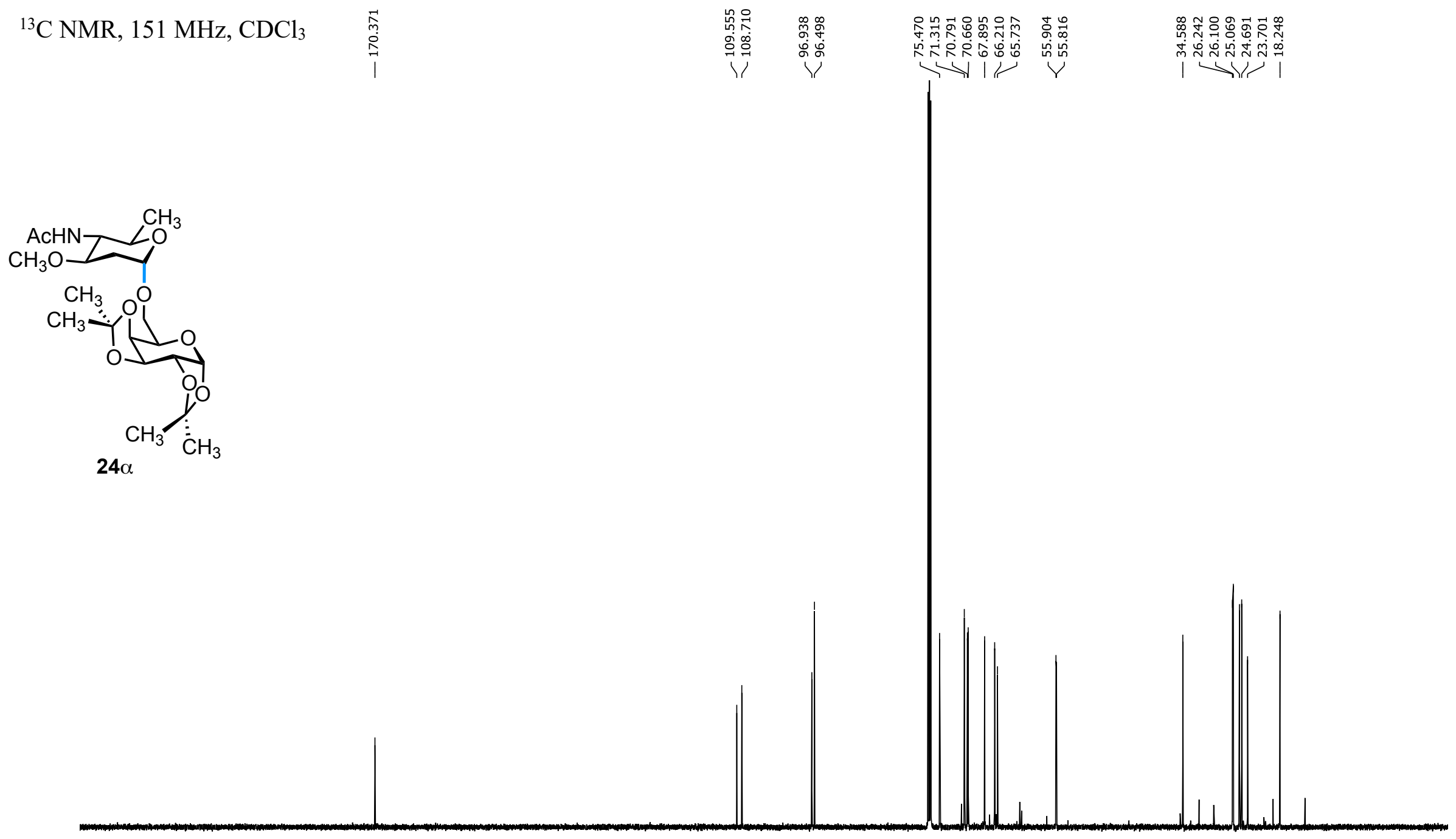

20

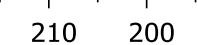

190

180

$170 \quad 160$

$150 \quad 140$

130

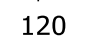

$110 \quad 100$

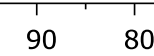

$70 \quad 60$
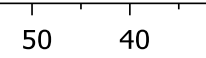

Hoang et al. "General method for the synthesis of $\alpha$ - or $\beta$-deoxyaminoglycosides bearing

S165

basic nitrogen" 
HSQC NMR, $600 \mathrm{MHz}, \mathrm{CDCl}_{3}$

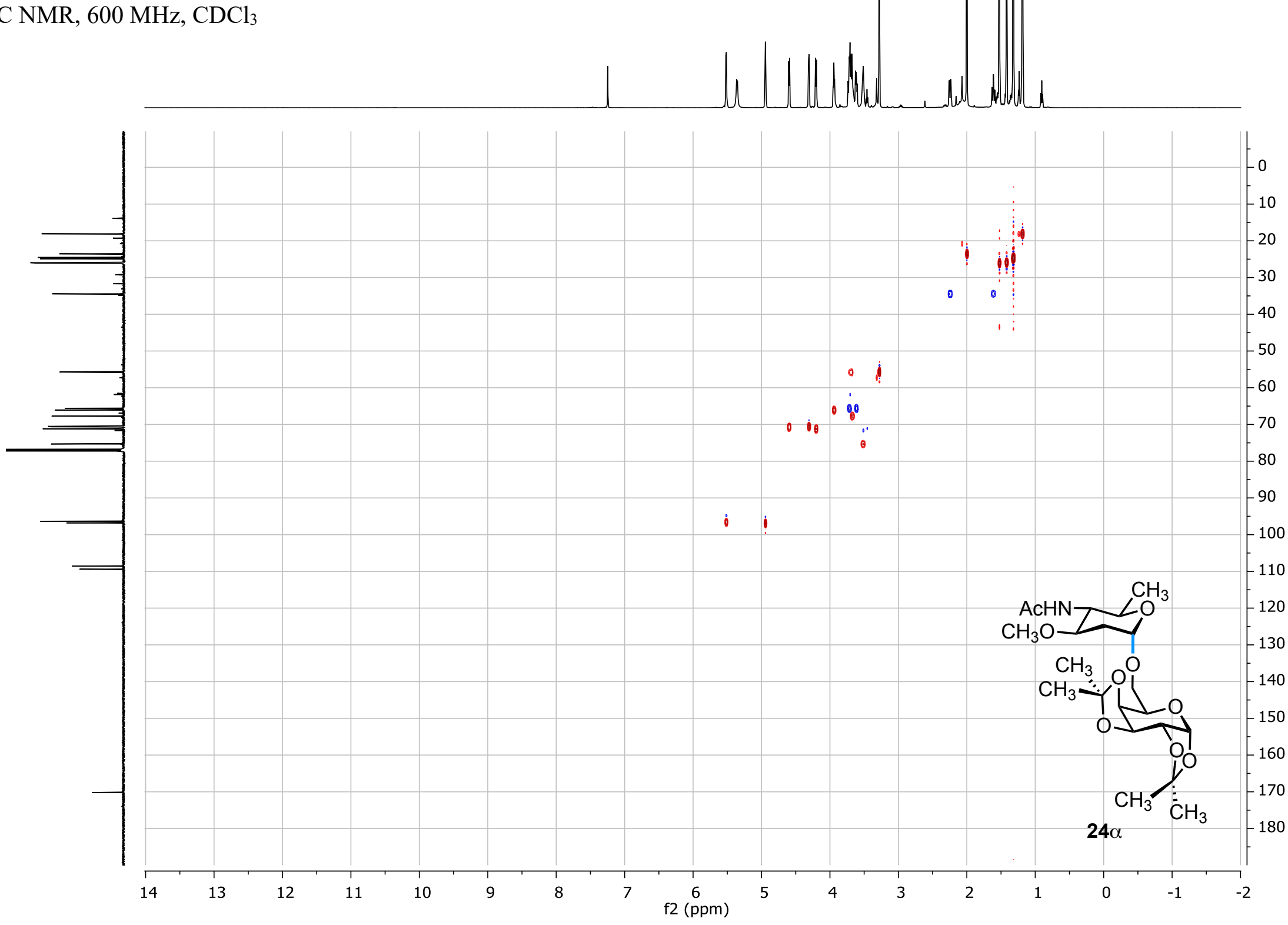

Hoang et al. "General method for the synthesis of $\alpha$ - or $\beta$-deoxyaminoglycosides bearing $\quad$ S166 basic nitrogen" 
${ }^{1} \mathrm{H}$ NMR, $600 \mathrm{MHz}, \mathrm{C}_{6} \mathrm{D}_{6}$

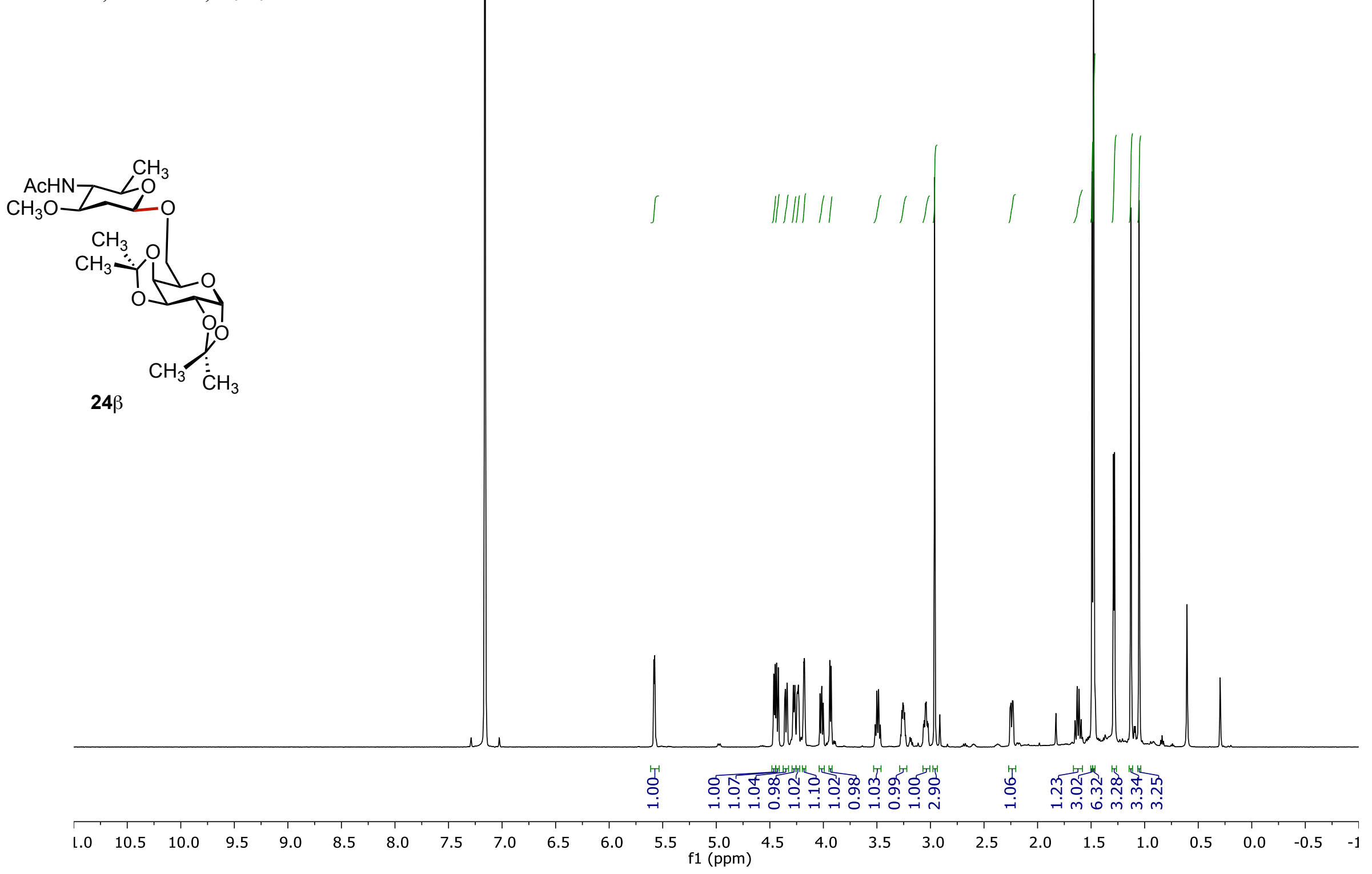

Hoang et al. "General method for the synthesis of $\alpha$ - or $\beta$-deoxyaminoglycosides bearing $\quad$ S167 basic nitrogen" 

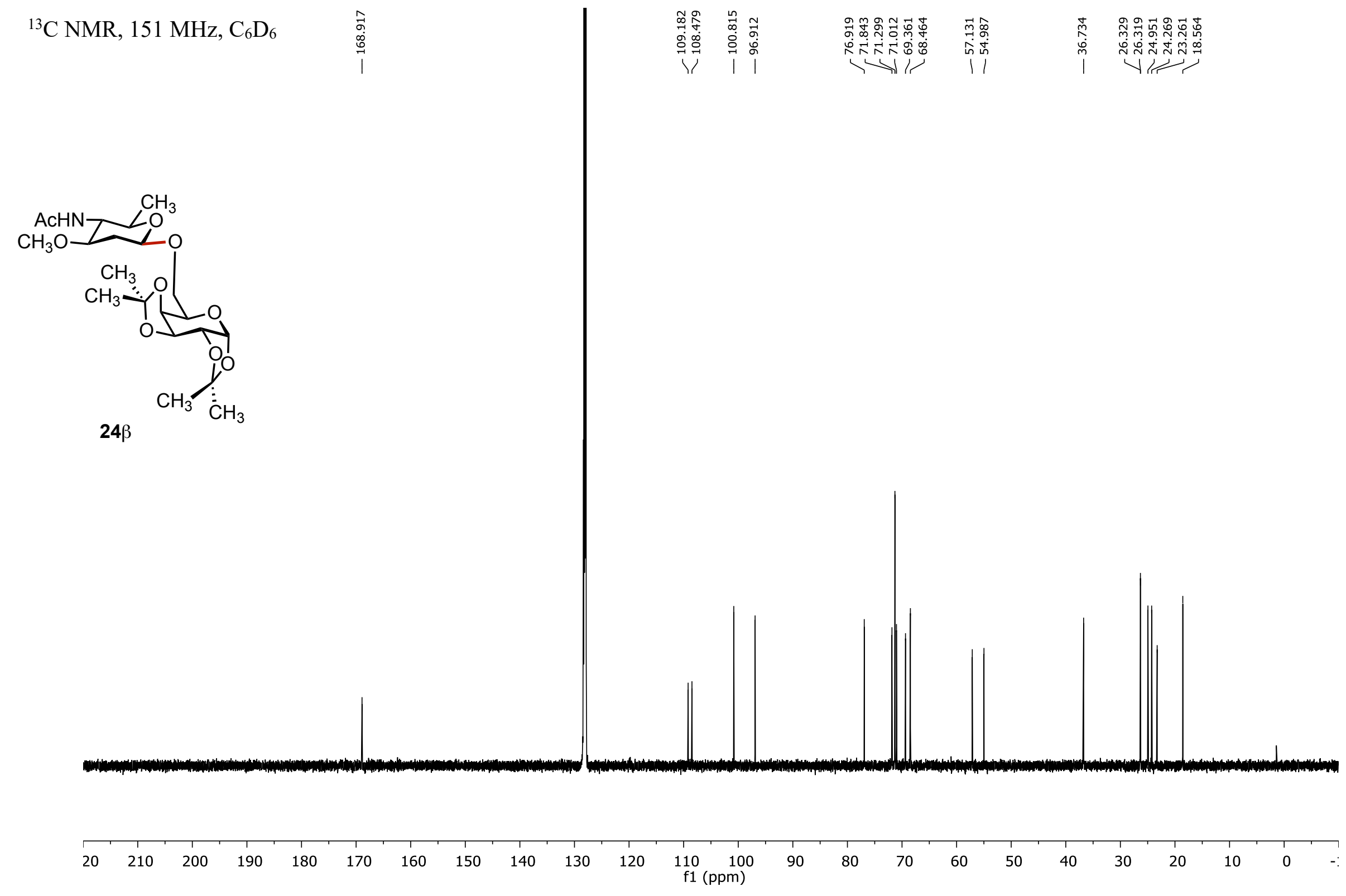

Hoang et al. "General method for the synthesis of $\alpha$ - or $\beta$-deoxyaminoglycosides bearing $\quad$ S168 basic nitrogen" 
HSQC NMR, $600 \mathrm{MHz}, \mathrm{C}_{6} \mathrm{D}_{6}$

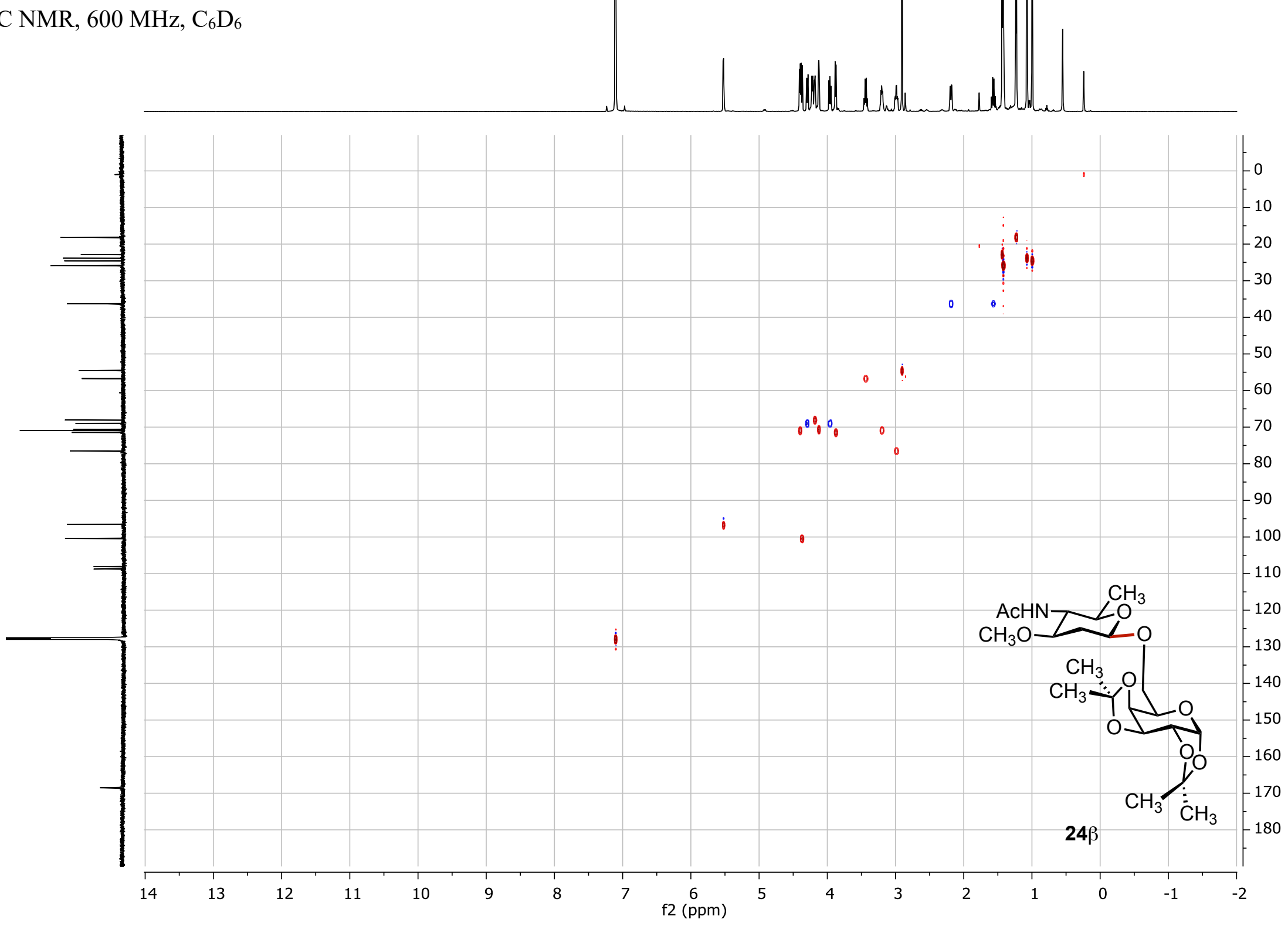

Hoang et al. "General method for the synthesis of $\alpha$ - or $\beta$-deoxyaminoglycosides bearing

S169

basic nitrogen" 
${ }^{1} \mathrm{H} \mathrm{NMR}, 500 \mathrm{MHz}, \mathrm{CDCl}_{3}$
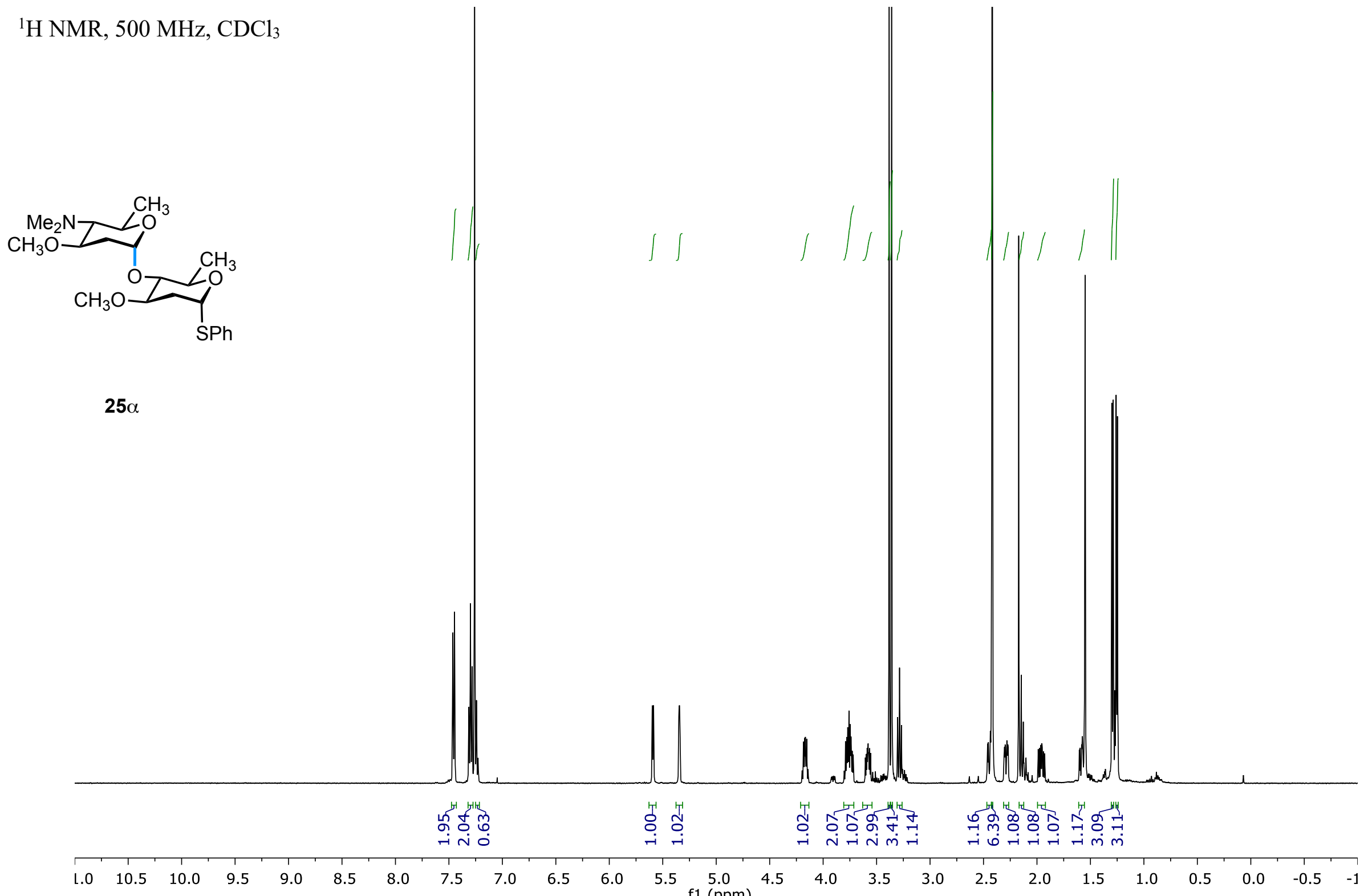

$25 \alpha$

Hoang et al. "General method for the synthesis of $\alpha$ - or $\beta$-deoxyaminoglycosides bearing $\quad$ S170 basic nitrogen" 
${ }^{13} \mathrm{C} \mathrm{NMR,} 126 \mathrm{MHz}, \mathrm{CDCl}_{3}$

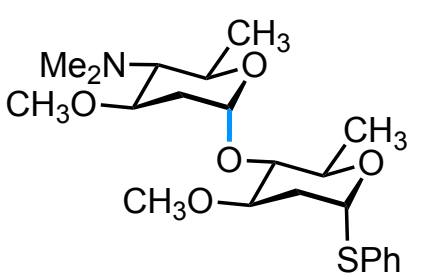

$25 \alpha$

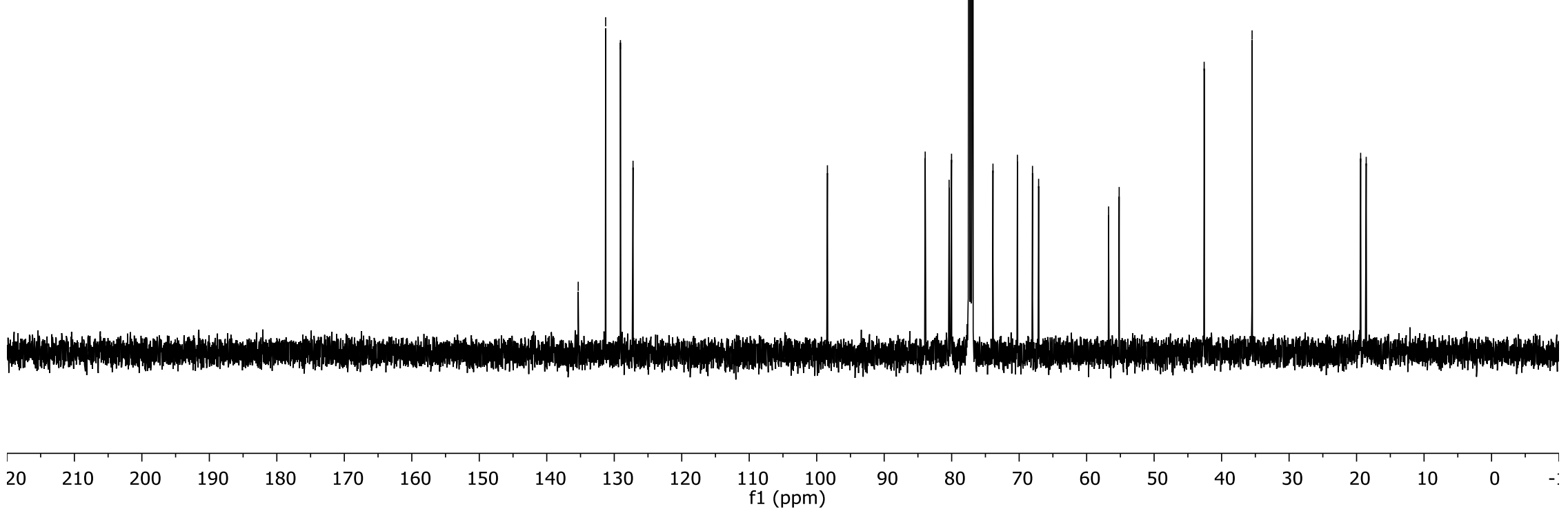

Hoang et al. "General method for the synthesis of $\alpha$ - or $\beta$-deoxyaminoglycosides bearing $\quad$ S171 basic nitrogen" 
HSQC NMR, $500 \mathrm{MHz}, \mathrm{CDCl}_{3}$
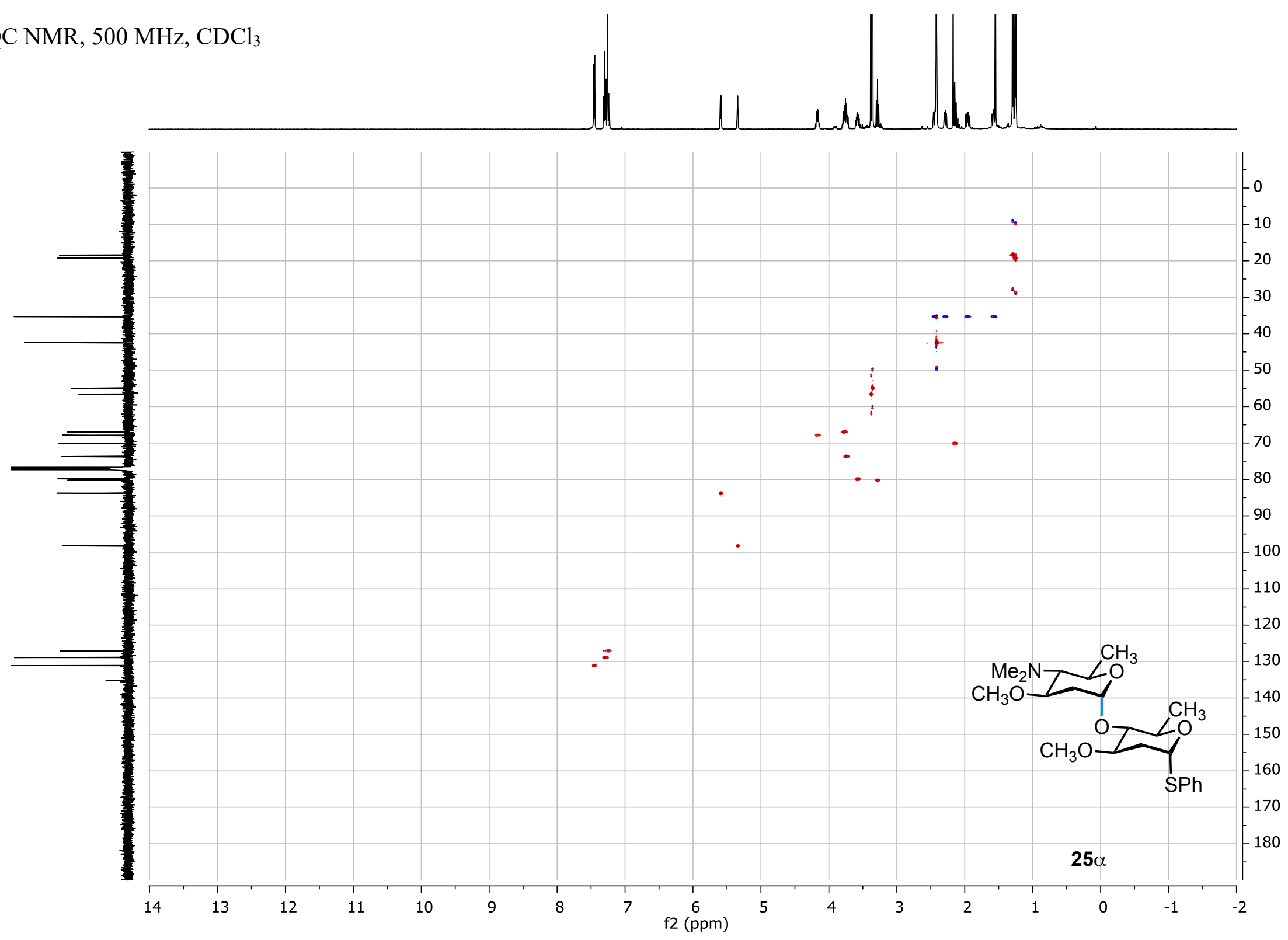

Hoang et al. "General method for the synthesis of $\alpha$ - or $\beta$-deoxyaminoglycosides bearing

S172 basic nitrogen" 
${ }^{1} \mathrm{H} \mathrm{NMR}, 600 \mathrm{MHz}, \mathrm{CDCl}_{3}$
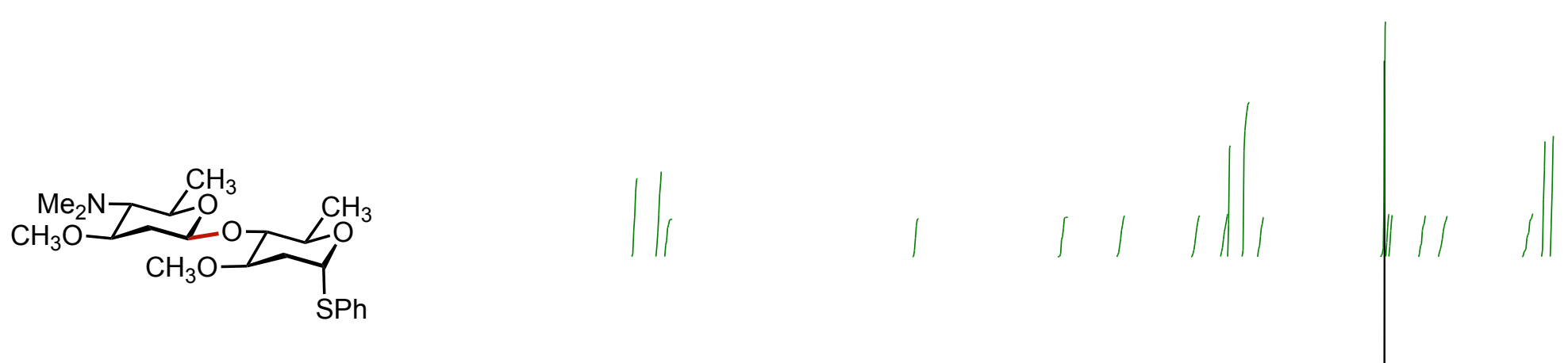

$25 \beta$

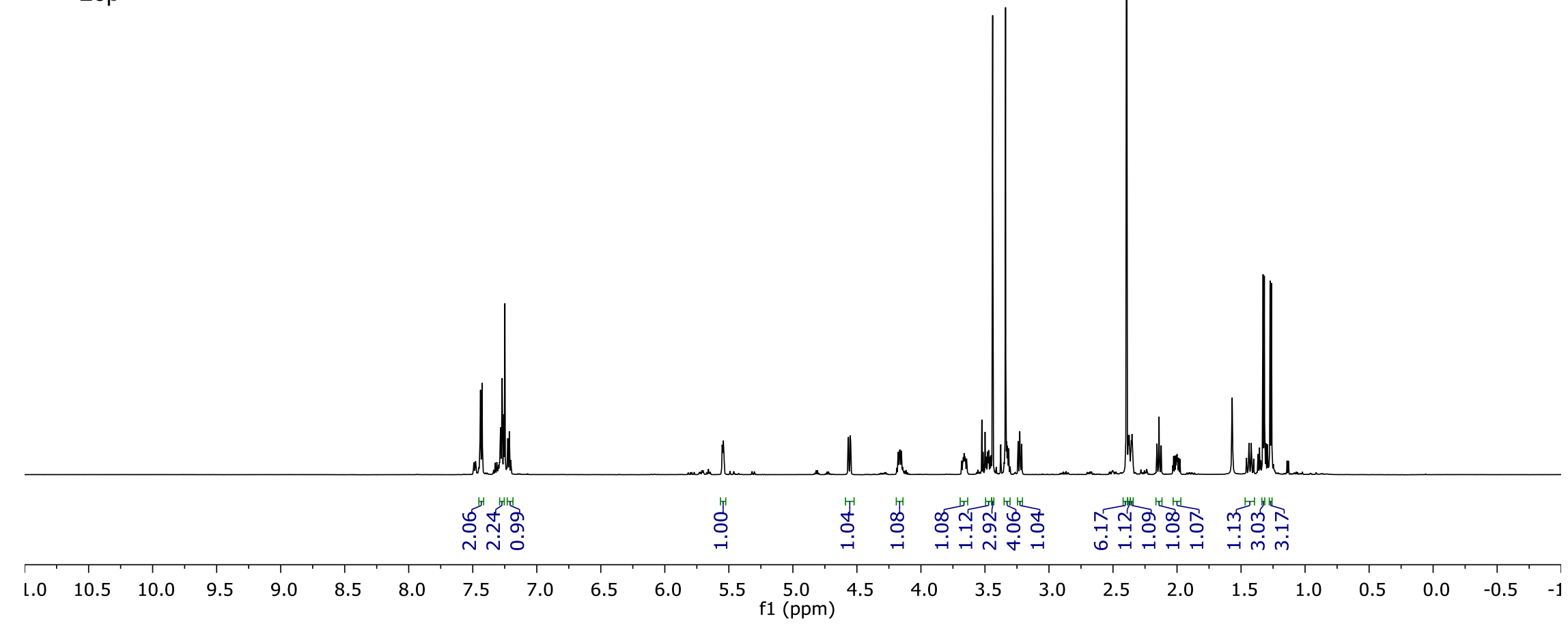

Hoang et al. "General method for the synthesis of $\alpha$ - or $\beta$-deoxyaminoglycosides bearing $\quad$ S173 basic nitrogen" 
${ }^{13} \mathrm{C} \mathrm{NMR,} 151 \mathrm{MHz}, \mathrm{CDCl}_{3}$

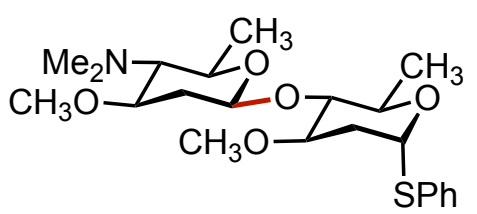

$25 \beta$

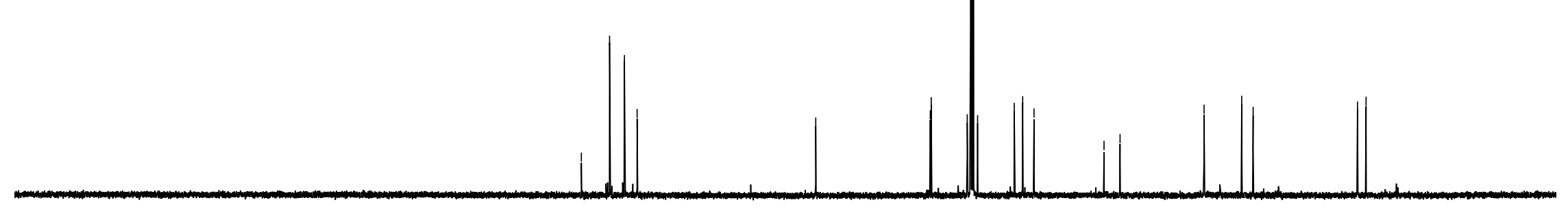

20

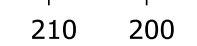

190

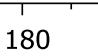

$\begin{array}{llll}170 & 160 & 150 & 140\end{array}$

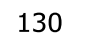

120

$110 \quad 100$

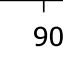

80

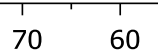

50

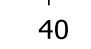

Hoang et al. "General method for the synthesis of $\alpha$ - or $\beta$-deoxyaminoglycosides bearing

S174

basic nitrogen" 
HSQC NMR, $600 \mathrm{MHz}, \mathrm{CDCl}_{3}$
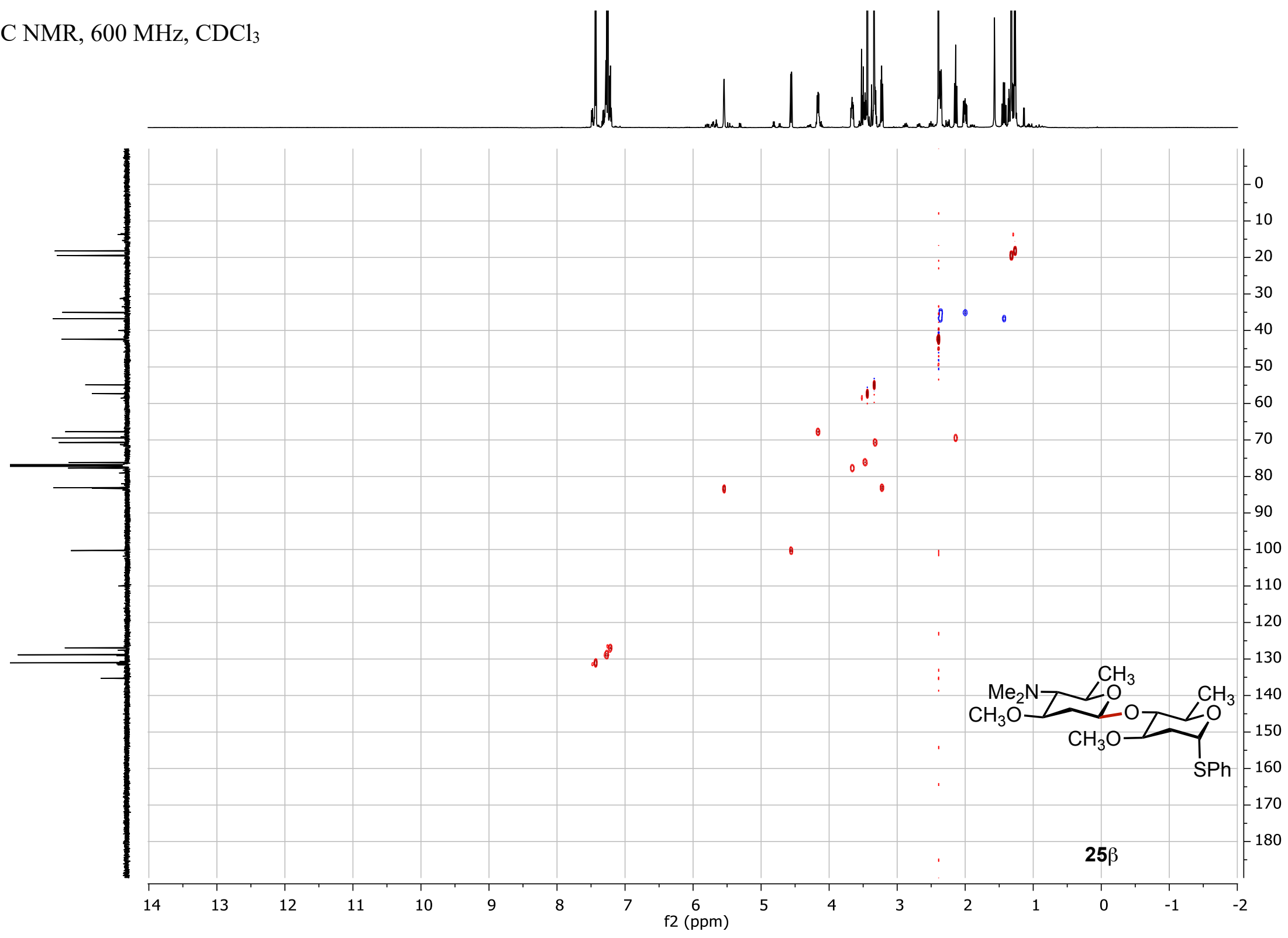

Hoang et al. "General method for the synthesis of $\alpha$ - or $\beta$-deoxyaminoglycosides bearing $\quad$ S175 basic nitrogen" 
${ }^{1} \mathrm{H} \mathrm{NMR}, 400 \mathrm{MHz}, \mathrm{CDCl}_{3}$
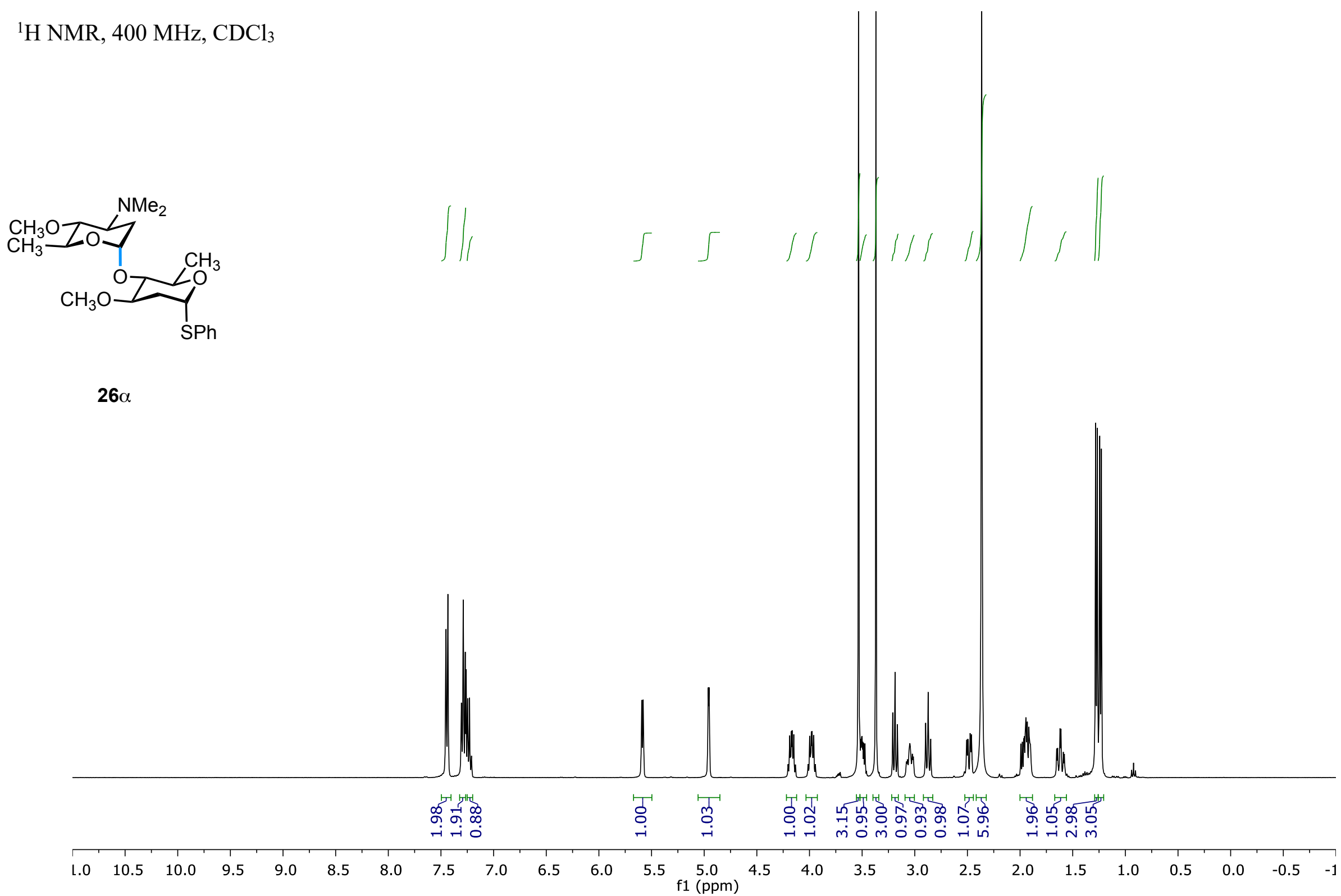

$26 \alpha$

Hoang et al. "General method for the synthesis of $\alpha$ - or $\beta$-deoxyaminoglycosides bearing $\quad$ S176 basic nitrogen" 
${ }^{13} \mathrm{C} \mathrm{NMR}, 151 \mathrm{MHz}, \mathrm{CDCl}_{3}$

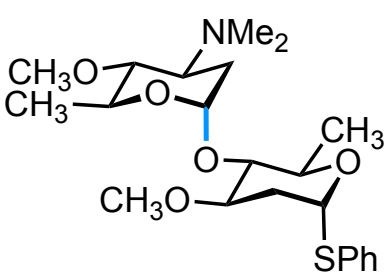

$26 o$

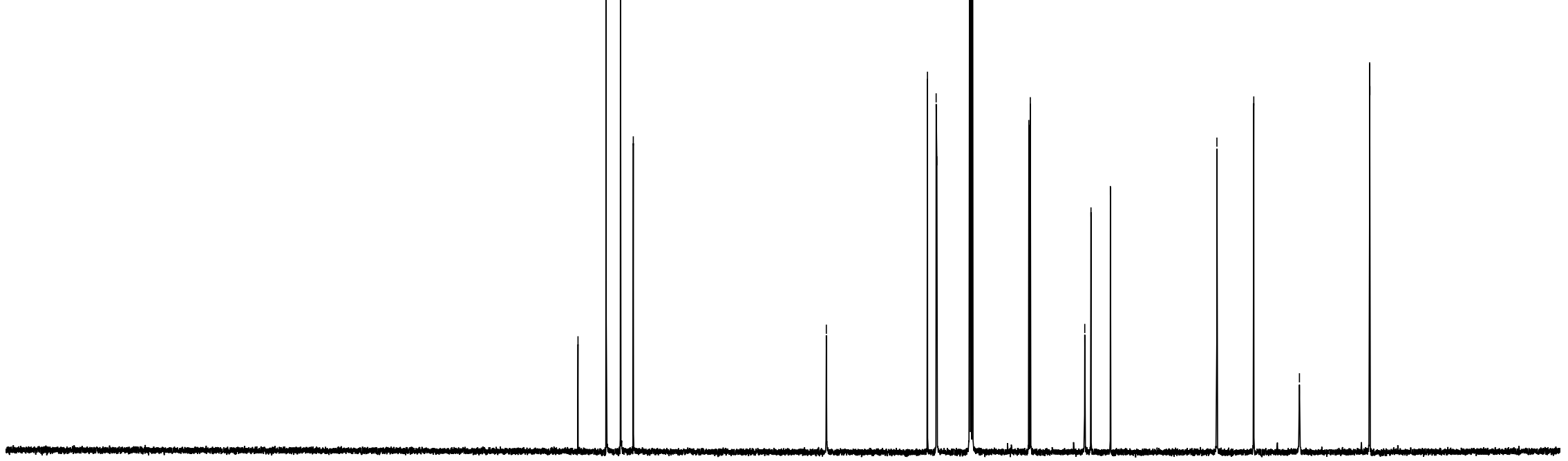




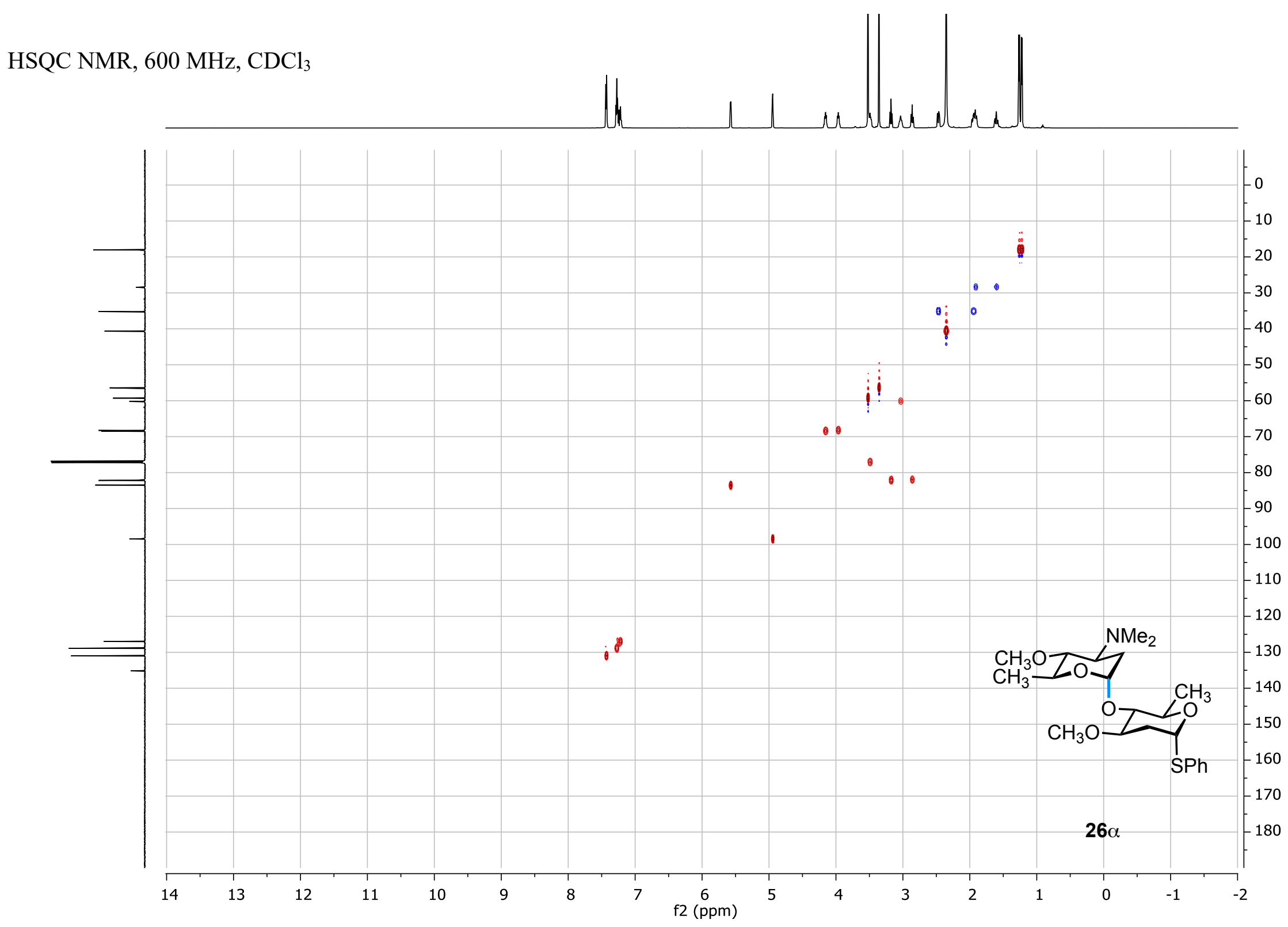

Hoang et al. "General method for the synthesis of $\alpha$ - or $\beta$-deoxyaminoglycosides bearing $\quad$ S178 basic nitrogen" 


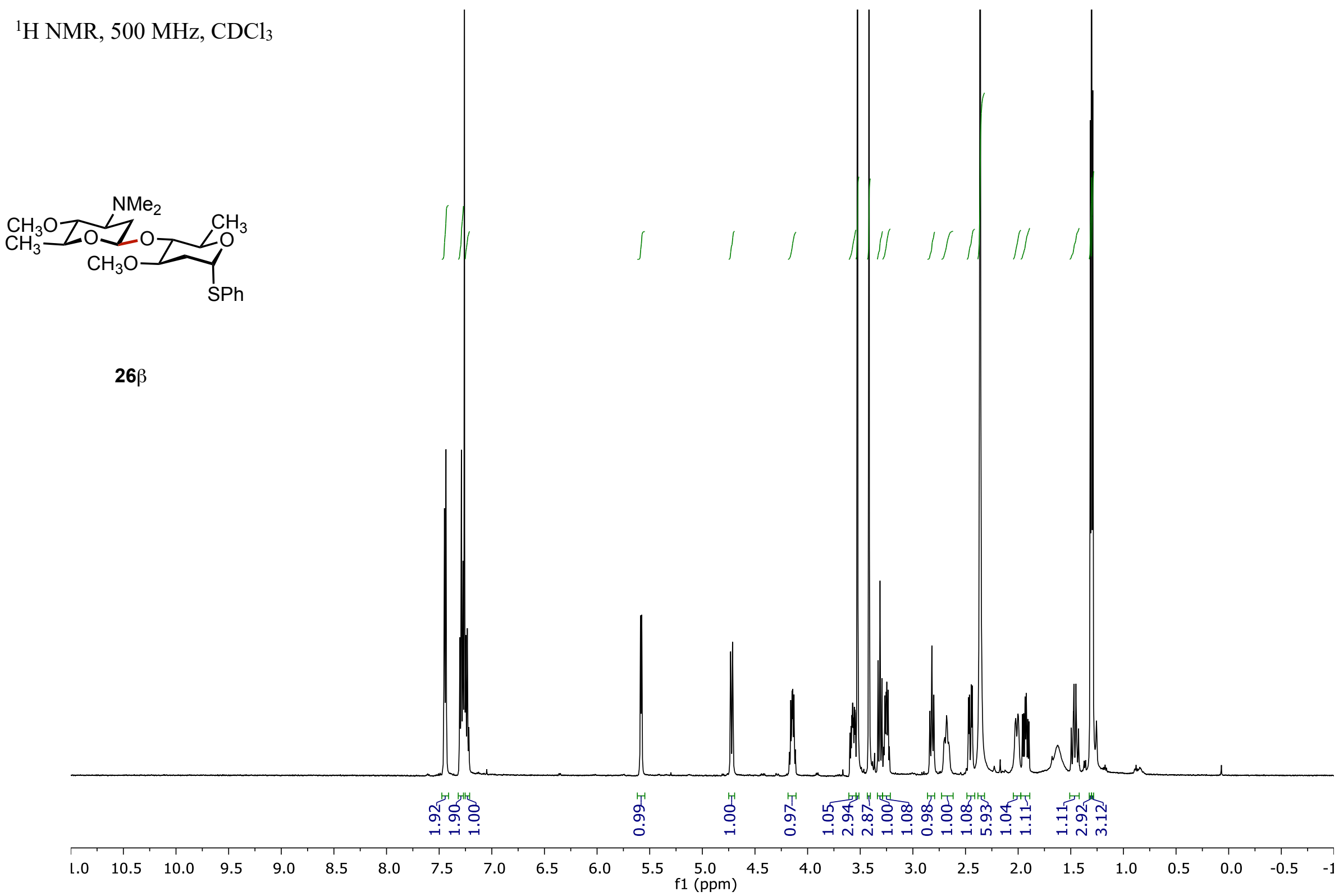

Hoang et al. "General method for the synthesis of $\alpha$ - or $\beta$-deoxyaminoglycosides bearing $\quad$ S179 basic nitrogen" 
${ }^{13} \mathrm{C} \mathrm{NMR,} 126 \mathrm{MHz}, \mathrm{CDCl}_{3}$

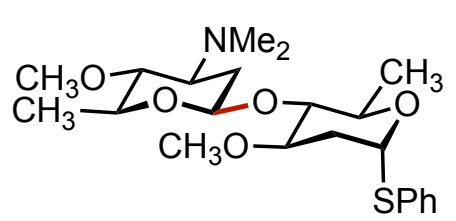

$26 \beta$

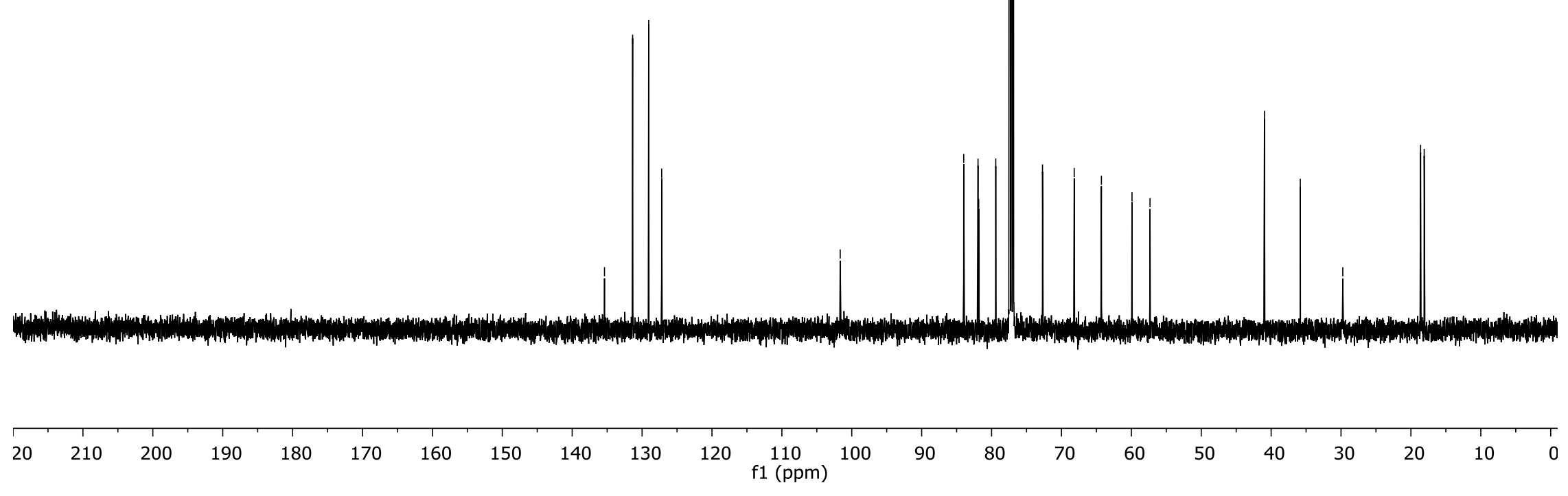

Hoang et al. "General method for the synthesis of $\alpha$ - or $\beta$-deoxyaminoglycosides bearing $\quad$ S180 basic nitrogen" 
HSQC NMR, $500 \mathrm{MHz}, \mathrm{CDCl}_{3}$
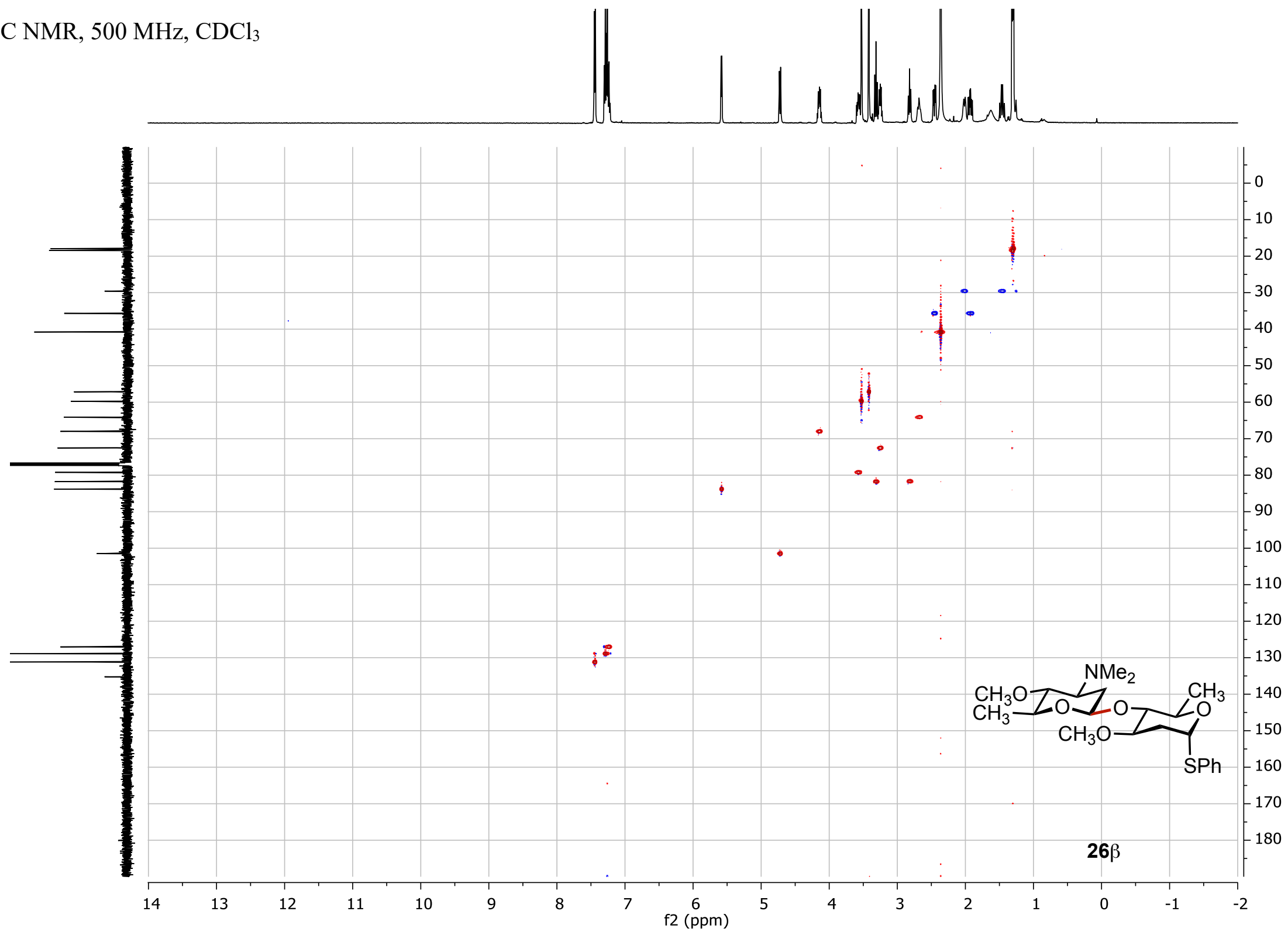

Hoang et al. "General method for the synthesis of $\alpha$ - or $\beta$-deoxyaminoglycosides bearing $\quad$ S181 basic nitrogen" 
${ }^{1} \mathrm{H} \mathrm{NMR}, 400 \mathrm{MHz}, \mathrm{CDCl}_{3}$
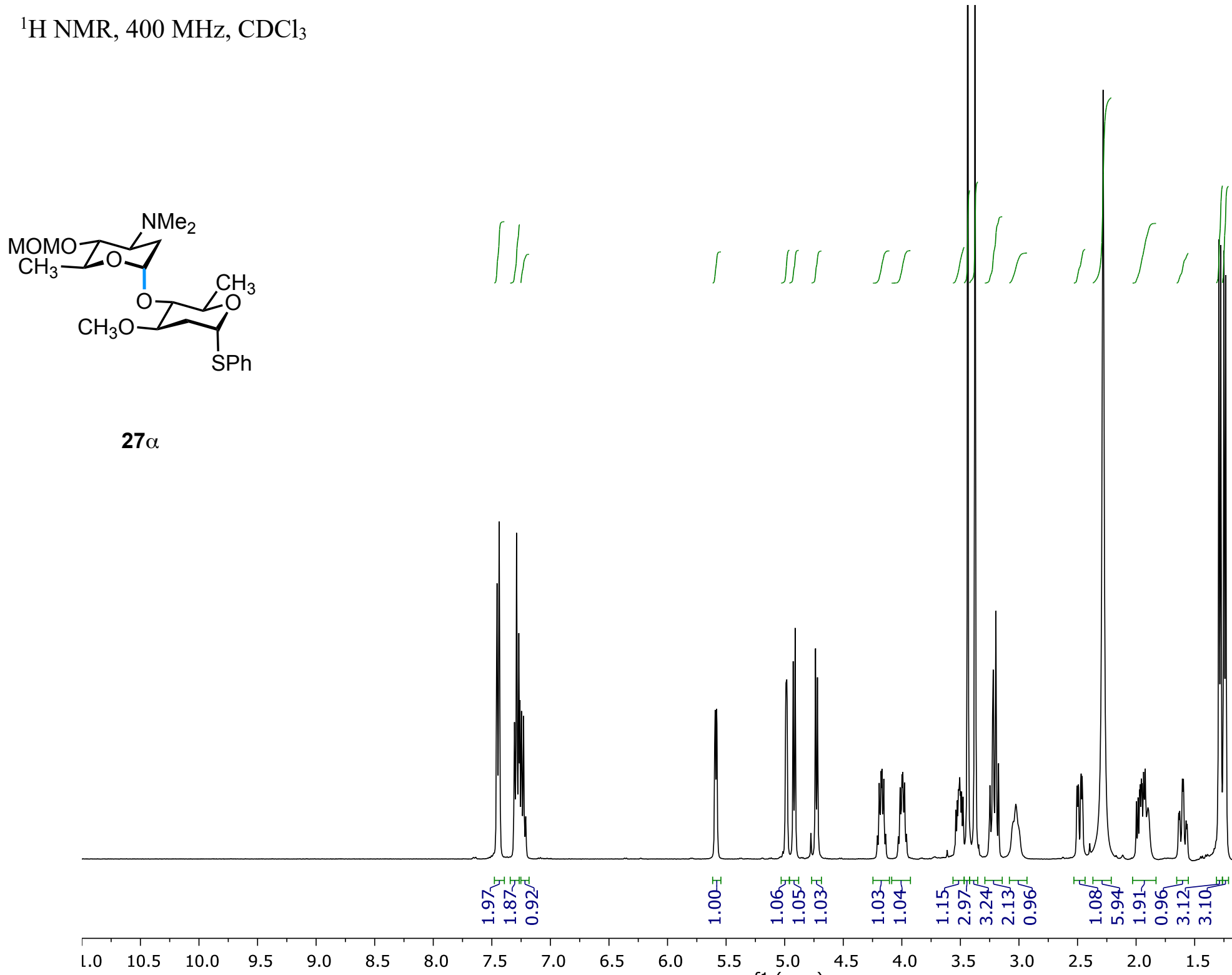

$f 1(\mathrm{ppm})$

Hoang et al. "General method for the synthesis of $\alpha$ - or $\beta$-deoxyaminoglycosides bearing

S182

basic nitrogen" 
${ }^{13} \mathrm{C} \mathrm{NMR,} 151 \mathrm{MHz}, \mathrm{CDCl}_{3}$

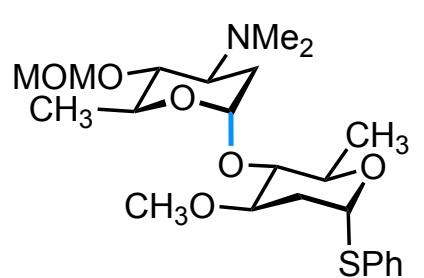

$27 \alpha$

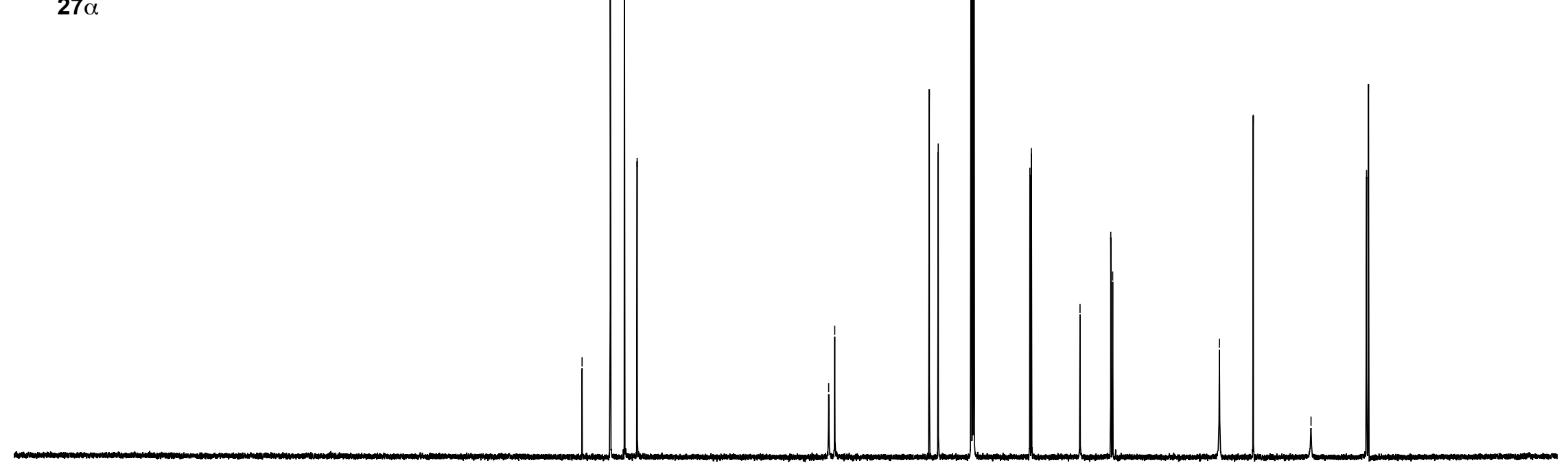

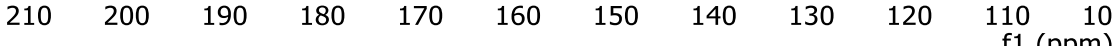

Hoang et al. "General method for the synthesis of $\alpha$ - or $\beta$-deoxyaminoglycosides bearing

S183

basic nitrogen" 
HSQC NMR, $600 \mathrm{MHz}, \mathrm{CDCl}_{3}$
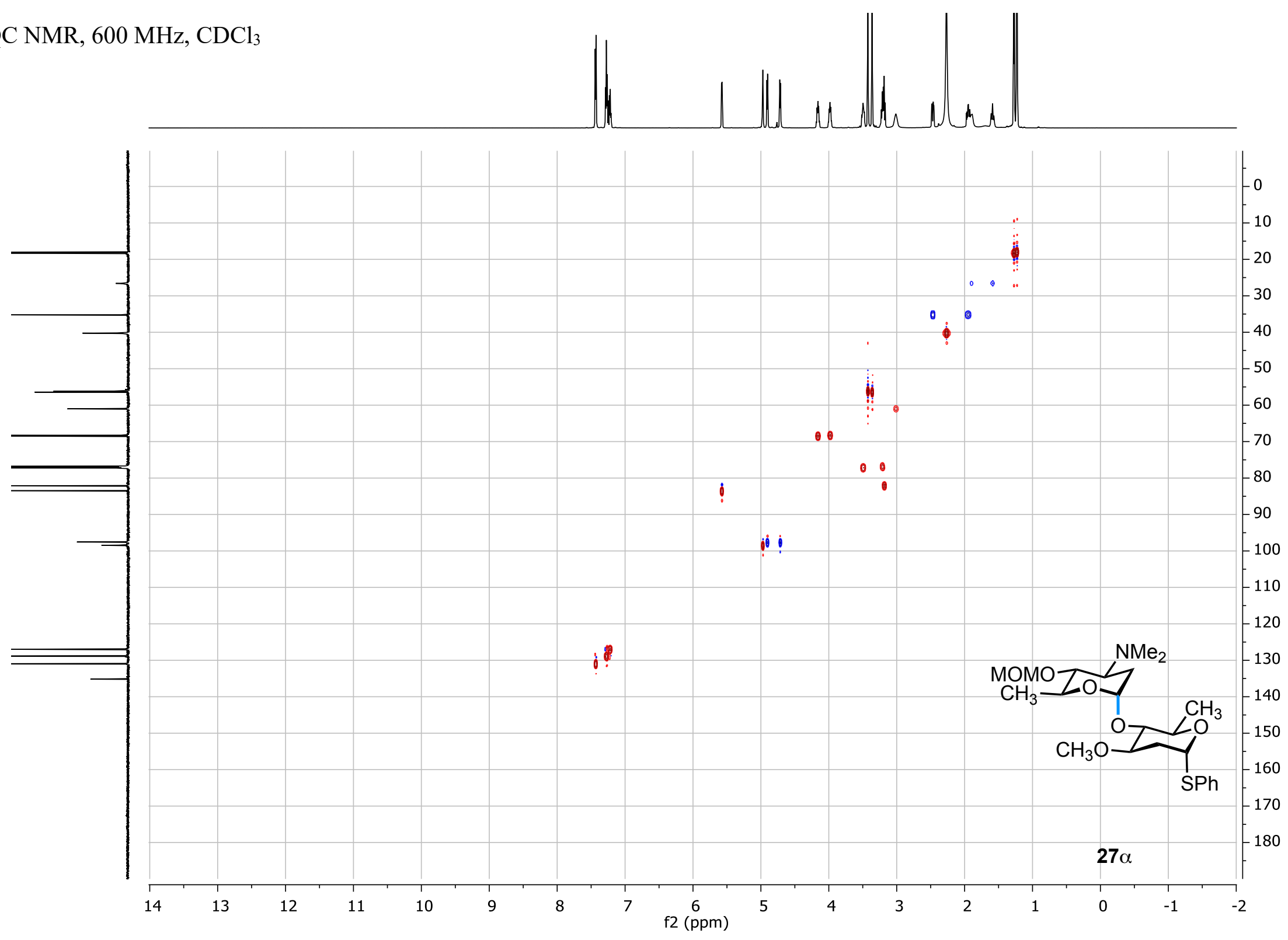

Hoang et al. "General method for the synthesis of $\alpha$ - or $\beta$-deoxyaminoglycosides bearing $\quad$ S184 basic nitrogen" 
${ }^{1} \mathrm{H} \mathrm{NMR}, 600 \mathrm{MHz}, \mathrm{C}_{6} \mathrm{D}_{6}$
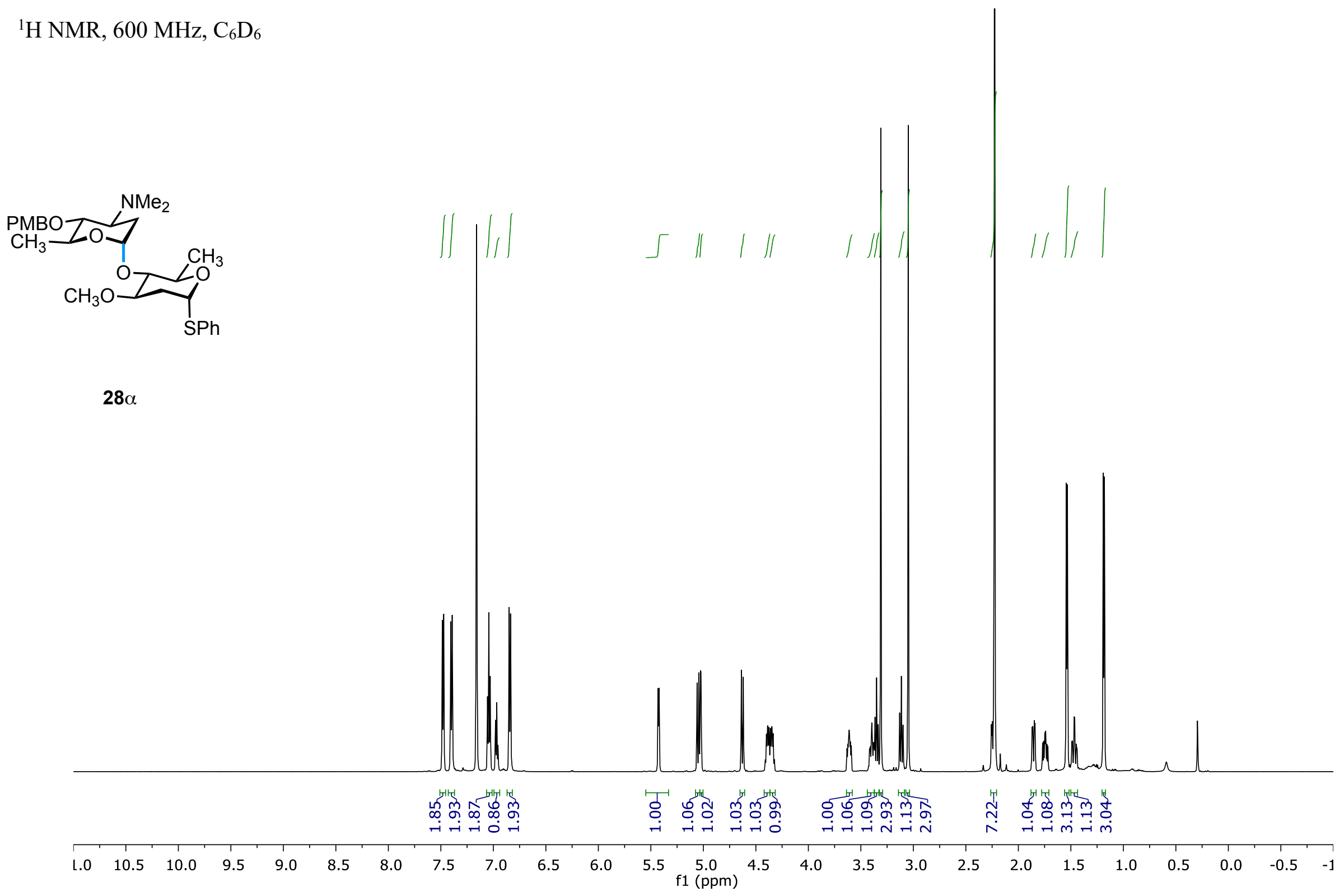

Hoang et al. "General method for the synthesis of $\alpha$ - or $\beta$-deoxyaminoglycosides bearing $\quad$ S185 basic nitrogen" 
${ }^{13} \mathrm{C} \mathrm{NMR}, 151 \mathrm{MHz}, \mathrm{C}_{6} \mathrm{D}_{6}$

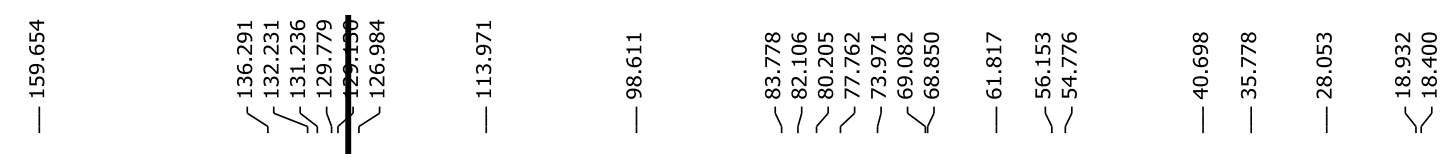

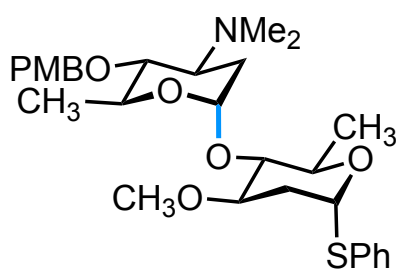

$28 \alpha$
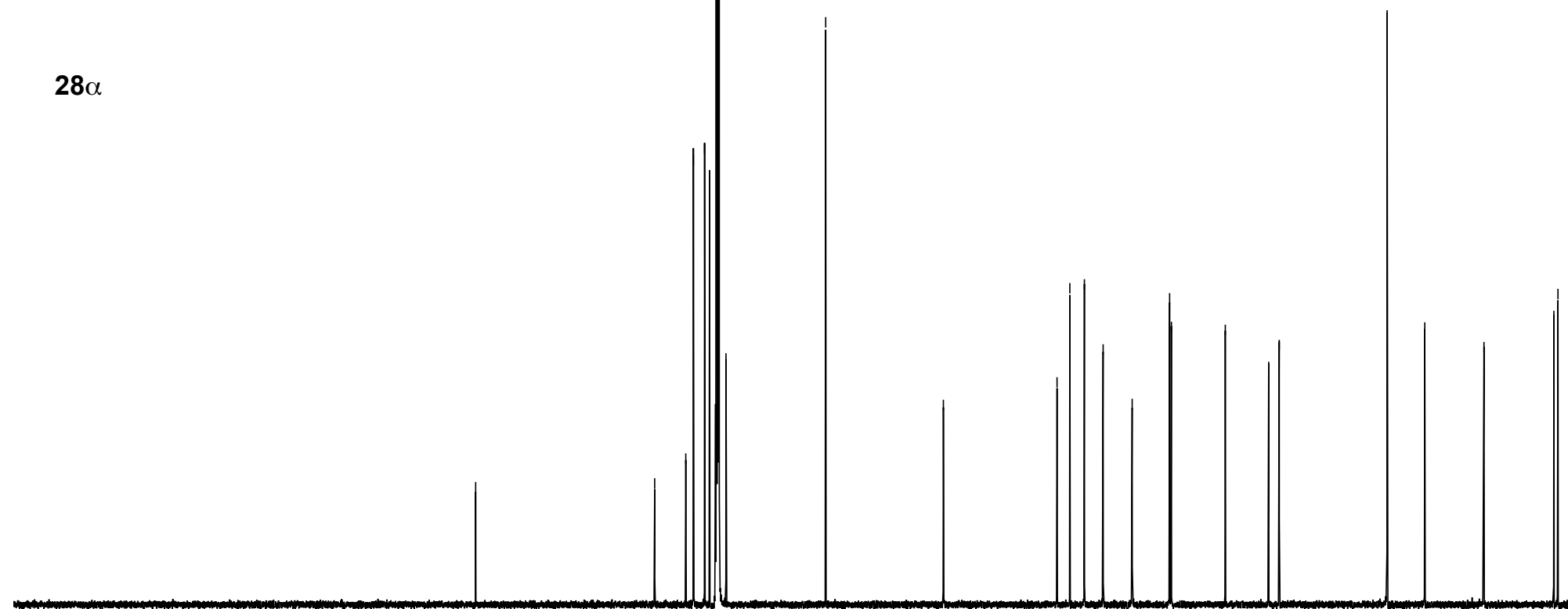

20

$210 \quad 200$

190

180

170

150

140

130

120

$110(\mathrm{ppm})$

Hoang et al. "General method for the synthesis of $\alpha$ - or $\beta$-deoxyaminoglycosides bearing

basic nitrogen" 


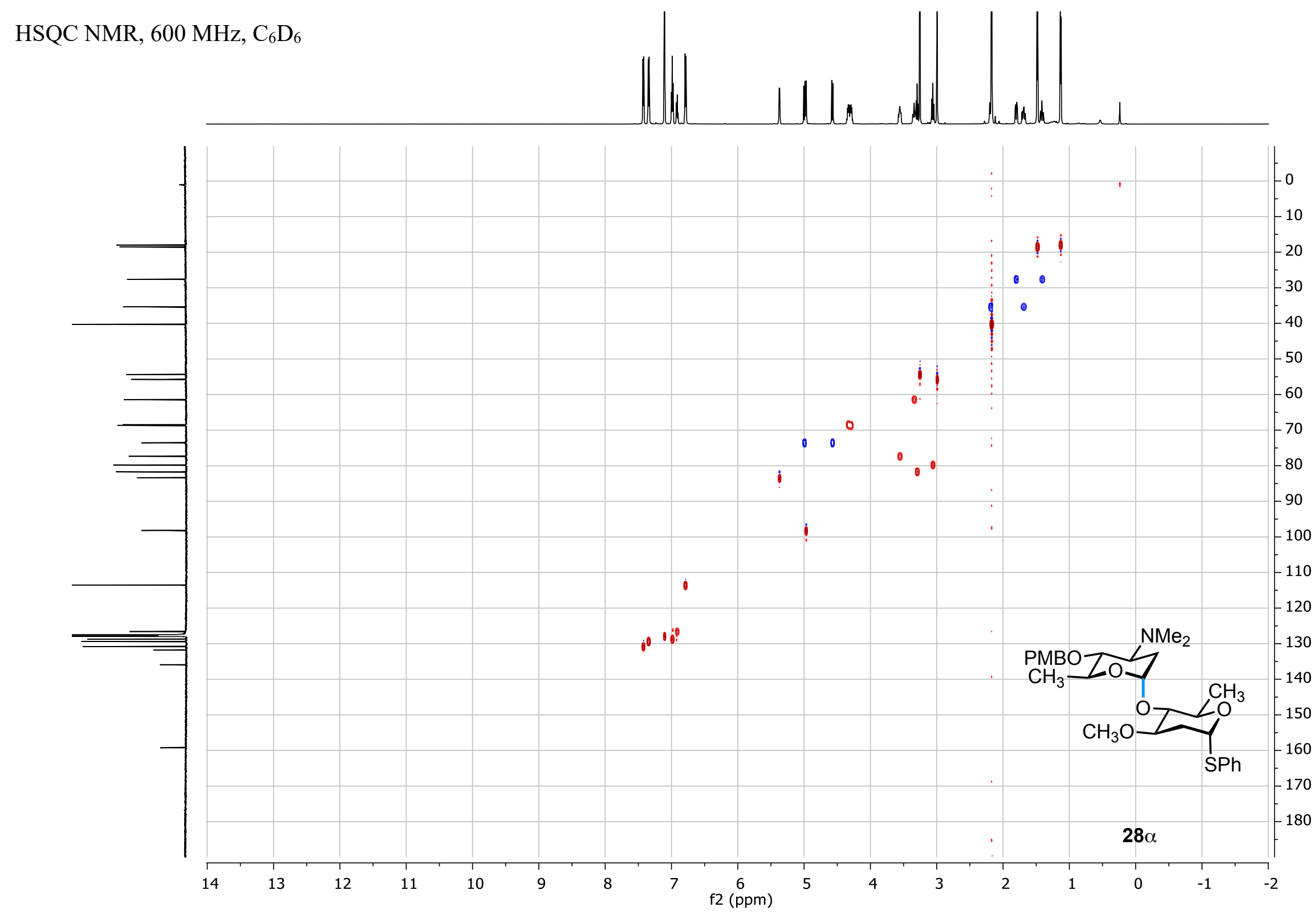

Hoang et al. "General method for the synthesis of $\alpha$ - or $\beta$-deoxyaminoglycosides bearing $\quad$ S187 basic nitrogen" 
${ }^{1} \mathrm{H}$ NMR, $600 \mathrm{MHz}, \mathrm{C}_{6} \mathrm{D}_{6}$
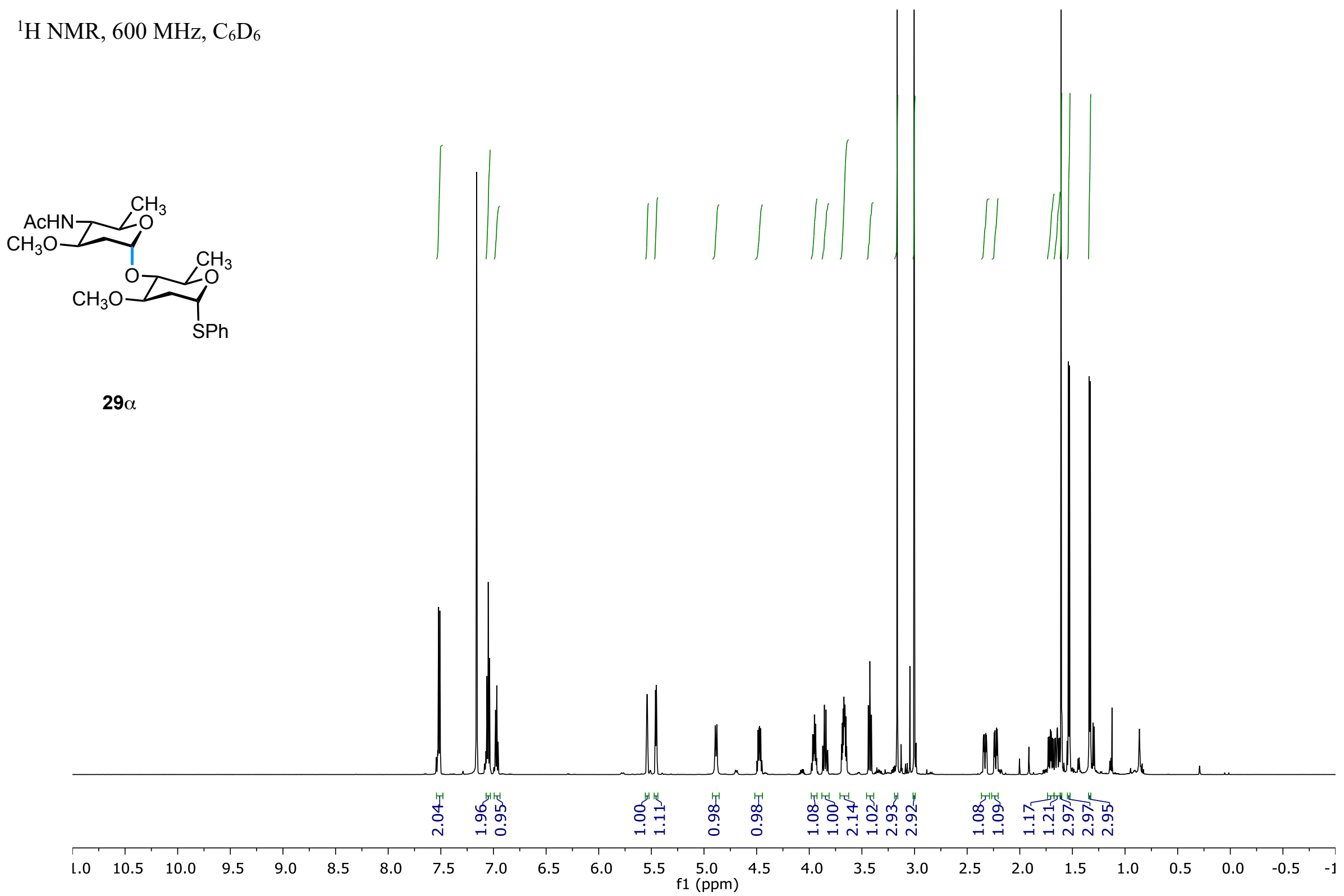

Hoang et al. "General method for the synthesis of $\alpha$ - or $\beta$-deoxyaminoglycosides bearing $\quad$ S188 basic nitrogen" 
${ }^{13} \mathrm{C} \mathrm{NMR}, 151 \mathrm{MHz}, \mathrm{C}_{6} \mathrm{D}_{6}$
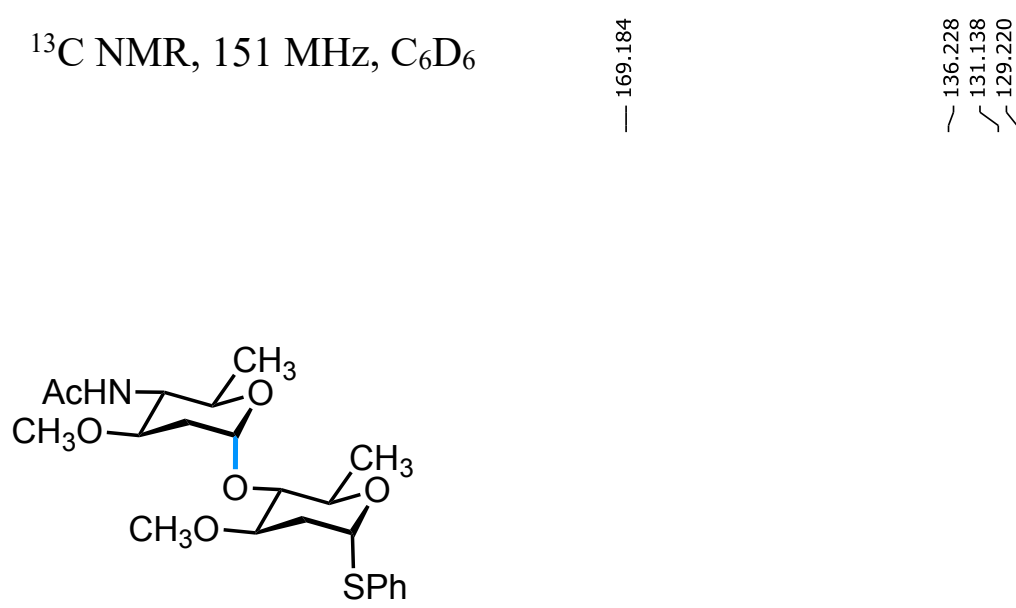

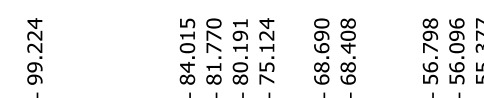

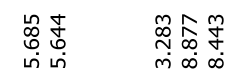

$29 \alpha$
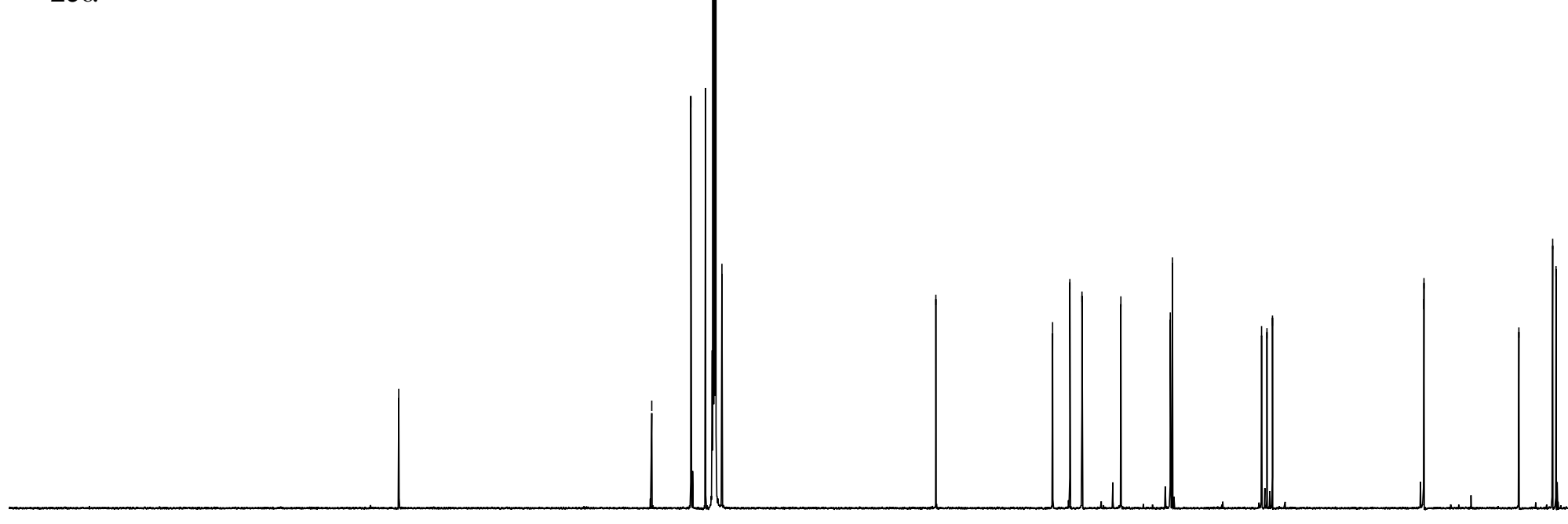


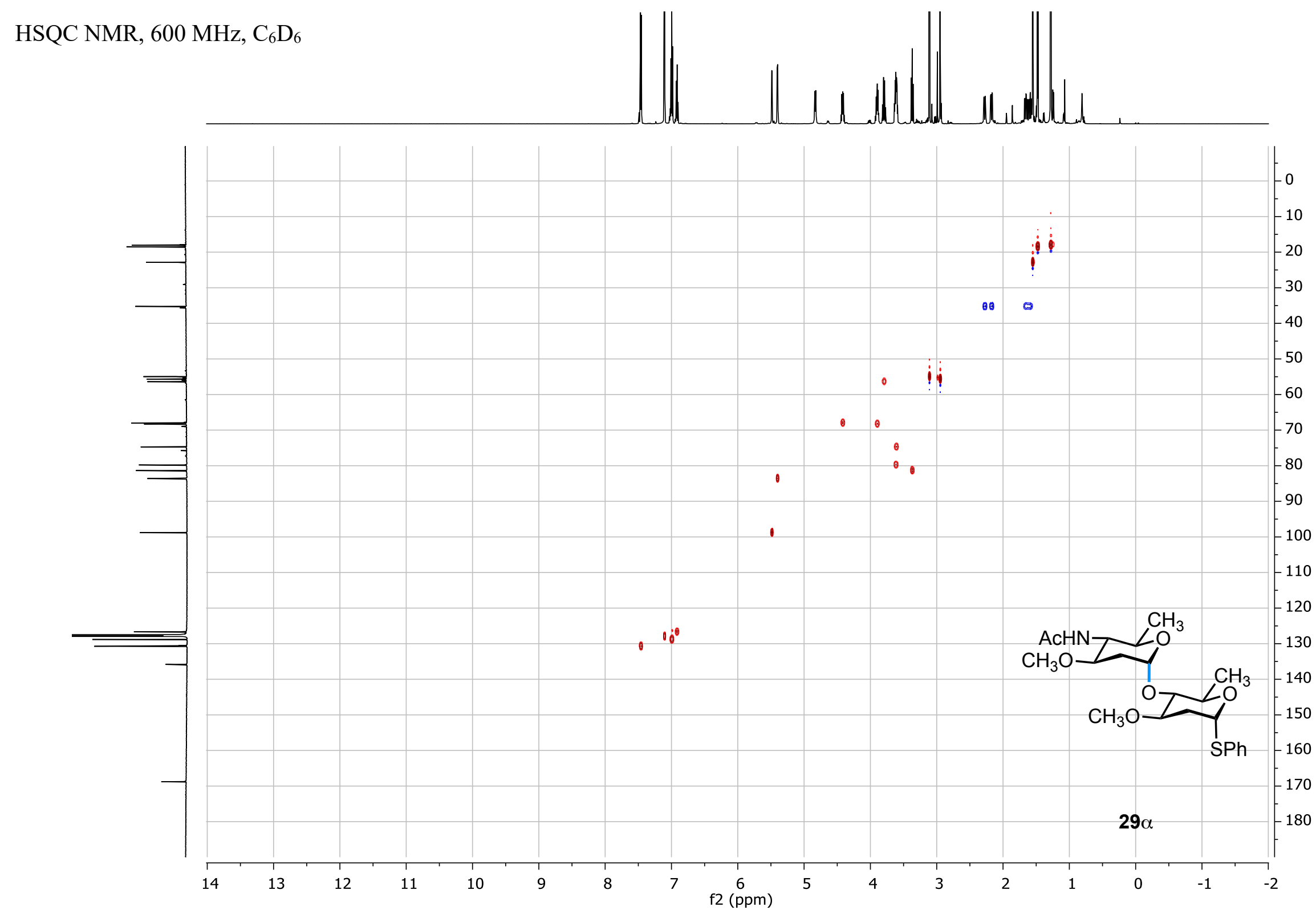

Hoang et al. "General method for the synthesis of $\alpha$ - or $\beta$-deoxyaminoglycosides bearing $\quad$ S190 basic nitrogen" 
${ }^{1} \mathrm{H} \mathrm{NMR}, 400 \mathrm{MHz}, \mathrm{CDCl}_{3}$
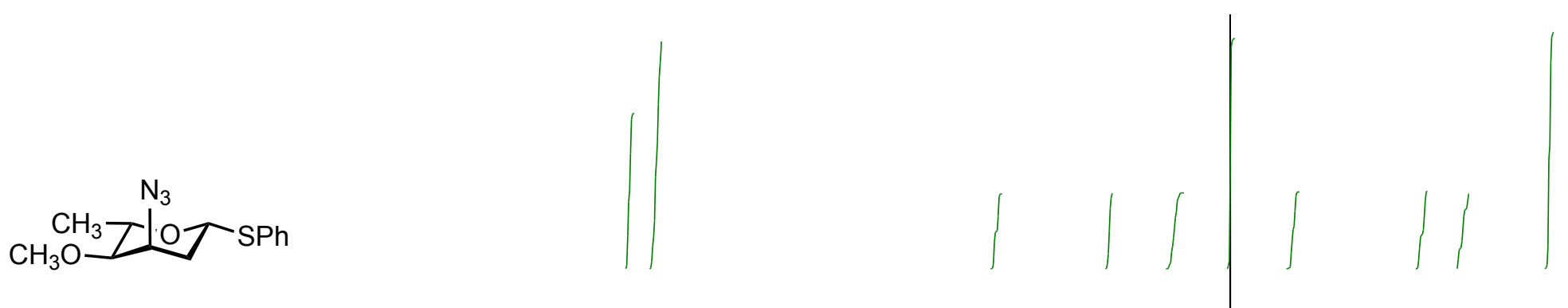

S16

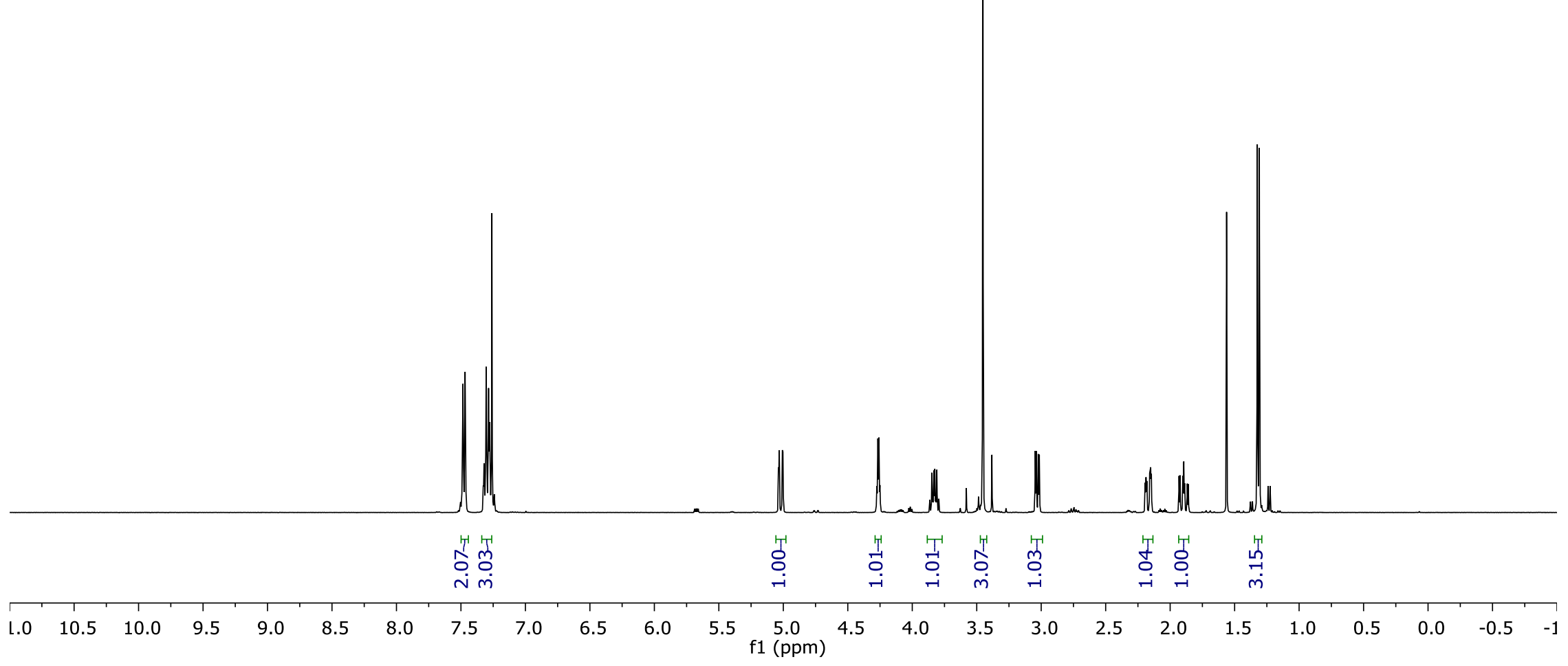

Hoang et al. "General method for the synthesis of $\alpha$ - or $\beta$-deoxyaminoglycosides bearing $\quad$ S191 basic nitrogen" 
${ }^{13} \mathrm{C} \mathrm{NMR}, 151 \mathrm{MHz}, \mathrm{CDCl}_{3}$

$\mathrm{CH}_{3} \mathrm{O} \mathrm{CH}^{\mathrm{N}} \mathrm{O}-\mathrm{SPh}^{\mathrm{N}}$
궁ํํ윯ำ

S16

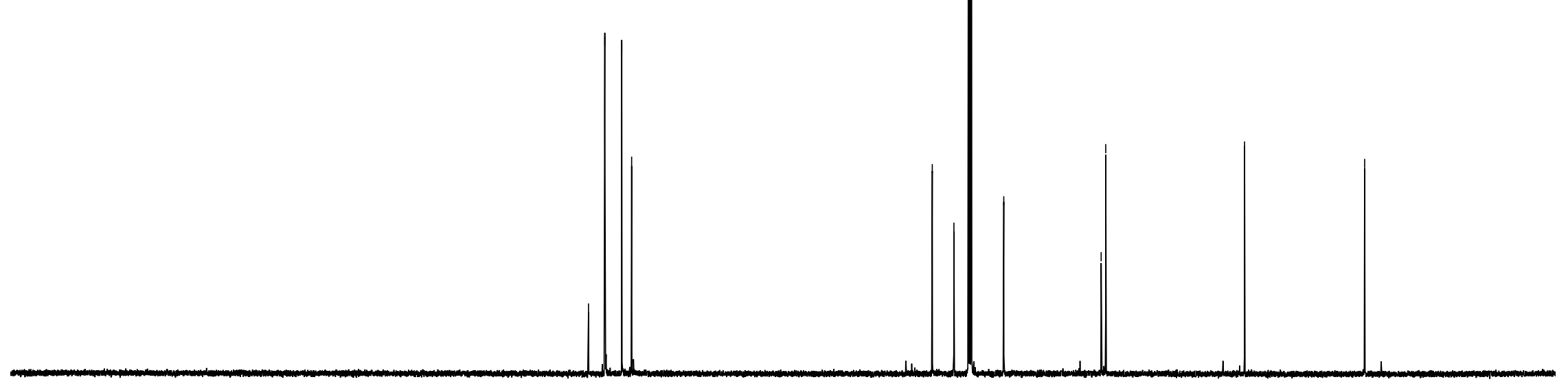


HSQC NMR, $600 \mathrm{MHz}, \mathrm{CDCl}_{3}$
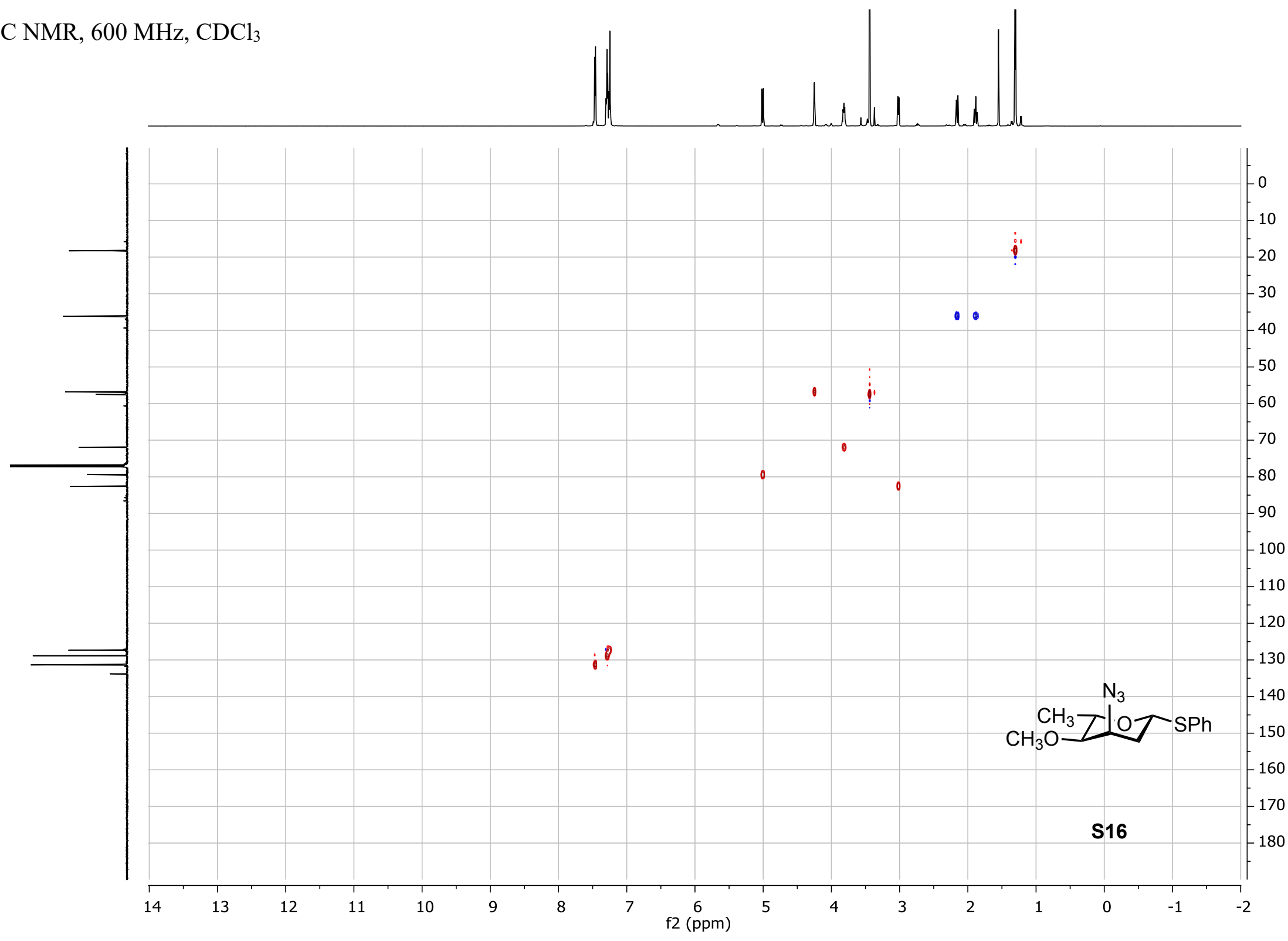

Hoang et al. "General method for the synthesis of $\alpha$ - or $\beta$-deoxyaminoglycosides bearing

S193

basic nitrogen" 


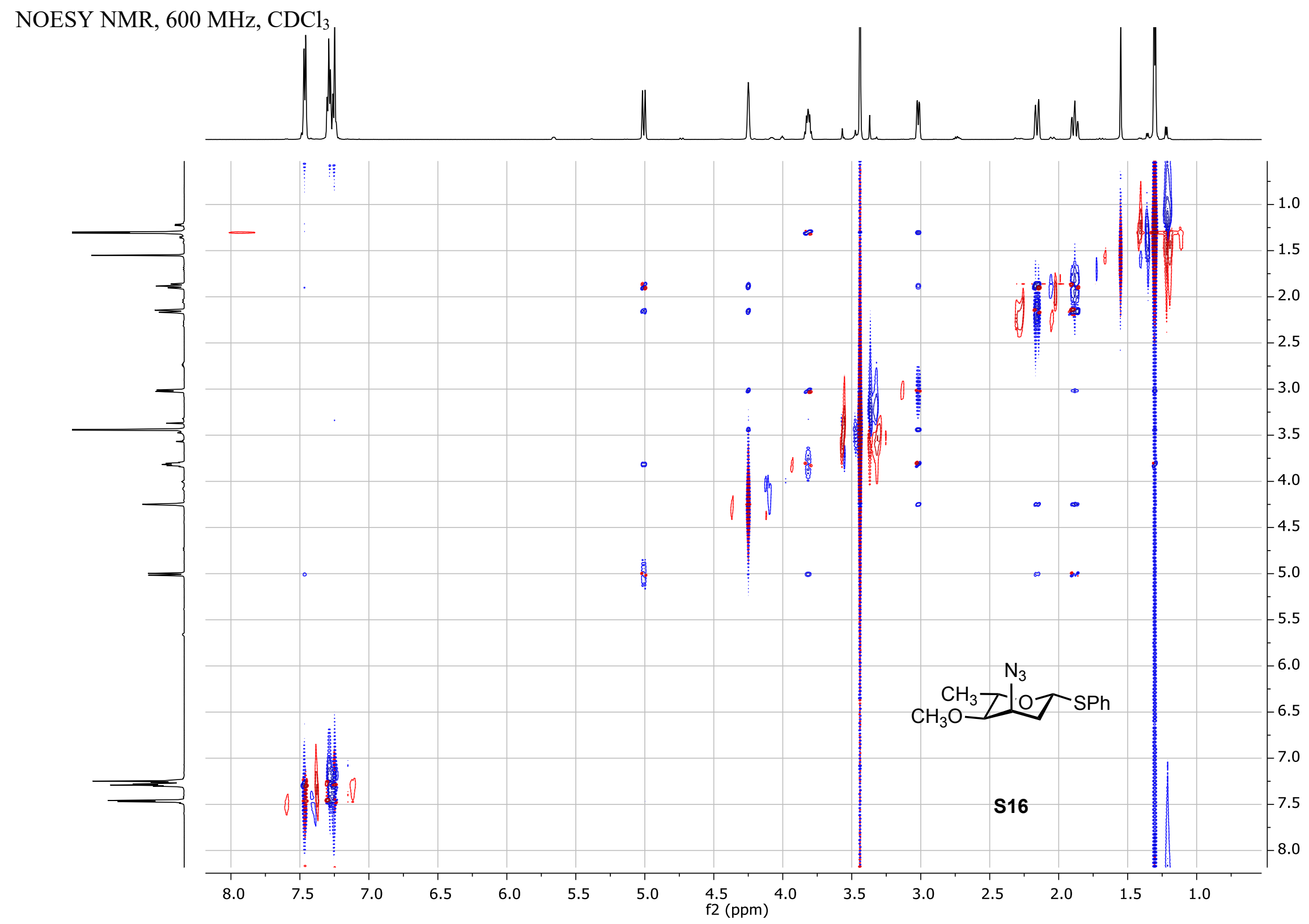

Hoang et al. "General method for the synthesis of $\alpha$ - or $\beta$-deoxyaminoglycosides bearing S194 basic nitrogen" 
${ }^{1} \mathrm{H} \mathrm{NMR}, 600 \mathrm{MHz}, \mathrm{CDCl}_{3}$
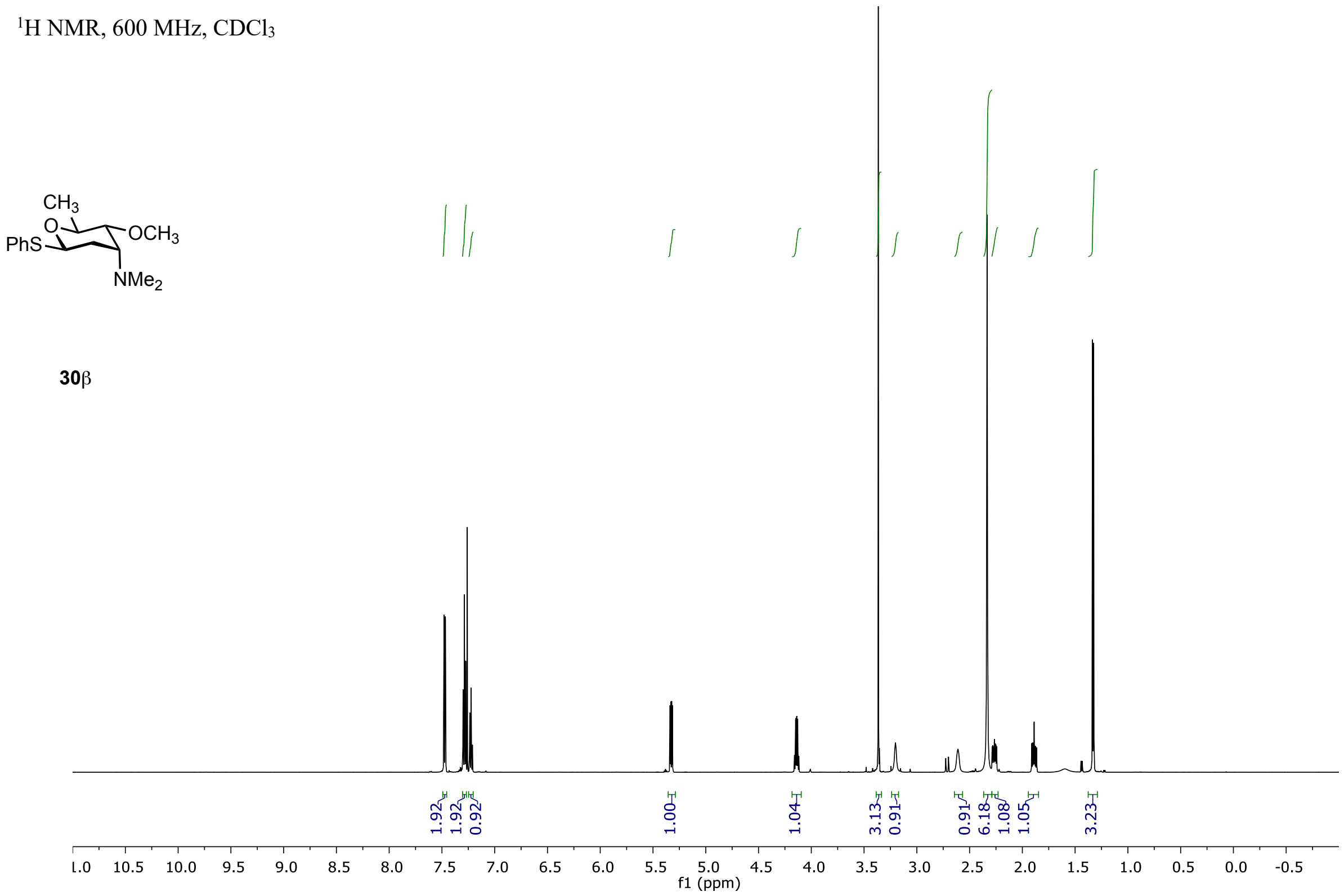

$30 \beta$

Hoang et al. "General method for the synthesis of $\alpha$ - or $\beta$-deoxyaminoglycosides bearing

S195

basic nitrogen" 
${ }^{13} \mathrm{C} \mathrm{NMR,} 151 \mathrm{MHz}, \mathrm{CDCl}_{3}$

$\mathrm{CH}_{3}$

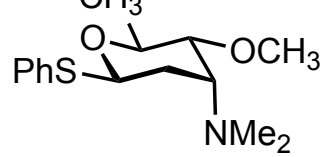

$30 \beta$

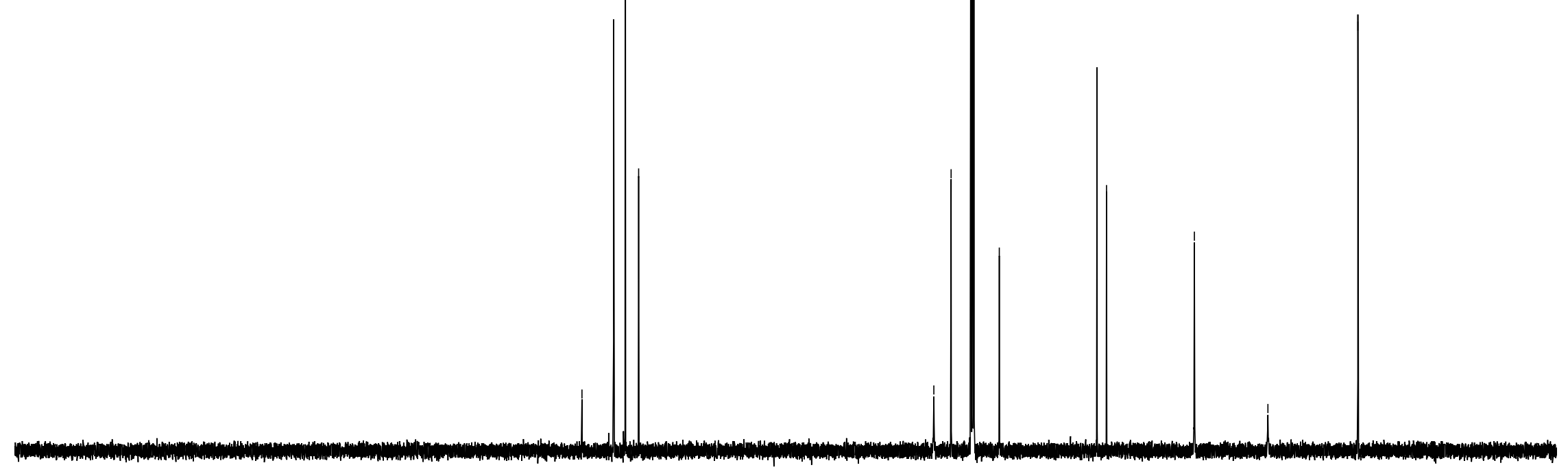

$20 \quad 210$

200

190

$\begin{array}{llll}170 & 160 & 150 & 140\end{array}$

130

120

$110 \quad 100$

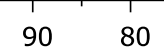

$70 \quad 60$

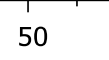

$40 \quad 30 \quad 20$

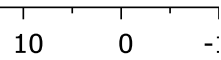

Hoang et al. "General method for the synthesis of $\alpha$ - or $\beta$-deoxyaminoglycosides bearing

basic nitrogen" 
HSQC NMR, $600 \mathrm{MHz}, \mathrm{CDCl}_{3}$
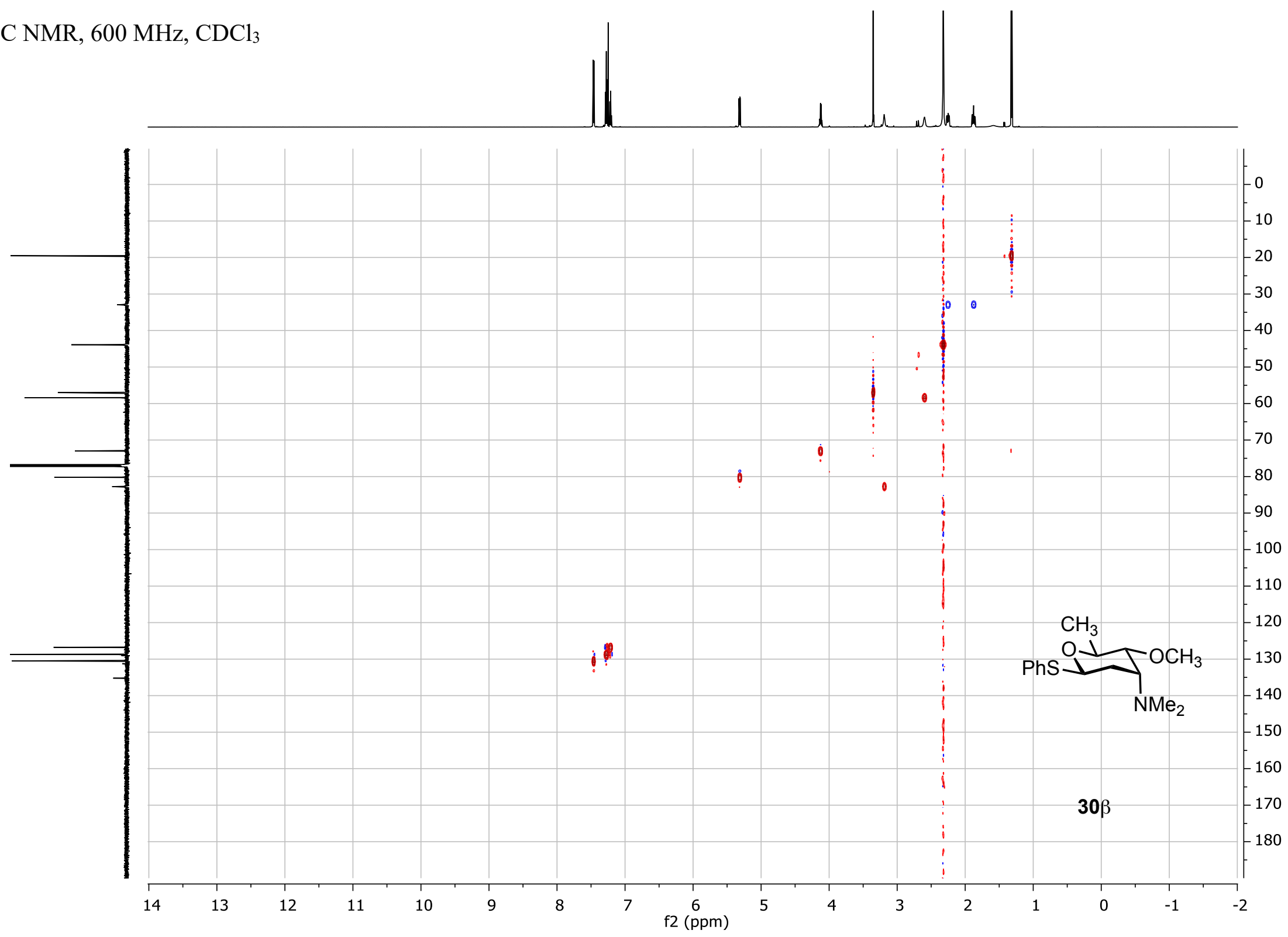

Hoang et al. "General method for the synthesis of $\alpha$ - or $\beta$-deoxyaminoglycosides bearing

S197 basic nitrogen" 
NOESY NMR, $600 \mathrm{MHz}, \mathrm{CDCl}_{3}$

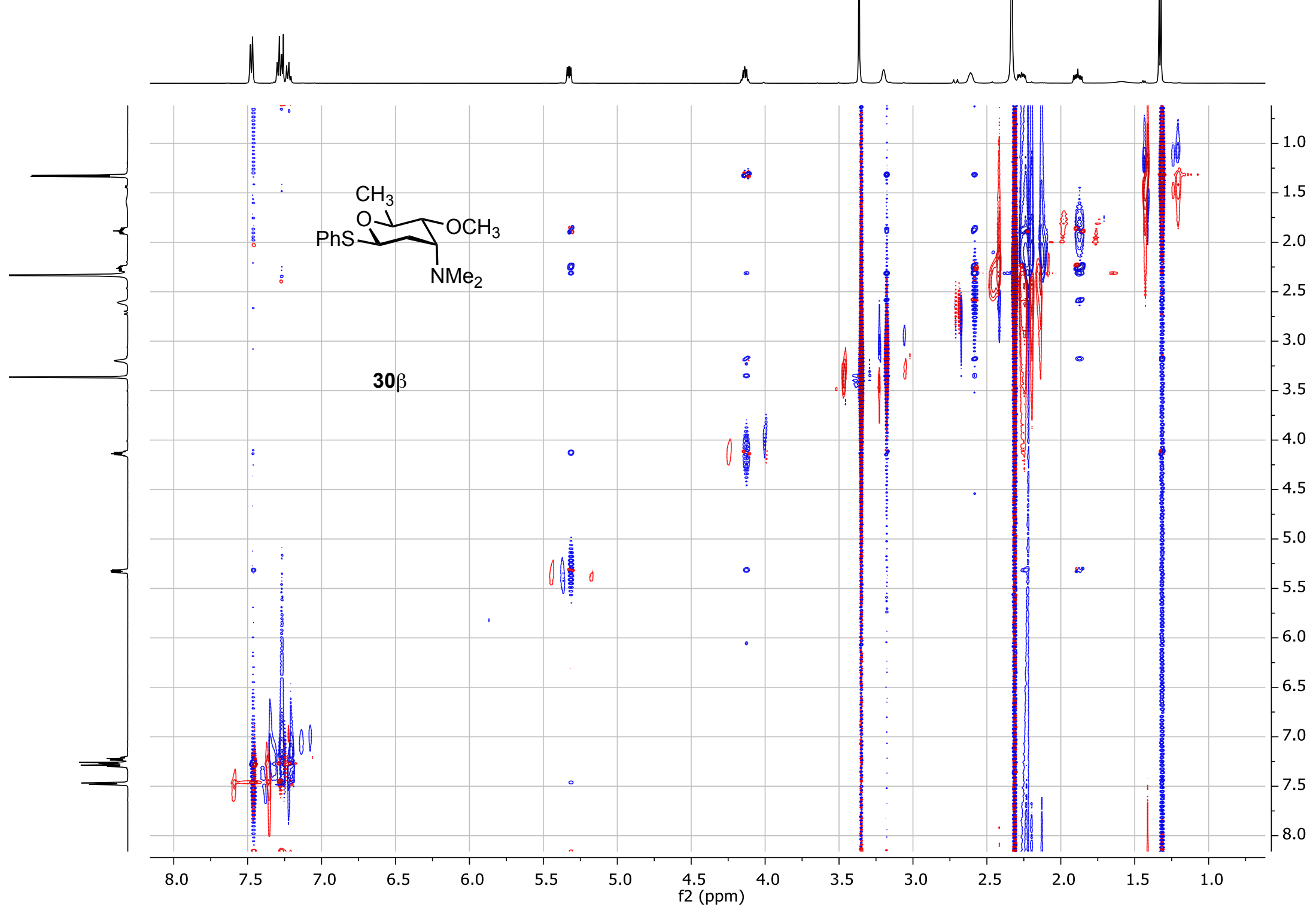

हैㅡㅡㄹ

Hoang et al. "General method for the synthesis of $\alpha$ - or $\beta$-deoxyaminoglycosides bearing $\quad$ S198 basic nitrogen" 
${ }^{1} \mathrm{H} \mathrm{NMR}, 400 \mathrm{MHz}, \mathrm{CDCl}_{3}$
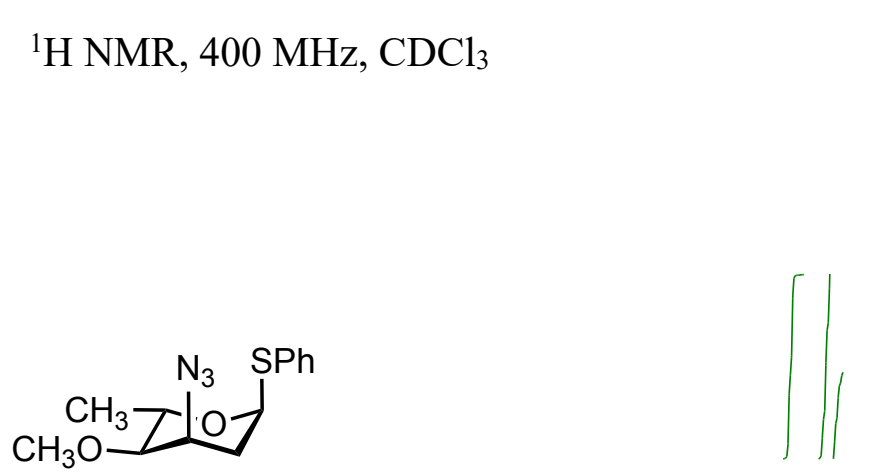

S17

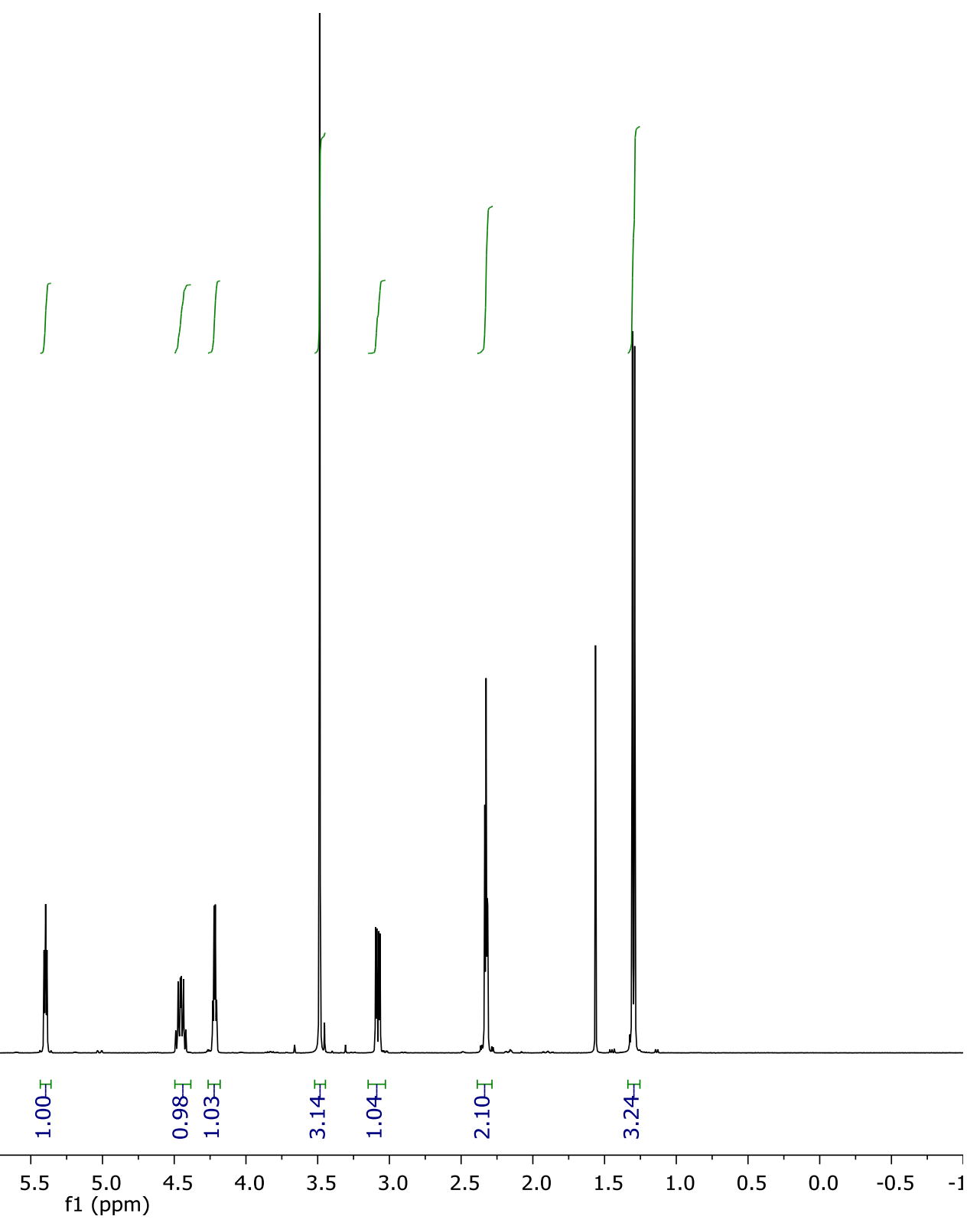

Hoang et al. "General method for the synthesis of $\alpha$ - or $\beta$-deoxyaminoglycosides bearing

S199

basic nitrogen" 
${ }^{13} \mathrm{C} \mathrm{NMR,} 151 \mathrm{MHz}, \mathrm{CDCl}_{3}$

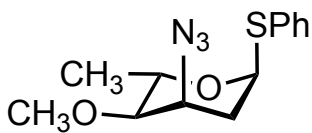

S17

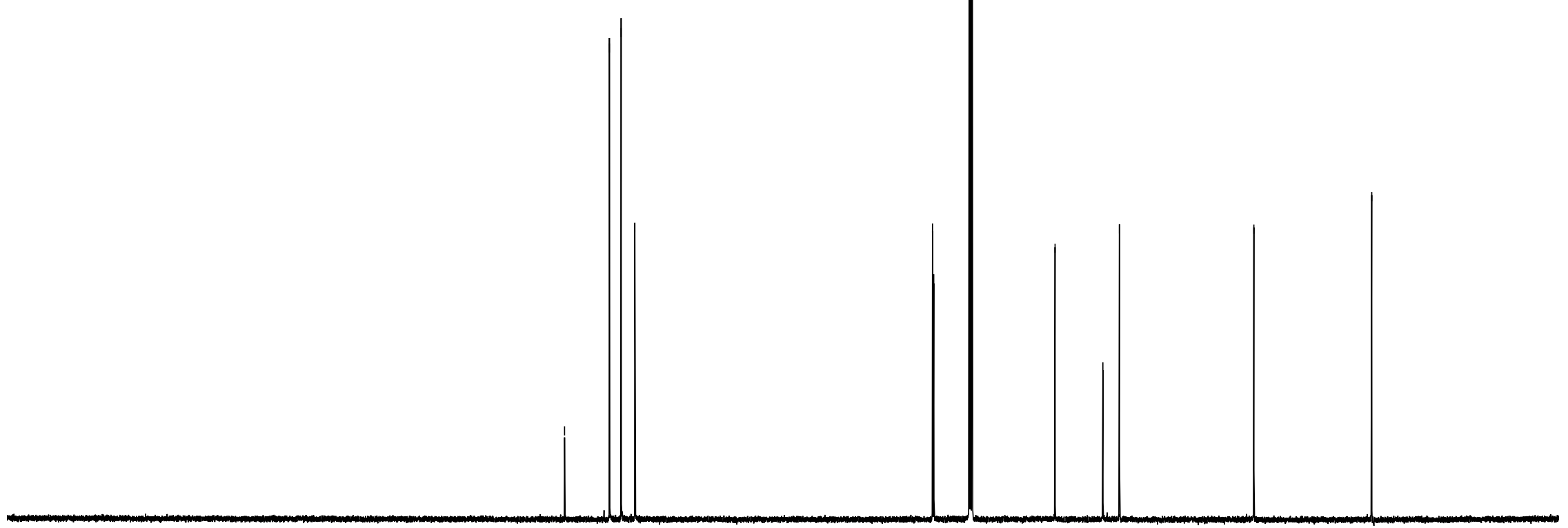

Hoang et al. "General method for the synthesis of $\alpha$ - or $\beta$-deoxyaminoglycosides bearing basic nitrogen" 
HSQC NMR, $600 \mathrm{MHz}, \mathrm{CDCl}_{3}$
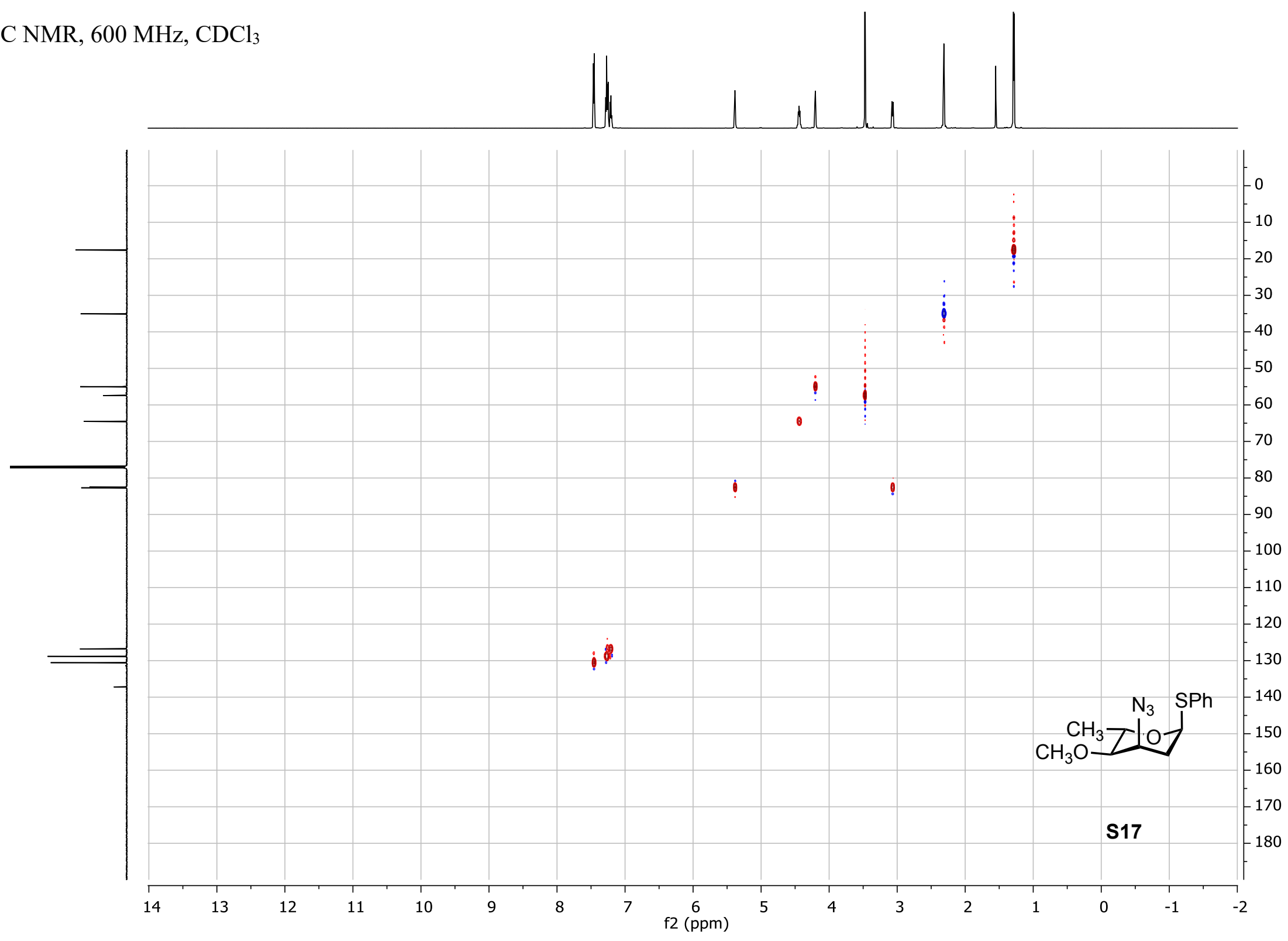

Hoang et al. "General method for the synthesis of $\alpha$ - or $\beta$-deoxyaminoglycosides bearing

S201

basic nitrogen" 


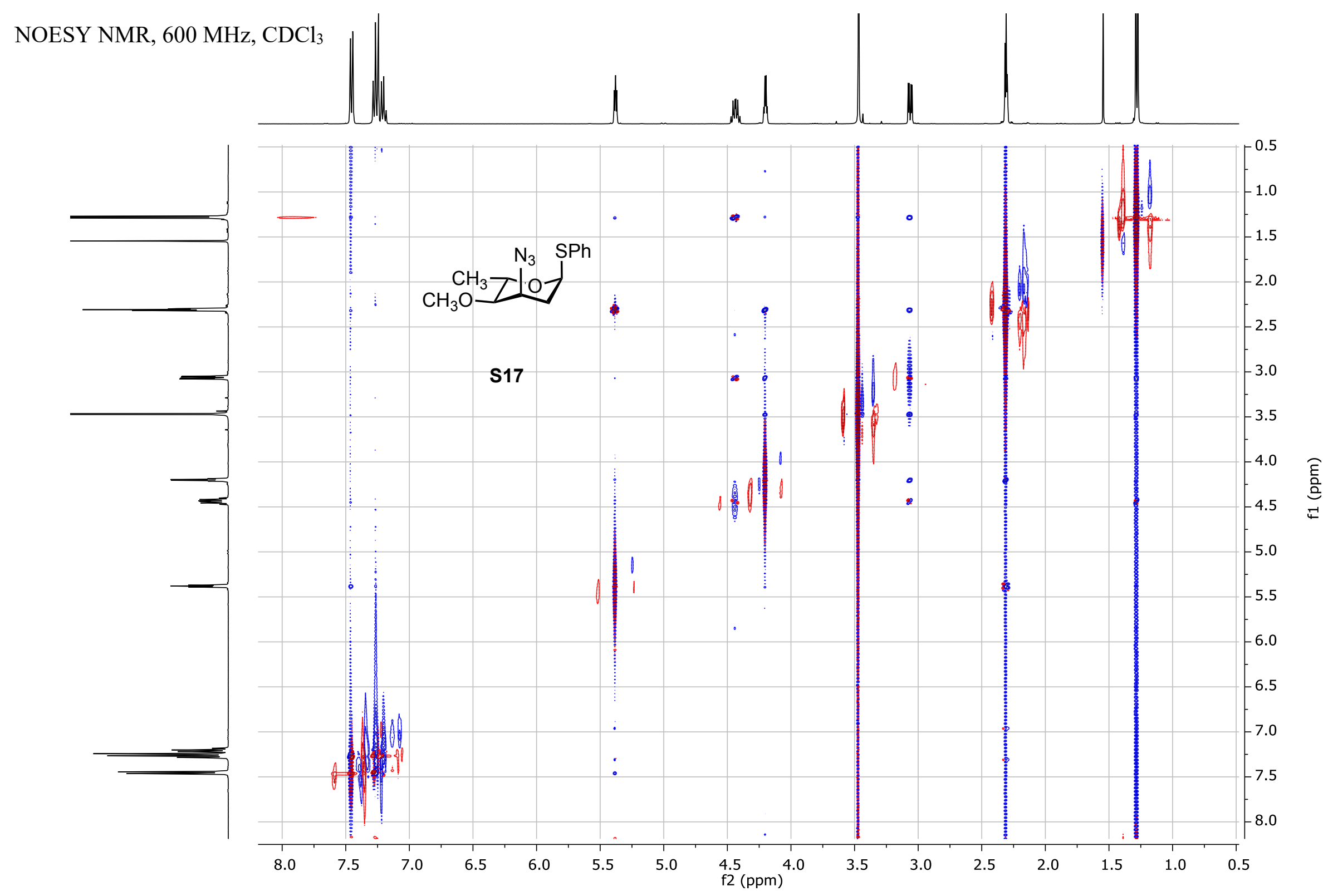

Hoang et al. "General method for the synthesis of $\alpha$ - or $\beta$-deoxyaminoglycosides bearing

S202 basic nitrogen" 
${ }^{1} \mathrm{H} \mathrm{NMR}, 400 \mathrm{MHz}, \mathrm{CDCl}_{3}$

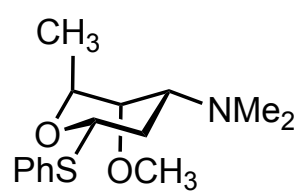

$30 \alpha$

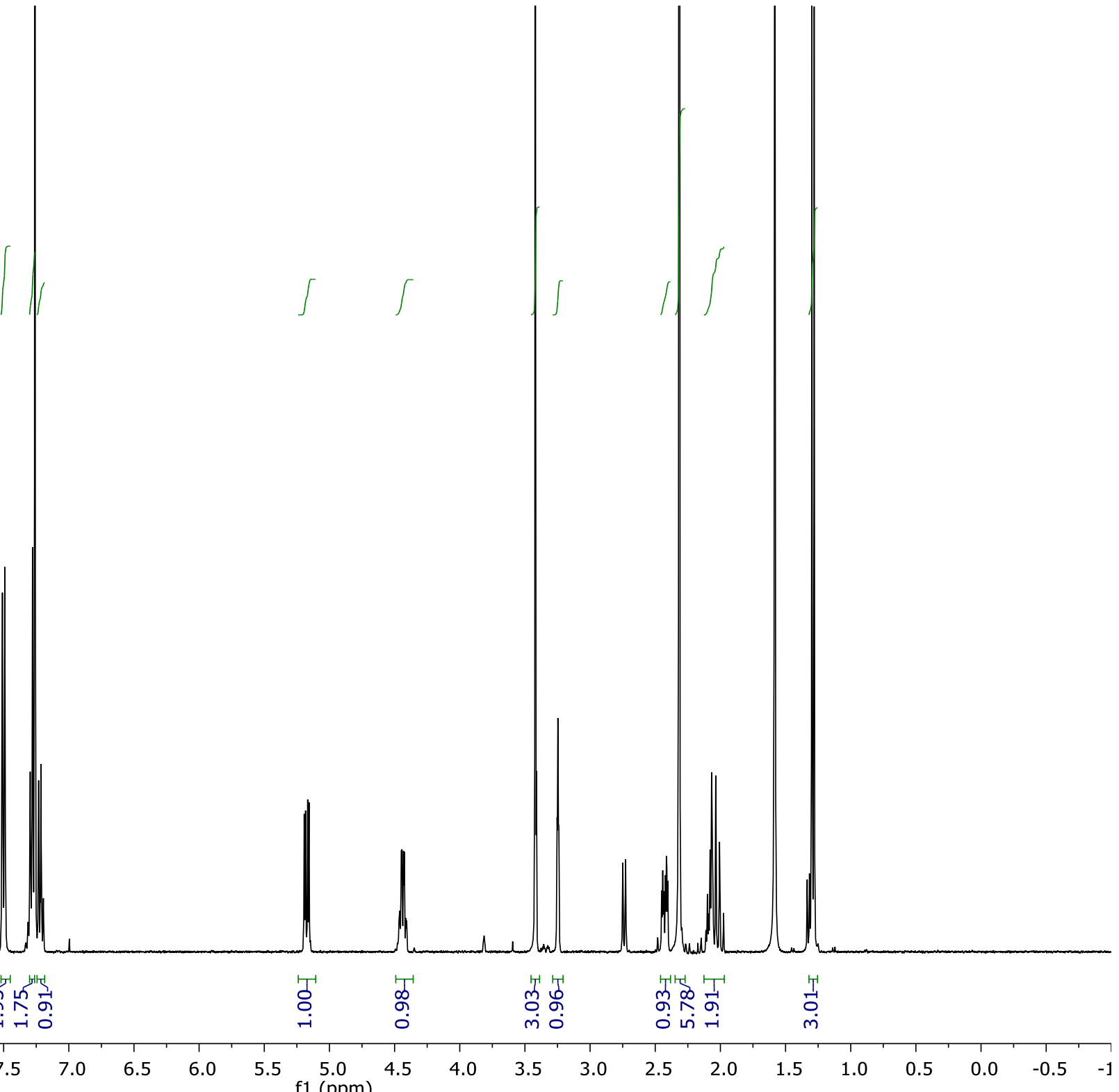

Hoang et al. "General method for the synthesis of $\alpha$ - or $\beta$-deoxyaminoglycosides bearing

S203

basic nitrogen" 
${ }^{13} \mathrm{C} \mathrm{NMR,} 151 \mathrm{MHz}, \mathrm{CDCl}_{3}$

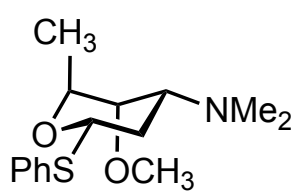

$30 \alpha$

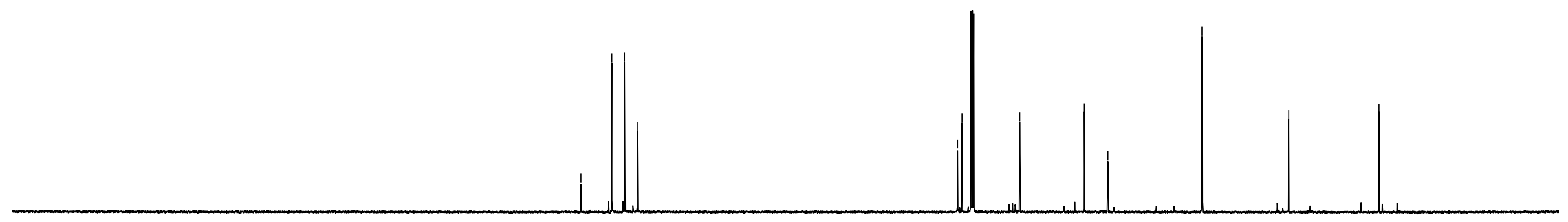


HSQC NMR, $600 \mathrm{MHz}, \mathrm{CDCl}_{3}$
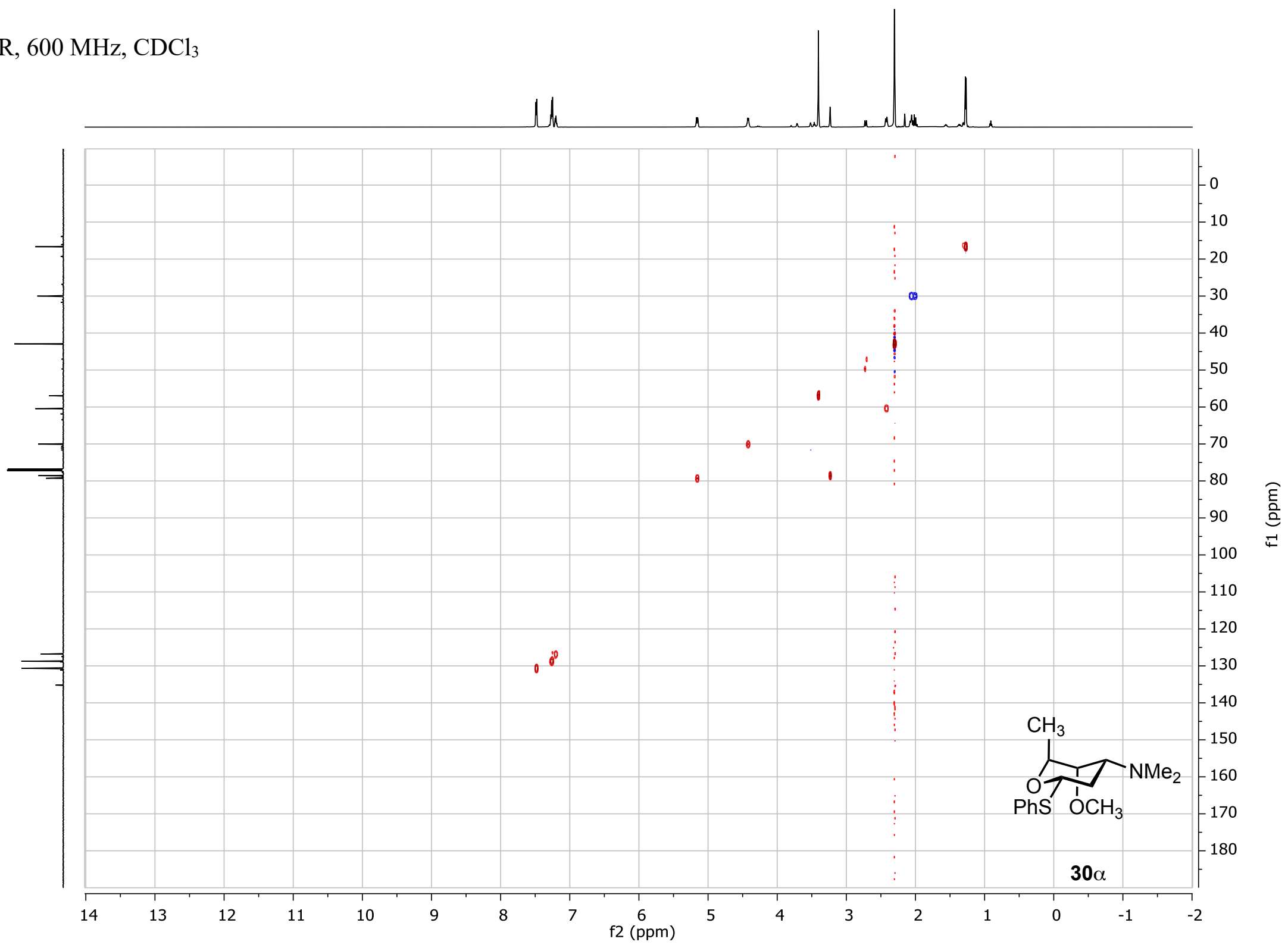

Hoang et al. "General method for the synthesis of $\alpha$ - or $\beta$-deoxyaminoglycosides bearing $\quad$ S205 basic nitrogen" 
NOESY NMR, $600 \mathrm{MHz}, \mathrm{CDCl}_{3}$

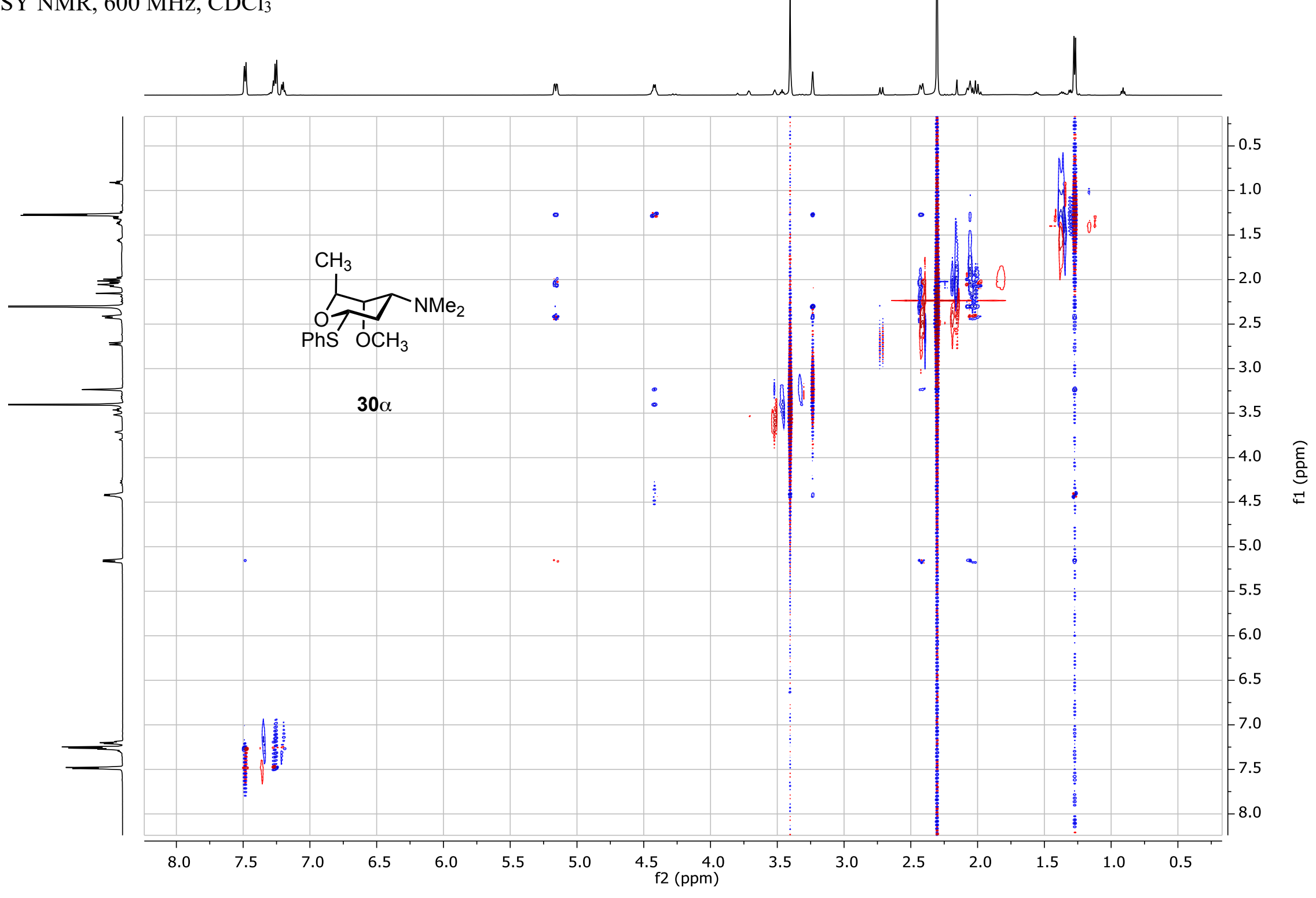

Hoang et al. "General method for the synthesis of $\alpha$ - or $\beta$-deoxyaminoglycosides bearing

S206 basic nitrogen" 
${ }^{1} \mathrm{H} \mathrm{NMR}, 600 \mathrm{MHz}, \mathrm{CDCl}_{3}$
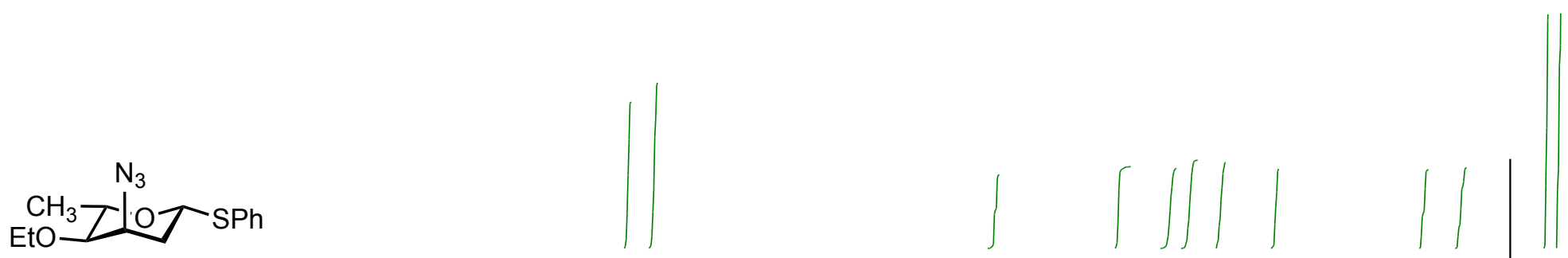

S18

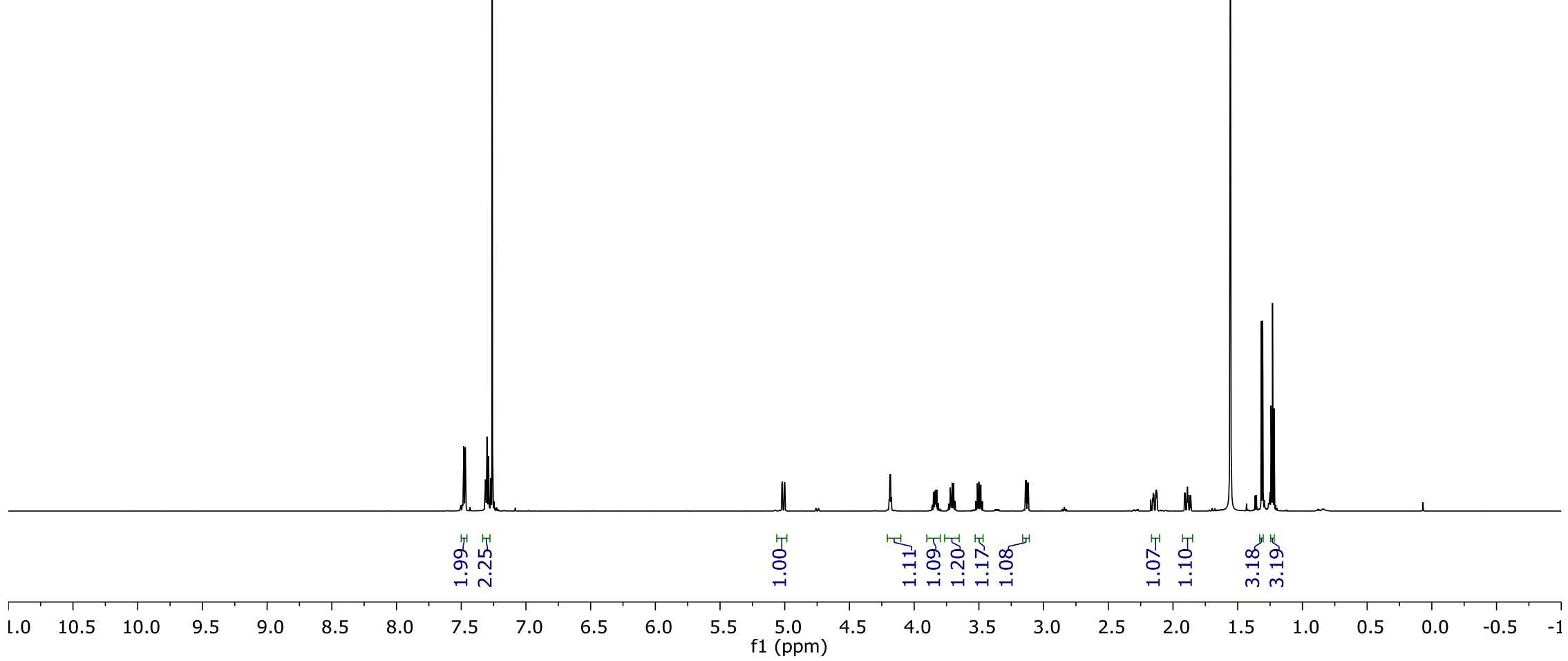

Hoang et al. "General method for the synthesis of $\alpha$ - or $\beta$-deoxyaminoglycosides bearing

S207

basic nitrogen" 
${ }^{13} \mathrm{C} \mathrm{NMR,} 151 \mathrm{MHz}, \mathrm{CDCl}_{3}$

${ }_{\mathrm{EtO}}^{\mathrm{CH}_{3}} \stackrel{\mathrm{N}_{3}}{\mathrm{SPh}}$

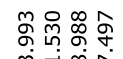



S18

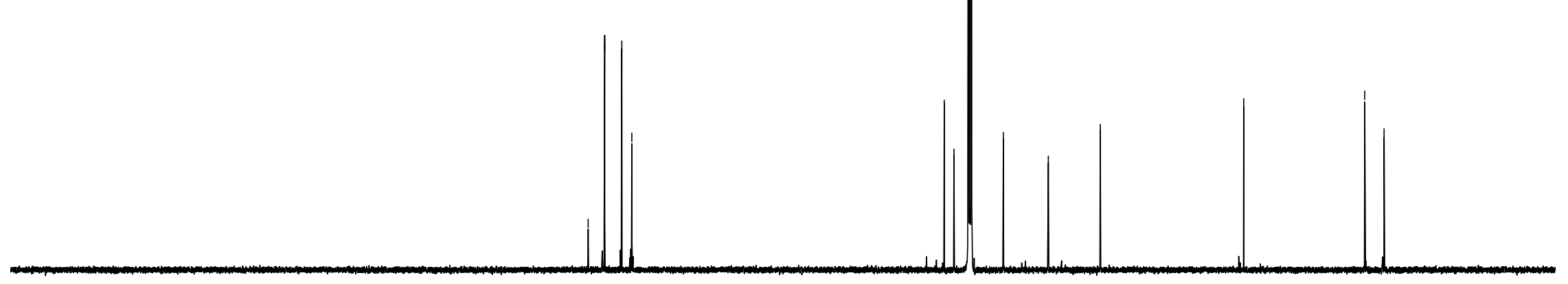

20 200 
HSQC NMR, $600 \mathrm{MHz}, \mathrm{CDCl}_{3}$
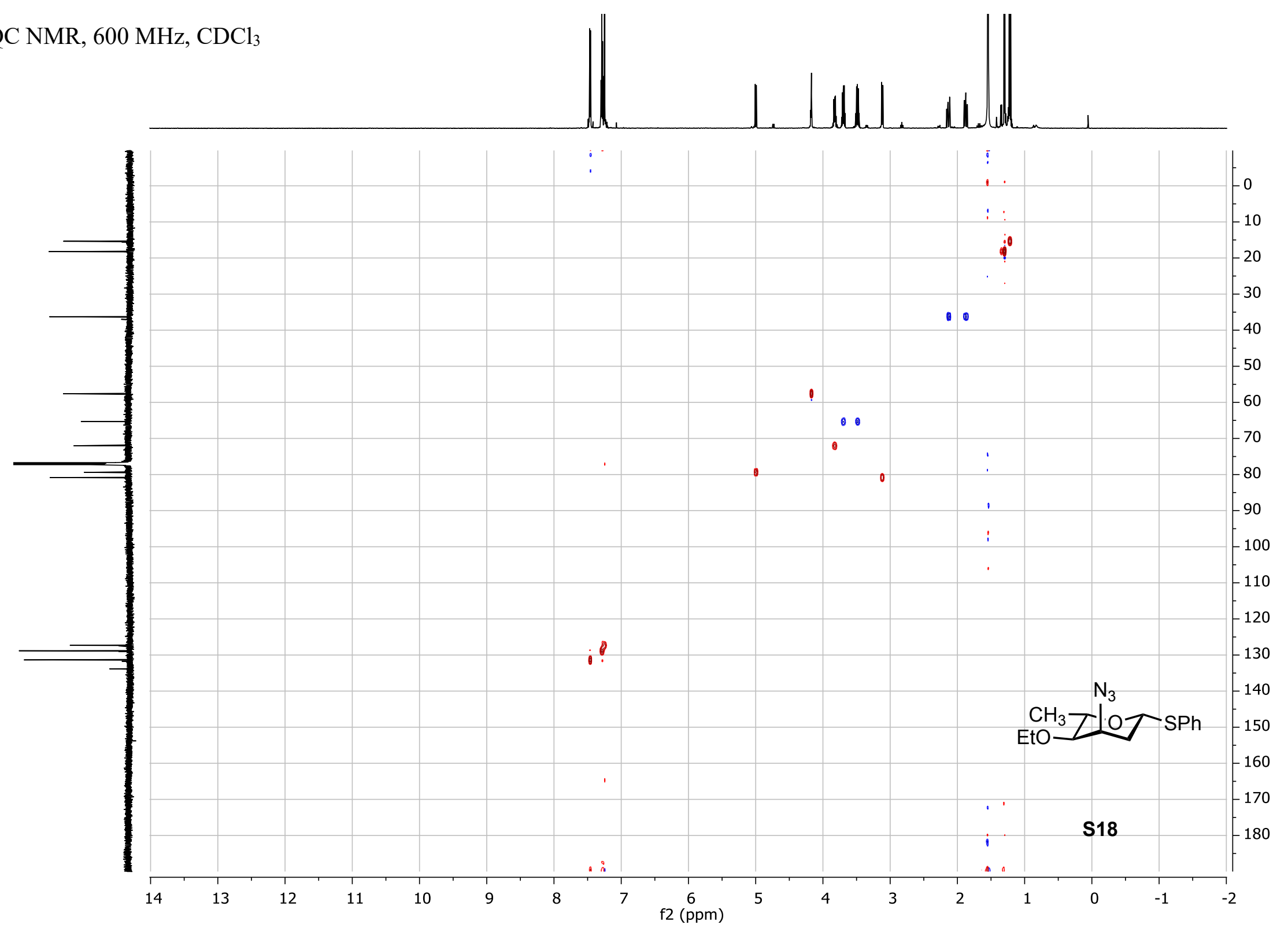

Hoang et al. "General method for the synthesis of $\alpha$ - or $\beta$-deoxyaminoglycosides bearing

S209

basic nitrogen" 
${ }^{1} \mathrm{H}$ NMR, $600 \mathrm{MHz}, \mathrm{C}_{6} \mathrm{D}_{6}$
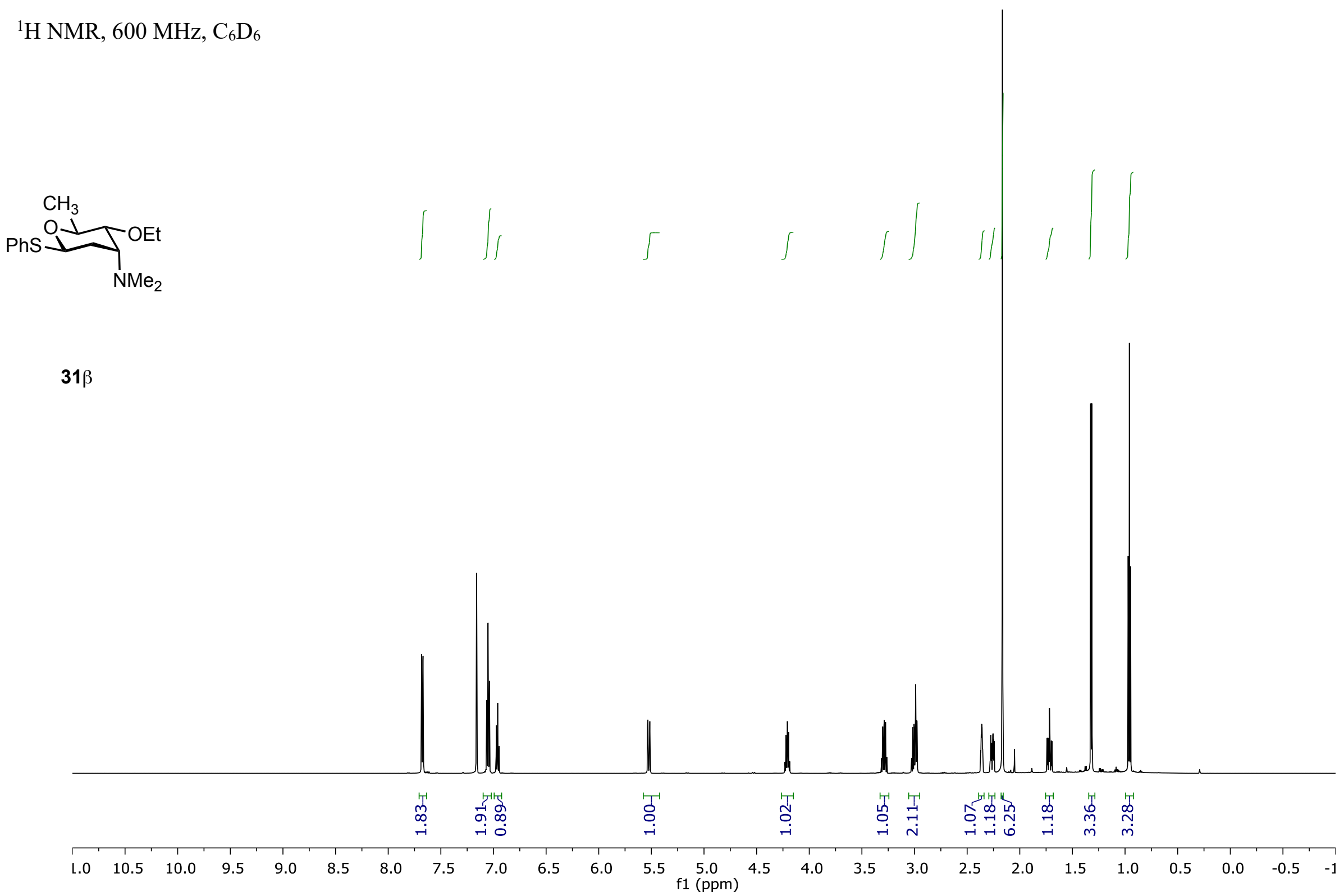

$31 \beta$

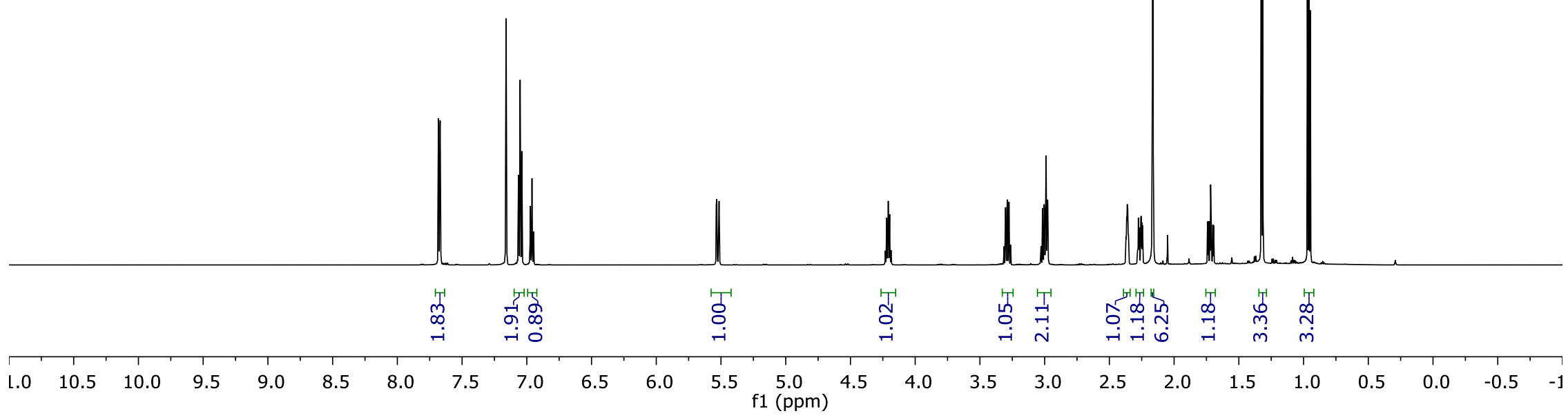

Hoang et al. "General method for the synthesis of $\alpha$ - or $\beta$-deoxyaminoglycosides bearing $\quad$ S210 basic nitrogen" 

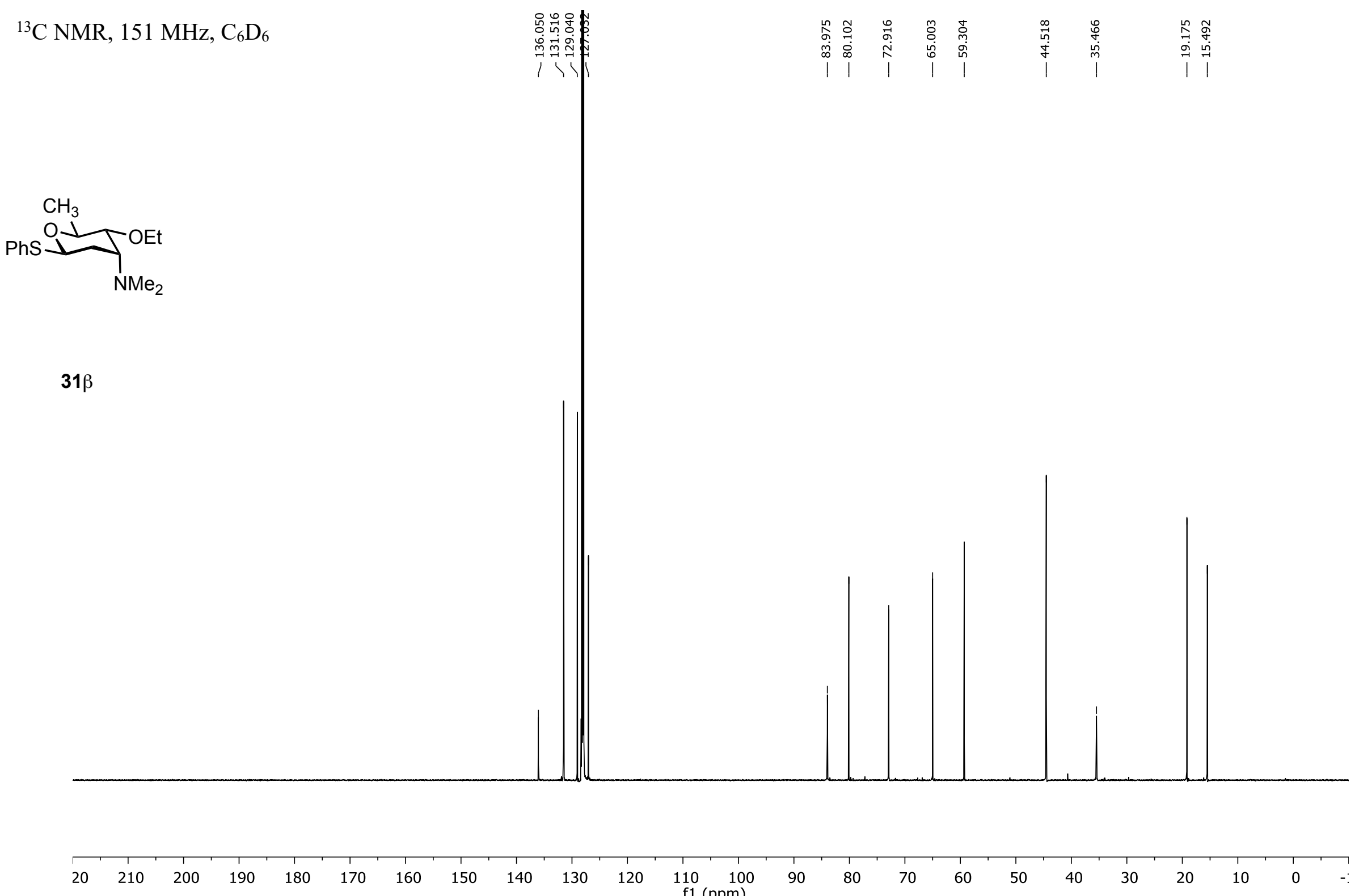

Hoang et al. "General method for the synthesis of $\alpha$ - or $\beta$-deoxyaminoglycosides bearing $\quad$ S211

basic nitrogen" 
HSQC NMR, $600 \mathrm{MHz}, \mathrm{C}_{6} \mathrm{D}_{6}$
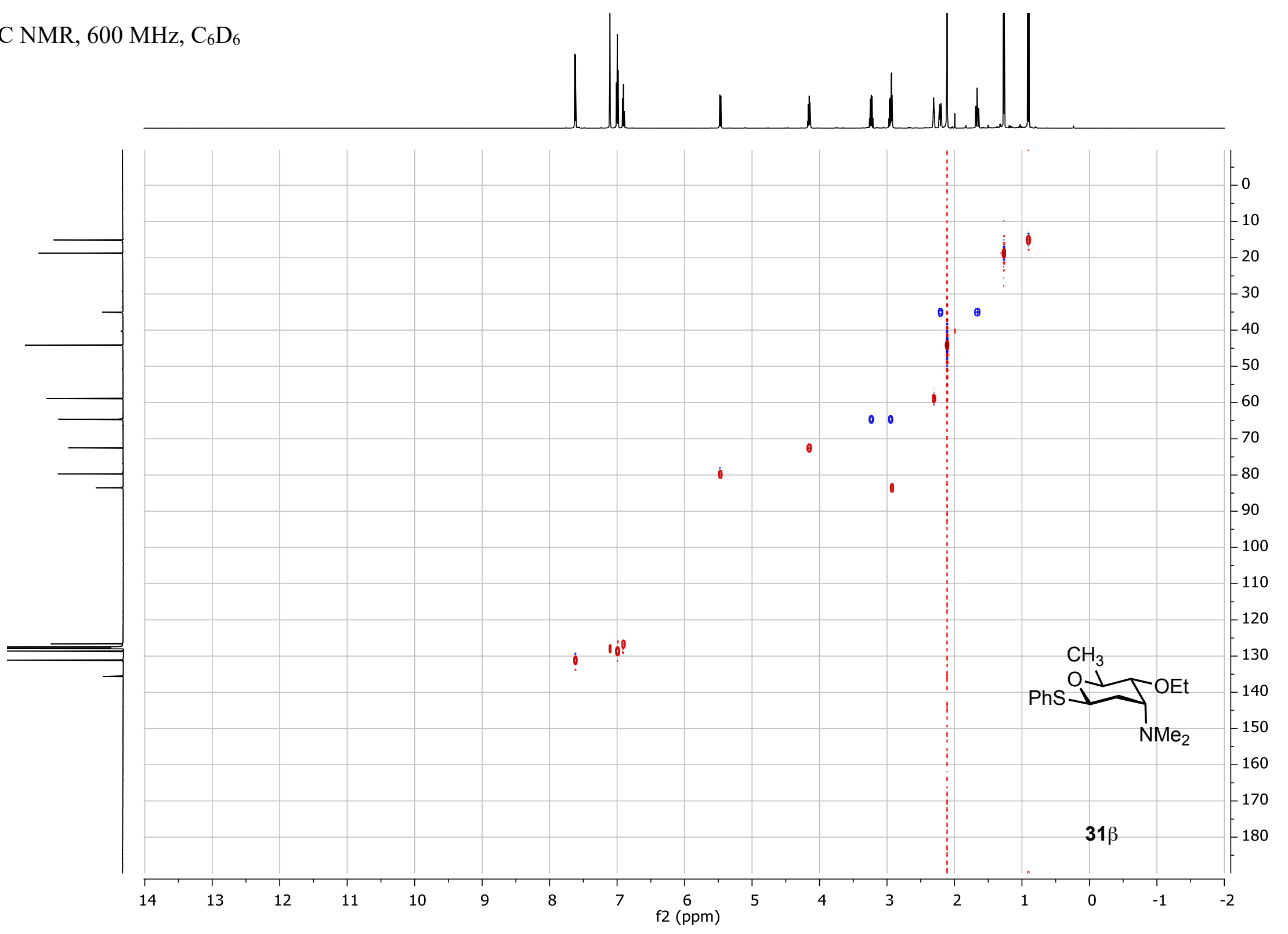

Hoang et al. "General method for the synthesis of $\alpha$ - or $\beta$-deoxyaminoglycosides bearing $\quad$ S212 basic nitrogen" 


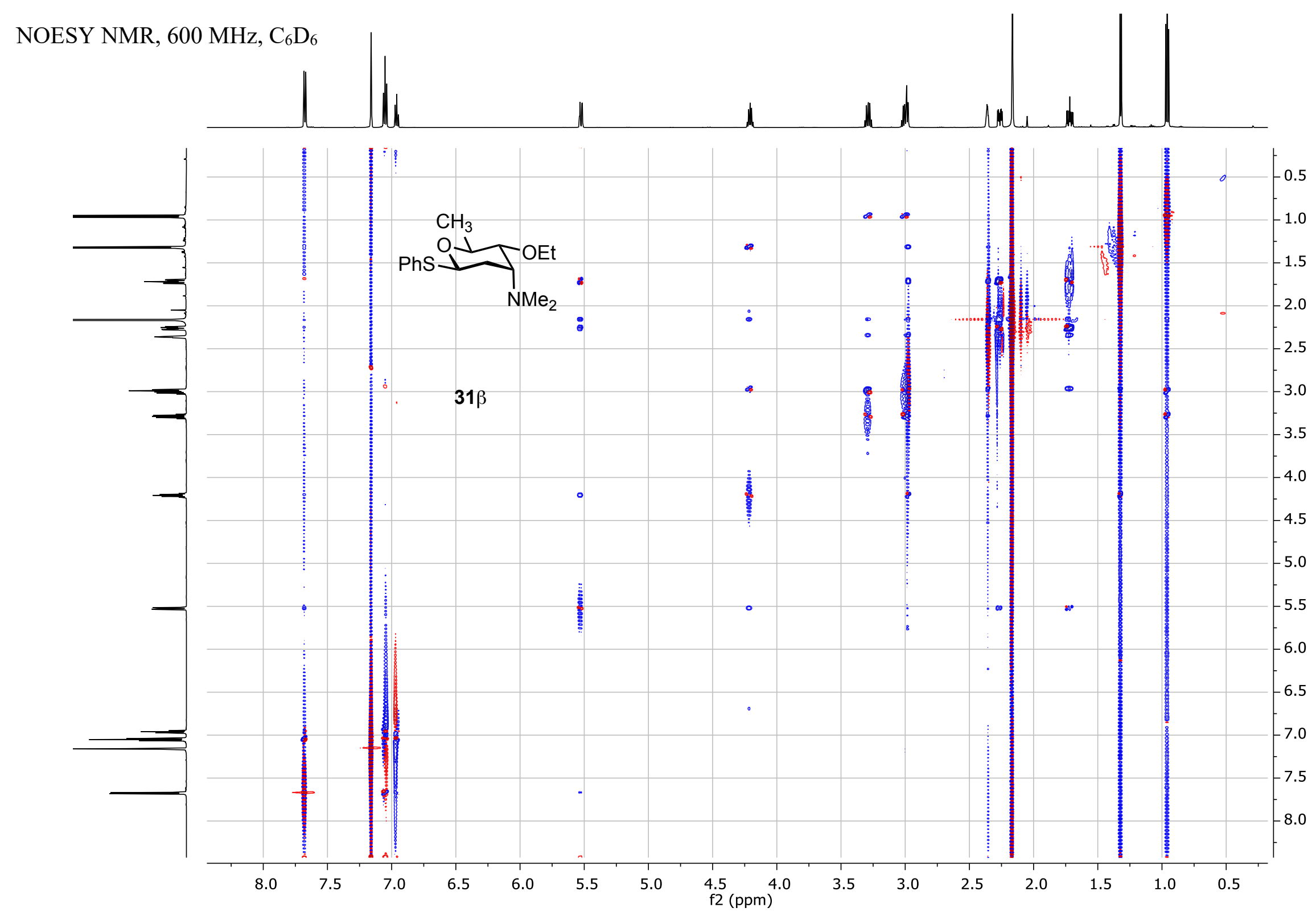

Hoang et al. "General method for the synthesis of $\alpha$ - or $\beta$-deoxyaminoglycosides bearing $\quad$ S213 basic nitrogen" 
${ }^{1} \mathrm{H} \mathrm{NMR}, 500 \mathrm{MHz}, \mathrm{CDCl}_{3}$
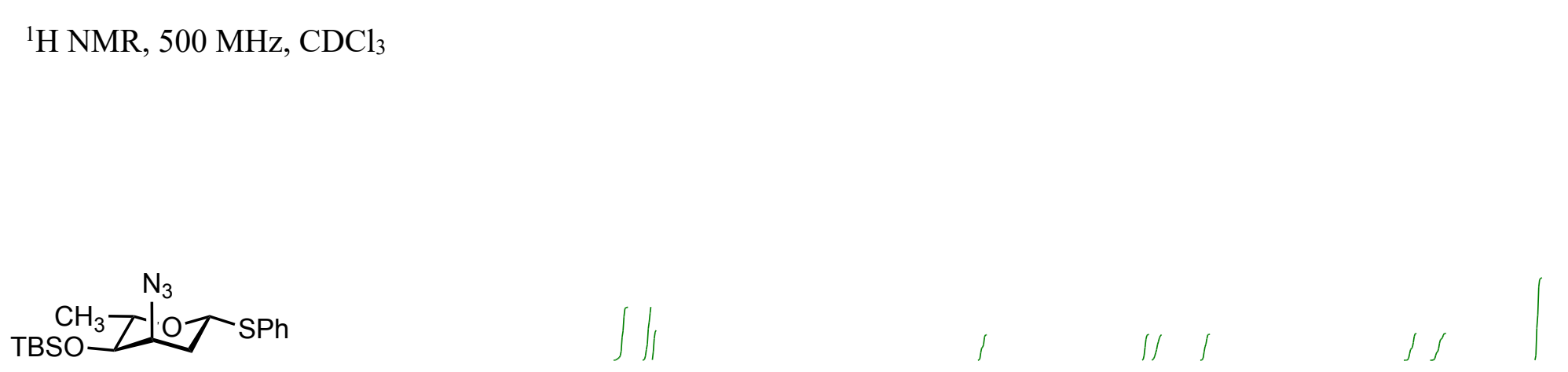

S19

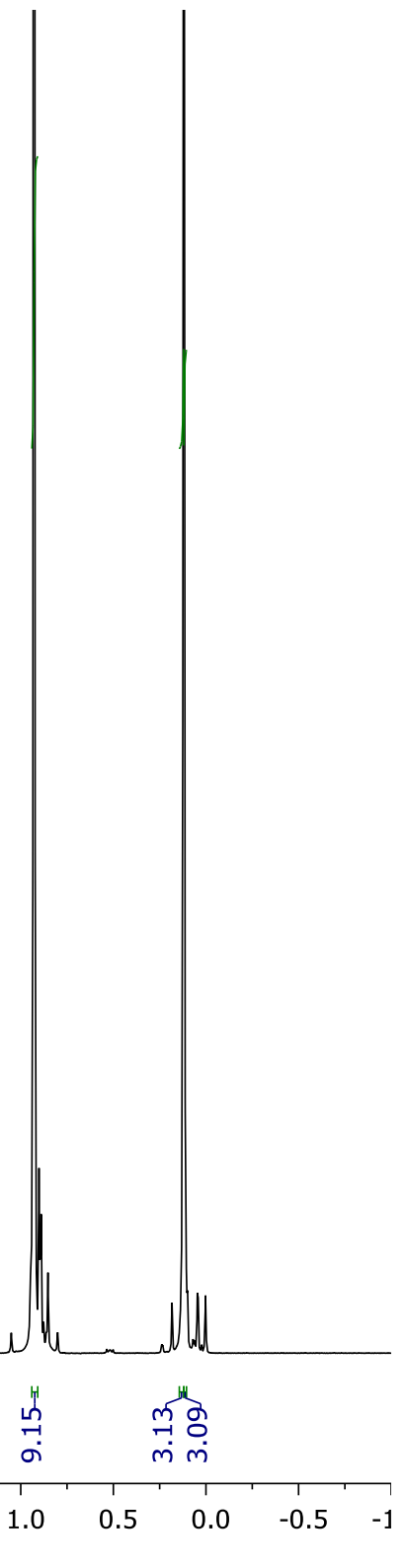

Hoang et al. "General method for the synthesis of $\alpha$ - or $\beta$-deoxyaminoglycosides bearing

S214

basic nitrogen" 
${ }^{13} \mathrm{C} \mathrm{NMR}, 126 \mathrm{MHz}, \mathrm{CDCl}_{3}$

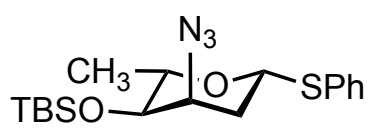

S19

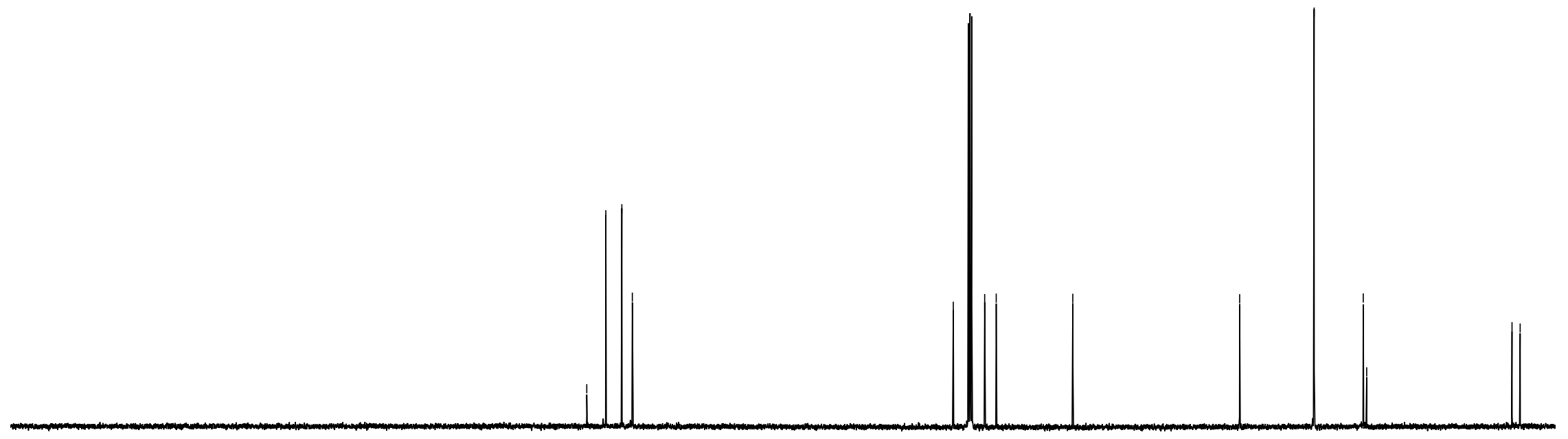

20

$210 \quad 200$

190

180

$170 \quad 160$

$150 \quad 140$

130

120

$110 \quad 100$

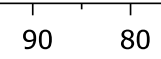

$70 \quad 60$

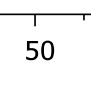

40

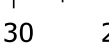

Hoang et al. "General method for the synthesis of $\alpha$ - or $\beta$-deoxyaminoglycosides bearing

S215

basic nitrogen" 
HSQC NMR, $500 \mathrm{MHz}, \mathrm{CDCl}_{3}$
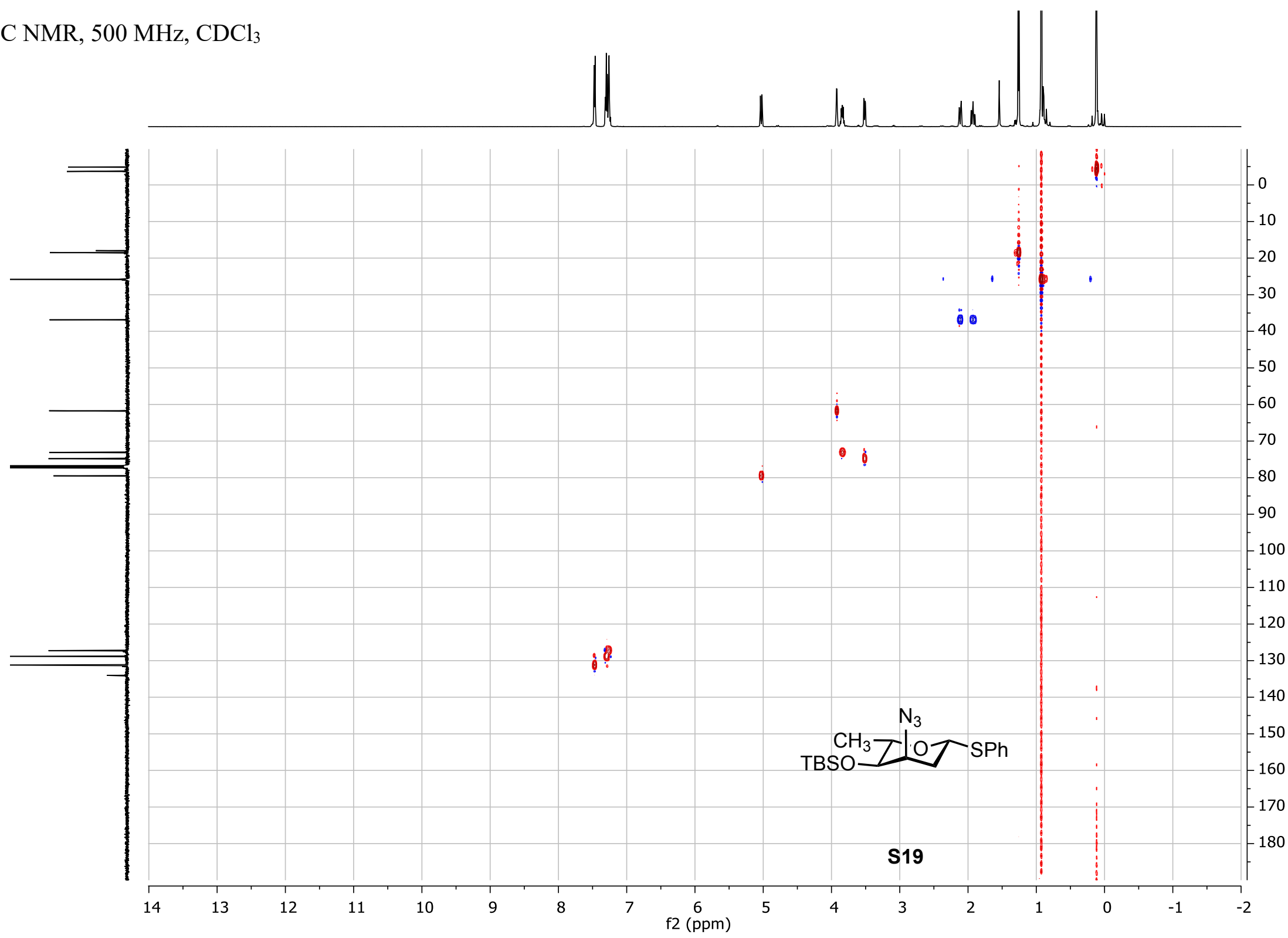

Hoang et al. "General method for the synthesis of $\alpha$ - or $\beta$-deoxyaminoglycosides bearing

S216 basic nitrogen" 
${ }^{1} \mathrm{H}$ NMR, $600 \mathrm{MHz}, \mathrm{C}_{6} \mathrm{D}_{6}$

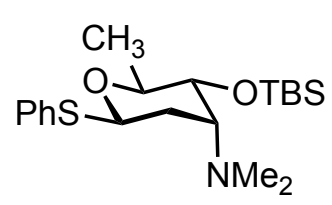

$32 \beta$

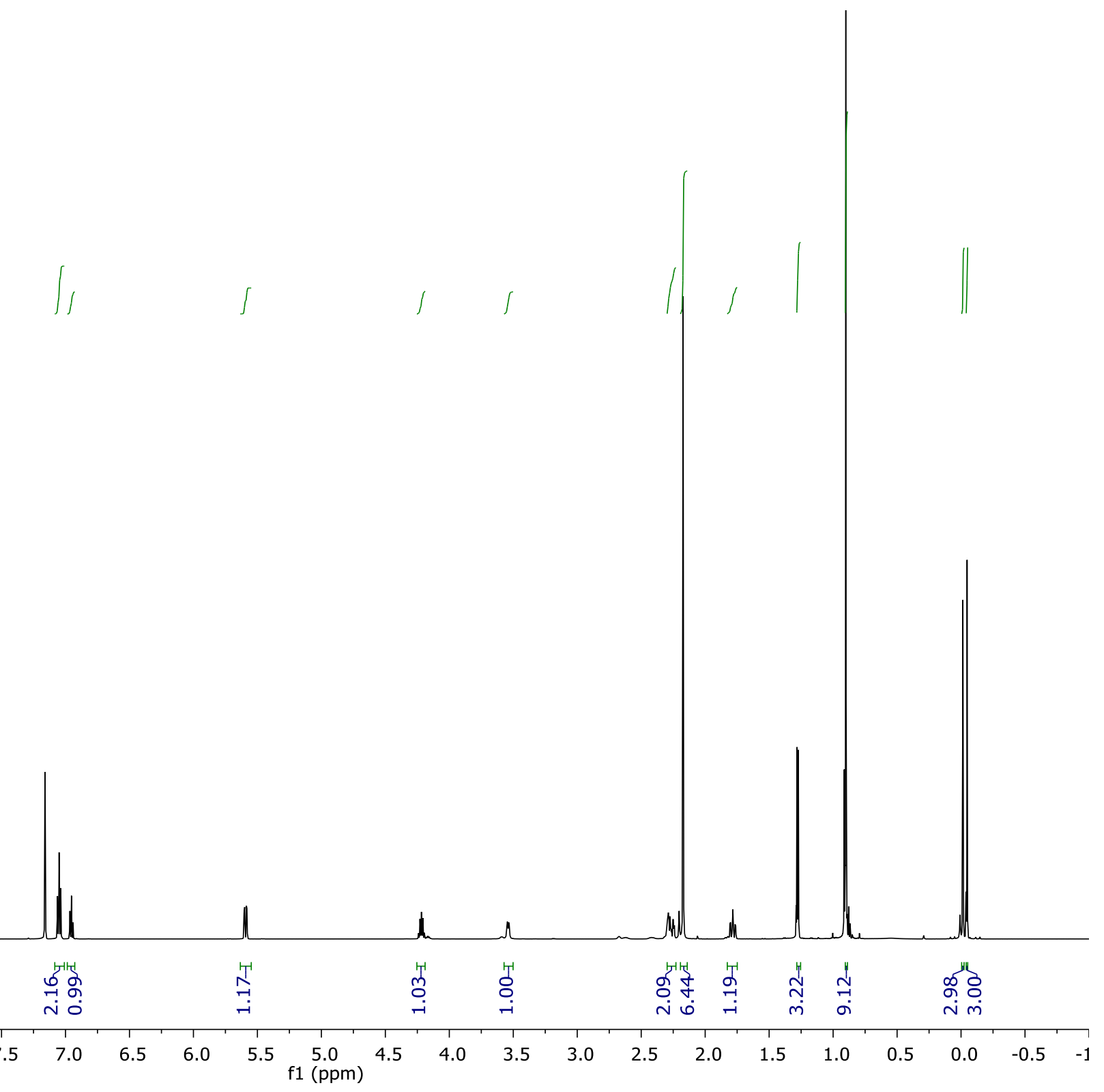

Hoang et al. "General method for the synthesis of $\alpha$ - or $\beta$-deoxyaminoglycosides bearing $\quad$ S217 basic nitrogen" 
${ }^{13} \mathrm{C}$ NMR, $151 \mathrm{MHz}, \mathrm{C}_{6} \mathrm{D}_{6}$

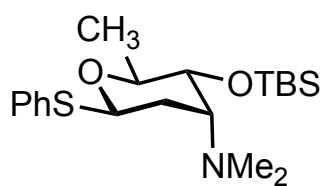

$32 \beta$

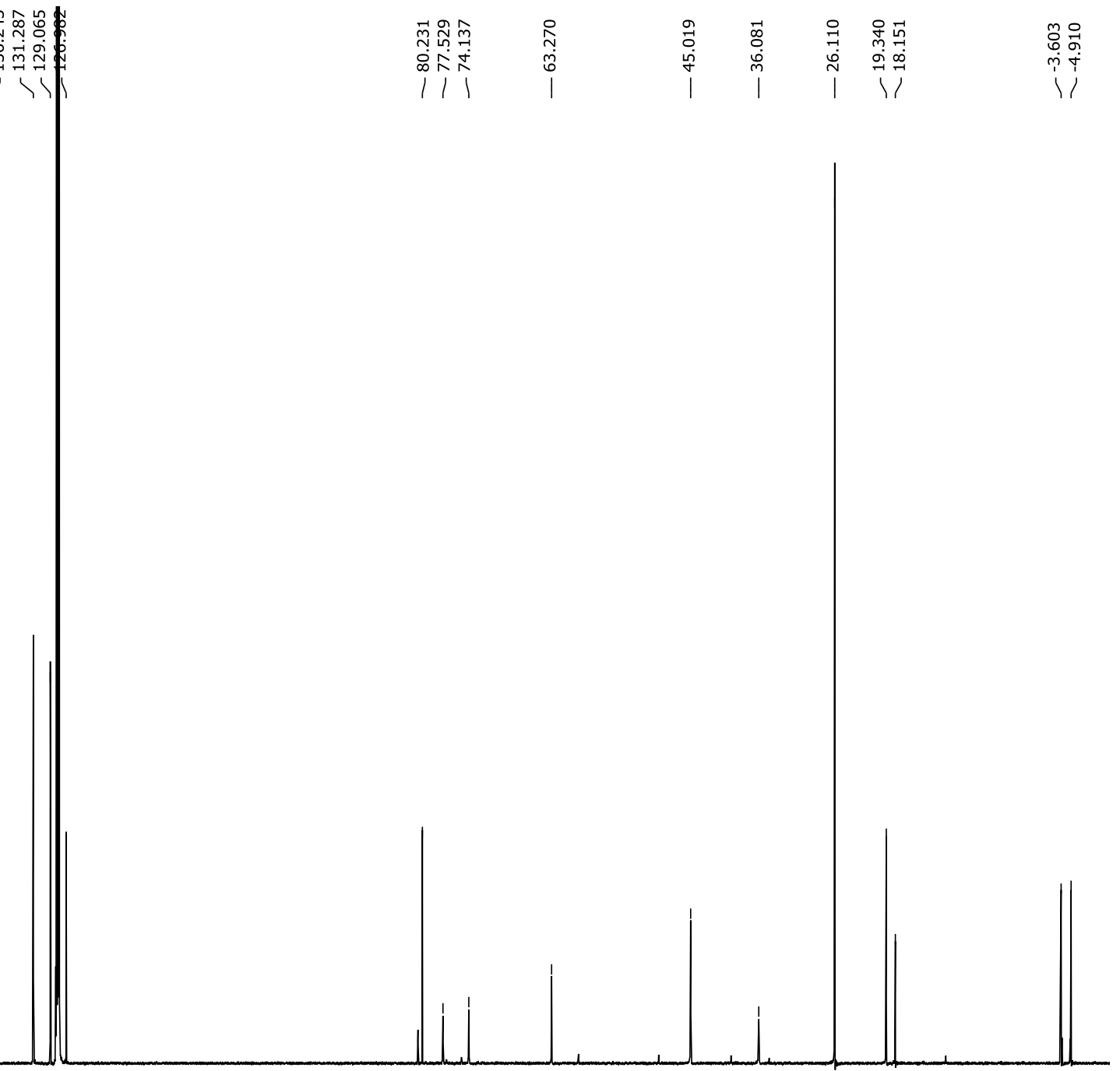

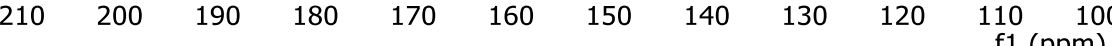

Hoang et al. "General method for the synthesis of $\alpha$ - or $\beta$-deoxyaminoglycosides bearing

S218

basic nitrogen" 
HSQC NMR, $600 \mathrm{MHz}, \mathrm{C}_{6} \mathrm{D}_{6}$
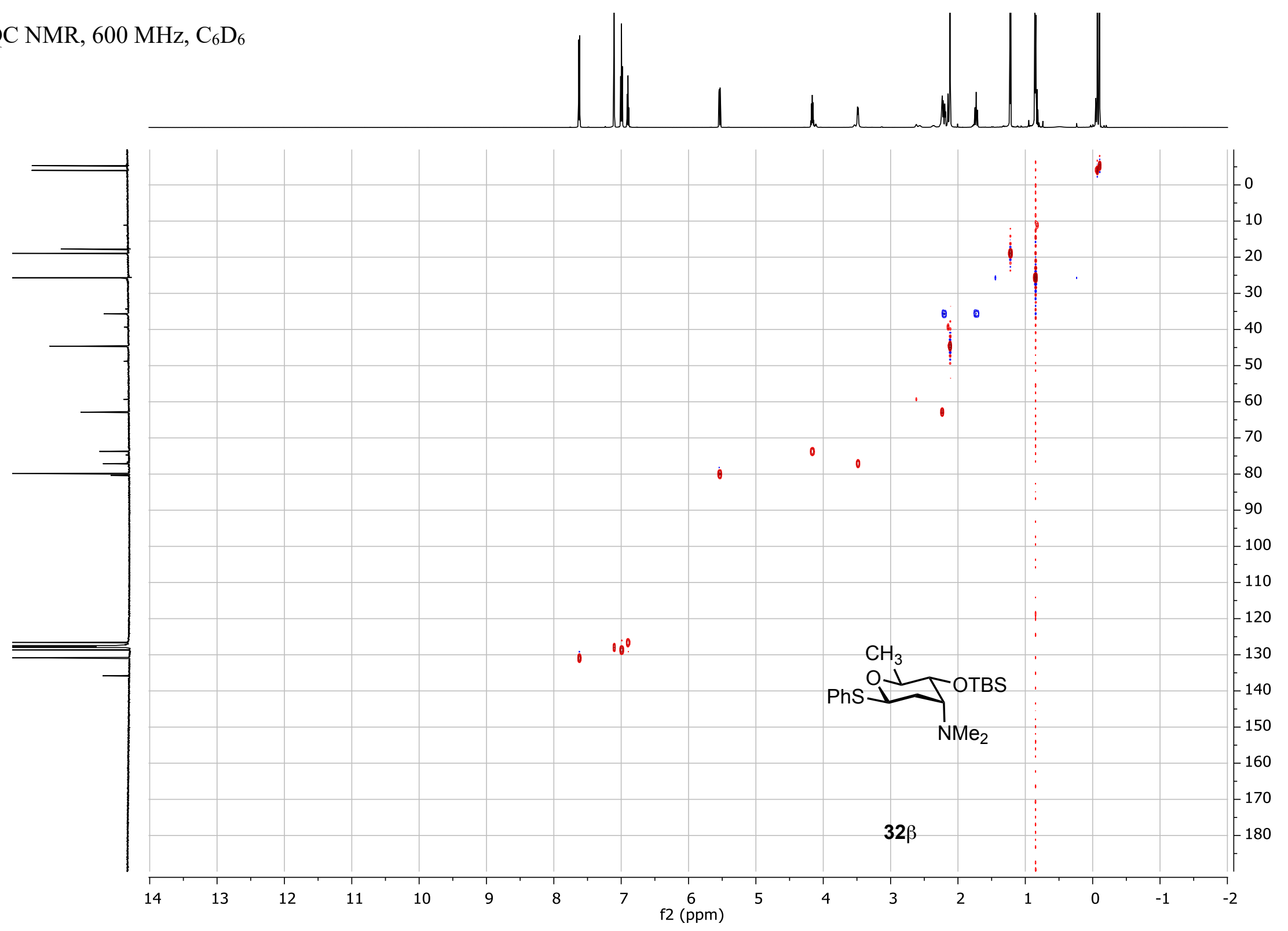

Hoang et al. "General method for the synthesis of $\alpha$ - or $\beta$-deoxyaminoglycosides bearing

S219

basic nitrogen" 


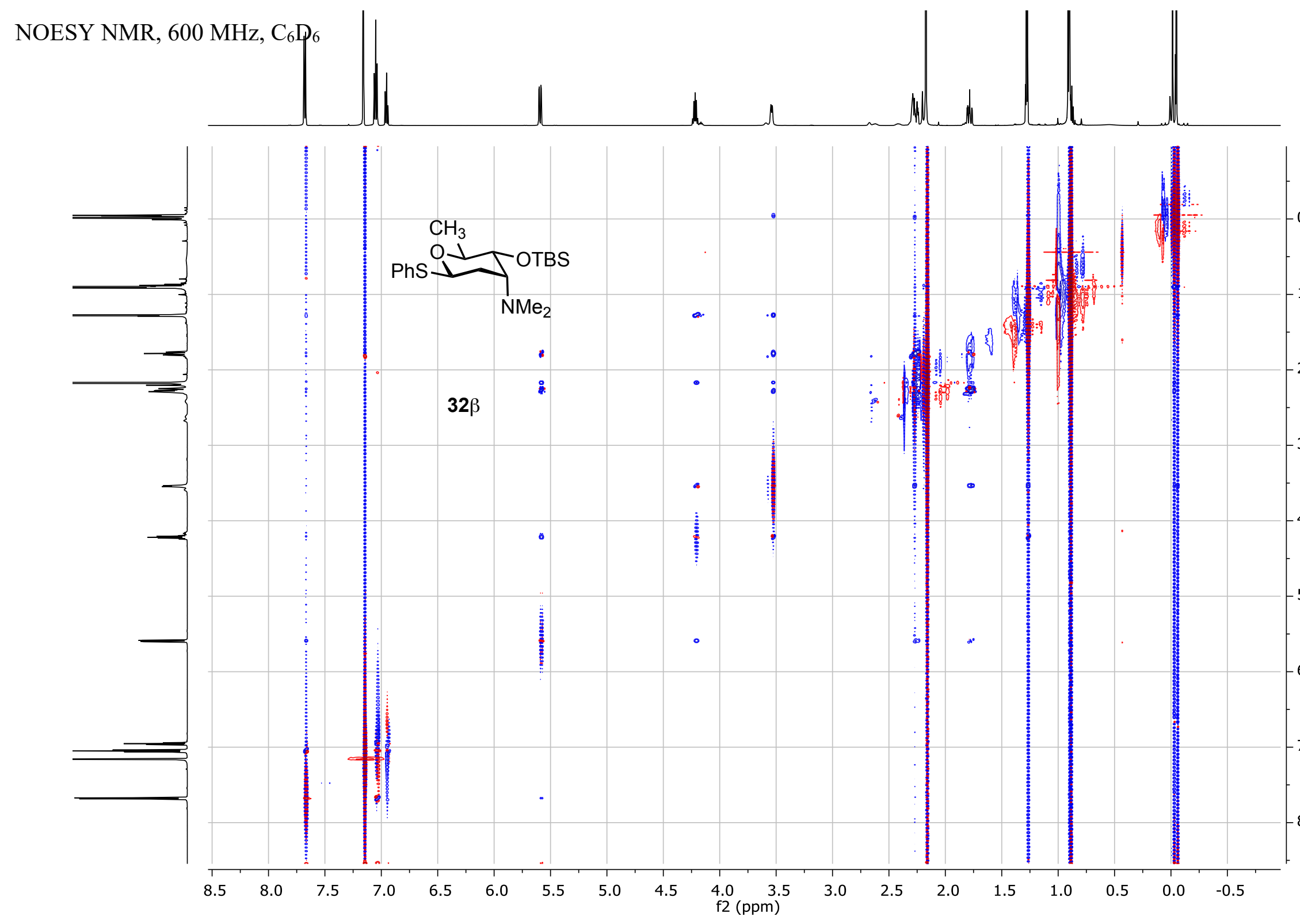

틀

Hoang et al. "General method for the synthesis of $\alpha$ - or $\beta$-deoxyaminoglycosides bearing

S220

basic nitrogen" 
${ }^{1} \mathrm{H}$ NMR, $500 \mathrm{MHz}, \mathrm{C}_{6} \mathrm{D}_{6}$

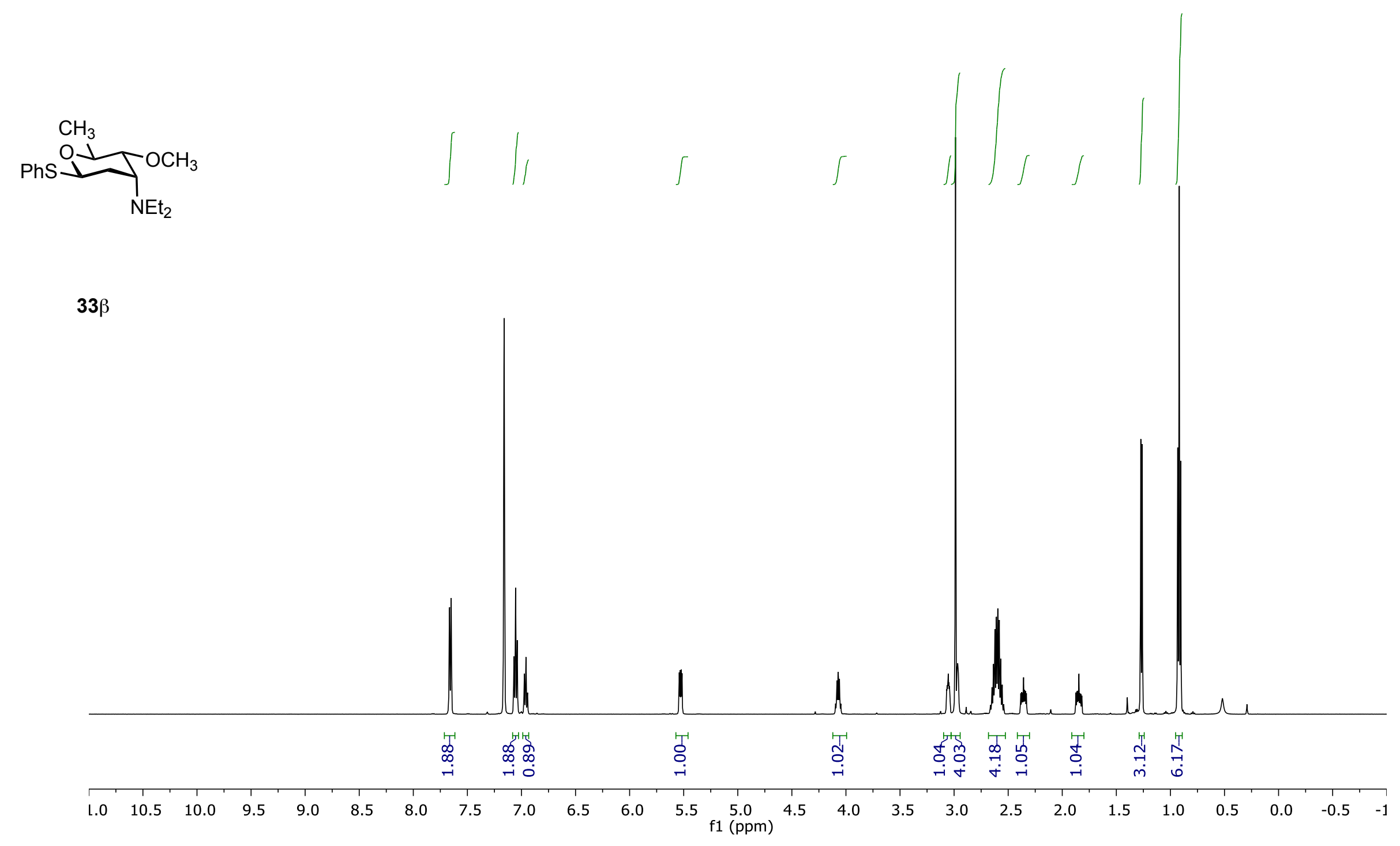

Hoang et al. "General method for the synthesis of $\alpha$ - or $\beta$-deoxyaminoglycosides bearing

S221

basic nitrogen" 

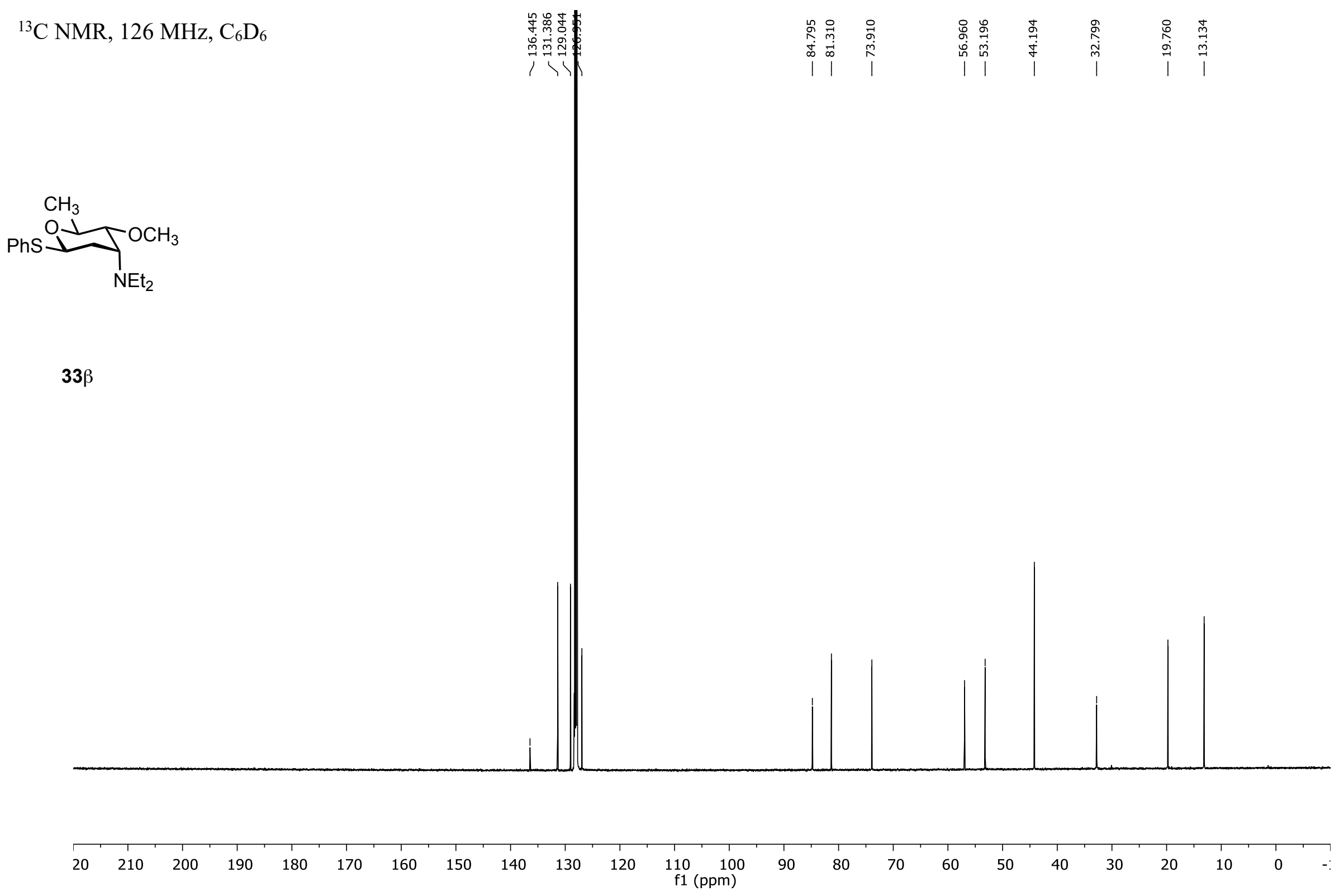

Hoang et al. "General method for the synthesis of $\alpha$ - or $\beta$-deoxyaminoglycosides bearing $\quad$ S222 basic nitrogen" 


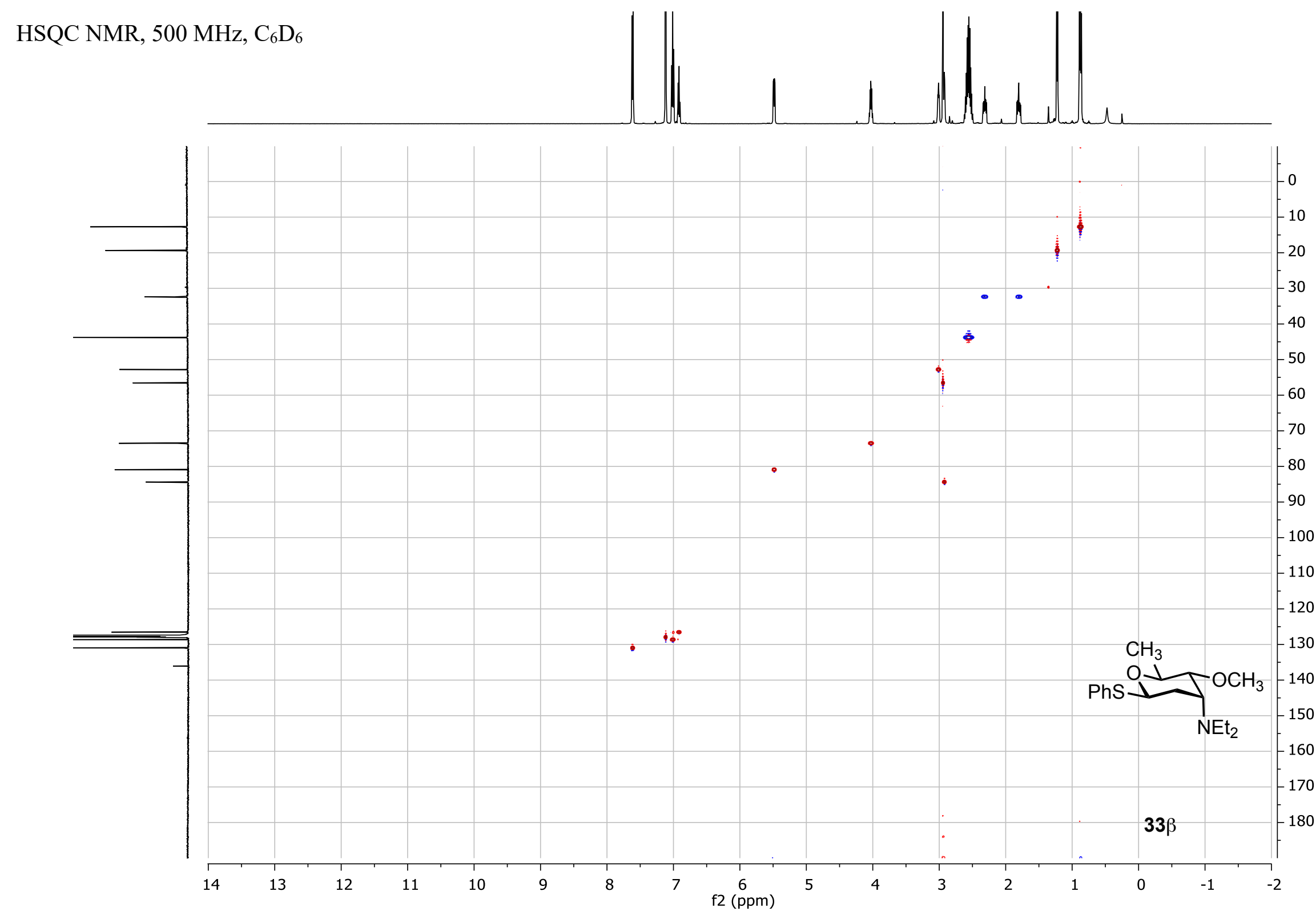

Hoang et al. "General method for the synthesis of $\alpha$ - or $\beta$-deoxyaminoglycosides bearing

S223

basic nitrogen" 


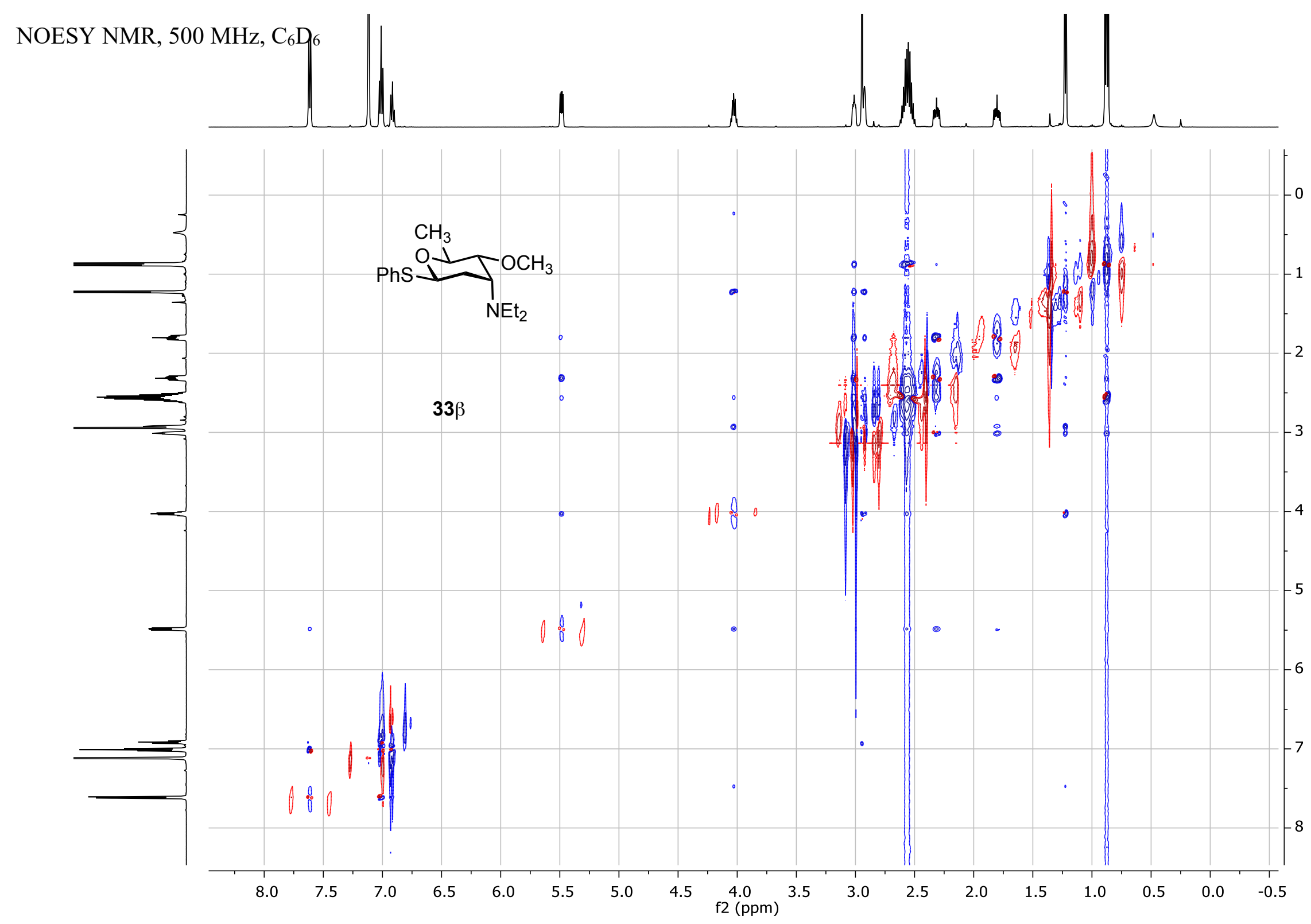

Hoang et al. "General method for the synthesis of $\alpha$ - or $\beta$-deoxyaminoglycosides bearing S224 basic nitrogen" 
${ }^{1} \mathrm{H} \mathrm{NMR}, 600 \mathrm{MHz}, \mathrm{CDCl}_{3}$

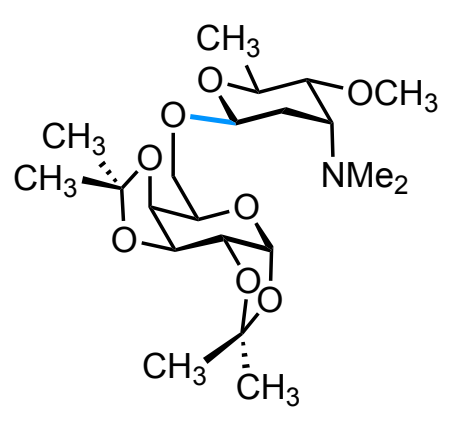

$35 \beta$

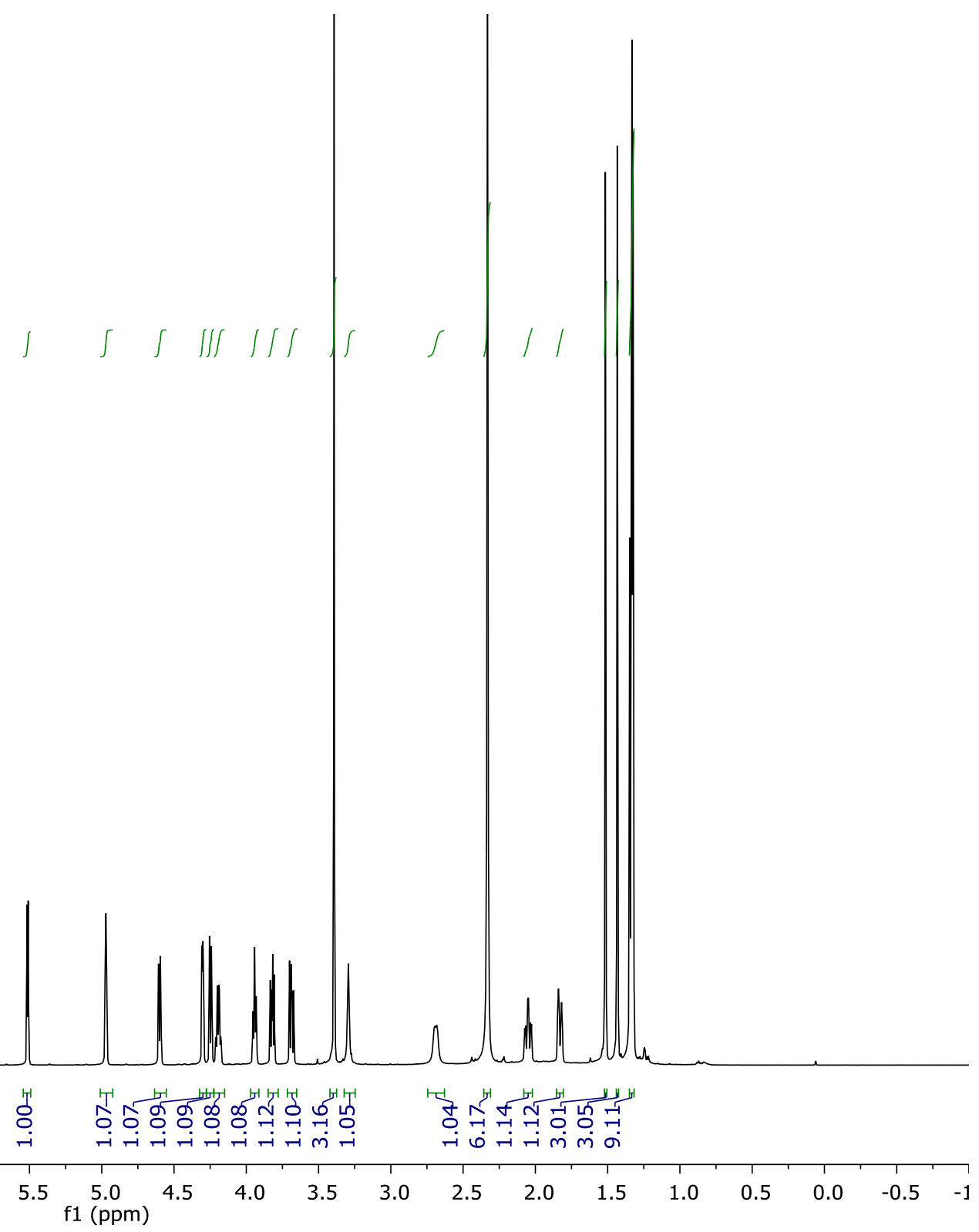

Hoang et al. "General method for the synthesis of $\alpha$ - or $\beta$-deoxyaminoglycosides bearing

S225

basic nitrogen" 
${ }^{13} \mathrm{C} \mathrm{NMR}, 151 \mathrm{MHz}, \mathrm{CDCl}_{3}$

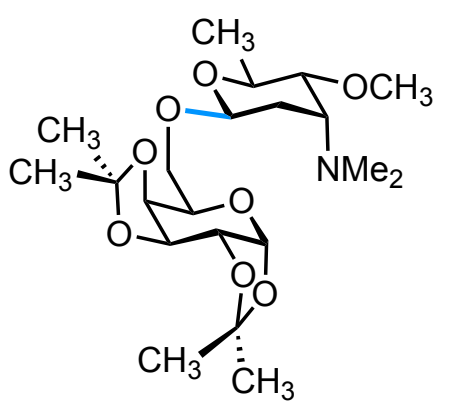

$35 \beta$ 
HSQC NMR, $600 \mathrm{MHz}, \mathrm{CDCl}_{3}$
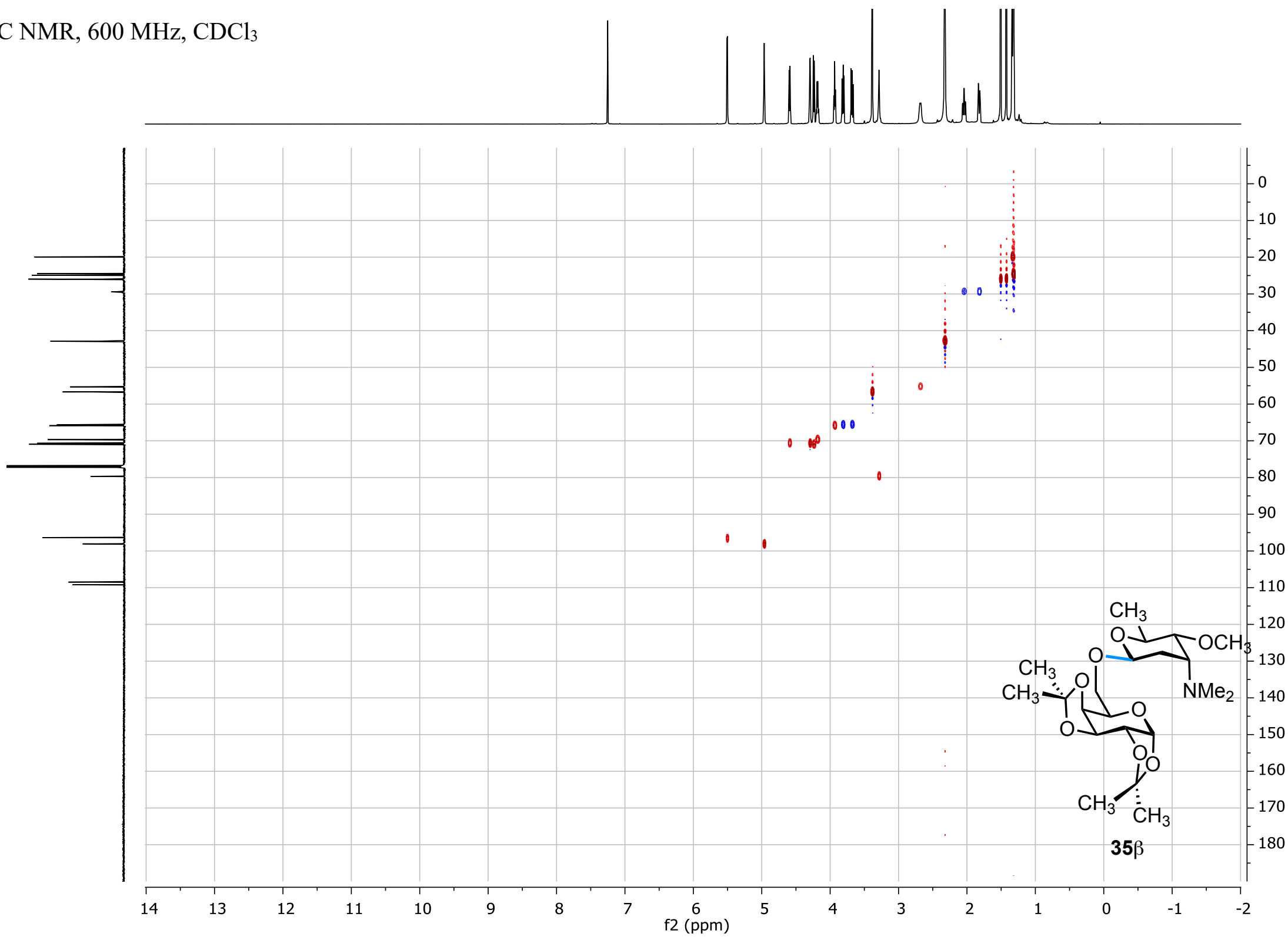

Hoang et al. "General method for the synthesis of $\alpha$ - or $\beta$-deoxyaminoglycosides bearing

S227

basic nitrogen" 


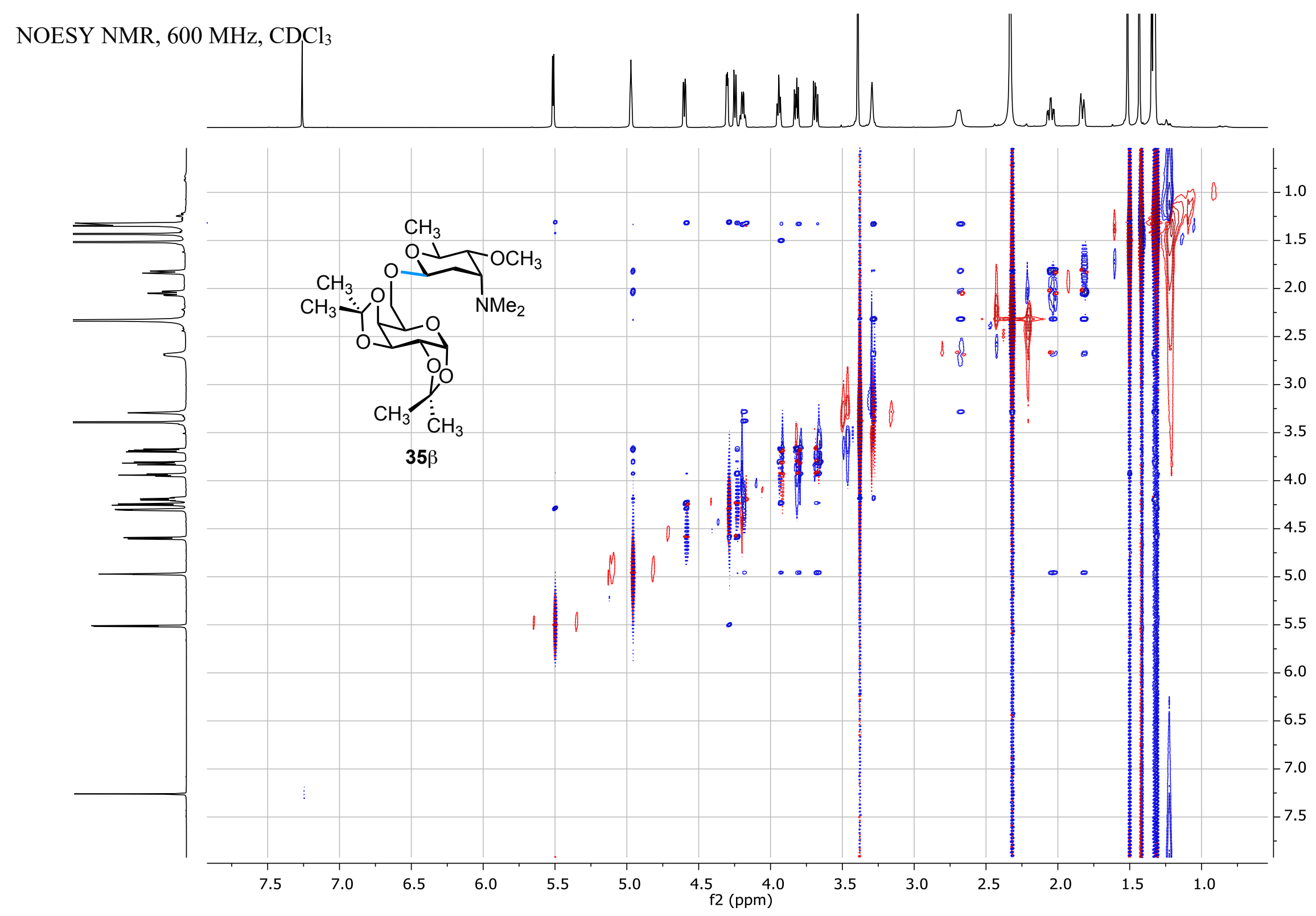

Hoang et al. "General method for the synthesis of $\alpha$ - or $\beta$-deoxyaminoglycosides bearing

S228 basic nitrogen" 
${ }^{1} \mathrm{H} \mathrm{NMR}, 400 \mathrm{MHz}, \mathrm{CDCl}_{3}$
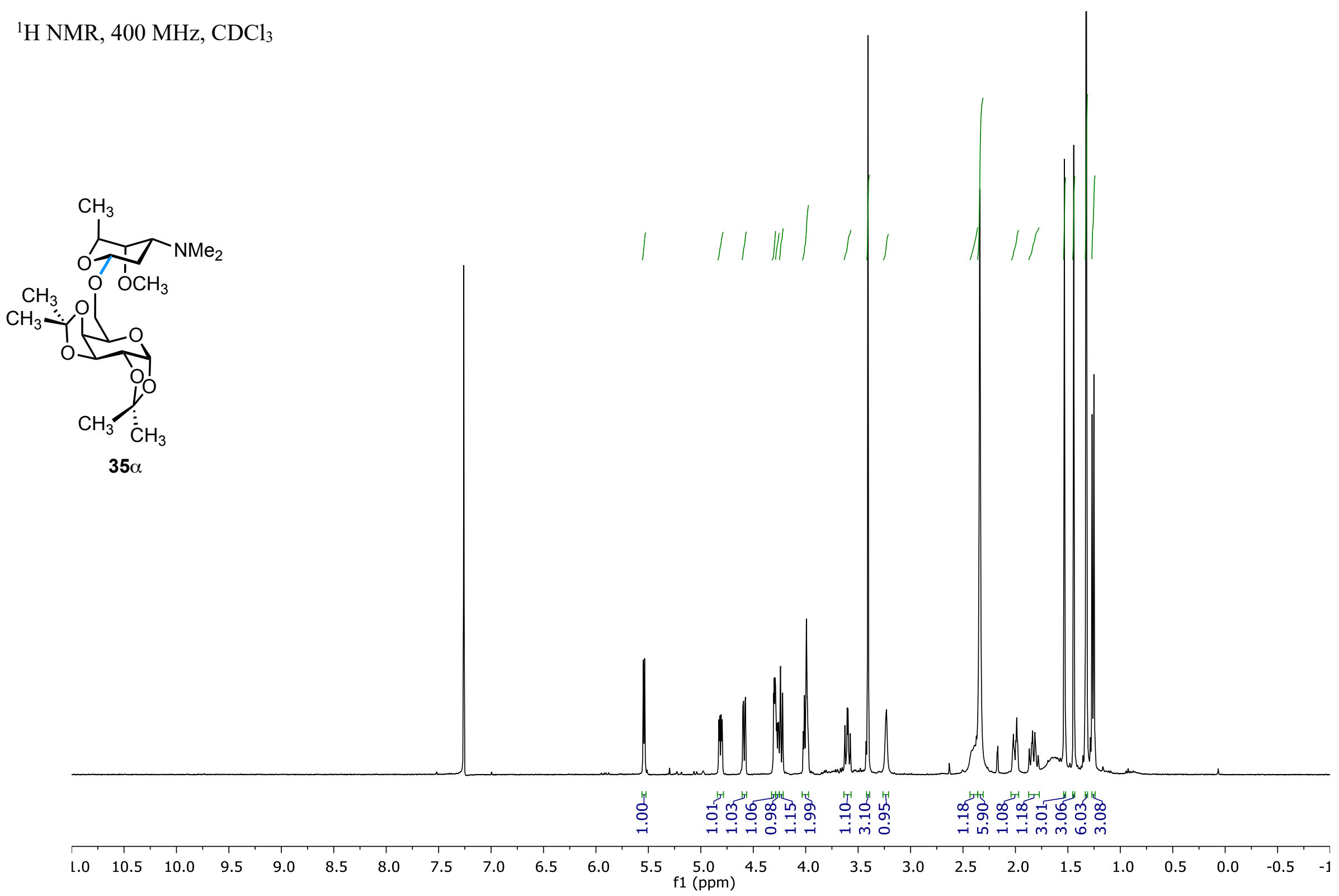

Hoang et al. "General method for the synthesis of $\alpha$ - or $\beta$-deoxyaminoglycosides bearing S229 basic nitrogen" 
${ }^{13} \mathrm{C} \mathrm{NMR}, 151 \mathrm{MHz}, \mathrm{CDCl}_{3}$
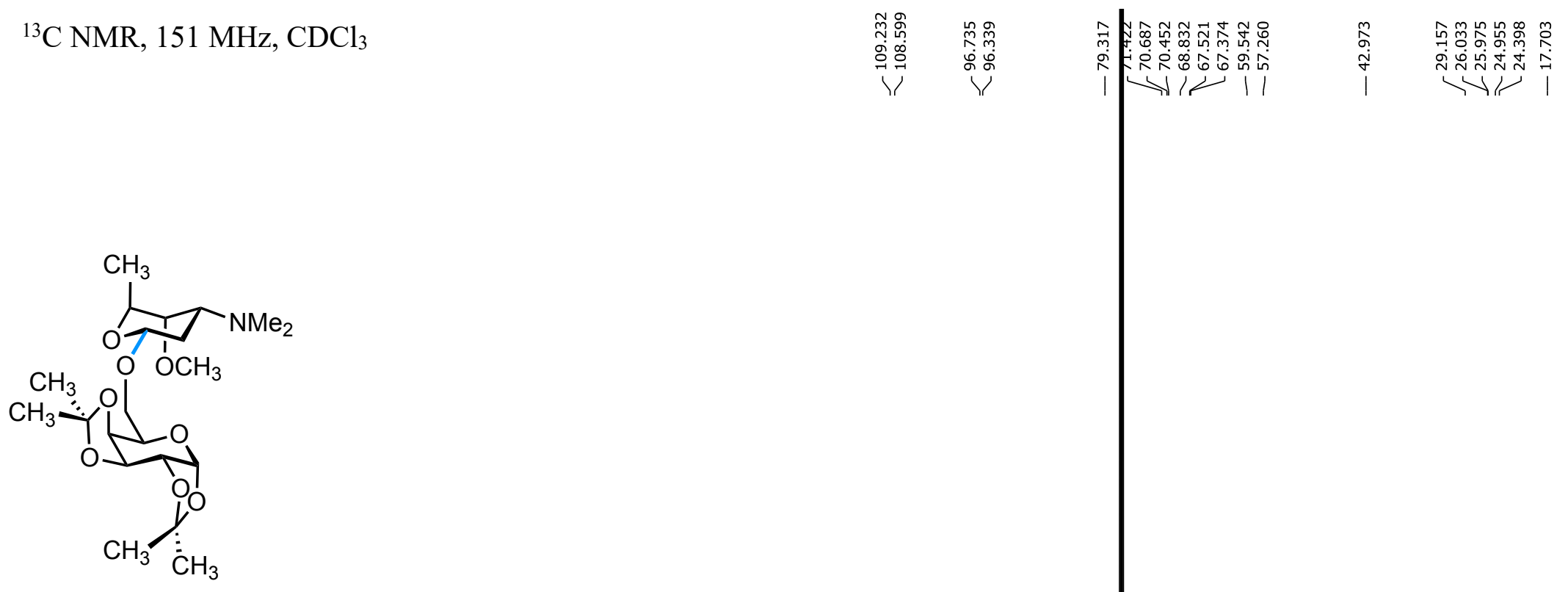

$35 \alpha$

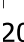

$210 \quad 200$

190

180

$170 \quad 160$

$150 \quad 140$

130

Hoang et al. "General method for the synthesis of $\alpha$ - or $\beta$-deoxyaminoglycosides bearing

basic nitrogen" 
HSQC NMR, $600 \mathrm{MHz}, \mathrm{CDCl}_{3}$

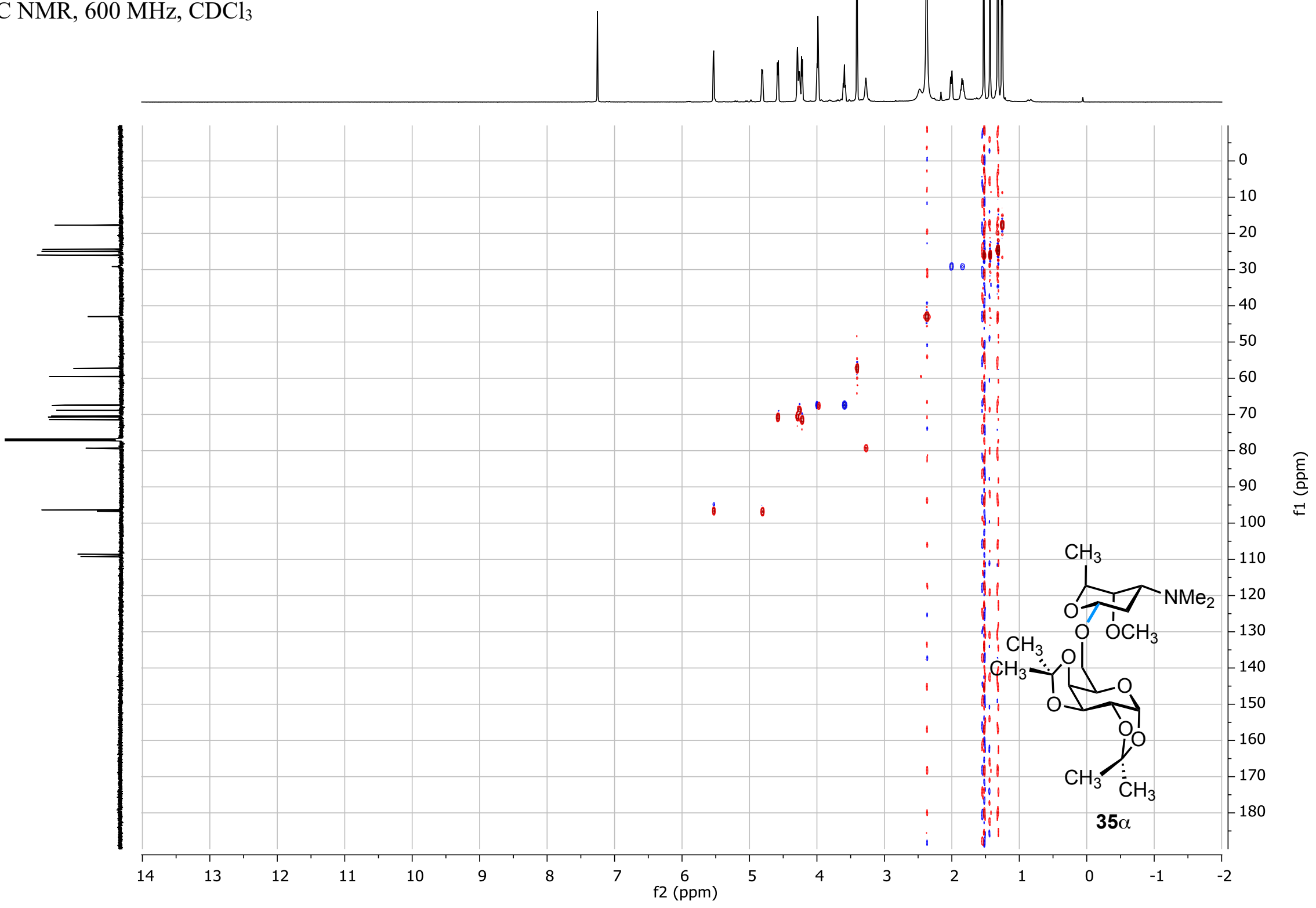

Hoang et al. "General method for the synthesis of $\alpha$ - or $\beta$-deoxyaminoglycosides bearing

S231

basic nitrogen" 


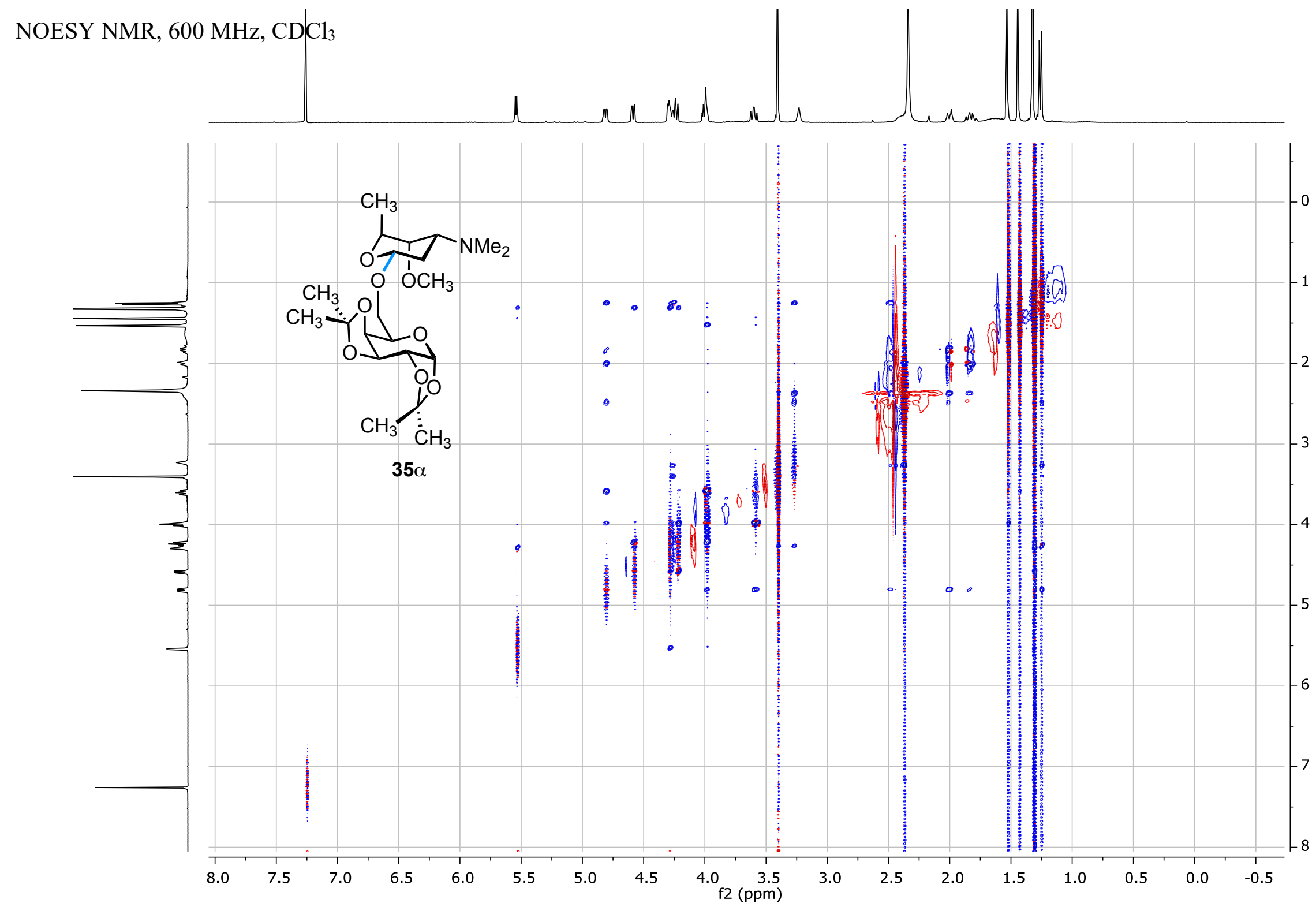


${ }^{1} \mathrm{H}$ NMR, $600 \mathrm{MHz}, \mathrm{C}_{6} \mathrm{D}_{6}$

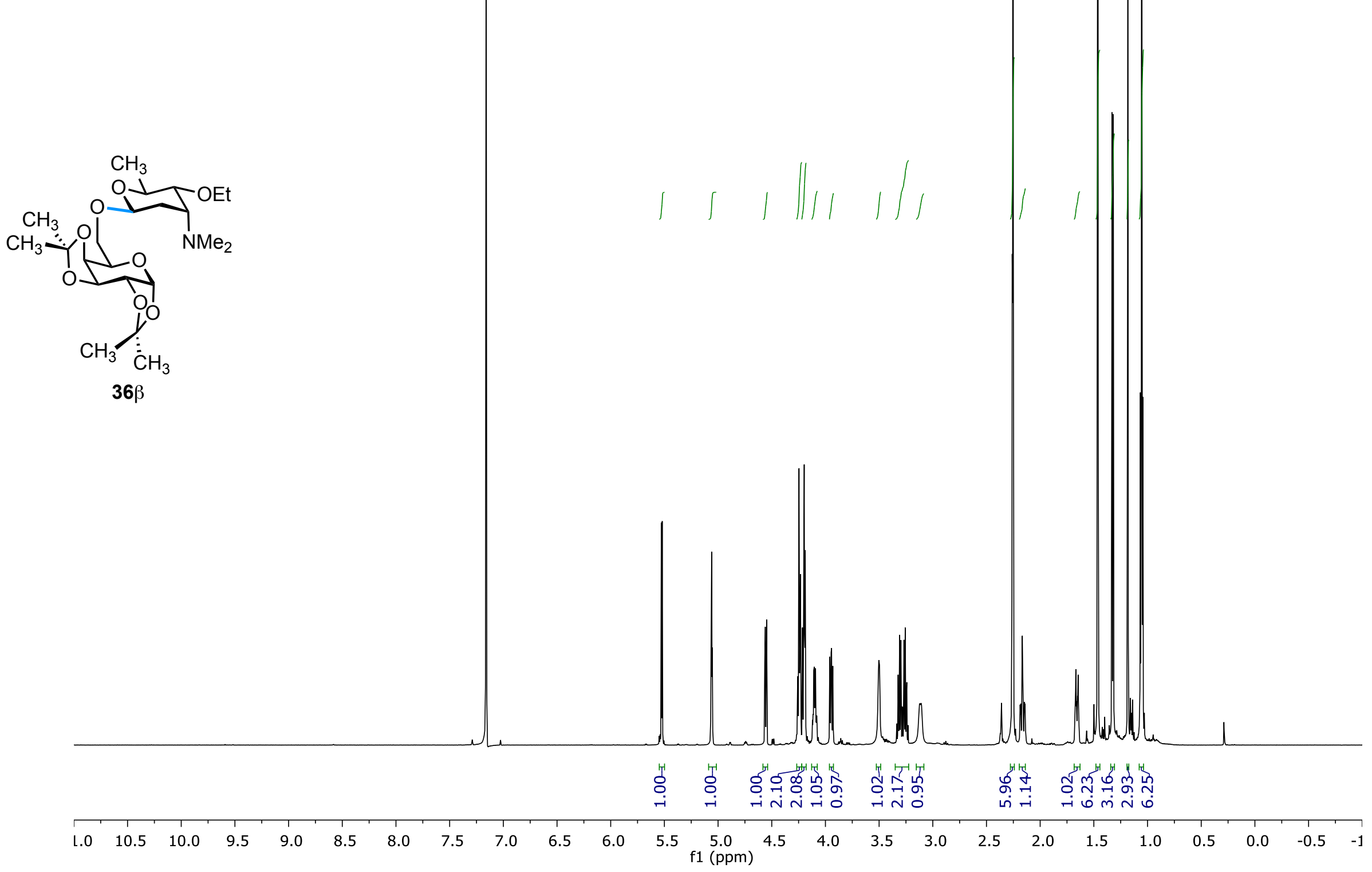

Hoang et al. "General method for the synthesis of $\alpha$ - or $\beta$-deoxyaminoglycosides bearing $\quad$ S233 basic nitrogen" 
${ }^{13} \mathrm{C} \mathrm{NMR}, 126 \mathrm{MHz}, \mathrm{C}_{6} \mathrm{D}_{6}$

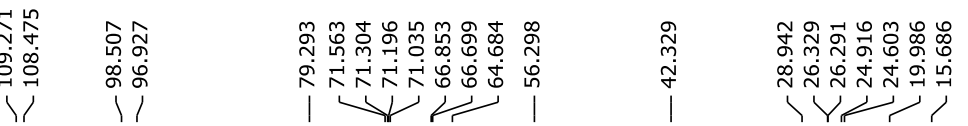

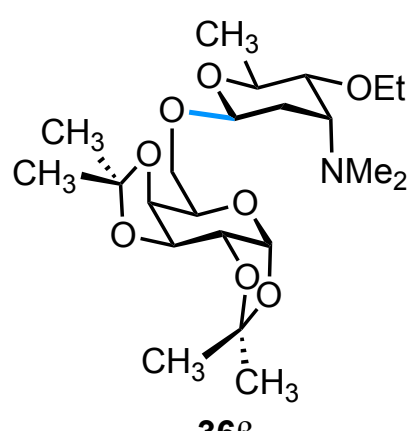

$36 \beta$ 
HSQC NMR, $500 \mathrm{MHz}, \mathrm{C}_{6} \mathrm{D}_{6}$

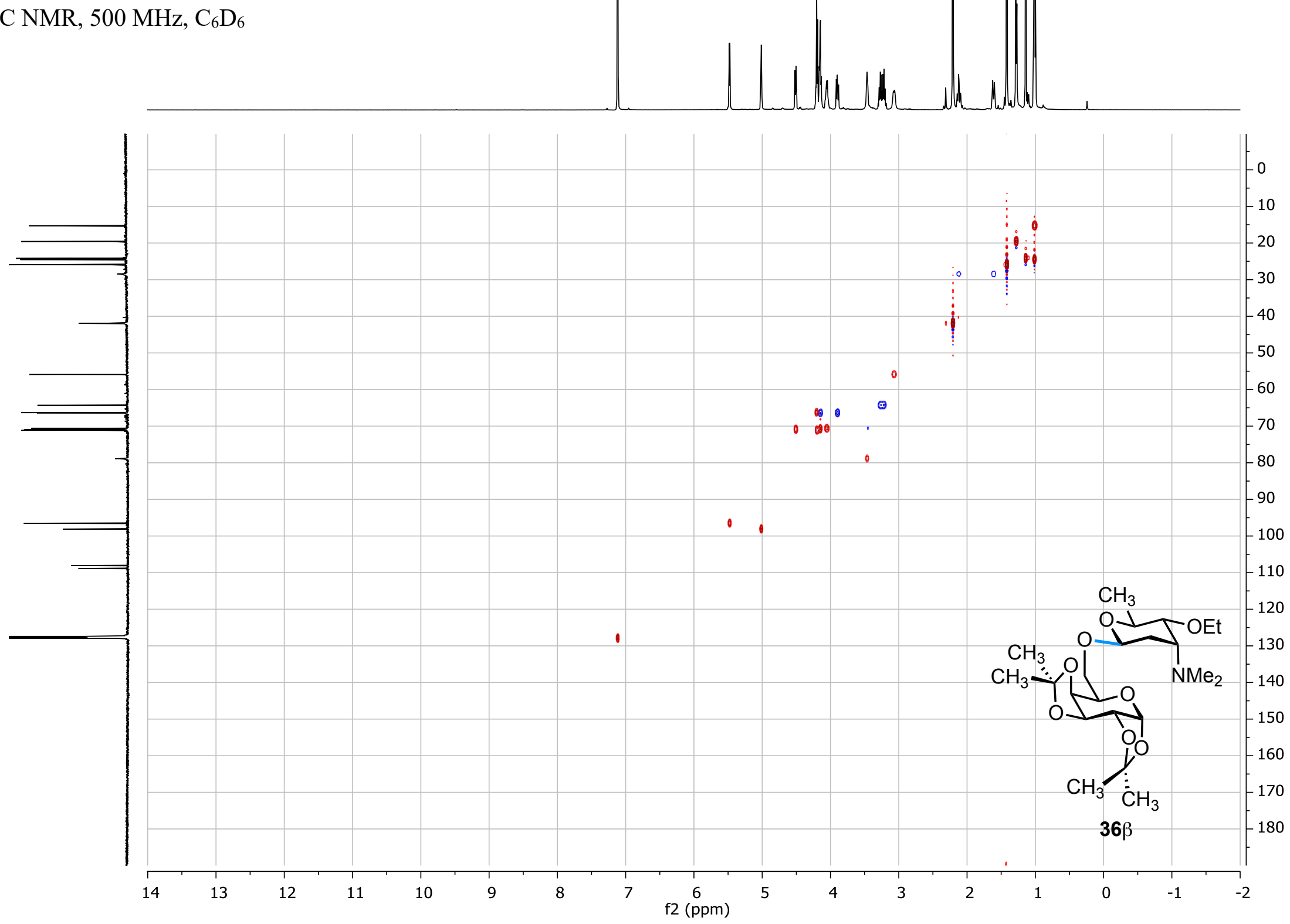

Hoang et al. "General method for the synthesis of $\alpha$ - or $\beta$-deoxyaminoglycosides bearing

$\mathrm{S} 235$ basic nitrogen" 


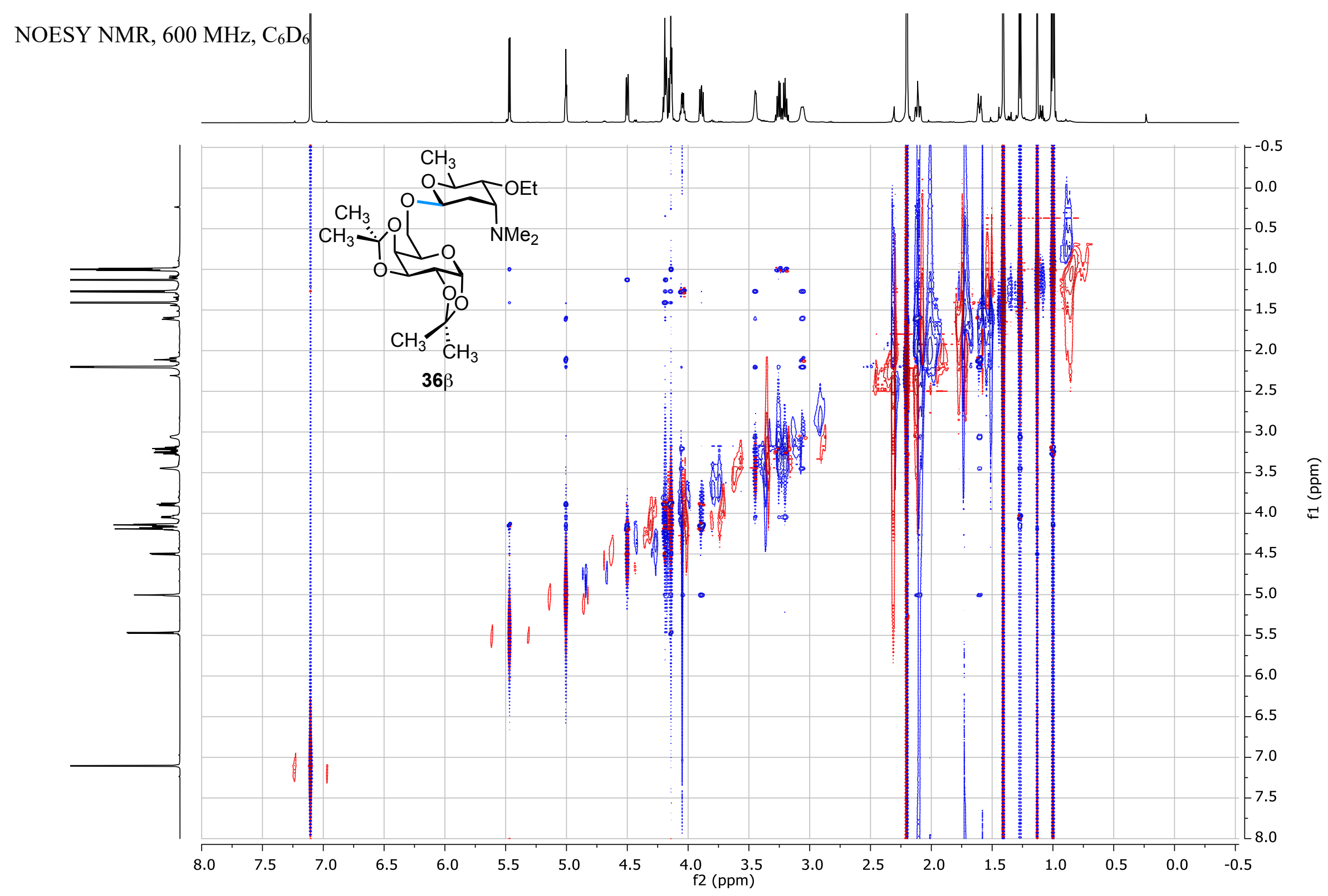

Hoang et al. "General method for the synthesis of $\alpha$ - or $\beta$-deoxyaminoglycosides bearing $\quad$ S236 basic nitrogen" 
${ }^{1} \mathrm{H}$ NMR, $500 \mathrm{MHz}, \mathrm{C}_{6} \mathrm{D}_{6}$
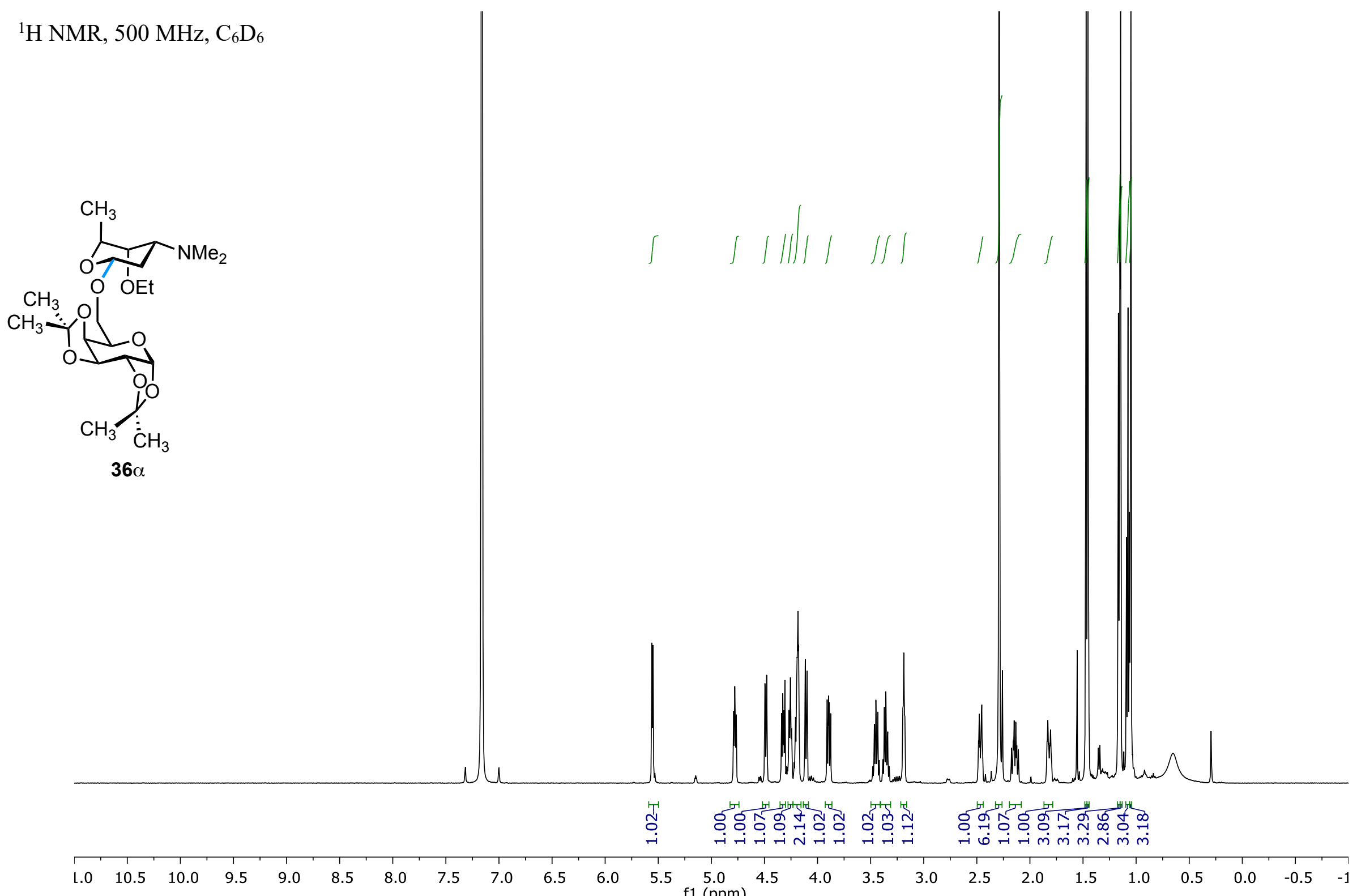

Hoang et al. "General method for the synthesis of $\alpha$ - or $\beta$-deoxyaminoglycosides bearing S237 basic nitrogen" 
${ }^{13} \mathrm{C} \mathrm{NMR}, 126 \mathrm{MHz}, \mathrm{C}_{6} \mathrm{D}_{6}$

\begin{tabular}{|c|c|c|}
\hline 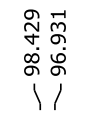 & 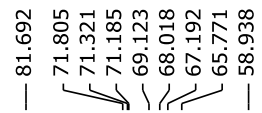 & $\stackrel{\substack{m \\
m \\
\dot{q}}}{\mid}$ \\
\hline
\end{tabular}

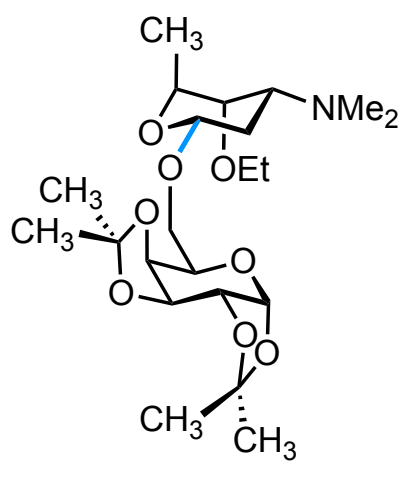

$36 \alpha$
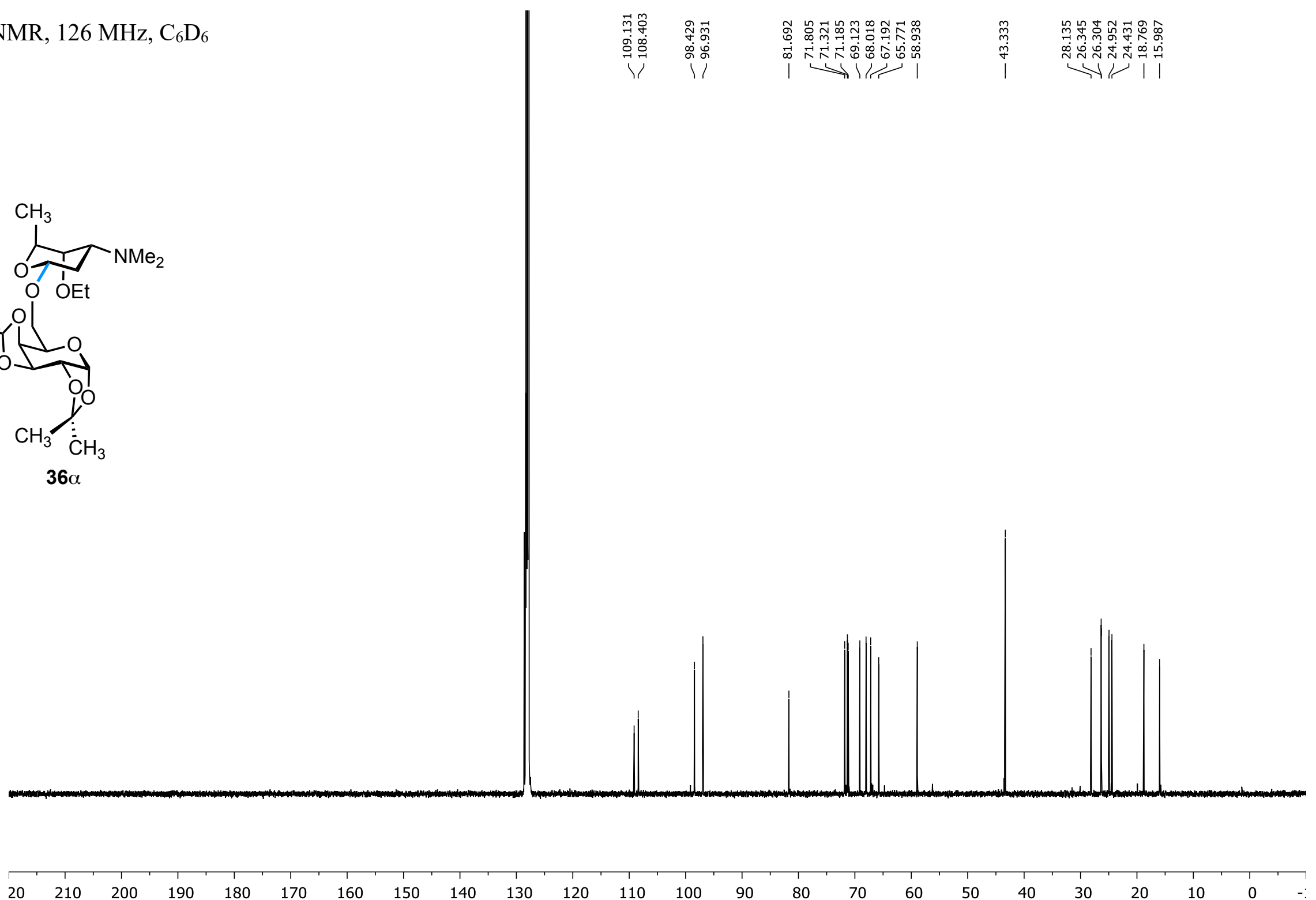

190

180

$170 \quad 160$

$150 \quad 140$

130

120

$110 \quad 100$

Hoang et al. "General method for the synthesis of $\alpha$ - or $\beta$-deoxyaminoglycosides bearing

S238

basic nitrogen" 
HSQC NMR, $500 \mathrm{MHz}, \mathrm{C}_{6} \mathrm{D}_{6}$
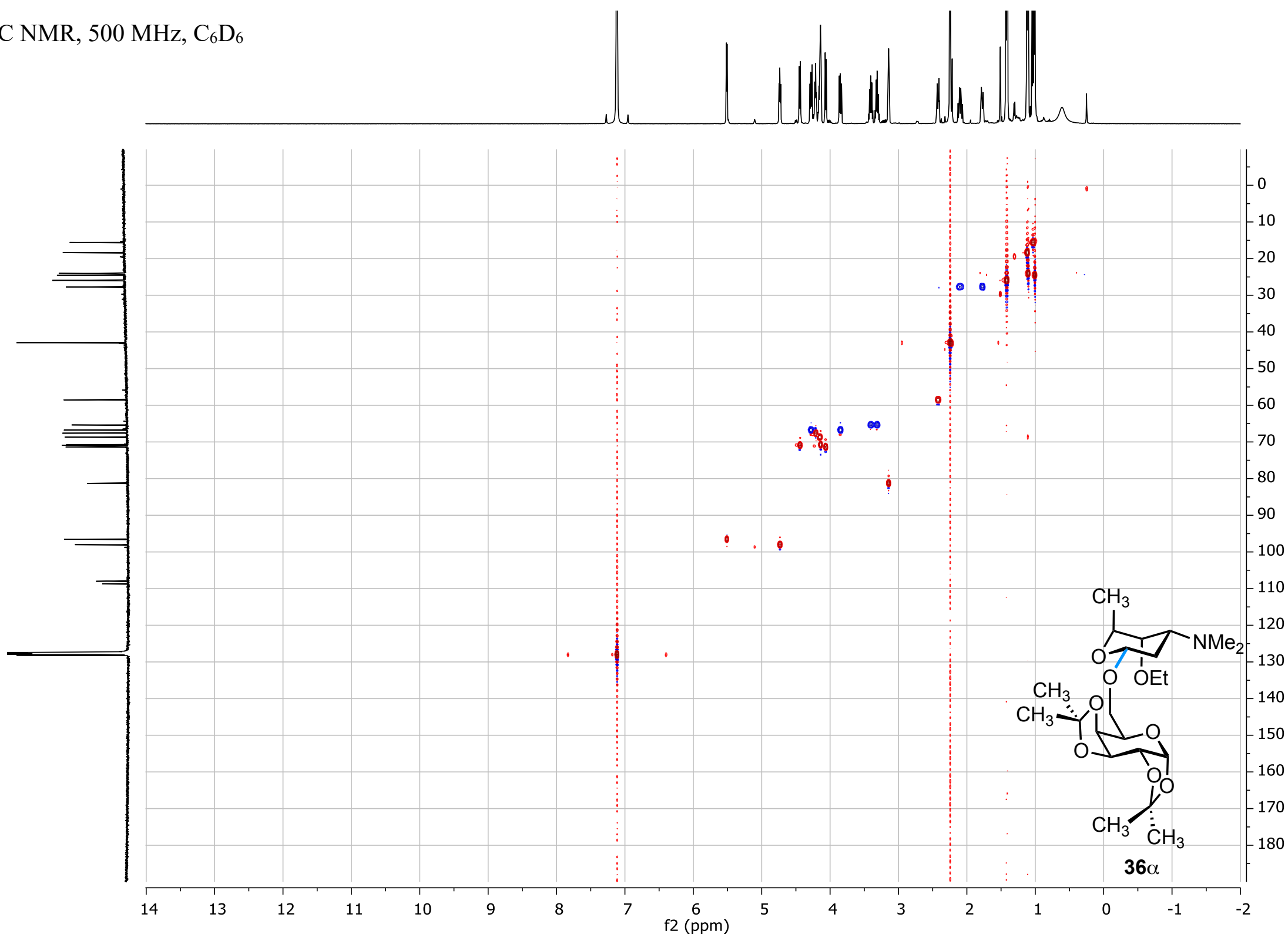

Hoang et al. "General method for the synthesis of $\alpha$ - or $\beta$-deoxyaminoglycosides bearing

S239

basic nitrogen" 


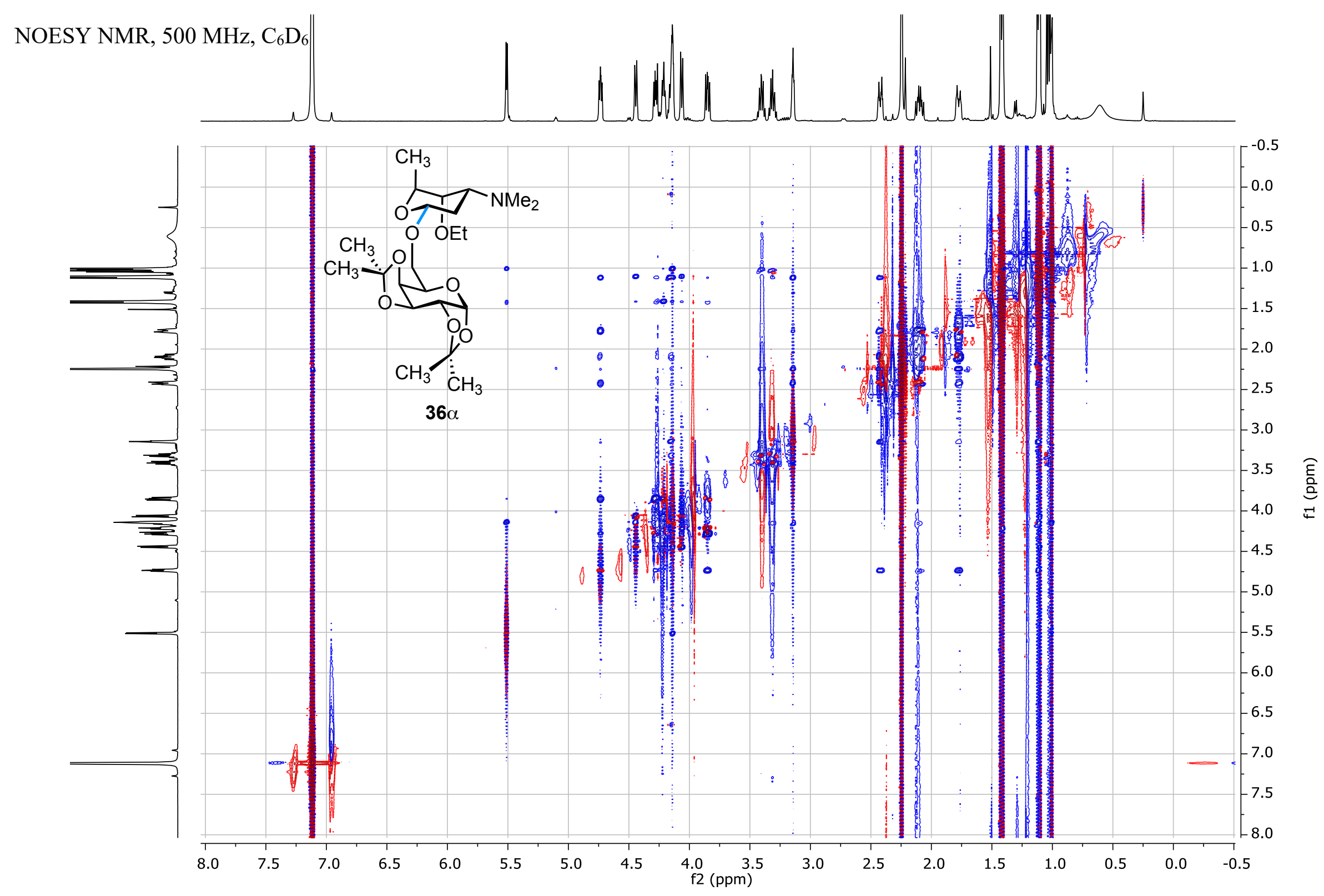

Hoang et al. "General method for the synthesis of $\alpha$ - or $\beta$-deoxyaminoglycosides bearing $\quad$ S240 basic nitrogen" 
${ }^{1} \mathrm{H}$ NMR, $600 \mathrm{MHz}, \mathrm{C}_{6} \mathrm{D}_{6}$
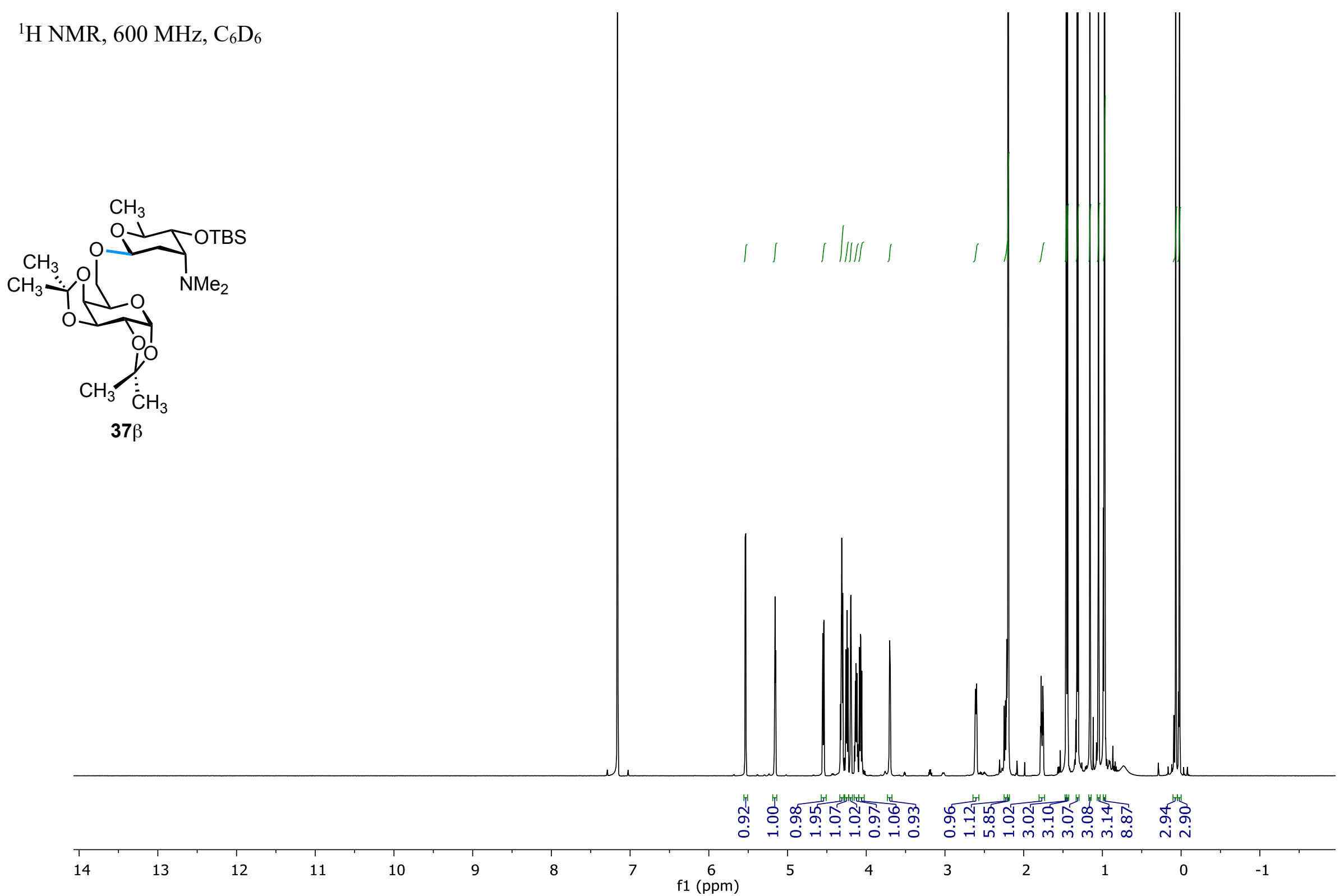

Hoang et al. "General method for the synthesis of $\alpha$ - or $\beta$-deoxyaminoglycosides bearing

S241

basic nitrogen" 
${ }^{13} \mathrm{C}$ NMR, $151 \mathrm{MHz}, \mathrm{C}_{6} \mathrm{D}_{6}$

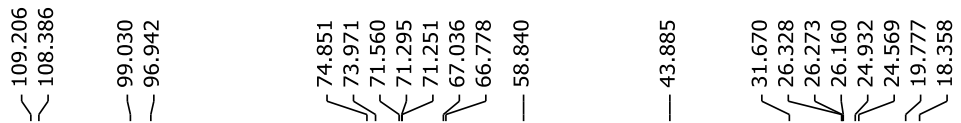
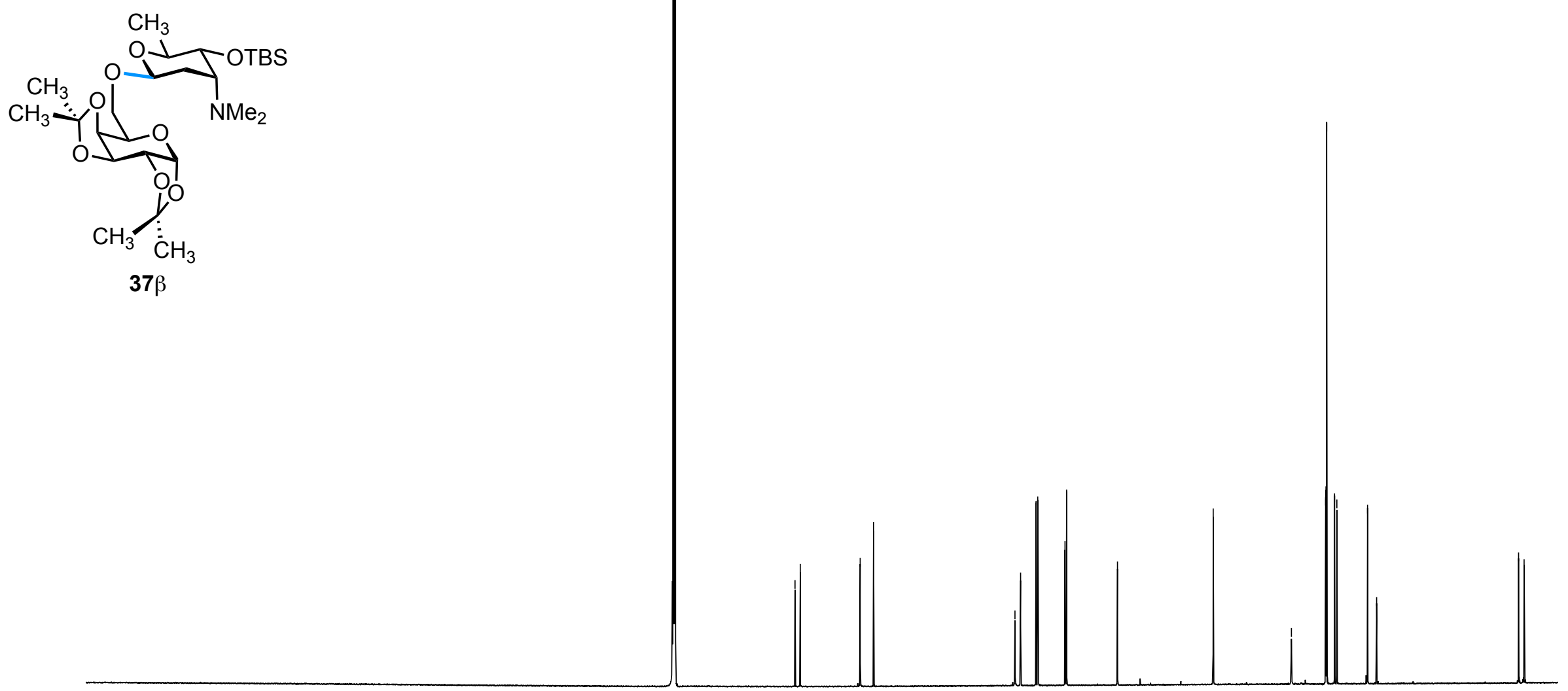

$20 \quad 210$

200

190

180

$170 \quad 160$

$150 \quad 140$

130

Hoang et al. "General method for the synthesis of $\alpha$ - or $\beta$-deoxyaminoglycosides bearing

S242

basic nitrogen" 
HSQC NMR, $600 \mathrm{MHz}, \mathrm{C}_{6} \mathrm{D}_{6}$

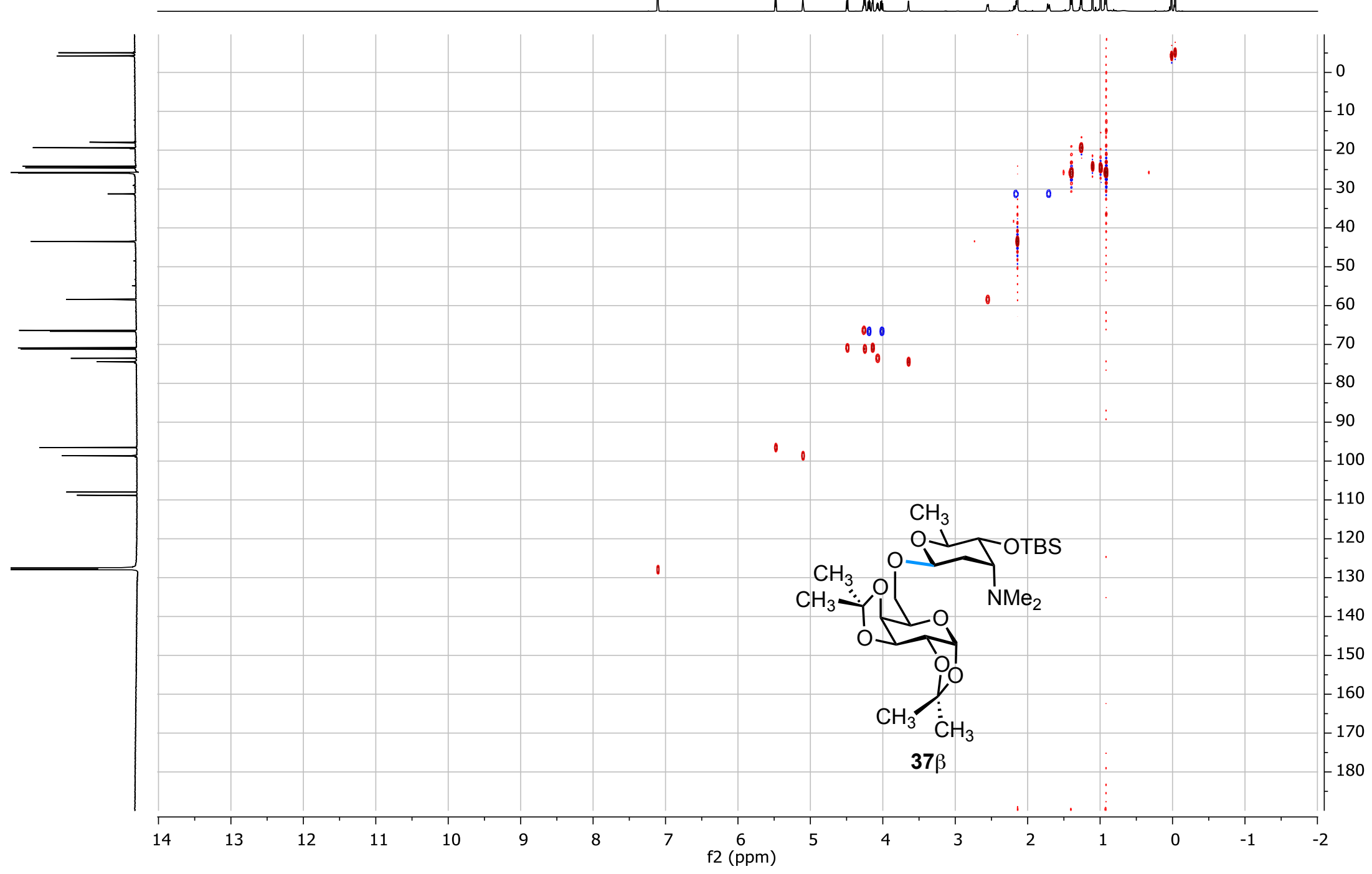

Hoang et al. "General method for the synthesis of $\alpha$ - or $\beta$-deoxyaminoglycosides bearing

S243

basic nitrogen" 


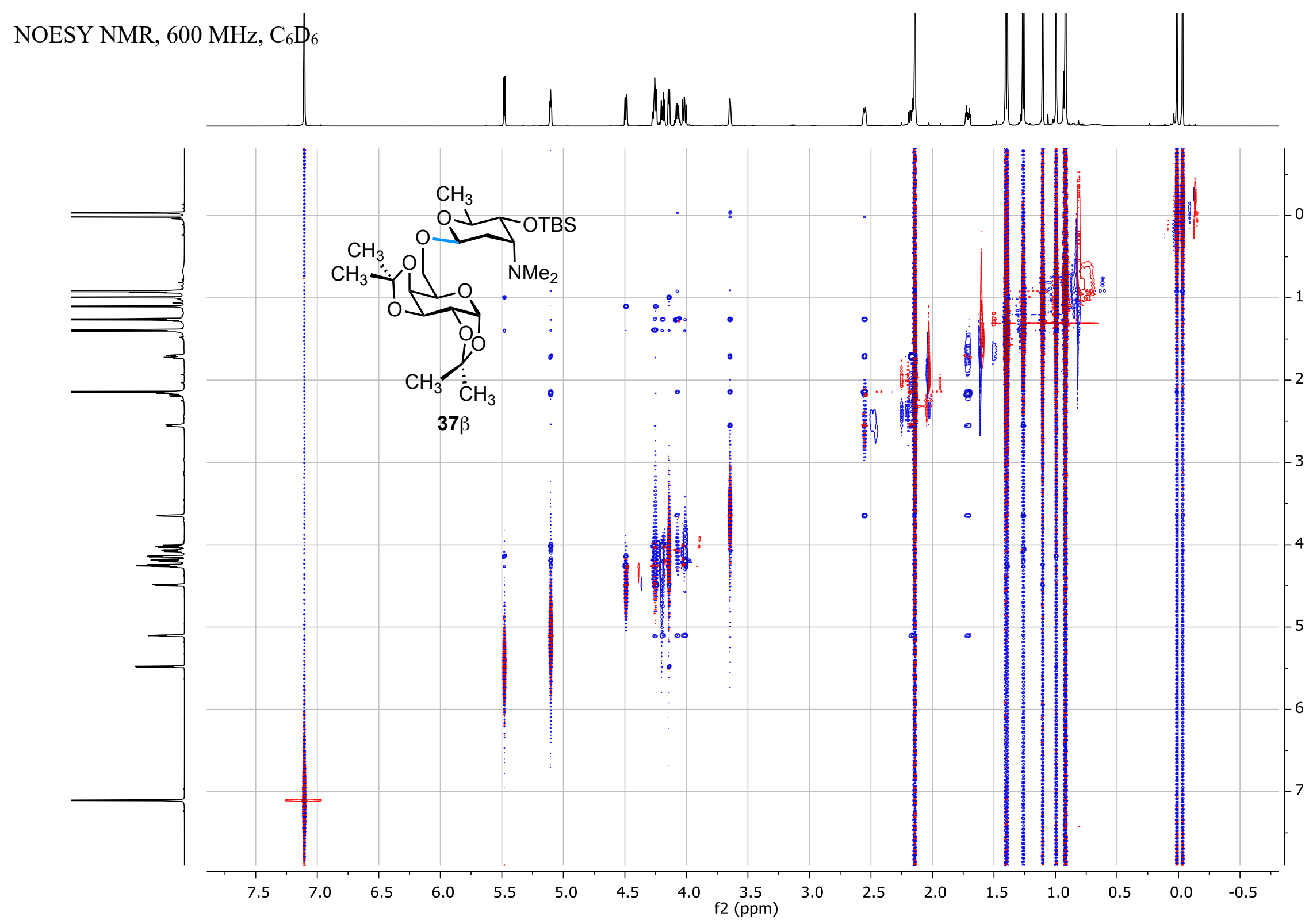

Hoang et al. "General method for the synthesis of $\alpha$ - or $\beta$-deoxyaminoglycosides bearing basic nitrogen" 
${ }^{1} \mathrm{H}$ NMR, $600 \mathrm{MHz}, \mathrm{C}_{6} \mathrm{D}_{6}$

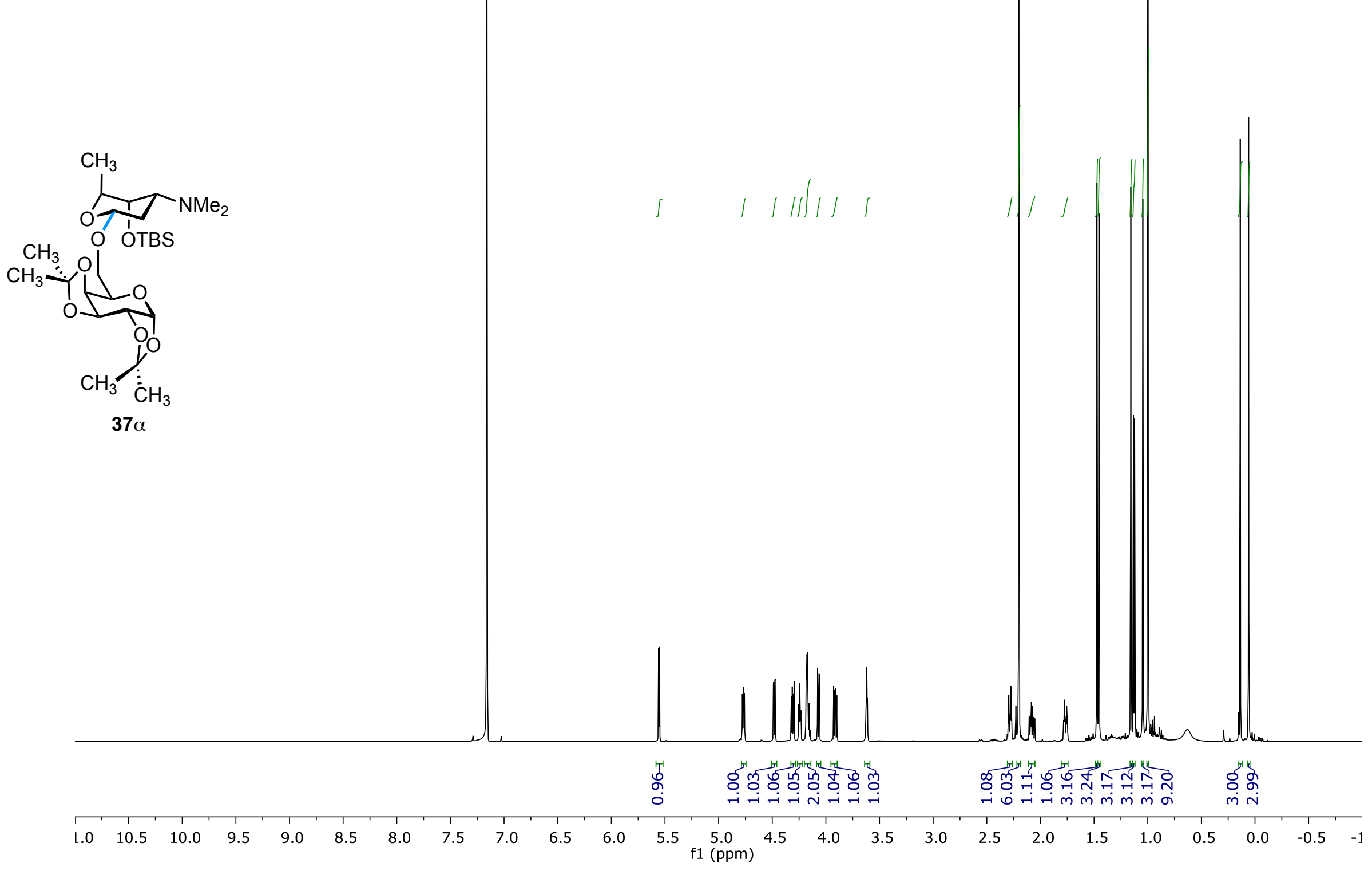

Hoang et al. "General method for the synthesis of $\alpha$ - or $\beta$-deoxyaminoglycosides bearing S245 basic nitrogen" 


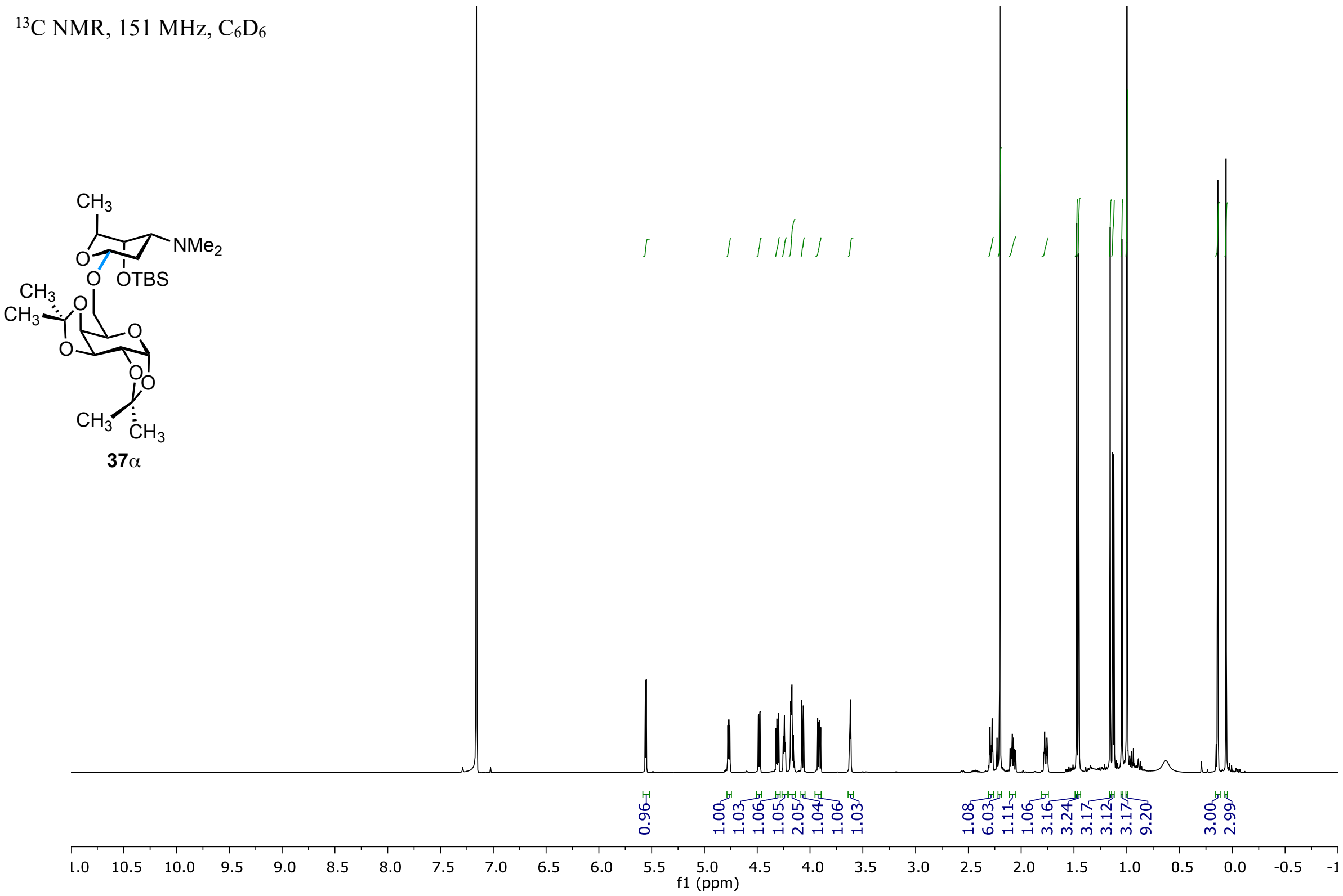

Hoang et al. "General method for the synthesis of $\alpha$ - or $\beta$-deoxyaminoglycosides bearing S246 basic nitrogen" 


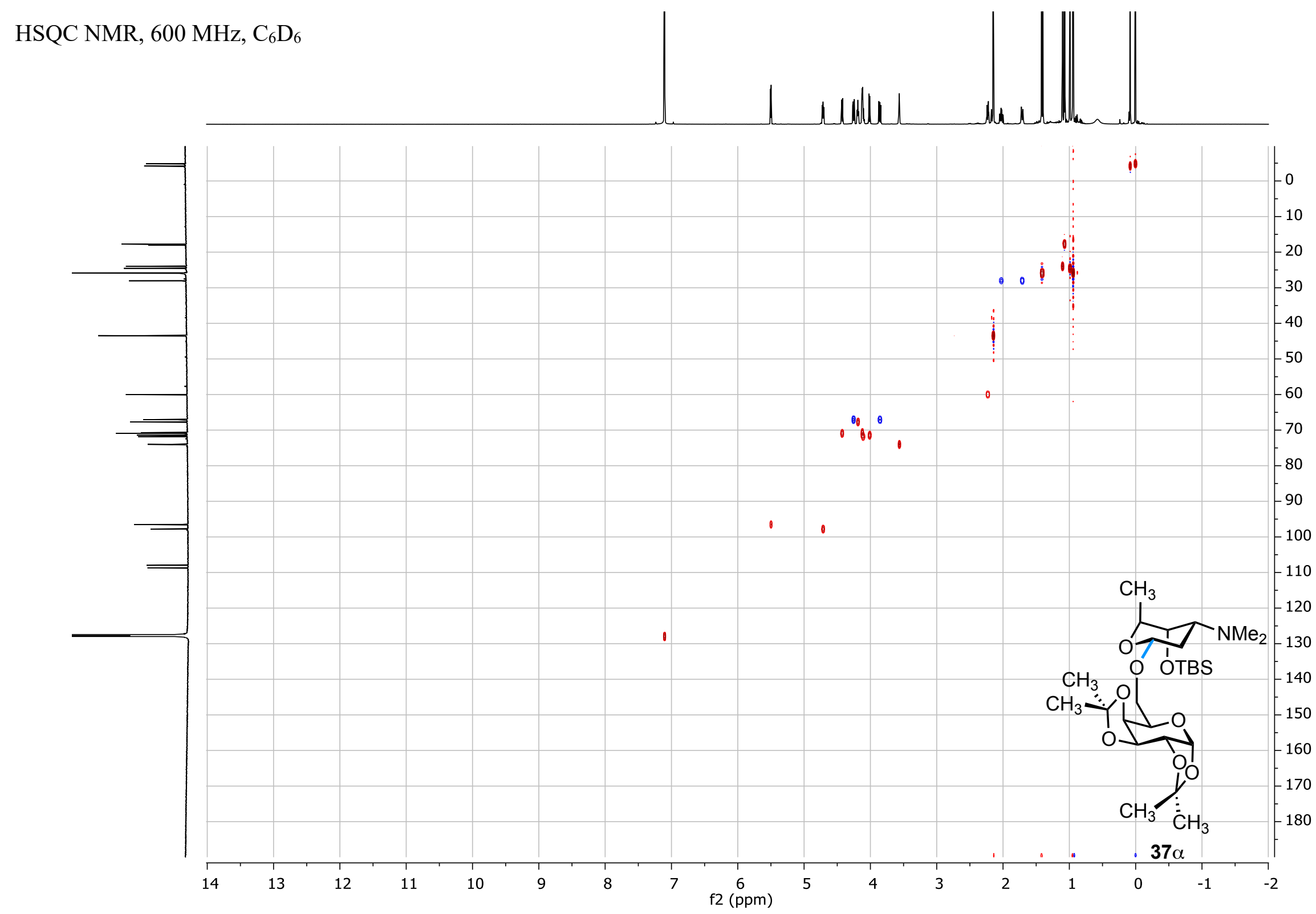

Hoang et al. "General method for the synthesis of $\alpha$ - or $\beta$-deoxyaminoglycosides bearing

S247

basic nitrogen" 


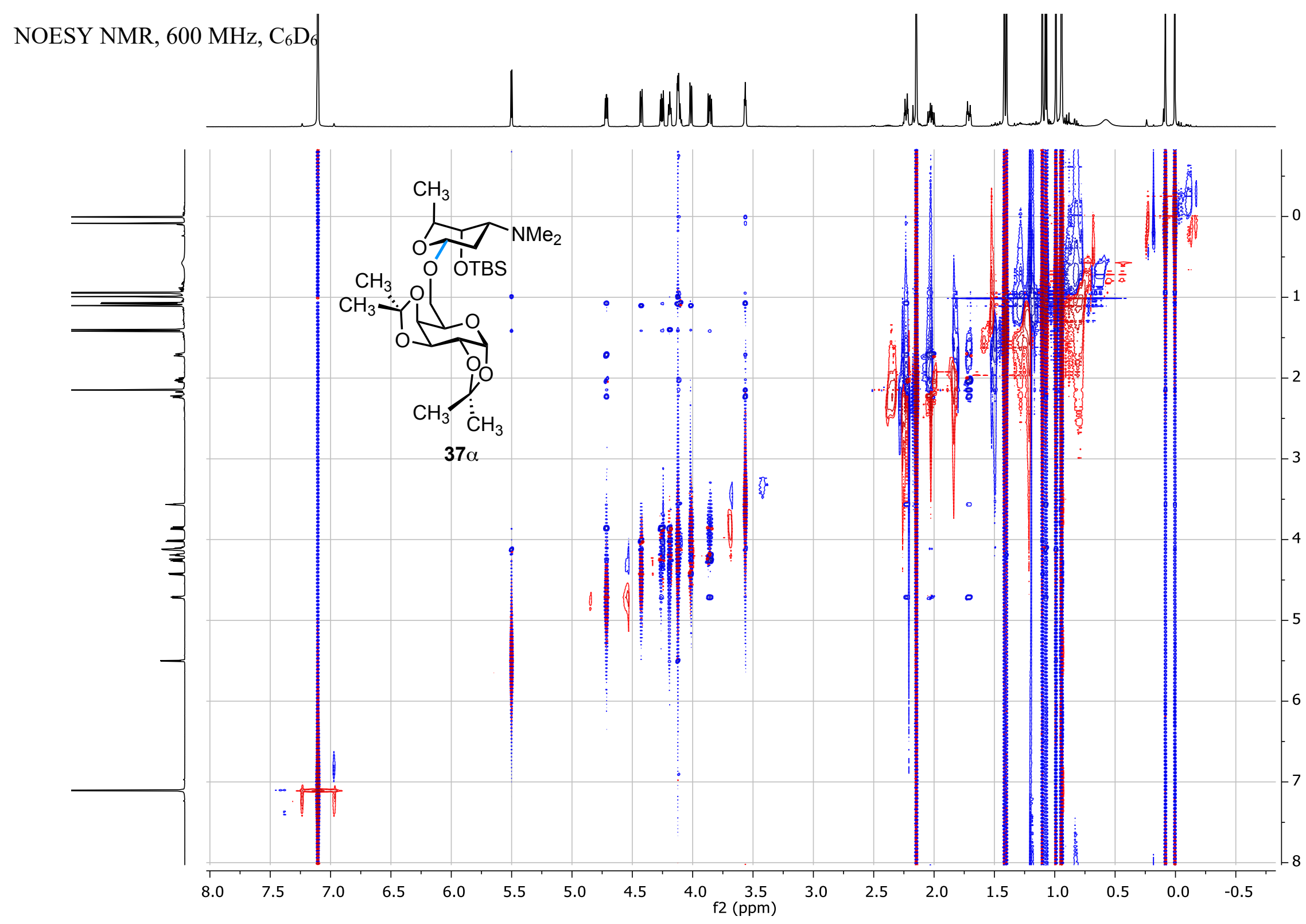

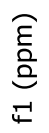

Hoang et al. "General method for the synthesis of $\alpha$ - or $\beta$-deoxyaminoglycosides bearing basic nitrogen" 
${ }^{1} \mathrm{H}$ NMR, $600 \mathrm{MHz}, \mathrm{C}_{6} \mathrm{D}_{6}$
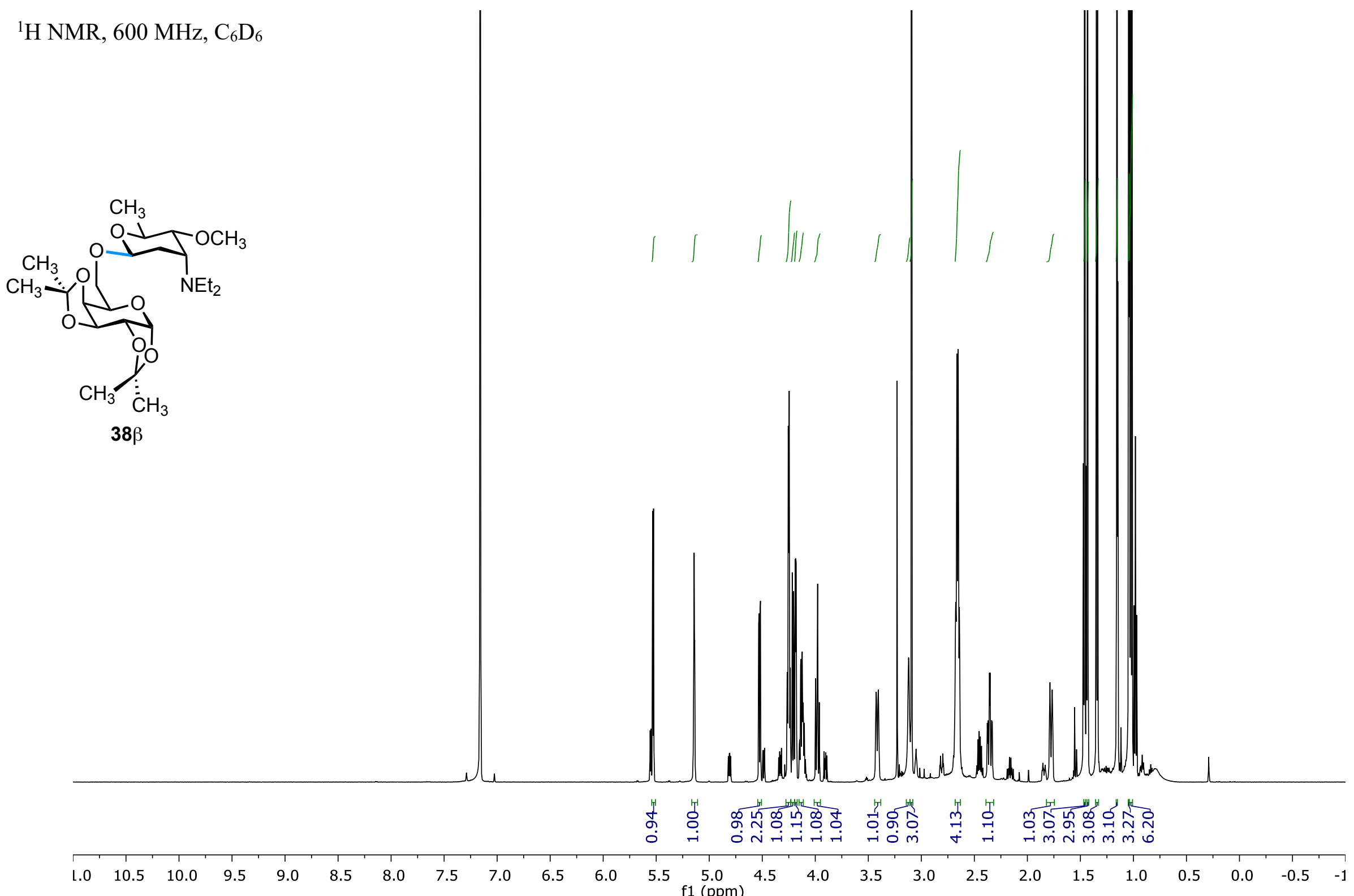

Hoang et al. "General method for the synthesis of $\alpha$ - or $\beta$-deoxyaminoglycosides bearing S249 basic nitrogen" 
${ }^{13} \mathrm{C} \mathrm{NMR}, 151 \mathrm{MHz}, \mathrm{C}_{6} \mathrm{D}_{6}$

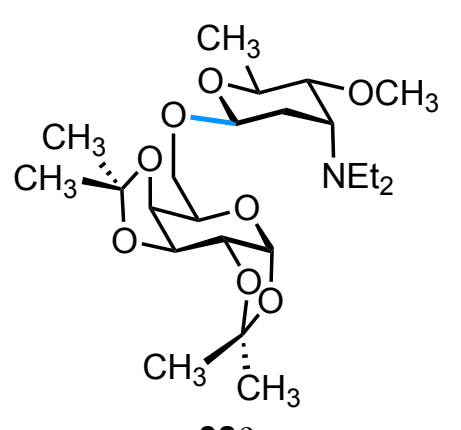

$38 \beta$

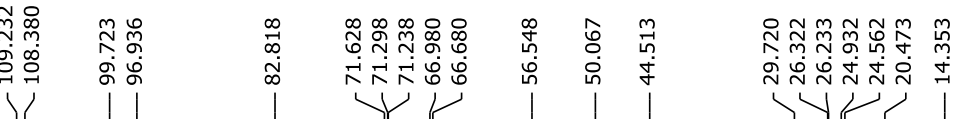

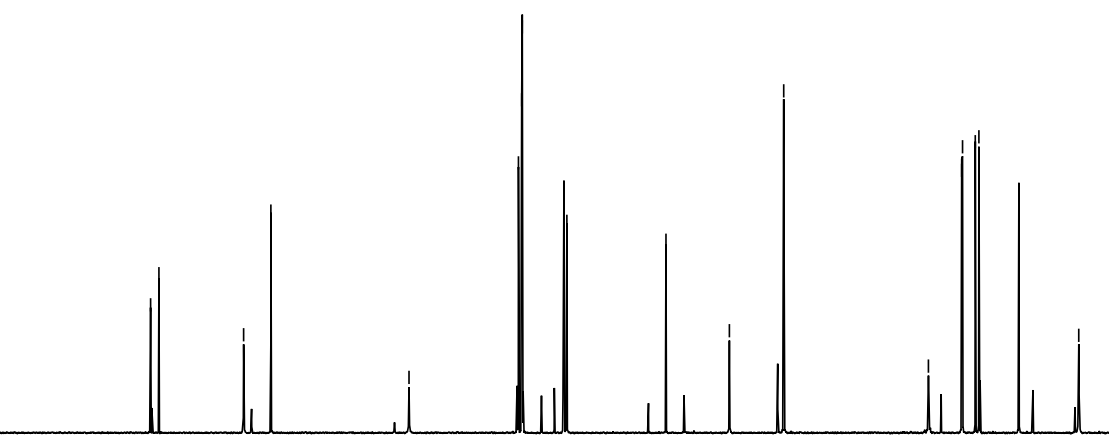


HSQC NMR, $600 \mathrm{MHz}, \mathrm{C}_{6} \mathrm{D}_{6}$
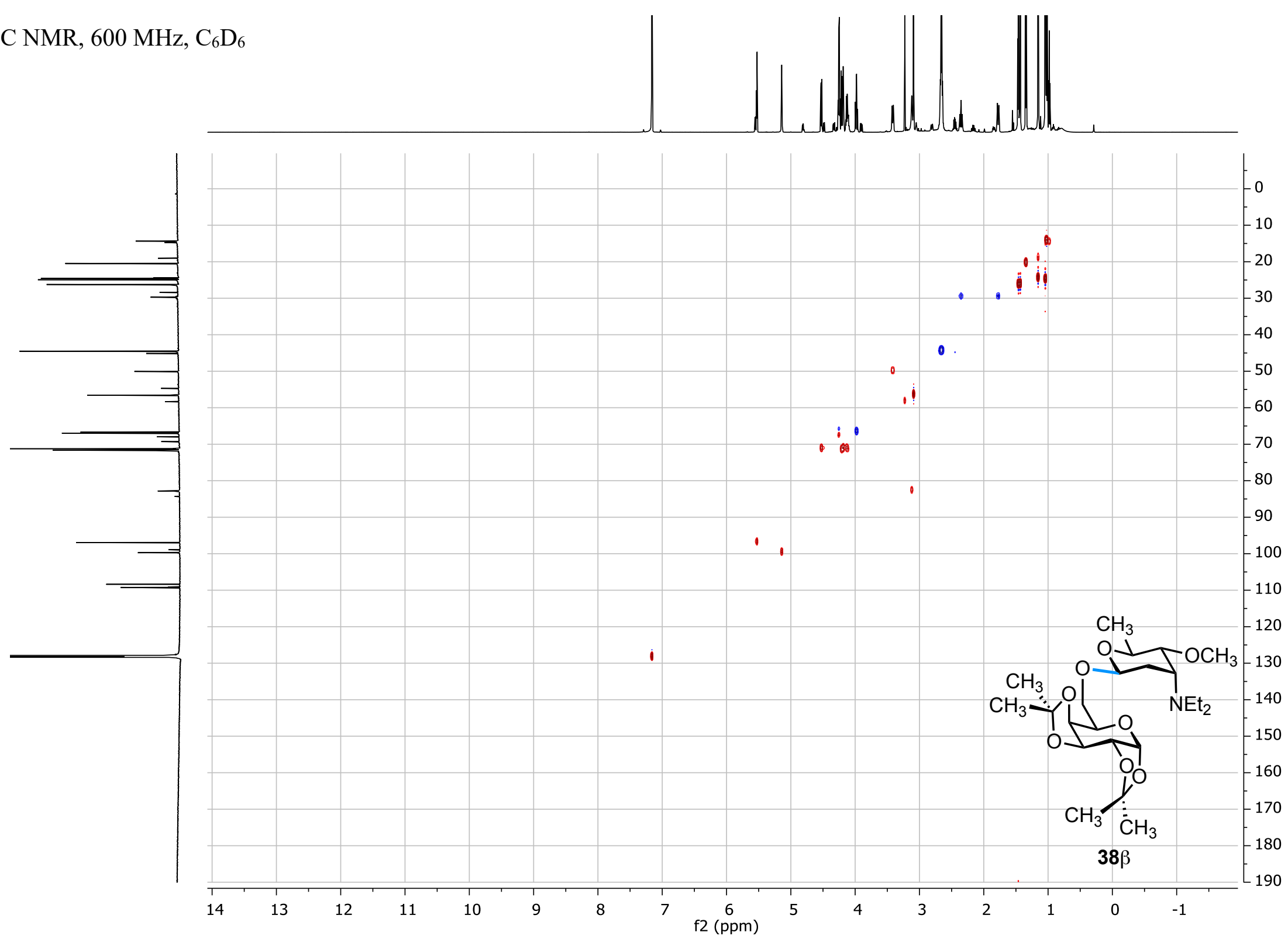

Hoang et al. "General method for the synthesis of $\alpha$ - or $\beta$-deoxyaminoglycosides bearing

S251

basic nitrogen" 


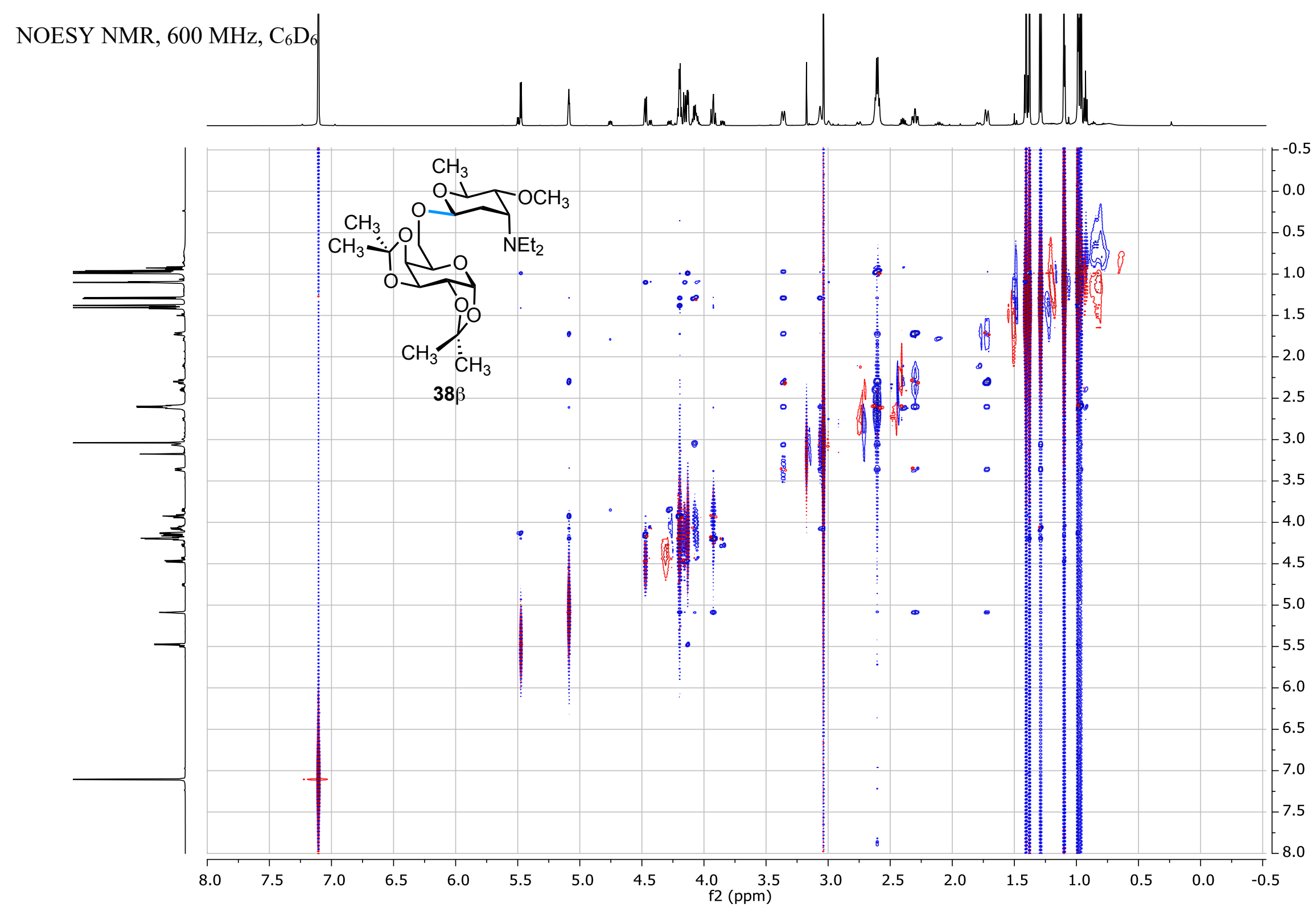

틈

Hoang et al. "General method for the synthesis of $\alpha$ - or $\beta$-deoxyaminoglycosides bearing

S252 basic nitrogen" 


\section{References.}

1. Still, W. C.; Kahn, M.; Mitra, A., Rapid Chromatographic Technique for Preparative Separations with Moderate Resolutions. J. Org. Chem. 1978, 43, 2923.

2. Pangborn, A. B.; Giardello, M. A.; Grubbs, R. H.; Rosen, R. K.; Timmers, F. J., Safe and Convenient Procedure for Solvent Purification. Organometallics 1996, 15, 1518.

3. Lin, H.-S.; Paquette, L. A., A Convenient Method for Determining the Concentration of Grignard Reagents. Synth. Commun. 1994, 24, 2503.

4. Yin, B.-L.; Cai, C.-B.; Lai, J.-Q.; Zhang, Z.-R.; Huang, L.; Xu, L.-W.; Jiang, H.-F., Sodium Borohydride-Nickel Chloride-Methanol Catalytic System for Regioselective Reduction of Electron-Rich Conjugated Dienes and Reductive Cleavage of Allyl Esters Involving $\pi$-Allylnickel Intermediates. Adv. Synth. Catal. 2011, 353, 3319.

5. Hoang, K. M.; Lees, N. R.; Herzon, S. B., Programmable Synthesis of 2-Deoxyglycosides. J. Am. Chem. Soc. 2019, 141, 8098.

6. Florent, J.-C.; Monneret, C., Stereocontrolled route to 3-amino-2,3,6-trideoxyhexopyranoses. K-10 Montmorillonite as a glycosidation reagent for acosaminide synthesis. $J$. Chem. Soc., Chem. Commun. 1987, 1171.

7. Sherry, B. D.; Loy, R. N.; Toste, F. D., Rhenium(V)-Catalyzed Synthesis of 2-Deoxy- $\alpha$ glycosides. J. Am. Chem. Soc. 2004, 126, 4510.

8. Hill, R. R.; Rychnovsky, S. D., Generation, Stability, and Utility of Lithium 4,4'-Di-tertbutylbiphenylide (LiDBB). J. Org. Chem. 2016, 81, 10707.

Hoang et al. "General method for the synthesis of $\alpha$ - or $\beta$-deoxyaminoglycosides bearing 